UNIVERSIDADE DE SÃO PAULO

FACULDADE DE EDUCAÇÃO

\author{
DANIEL REVAH
}

\title{
Construtivismo
}

Uma palavra no circuito do desejo 


\section{DANIEL REVAH}

\section{Construtivismo}

\section{Uma palavra no circuito do desejo}

Tese apresentada à Faculdade de Educação da Universidade de São Paulo, como exigência parcial para a obtenção do título de Doutor.

Orientador:

Professor Doutor Leandro de Lajonquière 



\section{Agradecimentos}

A Regina e Clara, agradeço pelos momentos de incentivo e paciência e por tudo o que fizeram, postergaram e compartilharam para que esta segunda e longa tese pudesse ser concluída.

A Leandro de Lajonquière, com quem pude iniciar certo percurso pela psicanálise e que apoiou a perspectiva desenvolvida neste trabalho quando não era mais do que um esboço. A leitura desses primeiros textos, as suas sugestões e críticas, ajudaram-me a repensar o tipo de análise do discurso que vinha experimentando. Sou-lhe grato, ademais, por ter sustentado um lugar que foi fundamental para a realização e conclusão deste trabalho.

Aos professores Angela Vorcaro, Sandra Corazza, Rinaldo Voltolini e Nina de Araújo Leite, agradeço pela leitura atenta do texto da qualificação, pelas observações, críticas e sugestões de leitura, que em alguns casos foram fundamentais.

A Alfredo Jerusalinsky, de cujos seminários e grupos de discussão procedem falas que parecem perpassar este trabalho sem que possa precisar onde estão. Se nesta análise do discurso falo tanto em significantes, pontos, nós, amarrações ... isso em boa parte deve ser creditado ao que procede dessa escuta.

A Ana Maria Costa, Ricardo Goldenberg e aos colegas dos grupos de estudo e discussão sobre a obra de Lacan, agradeço pelo que pude aprender escutando e participando das discussões, das quais também procedem falas que provavelmente estão em algum lugar deste trabalho.

A professores e colegas da Pós-graduação, que em alguns momentos e cursos contribuíram para repensar questões aqui desenvolvidas.

A Miriam Warde, que, como aluno-ouvinte, permitiu-me conhecer certos aspectos da História da educação brasileira que me ajudaram a situar algumas questões deste trabalho. 
Aos que na Faculdade de Educação da Universidade de São Paulo possibilitaram o meu retorno ao programa de Pós-graduação. Sou grato pela acolhida e pela confiança.

Aos colegas de trabalho e amigos, pelo apoio e incentivo.

A Junior e Cheila, que digitaram inúmeros textos utilizados neste estudo. Ao CNPQ, pela concessão da bolsa de estudos. 



\section{SUMÁRIO}

Introdução

\section{Seção 1}

$U m$

I. Desvios, confusões, equívocos ...

1. Do "lugar natural" ao "lugar des-naturalizado" 23

2. Um desvirtuamento de idéias jamais visto 27

3. A conversão inadequada 32

4. Transposição ilegítima 35

5. Um passado equivocado 38

II. O desvio como verdade 53

1. A primazia da ordem significante 55

2. A operação de costura 64

3. Os pontos de ressonância __ 70

4. O lugar da verdade 81 


\section{Seção 2}

As palavras da ciência

III. Emília Ferreiro: uma revolução conceitual 109

1. Primeiras costuras 109

2. Um histórico nó 114

3. Um outro caminho 123

4. O nome Emilia Ferreiro 162

5. De novo, a ciência 201

IV. Construtivismo: um saber positivo 209

1. O construtivismo é o caminho 210

2. Na direção do futuro 286

$\begin{array}{ll}\text { V. Piaget: um todo coerente } & 379\end{array}$

1. A criança constrói seu próprio conhecimento 380

2. Da realidade da criança ao padrão nacional 419

VI. O lugar do saber $\quad 437$

1. Discurso e saber 438

2. Um lugar de fantasmas 466

3. Dos retornos 473

$\begin{array}{ll}\text { Referências } & 479\end{array}$

$\begin{array}{ll}\text { Apêndice } & 497\end{array}$

$\begin{array}{ll}\text { Anexos } & 499\end{array}$ 


\section{Introdução}

$\mathrm{Na}$ década de 90, no Brasil, tornou-se comum a avaliação de que o problema relativo à universalização do acesso à escola pública, no Ensino Fundamental, estava praticamente solucionado. Ao mesmo tempo, o tema da qualidade do ensino transformou-se no único eixo da maioria dos discursos oficiais e dos debates acadêmicos sobre a educação escolar, que já vinham pondo em foco o histórico problema do chamado fracasso escolar, referido principalmente às primeiras séries do Ensino Fundamental e à alfabetização. Nesses debates, portanto, um dos termos do histórico binômio qualidade/quantidade tende a desaparecer, o que não é sem conseqüências. ${ }^{1}$

O adensamento do tema da qualidade do ensino corresponde ao período em que a palavra construtivismo começou a circular com insistência nos debates sobre a educação escolar, até ocupar o centro da cena. A princípio relacionada com uma nova perspectiva de alfabetização, quando ficou num primeiro plano na segunda metade da década de 80 , tornou-se rapidamente o mote de inúmeras iniciativas e propostas pedagógicas para a Educação Infantil e as primeiras séries do Ensino Fundamental, na rede pública de ensino e na rede privada, de governos municipais e estaduais de diferentes partidos, em particular daqueles cuja trajetória remetia às forças políticas que se opuseram à ditadura militar. ${ }^{2}$

Por último, a palavra construtivismo tornou-se uma referência nacional com as propostas curriculares produzidas pelo governo federal durante a presidência de Fernando Henrique Cardoso. Com elas, foi definido o padrão de qualidade almejado pelo MEC para todas as escolas do país. A primeira proposta, chamada de Parâmetros Curriculares Nacionais, na sua versão inicial foi divulgada em fins de 1996 para as primeiras séries do Ensino Fundamental e posteriormente para as demais séries desse mesmo nível do ensino. Outras propostas curriculares foram produzidas para outros níveis e modalidades do ensino: Educação Infantil,

\footnotetext{
${ }^{1}$ Uma das consequências é a de terem ficado num segundo plano as questões que ainda diziam respeito ao problema da quantidade, incidindo diretamente sobre o problema da qualidade do ensino, como é o caso da superlotação das salas de aula.

${ }^{2}$ Um bom exemplo é o da prefeitura de Porto Alegre, com a pedagoga Esther Pillar Grossi como Secretária de Educação, quando o Partido dos Trabalhadores ganhou as eleições municipais em fins dos anos 80.
} 
Educação Indígena, Educação de Jovens e Adultos e Ensino Médio. De caráter não obrigatório, essas propostas curriculares foram complementadas por outras ações. Por exemplo, as que pretenderam induzir mudanças nos livros didáticos adotados nas escolas - livros que foram avaliados por especialistas - e as ações que procuraram incidir sobre a formação dos professores, envolvendo também a elaboração de uma proposta pedagógico-curricular denominada Referenciais para Formação de Professores. Esses foram basicamente os pilares iniciais da política articulada em nível nacional com o objetivo explícito de mudar a qualidade do ensino, principalmente nas escolas públicas e tendo em vista o padrão construtivista definido pelos especialistas do MEC.

Em suma, nesse período que se inicia na segunda metade dos anos 80, a palavra construtivismo converteu-se no significante sob o qual e por meio do qual foram sendo produzidas e ordenadas inúmeras ações e discursos, tornando-se hegemônico o discurso pedagógico definido e reconhecido por meio desse significante-mestre, sobretudo entre professores e especialistas da educação. Há alguns anos, porém, começou a se tornar perceptível um certo refluxo no uso do termo construtivismo, em parte porque foi crescentemente obnubilado e até substituído pela expressão Parâmetros Curriculares Nacionais ou PCN, sem contar os deslocamentos que a chamada educação inclusiva começou a provocar.

Empregado como um nome que identificava um tipo de proposta pedagógica ou didática, concebida em geral como um desdobramento de concepções desenvolvidas primeiramente por Piaget e Emilia Ferreiro, o significante construtivismo começou a ser utilizado como sinal de reconhecimento de qualidade no ensino, desse modo designando e ocupando o lugar de algo situado no registro do que se tornou fundamental. $E$ à semelhança de tudo o que ocupa esse lugar, gerou inúmeras controvérsias. Assim, se a segunda metade dos anos 80 constituem a cena em que o construtivismo emerge, a década de 90 corresponde ao momento em que se instala a polêmica sobre o seu significado. Nesse período alguns conflitos e diferenças tornam-se explícitos, tanto nas conversas informais, quanto no discurso teórico, em palestras, conferências, cursos, publicações. Discute-se, por exemplo, sobre o seu caráter regressivo ou progressista e os que assumiam a sua defesa costumavam apontar a existência 
de desvios, enganos ou equívocos, a partir de uma perspectiva que servia como norma e que geralmente remetia para as formulações piagetianas. ${ }^{3}$

A própria palavra construtivismo tornou-se o alvo da disputa. $E$ não era para menos, pois nela começaram a confluir todo um conjunto de articulações discursivas de forte ressonância entre os profissionais da educação, adquirindo assim um poder particular, próprio de determinados significantes. Essa palavra, por exemplo, não raro mobilizava energias e discursos que buscavam esclarecer mal-entendidos, às vezes dando origem a acaloradas polêmicas e a atitudes e sentimentos os mais diversos, desde o deboche até as tomadas de posição firmes e quase religiosas em relação ao seu significado. ${ }^{4}$ Esses debates evidenciaram que o mesmo nome abrigava correntes e idéias bem diversas e até conflitantes, criando uma identidade que tendia a se dissolver quando determinadas diferenças ficavam em evidência. Isso, porém, não parece ter diminuído o seu poder e o seu efeito unificador, como atestam as situações em que o nome construtivismo atraia e sobrepujava práticas e discursos que dele buscavam se distanciar, colando-se nessas práticas e discursos com facilidade, como uma etiqueta, mesmo que à revelia dos que não se identificavam com esse nome. Dentre as tentativas de diferenciação, surgiram algumas que investiram de modo incisivo no próprio nome, como é o caso do sócio-construtivismo, também chamado de sóciointeracionismo, dos que afirmavam apoiar-se na obra do teórico russo Lev Vigotsky $^{5}$, para assim distanciar-se dos que teriam a obra de Piaget como principal fonte teórica. Tudo isso, enfim, concerne ao lugar que essa palavra ocupou e definiu.

Este estudo pretende contribuir no debate sobre o construtivismo e por isso insere-se no mesmo movimento dos discursos que o definem. O construtivismo

\footnotetext{
3 A esse respeito é ilustrativo o debate estabelecido entre Tomaz Tadeu da Silva (1993) e Fernando Becker (1994a).

${ }^{4}$ Esse fenômeno é parcialmente constatado na revista Nova Escola, n 82, mar./95, p.3. Nessa ocasião, o Diretor de Redação (João Vitor Strauss) abre esse número com um editorial cujo título é "A maratona do construtivismo" e no texto faz esta constatação: "Se há um assunto que mexe com o nosso leitor, é a nova linha pedagógica conhecida por construtivismo, tema sobre o qual NOVA ESCOLA mais recolhe manifestações - de nariz torcida algumas, de sincera admiração outras e de neutra curiosidade a maioria".

${ }^{5}$ Esse nome geralmente apresenta duas grafias nos textos em português: Vigotsky e Vygotsky. Neste trabalho optou-se por usar a primeira, à exceção feita das citações.
} 
aqui é concebido como um discurso pedagógico cuja emergência, na segunda metade dos anos 80, resulta de uma operação discursiva que implica no (re)ordenamento dos discursos educacionais que o precederam. Esse (re)ordenamento, do qual esse discurso e a sua hegemonia são os seus efeitos, ocorre sob a direção do significante construtivismo, mas não apenas dele, pois há outros que ocupam o mesmo lugar e operam do mesmo modo, como o nome Emilia Ferreiro. Esse significante aqui é chamado de significante-mestre, conforme uma concepção de discurso que em grande parte procede da obra teórica de Lacan. A questão principal é sobre o lugar que esse significante suporta e define, conjugado à ampla rede discursiva que Ihe dá consistência. Trata-se de interrogar esse lugar hegemônico, em particular como se constitui enquanto tal e como mantém essa condição. Em outras palavras, o objetivo primordial é esclarecer como o discurso construtivista se configura e como, nesse percurso, constrói e sustenta a sua hegemonia. O que aí está em causa é como uma única palavra entrou no circuito do desejo de tantos educadores brasileiros e os efeitos disso decorrentes, todos eles relacionados com o circuito que essa mesma palavra engendrou. Ao desenvolver essa questão, pretende-se evidenciar as condições que no interior do próprio discurso tornaram possível a sua emergência, como essa emergência ocorreu e alguns dos efeitos que ela produziu, conforme o construtivismo foi se tornando o centro dos debates brasileiros sobre a educação escolar, aí incluídos os deslocamentos discursivos que os próprios debates provocaram. O período em discussão abrange basicamente a segunda metade de década de 80 até fins dos anos 90 .

O novo discurso pedagógico começa a ganhar os seus primeiros contornos com as costuras feitas com o nome Emilia Ferreiro. Com esse significante-mestre, portanto, inicia-se o (re)ordenamento dos discursos educacionais precedentes. Entretanto, ele é crescentemente substituído pelo significante-mestre construtivismo. O significante-mestre é aquele que no discurso é alçado à posição de comando, na medida em que nele convergem as séries discursivas que estão como que à procura de um sentido último, mesmo que nele nunca o encontrem. No caso da palavra construtivismo, ela adquire o status de um significante-mestre em virtude das articulações discursivas que nela vão sendo amarradas e que assim definem o seu lugar no discurso. 
Essa ampla rede discursiva, coletiva e virtual, não deve ser entendida como se fosse um espécie de ente ou de substância que paira sobre os sujeitos. As articulações discursivas que the dão consistência surgem nos atos de fala, nas produções lingüísticas que definem esse discurso. São montagens discursivas singulares, porque relativas a cada sujeito, mas também são obras coletivas. Nessas várias montagens discursivas sempre é possível destacar os pontos significantes que adquirem ressonância social, pontos de ressonância que podem ser reconhecidos pela sua insistente presença nos discursos que delimitam o mesmo campo. São pontos de ressonância dos discursos vinculados ao mesmo significante-mestre e que, em nosso caso, permitem falar da existência de um discurso pedagógico construtivista, muito embora sempre estejamos em face de uma diversidade de discursos. Esses discursos são sustentados pela matriz simbólica que está no seu cerne e que deles por sua vez resulta. Uma matriz que se repete em cada ato de enunciação, embora sempre de um modo diferente. Para apreender essas diferenças é necessário considerar o próprio sujeito, em particular os traços que definem o seu discurso e a posição que nele ocupa.

Além do sujeito e da rede discursiva amarrada ao significante-mestre construtivismo, um outro aspecto a considerar no que aqui está sendo chamado de matriz simbólica é o que em determinada ordem simbólica adquire a feição do que não se deixa capturar, do que marca os seus limites, do que impede a completude com que acena aos sujeitos nela implicados. Esse resto, que resiste a ser integrado na ordem simbólica, no discurso construtivista é o que afigura um empecilho para que a ação pedagógica seja plenamente eficaz.

Enfim, o que acima foi sumariamente exposto são os elementos do que neste trabalho é chamado de matriz simbólica: o significante-mestre $\left(S_{1}\right)$, a rede discursiva nele amarrada $\left(\mathrm{S}_{2}\right)$, o sujeito e o que é da ordem de uma perda, daquilo que não se realiza, do que resta. O discurso assim concebido é o que Lacan chama de discurso do Mestre e aqui serve de referência para pensar a configuração do discurso pedagógico construtivista ou do que também pode ser chamado de matriz simbólica construtivista. Quanto ao sujeito, ele também é pensado a partir das conceitualizações de Lacan, portanto como sujeito do desejo. Esses elementos da matriz simbólica foram tematizados e conceitualizados ao longo deste estudo. Ademais, foi desenvolvido o conceito de ponto de 
ressonância, que é um pequeno desdobramento do conceito de ponto de basta formulado por Lacan. Os fatos do discurso tomados como objeto concernem aos pontos de ressonância desse discurso pedagógico e às operações de costuras correspondentes. Esses pontos foram denominados de diversas maneiras, conforme a sua função no processo de configuração do novo discurso. São eles o ponto de arremate, os pontos de ancoragem, os pontos limítrofes (ou pontos de fuga) e os pontos de estrutura.

Quando aqui se afirma que o construtivismo se tornou um discurso hegemônico, isso significa concebê-lo como um discurso que sobrepuja outros discursos educacionais, ordenando o campo da educação escolar de uma determinada maneira. De modo que afirmar a sua hegemonia, tendo em vista por exemplo as práticas pedagógicas, não significa dizer que essas práticas sejam construtivistas nos termos em que muitos autores as concebem. Antes de tudo implica entender que todas as práticas tendem a ser pensadas e avaliadas a partir do que esse discurso instaura como saber legítimo, válido ou verdadeiro. É nesse sentido que aqui se fala em hegemonia do construtivismo. Hegemônico, portanto, não é apenas ou não é propriamente o que diz respeito à maioria. Antes é hegemonia de uma determinada ordem discursiva que a todos se impõe e a todos avalia, infiltrando-se em nossas práticas e em nossos discursos, de modo que não podemos deixar de considerá-la ao avalizar, discutir ou contestar qualquer idéia ou prática que adquire alguma relevância no campo da educação escolar, especialmente entre os professores.

É comum que se pense o predomínio do construtivismo recorrendo-se a sua referência inaugural. Ela sustenta a crença de que a entrada em cena do construtivismo e a sua hegemonia é conseqüência do grande impacto que teve a bem fundamentada e importante investigação realizada por Emilia Ferreiro e Ana Teberosky sobre a psicogênese da língua escrita, aliada à solidez teórica da sua principal referência nesse registro teórico, a obra de Piaget. Vale lembrar, porém, que durante muito tempo vários pensadores e até o próprio Piaget passaram inadvertidos ou pouco repercutiram nos debates sobre a educação escolar, mesmo com suas obras publicadas. Portanto, o que suscita a entrada em cena de determinados discursos, idéias ou teorias que se tornam hegemônicos deve ser 
procurado em outro lugar e não propriamente ou não unicamente no seu suposto poder explicativo, na sua solidez teórica ou no seu caráter científico.

Isso não significa desconsiderar ou desprezar o que essa referência inaugural instaura, em particular o registro a partir do qual as práticas e discursos educacionais tendem a ser avaliados. Esse registro em grande parte é definido pelos discursos que os significantes ciência e teoria delimitam e legitimam, com a psicologia genética no papel de principal fonte conceitual, estabelecendo-se a partir deles o que deve ser aceito ou recusado, tendo em vista aspectos direta ou indiretamente relacionados com a educação escolar. Pode-se dizer que esse é o "lugar natural" do construtivismo, o lugar onde convergem os discursos construtivistas e mesmo boa parte dos que se alinham no campo da crítica, permanecendo incólume no seu lugar "original", mesmo quando questionado nos seus princípios teóricos ou na sua pretensão de verdade. Em outras palavras, costuma-se considerar que o construtivismo corresponde primeiramente ao campo da teoria e da ciência, com forte presença da psicologia genética, e que a sua aplicação na educação teria dado lugar a propostas didáticas ou pedagógicas chamadas também de construtivistas; a partir daí produzindo-se desvios, confusões e toda sorte de arbitrariedades, perdendo-se até o próprio sentido do nome construtivismo, na medida em que as suas fronteiras teriam sido imprudentemente alargadas.

A referência inaugural do construtivismo aqui interessa na medida em que concerne à sua configuração e também à dimensão ideológica desse discurso. Pôr em foco essa dimensão não implica desenvolver qualquer reflexão sobre o valor de verdade de determinada teoria. Ao contrário, supõe tratar todo e qualquer discurso do mesmo modo, no mesmo plano, pois o que importa são os efeitos de verdade que os discursos produzem, os objetos que eles criam e as posições subjetivas que definem. $E$ aí é preciso atentar para o que a maioria das reflexões sobre o construtivismo costuma desprezar, desvalorizar ou ignorar, porque visto como simples retórica, mero jogo de palavras vazias, um texto feito de slogans e clichês, enfim, frases e expressões que se repetem aqui e ali, em todo e qualquer discurso construtivista como núcleos inseparáveis desse discurso. O ideológico aqui é entendido, basicamente, como o que concerne a essa dimensão da verdade que o discurso sustenta — incluído aí o discurso científico — toda vez 
que adquire o semblante de um discurso transparente, de uma representação acabada do real.

Atentar para a dimensão ideológica do discurso construtivista implica explicitar as operações discursivas que o engendraram e que (re)ordenaram os discursos anteriores ao inserir os significantes desses discursos em novas relações. Essas novas relações são as que tendem a apagar todo e qualquer vestígio desse (re)ordenamento, resultando disso um discurso que tudo supõe derivar de uma teoria científica. Em outras palavras, esta análise do discurso construtivista objetiva revelar as operações discursivas que o engendraram e que ocultam esse mesmo processo. Isso supõe entender esse discurso como uma rede simbólica sobredeterminada onde essas relações que o engendraram não estão à vista, sendo necessário penetrar nessa rede e acompanhar a sua constituição para apreendê-las, mesmo que esse trabalho somente possa ser feito de modo parcial.

Em relação a como é construída e sustentada a hegemonia do construtivismo, a análise avançou em direção a um registro do discurso que neste trabalho é chamado de fantasmático. Ao interrogar esse lugar hegemônico pela via desse registro, pretendeu-se deixar em evidência a fonte de alguns dos mecanismos discursivos que estão na raiz desse poder de fascínio que o construtivismo exerceu e ainda exerce sobre inúmeros professores e especialistas da educação, capturando e também produzindo tudo o que é da ordem dos desejos aí implicados. O desejo aqui entendido como inconsciente e fruto de uma articulação subjetiva, singular, mas também efeito de uma ordem que remete ao social, pela via da linguagem e do discurso.

A análise do discurso construtivista teve então como objetivo último penetrar no registro fantasmático que o sustenta. Por isso, tratar da configuração e hegemonia desse discurso aqui também implicou conceber o lugar que ele define como um lugar de fantasmas. Um lugar cujo engendramento e transformação igualmente estão na mira deste trabalho, em especial para esclarecer questões relacionadas com a hegemonia desse discurso.

Esse registro fantasmático é uma construção cujo principal suporte é dado por significantes de ampla repercussão nesse e em outros discursos 
educacionais, presentes inclusive num passado distante, como é o caso do significante escola tradicional, que se afirma em discursos pedagógicos das primeiras décadas do século passado. Há também um outro significante cuja presença pode ser detectada antes dos anos 80 , mas que não havia adquirido maior relevância e que igualmente foi incorporado ao discurso construtivista: o significante espontaneísmo. Ambos significantes estão na base de importantes articulações discursivas. Por exemplo, a que define o lugar do construtivismo como equidistante de dois extremos (escola tradicional e espontaneísmo). Tudo isso atesta que o discurso construtivista é um discurso moderno, aparentado com os vários discursos pedagógicos nascidos no solo da modernidade. O que não significa dizer que o construtivismo seja um simples prolongamento de um discurso anterior. Justamente, o desafio deste estudo é mostrar como o discurso pedagógico construtivista é simultaneamente velho e novo. Velho porque efetivamente é feito com significantes existentes há décadas e de ampla ressonância no discurso pedagógico. Mas também novo, porque apresenta elementos e características que o diferenciam dos discursos precedentes.

Neste estudo, argumenta-se que o discurso pedagógico construtivista emergiu num processo que envolveu o (re)ordenamento dos discursos educacionais precedentes. Esses discursos são os que alavancaram e sustentaram a sua emergência, em particular os que no início da década de 80 eram considerados críticos: os discursos educacionais alternativos e a chamada pedagogia dos conteúdos. O embate que ocorreu entre esses discursos, com as diferenças e conflitos que então surgiram, criou o terreno onde o construtivismo inicialmente se instalou. Ou seja, ele se instalou no vácuo criado por esses debates, sendo sustentado ademais por esses discursos críticos, na mesma medida em que eles forneceram os seus pontos de ancoragem: os pontos significantes que o alavancaram e projetaram no cenário dos debates sobre a educação escolar. Democracia, fracasso escolar, analfabetismo, qualidade de ensino, escola tradicional, são alguns desses pontos de ancoragem. Neles foram amarradas inúmeras articulações discursivas procedentes desses discursos críticos e que o novo discurso pedagógico incorporou e (re)ordenou. O que essencialmente divide os discursos implicados nesse processo concerne a seus pontos de arremate, que são diferentes em cada caso. O ponto de arremate de cada discurso é o que condensa toda a rede discursiva que conflui em sua 
direção. Nele encontram-se justapostos todos os pontos de ressonância de determinado discurso, entre si vinculados e cada um contendo a sua própria rede. Esses pontos sempre são definidos por um ou mais significantes-mestres, estes sendo equivalentes quando definem o mesmo ponto. Por exemplo, Emilia Ferreiro, Piaget e construtivismo são significantes equivalentes, os três definem o mesmo ponto, nesse caso o ponto de arremate do discurso pedagógico construtivista, que é também um ponto de ressonância. Também definem esse mesmo ponto os significantes que derivam dos anteriores, como proposta construtivista, linha construtivista, etc. No caso desse discurso pedagógico, é importante destacar estes dois significantes-mestres: escola tradicional e espontaneísmo, pois são os que costumam fixar os limites desse discurso, ou seja, os lugares por onde escoa tudo o que é rejeitado. Nesse suporte, nesses dois pontos limítrofes, reside o que explica a hegemonia desse discurso. Um discurso com três pontos de estrutura - o ponto de arremate e os pontos limítrofes.

Este trabalho está dividido em duas partes. Na primeira Seção, no primeiro corte, o ponto de ressonância dos "desvios, confusões, equívocos ..." é a nossa via de acesso ao discurso construtivista. Essa Seção contém dois capítulos. No primeiro são parcialmente analisados alguns discursos educacionais que nutrem esse ponto de ressonância e que desse modo fixam determinada posição dos sujeitos implicados nesses e por esses discursos, mas também pelo discurso construtivista, mesmo que esse vínculo seja negado no plano do enunciado. Em outras palavras, cada Um dos discursos discriminados na Seção 1 converge em Um ponto que a todos eles vincula. E mais, esse ponto é onde no discurso construtivista é possível encontrar o que é da ordem da sua verdade, ou seja, do enigma que define as posições dos sujeitos educadores implicados na rede simbólica que é própria desse discurso pedagógico. Sobre esse lugar, porém, pouco se avança na primeira Seção, a não ser do ponto de vista teórico, na medida em que a reflexão se estende em direção ao que neste trabalho é chamado de verdade, assim esclarecendo por que os desvios são aqui 
considerados a via por excelência para dela nos aproximarmos. Essa é a temática desenvolvida no segundo capítulo, onde também é (re)criada parte da rede conceitual que permite realizar esta experiência.

A segunda Seção foi produzida tendo como gume estes significantes de arremate: Emilia Ferreiro, construtivismo, Piaget. Todos eles significantes equivalentes ao significante-mestre ciência e intercambiáveis nessa função do discurso que corresponde ao ponto de arremate. Esses significantes definem o que no discurso construtivista afigura o lugar do saber considerado legítimo, válido, verdadeiro. Cada um dos três primeiros capítulos dessa Seção põe em foco um desses significantes de arremate, para assim destacar, descrever e analisar algumas das articulações discursivas que neles vão sendo amarradas e que desse modo os projetam, servindo ainda para sustentá-los no lugar de comando. Portanto, nessa segunda Seção, discute-se como o discurso construtivista se configura e as transformações que nele ocorrem desde a sua emergência até 1998. Ademais, na Seção 2, que em parte reproduz e contém a Seção 1, é realizado um percurso que procura avançar - ou retroagir — sobre o lugar que constitui o ponto de partida deste trabalho e que é o lugar em foco na primeira Seção. Esse retorno ocorre de modo incisivo no último capítulo e responde ao objetivo de penetrar e circular no lugar que em última instância sustenta o discurso construtivista, um lugar que a ciência positiva esquece e que precisa mesmo esquecer para se tornar tal. É desse e nesse lugar que aqui procurou-se extrair algum saber.

A principal fonte pesquisada para produzir a Seção 2 é uma revista que no meio acadêmico não raro é vista como fonte de "desvios, confusões, equívocos ..." em relação ao que deve ser entendido por construtivismo. Trata-se da revista Nova Escola, que foi pesquisada desde o primeiro número, publicado em 1986, até 1998. Foram selecionadas e lidas cerca de quatrocentas matérias. A opção por essa publicação foi feita em razão das suas características, dentre as quais podem ser destacadas as seguintes:

- é publicada ininterruptamente desde o primeiro número (março/86) até hoje, numa média de dez números por ano; 
- desde o início e por vários anos, a revista foi distribuída em "cada uma das 220.000 escolas públicas de $1^{\circ}$ Grau existentes no país" ${ }^{\circ}$, graças a um contrato firmado entre a Fundação Victor Civita, responsável pela edição da mesma, e o Ministério da Educação;

- o seu público alvo são os professores do 1ํ Grau ou do Ensino Fundamental;

- durante vários anos foi produzida por uma equipe de jornalistas que nas reportagens costumava reproduzir falas de professores, alunos, pais de alunos, políticos, ocupantes de cargos em secretarias e especialistas vinculados às universidades;

- as matérias cobrem todas as regiões do país.

Essas e outras características foram relevantes por várias razões, vejamos algumas. A revista começou a ser publicada num momento em que o termo construtivismo ainda não tinha adquirido maior ressonância. A sua periodicidade permitia um acompanhamento bastante próximo em relação ao surgimento e relevância de determinadas temáticas, idéias ou preocupações que circulavam entre os educadores, em particular entre os professores do $1^{\circ}$ Grau. A Nova Escola apresentava-se também como uma publicação especialmente sensível à mudança e ao novo, que são algumas das marcas que definem o semblante com que surge o construtivismo, delimitando assim um terreno propício para acompanhar a sua emergência. Seria possível então seguir de perto como esse discurso se configurou sob a órbita desse significante e como, no mesmo movimento, reordenou os discursos que o precederam. Outro aspecto relevante diz respeito à repercussão dessa revista entre os professores, pois não eram poucos os que nela se espelhavam, utilizando-a ainda como fonte para recriar as suas práticas.

A opção por essa publicação periódica não implicou deixar de lado outras fontes, as quais, no entanto, não foram pesquisadas de um modo tão exaustivo, abrangente e sistemático. Quanto a essa abrangência, no caso da revista Nova Escola, procurou-se acompanhar uma diversidade de discursos sobre a educação escolar que não faziam referência explícita ou não se encontravam vinculados ao

\footnotetext{
${ }^{6}$ Cf. "Carta do editor" assinada por Victor Civita, Nova Escola, n 1, mar./86, p. 5.
} 
construtivismo, principalmente para acompanhar o que ocorria com esses discursos conforme o construtivismo se tornava hegemônico. Quanto aos textos de natureza acadêmica que informam e discutem o construtivismo, eles constituíram uma referência importante para desenvolver determinadas questões. Contudo, muito mais do que interlocutores para discutir as questões deste trabalho, eles foram tomados como conformadores do objeto que aqui está em causa. 
Seção 1

Um 


\section{Desvios, confusões, equívocos ...}

"o erro é a encarnação habitual da verdade" 1

Nas reticências que prolongam as palavras que compõem o título deste capítulo, em qualquer professor que participou dos debates educacionais da última década é bem provável que façam eco outras tantas palavras com elas aparentadas e inseparáveis da nossa comum e principal referência: o construtivismo. Esses significantes constituem um dos pontos de ressonância do discurso pedagógico construtivista, com certeza o mais importante, pois é justamente nesse particular ponto de basta que se revela o que pode ser chamado de a sua verdade. Esta entendida não como um fundo primeiro e definitivo, capaz de nos ofuscar com a luz própria do que é evidente. Mas, ao contrário, a verdade como enigma, que é o sentido que Lacan nos sugere (19691970 , p. 96). A verdade que é sempre meia-verdade, semi-dizer, aquela que Freud encontrou nos atos falhos, nos lapsos, nos sonhos e também nos sintomas. Uma verdade que está nos desvios, nas confusões, nos equívocos e em tudo o que afigura uma espécie de barreira para alcançarmos a nossa plenitude. Neste caso, o tipo de plenitude com que o discurso pedagógico construtivista tende a nos seduzir. Uma plenitude que não raro evoca a natureza, à qual, talvez por isso mesmo, não conseguimos deixar de recorrer. Comecemos então por ela.

\section{Do "lugar natural" ao "lugar des-naturalizado"}

No estudo de Vasconcelos (1996) sobre a difusão das idéias de Piaget no Brasil, encontra-se formulada uma idéia presente em inúmeros trabalhos e falas sobre a procedência do construtivismo:

(...) a partir dos anos oitenta, o construtivismo, baseado principalmente nas idéias de Piaget e Emilia Ferreiro, se expandiu pelo país, de tal maneira que muitos professores, ao denominá-lo, referem-se à "febre construtivista". (p. 1)

Apresentado como o "exemplo mais notório" da presença das idéias de Piaget no "meio educacional", o construtivismo é temporalmente situado na década de 80 , como um fato próprio do nosso tempo, um fato contemporâneo. $\mathrm{E}$,

\footnotetext{
${ }^{1}$ Cf. Lacan, 1953-1954, p. 300.
} 
ao mesmo tempo, é remetido a um passado distante, por isso afirma-se que "se expandiu". Em outras palavras, o que hoje chamamos de construtivismo é apresentado como o prolongamento de uma corrente de idéias oriunda sobretudo da obra teórica de Piaget, que remonta às primeiras décadas do século $X X$, mas também das pesquisas e reflexões desenvolvidas por Emilia Ferreiro no campo da alfabetização, as quais fincam o construtivismo no presente. Desse modo, Vasconcelos apresenta o construtivismo referido aos dois autores que na maioria dos discursos são considerados as suas primeiras e legítimas fontes, os autores cujas obras delimitam uma espécie de "lugar natural" do construtivismo. Sem dúvida é o lugar aonde a maioria dos profissionais da educação costuma remeter tudo ou quase tudo que tende a ficar sob a égide desse termo, principalmente quando se trata de validar ou criticar determinada idéia, posição ou prática pedagógica, definir as origens do construtivismo ou explicar o que ele é. Sandra Corazza (1994, p. 121), por exemplo, refere-se ao construtivismo em termos semelhantes, vinculando-o à Psicologia:

Nesse "lugar natural" [Psicologia da Criança], onde o Construtivismo está, para o qual se movimenta, ou ao qual volta quando afastado, é forjada a Epistemologia Genética - uma teoria do conhecimento que Piaget desloca da Filosofia para investigar como o sujeito humano produz conhecimento.

Nesse artigo, a autora faz várias considerações sobre a obra de Piaget e esboça algumas críticas $^{2}$, mas o foco principal é o que ela concebe como o outro lugar do construtivismo, o "lugar des-naturalizado”, o da prática pedagógica:

Desse lugar, o pedagógico, só é possível falar dos efeitos do discurso construtivista que, como costuma ocorrer, são polissêmicos.

"Construtivismo" é o nome genérico que vimos dando, enquanto comunidade educativa escolar, a múltiplas e diferentes tentativas de aplicar, nas salas de aula e nas escolas, às concepções desenvolvidas pela Epistemologia Genética de Piaget, revitalizadas pelas pesquisas básicas acerca da alfabetização, que Ferreiro e equipe desenvolveram ao final da década de 70. (p. 122)

\footnotetext{
${ }^{2}$ As críticas da autora apóiam-se no que ela considera duas vertentes da crítica. Uma corresponde a "um segmento do pensamento marxista": censura-se, na obra de Piaget, a presença de "uma concepção universalizada de sociedade, como meio social ou cultural homogeneizado e indiferenciado". A outra vertente é vinculada ao campo da psicanálise: critica-se "uma concepção de criança, naturalmente lógica, em que fica privilegiado tudo o que não vem do campo do desejo" (Corazza, 1994, p. 122).
} 
Sempre tomando como referência o construtivismo no seu "lugar natural", Corazza caracteriza o lugar da prática pedagógica discriminando quatro formas ou tipos de práticas. Primeiramente, destaca a ausência de construtivismo, devida a vários fatores, como as "péssimas condições" em que os professores trabalham e a "resistência" dos professores "a escutar estas idéias". Outro tipo de prática resulta das "aplicações apressadas e superficiais", o construtivismo torna-se aqui "um método organizado em passos e traduzido em exercícios, tarefas e atividades rotinizadas". Segundo a autora, essa "é a prática continuísta do que é velho, repetindo-se sob a máscara do que parece novo". Um outro lugar da prática pedagógica diz respeito aos:

(...) trabalhos sérios e responsáveis, em que os professores estudam, discutem, indagam à teoria, confrontam as idéias com suas práticas, fazem-se pesquisantes, além de ensinantes (embora sabendo que a Pedagogia nunca vai poder ser ciência, ao menos positivista), reconhecem os limites e as impossibilidades, tanto da teoria quanto da prática; buscam superações, inventam. (Corazza, 1994, p. 124)

Por último, Corazza refere-se aos que transformaram o construtivismo num "dogma", "um paradigma educacional monolítico e totalizador", são os que operam com o "Mito Construtivista", "repetindo a ilusão - tão cara ao liberalismo - de que a escola é a alavanca da transformação social. Estes atrapalham, mais do que ajudam". ${ }^{3}$

O que acima foi apresentado constitui uma forma muito comum, quase única, de conceber o construtivismo: primeiro, no plano da produção teórica e científica, principalmente o da psicologia genética; e, em segundo lugar, como desdobramento no campo da educação escolar e na prática pedagógica, como aplicação de uma teoria ou de concepções que em última instância remetem a Ferreiro e Piaget - nomes através dos quais o discurso pedagógico construtivista é vinculado ao campo da produção teórica e científica.

A própria palavra construtivismo procede desse campo, pois é utilizada por Piaget, embora não com frequência, como lembram Macedo (1994, p. XVI) e

\footnotetext{
${ }^{3}$ Essa divisão é matizada pela própria autora, a qual adverte que toda classificação envolve reducionismos e, com a intenção explícita de escapar desse quadro que ela mesma chama de maniqueísta, afirma que "cada educador dos tempos de agora vivencia (...) fragmentos de práxis de cada uma das quatro tendências" (p. 124).
} 
Carvalho (2000, p. 192). Em seus escritos, entretanto, é comum encontrar o uso de termos que procedem da mesma raiz, como o verbo construir, o adjetivo construtiva/o ou o substantivo construção. Esses termos amiúde são utilizados para compor imagens que ilustram em que consiste o desenvolvimento psíquico, sobretudo do ponto de vista cognitivo. ${ }^{4}$ Por exemplo, quando Piaget compara o desenvolvimento mental, entendido como construção contínua, à edificação de um prédio que fica mais sólido à medida que se acrescenta algo (Piaget, 1982, p. 12). O uso desses termos, porém, concerne principalmente ao plano conceitual, aos conceitos que Piaget desenvolve ao longo da sua obra, como o de erros construtivos e o que nela constitui o seu tema central: o conhecimento, concebido basicamente como construção (1996, p. 409).

Em relação à palavra construtivismo, antes do que o seu uso por Piaget é importante reparar num outro fato: ao ser simultaneamente utilizada como nomesíntese da sua teoria e do que no campo da educação escolar é delimitado com o mesmo nome, ela repõe constantemente a divisão que é inerente à matriz simbólica construtivista: o "lugar natural" e a sua aplicação, igualmente naturalizada, mesmo quando se fala em "lugar des-naturalizado". ${ }^{5}$ Quando se opera com essa divisão, de modo explícito ou implícito, fica obscurecido o (re)ordenamento discursivo e as apropriações que nesse processo ocorreram, relativas a domínios e registros diversos, que extrapolam o campo da educação escolar e o da psicologia. Sem contar outros efeitos, como o de nutrir o insistente tema dos desvios, das confusões e das apropriações indevidas da teoria piagetiana ou das descobertas da Emilia Ferreiro e a sua equipe, males esses atribuídos em geral aos professores, os quais supostamente não aplicam a teoria como deveriam.

Aqui não se pretende colocar em dúvida a forte presença das concepções piagetianas ou das formulações de Ferreiro nos discursos pedagógicos

\footnotetext{
${ }^{4}$ A esse respeito, Carvalho (2000, pp. 192-3) afirma: "É freqüente encontrarmos em seus escritos a referência a essa imagem da 'construção' como uma metáfora considerada elucidativa de sua teoria, tanto no plano do desenvolvimento cognitivo da criança como no da espécie".

${ }^{5}$ No caso do artigo de Corazza, na sua análise é introduzida certa dimensão histórica. Ademais, utiliza aspas cada vez que se refere ao construtivismo como lugar natural, provavelmente querendo indicar com isso que não o toma como algo fora da história. Entretanto, a sua perspectiva de interpretação não foge dessa mesma divisão com que ela opera e que em outros artigos abandona, pois neles o construtivismo é pensado antes de tudo como uma prática discursiva ou como um discurso que repete o "discurso pedagógico da Modernidade" (1996b).
} 
construtivistas, nem tampouco trata-se de negar possíveis apropriações das concepções desses autores que pouco se relacionam com o que eles propõem. Ao contrário, é óbvio que isso ocorre com qualquer teoria e que esses discursos pedagógicos são atravessados pela ampla rede discursiva que procede do trabalho desses autores. Essa rede aqui interessa não para mensurar a maior ou menor adequação das práticas e discursos pedagógicos em face dela, mas na medida em que participa da configuração do discurso pedagógico construtivista e com o intuito de investigar qual é o seu lugar nesse processo, pois esse discurso não é propriamente uma derivação ou desdobramento da obra desses autores e das pesquisas e reflexões teóricas que em maior ou menor grau os tomam como referência. Por isso, um dos problemas deste trabalho é determinar, pelo menos parcialmente, como essa produção teórica incide nos discursos educacionais dos anos 80 , de que modo ela própria constitui o discurso pedagógico construtivista e o que dos discursos anteriores é apropriado para constituir esse novo discurso. Nesse processo é preciso considerar, por exemplo, que a obra de Piaget já vinha sendo objeto de apropriação há várias décadas, embora tenha sido reatualizada de um modo peculiar na década de 80, alterando o seu lugar no conjunto dos discursos educacionais. Em outros palavras, o (re)ordenamento que ocorre nos anos 80 corresponde também a um processo de realinhamento de todo um conjunto de articulações discursivas procedentes da obra de Piaget e do que dela tinha sido objeto de apropriação, em discursos educacionais que ainda não eram propriamente construtivistas.

\section{Um desvirtuamento de idéias jamais visto}

No Brasil, como vários autores costumam salientar (Freitag, 1985, p. 11; Vasconcelos, 1996, p. 41), a obra de Piaget e o seu nome foram associados principalmente aos temas educacionais e/ou pedagógicos. Em consequência, as suas concepções foram sobretudo incorporadas em reflexões voltadas para os problemas próprios da educação escolar.

Segundo Vasconcelos (1996, p. 9), cujo importante e vasto levantamento será aqui tomado como fonte, a presença do nome e das idéias de Piaget remonta a fins da década de 20, com o movimento da Escola Nova, que proporcionou o 
"quadro de inserção" das suas idéias no Brasil. ${ }^{6}$ Dos anos trinta aos anos sessenta, essas idéias foram "veiculadas exclusivamente na área educacional" ( $p$. 264). Nessa primeira etapa, essa difusão "era livresca e quase sempre dependia do interesse individual", sendo "raras as pesquisas teóricas ou empíricas que incluíam Piaget como referência". Era principalmente uma "difusão individualizada", feita por "profissionais que procuravam conhecer a psicologia genética, para melhor instrumentarem sua ação pedagógica" (1996, p. 264). Nessa primeira etapa, poucos textos de Piaget foram traduzidos e publicados. ${ }^{7}$

A partir de meados dos anos 60, além dessa difusão individualizada, há "uma difusão 'institucional' mais persistente, voltada para a pesquisa", nas "áreas de psicologia e pedagogia, principalmente após a criação dos cursos universitários de graduação em psicologia" (Vasconcelos, 1996, p. 264). Nesse período, que se estende até o presente (meados dos anos 90), foram desenvolvidas pesquisas teóricas e/ou empíricas que consolidaram, em vários Estados, o que Vasconcelos chama de "núcleos piagetianos". Surgem então "pesquisas piagetianas nas mais variadas áreas de conhecimento" (p. 264). Quanto aos textos de Piaget publicados nessa segunda etapa, o número cresce significativamente já na década de 60 , bem como os livros e artigos relacionados às idéias de Piaget, sobretudo a partir dos anos $70 .^{8}$

No início, segundo Vasconcelos (1996, p. 264), essa "fase universitária" avançou lentamente, "em função da grande penetração do behaviorismo no cenário brasileiro". Nesse período pós 64, durante o regime militar portanto, o autor lembra do predomínio da "pedagogia tecnicista" e afirma que o "ideário

\footnotetext{
${ }^{6}$ Nesse momento inicial, Vasconcelos destaca a criação do Laboratório de Psicologia da Escola de Aperfeiçoamento Pedagógico, em Belo Horizonte. Em 1929, no mesmo ano em que foi criado, passa a ser dirigido por Helena Antipoff, que havia trabalhado no Instituto Jean-Jacques Rousseau, em Genebra. Nele foi assistente de Claparède, que era o seu diretor, e colega de Piaget, que desde 1921 trabalhava no Instituto. Na direção do Laboratório até a sua extinção, em 1946, Helena Antipoff trouxe vários pesquisadores e educadores europeus para ministrarem cursos na Escola de Aperfeiçoamento Pedagógico, veio inclusive Claparède. Por essa via são divulgados os trabalhos do Instituto e também do jovem pesquisador Piaget (Vasconcelos, 1996, pp. 37-9).

7 "O trabalho por equipes em escolas: bases psicológicas" é o primeiro e único artigo traduzido e publicado nesse período, em 1936, na Revista de Educação, um periódico da Diretoria Geral do Ensino do Estado de São Paulo (Vasconcelos, 1996, p. 66). Em fins dos anos 50, foram ainda traduzidos e publicados dois livros: A Psicologia da inteligência, em 1958, e $A$ linguagem e o pensamento da criança, em 1959 (baseado em levantamento feito por Vasconcelos (1997), onde alguns livros não têm data de publicação).

${ }^{8}$ A esse respeito, veja-se o levantamento feito por Vasconcelos (1997).
} 
escolanovista" apresentava "sinais de exaustão" (p. 265). Ademais, as "poucas propostas educacionais, de base piagetiana, formuladas no início dos anos 70, geralmente foram assimiladas de uma maneira técnica ou não foram assimiladas" (p. 265). ${ }^{9} \mathrm{Na}$ universidade, "expandiram-se entre os piagetianos as 'pesquisas puras', sem conotação educacional 'aparente', voltadas para (...) aspectos da epistemologia genética" (p. 266). Vasconcelos atribui essa tendência ao rumo dos estudos genebrinos dessa época e também ao fato das "idéias piagetianas terem sido temporariamente 'expulsas', pelo behaviorismo, de nosso meio educacional" (p. 266). Sem contar um outro fator: o "receio da repressão", que levou a relegar "a temática social” em prol de pesquisas "mais epistemológicas" (p. 266).

No início dos anos 80, conforme aponta Vasconcelos, essa situação começou a mudar com a abertura política. "Começava a se fazer sentir a presença de pesquisas piagetianas interculturais, dirigidas à realidade brasileira", uma "tendência de pesquisa comprometida com a realidade social de uma população marginalizada e de baixo rendimento econômico" (ibidem, p. 266). Nesse momento, "a teoria de Piaget mostrava-se uma alternativa ao behaviorismo e ao tecnicismo educacional" (p. 266). Ademais, nas pesquisas buscava-se "conhecer a pessoa além do sujeito epistêmico", surgem "discussões sobre os limites sociológicos da teoria piagetiana" e muitos buscaram a superação dessas limitações (p. 267). Nos anos 90, entre outras coisas Vasconcelos constata que "tem sido grande 0 interesse por Piaget nas mais variadas áreas de conhecimento" (p. 267).

Além das duas etapas já referidas, Vasconcelos faz um outro recorte temporal. Até os anos 80 , a maioria dos piagetianos estudava "os aspectos estruturais da explicação genética, isto é, os estádios de desenvolvimento e sua caracterização". E depois, nessa mesma década:

(...) parece ocorrer um aumento de interesse pela pesquisa dos aspectos funcionais, quer dizer, pela concepção construtivista e interacionista do desenvolvimento. Essa tendência abrange pesquisas dedicadas a várias áreas do conhecimento e vai ao encontro dos

\footnotetext{
9 O autor dá como exemplo "mais marcante" a lei 5.692, de 1971, que define as diretrizes e bases para o ensino de primeiro e segundo graus, "com sua doutrina baseada na psicologia genética" ( $p$. 265).
} 
educadores e/ou piagetianos que abraçaram as idéias de Emilia Ferreiro. (ibidem, p. 267)

Dentre as aplicações à educação que Vasconcelos comenta, há dois autores cujos trabalhos exerceram grande influência, antes da suposta "expansão" do construtivismo nos anos 80. Um deles é Hans Aebli, o qual propõe uma "didática operatória" concebida a partir da obra de Piaget. ${ }^{10} \mathrm{O}$ seu livro, aprovado pelo próprio Piaget e intitulado Didática Psicológica: Aplicação à Didática da Psicologia de Jean Piaget, foi traduzido e publicado no Brasil em 1971. Segundo Vasconcelos, a obra de Hans Aebli "foi bem recebida pelos educadores brasileiros":

(...) principalmente por aqueles que, influenciados pelo escolanovismo, procuravam redirecionar a pedagogia para os quadros estritos da ciência e reconheciam na psicologia do desenvolvimento o melhor caminho para atingir esses fins. (ibidem, p. 72)

O outro autor por ele destacado é o professor Lauro de Oliveira Lima, que desde o final da década de 50 divulgou intensamente as idéias de Piaget no Brasil, bem como a obra de Hans Aebli. Ademais, criou e divulgou o "método psicogenético" ou o método piagetiano, como muitos também o chamaram, tendo recebido diversas críticas porque teria descaracterizado a obra de Piaget (ibidem, pp. 74-82).

No tipo de análise que Vasconcelos faz do percurso da obra de Piaget no Brasil, a sua apropriação é concebida sobretudo em termos da sua maior ou menor penetração, das dificuldades ou empecilhos que surgiram na sua difusão, dos espaços de abertura existentes para que a sua divulgação ocorresse, estreitamente vinculada aos grupos que se consolidaram inspirados em suas idéias. Estas, segundo o autor, foram mais ou menos desvirtuadas ou distorcidas nas diferentes instâncias aonde afinal chegaram, seja por meio de grupos, iniciativas individuais, publicações ou através de cursos. Vasconcelos também afirma que foram aprofundados pontos da teoria piagetiana de acordo com as condições próprias de cada momento histórico, que a teoria foi ampliada para novas áreas de conhecimento e que procurou-se superar as suas limitações, registrando inclusive algumas críticas. Como a sua apropriação ocorreu

\footnotetext{
${ }^{10} \mathrm{Na}$ década de 40, Hans Aebli fez parte de um grupo que passou a colaborar com Piaget (Vasconcelos, 1996, pp. 68-9).
} 
basicamente no campo da educação escolar, Vasconcelos faz apreciações principalmente com o intuito de avaliar em que medida a transposição dessa teoria para a educação provocou distorções ou desvirtuamentos. $E$ isso em grande parte decorre do modo como o autor tende a conceber toda e qualquer apropriação das idéias de Piaget, isto é, como uma aplicação da sua teoria, boa ou má, melhor ou pior. É o viés que predomina quando avalia a sua presença nos anos 80 e 90 :

\begin{abstract}
Atualmente, o "construtivismo" configura-se como a maior corrente propulsora da difusão das idéias de Piaget no Brasil. Por outro lado, as concepções dessa pesquisadora [Emilia Ferreiro], consequentemente as de Piaget, têm sido amplamente distorcidas. Na verdade, nunca se viu na história da educação brasileira um desvirtuamento de idéias em tal proporção. (ibidem, p. 267)
\end{abstract}

Vasconcelos também acrescenta que até mesmo Emilia Ferreiro, em suas visitas ao Brasil, mostrou-se preocupada com essa situação. É o que também aparece em falas de Ferreiro presentes em algumas publicações, como a revista Nova Escola, onde é registrada, por exemplo, a sua preocupação com o fato de terem-na transformado em método. ${ }^{11}$

$\mathrm{Na}$ reconstrução histórica de Vasconcelos, o que é delimitado pelas referências inaugurais torna-se também um lugar natural: o lugar ao qual é preciso recorrer para avaliar o que tende a ser reduzido a uma aplicação das idéias de Piaget e/ou Ferreiro. Daí a sua insistência ao longo do livro com o tema das deturpações, distorções e desvirtuamentos, trazido à tona inclusive pelas próprias pessoas que o autor entrevistou durante a sua pesquisa. Esse tema infiltrou-se em inúmeros discursos, mesmo entre os que faziam algumas críticas e restrições às concepções piagetianas ou que denunciavam, com ênfase, o caráter dogmático ou religioso que muitas vezes impregnava ou assumia o discurso construtivista, como é o caso do trabalho que será comentado a seguir, de Martha Vieira (1995). ${ }^{12}$

\footnotetext{
${ }^{11}$ Cf. "Meu trabalho não é um método", Nova Escola, n 34, out/89, pp. 18-9.

${ }^{12}$ A "boa" interpretação das concepções piagetianas gerou intensas polêmicas entre os próprios piagetianos. Um bom exemplo é o debate estabelecido entre Fernando Becker $(1987,1988)$ e Bárbara Freitag (1987), com acusações mútuas por causa das supostas "confusões conceituais" que um ou outro teria cometido.
} 


\section{A conversão inadequada}

Vieira concebe o construtivismo como um discurso e toma como fonte a revista Nova Escola (entre 1986 e 1995). O seu objeto, portanto, é o discurso construtivista veiculado por essa publicação. A sua análise focaliza os "fatores que constituem e condicionam o seu processo de produção" (Vieira, 1995, p. 69). Apoiando-se numa das linhas teóricas que nutrem a linguística, a autora concebe a linguagem como uma atividade social, como uma forma de interação, sempre concebida dentro de um determinado contexto social de comunicação. O processo de produção do construtivismo pela revista é então concebido como um processo de interação ou de interlocução que "se configura como uma situação interativa que envolve o Autor, o Texto, o Leitor e as circunstâncias de produção" (p. 69).

Dos elementos que intervém nesse processo de produção, Viera destaca a adoção de um tipo de linguagem pela revista: a linguagem jornalística, que a diferencia de outras publicações da área de educação. Ela constitui "a condição primeira de instauração do processo de interlocução" que na revista se configura (ibidem, p. 69). Dessa linguagem "decorre a forma sob a qual são construídos os demais fatores envolvidos no processo de interlocução" (p. 69). E mais: essa linguagem jornalística "determina todo o processo de elaboração da revista" ( $p$. 70). Com essa linguagem, que parece objetiva, neutra e imparcial, o AUTOR aparentemente não se compromete com nenhuma posição ideológica, podendo camuflar o seu posicionamento (p. 70). Ademais, através dessa linguagem, "a revista se constrói a serviço de um determinada visão de educação" (p. 70) e constitui um LEITOR, concebido pela autora como um leitor virtual (p. 8), que "deve ser enquadrado nessa visão" (p. 70). Essa linguagem também "condiciona e determina a escolha dos temas veiculados, no sentido de concretizar as intenções do AUTOR" (p. 70). Segundo Vieira, o construtivismo é um desses temas que se constitui em função dessas intenções. Esses temas são considerados pela autora como conteúdos e também como estratégias para a construção do seu LEITOR e da "visão de educação que se pretende divulgar" (p. 70).

Essa "visão de educação" é extraída pela autora dos "textos construtivistas" (ibidem, p. 70), cuja análise permite-Ihe discriminar "várias características que aproximam o discurso da revista do discurso religioso". Esse "caráter religioso é 
uma marca constante nas reportagens sobre o construtivismo" (p. 61). A sua tese central é que o construtivismo apresentado na revista é concebido principalmente como um caminho a ser percorrido pelo professor que quer se tornar um construtivista. Além disso, esse caminho é semelhante à conversão religiosa:

Os passos para a conversão são os mesmos tanto no "construtivismo" quanto na doutrina religiosa: no início, a descrença e resistência; depois, as dúvidas, dificuldades e críticas dos que não optaram pelo mesmo "caminho"; e, finalmente, a conversão total e a certeza da escolha - o convertido passa a apregoar e defender os princípios que o transformaram. $\mathrm{E}$, durante todo o processo, a conquista de adeptos (...) (Vieira, 1995, p. 47) ${ }^{13}$

A aproximação feita por Vieira, entre a conversão religiosa e o construtivismo concebido como caminho, é o que fundamentalmente justifica o título da sua dissertação de mestrado: "Construtivismo": a prática de uma metáfora. ${ }^{14}$ Do ponto de vista da autora, o construtivismo produzido pela revista consiste na efetivação de um caminho análogo à conversão religiosa, um caminho ascendente em direção às concepções e práticas que seriam próprias do construtivismo, que foi transformado em algo semelhante a um dogma ou doutrina religiosa.

A análise de Vieira põe em evidência inúmeros aspectos que convergem no sentido de aproximar e até identificar os discursos da revista, onde o "construtivismo" aparece em toda a sua extensão (ibidem, p. 32), e o discurso religioso. Esse é o caso da análise feita sobre a matéria de capa da Nova Escola de outubro de 1989, composta por um artigo e uma entrevista com Emilia Ferreiro, por ocasião da sua passagem por Porto Alegre, onde proferiu "uma aula inédita para 10 mil professores" (p. 55). Vieira mostra como é construída a imagem de Ferreiro, destacando por exemplo um trecho onde "é comparada à figura de um messias, que adverte os seus adeptos e seguidores" (p. 57). Além disso, compara o "tratamento jornalístico conferido ao ritual de sua visita" ao "tratamento jornalístico dado ao ritual da passagem do Papa pelo Brasil”, de uma edição especial da revista Manchete de julho de 1980, evidenciando assim a semelhança

\footnotetext{
${ }^{13}$ Esse trecho do texto foi retirado do capítulo onde a autora analisa um único artigo da revista Nova Escola, intitulado "As agruras do caminho construtivista", de abril de 1993. Entre outras coisas, escolhe esse artigo "Por ser construído inteiramente em função da metáfora do "caminho construtivista', o artigo apresenta a essência das idéias expressas nos demais textos 'construtivistas' (...)" (p. 44).

${ }^{14}$ Vieira justifica o título da sua dissertação de diversos modos. Cf. pp. 69-71.
} 
em relação ao tratamento recebido por Ferreiro na Nova Escola (p. 61). Vieira mostra ademais as semelhanças entre as fotos onde aparecem o Papa e Ferreiro (pp. 62-65), bem como entre os tipos de textos construídos em cada matéria (pp. 66-7). E ainda refere-se ao modo como o discurso da revista delimita o lugar do professor, no caso dessa matéria pela particular apropriação que faz do discurso de Ferreiro. A pesquisadora argentina, segundo a Nova Escola, teria "conclamado" os educadores "a se integrarem numa cruzada pela mudança desta visão de alfabetização", própria da escola tradicional. Vieira destaca o uso dos termos "conclamar" e "cruzada", inserindo-os diretamente no discurso religioso:

Assim como faziam os "Cruzados" [na Idade Média], os professores devem renunciar a suas práticas tradicionais de alfabetização e tomar em suas mãos a "cruz" (...) (Vieira, 1995, p. 61)

Nessa aproximação com o discurso religioso, a "cruz" seria "o Construtivismo de Emilia Ferreiro, na busca da salvação e redenção da educação". No discurso da revista, Vieira também ressalta que é dominante "a visão do trabalho do professor como 'missão', como 'apostolado'”, como no "discurso da educação de um modo geral" (ibidem, p. 61). Essas características do discurso da Nova Escola, somadas a outras que a autora aponta, são as que Ihe permitem aproximar o construtivismo do discurso religioso:

É a presença de todas essas características que dá à metáfora do "caminho" o significado da conversão religiosa. O "caminho construtivista" deve ser entendido não como uma trajetória metodológica, mas como passos para a conversão, como o ritual de passagem dos professores do grupo de "tradicionais" para o grupo de "construtivistas" (...) (ibidem, p.70)

A análise de Vieira traz inúmeros aspectos enriquecedores para o debate sobre o construtivismo, em especial quanto ao modo como se configura como discurso numa determinada publicação. Ela aprofunda e demonstra uma idéia que já vinha ganhando ressonância na década de 90 , sobre o caráter dogmático ou religioso que o construtivismo vinha adquirindo em alguns grupos e experiências, e que Corazza (1994) também aponta.

Com relação ao tipo de interpretação que Vieira desenvolve, assenta-se na premissa de que a referência legítima e primeira do construtivismo concerne ao campo teórico e científico e à sua referência inaugural - nesse caso, as concepções desenvolvidas por Emilia Ferreiro. E assim também faz eco ao 
“inevitável" discurso dos desvios, das confusões, do que não foi adequadamente apropriado, supondo um lugar primeiro, quase sagrado, de onde tudo ou a maior parte do que merece ser chamado de construtivismo deriva ou ao menos deveria derivar. Desse modo, aproxima-se do que ela própria critica, como costuma ocorrer com todos os que operam a partir da divisão que é inerente à matriz simbólica construtivista. Vieira manifesta essa preocupação logo no início do seu trabalho:

Estudos realizados em escolas que vêm adotando o construtivismo indicam que os professores não têm demonstrado uma compreensão clara e adequada dessa teoria, apresentando deformações e distorções em suas práticas. (p. 3)

Partindo da constatação de que o "construtivismo" tem sofrido distorções e deformações ao ser assimilado nas escolas, pretendemos realizar uma análise do construtivismo veiculado pela revista NOVA ESCOLA (...)

Dessa forma, é objetivo do nosso estudo analisar a presença e as eventuais modificações conceituais e metodológicas do "construtivismo", como quadro referencial do processo de alfabetização, ocorridas no seu processo de divulgação aos professores. (p. 5)

\section{Transposição ilegítima}

Um outro exemplo de uma operação discursiva que não está muito distante das já analisadas, encontra-se no trabalho de José Sérgio Carvalho (2000), que basicamente questiona a validade da "transposição" das concepções piagetianas, forjadas num determinado contexto e com finalidades específicas, para um outro campo, diverso do original: o campo da educação escolar. Uma transposição feita inclusive pelo próprio Piaget.

O seu principal objeto de análise é a obra do pesquisador suíço, em particular os seus poucos textos sobre "educação e pedagogia", pois esses escritos são considerados "exemplares ilustrativos de uma tendência ampla e influente nos discursos educacionais" (ibidem, p. 223). Carvalho pretende examinar um conjunto de problemas:

(...) decorrentes da própria transferência e aplicação acrítica de conceitos e referenciais de uma área de estudo - a psicologia do desenvolvimento ou a epistemologia genética de Piaget - a outra - a educação. (ibidem, p. 4) 
O que o autor chama de transposição é essencialmente a aplicação dos fundamentos teóricos do construtivismo "acerca do desenvolvimento psicológico ao âmbito educativo". E o que ele questiona é a pretensão de derivar desses fundamentos "perspectivas e concepções educacionais" (ibidem, p. 119).

Segundo Carvalho, essa transposição ocorre de três formas:

A primeira delas foi o esforço de veiculação e transposição, para a educação, de concepções e conceitos oriundos de suas investigações e teorias psicológicas, conferindo pretensas "bases científicas" para a compreensão e a transformação das ações educacionais.

A segunda caracteriza-se, como vimos, pela tentativa de estabelecer, a partir da perspectiva construtivista, os ideais e objetivos do processo educacional, derivando-os de sua visão sobre os mecanismos, as etapas e a natureza do desenvolvimento psicológico infantil nos planos cognitivo e moral. Em síntese, o construtivismo aponta o pleno desenvolvimento de capacidades e competências psicológicas como a principal finalidade do processo educacional.

Uma terceira forma pela qual o construtivismo exerceu influência marcante no discurso educacional foi pela proposição de novas técnicas didáticas e metogologias de ensino, também elas alegadamente derivadas ou vinculadas às suas teorias e concepções sobre o desenvolvimento infantil. (ibidem, pp. 119-20).

De acordo com Carvalho, o principal problema dessa transposição é que dela resulta uma pedagogia "esquecida do professor, do aluno .. e da escola" (ibidem, p. 5), pois a perspectiva psicologizante do "construtivismo educacional" abstrai as "condições concretas do contexto escolar", as quais "fazem da criança um aluno, do professor um agente institucional do ensino e da escola uma instituição social' (p. 226). O que está na base de seus questionamentos é a adequação do modelo teórico piagetiano para tratar de questões que seriam próprias da educação escolar. Por isso afirma descartar o que freqüentemente se alega na defesa das proposições construtivistas: a de que muitos dos problemas e críticas feitas ao construtivismo são decorrentes de desvios ou desvirtuamento relativos à sua aplicação:

(...) essas críticas, em geral, caracterizam-se por denunciar o que seria um pretenso "desvirtuamento" das idéias originais ou ainda uma "má aplicação prática" de seus princípios psicológicos e pedagógicos, evitando, assim, o questionamento da própria viabilidade ou adequação do construtivismo educacional como um empreendimento teórico. (Carvalho, 2000, p. 2) 
O estudo desenvolvido por Carvalho conflui com outros trabalhos que também fazem o mesmo tipo de crítica e que acusam o construtivismo de reducionismo, porque teria encerrado os problemas da educação escolar no âmbito da psicologia, em particular a psicologia da criança, numa vertente onde são centrais os aspectos relativos ao desenvolvimento cognitivo, como é o caso da perspectiva piagetiana. Para além da pertinência de alguns dos problemas que Carvalho aponta, como a prevalência em muitas reflexões alegadamente construtivistas dos conceitos da psicologia cognitiva e o consequente reducionismo impingido ao tratamento de questões próprias da educação escolar, o que aqui importa ressaltar é o modo como autor repõe, de um outro modo, a mesma matriz simbólica que está na base de um sem número de reflexões, isto é, a idéia de que o construtivismo é sobretudo uma aplicação de concepções teóricas oriundas da teoria piagetiana, em especial das suas pesquisas e reflexões sobre o desenvolvimento infantil. Além disso, apesar da crítica ao discurso dos desvios e dos desvirtuamentos, Carvalho aproxima-se também do mesmo discurso que critica. Ao longo do seu trabalho, é recorrente a preocupação com os equívocos próprios dessa transposição, com as "passagens ilegítimas" (ibidem, p. 56), com as "impropriedades cometidas nessas transferências conceituais" (p. 78), com o caráter adequado ou não das apropriações do discurso pedagógico em relação a concepções forjadas numa outra "área de estudo". Para o autor, esses equívocos teriam sido cometidos pelo próprio Piaget e seriam o resultado da descontextualização dos problemas escolares e até de certa simplificação conceitual por ele próprio operada, ao realizar essa passagem de um âmbito a outro (p. 143).

Em suma, Carvalho não apenas repõe de uma outra forma a divisão própria da matriz simbólica construtivista, relativa ao lugar teórico natural e à sua aplicação igualmente natural, como também o próprio tema dos desvios, dos equívocos e das confusões, que adquire um outro caráter, ele é deslocado para um outro registro, não muito distante do anterior. Agora não se trata propriamente de uma má ou boa aplicação do construtivismo, a idéia de aplicação em si é questionada porque o modelo teórico não pode ser transposto para a educação. Em face dessa aplicação, porém, Carvalho reenvia para o mesmo lugar, na medida em que se preocupa com os equívocos, com os seus limites, com o que seria ou não aceitável, supondo a existência de um certo registro que nos 
permitiria validar ou não essa transposição, o próprio "construtivismo educacional" e mesmo qualquer idéia sobre a educação escolar. Esse registro concerne sobretudo ao campo da teoria e da ciência, mesmo que o autor lembre que a educação não pode ser orientada pela ciência nem reduzida ao que dela procede, dado o papel dos valores e das tradições culturais. Os "enunciados de valores", lembra, não podem ser julgados em termos da sua verdade ou falsidade (ibidem, pp. 32-3). Um dos aspectos que questiona no construtivismo é justamente o fato dele estabelecer parâmetros numa dimensão que não caberia, pois concerne aos valores e tradições culturais, como é o caso das finalidades da educação. Embora faça essas considerações, tende a centrar as suas críticas nos tais equívocos e na pretensão científica do construtivismo, observando que não está julgando o valor científico das pesquisas de Piaget (p. 81), mas a indevida aplicação das suas conclusões em outro campo de investigação e estudo. O construtivismo é principalmente criticado porque a sua perspectiva seria exterior ao "mundo escolar". E isso em grande parte significa que não seria suficientemente científico, afinal:

Suas "descrições" e análises não são produtos de uma observação sistemática de situações de ensino e aprendizagem em um contexto escolar, mas o simples transporte de certos conceitos e perspectivas gerais do desenvolvimento infantil para um novo âmbito da realidade social. (ibidem, p. 229)

\section{Um passado equivocado}

O tema dos desvios, confusões, equívocos e outros males semelhantes certamente não é privativo do discurso pedagógico construtivista. É, no entanto, a sua marca característica, um diferencial importante em face de outros discursos, como os que concernem ao campo da educação popular ou da educação alternativa próprio dos anos 70 e parte dos 80. Nesses discursos alternativos, as diferenças de concepção ou nas práticas educacionais eram antes avaliadas em termos ideológicos, colocando-se um forte peso nas questões de natureza política, social e cultural. Nesse campo alternativo não havia a necessidade imperiosa e constante de remeter o que se fazia e pensava a uma determinada teoria para avaliar se haviam sido cometidos desvirtuamentos, desvios ou confusões. As teorias eram incorporadas de um outro modo. Os padrões avaliativos que consigo traziam a marca da ciência não eram tão relevantes ou 
pelo menos, quando essa marca surgia ou adquiria importância, em geral não emudecia os espíritos, levando-os simplesmente a avaliar a distância em face dessa referência, como se tornou freqüente em relação a alguns princípios considerados construtivistas. Ao contrário, em certas experiências educacionais havia até mesmo um certo receio ou desconfiança em relação à ciência, em particular se alguém buscasse sustentar um argumento recorrendo a essa marca, desse modo querendo evidenciar por exemplo o seu caráter neutro e objetivo. Uma referência essencial para julgar qualquer coisa era a própria experiência, definida pelas articulações discursivas que passavam pelos pontos de ressonância característicos desses discursos alternativos.

Esses discursos tinham um forte ponto aglutinador: a sua rejeição a tudo o que era vinculado à ditadura militar. Nesse significante-mestre às avessas, porque nos discursos alternativos ordenava os discursos situados no lado oposto, confluíam diversas articulações discursivas, dentre elas as que encontravam-se frouxamente amarradas ao significante moderno. O moderno que o regime militar então desenhava, com a chamada tecnocracia, a crescente afirmação da indústria cultural e outras figuras que os discursos de oposição destacavam, quando das suas críticas à modernização que a partir do Estado era impingida a toda a sociedade. A ciência por vezes caia sob essa órbita, em especial no difuso campo da contracultura e no circuito de certos debates universitários, aos quais era particularmente sensível um setor das camadas médias. Justamente esse era o setor social que demarcava uma parte do campo alternativo, que ainda estendiase em direção aos setores populares, nos quais, por vezes, também era possível encontrar pessoas oriundas das camadas médias com um discurso alternativo dissonante, como atestam os conflitos e diferenças entre os movimentos chamados de mulheres e as feministas (Rosemberg, 1989).

Ficando apenas no campo educacional, é possível notar consideráveis diferenças de um extremo a outro. De um lado, o alternativo popular, com forte presença dos discursos pastorais da Igreja Católica e de discursos educacionais marcados pelo nome e a obra de Paulo Freire e ordenados por significantes como educação popular, alternativa, comunidade ou comunitário, como era próprio das creches e escolas comunitárias surgidas nos bairros periféricos de grandes 
centros urbanos. ${ }^{15}$ De outro, o alternativo típico de um setor intelectualizado das camadas médias. Esses extremos, porém, eram parcialmente soldados ou vinculados por pessoas das camadas médias que transitavam nos setores populares. Por exemplo, os militantes ou intelectuais de esquerda que desenvolviam certo tipo de trabalho político e educacional nos setores populares e que, ao mesmo tempo, mantinham alguma relação com experiências educacionais desenvolvidas apenas entre as camadas médias, às vezes porque seus filhos freqüentavam escolas particulares então chamadas de alternativas, como ocorreu na cidade de São Paulo.

Nessa cidade, na década de 70 e início dos anos 80 , surgiram várias préescolas sob o influxo do que o campo alternativo então delimitava e que essas experiências também definiam. Nesse campo e no lugar social próprio das camadas médias, além da temática da esquerda, confluíam a produção característica da imprensa alternativa, do cinema independente, de determinados grupos musicais, certos tipos de terapias, a preocupação com a alimentação natural, os temas ecológicos, a medicina alternativa, determinados cuidados com o corpo, o questionamento enfático das relações de gênero e dos padrões sexuais então vigentes e até mesmo uma forma peculiar de se vestir, próxima do que o termo hippie rapidamente situa e que então era bem característico das educadoras das pré-escolas alternativas. ${ }^{16}$ Nelas, em face do que nesses discursos alternativos era objeto de crítica, como certo valor atribuído à ciência, adquiriram relevância as formas de apreensão da realidade julgadas intuitivas, pouco precisas, alheias à quantificação ou medição e próximas do que era vinculado à ordem da emoção e de uma sensibilidade difusa, expressa de modos não padronizáveis e por uma linguagem com a qual pretendia-se, sobretudo, sensibilizar o ouvinte ou o leitor, como era o caso dos inúmeros relatórios produzidos por essas educadoras sobre as atividades que desenvolviam junto às crianças e que eram dirigidos aos pais de alunos. ${ }^{17}$ Nesses relatórios, antes de mais nada importava desenvolver uma narrativa que trouxesse à tona a singularidade das situações vividas com as crianças, que fosse rica em histórias,

\footnotetext{
${ }^{15}$ A propósito do que foi chamado de discursos pastorais, veja-se: Sader, 1988, pp. 146-67.

${ }^{16}$ Usa-se o termo educadoras porque tratava-se sobretudo de mulheres.

${ }^{17} \mathrm{Um}$ exemplo desse tipo de relatórios pode ser encontrado no livro $A$ paixão de conhecer 0 mundo, de Madalena Freire, da época em que trabalhou em algumas escolas alternativas.
} 
em fatos que evidenciassem a vivacidade almejada no dia-a-dia escolar. Nesses discursos alternativos, a precisão conceitual e o domínio de uma linguagem técnica eram relegados ou sobrepujados por um discurso que antes devia evidenciar o seu caráter crítico, emotivo e até poético. A compreensão e a comunicação eram antes buscadas pela via de uma sintonia ou afinidade em relação a um certo estilo de trabalho e de vida e menos pelo domínio de uma linguagem técnica comum, como foi se afirmando de modo crescente no campo educacional dominado pelo construtivismo. Nesse campo, na década de 90, determinada linguagem técnica foi se tornado uma referência essencial para situar o que é o construtivismo e quem é construtivista, em particular a linguagem própria da arquitetura conceitual presente nos Parâmetros Curriculares Nacionais (PCN) e nos documentos curriculares produzidos posteriormente, durante o governo Fernando Henrique Cardoso. Nessas propostas curriculares, com as quais o governo federal buscava reorientar o ensino em todas as escolas do país, encontra-se o bê-á-bá construtivista na sua última e hegemônica versão, com os seus termos característicos: conhecimentos prévios, aprendizagem significativa, conteúdos conceituais, procedimentais e atitudinais, etc.

Uma das pré-escolas alternativas paulistanas era a Escola da Vila, que nela própria reteve parte do nome do bairro onde começou: a Vila Madalena, que também era reconhecido pela marca do alternativo, pois era visto como um bairro típico das várias formas de manifestação alternativa, dentre elas as próprias escolas alternativas. Aliás, várias dessas escolas começaram nesse bairro ou próximas dele, isto é, eram Escolas da Vila Madalena, como de fato por vezes eram assim chamadas. ${ }^{18}$ A referência à Escola da Vila não é aqui um mero exemplo, dado que a sua trajetória, assim como a das escolas alternativas, está diretamente vinculada à emergência do discurso pedagógico construtivista e ao concomitante (re)ordenamento dos discursos educacionais precedentes, pelo menos numa das suas vertentes. A importância dessa escola em grande parte decorre do papel que indiretamente desempenhou na elaboração dos PCN. Como foi noticiado pela imprensa, parte dos profissionais que participaram da sua

\footnotetext{
${ }^{18}$ Em relação às características desse campo alternativo delimitado pelas camadas médias em São Paulo, bem como sobre a trajetória da Escola da Vila e das escolas alternativas, veja-se a minha dissertação de mestrado (Revah, 1994).
} 
elaboração havia trabalhado nessa escola privada. ${ }^{19}$ Ademais, para a confecção dos PCN foram fundamentais os trabalhos e a presença do professor César Coll, que foi um dos consultores e uma das figuras centrais da reforma educacional espanhola, sem contar o seu papel em outros países da América Latina, onde prestou assessoria às equipes que efetuaram outras tantas reformas. A sua participação como consultor dos PCN pode ser creditada à intermediação da filha do presidente Fernando Henrique Cardoso, que havia trabalhado no início da Escola da Vila, e também a essa instituição de ensino, que promoveu alguns encontros com ele no Brasil. ${ }^{20}$ Além do seu papel na formação de centenas de professores da rede pública e privada através do seu Centro de Estudos, a Escola da Vila foi se tornando uma espécie de paradigma de escola construtivista bem sucedida. Além do mais, algumas das profissionais que nela haviam trabalhado durante a década de 80, como Telma Weisz e Madalena Freire, ganharam o status de "pioneiras" do construtivismo, pelo menos na revista Nova Escola, de forte presença entre os professores. ${ }^{21}$ Nessa publicação, o lugar paradigmático da Escola da Vila surge de maneira nítida, em particular numa matéria com um box que tem este sugestivo título: "Até a Escola da Vila chegou a cometer enganos". Eis o que segue:

A Escola da Vila se denomina construtivista desde que foi criada há 10 anos, no Bairro do Butantã, Zona Sul de São Paulo. Durante esse tempo todo ela tem sido uma espécie de paradigma e fonte de experiências e conhecimentos sobre a teoria de Emilia Ferreiro. "Depois de alguns anos, fomos percebendo que faltavam algumas coisas para que pudéssemos chamar nossa metodologia de construtivista", afirma a coordenadora da pré-escola, Zélia Cavalcante. Apesar de toda seriedade no trabalho, a Escola da Vila se deu conta dos enganos que podiam ser cometidos. (p. 16)

Nessa matéria, de maio de 1991, procura-se fazer uma espécie de balanço do construtivismo no Brasil, após "dez anos", como se afirma no seu título. ${ }^{22}$ Para

\footnotetext{
${ }^{19}$ Essa informação foi divulgada pela Folha de S.Paulo, em 15/08/95.

${ }^{20}$ Cf. Silva, 1996, p. 199.

${ }^{21}$ Cf. "Dez anos de construtivismo no Brasil", Nova Escola, n 48, maio/91, p. 11. Um bom exemplo dos vínculos existentes entre 0 alternativo popular e o alternativo típico das camadas médias encontra-se em Madalena Freire, não apenas por ser filha do Paulo Freire. Ela própria, ao deixar a Escola da Vila, desenvolveu uma experiência num bairro popular (Vila Helena), na periferia de São Paulo, aonde levou consigo uma experiência e um discurso que carregava muitas das marcas próprias do que então caracterizava o campo alternativo delimitado pelas camadas médias. Essa experiência é relatada em artigo publicado pela autora (Freire, 1986).

${ }^{22}$ Na própria matéria, fala-se também em "mais de 10 anos".
} 
a Nova Escola, esse é o tempo transcorrido desde que o construtivismo chegou ao Brasil, com as pesquisas de Emilia Ferreiro, as quais aos poucos foram sendo conhecidas pelos educadores. ${ }^{23} \mathrm{Um}$ período que praticamente corresponde ao tempo de vida da Escola da Vila, que iniciou as suas atividades em $1980 .{ }^{24} \mathrm{De}$ modo que, nessa avaliação, a origem da Escola da Vila e do construtivismo coincidem. E nesse suposto início do construtivismo, cuja referência primeira é o nome e a pesquisa de Emilia Ferreiro, todos cometeram equívocos, até mesmo os "professores mais bem-intencionados":

Mesmo os grupos de professores mais bem-intencionados cometem equívocos. É o caso da Escola da Vila, onde a própria diretora Zélia Cavalcanti alerta para os cuidados que se deve ter ao trabalhar com o construtivismo. "A escola se imaginava construtivista desde a sua fundação, há 10 anos, mas só nos últimos quatro anos podemos realmente dizer que somos construtivistas", confessa Zélia. (p. 15)

Na reconstrução histórica que muitos fazem do construtivismo e que está presente em várias matérias da Nova Escola, em particular da década de 90 em diante, é desenhado um lugar primevo, original, onde fazem-se confluir todos os erros, enganos e equívocos. Esse lugar costuma ser demarcado por um significante, no qual condensam-se todos esses males: o significante espontaneísmo. Este em grande parte sustenta e estabelece as margens de um passado que na verdade não passa, pois sempre retorna em alguma prática pedagógica, de alguma professora que supostamente não entendeu como devia os princípios construtivistas. Esse passado, com essa marca, também aparece muito bem fixado numa matéria da Nova Escola, numa edição onde o construtivismo é "trocado em miúdos", não sem antes serem consultadas "cinco respeitadas especialistas", dentre elas a diretora pedagógica da Escola da Vila, que na época também era "coordenadora nacional da Rede Latino-Americana de alfabetização, criada por Emilia Ferreiro". Quanto a esse lugar primevo, ele é assim definido:

\footnotetext{
${ }^{23} \mathrm{~A}$ data, ano ou época desse primeiro momento do construtivismo muda de autor para autor e na própria Nova Escola. Nessa revista, o substantivo construtivismo e o adjetivo construtivista somente começam a ser utilizados a partir de 1989, conforme foi verificado em levantamento feito para este estudo desde a sua primeira edição.

${ }^{24}$ A maior parte da equipe que inicialmente formou a Escola da Vida provinha de uma mesma experiência escolar, desenvolvida na pré-escola Criarte, surgida em 1972 (Revah, 1994, pp. 285$6)$.
} 
A fase inicial, em que o aluno era deixado muito solto, como se a professora não estivesse na sala de aula (prática espontaneísta), está superada. Hoje se quer do professor uma atuação firme e planejada (prática intervencionista). No geral, contudo, o núcleo pedagógico do construtivismo permanece inalterado. ${ }^{25}$

De um modo semelhante, com um "núcleo pedagógico" que permanece inalterado, é publicamente avaliada por suas proprietárias e educadoras a trajetória da Escola da Vila. Nessa reconstrução histórica, certos traços do passado não aparecem, são apagados, em particular quase tudo o que se encontra vinculado ao seu passado alternativo, ou melhor, quase tudo o que pode trazer à tona as articulações discursivas que no passado definiam o lugar desse significante-mestre, que desde meados dos anos 80 ganhou um tom pejorativo, até desaparecer, adquirindo novamente o status de uma palavra qualquer. Esse apagamento e o (re)ordenamento discursivo nele implicado é o que permite que a trajetória da Escola da Vila fique semelhante ou parecida com o suposto percurso do construtivismo no Brasil. Na trajetória do seu "projeto pedagógico" ou da sua "metodologia de educação", não há "rupturas significativas", apenas um tipo de continuidade evolutiva cujos principais marcos são dados pelo próprio construtivismo, ao menos na história que a escola torna pública (Cavalcanti, 1997). Nessa trajetória, guiada desde o início por "uma visão construtivista", são estabelecidos três momentos.

Em relação ao primeiro momento (1980-1984), destaca-se a herança das idéias divulgadas pela "proposta da Escola Nova", "orientada pela Epistemologia Genética de Jean Piaget", sendo ademais reconhecida "a importância da visão educacional de Paulo Freire" (Cavalcanti, 1997, p. 28). Aponta-se também que a "Escola da Vila partilhava com algumas escolas particulares de São Paulo a idéia de ser experimental e uma alternativa à escolaridade tradicional” (p. 29). E aqui, na palavra alternativa, sobrou apenas o seu significado dicionarizado. Ademais, essa palavra fica desvinculada da figura de Paulo Freire, a principal fonte teórica inspiradora da chamada educação popular, por vezes qualificada de alternativa. Nessa reconstrução histórica, o que ocorre com a figura de Paulo Freire não está muito distante da operação que se tornou comum no discurso pedagógico

\footnotetext{
${ }^{25}$ Cf. "O tira-teima do Construtivismo: 50 grandes e pequenas dúvidas esclarecidas", Nova Escola, $\mathrm{n}^{\circ} 82$, março/95, p. 13.
} 
construtivista. Neste, a sua figura é por ele e nele subsumida, isto é, Paulo Freire é transformado num construtivista. Ainda em relação a esse primeiro momento, afirma-se que era realizado "um trabalho voltado para o desenvolvimento integral das crianças (...) a partir de um planejamento que respeitava a individualidade", considerando-se a escola como um lugar onde a cooperação ocupa "um lugar fundamental". Além disso, salienta-se que a ação educativa era "centrada no que se reconhecia como interesses e necessidades do desenvolvimento afetivo e social dos alunos" e que relegavam para um segundo plano os "conteúdos escolares tradicionais" (pp. 28-9).

Em relação ao segundo período (1984-1992), ressalta-se que houve "o reconhecimento de que a teoria genética não era suficiente para iluminar os processos de aprendizagem escolar". É o momento em que a Escola da Vila tem acesso ao trabalho de Ferreiro e Teberosky sobre a psicogênese da língua escrita, esta sim uma explicação considerada genuína, que é o que então avaliase necessário conhecer, isto é, explicações "que dessem conta da forma como as crianças constroem os diferentes conteúdos escolares". Ademais, aponta-se a importância do início do $1^{\circ}$ Grau e as "supervisões" que a escola teve com vários profissionais, "sempre dentro de uma visão psicogenética", em especial as relacionadas com a aprendizagem da língua escrita, com Ana Teberosky e Liliana Tolchinsky (Cavalcanti, 1997, p. 29).

O que marca o início do terceiro momento, que em 1997 considerava-se "em andamento", é o fato das educadoras da Escola da Vila terem conhecido "os textos de autores que vinham contribuindo para os fundamentos da que hoje é conhecida como uma concepção construtivista de ensino e aprendizagem" (Cavalcanti, 1997, p. 29). E nesse ponto é destacado "César Coll e seu grupo do Departamento de Psicologia da Educação em Barcelona”(p. 30). É o momento em que preocupam-se em definir "um currículo desenhado a partir dos marcos teóricos" dessa concepção, baseada principalmente nos escritos e idéias de César Coll. Uma perspectiva que com os PCN torna-se "a" concepção construtivista, numa operação discursiva e política que constrói a unidade e a hegemonia desse discurso pedagógico.

Em relação a essa trajetória, com seus três momentos, aponta-se também o papel central do exercício contínuo de reflexões, registros e avaliações do que é 
desenvolvido nas classes. E ainda, o "estilo de trabalho em equipe" e a importância de ter começado a escola junto com um Centro de Estudos, sem o qual "essa história certamente seria diferente" (Cavalcanti, 1997, p. 30).

Sem dúvida, qualquer reconstrução histórica deixa elementos de fora, que não são incorporados nos relatos, seja porque essa é a intenção ou porque esses elementos foram esquecidos, apagados por um processo histórico e discursivo que não deixou à vista qualquer vestígio dessa mesma operação. Como já foi apontado, essa história da Escola da Vila deixa de lado a parte do passado relacionada com um discurso cujo significante-mestre era a palavra alternativa. Isso não significa negar certo papel atribuído desde o início às concepções piagetianas e até mesmo antes, pois a maioria dos profissionais que começaram a Escola da Vila vinha da pré-escola Criarte. E nesta, nos relatórios que eram produzidos nos anos 70, é visível a presença de Piaget, cujos escritos eram objeto de estudo, bem como os de outros autores. Como se afirma no artigo, poder-se-ia dizer que já tinham "uma visão construtivista do processo de construção do conhecimento" (Cavalcanti, 1997, p. 28), cuja continuidade busca-se salientar, até mesmo destacando três idéias que desde então "são consideradas fundamentais na metodologia do trabalho": "Os seres humanos não aprendem diretamente da experiência, mas da interpretação que fazem da experiência"; "Conhecer é antes de tudo e sobretudo atuar"; "O psiquismo humano modifica e reorganiza seus esquemas sempre que a assimilação de um novo objeto de conhecimento o exige" (p. 30). Na linha evolutiva que mantém essas idéias fundamentais num primeiro plano, os marcos construtivistas são claros e poderiam ser sintetizados usando-se uns poucos nomes: primeiro Piaget, depois Ferreiro/Teberosky e por último César Coll. Nada melhor para um brilhante e exemplar percurso construtivista, ao menos conforme os pontos nucleares do devir que na década de 90 tornou-se hegemônico.

Sempre é possível construir uma história feita de continuidades, de linhas que nos remetem a uma origem onde já estava como que delineado o nosso futuro. E é nisso que basicamente consiste a história da Escola da Vila que as suas proprietárias e educadoras costumam tornar pública. Entretanto, se vista sob outro prisma, com o acento colocado no campo em que essa escola e as suas educadoras inscreviam a suas ações e falas no início dos anos 80 , é possível falar 
de uma inflexão ou ruptura importante, própria do momento em que o tema e a palavra limites ecoava em todas as escolas alternativas.

A insistente presença do significante limites, que então como que ordenava o rumo mesmo dessa inflexão, sucede a um período caracterizado por um discurso que se encontrava sob o signo do "proibido", na medida em que era próprio de experiências que buscavam transgredir o que, nesse momento, era cultural e politicamente hegemônico ou simplesmente imposto pelo regime militar. Nesse período inicial, as escolas alternativas afiguravam espaços de "experiências proibidas", com um discurso que desenhava dois territórios nitidamente separados. De um lado, essa espécie de oásis que as escolas alternativas representavam para a suas educadoras e pais de alunos, um lugar de encontro, familiar e caseiro, onde as crianças poderiam viver a plenitude da sua primeira infância. De outro, os espaços considerados característicos da ordem autoritária e não raro qualificada de "careta". ${ }^{26}$

Embora esse também seja o caso da Escola da Vila, nela é necessário recuar até a pré-escola Criarte para encontrar de modo mais nítido os traços próprios das práticas e dos discursos alternativos marcados pelo "proibido". O início da Escola da Vila corresponde mais ao momento de transição das experiências escolares alternativas, quando nelas houve um forte questionamento das suas práticas, idéias e valores característicos.

Nesse "momento dos limites", boa parte das escolas alternativas paulistanas recorreu a um profissional que no Brasil dos anos 80 dava os seus primeiros passos: o "analista institucional", também chamado de supervisor ou terapeuta, em geral psicólogos com formação em psicanálise. Em relação a esse trabalho, desenvolvido em grupo e envolvendo os diversos segmentos de uma mesma escola, o que essencialmente estava em jogo era tudo o que o significante limites sobrepujava e que as palavras fantasias e fantasmas também situavam, tendo como pano de fundo os vínculos profissionais e pessoais estabelecidos entre os adultos. No caso da Escola da Vila, depois de cerca de um ano de trabalho com esse tipo de profissional, os "grandes fantasmas acabaram" e se "avançou demais", na avaliação feita por uma das educadoras que participou

\footnotetext{
${ }^{26}$ A esse propósito, veja-se o capítulo "A experiência 'proibida", em Revah (1994).
} 
desse processo (Revah, 1994, p. 180). E houve, com efeito, uma mudança de rumo importante na Escola da Vila, que começou a delinear-se já na primeira metade dos anos 80, confundindo-se com o momento em que a escola tomou conhecimento da pesquisa de Ferreiro/Teberosky. E não apenas na Escola da Vila, mas em todas as escolas alternativas da zona Oeste da cidade de São Paulo, que entre si mantinham diversos vínculos informais. Uma mudança que ocorreu em sintonia com as transformações que se desenrolaram em outros âmbitos, conforme avançou o processo de redemocratização das instituições, com o fim da ditadura militar. ${ }^{27}$ Em relação à Escola da Vila, todo um conjunto de idéias já havia sido abandonado na segunda metade da década de 80 , como a de transformar a escola em uma cooperativa.

Essa história institucional é importante pois permite situar uma dimensão das transformações ocorridas que também incide sobre os tais projetos pedagógicos e de um modo capital. Uma dimensão que no discurso pedagógico construtivista não adquiriu qualquer relevância, centrado que é nas questões didáticas e numa rede conceitual que muito deve à psicologia genética e a perspectivas onde a escola como instituição praticamente não existe. ${ }^{28}$

No caso da Escola da Vila, na segunda metade dos anos 80, procura-se deixar bem "claros" determinados aspectos relacionados com o encaminhamento da instituição e o seu viés empresarial. A divisão patrão-empregado não

\footnotetext{
${ }^{27}$ Uma dessas transformações diz respeito ao visível recuo dos chamados novos movimentos sociais que haviam emergido na década anterior e que Eder Sader aponta, no primeiro trabalho onde procura-se fazer uma análise de conjunto dos movimentos sociais dos anos 70 surgidos em São Paulo. Nesse trabalho, Sader constata a avaliação que deles se fazia nesse momento, em 1987: "hoje suas promessas são vistas freqüentemente como ilusões, mistificações, erros de avaliação" (1988, p. 314). Uma avaliação não muito diferente do modo como a trajetória das escolas alternativas começou a ser avaliada pelas próprias educadoras e pais de alunos que haviam acompanhado esse processo.

${ }^{28}$ Esse foi pelo menos o viés que predominou ao longo do período considerado neste trabalho. $\mathrm{Na}$ segunda metade da década de 90, porém, determinadas questões relacionadas com a escola enquanto instituição começaram a ganhar relevo, inclusive no âmbito da didática, como se observa por exemplo nas reflexões desenvolvidas por Delia Lerner, que foi "consultora" durante a elaboração dos PCN. Em texto publicado em espanhol em 1996, a inclusão dessas questões é indicada e feita deste modo: "Perdemos a ilusão de naturalidade. Antes, nos parecia simples introduzir na escola a versão social da leitura. Para conseguir que as crianças chegassem a ser leitores, parecia suficiente preencher dois requisitos: respeitar a natureza da prática social da leitura e levar em conta os processos construtivos das crianças. Cumpridas essas duas condições, tudo aconteceria naturalmente. Agora sabemos que a concepção que se tem do objeto e do sujeito está longe de ser o único fator determinante da versão escolar da leitura, que a persistência das concepções vigentes se explica por sua perfeita articulação com regras e exigências próprias da instituição escolar" (Lerner, 2002, p. 78).
} 
incomodava mais, já estava claro que "patrão é patrão e empregado é empregado", como disse uma educadora que participou desse processo (Revah, 1994, p. 203). Surgiu então a necessidade de pensar nas questões próprias de todo empreendimento empresarial, como o lucro, em relação ao qual havia que evidenciar a sua importância para a sobrevivência e crescimento da escola e até deixar à mostra de onde provinha. Mas o que nesse momento tornou-se essencial foi responder às exigências da clientela, que não mais desejava uma escola alternativa e sim uma escola séria, moderna, que preparasse as crianças para um mercado de trabalho que se mostrava cada vez mais competitivo, como deixou evidente uma pesquisa encomendada em 1989 pelas escolas que alguns ainda chamavam de alternativas e que nessa época formavam um grupo chamado

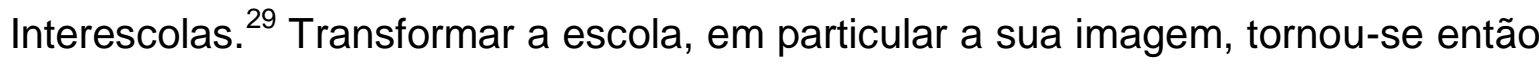
uma tarefa inadiável e vital.

Já em meados da década de 80, quando a palavra alternativa havia se tornado um termo pejorativo entre as mesmas pessoas que a usavam num sentido positivo, surge a preocupação com "a imagem do alternativo". Em 1987, por exemplo, o grupo Interescolas pensa em organizar um evento para mostrar que "a imagem do 'alternativo' não cabe mais dentro do momento atual", considerando necessário para tanto que sejam destacados e abordados os temas sobre os quais estavam sendo mais questionados: "disciplina (limites) e a questão do conhecimento (conteúdo)" (Revah, 1994, p. 245). A imagem, então, direcionada para o mercado, é o que ganha o centro da cena, tornando-se o eixo da mudança almejada nessas instituições educacionais, concomitante à afirmação da "visão construtivista", agora sim, não mais alternativa.

Para alavancar essa escola moderna, essa escola construtivista, é preciso então cuidar da imagem. E, com esse objetivo, são contratados outros especialistas, bem diferentes dos "analistas institucionais". Como relata uma das educadoras da Escola da Vila, em entrevista realizada em fins de 1991, nessa escola foi contratado um especialista na "área de marketing de imagem", para "projetar a imagem da escola de uma maneira coerente" (p. 246). Todos os papéis e relações deveriam ficar claros, não mais sob a perspectiva que havia

\footnotetext{
${ }^{29}$ Esse grupo surgiu em 1986 e dissolveu-se nos anos 90. Dele faziam parte as pessoas que administravam essas escolas. Sobre a pesquisa acima referida, veja-se: Revah, 1994, pp. 238-44.
} 
prevalecido no início das escolas alternativas, com a romântica busca de relações intersubjetivas plenas, transparentes, num grupo sem hierarquias. Agora, tornavase importante uma "política de recursos humanos" e todos deviam saber que:

(...) aqui existe sim o lucro, como é que ele funciona e tal, e qual é a unidade de participação de cada um, qual é o papel de cada um nesse processo: quem é pai, escola e professores. (ibidem)

Nesse momento, tornou-se necessário trabalhar o discurso para que ficasse coerente, deviam ser evitadas as duplas mensagens, as falas desencontradas, principalmente em face de uma clientela que exigia solidez. Por isso, nada de ambigüidades nem de projetos que parecessem pouco definidos, experimentais ou sem contornos precisos. Nesse momento, segundo a mesma a educadora da Escola da Vila, importava "ter um discurso que une, a estrutura da escola tem que corresponder a esse discurso, então a imagem, no caso da imagem" (ibidem).

Nessa imagem projetava-se uma "escola conteudística", "uma escola onde as crianças aprendam muito", não com conteúdos desvinculados da cultura, pois nesta deveriam se inserir. Uma escola que continuava sendo vista como oposta à escola tradicional, sem "padrões de disciplina rígidos" e onde as crianças não vão para ser treinadas (Revah, 1994, p. 230). Uma escola que define os seus objetivos e conteúdos, com um professor que intervém, que toma as decisões. Essa "escola séria", atenta à nova cidadania "crítica" que se perfila no final da década de 80 , fortemente marcada pelas demandas do mercado de trabalho, pretende formar pessoas "competitivas", que se destaquem, que vão e saibam enfrentar a vida, a vida que se desenha no mundo mercantil e altamente competitivo desse período. É o que a escola quer e o que os pais exigem: "eles querem uma criança disciplinada, estudiosa e bem preparada" e não um "babaca bonzinho", conforme expressão usada de modo incisivo em uma descontraída entrevista feita com a educadora já referida (p. 238). Pelo que pode ser inferido das convergências produzidas por esse discurso, nessa entrevista, esse suposto "babaca bonzinho" remete às educadoras da outrora escola alternativa e às crianças formadas nessa "linha espontaneísta", assim chamada em conformidade ao significante que então se consolida para fazer referência ao próprio passado. Em relação a esse passado, ao longo dos anos 80 foram sendo criadas as piores imagens, de uma escola onde apenas pensava-se em "ser feliz", com "todo 
mundo comendo arroz integral, as crianças todas peladas, sujas, com o nariz escorrendo, sabe uma coisa meio assim, meio sem definição pedagógica” ${ }^{30}$

Esse passado equivocado desaparece na reconstrução histórica feita publicamente pela Escola da Vila, ou melhor, fica encerrado no significante espontaneísmo. Um passado cujo marco avaliativo é dado pelo discurso pedagógico construtivista. E neste deve ser incluído tudo o que essa escola "séria e moderna" supõe, inclusive o que acima foi delineado, mesmo que não costume aparecer no discurso construtivista, com a sua linguagem psicológica e didática bem arrumada.

\footnotetext{
${ }^{30}$ Esse é um trecho de uma entrevista feita com outra educadora da Escola da Vila, em fins de 1990 (Revah, 1994, p. 159). Essas entrevistas, feitas para o estudo desenvolvido em minha dissertação de mestrado, foram feitas com educadoras que estavam na Escola da Vila desde o seu início.
} 


\section{O desvio como verdade}

A reconstrução histórica feita pela Escola da Vila a respeito da sua própria trajetória, já comentada no último item do primeiro capítulo, corresponde a um discurso que se configura na segunda metade dos anos 80 e que apaga e (re)ordena várias séries discursivas que outrora confluíam no significante-mestre alternativa ou escola alternativa. Essa operação discursiva torna-se mais ou menos evidente quando começamos a indagar o passado desse discurso, à semelhança do que ocorre com outros discursos. É por isso que no passado encontra-se a chave para compreendermos algo do nosso presente. Mas também, como notou Benjamin, nele encontra-se a possibilidade de abrir o futuro, de romper com o que no presente se cristaliza, enrijecendo nossas formas de pensar e atuar, como ocorreu com o construtivismo em parte da década de 90, ao ficar cada vez mais parecido com o chamado tecnicismo. ${ }^{1} \mathrm{E}$ foi no passado que Freud também procurou as chaves para lançar alguma luz sobre os sintomas, sobre essas formações psíquicas cristalizadas que, pelo uso da palavra, tentou e às vezes conseguiu remover. Um passado que não apenas revelou a razão dos sintomas, mas também o próprio funcionamento do psiquismo no seu estado digamos normal, ou seja, neurótico. E a porta que abriu o acesso a esse enigma foi justamente o que afigurava um desvio, o que saia do curso normal das coisas: os atos falhos, os lapsos, os sonhos e os sintomas. Essa foi a via freudiana do acesso ao passado, do passado que do ponto de vista subjetivo efetivamente interessa e que concerne ao inconsciente. Um passado que não passa e que em última instância é uma criação nossa, uma criação simultaneamente subjetiva e social.

O que no discurso pedagógico construtivista costuma ser visto como algo da ordem de um desvio, de um equívoco ou de uma confusão aqui é tomado como um indício do que nele e precisamente nesse ponto há de fundamental. Segue-se aí o que Freud indica e o que Lacan localiza em Marx, pois deste procederia essa forma peculiar de abordar o que costuma ser visto como o estado normal das coisas pela via daquilo que justamente rompe com esse estado. Para

\footnotetext{
${ }^{1}$ Aqui estão sendo consideradas as teses de Walter Benjamin sobre a história e a temporalidade (1985, pp. 222-32).
} 
Marx, as crises de superprodução típicas do capitalismo, por exemplo, não constituíam propriamente fatos que escapavam do seu curso normal, mas o contrário disso, na medida em que revelavam o essencial do seu funcionamento: o antagonismo social sobre o qual se sustenta e do qual se nutre a sociedade capitalista. É por essa razão que Lacan afirma que Marx inventou o sintoma. ${ }^{2}$ No caso do construtivismo, pode-se dizer que nos desvios encontra-se justamente o que nos abre o caminho para desconstruir o seu sentido espontâneo e familiar, permitindo assim evidenciar a sua dimensão propriamente ideológica. Ademais, por essa via podemos chegar até o que nesse discurso nos seduz. Em outras palavras, entrando por essa porta podemos simultaneamente analisar o construtivismo como um discurso ideológico e ainda adentrarmos no registro fantasmático que o sustenta. É o que em parte será feito neste capítulo, mas também e em alguma medida em todos os outros.

O tipo de análise do discurso que aqui está sendo ensaiado recolhe as suas principais ferramentas conceituais da obra de Lacan, seguindo em grande medida o que Zizek sugere a esse propósito, a começar pelo que esse autor define como "o método básico da 'crítica da ideologia': identificar, num dado edifício ideológico, o elemento que representa sua própria impossibilidade" (1992, p. 124). Zizek na verdade propõe dois métodos complementares, que correspondem ao que neste estudo tenciona-se desenvolver:

- um é discursivo, é a "leitura sintomal" do texto ideológico que traz a "desconstrução" da experiência espontânea de seu sentido, isto é, que demonstra como um dado campo ideológico é o resultado de uma montagem de "significantes flutuantes" heterogêneos, de sua totalização por intermédio da intervenção de alguns "pontos de basta";

- o outro visa a extrair o núcleo do gozo, a articular o modo como, além do campo da significação, mas, ao mesmo tempo, no interior desse campo, uma ideologia implica, manipula e produz um gozo pré-ideológico estruturado na fantasia. (p.122)

Em relação ao primeiro dos dois planos discriminados por Zizek, não é difícil evidenciar o caráter ideológico do discurso pedagógico construtivista, até porque isso vem sendo feito de modo crescente desde pelos menos meados dos anos 90 , quando o construtivismo parece ter chegado ao ápice da sua hegemonia e simultaneamente iniciado uma fase em que começou a refluir. Para tanto foram

\footnotetext{
${ }^{2}$ A esse propósito, veja-se: Zizek, 1992, p. 125.
} 
fundamentais as críticas que desde essa época foram se avolumando, tendo como um primeiro marco importante o debate público entre Tomaz Tadeu da Silva (1993) e Fernando Becker (1994a).

Sobre essa dimensão ideológica e o registro da fantasia, neste capítulo apenas interessa desenvolver algumas questões teóricas, importantes para sustentar a análise que continuará sendo realizada nos próximos capítulos. Para desenvolver essas questões, as articulações discursivas já descritas no primeiro capítulo serão a nossa principal referência, em particular as relacionadas com a vertente do construtivismo que procede das experiências alternativas paulistanas.

\section{A primazia da ordem significante}

Desde meados dos anos 80, nessas experiências educacionais alternativas foram sendo produzidos discursos que criaram novos pontos de ressonância, relacionados tanto com a nova perspectiva de alfabetização que então começava a ganhar as suas primeiras feições, quanto com tudo o que já desde a primeira metade dessa década era alvo de crítica. Nesse processo ocorreram vários deslocamentos, alguns deles devidos à presença de palavras antes impronunciáveis, porque praticamente proibidas, como disciplina e lucro. Em outros casos, por força de um movimento contrário, de palavras que foram perdendo o status que outrora tinham e que então serviam para demarcar certas regiões do discurso. Por exemplo, o que era associado ao afetivo, à emoção, à idéia de um desenvolvimento natural e espontâneo, tudo isso fazendo parte do que no discurso cotidiano costumava receber a etiqueta de psicológico, em oposição ao chamado pedagógico. Em outras palavras, nesse período, entre os protagonistas dessas experiências firmava-se a idéia de que as escolas alternativas ficaram centradas na psicologia, perdendo de vista ou relegando o pedagógico, ou seja, a definição de objetivos, os conteúdos, as áreas do conhecimento, as questões curriculares, etc. $O$ tal viés psicológico ficou então associado ao passado e a significantes como os acima relacionados e não ao discurso cujos pontos de ressonância estavam se configurando. ${ }^{3}$ Esse é justamente o período em que se torna prioritária a definição de um projeto pedagógico, que no caso da reconstrução histórica feita pela Escola da Vila

\footnotetext{
${ }^{3}$ Pelo menos essa foi a deriva dessa vertente do discurso construtivista até inícios dos anos 90.
} 
parece ter sido transformado no eixo de toda a sua história, de uma história construtivista, que é a marca que busca-se ressaltar. Essa marca é a que então se torna a mais adequada para definir o lugar da escola "séria e moderna" que muitas escolas privadas então almejavam. E aqui deve ser incluído o amplo espectro de instituições escolares que o significante-mestre construtivismo começa como que a arrastar, desde aquelas escolas particulares que no início dos anos 80 eram por muitos qualificadas de tradicionais, até as que eram situadas no extremo oposto, chamadas de experimentais, renovadas ou alternativas.

Em face desse novo ideal, o passado de inúmeras escolas da rede privada tornou-se outro, por vezes de maneira súbita. É o que pode ser observado, por exemplo, num folder do final dos anos 90 do colégio paulistano Pio XII, que na década anterior muitos provavelmente consideravam uma instituição com uma linha de ensino tradicional. Nesse folder, logo no início e depois de serem relacionadas algumas questões, destaca-se, com uma outra cor, o seguinte: "Desde 1954, o Colégio Pio XII responde a estas questões fundamentais de todo pai e toda mãe por meio de sua filosofia pedagógica sócio-construtivista”. ${ }^{4} \mathrm{O}$ que é curioso, porém, é que em outras partes do mesmo folder é delineada uma outra perspectiva em relação a essa mesma trajetória, pois afirma-se que o colégio "já há dez anos, tem sua proposta metodológica voltada para o sócio-construtivismo". E ainda, na última dobra do folder, abaixo do nome da escola e em caracteres bem menores, foi escrita esta frase: "Unindo a tradição à modernidade sócioconstrutivista". Nesses últimos dois trechos do texto acima citados, indica-se que houve uma mudança na escola, que não deixou para trás a "tradição", pois esta foi unida à modernidade construtivista, ou melhor, sócio-construtivista, como de fato é caracterizada a proposta. Como se vê, há um deslizamento na interpretação da mesma história e dentro de um mesmo texto. De um lado, temos um colégio que desde o início dos anos 50 era sócio-construtivista e, de outro, o mesmo colégio, que somente há dez anos segue essa linha pedagógica. Esse aparente equívoco, isso que talvez tenha passado despercebido na sua confecção ou até, poder-se-ia pensar, a acomodação que é feita para manter o significante sócioconstrutivismo em períodos diferentes, ao mesmo tempo estabelecendo alguma

\footnotetext{
${ }^{4} \mathrm{Na}$ dobra que abre o folder, foi colocada esta única frase: "Lapidamos talentos".
} 
diferença por meio de termos de abrangência e sentidos diversos - "filosofia pedagógica" (desde 1954) e "proposta metodológica" (há dez anos) —, traz à tona um dos deslocamentos discursivos que faz com que uma história se torne outra, na medida em que o próprio passado começa a ser transformado. Em outras palavras, em determinado momento do passado começa a ser visto algo que o próprio presente inseriu, como se desde sempre tivesse estado aí, nesse lugar. $\mathrm{E}$ mesmo que essa seja uma operação ideológica intencional, com o passar do tempo os vestígios dessa operação apagam-se, até mesmo para quem intencionalmente em algum momento a realizou, passando então a acreditar o que daí em mais o presente não faz mais do que confirmar. E esse apagamento resulta do (re)ordenamento discursivo próprio desse processo, onde inúmeras marcas desaparecem ou são substituídas por outras.

O que nesse folder ficou registrado é muito comum nos atos de fala, que é onde por excelência esses deslocamentos ocorrem, ao menos de modo evidente, inclusive de uma maneira espontânea e até acidental, devido a equívocos, trocas de palavras e sentidos que inesperadamente aparecem, por vezes porque na fala irrompem palavras ou expressões antes impensáveis, ao menos em determinadas articulações. ${ }^{5}$ É desse modo que pode ser vista, por exemplo, a expressão significante "babaca bonzinho" ou "babaca", usada de modo incisivo em alguns momentos da entrevista já referida, de uma educadora da Escola da Vila. ${ }^{6}$ Essa expressão quase que irrompia na fala, em parte para assinalar o que então avaliava-se como atitudes por demais ingênuas, até mesmo da própria educadora entrevistada. Ao ser utilizada, ela confluía com outras figuras que demarcavam o mesmo passado e que eram contrapostas, por sua vez, ao presente. Essa expressão e a maneira como ela surgiu não revelam apenas o lugar reservado a

\footnotetext{
${ }^{5}$ Os atos de fala são aqui entendidos como atos de enunciação singulares e, nesse sentido, próximos do que Saussure chama de fatos da fala, que são sempre individuais e distintos dos fatos da língua (2000, p. 21). O lingüista genebrino coloca a fala no centro das modificações que ocorrem na linguagem verbal: "É na fala que se acha o germe de todas as modificações: cada uma delas é lançada, a princípio por um certo número de indivíduos, antes de entrar em uso." (p.115). "Nada entra na língua sem ter sido antes experimentado na fala" (p.196). Saussure também aponta o caráter acidental e espontâneo dessas modificações, sempre relativas a determinados elementos e não ao sistema como um todo, ou seja, à língua.

${ }^{6}$ Ver o último item do primeiro capítulo.
} 
um certo passado, pois também indicam o modo como um outro passado foi ou estava sendo criado, em função de injunções de natureza diversa. ${ }^{7}$

À primeira vista, a criação de um novo passado pode ser pensada como um processo onde ocorrem sucessivos deslocamentos de significado, de modo que o seu simples acúmulo ou superposição resultaria numa nova significação. Se concebido desse modo, porém, estaria sendo deixado de lado o essencial, isto é, a operação de costura que fixa determinada significação. Em outras palavras, o papel que é próprio da ordem significante e que Lacan esclarece quando trata dessa operação de basteamento. E aqui é importante delinear em que consiste essa operação.

Ao tratar da relação entre significante e significado, que é o que aqui está em jogo, Lacan parte da diferenciação estabelecida por Saussure, que é a grande referência da lingüística estruturalista. O que Saussure toma como objeto de estudo é a língua enquanto sistema, desenvolvendo todo um conjunto de conceitos que praticamente demarcam um novo objeto. A língua é por ele concebida como uma parte da linguagem, é a sua parte social, à diferença da fala, que é sempre individual, sendo a língua o seu instrumento e ao mesmo tempo o seu produto (Saussure, 2000, p. 27). ${ }^{8}$ A linguagem é entendida como uma faculdade humana que em suas diversas manifestações apresenta-se sempre de maneira dual, com duas faces: o pensamento e o som, o lado individual e o lado social, um sistema estabelecido e uma evolução (p.16). Para Saussure, dentre "tantas dualidades" somente a língua fornece um ponto de apóio satisfatório para a reflexão que busca desenvolver (p.17). A língua é "um todo por si”, não como a linguagem, que é multiforme e heteróclita e da qual "não se sabe como inferir sua unidade" (p.17). A sua unidade na verdade é feita pela língua, a qual, além de um produto social da faculdade de linguagem, é uma convenção adotada pela coletividade, necessária para o exercício dessa faculdade nos indivíduos (pp.1718). E aqui vale observar que a língua, apesar de concebida como um sistema de

\footnotetext{
${ }^{7}$ Sobre essas injunções, próprias da trajetória das escolas particulares chamadas de alternativas, veja-se, em Revah (1994), o capítulo "O 'novo' moderno".

${ }^{8} \mathrm{Em}$ todas as citações do livro Curso de lingüística geral (2000) será colocado o nome Saussure, a ele sendo atribuída a autoria do texto. Vale esclarecer, entretanto, que se trata de uma obra póstuma, que não foi escrita pelo lingüista suíço. O texto foi produzido a partir das anotações feitas por estudantes que freqüentaram seus cursos.
} 
signos virtual e exterior aos indivíduos, não é uma abstração, a sua natureza é concreta, ou melhor, psíquica (p.22-3).

A princípio, sugere Saussure, a língua não se apresenta como um conjunto de signos previamente delimitados, é antes "uma massa indistinta" (p.120). Para tratar dessa massa, ele estabelece uma distinção básica entre duas ordens de natureza diversa e que concebe vinculadas: a ordem do significado e a do significante - acima de certo modo referidas com os termos pensamento e som. E esse é precisamente o ponto de partida de Lacan num dos textos onde explica em que consiste o ponto de basta, o ponto de capitonê. ${ }^{9}$ Nesse texto, refere-se à oposição existente entre essas duas ordens e ao "esquema das duas curvas", por meio do qual Saussure (2000, p. 131) representa essas duas massas que correm paralelas:

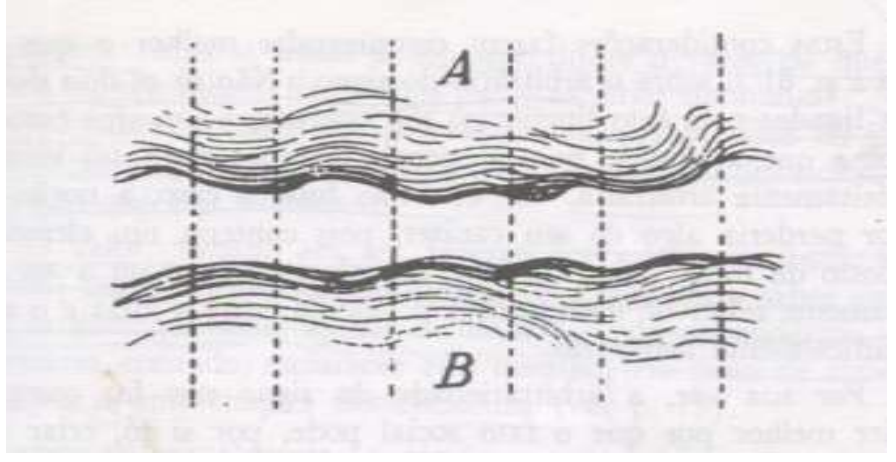

Um grande problema que Saussure procura resolver é justamente o das unidades lingüísticas, isto é, como definir os cortes nesse continuum que é "o fato lingüístico em seu conjunto", pelo menos à primeira vista, dado que não é possível captar diretamente as suas entidades concretas ou unidades (Saussure, 2000, pp. 130-2). Na figura acima, a língua já é representada como "uma série de subdivisões contíguas", indicadas pelas linhas verticais que atravessam ambos os planos. Nesse caso, "o plano indefinido das idéias confusas (A)" e o "plano não menos indeterminado dos sons (B)" (p.130). Como aponta Lacan (1955-1956, p. 296), "Saussure tenta definir uma correspondência entre essas duas ondas, que as segmentaria", mas a sua solução permanece aberta. ${ }^{10}$

\footnotetext{
${ }^{9}$ Cf. Lacan, 1955-1956, "O ponto de basta".

${ }^{10}$ O lingüista genebrino chega mesmo a desconfiar da possibilidade de estabelecer essas unidades concretas: "sua delimitação é um problema tão delicado que nos perguntamos se elas, as unidades, existem de fato" (Saussure, 2000, p. 124).
} 
As unidades que Saussure define são os signos lingüísticos, o signo entendido como entidade psíquica de duas faces. De um lado, as imagens, as idéias, os conceitos, os pensamentos; de outro, a imagem acústica, que não é o "som material", a "coisa puramente física", mas a impressão psíquica desse som, a sua imagem sensorial, a sua "imagem acústica" (2000, p. 80 ). Temos aí o significado, que deve ser distinguido da coisa ou referente real, e o significante. A sua união constitui o signo lingüístico, uma união indissolúvel, pois esses dois elementos nunca estão separados:

A língua é também comparável a uma folha de papel: o pensamento é o anverso e o som o verso; não se pode cortar um sem cortar, ao mesmo tempo, o outro; assim tampouco, na língua, se poderia isolar o som do pensamento, ou o pensamento do som (...) (Saussure, 2000, p. 131)

Essa unidade indissolúvel entre o significado e o significante e o encadeamento dessas unidades lingüísticas são assim representados (p.133):
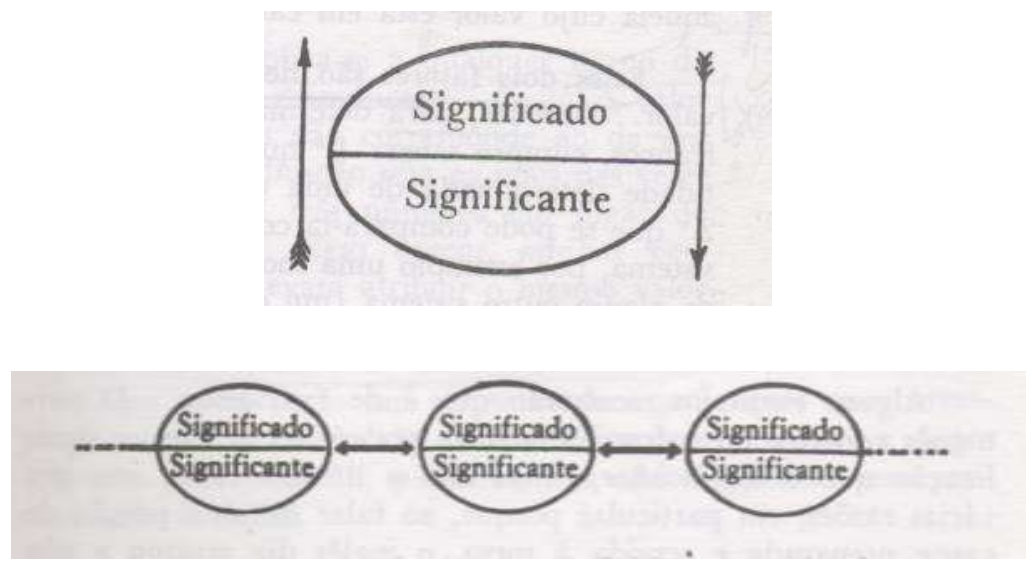

$\mathrm{Na}$ primeira figura, temos representado o signo como uma totalidade a princípio fechada, as setas representando a relação positiva entre dois elementos distintos: o significado e o significante. Na segunda figura, o que é ressaltado é o vínculo entre as unidades da língua, pois nela nenhum termo encontra-se isolado, a língua é um sistema. Nesse caso, as setas representam a dependência recíproca entre um termo e outro, cada termo adquirindo um determinado valor em função da sua relação negativa e diferencial com um outro. Essas múltiplas relações, representadas pelas setas verticais e horizontais, são as que definem o valor dos termos envolvidos. De modo que o valor lingüístico resulta tanto da relação positiva entre significante e significado, quanto das relações de caráter negativo e diferencial estabelecidas em cada um desses planos, entre os 
significados ou entre os significantes (2000, p. 139). Neste último caso, relações entre termos que pertencem a uma mesma ordem, sendo entre si diferentes. Há portanto duas ordens de diferenças, uma ordem relativa ao plano dos significados e, a outra, ao plano dos significantes (p.140). No caso da relação entre signos, para Saussure seria impróprio falar de diferença: "dois signos que comportam cada qual um significado e um significante não são diferentes, são somente distintos" (p.140). Em suma, o valor lingüístico dos termos da língua é sempre relativo, isto é, depende de um sistema de relações complexo, relações arbitrárias, porque não são naturais, e de oposição, pois trata-se de "um sistema baseado completamente na oposição de suas unidades concretas" (p.124).

Quando Saussure trata do valor lingüístico, primeiro considera separadamente as duas ordens envolvidas: há uma parte conceitual do valor e outra material. Ambas partes são constituídas por relações e diferenças com os outros termos da língua (2000, p. 136). Ao considerar a primeira, Saussure aponta que o valor constitui um elemento da significação (p.133). Esta então não pode ser considerada como sendo um significado isolado, na sua relação com determinado significante. É sempre necessário considerar a sua relação negativa com os outros termos que fazem parte do sistema (p.136). Portanto, a significação do signo lingüístico resulta em última instância dessas múltiplas relações que definem o valor dos termos envolvidos. O signo por si só não tem nenhuma significação própria (p.151).

Essas relações e diferenças entre termos lingüísticos são por Saussure desdobradas, para um dado estado da língua, em duas esferas distintas, que correspondem a duas formas de atividade mental (2000, p. 142). Uma dessas esferas diz respeito à sucessão de termos própria da cadeia da fala, que é uma sucessão porque dois termos não podem ser pronunciados ao mesmo tempo. As relações aí implicadas, baseadas no caráter linear da língua e estabelecidas entre termos igualmente presentes na série efetiva (p.142), são por Saussure chamadas de sintagmáticas e envolvem relações da parte com o todo e das partes entre si (p.149). O outro plano ou esfera corresponde a relações associativas entre termos que fazem parte de uma série mnemônica virtual, tendo a sua sede no cérebro de cada indivíduo (p.143). Assim, por exemplo, a determinado termo da cadeia falada corresponde toda uma série de termos virtuais a ele associados e que 
efetivamente não fazem parte da cadeia. Temos então relações, séries e agrupamentos ora sintagmáticos ora associativos, igualmente presentes no discurso. Em outras palavras, para Saussure, no discurso é preciso considerar "o jogo desse duplo sistema" (p.150), um jogo que na verdade constitui o mecanismo da língua, ou seja, ele a constitui e preside o seu funcionamento (pp.148-55). $\mathrm{Na}$ língua, então, é preciso considerar as relações negativas e diferenciais relativas a esse duplo sistema, porque essas relações podem ser sintagmáticas ou associativas, em cada uma das duas ordens que fazem parte do signo lingüístico (significado e significante).

A unidade do signo lingüístico e a sua significação resulta no fim das contas das múltiplas relações de oposição implicadas nesse jogo, pois os termos da língua e o seu valor são determinados precisamente por meio dele, isto é, do jogo das oposições lingüísticas (Saussure, 2000, p. 141), e de um modo que escapa ao controle do indivíduo (p.85). A língua, afinal, é um produto social, arbitrário e por isso livre, embora seja ao mesmo tempo próprio de determinada coletividade e permaneça amarrado ao seu passado, às relações e termos cristalizados pela tradição (p.88). O problema das unidades lingüísticas e também o da significação fica em Saussure em aberto, porque na verdade o critério último remete para o funcionamento do sistema, para as relações diferenciais e de oposição entre os termos lingüísticos, que é um dos pontos por onde Lacan retoma as teses do lingüista genebrino.

Lacan retoma essas teses para tratar do que na sua obra constitui o seu principal objeto: o sujeito do desejo. $O$ desejo entendido como inconsciente e pensado a partir das conceitualizações desenvolvidas por Freud. Nelas cabe à linguagem um papel preponderante, um fato que com Lacan fica em evidência e que ele sempre traz à tona com a sua repetida máxima "o inconsciente é estruturado como uma linguagem". De Saussure, Lacan vai retomar como fundamentais as relações diferenciais e de oposição presentes na linguagem, que são as relações que definem o valor dos termos lingüísticos, e vai reformular a relação significado-significante. Com respeito a essa última relação, Lacan (19551956, p. 296) lembra da sua fluidez, do fato de sempre estar pronta a se desfazer, como já havia apontado Saussure (2000, p. 90), para quem nada a rigor limita os deslocamentos suscetíveis de ocorrer em qualquer língua. E o que Lacan faz, no 
intuito de avançar nas questões próprias do funcionamento inconsciente, é romper com o vínculo entre significado e significante, destruindo assim a totalidade concebida por Saussure, ou seja, o signo lingüístico. Ele formaliza essa separação num algoritmo cuja formulação atribui a Saussure (Lacan, 1957, p. 500):

\section{$\frac{S}{S}$}

Esse algoritmo se lê: significante sobre significado, correspondendo o "sobre" à barra que separa as duas ordens aí envolvidas. A barra não indica a existência de uma relação ou comunicação. Ao contrário, ela representa a separação radical entre esses dois planos, a impossibilidade de comunicação e de uma correspondência efetiva. É uma ilusão, afirma Lacan, pensar:

(...) que o significante atende à função de representar o significado, ou, melhor dizendo: de que o significante tem que responder por sua existência a título de uma significação qualquer. (1957, p. 501).

Na verdade, no plano do significante o que temos é uma remissão de um significante a outro, isto é, uma cadeia significante. A significação resulta desse encadeamento, das relações que se estabelecem nesse plano. Ou seja, a produção de sentido é um efeito dessa concatenação significante, sob a qual sempre existe um incessante deslizamento do significado (1957, p. 506). Aí é primordial considerar a articulação significante como uma estrutura, uma estrutura articulada e sujeita a determinadas leis, como na língua. Em outras palavras, para Lacan, o significante tampouco se encontra isolado, ele faz parte de um sistema de relações diferenciais. Ademais, no funcionamento da linguagem, a ordem significante tem primazia, por isso o " $\mathrm{S}$ " maiúsculo colocado na parte superior do algoritmo, ao contrário do que pode ser observado nas várias representações feitas por Saussure sobre as duas ordens que constituem o signo lingüístico.

Essa autonomia da ordem significante pode-se dizer que é plena no âmbito do inconsciente, onde domina a materialidade significante como que desvinculada do sentido, como Freud evidência em suas análises sobre os mecanismos do 
inconsciente. ${ }^{11}$ Neles, Freud destaca dois processos básicos: a condensação e o deslocamento, que Lacan (1955-1956, p. 252) compara respectivamente com a metáfora e a metonímia, acentuando desse modo o que Freud já indicara, mesmo que tenha passado despercebido por muito tempo: o papel primordial da ordem significante. Para Lacan, os processos metafóricos e metonímicos constituem leis da linguagem que regem a ordem significante e estão no cerne dos processos de produção de sentido. ${ }^{12}$

\section{A operação de costura}

A linguagem é por Lacan concebida como uma espécie de gume. E esta é uma característica essencial do significante, da sua estrutura, a qual funda-se no que ele denominou função de corte (1964, p. 196; 1960, p. 815). Graças a essa função, o significante estrutura ou instala no sujeito determinada significação. Essa função pode ser pensada de diversos modos. Por exemplo, colocando no centro da análise a relação entre o sujeito e o que Lacan chamou de Outro, isto é, o universo simbólico, o campo da linguagem e do significante: "o lugar em que se situa a cadeia do significante que comanda tudo que vai poder presentificar-se do sujeito", quando da sua constituição, mas também no movimento circular que o repõe e desloca, envolvendo o sujeito e o Outro (1964, pp. 193-4). Nesse caso, a função do significante estaria sendo articulada pelo viés do processo de constituição subjetiva. Sob essa perspectiva, antes de mais nada é preciso pensar que um determinado significante representa um sujeito para um outro significante, aí estando em jogo determinada posição subjetiva (p.197). Entretanto, agora aqui interessa focalizar a própria cadeia de significantes e pensar nesse corte como

\footnotetext{
${ }^{11}$ Um bom exemplo encontra-se no texto de Freud onde trata do esquecimento de nomes próprios (1900-1901, pp. 755-9). Nesse texto, analisa o que aconteceu com ele mesmo, quando não conseguiu lembrar do nome de um pintor (Signorelli), trocado-o por outros dois nomes errôneos.

${ }^{12}$ Essas leis da linguagem são estabelecidas por Lacan a partir dos trabalhos de Jakobson. Para Lacan, tanto a metonímia quanto a metáfora implicam no desaparecimento de um significante. No caso da metonímia, ela não consiste propriamente em tomar a parte pelo todo, em sua relação com determinado referente. É antes de tudo uma conexão entre significantes. No processo metonímico, a conexão com o significante em falta permanece oculta e concerne a uma relação de contigüidade. A metonímia é caracterizada com a fórmula "de palavra em palavra" (Lacan, 1960, p. 509). Um exemplo trabalhado por Lacan é o da expressão "trinta velas", que equivale a "trinta barcos". A ligação entre barco e vela não é dada pela sua relação com qualquer referente, ela está na própria ordem significante, no "barco à vela". A fórmula da metáfora é "uma palavra por outra". Nesse caso, trata-se da substituição de um significante por outro, este assumindo o lugar do primeiro na cadeia significante, "enquanto o significante oculto permanece presente em sua conexão (metonímica) com o resto da cadeia" (Lacan, 1960, p. 510).
} 
uma operação de costura que se efetiva nesse mesmo plano e cujo efeito é a produção de uma determinada significação, a qual, é claro, supõe em última instância determinado sujeito, este não sendo mais do que um efeito dessa operação significante.

A significação efetiva-se, em qualquer discurso, de um modo retroativo. Como afirma Zizek, esse é a "tese lacaniana fundamental a propósito da relação significante/significado: em vez da progressão linear, imanente e necessária, temos um processo radicalmente contingente de produção retroativa de significação". $^{13}$ O significante, afirma Lacan, "por sua natureza, sempre se antecipa ao sentido, desdobrando como que adiante dele sua dimensão" (1957, p. 505). O sentido é um efeito que surge a posteriori, depois que a cadeia significante atravessou determinado ponto. Esses pontos, na obra de Lacan, adquirem feições diversas. Podem corresponder, por exemplo, a um termo significativo numa frase, onde a sua ausência como que evidencia esse caráter antecipatório do significante. Eis as frases não concluídas que Lacan fornece a título de exemplo: "Eu nunca..., A verdade é que..., Talvez, também..." (ibidem). O termo significativo sela 0 sentido dos termos precedentes por seu efeito retroativo. ${ }^{14}$ Esses pontos podem também corresponder a um significante ou uma articulação significante cujo efeito na cadeia que os contém é produzir uma espécie de reordenamento de tudo o que os precede. Isto é próprio do que Lacan chama de ponto de basta, que é mais do que um termo significativo numa série qualquer, pois antes trata-se de um nó onde convergem diversas articulações significantes.

Um exemplo que Lacan trabalha, para nele mostrar em que consiste o ponto de basta, é a tragédia Atália, de Jean Racine. ${ }^{15}$ No diálogo estabelecido entre dois personagens - Abner, oficial da rainha Atália, e Joad, o SumoSacerdote -, num momento bem preciso o Sumo-Sacerdote "tira de seu bolso", como afirma Lacan, uma expressão significante que produz nesse diálogo uma

\footnotetext{
${ }^{13}$ Esse efeito de retroação já está presente nas concepções desenvolvidas por Freud, como lembra Hornstein (1993, p. 85): "La retroacción es central en la concepción freudiana de la temporalidad y de la causalidad psíquica, ya que experiencias inscritas como huellas mnémicas son modificadas por lo actual. Es a partir de lo actual que adquieren un sentido nuevo e eficacia psíquica."

${ }^{14}$ Sobre esses pontos na frase, veja-se também: Lacan, 1960, p. 820

${ }^{15}$ Cf. Lacan, 1955-1956, "O ponto de basta".
} 
inflexão particular. Trata-se da expressão "Temo a Deus", cujo valor numa certa tradição Lacan não deixa de apontar (1955-1956, p. 301). Nesse discurso, que efetiva-se no diálogo entre os personagens, o ponto de basta é a palavra temor (p.303). Essa palavra, no lugar muito preciso em que emerge, tem o poder de transfigurar completamente determinadas significações iniciais, cuja ambiguidade ou imprecisão deixava-as como que suspensas. Pelo menos até o momento em que, ao ser usada naquela expressão por Joad, "realiza o lance de prestidigitação de transformar, de um minuto a outro, todos os temores numa perfeita coragem" (p.302). E mais, em torno desse significante, afirma Lacan, "tudo se irradia e tudo se organiza (...) É o ponto de convergência que permite situar retroativa e prospectivamente tudo o que se passa nesse discurso" (p.303). Ademais, esse significante opera de um modo peculiar sobre Abner, o oficial da rainha, digamos que 0 marca em determinada posição subjetiva, que até 0 momento desse acontecimento encontrava-se como que indefinida.

Da literatura brasileira é possível extrair bons exemplos para ilustrar em que consiste o ponto de basta. Tomemos, por exemplo, o conhecido romance Dom Casmurro, de Machado de Assis. Nele, o próprio personagem Dom Casmurro conta-nos a sua vida retrospectivamente, ou melhor, a história do amor com Capitu, de quem se apaixonara quando menino e com quem finalmente casou. O livro começa com o narrador-personagem esclarecendo o porquê do seu nome, alcunhado por um eventual companheiro numa viagem de trem e que ficou aborrecido com ele, dado que quase adormeceu enquanto o rapaz recitava-Ihe alguns versos. O rapaz, que vivia no mesmo bairro e que conhecia de vista, no dia seguinte espalhou o nome que daí em mais não o abandonaria, pois os seus próprios amigos, a quem contou-lhes o sucedido, assim começaram a chamá-lo. O nome "pegou", o nosso personagem o aceitou e até o tornou o título do "seu" livro, e não por acaso, a história está aí para confirmá-lo. Dom Casmurro, entretanto, somente parece nascer em certo ponto da narrativa, em certo momento da história do Bentinho, que é como o nosso narrador-personagem era conhecido e chamado desde criança. A sua casmurrice, portanto, não é congênita ou não marca o seu caráter desde criança, embora sempre seja possível ficar com alguma dúvida a esse respeito, pois em Bentinho poder-se-iam encontrar traços de Dom Casmurro. Deste, o próprio personagem dá a sua definição: um "homem calado e metido consigo". Também pode-se recorrer ao dicionário, que 
ele desaconselha consultar, muito embora aí seja possível encontrar uma boa definição do que Bentinho afinal se torna. Segundo o que o nosso atual Aurélio registra, casmurro significa: "que, ou aquele que é teimoso, implicante, cabeçudo"; "ensimesmado, sorumbático, triste".

$\mathrm{Na}$ história, há um outro personagem importante, afora os seus dois principais protagonistas, que é o amigo íntimo de Bentinho, Escobar, amigo desde a época em que freqüentava o seminário, quando a família queria que fosse padre. Escobar casa-se com uma amiga de Capitu e ambos os casais formam dois pares como que ideais. Até o acontecimento que produz um giro em toda a história, inclusive para o leitor, para o qual a história começa a se tornar outra, pois o passado subitamente muda, torna-se outro. Esse acontecimento marca também o futuro, isto é, o que de aí em mais acontece, pois a vida de seus protagonistas muda radicalmente. E por um fato do discurso, da ordem significante, que não se encontra desvinculada da experiência. Sem esta, a rigor, nada é possível, o real da experiência é um registro necessário. Mas a experiência apenas torna-se tal, torna-se apreensível, consiste efetivamente numa experiência, em algo que pode ser chamado de realidade, na medida em que intervém a ordem simbólica. A esta cabe a função de cortar o real, de estabelecer os contornos imaginários em função dos quais os objetos e as pessoas tornam-se tais, com os nomes e as características que lhes atribuímos. ${ }^{16}$

O fato em questão desenrola-se a partir da fatalidade que acomete o amigo íntimo do Bentinho, que morre afogado ao se aventurar no mar agitado e sob forte ressaca. No enterro, o acontecimento que poderia ser visto como aquele que sela a vida de Bentinho e faz nascer Dom Casmurro: algumas lágrimas de Capitu e os seus olhares suspeitos:

(...) Capitu olhou alguns instantes para o cadáver tão fixa, tão apaixonadamente fixa, que não admira lhe saltassem algumas lágrimas poucas e caladas ...

(...) Capitu enxugou-as depressa, olhando a furto para a gente que estava na sala (...) Momento houve em que os olhos de Capitu fitaram o defunto, quais os da viúva (...) (capítulo CXXIII: "Olhos de ressaca")

A partir daí, as suspeitas e desconfianças de Bentinho sobre o amor da sua

\footnotetext{
${ }^{16}$ Acima estão sendo considerados os três registros que Lacan conceitualiza para situar tudo o que é da ordem humana: o real, o imaginário e o simbólico.
} 
vida não fazem mais do que aumentar, alterando por completo a sua personalidade e a vida do casal, que termina separando-se. Convencido de ter sido traído por Capitu e o seu melhor amigo, Bentinho torna-se outro. Ademais, todo um conjunto de traços da Capitu, que foram sendo arrolados ao longo da história, confluem agora nesse ponto: a pequena "desmiolada" que o agregado da família de Bentinho, José Dias, já advertia e quando apenas estava com seus catorze anos, uma menina calculista, fingida, com olhos de "cigana oblíqua e dissimulada", conforme a certeza que se consolida no espírito de Bentinho, agora Dom Casmurro: "se te lembras bem da Capitu menina, hás de reconhecer que uma estava dentro da outra, como a fruta dentro da casca", afirma o nosso narrador-personagem no último capítulo. Uma certeza que um outro fato não faz mais do que confirmar, no dia-a-dia, com o tempo oferecendo-lhe a prova, para ele, definitiva: a semelhança física entre o seu filho Ezequiel e o seu amigo Escobar. É por essa via que o leitor também começa a desconfiar, por algumas poucas situações que antecedem o momento crucial e que o colocam quase que à espera do que está por vir. ${ }^{17}$ Mas é somente a partir daquele momento crucial, dos "olhos de ressaca", com a confirmação que daí em mais vem da fisionomia e maneiras de Ezequiel, que todas as ambiguidades no comportamento de Capitu, como que flutuando ao longo da história, ganham um sentido. E também vários traços de Bentinho, como os seus ciúmes, que afinal também pode-se pensar o fizeram sucumbir. Para o leitor, sobram as dúvidas, ainda mais em face da estupefação e indignação que demonstra Capitu ao saber da convicção do marido. $^{18}$

O ponto de basta, o acontecimento significante que provoca um giro na narrativa e na vida dos personagens são algumas lágrimas e olhares. Esse acontecimento funciona, para colocá-lo nos termos que Lacan emprega, como uma "agulha do colchoeiro" que entra no momento exato, no lugar preciso, fazendo uma costura que ata toda uma história, a partir de uma certeza que aí se configura. Uma certeza que se afirma nesse ponto de acolchoado, nesse ponto onde significado e significante ficam como que atados (Lacan, 1955-1956, p. 303). E esse é o nó que justamente parece atar os dois extremos da vida do nosso

\footnotetext{
${ }^{17}$ A esse respeito, veja-se os capítulos CXII ("As imitações de Ezequiel) e CXVI ("Filho do homem").

${ }^{18}$ Cf. capítulo CXXXVIII (“Capitu que entra”).
} 
narrador-personagem, marcada por dois nomes: Bentinho e Dom Casmurro. Este, no segundo capítulo, externa inclusive essa intenção ao escrever o livro: "O meu fim evidente era atar as duas pontas da vida, e restaurar na velhice a adolescência. Pois, senhor, não consegui recompor o que foi nem o que fui”. Digamos que não conseguiu realizar o que pretendia porque o que ata os dois extremos é esse ponto em torno do qual tudo passa a girar, produzindo um efeito de sentido retroativo e prospectivo. Só consegue pensar a sua própria história, o seu próprio passado, segundo a significação que emerge a partir desse ponto para onde tudo converge e de onde tudo se ordena. Um ponto que divide a vida do narrador-personagem em dois momentos, cada um deles marcado por um nome, que, por sua vez, corresponde a determinada posição subjetiva.

A natureza do significante que faz a costura própria do ponto de basta é diversa, não é necessariamente uma palavra. No relato de Dom Casmurro, algumas frases, alguns trechos de determinado capítulo provocam esse giro, essa particular inflexão na história narrada. No entanto, se fosse possível materializar a cena narrada, poder-se-ia dizer que a materialidade significante que provoca a grande virada na vida dos personagens é feita de olhares e de lágrimas. Em outros termos, a materialidade do significante não consiste apenas em palavras, embora destas dependa de modo radical, o universo humano simplesmente não existiria sem a presença da palavra, da linguagem verbal, que em alguma medida sempre está presente. É justamente o que Lacan sublinha ao atribuir um papel primordial à instância da letra, sendo a letra a materialidade própria e primeira do significante.

Tampouco é possível definir a priori a extensão do que intervém à maneira de um ponto de basta, pode ser um grito, um gesto, uma palavra, uma frase, um artigo. ${ }^{19}$ No caso do construtivismo, a pesquisa de Ferreiro e Teberosky divulgada

\footnotetext{
${ }^{19}$ Zizek, por exemplo, ao analisar o "caso Dreyfus", de um oficial francês de origem judaica acusado de alta traição e que criou grande polêmica na França em fins do século XIX, destaca o papel que nesse momento teve um artigo de jornal então publicado. Esse artigo criou um ponto de basta, provocando uma reviravolta no caso: "o que era, num dado momento, a própria fonte da desordem, transforma-se mais ou menos na prova e no testemunho de um triunfo" (1991, p. 47); "uma disputa judiciária relativa à legalidade e à eqüidade de um veredicto" transforma-se no "pivô de uma batalha política pela qual toda a vida nacional foi abalada" (pp.45-6). O próprio "caso Dreyfus", considerado como um todo, é concebido por Zizek como um ponto de basta devido ao seu papel na história política francesa e européia: "o caso reestruturou o campo inteiro e desencadeou, direta ou indiretamente, toda uma série de deslocamentos que ainda hoje determinam o cenário político: a separação final entre a Igreja e o Estado nas democracias
} 
no Brasil em meados dos anos 80 é o acontecimento que inicia o (re)ordenamento de todo um campo discursivo, a princípio basicamente (re)ordenado em torno e por meio de um nome: Emilia Ferreiro; encontrando posteriormente o seu ponto de basta definitivo na palavra construtivismo, conforme um (re)ordenamento que prossegue alargando as suas fronteiras iniciais, relativas ao campo da alfabetização.

\section{Os pontos de ressonância}

Nos exemplos aqui brevemente apresentados, o da tragédia Atália e o do romance Dom Casmurro, o acontecimento que provoca uma inflexão ou reviravolta no desenrolar dos fatos é precedido por inúmeras marcas, por significantes ou articulações significantes que estão como que à espera de um sentido que somente vem no ponto de basta: o ponto "pelo qual o significante detém o deslizamento da significação, de outro modo indefinido" (Lacan, 1960, p. 820). A operação de costura aí implicada é a mesma mencionada por Zizek quando se refere ao "texto ideológico": determinado campo ideológico resulta de uma montagem de "significantes flutuantes", de sua totalização graças à intervenção de "alguns" pontos de basta (1992, p. 122). E aqui Zizek sugere pelo menos duas coisas: a operação de costura realiza-se sobre significantes que se encontram frouxamente amarrados e envolve vários pontos de basta. Esses vários pontos, porém, não parecem ter o mesmo valor nem a mesma função quando da sua presença em determinado discurso, seja ele um monólogo, uma peça teatral, um romance, um artigo ou uma fala qualquer. Dentro de determinada cadeia significante, onde vários pontos de basta podem ser discriminados, se dela é possível falar como algo que possui um certa unidade é porque existe um ponto de basta cujo papel é primordial, na medida em que ele faz uma costura que enlaça todo a cadeia. Esses vários pontos de basta esparramados na cadeia significante e cuja função não é a de atar o conjunto, como podem ser encontrados em Dom Casmurro, constituem algo semelhante a pequenas costuras, como inflexões que estão presentes em diferentes momentos, digamos que são costuras inconclusas e que criam justamente a imprecisão e o tom de espera que acompanha a cadeia significante que os contêm, pelo menos até o ponto que cria propriamente uma unidade significante que fecha parcialmente um

burguesas (...) etc." (p.45). 
sentido, que faz cair o que parecia impreciso e ambíguo, que cria enfim algo que é da ordem de uma certeza. Mas esta somente surge graças ao que a precedeu, isto é, porque antes que ela surgisse e criando as condições para tanto foram se afirmando todo um conjunto de traços, de marcas, de significantes com suas pequenas costuras que criaram um território de limites imprecisos, definidos somente no e pelo ponto de basta da cadeia significante.

Essa operação de costura, com suas várias facetas e tipos de pontos, é essencial no processo de configuração do discurso pedagógico construtivista, bem como na criação dos passados que ele sustenta. Um novo discurso emerge, uma nova montagem coletiva se constitui graças a essa operação, isto é, graças à intervenção do que nos discursos opera criando um ponto de basta. Essa intervenção, como já foi assinalado, não se reduz a um único ponto de basta, embora sempre exista um ponto significante cujo papel é preponderante. No caso desse discurso, o significante construtivismo e os seus equivalentes são essenciais nas operações de costura das quais esse discurso resulta. Esses significantes cumprem com essa função que é própria do ponto de basta que cria a unidade da cadeia e que permite falar na existência de um discurso construtivista, muito embora sempre se trate de uma diversidade de discursos. $\mathrm{O}$ significante-mestre que está nesse lugar, que cumpre com essa função, faz o enlace de toda a cadeia, ele constitui o seu ponto de arremate. Por isso, aliás, o significante construtivismo está precisamente no ponto de emergência desse discurso, no ponto em que propriamente se constitui. Esse significante cumpre também uma outra função: em si condensa a montagem coletiva e discursiva da qual faz parte, a montagem constituída por ele próprio e a rede discursiva que lhe é solidária.

Nessa rede é preciso considerar a existência de outros pontos de basta, de outros pontos de ressonância, em particular os pontos cujo processo de constituição antecede a emergência do discurso pedagógico construtivista. A sua função é justamente alavancar essa emergência e sustentar o discurso uma vez constituído. Uma função que se aproxima do papel que os vários traços dos personagens de Dom Casmurro jogam no momento crucial. Sem esses traços, a história não seria verossímil, até para o próprio Dom Casmurro, ou melhor, sem eles não haveria esse ponto de basta constituído por algumas lágrimas e olhares 
da Capitu, sem eles não seria possível tamanha inflexão na narrativa e na história, pelo menos do modo como ocorreu e no ponto onde isso aconteceu. No caso do discurso construtivista, esses pontos de ressonância criam as condições necessárias para a emergência e conseqüente sustentação de um novo discurso. São os seus pontos de ancoragem, tanto porque criam o campo próprio para esse novo discurso surgir, sustentando assim a sua emergência, quanto também porque uma vez constituído passam a sustentá-lo, pelo menos durante certo tempo, juntamente com outros pontos de ressonância que então se constituem e que cumprem com a mesma função. Por isso, detectá-los e focalizar as articulações discursivas neles amarradas é, neste estudo, tarefa primordial.

Em relação à operação de costura ou de basteamento ainda é preciso considerar outras questões que tornam ainda mais complexa a sua conceitualização. Por exemplo, sempre estamos em face de uma diversidade de discursos e com o problema básico de esclarecer como se constitui o que aqui é concebido como um único discurso: a matriz simbólica construtivista. Ademais, há uma dimensão temporal até agora pouco considerada, relativa a deslocamentos que se processam ao longo de anos e até décadas. Para situar melhor o problema e avançar no entendimento dessa operação de costura, pode ser estabelecido um certo paralelo com o que Saussure define como o campo próprio da lingüística diacrônica, que distingue da sincrônica. Esta ocupa-se da língua do ponto de vista estático, ou seja, de um determinado estado da língua; enquanto a primeira trata das suas evoluções, das suas fases (2000, p. 96). Ao referir-se à evolução da língua, Saussure adverte que nunca muda o sistema como um todo, a evolução não se dá nesse plano de conjunto, da língua como totalidade:

Como as alterações jamais são feitas no bloco do sistema, e sim num ou noutro de seus elementos, só podem ser estudadas fora do sistema. Sem dúvida, cada alteração tem sua repercussão no sistema; o fato inicial, porém, afetou um ponto apenas; não há nenhuma relação interna com as consequências que se podem derivar para o conjunto. (p.102-3).

Saussure afirma ser necessário separar radicalmente o diacrônico e o sincrônico (p.105), pois um não explica o outro. Para compreender um dado equilíbrio da língua, para tratar das múltiplas relações que compõem um dado sistema, não interessa o seu estado anterior nem as alterações que levaram a esse novo estado. As alterações, sempre relativas a elementos isolados da língua, 
tampouco obedecem a qualquer regra relativa ao sistema do qual fazem parte, essas regras não explicam nada. Até mesmo esses deslocamentos ocorrem de maneira espontânea e fortuita (p.105) e os termos que se substituem uns aos outros não formam sistema entre si. Inclusive, esses termos que se sucedem na diacronia não são percebidos por uma mesma consciência coletiva. Enfim, esses são os fatos estudados pela lingüística diacrônica, ou seja, ela estuda as relações que unem esses termos sucessivos (p.116).

Esses aspectos, relativos ao "jogo da língua", são por Saussure esclarecidos por meio de uma analogia com o jogo de xadrez, em relação ao qual apenas aponta uma diferença: no xadrez existe a intenção de executar certo deslocamento com determinada peça e de assim exercer uma ação sobre o sistema (2000, p. 105), o que não é o caso da língua, cujos deslocamentos são espontâneos e fortuitos. De resto, Saussure destaca as semelhanças. Uma posição de jogo no xadrez corresponde a um estado da língua e o "valor respectivo das peças depende da sua posição no tabuleiro, do mesmo modo que na língua cada termo tem seu valor pela oposição aos outros termos" (p.104). No xadrez, como na língua, para situar o valor relativo das peças em determinado estado do jogo, não é relevante saber o que ocorreu antes. Quando é feito um novo lance, este sempre concerne a apenas um elemento, nunca a mudança é geral, o que não quer dizer que o que a seguir acontece não condicione o sistema todo. Do mesmo modo, "na língua, as mudanças não se aplicam senão a elementos isolados" (p.104). Uma nova posição, um novo valor, incide sobre o conjunto porque cria uma nova condição, mas esta resulta do deslocamento de um elemento e o que motivou ou levou a essa alteração nada tem a ver com o sistema.

Pensando agora do ponto de vista do discurso, das questões aqui colocadas, os pontos de ressonância a princípio poderiam ser considerados isoladamente, como elementos discursivos que se afirmam em função da sua insistente e crescente presença na fala. $E$ em parte é por isso que aqui são chamados de pontos de "ressonância", de ressonância social, pois repetem-se nas falas de inúmeros sujeitos. Esse é o modo, aliás, como Saussure tende a ver o que entra no sistema da língua, como o resultado de uma espécie de acúmulo, de repetição por um sem número de indivíduos de um forma surgida na fala e que, 
ao ser aceita pela comunidade, torna-se um fato de língua (2000, p. 115). Quanto à emergência do discurso construtivista, pode-se dizer que ele não procede de uma mudança ou deslocamento em bloco de outro discurso, à semelhança das alterações que Saussure vê na língua. Ao invés disso, o que ocorre é todo um conjunto de múltiplos deslocamentos, em inúmeros e diversos pontos, os quais criam as condições para a emergência de um novo discurso. $E$ aí é preciso observar que esses pontos de ressonância cumprem também uma função corrosiva, na medida em que vão como que socavando o terreno já consolidado de outros discursos.

Esses deslocamentos, porém, não podem ser considerados do modo como Saussure concebe as mudanças na língua, radicalmente separadas do que é da ordem do sistema. E esse é um passo que Lacan permite realizar, na medida em que não desvincula, como Saussure, a ordem diacrônica da sincrônica. E aqui vale lembrar que o que estava em jogo na reflexão de Saussure era a língua e não o discurso. Neste estudo, entretanto, o alvo é o discurso e neste, como sugere Lacan, a análise dos pontos de basta é capital: "Esse ponto em torno do qual deve exercer-se toda análise concreta do discurso, chamá-lo-ei um ponto de basta" (1955-1956, p. 303). Pode-se dizer, então, que os fatos do discurso são os pontos de basta e as operações de costura correspondentes. E esses são os fatos que este estudo toma como principal objeto.

O vínculo entre aquelas duas ordens, diacrônica e sincrônica, é essencial na própria operação de costura, na "laçada enlaçada" que cria a unidade significante e que assim situa os seus diferentes elementos (Lacan, 1955-1956, p. 297): o nó que um determinado significante faz, no lugar preciso, enlaça toda a cadeia diacrônica e ao mesmo tempo a contém, exatamente nesse ponto de achatamento onde significante e significado se encontram. Esse é o ponto de capitonê, o botão que liga os dois tecidos da "massa indistinta" da fala e que aí cria um ponto que pode ser reconhecido como algo distinto, que prende o conjunto, que cria uma unidade.

Isso significa que os pontos de ressonância são antes de mais nada nós onde concentram-se articulações as mais diversas, costuradas, no caso do mesmo ponto, com um mesmo significante ou com significantes que são equivalentes. Em outras palavras, os próprios nós podem ser considerados 
montagens discursivas que em si encerram um significante-mestre e uma cadeia de significantes nele amarrada. Uma montagem que se (re)atualiza em cada ato de enunciação em que se opera a partir de determinado ponto de basta. Por isso, nunca é idêntica. Embora cada laço possa ser feito com o mesmo significantemestre, cada enlaçada produz uma repetição diferente, ou seja, sempre ocorre algum deslocamento. E já vimos aqui que o discurso dos desvios, das confusões e dos equívocos assume diferentes formas, penetra inclusive em discursos que buscam se distanciar do construtivismo.

Essas montagens discursivas, que podem ser consideradas em diferentes planos, pois concernem também ao pensamento inconsciente, entre si se articulam e formam a rede significante que dá consistência ao discurso construtivista. Este, por sua vez, é uma montagem discursiva que se articula com outras e que, como elas, sempre contém aqueles dois componentes básicos, que podem ser representados com a fórmula criada por Lacan: $S_{1} \rightarrow S_{2}$, o primeiro representando o significante-mestre e o segundo, a rede discursiva nele amarrada. Quanto à seta, ela pode ser entendida como representando essa função de comando que é própria do significante-mestre. Este, lembremos, (re)ordena toda a cadeia de significantes $S_{2}$, estabelecendo assim as margens da significação, embora nunca sozinho, pois existe aí uma espécie de jogo, de dependência mútua entre o $S_{1}$ e a rede significante $S_{2}$.

O tipo de enlace que é feito através do $S_{1}$, do significante-mestre, também pode ser entendido como um processo metafórico. $\mathrm{O} \mathrm{S}_{1}$ é um significante metafórico, ele estabelece as margens da significação, isto é, detém os deslocamentos da cadeia, na qual um significante remete a outro - como ocorre no plano da significação, onde uma remete a outra. ${ }^{20}$ No ponto de basta, esse deslizamento é como que contido, ficando assim estabelecido um determinado campo de significações, mais ou menos fluído. Essas significações, amarradas nesse ponto de enodamento fixado pelo $S_{1}$, resultam em última instância da rede significante $S_{2}$, que retroage também sobre o $S_{1}$. Esse é o jogo que estabelece o sentido que emerge no ponto de basta.

\footnotetext{
${ }^{20} \mathrm{O}$ entendimento do $\mathrm{S}_{1}$ como significante metafórico pode ser encontrado em Nasio (1993, pp. 48-69), que também refere-se aos processos metafóricos e metonímicos, num tipo de análise restrito ao campo do inconsciente e às questões próprias da clínica psicanalítica.
} 
O construtivismo pode ser então entendido como metáfora e conforme o mesmo enunciado que de um modo tão preciso Vieira (1995) propõe no título de seu trabalho: "Construtivismo": a prática de uma metáfora - um enunciado onde a riqueza do que ele contém parece ter ultrapassado o fértil trabalho desenvolvido pela autora, como se aí houvesse um saber não sabido. A "prática de uma metáfora" pode ser entendida justamente como essa operação de basteamento que, cada vez que é realizada, redefine as margens do construtivismo. E essa é a metáfora que conforma os sujeitos, que os afeta, é ela a que na verdade define o "caminho construtivista", seja o da "conversão religiosa", como afirma Vieira (p.70), ou qualquer outro igualmente construtivista, como aquele que se anuncia nesse mesmo trabalho de Vieira. Nele, vale salientar, a linguagem ocupa um lugar central e é por essa trilha que a autora chega àquele enunciado.

O discurso pedagógico construtivista configura-se justamente quando essa metáfora se constitui, ou melhor, quando ela se torna uma prática social. Nesse momento, constitui-se o que também pode ser chamado de Outro, aqui entendido não num sentido amplo, isto é, como universo simbólico cujas fronteiras não estão definidas ou cujos limites concernem a determinado campo sócio-cultural. Referido à matriz simbólica construtivista, o Outro resulta da relação entre o significante-mestre construtivismo, ou seus equivalentes, e a cadeia de significantes $S_{2}$, com seus pontos de ressonância. O Outro, chamemo-lo de construtivista, pode ser entendido como sendo a própria montagem coletiva que dessa relação resulta. O termo coletiva é utilizado para indicar que os seus pontos de basta, além de serem o resultado de um processo de elaboração coletiva, são socialmente compartilhados, são pontos de ressonância social, pontos de basta constantemente repostos em inúmeras práticas discursivas, no caso relacionadas ao campo da educação escolar.

E aqui vale fazer a ressalva de que o Outro não existe desencarnado, não é um ente ou substância que paira sobre os sujeitos, à maneira da sociedade em Durkheim. O Outro sempre encontra-se referido a determinado sujeito. Digamos que cada sujeito implicado no e pelo discurso construtivista realiza a sua própria costura, reafirmando seu ponto de arremate e alguns dos pontos de ressonância dessa montagem coletiva, que não é um bloco sempre o mesmo. Essa montagem coletiva é diferente em cada sujeito. É chamada de coletiva apenas porque os 
seus pontos de basta são compartilhados, mas eles afetam os sujeitos de modo diferente e podem variar de sujeito para sujeito. Ademais, em cada sujeito, compõem-se com outros discursos que circulam na sociedade e que são de natureza diversa: políticos, religiosos, etc. Isto é, compõem-se com os pontos de ressonância desses discursos, por vezes porque compartilham um mesmo ponto. Os pontos de ressonância de um determinado discurso podem ou não marcar determinado sujeito, podem ou não fazer alguma inscrição. Certamente, no caso do discurso construtivista, eles concernem primeiramente aos que assumem esse discurso, mas também a muitos que dele buscam se distanciar. E disso em parte resulta a sua hegemonia: das marcas que esses pontos de ressonância deixam sem que nos apercebamos disso.

Além dos pontos de ressonância, é preciso considerar o que é da ordem estritamente singular, nos vários planos ou instâncias subjetivas. Em outras palavras, é preciso considerar os pontos de capitonê firmados em determinado sujeito e que dizem respeito à sua singularidade, ao seu estilo, às posições singulares que o definem e que a rigor não é possível separar do que está sendo chamado de pontos de ressonância. O Outro de determinado sujeito contém as marcas que dizem respeito à sua história, àquilo que da sua história ficou e que pauta a sua vida, uma história singular, mas simultaneamente social. O que o marcou vem precisamente do Outro, que é sempre social, pois diz respeito ao campo da linguagem e do significante, embora os seus efeitos sejam sempre singulares. Daí o entendimento de que o Outro é singular e ao mesmo tempo social, não existindo na verdade mais do que um único Outro, o do sujeito.

Enfim, o Outro construtivista consiste naquilo que na cadeia significante que orienta todo sujeito, de um modo que em última instância lhe escapa, corresponde aos pontos de ressonância desse discurso. É portanto parte constitutiva da rede simbólica que cria a consistência do Outro de cada sujeito. Ou seja, o Outro construtivista é apenas o nome dado ao que no Outro do sujeito diz respeito aos pontos de ressonância do discurso construtivista, não existindo portanto dois ou mais Outros, mas apenas Um.

Uma vez que o Outro construtivista se constitui, ele opera no discurso como uma montagem sincrônica e de modo retroativo sobre a cadeia significante diacrônica, sobre o que é da ordem da sucessão temporal, quando da produção 
de uma fala ou de um texto qualquer por determinado sujeito. Nesse caso, o Outro, que é uma montagem sujeita a alterações cada vez que se produz a operação de basteamento, cavalga num significante, condensa-se nele, no Um constituído pelo significante-mestre. E é desse modo que opera. Quer dizer, uma vez que o discurso pedagógico construtivista se configura, nos discursos ele já opera como tal, como Outro, através justamente do significante-mestre desse discurso, que pode estar implícito e à maneira de um ponto de basta, isto é, ordenando a cadeia. A significação que dessa operação resulta é uma função do Outro, surge em função do (re)ordenamento que ele produz em determinada série significante diacrônica e pode se traduzir em determinada "missão", em determinada tarefa que o sujeito resolve realizar, em certa posição que ele assume. Essa significação, essa "pontuação" é instaurada pelo Outro, pelo corte retroativo que o significante-mestre realiza. Esse corte aqui é pensado como sendo feito por qualquer Um dos significantes-mestres desse discurso, por qualquer Um dos seus pontos de ressonância, todos justapostos no Um do ponto de arremate.

Esses significantes-mestres parecem incidir no sujeito a maneira de projéteis arremessados em sua direção, numa série que penetra pelo mesmo ponto e cujo impacto é o que o move. Digamos que cada impacto é um corte feito com um significante-mestre, que apesar de eventualmente ser o mesmo em várias séries diacrônicas, relacionadas com diferentes momentos e circunstâncias, pode produzir efeitos diferentes. Imaginemos, por exemplo, um professor cuja fala e ação articulam-se, em determinadas situações, em função do ponto de ressonância que pauta esta exigência: "conhecer a criança". Sob o influxo do discurso construtivista, essa exigência pode implicar "pontuações" diversas, pode se traduzir de muitas formas. Por exemplo, pode significar que o professor se sinta obrigado a fazer periodicamente um ditado avaliativo para conhecer as hipóteses das crianças a respeito do sistema de escrita, pode levá-lo a insistir com seus colegas sobre a necessidade de sempre considerar os "conhecimentos prévios" dos alunos, pode implicar numa prática pedagógica que "religiosamente" sempre começa pelo levantamento do que as crianças já sabem sobre determinado assunto, etc. As significações que resultam do impacto dos pontos de ressonância no sujeito não se esgotam no plano consciente. Ao contrário, do 
modo como esse impacto está sendo aqui concebido, ele concerne sobretudo ao plano inconsciente.

Nessas considerações, segue-se em grande parte as sugestões de Lacan (1960, pp. 820-1), certamente transferidas para um outro campo de análise. Para Lacan, no ponto de basta temos o lugar do Outro, de uma certa "bateria significante" que incide sobre a cadeia significante diacrônica. É o que Zizek também aponta:

Poderíamos dizer que o ponto de basta representa, ocupa o lugar do grande Outro, do código sincrônico, na cadeia significante diacrônica: esse é um paradoxo propriamente lacaniano, no qual uma estrutura sincrônica paradigmática só existe na medida em que é encarnada no Um, num elemento singular e excepcional. (Zizek, 1992, p. 102)

Esse "elemento singular e excepcional" aqui é entendido como sendo o que no plano subjetivo concerne ao que Lacan chama de traço unário e que aqui supõe-se estreitamente vinculado, quando dos efeitos do discurso construtivista sobre o sujeito, ao significante-mestre dessa montagem coletiva. Digamos que esse significante-mestre penetra justamente no furo que o traço unário deixa em seu rasto - um assunto que ainda será melhor desenvolvido. Supõe-se aqui que essa seja a via pela qual o Outro construtivista incide sobre o sujeito, seduzindo-o. Concebida essa incidência desse modo, pode-se dizer que o Um que condensa a montagem coletiva, confunde-se com o Um do traço unário, que é um elemento desconhecido do próprio sujeito, o elemento significante que na verdade o funda.

A palavra bateria é bem sugestiva a respeito do papel que cabe atribuir ao Outro no que se refere à sua incidência sobre a posição do sujeito, do sujeito educador. A bateria significante é a fonte que o nutre, mas também, como já foi insinuado, ela como que marca os seus passos, ou melhor, a sua atuação. $E$ a imagem de uma bateria típica de uma escola de samba pode também ilustrar de que se trata: os mesmos instrumentos de percussão, com suas batidas e timbres particulares, com os tempos que eles marcam, poderiam ser tomados como algo semelhante aos pontos de ressonância. Na bateria, o que cada instrumento produz, sempre se relaciona com os demais instrumentos, todos estão aí para produzir um efeito de conjunto. E o que resulta dessa particular combinação, aliada a seu samba-enredo, pauta os floreios de seus passistas, à semelhança do que ocorre com o educador cuja atuação é pautada por determinado discurso, 
neste caso pelos pontos de ressonância do discurso construtivista, de acordo com a "bateria significante" que ele próprio arquitetou. Digamos que a bateria, em ambos os casos, faz a "alegria" desses "passistas".

A bateria significante constitui então o Outro que pauta os passos do sujeito, que pauta a sua atuação, é o que nele e através dele "fala". Esse Outro é mesmo um Sujeito, que comanda o sujeito, este antes de mais nada um objeto do primeiro. Isso é o que cabe atribuir ao que é da ordem da fantasia ou do fantasma fundamental do sujeito, de acordo com as formulações de Lacan. Em outras palavras, os nossos fantasmas são os que em última instância definem o nosso desejo. Fantasmas que "estão" no discurso, que dele resultam e nele circulam. Esse registro fantasmático, relativo ao terreno escorregadio sobre o qual assentamos as nossas convicções, é um produto do Outro, faz parte dele e é o que principalmente deve ser considerado quando a questão é sobre o que orienta a ação do professor. O que orienta a sua ação encontra as suas raízes na ordem própria dos seus fantasmas, o que não significa que ele seja uma espécie de títere em face deles. Mas sim que, o que ele pensa, fala, faz ou deixa de fazer, encontra-se amarrado num registro que ele próprio precisa considerar e até mesmo trabalhar para que algo da ordem da sua autonomia se torne possível. Ou seja, o educador precisa considerar o que está se configurando no campo do Outro, no campo do discurso, que extrapola a sua singularidade e as suas conscientes convicções.

Em suma, o Outro do sujeito é primordialmente o que nele "fala". E "fala", se o referirmos ao discurso construtivista, em e pelos seus pontos de ressonância, nos quais e através dos quais articula-se a dimensão fantasmática desse discurso. Essa "fala", se considerada como um todo, como montagem sincrônica, é o que incide sobre a cadeia significante diacrônica fazendo um corte, de modo retroativo, em algum ponto que Lacan chama de pontuação, que é onde "a significação se constitui como produto acabado" (1960, p. 820). Em outras palavras, a bateria significante marca o sujeito incidindo em algum ponto da cadeia significante diacrônica, por meio de um vetor que passa pelo que é da ordem dos seus fantasmas. Nessa escansão, que sempre se repete de uma maneira diferente, define-se a posição do sujeito, do sujeito que realiza os seus floreios, a sua encenação, comandado desde um lugar que lhe é vedado, uma 
outra cena, que é onde acontecem os atos que realmente pesam e definem essa atuação. Esse lugar-limite é o lugar da verdade, da sua verdade, do enigma que define a sua posição e regula a sua atuação.

\section{O lugar da verdade}

No caso de um discurso estruturado a partir de determinado ponto de arremate, com os pontos de ressonância que o definem, o que é da ordem da (sua) verdade, da verdade do sujeito por ele e nele implicado, concerne a seus limites, que é o lugar por onde escoa tudo o que é rejeitado e de onde também procede o que o sustenta. A esse respeito é ilustrativa a trajetória das escolas alternativas paulistanas que se tornaram construtivistas, logo após a inflexão que ocorreu precisamente no momento em que o significante-mestre limites ecoava em todas essas instituições educacionais. Esse "momento dos limites" corresponde a um período de intensas discussões, sendo nelas questionadas várias facetas da experiência presente e passada. Nesse momento não havia surgido ainda um novo discurso. Digamos que a antiga montagem discursiva, tendo o termo alternativa como significante-mestre, estava em crescente processo de decomposição, pois as suas costuras estavam sendo desamarradas. Ao mesmo tempo, outros laços nasciam, outros pontos de ressonância começavam a se afirmar. Por tudo isso o campo próprio desses discursos alternativos tornou-se em extremo ambíguo. ${ }^{21}$

Como já vimos, essa montagem coletiva em decomposição pode ser chamada de Outro. Ela constituía uma rede simbólica sobredeterminada cujos limites eram definidos por seus pontos de basta, sobretudo por aquele que amarrava toda a cadeia e que a continha: o significante alternativa ou escola alternativa. Quando esse Outro alternativo começa a ser corroído, exatamente no momento em que os então chamados fantasmas estavam em causa "exorcizados" inclusive com a ajuda de analistas então contratados por essas instituições - , encontrar um novo nome, um novo discurso, um novo significantemestre, tornou-se uma questão vital. Uma questão resolvida com um novo nome e com um discurso depurado do que no "momento dos limites" havia sido rejeitado, sendo daí em mais esquecido nesse impreciso e ambíguo lugar.

\footnotetext{
${ }^{21}$ A esse respeito, veja-se o capítulo "Limites", em Revah (1994).
} 
Nesse período, esses discursos educacionais alternativos ficaram como que num certo compasso de espera, uma espera carregada de ambiguidades, afetivamente carregada; ao que tudo indica e principalmente com o afeto que Lacan coloca no centro de todos os demais, o afeto fundamental, "aquele em torno do qual tudo se ordena": a angústia (1969-1970, p. 136). Para esclarecer brevemente esse ponto, tomemos aqui o modo como Freud a define num de seus escritos: a angústia como uma das reações defensivas do Eu em face de desejos reprimidos que adquiriram grande energia (1909, p. 1551). E situemos essa idéia no plano que melhor parece caracterizar esse afeto: o da sua relação com o desejo na dimensão que the é própria, isto é, a da falta, que é o modo como Lacan concebe $o$ desejo. Nos processos acima referidos, a intensa carga afetiva neles implicada parece relacionada, antes de mais nada, com o próprio desejo em sua dimensão de falta, de vazio, de abertura de possibilidades múltiplas que simultaneamente acenavam com um abismo, como toda transformação que resulta em uma mudança na posição subjetiva. Digamos que o que estava em jogo nesses processos era a sobrevivência de determinadas experiências e também a sua transformação. De modo que os seus protagonistas confrontavamse com algo que era da ordem da morte, no sentido de morte simbólica, implicando portanto uma profunda transformação no discurso, ou seja, implicando a dissolução do Outro que até então estabelecia o norte dessas experiências educacionais - um Outro relacionado sobretudo com o seu caráter de experiências proibidas. ${ }^{22} \mathrm{E}$ o que aí concernia à morte era precisamente o que pulsionava esses processos, o que trazia a dimensão da vida e fazia circular a palavra. Daí terem sido tantas as discussões e questionamentos. ${ }^{23}$

A intensa carga afetiva que é própria desses processos concerne também ao que nesse momento retorna, relativo a tudo o que nessas experiências havia sido excluído, como as séries discursivas atadas ao significante-mestre escola tradicional e a outros significantes que então alavancaram e trouxeram à tona o significante moderno. Esse retorno efetiva-se no momento em que estava se diluindo o ponto onde confluía tudo o que era rejeitado, ou seja, a ditadura militar. Conforme esse retorno se consolida, conforme essa transição se processa, tendo

\footnotetext{
${ }^{22}$ Veja-se, em Revah (1994), o capítulo "A experiência 'proibida"”.

${ }^{23} \mathrm{O}$ que acima está sendo afirmado não é mais do que colocar na base da própria vida a pulsão de morte, como postula Lacan.
} 
como pano de fundo conflitos de toda ordem (pessoais e profissionais), inicia-se um amplo processo de racionalização da experiência, por vezes intenso, tanto do ponto de vista pedagógico como administrativo. Desse processo resulta um outro e novo discurso, afetivamente carregado em seus pontos de ressonância, que é outra das dimensões que caracteriza esses pontos. Nesse período, um novo discurso é o que se procura de modo intencional, em particular um discurso que una, que integre, que gere adesão — um discurso "moderno".

O delineamento de "um discurso que une", como foi comentado a respeito do processo da Escola da Vila, ${ }^{24}$ implica o desenho de "uma imagem" que crie a unidade que está faltando, uma imagem com a qual procura-se responder à demanda do Outro pautado pelo mercado, da escola "séria e moderna" que educadores e pais de alunos de inúmeras escolas privadas então almejam. Podese dizer que essa imagem, alçada à posição de ideal, retroage sobre a própria história, unificando-a, ligando o que até então encontrava-se frouxamente amarrado. Em outras palavras, a configuração dessa imagem corresponde ao ponto em que uma certeza emerge, suprimindo boa parte das ambiguidades que até então como que mantinham o discurso em suspenso. Nessa imagem, que enquanto ideal indica o que tem de ser transformado, é onde também conflui o significante construtivismo, que não raro torna-se o carro chefe dos então prestigiados "projetos pedagógicos": o "todo coerente" que tudo ou quase tudo promete obturar, pelo menos no que se refere ao âmbito escolar.

A certeza ou certezas que emergem com esse novo ponto de basta, com esse novo discurso, pode-se dizer que constituem a sua verdade, embora não exatamente pelo que à primeira vista poderia se supor. Os pontos de ressonância são os lugares onde esse discurso finca os seus pés, onde ele constrói os seus pilares, são os lugares da certeza, onde o Outro como que fecha o seu circuito. Entre outras coisas, isso significa que através desses pontos e com as costuras que eles supõem fixa-se determinado passado ou passados, em particular por intermédio do significante que enlaça e constitui o ponto de arremate de toda a cadeia significante. Em função dessa particular operação de basteamento, um determinado sujeito pode encontrar um passado que na verdade é criado no e

\footnotetext{
${ }^{24}$ Ver o último item do primeiro capítulo.
} 
pelo presente. Em outras palavras, essa certeza, esse passado, é uma construção discursiva que resulta do efeito de retroversão próprio dessa operação de costura. Em virtude desse efeito, o sujeito tem a ilusão de ser ou - o que é o mesmo transforma-se em cada etapa em aquilo que supostamente já era (Lacan, 1960, p. 815). Como afirma Zizek (1992, p. 103), o efeito retroativo "é percebido como algo que sempre existiu, desde o começo". É desse modo que uma professora pode se auto-perceber como alguém que tinha uma prática espontaneísta, portanto alguém que em certo momento da sua trajetória estava no ponto inicial do construtivismo e que agora, porém, é construtivista. Ou então, uma prática tradicional, portanto fora do campo do construtivismo, digamos que no lado oposto. Mas é sempre o construtivismo que estabelece a medida, é ele o discurso padrão, o discurso certo, o Outro que baliza toda e qualquer posição do sujeito e as significações aí implicadas e retroativamente fixadas, por meio de uma operação ideológica que transformou em natural e dado o que na verdade foi o resultado de uma operação discursiva.

Através dos pontos de ressonância podemos encontrar então, não a certeza, mas sim o que constitui propriamente a dimensão da verdade. Conforme esses nós são desatados, pela única forma possível, isto é, pela criação de outros nós, de outro discurso, como este, que está nestas páginas, aqueles pontos começam a revelar as operações que os constituíram, os limites que necessariamente todo discurso tem de desprezar, evidenciando tratar-se de uma construção discursiva sobredeterminada pelas costuras e pontos que se tornaram tais em razão de injunções diversas. ${ }^{25}$ Essa é a "leitura sintomal" que do discurso construtivista pode ser feita. Um discurso cuja dimensão ideológica é tanto maior quanto mais segue a deriva do ideal de unidade que muitos colocam em seu horizonte, quanto mais cristaliza e torna cristalinos os seus pontos de ressonância, quanto mais se torna um Outro fechado sobre si mesmo; um Outro onde seus pontos frágeis desaparecem, onde as questões elementares e mais fundamentais se extinguem, onde a dimensão do enigma não mais existe; um Outro sem aberturas, a não ser as que ele próprio antecipa e desse modo fixa; um Outro, enfim, onde o que é da ordem do imaginário assume o lugar de comando.

\footnotetext{
${ }^{25}$ Nessa formulação, há alguns elementos próprios do que Zizek chama de ideologia (1992, p. 154).
} 
Para avançar nas questões teóricas acima implicadas, relativas ao lugar da verdade, neste último item serão desenvolvidos alguns pontos, a começar com o que está sendo chamado de ideológico.

\subsection{O discurso transparente}

O que aqui é chamado de ideológico em parte corresponde ao que Sercovich chama de discurso transparente. Para o autor, são transparentes os discursos cuja função imaginária prevalece, uma função por ele vinculada primeiramente ao campo das imagens e à capacidade de um discurso remitir-nos "em forma direta à realidade", de criar certa "sensação de realidade" ou "ilusão referencial" (1977, p. 30). Essa função imaginária, concebida desse modo, é na verdade inerente a todo discurso, é o que faz com que à primeira vista seja verossímil, como é próprio dos textos jornalísticos. Nesse caso, portanto, o imaginário não corresponde ao que é inverossímil, o qual, aliás, pode constituir uma característica de um discurso ideológico, como sugere o próprio Sercovich (p.38). Neste estudo, porém, o ideológico está sendo entendido antes de mais nada referido aos discursos onde predomina o imaginário, tal como Lacan o concebe e sobre o qual Sercovich apoia boa parte da sua argumentação. Como função do discurso, o imaginário pode ser pensado tanto no âmbito da sua produção quanto relacionado com os seus efeitos, dentre os quais devemos incluir a "sensação de realidade" referida por Sercovich. Essa ilusão, aliás, é o pão nosso de cada dia, é uma ilusão necessária à vida, ou seja, vivemos mergulhados na ideologia, no campo próprio do imaginário. ${ }^{26}$

Além da "relação de verossimilhança" que Sercovich destaca como sendo um dos efeitos do discurso transparente, da "transparência semiótica", refere-se também à "ilusão da autoria", que consiste na certeza que o sujeito tem ao pensar que é "o produtor autônomo e autodeterminado de sua produção semiótica" (p.38). ${ }^{27}$ A transparência semiótica resulta de um esquecimento que se opera no sujeito e que está relacionado com o que fica oculto: as condições de produção do discurso (pp.34 e 39). Em sua argumentação, essas condições remetem para os "interesses sociais"(p.44) e para as práticas sociais, que são "eminentemente"

\footnotetext{
${ }^{26}$ No que se refere à relação ideologia/imaginário, Sercovich entende que a "relação imaginária" é uma parte da "relação ideológica" (1977, p. 44).

${ }^{27}$ Todas as traduções dos trechos reproduzidos do texto de Sercovich são da minha autoria.
} 
discursivas (p.43). Isto último implica que "o imaginário discursivo constitui uma dimensão de toda prática social”, não sendo possível considerar o ideológico como "uma 'instância' ou 'nível' na tópica infra-superestrutura" (p.43), portanto como algo separado dessas práticas.

Segundo Sercovich, a transparência refere-se à relação entre um discurso e um sujeito (p.37), sendo o discurso o elemento aí dominante: o "discurso imaginário constitui o sujeito semiótico (determina suas representações) produzindo a 'realidade' (uma determinada realidade)" (p.36); "o imaginário, em suas múltiplas manifestações, constitui o sujeito: as imagens conformam a subjetividade" (p.48). O ideológico é situado, justamente, nessa relação entre o discurso e o sujeito: "é possível definir um processo ideológico como um complexo de relações interativas entre determinadas formações semióticas e o imaginário individiual" (p.44).

Segundo Sercovich, o "âmbito psíquico" é o lugar "por excelência" do discurso transparente, cuja origem deve ser reconhecida no desejo (p.48). Nesse plano do desejo, ele destaca o papel do fantasma e o lugar que aí também cabe atribuir às imagens: "o desejo se significa através de complexos sistemas semióticos compostos por imagens, e não deriva da relação com um objeto real senão com o fantasma" (ibidem). As condições de produção do discurso e da sua dimensão imaginária, que ficam ocultas para o sujeito, são aí remetidas à dimensão subjetiva, em particular a esse registro dos fantasmas e ao processo de constituição subjetiva. Nesse âmbito, portanto, o autor também situa a fonte dos efeitos ideológicos do discurso, a origem da transparência semiótica: "A fantasmática submerge o sujeito na ilusão da 'realidade' vivenciada, como as imagens e o efeito de transparência referem em forma direta à 'realidade'” (p.49).

Enfim, ao tratar das relações ideológicas, dos processos ideológicos, Sercovich considera basicamente dois âmbitos: os discursos transparentes e a fantasmática subjetiva. Dois âmbitos que assim relaciona:

Os discursos transparentes em uma formação social (...) determinam a natureza ou a forma da fantasmática subjetiva, estabelecendo uma conexão permanente entre as imagens discursivas e a estruturação dos fantasmas. (p.53) 
Esses dois âmbitos concernem, em síntese, ao discurso e ao sujeito, sendo o primeiro determinante em relação ao segundo. Essa determinação remete para o âmbito do inconsciente e sempre envolve o "componente afetivo" dos fantasmas (p.53), pois é "inconcebível a não ressonância afetiva de um discurso" (p.73). E é por essa via do inconsciente e dos fantasmas que ele concebe o modo como um determinado discurso captura um sujeito, o modo como se dão os processos de adesão.

\subsection{Compreensão, aceitação, adesão}

Esses processos estão relacionados com as formas de inscrição do discurso no sujeito, que sempre são múltiplas e variadas, "segundo os lugares do sujeito no sistema social, os efeitos de atribuição de sentido aos mesmos discursos e, em consequência, o que deles se compreenda ou se aceite" (p.74). Essa inscrição dos discursos no sujeito também é concebida por Sercovich como sendo sempre de caráter duplo, na medida em que é consciente e inconsciente (p.72).

Ao tratar dessa questão, Sercovich diferencia compreensão, aceitação (ou conformidade) e adesão, sugerindo que as diferenças entre esses termos, junto com os termos opostos que eles supõem, "possibilitam uma extensa combinatória que poderia dar conta da ação de numerosos discursos e de sua eficácia em função de determinados interesses sociais" (pp.72-3). Em outras palavras, "as oposições compreensão/incompreensão, acordo/desacordo e adesão/rechaço são apenas os pontos extremos de vetores contínuos que contém toda uma gama de lugares intermediários" (p.74). É possível, afirma o autor, aderir a um discurso sem compreendê-lo ou sem aceitá-lo; pode-se também aderir, compreendê-lo e não aceitá-lo (p.72). Por exemplo, pode-se criticar certo aspecto ou aspectos importantes do construtivismo e nessa medida não aceitá-lo, compreender teoricamente esses mesmos aspectos e paradoxalmente aderir a esses mesmos pontos (pontos significantes), sem propriamente aperceber-se disso. A compreensão e a aceitação estão relacionadas com o que é da ordem do eu, enquanto a adesão concerne ao registro dos fantasmas e do inconsciente (p.71).

Neste estudo, postula-se que determinado sujeito adere a um discurso em virtude dos cortes feitos pelos pontos de ressonância, cortes que incidem, 
precisamente, no plano que Sercovich destaca. Nesse plano, ele coloca em relevo o "componente pulsional" dos fantasmas: a adesão designa "a correlação entre certos elementos de um discurso e o componente pulsional dos fantasmas" (p.72). A adesão, então, é por ele remetida ao âmbito das pulsões. Digamos que nesse âmbito pode ser situado o que Zizek chama de "núcleo do gozo", o "gozo préideológico estruturado na fantasia", que é o que principalmente deve ser considerado quando está em foco a dimensão ideológica de um discurso e a produção da sua hegemonia. Além disso, na base da adesão do sujeito aos discursos que o capturam, Sercovich coloca os processos de identificação (p.77). Capturar, para ele, significa "pré-formar o ideal do eu", à semelhança do que se postula neste estudo (ibidem). Supõe-se aqui que os pontos de ressonância fazem justamente isso: eles penetram no ideal do eu, atravessam-no e deixam no sujeito algum traço, alguma marca. É desse modo que o capturam, que produzem a sua adesão.

A análise de Sercovich assenta-se sobre um tipo de relação entre o discurso e o sujeito semelhante à que Lacan postula ao tratar do processo de constituição do sujeito, isto é, uma relação entre o sujeito e o Outro. Para Lacan, essa relação é circular e dissimétrica. Nela, o elemento determinante é o Outro, a ordem simbólica, o campo da linguagem e do discurso (Lacan, 1964, p. 196). Para aprofundar essa questão e avançar na conceitualização desse registro do imaginário - fundamental para o que está sendo chamado de ideologia, para o delineamento do processo pelo qual um determinado discurso captura o sujeito e para assim nos aproximarmos do lugar da verdade —, veremos sucintamente como Lacan concebe esse registro do imaginário quando trata da sua constituição no próprio sujeito.

\subsection{Eu ideal e Ideal do eu}

Lacan situa a constituição desse registro do imaginário no primeiro tempo do Édipo, mais precisamente no ponto em que Freud localiza o narcisismo referido ao eu, ao ego. Para ilustrar e explicar o processo implicado nesse primeiro tempo, Lacan recorre à experiência que a criança pequena atravessa quando pela primeira vez reconhece a sua imagem num espelho, a partir dos seis meses de idade. Ainda "mergulhado na impotência motora e na dependência da 
amamentação" (Lacan, 1949, p. 97), nesse estádio do espelho o infans precipitase nessa imagem como num recipiente que o formata. Essa imagem antecipa a unidade que ainda não possui, pois é apenas um "corpo despedaçado" cujo futuro, no entanto, é prefigurado por essa forma à qual se agarra e na qual se articula a promessa de ser alguém, isto é, a possibilidade de um dia dizer eu e circular "entre os outros sentindo-se UM, falando como se fosse UM" (Lajonquière, 1996, p. 163), mesmo que essa unidade não passe de uma ilusão. Para que o eu se constitua é preciso que o infans se identifique com essa imagem que um outro recorta com as suas palavras e o seu olhar, uma imagem idealizada, narcísica, o eu ideal. Nessa exterioridade, nessa imagem que está "lá", fora, no espelho, o infans encontra a sua unidade e aí consegue se reconhecer, mas nesse mesmo movimento o sujeito fica para sempre nas sombras, desconhecido, excêntrico ao eu. ${ }^{28}$ Eis, em suma, a alienação fundamental que está na base dessa primeira matriz do sujeito e sobre a qual se darão todas as identificações subsequentes. A ilusão que ela engendra, própria da experiência especular, está no âmago desse registro chamado de imaginário, relativo ao eu imaginário e à imagem ideal de si mesmo (o eu ideal) e, ainda, aos outros objetos que se afiguram no campo que o sujeito recorta e instaura com seu discurso.

O primeiro tempo, bem como o próprio complexo de Édipo, é uma reconceitualização feita por Lacan a partir da formulação freudiana do Édipo. Lacan retoma o Édipo sob um novo eixo, que incorpora o seu viés original, relativo à construção da diferença sexual.29 O eixo de Lacan é a questão do desejo, a sexualidade tornando-se a via pela qual o sujeito procurará responder justamente a essa questão: o que me falta? O que nada mais é do que uma pergunta sobre uma falta entrevista no Outro/outro, pois o que no início o infans deseja é o desejo da mãe ou de quem vier ocupar esse lugar. Por isso, essa mesma pergunta também pode ser assim formulada: o que o outro quer de mim?

\footnotetext{
${ }^{28}$ Lacan refere-se à experiência especular em vários de seus seminários e escritos. Veja-se uma dessas reflexões, na qual ficam em evidência algumas das idéias acima expostas:

"O corpo despedaçado encontra sua unidade na imagem do outro, que é sua própria imagem antecipada - situação dual em que se esboça uma relação polar, porém não-simétrica (...)

$\mathrm{O}$ sujeito é ninguém. Ele é decomposto, despedaçado. E ele se bloqueia, é aspirado pela imagem, ao mesmo tempo enganadora e realizado do outro, ou, igualmente, por sua própria imagem especular. Lá, ele encontra sua unidade." (Lacan, 1954-1955, p. 74).

29 Sobre essa reconceitualização do Édipo na teoria lacaniana e a sua relação com a versão freudiana, veja-se: Lajonquière, 1996, pp.193-228.
} 
Num primeiro momento, dos três tempos lógicos delimitados por Lacan, o infans responde a essa falta vislumbrada no outro com o seu próprio ser, com o seu próprio corpo, procurando assim preencher o vazio que se anuncia na mãe. Ou seja, o infans torna-se o objeto que promete obturar essa falta, esse desejo da mãe. Como? Identificando-se com a imagem do eu, que está no espelho, isto é, a imagem desejada e projetada pela mãe, o eu ideal.

A dialética do Édipo, porém, o impulsiona em direção a uma outra posição, quando entra em jogo a função paterna e o chamado complexo de castração. A falta então continuará recortada na mãe, mas o falo - o significante da falta desta vez iluminará a figura paterna, deixando a criança sem o brilho que outrora tinha, quando era o falo imaginário da mãe. ${ }^{30}$ Estamos no segundo tempo do Édipo, quando o pai é transformado pela criança no próprio falo, no objeto que a mãe deseja e que simultaneamente interdita o vínculo incestuoso mãe-filho. Em outras palavras, o pai surge na cena primária como aquele que é capaz de preencher o vazio que se instala na mãe, passando a encarnar a própria lei que regula o desejo.

Pouco depois, entretanto, a figura paterna mostra-se igualmente incompleta, submetida ao falo, à lei simbólica, à lei que regula os intercâmbios sociais. Desse modo, já num terceiro e último tempo do Édipo, a falta se recorta sobre o horizonte da figura paterna, remetendo em última instância ao Outro, ao universo simbólico. O pai não é mais o falo, ele apenas tem atributos fálicos. É o tempo em que se constitui o ideal do eu, a instância simbólica que regulará e mediatizará a relação imaginária entre o eu especular e a sua imagem idealizada, o eu ideal, impedindo a sua colagem. $O$ ideal do eu, constituído por um conjunto de traços simbólicos, funciona aí como barreira e também como instância que

\footnotetext{
${ }^{30} \mathrm{O}$ falo é um conceito que foi progressivamente construído por Freud, apesar dele raramente ter usado esse termo. Lacan o retoma e mostra como é prevalente na teoria freudiana (Nasio, 1989, p. 33). O falo, segundo Nasio (1993, p. 31), é o pivô da experiência da castração no desenvolvimento da sexualidade humana. Nesse desenvolvimento, o falo inicialmente é o próprio pênis, porque é a parte do corpo que a criança toma como elemento para responder à questão do desejo. Em outras palavras, a "presença ou ausência do órgão genital masculino apenas se oferece como uma resposta contingente a uma pergunta inevitavelmente necessária acerca do desejo materno, ou a falta no Outro" (Lajonquière, 1996, p. 202). O falo portanto não se reduz ao pênis, ele é um conceito que em última instância remete para o significante que, no infans, cava uma falta, engendrando o sujeito do desejo. $O$ falo, enfim, é um significante diretamente vinculado à construção da diferença sexual e concerne também ao chamado traço unário.
} 
orienta o sujeito ao longo da vida: "Esse guia que comanda o sujeito é o ideal do eu" (Lacan, 1953-1954, p. 166).31

Completa-se assim um primeiro circuito do Édipo, do qual resulta um sujeito capaz de falar por si, mas cuja fala encontra-se atrelada ao Outro, ao que neste recorta-se como falta e também como objeto capaz de preenchê-la. Esse é o centro organizador do sujeito, o centro que articula a sua fala e que é sempre excêntrico ao eu, pois está no Outro, na ordem simbólica. A falta portanto está no Outro, o desejo é do Outro, do qual somos radicalmente dependentes. Por isso a conhecida frase de Lacan de que o desejo do sujeito é o desejo do Outro.

Esse primeiro circuito do Édipo nunca propriamente termina, na mesma medida em que os nossos ideais mudam, implicando em processos de reelaboração subjetiva que passam pela dimensão do inconsciente e pelo registro dos nossos fantasmas. E é por essa via dos ideais que pode ser pensada, tal como Lacan sugere, a integração do sujeito num dado campo sócio-cultural, através do mecanismo que aí entra em jogo e que diz respeito aos processos de identificação, envolvendo as duas instâncias já referidas, o eu ideal e o ideal do eu:

Essa articulação conjunta entre a identificação imaginária e a identificação simbólica, sob o domínio da identificação simbólica, constitui o mecanismo pelo qual o sujeito é integrado num dado campo sóciosimbólico, isto é, pelo qual assume certas "missões", como era perfeitamente claro para Lacan (...) (Zizek, 1992, p. 109)

A definição dessas "missões" que determinado sujeito assume são inseparáveis dos múltiplos discursos que circulam na sociedade, que ele mesmo produz e do qual ele próprio resulta, na mesma medida em que o marcam, em que definem a sua posição, de um modo que em última instância lhe escapa.

Retomemos agora a questão da qual partimos. Afirmar que um discurso é dominado pela dimensão imaginária e que nessa medida se torna ideológico, significa entender que os efeitos que esse discurso produz sobre os sujeitos por ele e nele implicados são no sentido de tornar essa dimensão prevalecente. Em outras palavras, são discursos que tendem a estreitar o campo dos ideais

\footnotetext{
${ }^{31}$ Sobre a constituição do eu ideal e o ideal do eu, veja-se "O conceito de Narcisismo", de Nasio (1989, pp. 45-74).
} 
simbólicos, da instância que faz a mediação necessária para o sujeito não colar na sua imagem ideal, no eu ideal, que é demarcado pelo mesmo discurso que no sujeito deixou alguma inscrição. Um ideal imaginário que vem à tona articulado nos e pelos pontos de ressonância dos discursos que circulam na sociedade, até mesmo em nomes que designam a realidade que eles anunciam. No caso do discurso construtivista não faltam exemplos, temos aí Emilia Ferreiro tornada um messias, como mostra Vieira (1995, p. 57), as "pioneiras do construtivismo", determinada escola privada que é vista como um paradigma de escola construtivista, professoras tradicionais que passaram pelas agruras do "caminho construtivista" e que finalmente chegaram lá, alcançando o tão almejado ideal32, etc. Essas imagens, quando desenhadas sem fissuras, quando criam a ilusão do ideal simbólico realizado, tornam-se semelhantes à imagem com que o infans busca se identificar no espelho, no primeiro tempo do Édipo. Nesse momento, lembremos, ele está na posição de objeto, objeto de um Outro materno que define o seu lugar, que afinal o infans não pode senão ocupar, pelo menos até o momento em que começa a operar o que o tira dessa posição, da qual o infans reluta em sair: o complexo de castração. Esse lugar de alienação primeira prevalece quando no imaginário tende a desaparecer o que nele pode vir a cumprir o papel de ideal simbólico, de instância que impede a colagem. Digamos que o que faz com que isso ocorra é o que na imagem aparece borrado, é tudo o que de vez em quando surge e distorce o que parecia tão belo, tão perfeito, tão claro. O ideal do eu é como se criasse uma mancha na imagem especular, uma mancha cujo lugar não conseguimos precisar.

\subsection{Uma mancha na imagem especular}

Para esclarecer esse ponto, é necessário desenvolver certa dimensão implicada na distinção feita entre o eu ideal e o ideal de eu, isto é, entre a identificação imaginária e a identificação simbólica. Vejamos o que Zizek afirma a esse respeito:

(...) a identificação imaginária é a identificação com a imagem na qual nos parecemos passíveis de ser amados, representando essa imagem "o que gostaríamos de ser", ao passo que a identificação simbólica se efetua em relação ao próprio lugar de onde somos observados, de onde nos olhamos

\footnotetext{
${ }^{32}$ Cf. "As agruras do caminho construtivista", Nova Escola, n 65, abr./93, pp. 8-14.
} 
de modo a parecermos amáveis a nós mesmos, merecedores de amor. (1992, p. 104)

Esse lugar do olhar é o lugar onde deve ser situado o Outro, para o qual no fim das contas fazemos a nossa encenação diária, a nossa história; é para esse olhar do Outro que representamos certos papéis, que fazemos certas escolhas. O que demarcamos então como imagem idealizada, como aquilo que gostaríamos de ser, já se encontra de antemão subordinado à identificação simbólica. Como afirma Lacan, o eu ideal é essa imagem que se fixa "desde o ponto em que o sujeito se detém como ideal do eu" (1960, p. 823). Em outras palavras, a identificação simbólica, que é "o ponto de onde somos observados", "a instância através da qual nós nos observamos e nos julgamos", é o que "domina e determina a imagem, a forma imaginária em que parecemos dignos de amor a nós mesmos" (Zizek, 1992, p. 107). Sempre então fazemos uma encenação para um Outro que nós mesmos inconscientemente criamos e com o qual primeiramente nos identificamos: "a identificação imaginária é sempre uma identificação para um certo olhar do Outro" (Zizek, 1992, p. 105). E esse é o mecanismo através do qual nos integramos num determinado campo sócio-cultural. No caso de um educador construtivista, pode-se dizer que ele assume certos papéis, desenvolve o seu trabalho de certa maneira, concebe a escola, os seus alunos e a educação de determinada forma porque identifica-se com certo discurso, não apenas no plano consciente, mas também no plano onde define-se o essencial de seu ser, no plano do desejo. Identifica-se com o que no discurso remete para a dimensão própria da identificação simbólica, do Outro que escapa a qualquer tentativa de apreensão definitiva. É a dimensão que pode ser pensada como uma mancha e que, na conceitualização de Lacan, concerne ao olhar, que deve ser situado na própria imagem:

O olhar indica o ponto do objeto (da imagem) a partir do qual o sujeito que o vê já é olhado, ou seja, é o objeto que me olha. O olhar, longe de assegurar a presença-em-si do sujeito e de sua visão, funciona, pois, como uma mancha, um ponto na imagem que perturba sua visibilidade transparente e introduz uma distância irredutível em minha relação com a imagem: nunca posso ver a imagem no ponto de onde ela me olha, isto é, a visão e o olhar são essencialmente dissimétricos. O olhar, enquanto objeto, é uma mancha que me impede de olhar a imagem a partir de um distância "objetiva" e segura, enquadrando-a como uma coisa à disposição do domínio da minha visão (...) (Zizek, 1992, p. 151) 
A mancha então corresponde ao lugar de onde a própria imagem nos olha, de onde o Outro nos olha, o Outro que nunca sabemos ao certo onde está, nunca sabemos o que ele afinal quer. Em outras palavras, quando essa voz que vem do Outro nos interpela33, quando os pontos de ressonância de um discurso qualquer nos atingem porque algo em nós entrou com eles em sintonia, sempre alguma "coisa" escorrega, desliza nas entrelinhas. Esse problema da interpelação pode ser pensado a partir do próprio mecanismo de identificação:

(...) esse movimento circular entre a identificação simbólica e a identificação imaginária, nunca se dá sem um certo resto. Depois de cada basteamento da cadeia significante, que fixa retroativamente seu sentido, resta sempre um certo hiato, uma abertura que se expressa (...) pela famosa pergunta "Che vuoi?" - "Você está me dizendo isso, mas que quer fazer, aonde quer chegar?" (Zizek, 1992, p. 109)34

Nessa abertura entre o enunciado e a enunciação, entre o que alguém diz e o que quer dizer com isso, deve ser situado o que concerne ao desejo e à sua diferença com a demanda:

(...) no lugar do "Por que você está me dizendo isso?", que devemos situar o desejo (...) em sua diferença da demanda: você está me pedindo algo, mas o que quer, realmente? A que está visando através desse pedido? (ibidem)

\subsection{A fantasia como significação absoluta}

Nesse abismo da interpelação, do discurso do Outro que nos interpela com suas demandas, é que surge o lugar próprio das nossas fantasias ou dos nossos fantasmas. Com eles buscamos preencher o vazio criado justamente por aquela pergunta:

A fantasia funciona como uma construção, uma trama imaginária que preenche o vazio, a abertura deixada pelo desejo do Outro: ao nos dar uma resposta clara à pergunta "que quer o Outro?", ela nos permite escapar da situação insuportável e sem saída em que o Outro quer algo de nós, mas na qual, ao mesmo tempo, somos incapazes de traduzir esse

\footnotetext{
${ }^{33}$ A voz também pode ser concebida como o olhar, da forma acima delineada. A voz, como o olhar, fica do lado do objeto e é também uma espécie de mancha: "o mesmo acontece com a voz como objeto: essa voz, a voz do supereu, por exemplo, que se dirige a mim sem estar ligada a nenhum esteio particular, que flutua livremente em algum intervalo aterrorizante, funciona também como uma mancha cuja presença inerte incomoda como um corpo estranho e me impede de realizar minha própria identidade" (Zizek, 1992, pp. 151-2).

${ }^{34}$ Cf. Lacan, 1960, p. 829.
} 
desejo do Outro numa interpelação positiva, numa missão com que possamos nos identificar. (Zizek, 1992, p. 112)

A fantasia cumpre no psiquismo uma função de "significação absoluta" (Lacan, 1960, p. 830), pois o desejo, de onde tudo resulta no que se refere à ordem humana, é regulado a partir da fantasia (Lacan, 1960, p. 831).35 Como afirma Zizek (1992, pp. 115-6), a fantasia "fornece as coordenadas de nosso desejo, isto é, constrói o contexto que nos permite desejar algo". Ademais, enquanto resposta àquela pergunta, a fantasia oculta precisamente o vazio, a inexistência de uma resposta última, definitiva. E desse modo, protege-nos em face do próprio desejo, do desejo entendido em sua dimensão absoluta, isto é, como vazio, como nada. Eis aí o paradoxo sobre o qual estrutura-se a fantasia: o desejo torna-se uma defesa contra o desejo, ou seja, "o desejo estruturado pela fantasia é uma defesa contra o desejo do Outro, contra esse desejo 'puro' e transfantasístico (isto é, a pulsão de morte em sua forma pura)" (Zizek, 1992, p. 116). Também podemos dizer que a fantasia é uma defesa que nos protege para não chegarmos perto demais da "coisa", do objeto ao mesmo tempo impossível e proibido, um objeto que em última instância remete à relação primordial mãe-filho, correspondendo portanto a um desejo incestuoso. A fantasia é uma barreira em face do que na psicanálise é também chamado de real, distinto do registro do imaginário, mas que diante do que é impossível, de uma imagem una, perfeita, com esse registro tende a se confundir.

Embora na fantasia seja erigida uma espécie de barreira que impede o eu imaginário de grudar na sua imagem ideal, ela não anula a dimensão da ilusão necessária à vida. Na fantasia, sempre nos iludimos com a possibilidade de preencher o vazio, de apreender o real, de alcançar uma imagem perfeita, plena, de realizar enfim o nosso desejo, a plenitude que nos tornaria felizes e que, paradoxalmente, anularia o desejo, ou seja, o próprio sujeito. Eis aí a dimensão da morte implicada na própria vida, e na sua raiz: o que nos pulsiona na vida é a própria pulsão de morte.

\footnotetext{
${ }^{35}$ Embora o termo fantasia ou a expressão lógica da fantasia correspondam à tradução para o português desse registro que, para Lacan, funciona como significação absoluta, sendo as fantasias (no plural) produções nele enraizadas, em várias traduções dos textos de Lacan e em textos de psicanalistas que desdobram as suas formulações usam-se as expressões lógica do fantasma, fantasma fundamental ou simplesmente fantasma referidas àquele registro e fantasmas (no plural) como equivalente a fantasias. Neste trabalho não se pretende discutir essas diferenças e ambos termos serão aqui utilizados.
} 
A realização do desejo é o que Lacan chama de gozo, que não deve ser associado ao "prazer orgástico", como nos alerta Nasio (1993, p. 25), embora seja próprio da ordem pulsional. Ele corresponde a um estado de felicidade absoluta, ao desejo plenamente satisfeito. Tampouco deve-se confundir gozo com prazer. No prazer, como afirma Nasio, "trata-se de uma diminuição da tensão psíquica, no sentido do repouso e da distensão. O gozo, por sua vez, consiste numa manutenção ou num vivo aumento da tensão"(p.40). Por isso é possível dizer que, no caminho do desejo em direção ao gozo, o prazer se interpõe cortando-o, diminuindo a tensão, levando desse modo à reiteração do ciclo36. O gozo, portanto, nunca é propriamente alcançado, é um espécie de miragem. Por isso a idéia de um gozo sempre insuficiente, digamos que sempre gozamos pouco e o desejo só se realiza de maneira parcial (Nasio, 1993, p. 35). ${ }^{37}$

Nunca alcançamos o estado de gozo pleno porque o objeto capaz de preencher o que falta sempre nos escapa. Em isso reside o que gera 0 permanente deslocamento metonímico e metafórico da cadeia significante, ou seja, o seu movimento pode ser atribuído ao objeto que o causa e que Lacan chama de objeto a, o objeto causa do desejo. Esse objeto perdido, cuja procedência deve ser remetida ao primeiro circuito do Édipo, é recortado pelo mesmo movimento que recorta a falta, que cria o vazio que circula na cadeia significante. Esse lugar vazio atrai tudo o que no discurso resta, tudo o que sobra, os seus dejetos, o resto que mancha a nossa imagem narcísica e que nos obriga a fazer circular a palavra, a envolver-nos nas tentativas sempre frustradas de fechar o circuito do discurso ou de elaborar respostas definitivas. Afinal, como afirma Lacan, sempre existirá um significante que ficará fora do conjunto, o "menos um" que não pode ser integrado na rede simbólica. ${ }^{38}$

Relacionado ao sujeito, esse significante em falta é um significante-mestre, o S1 de uma cadeia S2, um significante que concerne ao furo que existe na

\footnotetext{
${ }^{36}$ Essa idéia foi expressa por Alfredo Jerusalinsky num seminário em São Paulo, em 2000. E é o que Lacan parcialmente sugere na seguinte passagem: "o que o princípio do prazer mantém é o limite em relação ao gozo" (Lacan, 1969-1970, p. 44).

${ }^{37}$ Lacan distingue três tipos de gozo: o gozo pleno ou máximo (gozo do Outro), na verdade uma impossibilidade; e duas formas de gozar pouco ou parcialmente, ou seja, do neurótico realizar parcialmente seu desejo, em torno do seu sintoma (gozo fálico) e da fantasia (mais-gozar ou maisde-gozar). Cf. Nasio, 1993, p.35.

${ }^{38}$ Cf. Lacan, 1966-1967, seminário do 23/11/66; 1960, p. 837.
} 
imagem e que não conseguimos precisar onde está. Nesse caso, o S1 corresponde ao que Lacan chama de traço unário, que é um traço singular, relativo portanto a determinado sujeito: é o traço "que se distingue ao retomarmos um a um cada significante de uma história" (Nasio, 1989, p. 114), é o que nessa história insiste, repetindo-se sempre de uma maneira diferente.39 Nesse traço, desconhecido do eu especular, deve ser situado o sujeito do inconsciente: "o sujeito do inconsciente está identificado com um traço, sempre o mesmo, que baliza invariavelmente uma vida significante e, apesar disso, é subtraído dessa vida" (p.115). O "menos um" é portanto o próprio sujeito do desejo, um lugar vazio: "um sujeito a menos na vida de alguém, o traço ausente, exterior a essa vida, e que no entanto a marca para sempre" (ibidem). Segundo Nasio, o traço unário pode ser situado em "contextos" diferentes, dependendo de como seja concebida a identificação simbólica:

Quando essa instância é chamada de traço unário, inscrevemo-la no contexto da repetição dos significantes; quando se chama ideal do eu pensamos nela como referencial constante que regula as identificações sucessivas do eu com as imagens; e por último, quando ela é chamada de falo concebemo-la como o referencial que ordena as diferentes modalidades de satisfação sexual. Em suma, trata-se sempre da mesma instância externa ao conjunto regulado por ela (...) (ibidem) ${ }^{40}$

A identificação simbólica é a identificação do sujeito com algum traço significante do Outro, da ordem simbólica, conforme lembra Zizek (1992, p. 103). Esse traço, que corresponde ao traço unário, é o significante relativo à definição que Lacan estabelece quando põe em foco a relação sujeito-Outro, segundo uma fórmula que já foi apresentada, mas que não foi desenvolvida: "um significante é o que representa um sujeito para um outro significante" (1964, p. 197). Uma fórmula que também pode ser assim expressa: um significante (S1) representa um Sujeito para outro significante (S2), não havendo Sujeito que não seja por um significante e para outro significante ${ }^{41}$. Nessa formulação, representar um Sujeito implica a idéia de que o $\mathrm{S} 1$ engendra um Sujeito ${ }^{42}$, que não corresponde a nenhum sujeito

\footnotetext{
${ }^{39}$ A respeito do termo traço unário, Nasio esclarece o seu sentido: "Traço porque marca cada instante repetido; unário por ser Um que unifica e reúne os diferentes significantes sucessivos" (1989, p. 114).

${ }^{40}$ Apesar de Nasio distinguir o traço unário do ideal do eu e do falo, também chama os últimos de traço unário.

${ }^{41}$ Cf. Lacan, 1966-1967, seminário do 23/11/66, p.2; seminário do 16/11/66, p.7.

42 Ibidem, seminário do 16/11/66, p.7.
} 
de carne e osso, mas a um Sujeito Outro, fantasmático e cindido, no caso dos neuróticos. E aqui estamos no registro onde Lacan situa o fantasma fundamental do sujeito, que é o que em última instância nos governa, na medida em que constitui essa espécie de "significação absoluta" já mencionada. Essa montagem, cuja constituição deve ser remetida à estruturação própria do Édipo, é diferente em cada sujeito, é uma construção singular e no seu interior "têm lugar os efeitos particulares da significação" (Zizek, 1992, p. 120). Efeitos que mudam, que estão relacionados com os processos de identificação do sujeito, com as torções que a sua particular fantasmática sofre em face deles. Relacionado com esse registro fantasmático, o traço unário então é o que marca a posição do sujeito. E, como afirma Zizek, "ele assume forma concreta num nome ou numa missão de que o sujeito se encarrega e/ou que é depositada nele" (1992, p. 103). Um nome, uma missão ou posição que não é mais do que uma resposta ao Outro, que ao ser delimitado pela operação de basteamento situa também a posição do sujeito.

Para esclarecer esse ponto, vejamos novamente a constituição do registro fantasmático sob um outro ângulo. O fantasma, como afirma Jerusalinsky, "se refere à relação impossível do sujeito com o objeto" (1996, p.147), impossível porque não existe objeto que, no real, possa preencher a falta que cinde todo sujeito e que o torna sujeito do desejo. Efeito do próprio funcionamento da linguagem, o desejo é uma espécie de fenda que não é possível suturar, muito embora o sujeito seja movido pela "crença" inconsciente de que isso seja possível. O que o fantasma designa é "a instalação do registro da falta desse objeto" (Jerusalinsky, 1996, p.146). A falta é recortada pelos significantes que definem esse registro fantasmático, configurando ao mesmo tempo o objeto em falta. Ambos, o objeto e a falta, ficam referidos ao Sujeito Outro que aí se configura. E é desse modo que o desejo, o desejo do Outro, a princípio indeterminado, ganha a sua determinação, precisamente com o sujeito ficando na posição de objeto do Outro. O sujeito está aí para preencher uma falta no Outro, é o seu objeto. Por isso é possível dizer que o sujeito é objeto de seus fantasmas, em particular quando alguém não consegue se reconhecer nessa posição própria da fantasia. Nesse reconhecimento deve ser situada a frase de Freud "Wo es war, soll ich werden", isto é, "onde isso estava, deve advir o sujeito" e não o eu, como às vezes é interpretada essa frase. O que o sujeito pode entrever nos seus fantasmas é justamente que é castrado. Essa é a sua verdade, a verdade que pode vislumbrar 
na lógica que impera nesse registro fantasmático, ou seja, em "isso" que escapa do reconhecimento do sujeito. ${ }^{43}$

As "missões" que o sujeito assume, a sua posição subjetiva, os seus sintomas, buscam responder a essa falta recortada no Outro. Ou seja, o sujeito responde a essa falta com o seu próprio corpo, com a sua própria vida. Nesta, o que ele procura é a completude que em última instância visa fechar o circuito do Outro, tornar o Outro completo. Enfim, o que ao sujeito Ihe falta impede-lhe obturar a falta existente no Outro, obturação necessária para o seu gozo, o gozo do Outro, que é o gozo do sujeito - o que é uma outra forma de dizer que o desejo do sujeito é o desejo do Outro.

\subsection{Verdade, saber, ignorância}

Em função desse registro paradoxal que o traço unário instaura, a cadeia significante que estabelece os contornos do Outro não cessa de produzir deslocamentos. Em outras termos, o que é da ordem do traço unário é o que no circuito do desejo mantém as respostas inconclusas, é o que faz como que a cadeia significante continue em movimento, é o que a corta e produz o que no discurso falha, por "razões" que ignoramos. E esse é precisamente o ponto onde a verdade emerge na sua dimensão plena, isto é, como enigma. Ela emerge nos desvios involuntários, no que escapa do nosso controle, nas manifestações que nos surpreendem e cujo sentido não está à vista. Nessas manifestações do inconsciente, que concernem a formações diversas (atos falhos, sonhos, sintomas, etc.), há um saber que se anuncia precisamente aí, na nossa ignorância. Na psicanálise, essa é a via que permite algum contato com a ordem da verdade: "A verdade não é outra coisa senão o que o saber só pode aprender que sabe ao pôr em ação sua ignorância" (Lacan, 1960, p. 812), ou seja, ao pôr em ação o inconsciente, que é "a ordem de um saber que o sujeito veicula, mas ignora" (Nasio, 1993, p. 21).

A instância do traço unário está relacionada com as pontuações do sujeito, com as significações que surgem em cada basteamento da cadeia significante, em cada operação de costura, que sempre implica significantes e discursos que

\footnotetext{
${ }^{43}$ A propósito dessa questão, veja-se: Lacan, 1966-1967, seminário do 11/01/67, p.13.
} 
circulam na sociedade. Os pontos de ressonância desses discursos, portanto, encontram-se aí implicados e podem ser concebidos como vetores que atravessam o sujeito, vetores que o interpelam porque incidem no seu ideal do eu, isto é, na instância do traço unário que regula os processos de identificação e integra o sujeito em determinado campo sócio-cultural. Poder-se-ia dizer, então, que a via inconsciente pela qual o sujeito adere a determinado discurso é pelo furo próprio do ideal do eu, que é onde esses vetores parecem incidir, ou seja, na dimensão propriamente inconsciente, no Um. Essa instância é atravessada com o auxílio da agulha onde esses vetores-linha estão amarrados, a agulha que os comanda, que estabelece a sua direção e que também faz a costura da montagem coletiva correspondente. Essa agulha é o significante-mestre dessa montagem, em nosso caso quase sempre relativa a uma única palavra: construtivismo - uma palavra que faz todo o circuito do desejo, dos múltiplos circuitos que reúne e costura.

Ao fazer esses circuitos, essa particular agulha produz os desvios próprios desse discurso. Esses efeitos podem ser vistos como sintomas, sintomas sociais. E aqui vale lembrar que o sintoma é uma das formações típicas do inconsciente, uma mensagem cifrada, um nó de significações que resulta dos processos de identificação e que é sustentado por toda uma rede de sobredeterminação simbólica que pode ser interpretada, ou seja, é um nó que a princípio poderia ser desatado e os seus efeitos sustados (Zizek, 1992, p. 123). Entretanto, os sintomas nunca podem ser propriamente elididos, pois o sujeito não é nada sem os seus sintomas, ele é de certo modo os seus sintomas. É por meio deles e de outras formações que ele goza, ou melhor, que o inconsciente goza. Ele goza onde a palavra falha e porque dribla o que impede a realização do desejo, ou seja, o que é dribaldo é a castração. ${ }^{44}$ Com os seus sintomas, o sujeito responde a seus fantasmas, que são os que em última instância o sustentam, isto é, são os que criam e mantém os seus sintomas, guardando também as chaves que podem mudá-los. Os sintomas são uma espécie de véu sobre um outro véu, o dos fantasmas, que constituem uma espécie de tela última cuja função é encobrir o real. Os sintomas, à semelhança dos fantasmas, são sempre sociais, mesmo que simultaneamente sejam singulares. Isso pode ser entendido pelo menos de duas

${ }^{44}$ O gozo aí implicado é o que Lacan chama de gozo fálico. Cf. Nasio, 1993, pp. 35 e 45. 
maneiras: o sintoma é social porque resulta de uma rede discursiva que é sempre social, sendo os seus efeitos singulares ou individuais; mas também é social porque pode ser concebido como sendo "formado por sujeitos que ocupam lugares distintos em sua estruturação" (Souza, 1991, p. 82). E é dessas duas formas que o termo sintoma social é aqui entendido.

O que Lacan chama de real deve ser tomado como um registro que corresponde ao que não pode ser simbolizado, o que não quer dizer que não exista. É por isso, aliás, porque existe, que funciona como limite. Mas também é um suporte, um suporte paradoxal, pois ao mesmo tempo é pleno e vazio. Esse paradoxo pode ser pensado de vários modos. Numa formulação simples, podemos afirmar que o real é vazio justamente porque corresponde àquilo que não conseguimos capturar com a nossa rede simbólica e pleno porque, afinal, o real é alguma coisa. Lugar do nada e de todas as possibilidades, o real é um enigma, o lugar próprio da verdade, conforme sugere Lacan (1969-1970, p. 96). Ademais, o lugar do real é o lugar do desejo, real e desejo confundem-se no mesmo buraco, na mesma medida em que ambos não podem ser apreendidos. $E$ aqui vale lembrar que o desejo é inconsciente e que o inconsciente é estruturado como uma linguagem, conforme a definição clássica de Lacan. $\mathrm{O}$ desejo, portanto, sempre supõe os outros registros: o imaginário e o simbólico. Nesse buraco, nesse lugar vazio, superpõem-se na verdade duas faltas. Segundo Lacan, uma é a falta real, que "é o que o vivo perde, de sua parte de vivo, ao se reproduzir pela via sexuada" (Lacan, 1964, p. 195). Quanto à outra, ela concerne ao significante, ao fato "de que o sujeito depende do significante e de que o significante está primeiro no campo do Outro" (pp.194-5), ao que poderíamos acrescentar: o significante está sempre no campo do Outro, escorregando, deslizando, e sempre haverá Um em falta, que não permitirá fechar o sentido. Essas duas faltas, essenciais no processo de constituição subjetiva, somente se tornam tais graças à estrutura do significante, em virtude da sua função de corte (Lacan, 1964, p. 196).

O real é um dos três registro que Lacan considera essenciais no processo de constituição subjetiva. Sem eles e sem o entrelaçamento que é feito no Édipo, não haveria sujeito nem tampouco qualquer coisa que possa ser chamada de realidade. Os três registros (Simbólico, Imaginário e Real) são por Lacan representados com o nó borromeu: três círculos unidos de tal modo que, se um 
fica solto, os outros dois também se soltam. ${ }^{45}$ Esse enlace supõe ainda um quarto círculo, que corresponde aos sintomas, a esse "nó de significações" que se dissolve na medida em que a rede de sobredeterminação simbólica que o institui e mantém é desfeita. Entretanto, como já foi assinalado, essa dissolução nunca é total. Ao penetrarmos nos sintomas, o que encontramos é o que corresponde ao registro dos nossos fantasmas. Segundo Zizek (1992, p. 168), num processo de análise o que se pretende é alcançar esse registro, não para nele ficar, mas para atravessá-lo. Uma vez atravessado, porém, no lugar do vazio há um resto que resiste a qualquer interpretação, um resto cujo estatuto é "psicossomático", um resto perpassado de gozo, um significante solto, fora do sentido, um signo do real: "uma letra que não pode ser reduzida à dimensão do significante, ou seja, que é pré-discursiva, ainda perpassada pela substância do gozo" (p.159). É o que Lacan chamou de sinthomem:

O sintoma como 'sinthomem' é uma certa formação significante perpassada de gozo (...) é, literalmente, nossa única substância, o único esteio positivo de nosso ser, o único ponto que dá consistência ao sujeito. (Zizek, 1992, p. 169)

O que chamamos de realidade é o que resulta da articulação daqueles três registros, uma articulação simultaneamente subjetiva e social. A realidade que esse entrelaçamento costura é feita antes de mais nada de contornos, que a princípio podem ser considerados como sendo as bordas imaginárias e necessárias para poder viver. São contornos que dizem respeito aos nossos sintomas e a tudo o que deles faz parte: os seus cenários, os seus objetos, as inúmeras atuações dos sujeitos, as suas falas. Os contornos constituem a nossa realidade, mas também concernem ao seu avesso, ou seja, ao desejo, cujo registro primordial é o dos fantasmas, pois nele o desejo nasce. Desejo e realidade, como afirma Lacan, são face e contraface de uma mesma superfície, constituem um mesmo tecido, sem solução de continuidade. Por isso, quando circulamos em torno das figuras que fazem a consistência da chamada realidade, simultaneamente sempre estamos fazendo o circuito do desejo, com o qual podemo-nos deparar, sobretudo se olharmos nos e pelos pontos apropriados, isto é, pelos desvios. Entre realidade e desejo existem várias diferenças, porém, há

\footnotetext{
${ }^{45}$ A propósito desse processo de constituição do sujeito a partir dos três registros, como linhas que vão se cruzando até produzir o enlace próprio desse nó, veja-se "A constituição subjetiva", de Vorcaro (1997, pp. 65-134).
} 
uma que é capital: "o desejo é a essência da realidade", ou seja, a realidade depende inteiramente do desejo, é uma superfície sustentada pelo desejo. ${ }^{46}$

Essa superfície, onde o real é suporte e limite, é costurada pelos sujeitos a partir dos pontos que o Outro fornece e conforme o circuito que ele estabelece, em nosso caso o circuito que apenas uma palavra define, que uma única agulha costura. A apreensão desses pontos e costuras sempre é problemática e parcial. O desafio aqui consiste, justamente, em penetrar nesses pontos e costuras, pelo menos em alguns, sabendo de antemão que a única maneira de fazê-lo é criar um outro tecido a partir do antigo, não sendo possível manter distância, pois no mesmo movimento em que desfiamos um discurso estamos tecendo outro, isto é, criando outras linhas, outros contornos, outras superfícies, num trabalho que caberia chamar de artesanal.

O modo como determinado discurso cativa nosso desejo está diretamente relacionado com aquela agulha, que faz a costura pela via do traço unário, pelo furo que está no cerne do ideal do eu. É uma agulha que passa pelos lugares vazios do real, do real do gozo. Essa é a maneira como determinada rede ideológica prende o sujeito. E o prende com o material que nessa operação de hegemonia é fundamental, o material próprio do que aquele buraco atrai e que o encontramos quando penetramos pela porta dos desvios: os restos, os dejetos não assimiláveis do discurso.

Esses restos estão em todo discurso, inclusive no discurso psicanalítico lacaniano, embora nele reduzidos a uma única letra: a, o objeto causa do desejo, o objeto que sempre nos escapa e sobre o qual somente podemos saber alguma coisa ficando na posição que lhe é própria. É o que de certo modo busca-se fazer aqui, num trabalho de interpretação cujo lugar mesmo deveria ser análogo ao

\footnotetext{
${ }^{46}$ A propósito dessas questões, Lacan afirma: "Lo que lleva el fantasma es una superficie cerrada, en forma de burbuja no-esférica, en la cual la tela sin costura está tejida de tal suerte que se pasa de una a otra de sus caras sin apercibirse de ello. Esa superficie tiene hablando con propriedad dos nombres - deseo y realidad - dado que se puede querer distinguir ahí un derecho de un revés, pero de hecho deseo y realidad se juegan en el discurso del Outro a cara o cruz. La realidad del "listo-para-llevar" que hace el cuadro del Fantasma, y que constituye toda la realidad humana, no es ninguna otra cosa que el montaje de lo Simbólico y de lo Imaginario; ella se distingue de lo real que nunca es mas que entrevisto, cuando la máscara que es aquella del Fantasma, vacila. (...) El deseo es la esencia de la realidad" (1966-1967, seminário do 16/11/66, p.1). A conhecida fita de Moebius, referida por Lacan em várias oportunidades, ilustra como pode ser entendida essa superfície.
} 
desse objeto, isto é, um lugar onde busca-se amarrar algo, mas de um modo paradoxal, ou seja, desatando-o.

No discurso construtivista, esse objeto não costuma escapar. Ao contrário, não raro busca-se apaixonadamente aprisioná-lo, pela única via possível: esbarrando nos limites desse discurso. Limites que então são cristalizados, constituindo os restos reificados desse discurso. Esses limites, esses restos, foram historicamente construídos, dizem respeito ao processo de constituição histórica da escola moderna, da escola de massas. Confluem em geral no que afigura os extremos desse discurso, extremos que supostamente impedem a sua plena efetivação. Duas barreiras criadas sobretudo com estes dois significantesmestres: escola tradicional e espontaneísmo. Dois grandes nós, dois pontos de ancoragem que podem ser encontrados penetrando em todos os outros pontos de ressonância desse discurso pedagógico. Nesses nós, há toda um rede simbólica sobredeterminada que pode ser vista em sua dimensão de sintoma, em sua dimensão ideológica. Neles, porém, encontra-se também a estrutura rígida de um bloco aparentemente impenetrável, um bloco onde diversos passados estão como que embaralhados. O primeiro bloco diz respeito a um imponente fantasma secular (a escola tradicional); o segundo não tem tanto lastro histórico, mas parece tão cristalizado quanto o primeiro. Essas duas figuras fornecem o material básico da fantasmática construtivista, elas infiltram-se nesse registro subjetivo onde o desejo encontra as suas coordenadas e assim o estruturam. E mais, na sua rigidez última, parecem constituir o núcleo de um certo gozo.

Esses dois significantes nutrem um outro e comum ponto de ressonância, o ponto onde esses dois significantes se encontram, na costura que a ambos amarra. Esse forte ponto de ressonância é o chamado fracasso escolar — um sintoma social secular. O construtivismo configura-se como uma resposta que procura dar conta desse grande problema, dessa espécie de urgência nacional. $\mathrm{Na}$ estruturação dessa resposta, mobiliza-se primeiramente a ciência, ou melhor, é produzido um discurso científico ou o que Lacan chama de discurso Universitário. É sobre esse terreno que o construtivismo finca seus pés, que afirma e engendra seus pontos de ressonância, configurando-se ademais como um discurso que não gira, que mantém certas posições imobilizadas. Sustentado por essa sorte de Pai-fundador que Piaget representa, desse tipo de discurso 
resulta parte do que pode ser concebido como ideológico, no sentido que antes foi explicitado. Enfim, trata-se de um discurso cujos pontos de ressonância atravessam a obra piagetiana e que emerge de modo a articular uma resposta para o fracasso escolar.

Nesse ponto, precisamente, no ponto onde se unem todos os que estão empenhados na melhoria da escola pública, parece estruturar-se a verdade última do discurso construtivista, ou melhor, a sua verdade mítica e simultaneamente real. Para sabermos algo sobre o que é da ordem dessa verdade, a via que neste trabalho será experimentada é a de penetrar nos aqui chamados pontos de ressonância, atentando sobretudo para o que afigura um desvio. Ademais, é necessário criar um tecido que nos permita aproximar-nos daqueles restos que ficam como que perambulando num único lugar, relativo ao registro fantasmático já mencionado. Esse registro, esse lugar de fantasmas, é o nosso ponto de chegada, o lugar onde este trabalho será concluído e de onde também estamos partindo.

Esse lugar de fantasmas é o lugar da verdade, ou melhor, da meiaverdade, porque a verdade está mesmo no real, que talvez possa ser entrevisto quando a máscara do fantasma ou da fantasia vacila, como disse Lacan. ${ }^{47} \mathrm{E}$ acrescentemos, num instante, que é o tempo próprio da verdade, como bem anteviu Walter Benjamin, para quem a verdade encontrava-se no passado, não qualquer passado, mas sim naquele que retorna com a velocidade própria de um relâmpago, o passado que está no "agora": um "instante" saturado de tensões, o ponto onde tudo está concentrado (Benjamin, 1985, pp. 222-232). Um lugar que Freud buscou nos lances imprevistos das associações inconscientes e que também parece ter sido pressentido pelo antecessor de todos eles, o filósofo das metáforas: Nietzsche, que também nos incita a mergulhar no passado, em "cada" instante — "precisamos de história, pois o passado continua a correr em nós em cem ondas; nós próprios nada somos senão aquilo que sentimos dessa correnteza a cada instante" (1983, p. 138).

Nessa correnteza, nos instantes, nos pontos de ressonância, no Um, no Outro, enfim, nesse tunel que conduz até o lugar dos fantasmas, espera-se aqui

\footnotetext{
${ }^{47}$ Ibidem.
} 
encontrar alguma resposta a respeito do grande poder de fascínio exercido por uma única palavra sobre tantos e tantos profissionais da educação. Uma resposta que sempre será uma meia-resposta, dado que a sua formulação ficará sujeita ao que é da ordem da temporalidade circular. Ou seja, para encontrarmos mesmo alguma certeza, ao chegarmos no último capítulo só nos restará recomeçar. Um recomeçar que aqui já está acontecendo, visto que antes de ter sido iniciado este trabalho já havia sido seguida uma outra trilha, que com esta se superpõe: a trilha da palavra alternativa (Revah, 1994), onde essa temporalidade, o valor dos instantes, do Outro e do Um já tinham ficado em evidência, antes de mais nada como um saber não sabido. Essa é a temporalidade própria do desejo, do circuito que aqui está sendo feito, agora o circuito de uma outra palavra: a palavra construtivismo. 


\section{Seção 2}

\section{As palavras da ciência}

A maioria dos trabalhos acadêmicos considera a obra de Piaget e os trabalhos de Emilia Ferreiro como a primeira e legítima fonte de tudo o que merece ser chamado de construtivismo. E eles, sem dúvida, constituem a mais importante fonte teórica dos discursos pedagógicos construtivistas, a sua fonte científica, com a forte inscrição que essa marca deixa. Sem ela não seria possível falar do construtivismo. Piaget, Emilia Ferreiro, construtivismo e ciência fazem parte de um mesmo discurso e nele são termos intercambiáveis, pois fixam e ocupam o mesmo lugar. Ademais, na matriz simbólica construtivista são solidários, portanto não podem nem admitem ser separados. Se isso ocorresse, o santuário construtivista por muitos edificado desabaria, a começar pelo seu principal pilar: a obra de Piaget, onde o significante ciência fica no lugar de comando, no lugar que é próprio do significante-mestre.

Esta segunda parte toma como objeto os significantes-mestres acima referidos, em cada um dos três primeiros capítulos pondo-se em foco um deles: Emilia Ferreiro, construtivismo e Piaget, com a ciência sendo tomada como um fio que os une. Aqui pretende-se descrever e analisar parte da rede simbólica amarrada nesses significantes-mestres e como se configura, sempre tendo em vista os discursos educacionais e/ou pedagógicos. Iniciaremos o nosso percurso orientados pelo significante-mestre Emilia Ferreiro, pois é com ele que o discurso pedagógico construtivista adquire os seus primeiros contornos. 


\section{Emilia Ferreiro: uma revolução conceitual}

Baseados no percurso e no objetivo último da obra piagetiana, não têm sido poucos os trabalhos a salientar esta dimensão do discurso pedagógico construtivista e incorporada à palavra construtivismo: a sua "indiscutível" raízes na ciência, em vários sentidos, os quais misturam-se com a própria biografia de Piaget. ${ }^{1}$ Certamente, seria difícil encontrar um fundador tão apropriado para a tarefa que, novamente e cada vez mais, sobretudo desde meados da década de 80, torna-se inadiável para os que então empenhavam-se por mudanças substanciais no campo da educação escolar: fundamentar a ação pedagógica, dar-lhe a solidez que nunca teve, pôr a ciência na sua base e até mesmo transformar a pedagogia numa ciência ou, ao menos, em uma disciplina próxima disso. E é com essa mesma marca da ciência que fica em evidência a pesquisa de Emilia Ferreiro e Ana Teberosky sobre a psicogênese da língua escrita. E mais do que isso, com essa marca na posição de significante-mestre opera-se um importante giro nos discursos educacionais então hegemônicos, que são (re)ordenados a partir do ponto de basta que então se constitui. Um giro que a rigor já vinha ocorrendo, mas com um outro discurso e com outros significantes na posição de comando, todos eles sobrepujados quando da divulgação ampla daquela pesquisa e da nova perspectiva de alfabetização que concomitantemente vai sendo delineada.

\section{Primeiras costuras}

A pesquisadora argentina em geral é vista como a grande responsável pelo fervilhar de idéias construtivistas que seria próprio dos anos 80 e que ainda se prolonga na década seguinte. Um fato que diversas expressões procuram evidenciar, como "febre construtivista", "abalo sísmico" (Corazza, 1994, p. 123) ou "maratona do construtivismo" ${ }^{2}$. A inflexão discursiva aí implicada, o ponto de basta que então se constitui, como uma primeira costura feita sobretudo com o nome Emilia Ferreiro e que (re)ordena os discursos sobre a alfabetização, está diretamente relacionado com a intensa divulgação da pesquisa de Ferreiro e

\footnotetext{
${ }^{1}$ A esse respeito, veja-se o capítulo $\mathrm{V}$.

${ }^{2}$ Cf. "A maratona do construtivismo", Nova Escola, n 82, mar./95, p. 3.
} 
Teberosky na segunda metade dessa década, a começar pelo livro onde é apresentada com maior detalhe: Psicogênese da língua escrita (1986), concomitante à publicação de outros escritos de Ferreiro. ${ }^{3}$ Essa pesquisa tinha como objetivo descobrir qual era o processo de construção da escrita em crianças que tinham entre 4 e 6 anos de idade. Os resultados dessa investigação na verdade já eram conhecidos em alguns círculos mais ou menos restritos, cuja ampliação inclusive antecede a divulgação ampla dessa pesquisa. Ou seja, a costura própria desse ponto de basta já vinha sendo feita. Segundo Vasconcelos, o contato com essa pesquisa e a presença de Ferreiro no Brasil data dos anos 70, no caso específico do GEEMPA, uma conhecida instituição de Porto Alegre:

Desde 1976, membros do GEEMPA participavam de um grupo de estudos sobre a obra de Emilia Ferreiro, no Laboratório de Metodologia e Currículo da Faculdade de Educação da Universidade Federal do Rio Grande do Sul. Foi nessa época, a convite de Léa Fagundes e Esther Grossi, que Emilia Ferreiro esteve pela primeira vez em Porto Alegre para ministrar um curso sobre psicogênese e alfabetização. (Vasconcelos, 1996, p. 211)

O GEEMPA é uma instituição cuja origem remonta ao início da década de 70, quando um grupo de professores vinculados ao Instituto de Educação, ao Colégio de Aplicação e ao Instituto de Matemática da Universidade Federal do Rio Grande do Sul começa a reunir-se para estudar questões relacionadas com o ensino da matemática moderna, desde o início tendo como referência a teoria piagetiana (Vasconcelos, 1996, p. 208). Em 1979, esse grupo amplia o seu campo de atuação e ocupa-se "basicamente com os processos de aprendizagem das classes populares em fase de alfabetização", mudando o significado da sua sigla: "Grupo de Estudos sobre o Ensino da Matemática de Porto Alegre" para "Grupo de Estudos sobre Educação, Metodologia de Pesquisa e Ação" (Freitag, 1994, p. 13). E ainda:

A partir de 1982, o GEEMPA passou a ministrar cursos de pósgraduação lato sensu em alfabetização e a desenvolver projetos de pesquisa sobre esse tema. Em 1984, o GEEMPA assumiu uma postura de

\footnotetext{
${ }^{3}$ No Brasil, Psicogênese da língua escrita foi publicado em 1985. Nesse mesmo ano, de Emilia Ferreiro foram também publicados Reflexões sobre alfabetização e um artigo, incluído nesse livro, intitulado "A representação da linguagem e o processo de alfabetização", divulgado no periódico Cadernos de Pesquisa. Em 1986, foi editado o livro Alfabetização em processo, escrito também por Ferreiro. Segundo Vasconcelos (1996, p. 185), esses foram os livros de Ferreiro mais divulgados no Brasil.
} 
maior intervenção na educação, trabalhando com classes experimentais e atuando no sentido de promover mudanças na rede estadual e municipal de ensino de Porto Alegre. (Vasconcelos, 1996, p. 213)

Como se vê, somente na década de 80 o GEEMPA faz um grande investimento no sentido de divulgar essa pesquisa. Além disso, tomando-a como base, dedica-se a formular uma proposta didática que seja adequada para a alfabetização de crianças dos setores populares. Em 1985, Esther Pillar Grossi, coordenadora desse grupo durante vários anos e que segundo Barbara Freitag (1994, p. 14) representava a "alma" do GEEMPA, apresenta "Didática do nível pré-silábico" como um produto da experimentação e reflexão da equipe de pesquisa do GEEMPA (Grossi, 1994, p. 30). Nesse texto, caracteriza esse "nível" a partir das conceitualizações de Ferreiro e Teberosky e sugere atividades para os professores desenvolverem em sala de aula. Grossi também publica outros dois textos que, com o primeiro, compõem uma "trilogia". São eles "Didática do nível silábico" e "Didática do nível alfabético". ${ }^{4}$ Do ponto de vista da sua importância na divulgação da pesquisa de Ferreiro e Teberosky, bem como do que será chamado de construtivismo, a figura de Esther Grossi em muito extrapola esse grupo. Em 1989, torna-se Secretaria Municipal de Educação na gestão do Partido dos Trabalhadores em Porto Alegre, projetando-se ainda como uma das figuras centrais do construtivismo. É o que pode ser acompanhado através da revista Nova Escola, que contribui para configurar e projetar nacionalmente a sua imagem. A revista inclusive chegou a chamá-la de "pioneira do construtivismo" sendo uma das poucas figuras públicas que teve a oportunidade de preencher, com a sua imagem, a capa de uma das edições dessa publicação, uma possibilidade reservada a poucos. ${ }^{6}$ É o que Vieira também observa, ao fazer o levantamento, até 1995, dos nomes de instituições e pessoas associadas pela revista ao construtivismo: "nenhum desses nomes possui a representatividade de Emilia Ferreiro e Esther Grossi", que aparecem em várias fotos e são citadas em diversas matérias, além de serem "as únicas 'construtivistas' objeto de matérias de capa sobre o tema"' (1995, pp. 32-3).

\footnotetext{
${ }^{4}$ Esses livros de Grossi compõem uma trilogia intitulada Didática da alfabetização (Grossi, 1994, 1995, 1996).

${ }^{5}$ Cf. "Dez anos de construtivismo no Brasil", Nova Escola, n 48, maio/91, p. 11

${ }^{6}$ Cf. Nova Escola, n ${ }^{\circ} 57$, maio/92.
} 
No caso de outros grupos e instituições, de outras cidades e estados, pelo levantamento feito por Vasconcelos (1996) pode-se concluir que a pesquisa de Ferreiro e Teberosky torna-se conhecida nos anos 80, em particular de meados dessa década em diante. Em Recife, por exemplo, Emilia Ferreiro esteve pela primeira vez em 1985 e, segundo Vasconcelos, "suas idéias foram fundamentais para que os educadores pernambucanos repensassem 0 processo de alfabetização" (1996, p. 232). No ano seguinte, através do Projeto Aprender Pensando, foi iniciado um programa de capacitação de professores da rede pública que incorporava as questões próprias do processo de alfabetização tal como formuladas por Ferreiro e Teberosky. Esse projeto já vinha sendo desenvolvido desde 1981 e havia surgido por iniciativa de Terezinha Nunes Carraher, tendo como fonte principal a teoria piagetiana (pp. 230-2). Em São Paulo, a divulgação entre os professores da rede pública se deu principalmente através da Coordenadoria de Estudos e Normas Pedagógicas (CENP), desde 1985, através de cursos, textos e vídeos. Segundo Vasconcelos, esses cursos "tiveram a participação de Telma Weisz e a colaboração de Madalena Freire" ( $p$. 186), que igualmente são consideradas pela Nova Escola "pioneiras" do construtivismo. Nesse mesmo ano, Telma Weisz, que Vasconcelos destaca pelo seu "intenso trabalho de capacitação de professores de todo o Estado" (p. 184), escreveu um texto inserido numa das publicações do Projeto Ipê, organizado pela CENP, onde apresenta as principais conclusões da pesquisa de Ferreiro e Teberosky (Weisz, 1985), tendo também escrito o prefácio do livro de Ferreiro Reflexões sobre alfabetização

Em todas essas iniciativas, que são as que Vasconcelos (1996) destaca ligadas ao nome de Ferreiro e à divulgação da nova perspectiva de alfabetização associada à psicóloga argentina, é possível rastear a presença da obra piagetiana, como ele faz. E ela está mesmo muito presente, é uma fonte teórica fundamental entre as profissionais acima mencionadas. Inclusive, nessa década de 80 , há uma intensificação da divulgação entre os professores das conceitualizações piagetianas sobre o desenvolvimento infantil. E como ele próprio observa, poder-se-ia dizer que "os trabalhos de Emilia Ferreiro foram responsáveis, em grande parte, pelo renovado interesse em Piaget na área educacional" (1996, p. 185). O que aqui se sustenta, entretanto, é que antes do que uma renovação, configura-se mesmo um outro discurso pedagógico, 
articulado primeiramente sob a forma de um discurso que fica mais ou menos circunscrito ao campo da alfabetização, mas cujos pontos de ressonância o lançam, cada vez mais, em direção a outros âmbitos. Nesses pontos de ressonância podem ser incluídas as conceitualizações piagetinas, mas também outras. E aí deve ser considerado um outro e fundamental nome: Paulo Freire, um significante-mestre cuja presença no discurso educacional é recorrente nos anos 80, em particular no discurso de muitos dos que primeiramente divulgam e defendem a nova perspectiva de alfabetização inspirada na investigação de Ferreiro e Teberosky. É claro que antes disso, desde os anos 70, as obras de Piaget e Paulo Freire já vinham sendo objeto de assimilação recíproca, um fato que pode ser acompanhado em alguns dos depoimentos recolhidos por Vasconcelos, especialmente dos profissionais da educação de Porto Alegre (1996, pp. 198-216). Mas que também pode ser observado no circuito das experiências educacionais alternativas desenvolvidas na cidade de São Paulo. Ou em textos ou publicações que consigo traziam a marca do alternativo, como Cuidado, escola! - um livro publicado no Brasil no início dos anos 80, apresentado por Paulo Freire e produzido pela equipe do IDAC ${ }^{7}$ (pp. 108-17).

A forte e simultânea presença dos três nomes - Emilia Ferreiro, Piaget e Paulo Freire - é comum às iniciativas antes arroladas ou pelo menos marcam os que as promovem. Esses nomes delimitam um campo teórico que nutre inúmeros profissionais da educação, um campo que inspira propostas pedagógicas ou didáticas que serão chamadas de construtivistas. Esses três nomes, por exemplo, precedem a proposta construtivista implementada em Porto Alegre, em 1989, pela Secretaria Municipal de Educação. Eles concernem ao que nela inicialmente constitui o seu alicerce teórico explícito (Vasconcelos, 1996, p. 214; Grossi, 1994, p. 8). ${ }^{8}$ Em Pernambuco, no programa de capacitação de professores desenvolvido "com o pessoal e a experiência do Aprender Pensando", durante a gestão de Silke Weber como Secretaria Estadual de Educação, esses três nomes são também destacados, como se vê na entrevista feita com Weber por Vasconcelos (1996,

\footnotetext{
${ }^{7}$ O IDAC (Instituto de Ação Cultural) era um centro de pesquisa e de intervenção em educação popular fundado em Genebra, em 1971, por Paulo Freire.

${ }^{8}$ Os três nomes são também mencionados na orelha dos livros que compõem a trilogia de Grossi Didática da Alfabetização: "Baseada no pensamento construtivista de Jean Piaget, nas descobertas de Emilia Ferreiro e sua teoria da construção léxica associada à antropologia pedagógica eminentemente engajada de Paulo Freire, esta trilogia (...)".
} 
pp. 233-4): "Fizemos um trabalho de parceria com as Secretarias Municipais de Educação. Algumas secretarias já desenvolviam um trabalho muito próximo ao nosso, com Piaget, Emilia Ferreiro e Paulo Freire". Além disso, as três profissionais que a revista Nova Escola qualifica de "pioneiras" do construtivismo (Esther Grossi, Telma Weisz e Madalena Freire) evidenciam também, em suas trajetórias profissionais e de vida, a forte presença dessas marcas, desses três nomes, que podem ser considerados três significantes-mestres justapostos no mesmo ponto de ressonância — o ponto que será próprio do significante-mestre construtivismo.

Nessa função do discurso, nessa função de Mestre, esses significantes podem ser colocados lado a lado com os seus equivalentes. Teríamos então, de uma parte, significantes como Paulo Freire, educação popular, escolas comunitárias, educação alternativa, escolas alternativas, alternativa; e, de outra, Piaget, Emilia Ferreiro, construtivismo (sem contar outros equivalentes, como proposta construtivista). Essas séries significantes poderiam ser reduzidas a apenas dois termos: alternativa/construtivismo, ou melhor, construtivismo/alternativa - uma equação que representa adequadamente a sobredeterminação do primeiro em relação ao segundo e o recalque que a deriva do discurso construtivista produziu ao longo da década de 80 e 90 , pelo menos numa das vertentes desse discurso. ${ }^{9} \mathrm{Um}$ bom exemplo disso é o que ocorreu com a figura de Paulo Freire, que nesse discurso tende a ser transformado num construtivista, até mesmo no verdadeiro construtivista, o que nada mais é do que o retorno do que foi recalcado, mas que não é assim reconhecido. Isso concerne à vertente discursiva que inicialmente impulsiona e configura esse novo discurso, impondo-se ainda na deriva que é própria do "caminho" construtivista e que resulta na metáfora que o absorve e desloca: os PCN (Parâmetros Curriculares Nacionais).

\section{Um histórico nó}

Esse "caminho" construtivista, no qual algumas conexões com o passado são rompidas, criando-se por sua vez outras relações, outras articulações significantes que sobrepujam e ordenam os discursos precedentes, tem o seu

\footnotetext{
${ }^{9}$ Cf. o item 5 do primeiro capítulo deste trabalho.
} 
ponto de basta inicial na referida pesquisa de Ferreiro e Teberosky. Essa pesquisa, amplamente divulgada na segunda metade da década de 80 , constitui o que pode ser chamado de um acontecimento, ou seja, um ponto de basta que então se configura e que (re)ordena todo um conjunto de articulações significantes, sobretudo as que "flutuavam" em torno do que no campo da educação escolar afigurava, há décadas, um grande problema, um grande buraco: o fracasso escolar. Esse grande problema mobiliza, por exemplo, o GEEMPA, conforme explicita Grossi ao se referir ao trabalho de pesquisa que precedeu a produção do seu texto "Didática do nível pré-silábico": "O núcleo central desta pesquisa é o insucesso escolar de crianças das periferias urbanas na $1^{\underline{a}}$ série do 1 grau - problema crucial da educação brasileira" (1994, p. 30). E é precisamente no cerne desse grande problema que desde o início Ferreiro e Teberosky buscam inscrever a sua pesquisa, apresentada como uma resposta capaz de apontar uma saída, de indicar um caminho, de superar sobretudo as tão debatidas perspectivas de alfabetização baseadas nos tradicionais métodos (sintéticos, analíticos ou mistos) - os métodos que apesar da sua variedade não resolviam o essencial, dado que "existe um grande número de crianças que não aprende" (Ferreiro e Teberosky, 1986, p. 15).

A pesquisa é amarrada nesse ponto de ressonância, nesse histórico nó já no começo da Introdução do livro que apresenta os seus resultados, pois as autoras começam fazendo referência ao fracasso escolar, aí relacionado à situação educacional na América Latina. Na Introdução, elas lembram que o cálculo elementar e a lecto-escrita constituem um dos objetivos da instrução básica e que a sua aprendizagem é condição de sucesso ou fracasso escolar, este último sendo fácil de constatar nas aprendizagens iniciais (1986, pp. 15-6). Apresentam para tanto as "cifras oficiais" (da UNESCO), mostrando a magnitude do problema. Destacam também os fatores que segundo a "versão oficial" provocam a subinstrução e o analfabetismo na maior parte da população da América Latina: o absenteísmo, a repetência e finalmente a deserção (p. 17). Em face disso, que a "versão oficial" chama de "males endêmicos", as autoras discutem brevemente as suas causas: remetem o problema do absenteísmo às "condições sociais", pois não o consideram consequência de responsabilidades pessoais, avaliando ser difícil mudar essa situação sem melhorar as condições de vida da população; definem a repetência como um dos maiores problemas da 
educação primária; e finalmente destacam o que consideram ser o "aspecto central do problema educativo: a deserção escolar", insistindo na dimensão social do problema. E mais, em lugar de "males endêmicos", propõem que se fale em “seleção social do sistema educativo; em lugar de se chamar de 'deserção' ao abandono da escola, teríamos de chamá-lo de expulsão encoberta". Aqui as autoras fazem a ressalva de que não estão se referindo "à intenção consciente dos docentes enquanto indivíduos particulares, e sim ao papel social do sistema educativo" (p. 18). Esse papel é relacionado com a desigualdade de natureza social e econômica: "a desigualdade social e econômica se manifesta, também, na distribuição desigual de oportunidades educacionais" (ibidem). $\mathrm{Na}$ investigação, a preocupação com esse tema está presente nas diferenças que elas procuram detectar entre crianças de setores sociais distintos (classe baixa e classe média), evidenciando de diversos modos como essas condições sociais e econômicas incidem negativamente sobre as possibilidades de sucesso escolar das crianças de "classe baixa", já nas aprendizagens iniciais relacionadas com o processo de alfabetização.

Essas questões, que nesse livro as autoras praticamente não desenvolvem, são porém importantes porque situam essa investigação e as próprias autoras no interior de certo campo de preocupações e discursos comum aos educadores brasileiros nesse período, principalmente de esquerda e que faziam parte das forças políticas que haviam se firmado na oposição ao regime militar. Digamos que há nesse plano uma grande sintonia com os discursos educacionais desse momento, nos quais era comum o tom de denúncia e a ênfase em temas que os situavam diretamente no campo político, com a atenção voltada para a rede pública de ensino e os setores populares. Em outras palavras, com o delineamento daquelas questões, dentre outras igualmente importantes pela mesma razão, as autoras fincam um pé nessas forças, inscrevem a sua investigação no circuito dos discursos hegemônicos no campo da esquerda, dos discursos educacionais por muitos qualificados de críticos ou progressistas ${ }^{10}$, sem

\footnotetext{
10 Um dos autores que nesse momento define o que pode ser chamado de crítico é Dermeval Saviani, cujos textos tiveram grande repercussão no início dos anos 80 . Num de seus textos afirma que o "critério de criticidade" de uma teoria educacional consiste na "percepção dos condicionantes objetivos", dos "determinantes sociais", da "estrutura sócio-econômica que condiciona a forma de manifestação do fenômeno educativo" (1984, p. 9). Libâneo, no mesmo período, destaca a mesma idéia: "o que define uma pedagogia crítica é a consciência de seus condicionantes histórico sociais" (1989, p. 39). Libâneo também usa a expressão pedagogia progressista, que empresta de
} 
contar o concurso de outros elementos, como as suas próprias trajetórias profissionais e pessoais, marcadas também pelo que nos anos 70 era o denominador comum a vários países latinoamericanos: as ditaduras militares. ${ }^{11}$

A histórica questão do fracasso da escola, cuja presença no discurso e no Brasil pode ser remontada ao final do Império, vinha ganhando particular intensidade desde os anos 70, alcançando um primeiro plano precisamente quando o significante fracasso escolar ficou no centro dos debates sobre o sistema público de ensino, em fins dessa década, marcando ainda a década seguinte. $^{12}$ Ademais, nesses discursos e nas pesquisas brasileiras sobre 0 fracasso escolar, a evasão escolar já comparecia como uma forma de expulsão da escola. ${ }^{13} \mathrm{O}$ que nesses discursos constitui o principal foco de atenção é o ensino de $1^{\circ} \operatorname{grau}^{14}$, em particular tudo o que é relacionado com os altos índices de repetência já na primeira série. E aí adquire destaque a alfabetização, que é indissociável de um outro grande ponto de ressonância histórico: o analfabetismo — "a vergonha nacional", ${ }^{15}$ uma marca que por vezes surge para distinguir o Brasil de outras nações, um traço não raro considerado aviltante, um mal que deve ser erradicado e que assim foi instalado no discurso desde a Primeira

Snyders, para agrupar as tendências pedagógicas que ele distingue das que reúne sob o termo pedagogia liberal (ibidem, p. 21).

${ }^{11}$ As autoras realizaram o trabalho experimental em Buenos Aires, nos anos de 1974, 1975 e 1976. Neste último ano, na Argentina, houve um golpe militar que impôs um regime ditatorial até 1983. A respeito da incidência desse fato sobre a trajetória de Ferreiro, eis o depoimento da professora Léa Fagundes, que a conheceu em 1976: "Na época ela estava fugindo da perseguição política. Ela e o marido, Rolando Garcia, eram de esquerda e estavam em Genebra, onde ela havia feito a tese de doutorado sobre alfabetização com dados colhidos na Argentina." (Vasconcelos, 1996, p. 193).

12 Sobre a presença desse tema já no Império, veja-se Souza (1998), que também constata a presença do "conceito" de fracasso escolar no centro dos debates do período: "Aqui no Brasil, o conceito de fracasso escolar atravessou os muros acadêmicos para se situar no centro dos debates políticos sobre a escola no final da década de 70 e início dos anos 80 quando, no processo de redemocratização do país, a sociedade civil assistia preocupada o crescimento dos índices de evasão e repetência no ensino fundamental." (p. 63).

${ }^{13}$ A esse respeito veja-se, por exemplo, o que Patto afirma em relação às pesquisas sobre o fracasso escolar do final dos anos 70 em diante (1988, p. 76).

14 Quanto ao que os discursos pedagógicos tendem a salientar, dentre os que se situam diretamente no campo político, um bom exemplo encontra-se no "Manifesto aos participantes da III conferência brasileira de educação", realizada em 1984, onde afirma-se esta exigência: "O ensino de $1^{\circ}$ grau deverá ser o setor a merecer maior atenção na política educacional brasileira na segunda metade dos anos 80" (p. 7). Essas conferências vinham sendo promovidas desde 1980, a cada dois anos, por três entidades: ANDE, ANPed e CEDES.

15 "Analfabetismo. A vergonha nacional" é a manchete de capa da revista Nova Escola $n^{\circ} 37$, de março de 1990. 
República. ${ }^{16}$ Essa marca parece estar no âmago do significante fracasso escolar e é sobre ela que incide o discurso pedagógico que se configura com o significantemestre Emilia Ferreiro, de início demarcando o que tende a ser visto como uma proposta didática que promete erradicar esse mal. E o que aí fica em foco é a atuação do professor.

Embora Ferreiro e Teberosky afirmem que o caráter seletivo do sistema educativo não decorre da "intenção consciente" dos docentes, isso não significa que a investigação não os tenha colocado em foco. Eles inclusive constituem uma referência importante na Introdução mesmo do livro Psicogênese da língua escrita. Depois das autoras discutirem brevemente o problema do fracasso escolar, apresentam as respostas que tentou-se dar para solucioná-lo, no âmbito que concerne diretamente ao docente, ao professor, envolvendo a "pedagogia que sustenta a ação educativa" (p. 18). Em outras palavras, o que colocam em causa é o "enfoque didático" baseado na adoção de determinado método de alfabetização, bem como os seus "supostos psicológicos" e as "concepções implícitas ou explícitas - sobre o processo de aprendizagem" (ibidem). Desse modo, apesar de terem feito referência aos condicionantes de natureza social e econômica, aos "fatores exógenos à instituição escolar", as autoras deslocam o problema e as causas do fracasso escolar para dentro da escola, para os "fatores de tipo endógeno" (1986, p. 97), à semelhança das articulações discursivas que de maneira crescente afirmavam-se no Brasil desde fins dos anos 70 e que ficam num primeiro plano nesse mesmo momento. Essas articulações significantes vinham sobrepujando a descrença que havia se instalado em setores da esquerda em relação ao sistema público de ensino, mas também os discursos que atribuíam às famílias e crianças dos setores populares um déficit ou carência de ordem cultural.

Essa descrença reflui na medida em que se ampliam os espaços de participação e de intervenção no âmbito do Estado, conforme se aproxima o fim da ditadura militar e avança a redemocratização das instituições, com eleições que ocorrem em âmbito estadual e municipal. Nesse período, acredita-se cada

\footnotetext{
${ }^{16}$ É o que evidencia Marta Carvalho (1989), que faz referência aos discursos da segunda e terceira década do século passado, quando o "analfabetismo passava a ser a marca da inaptidão para o Progresso" e, no caso de Sampaio Dória ("reformador da instrução pública em 1920"), "a questão nacional por excelência", "O monstro canceroso, que hoje desviriliza o Brasil” (p. 40).
} 
vez mais na possibilidade de transformar a escola pública e resolver o fracasso escolar incidindo diretamente sobre a escola e sobre as questões que fazem o dia-a-dia do trabalho do professor, envolvendo a pedagogia que o orienta e as práticas que desenvolve na sala de aula. Nesse período, aposta-se e investe-se na concretização de uma Nova Escola pública, como bem captou a Fundação Victor Civita quando iniciou a publicação homônima em 1986, uma publicação que impulsiona e instaura exatamente esse significante entre os professores, de um modo cujo sentido em grande parte revela-se na inversão dos termos que compõem esse significante: Escola Nova - o significante-mestre que então vinha sofrendo as investidas dos defensores da chamada pedagogia dos conteúdos e que essa publicação e o discurso construtivista contribuem para manter ou repor num lugar de prestígio. ${ }^{17}$ Em suma, no mesmo momento em que crescem as possibilidades das forças de oposição à ditadura militar implementarem políticas públicas nos sistemas de ensino municipais e estaduais, o chamado fracasso escolar começa a ser pensado como um produto inerente ao que ocorre no interior da escola e, em particular, na sala de aula.

Nesse deslocamento discursivo incidem também as intensas críticas à chamada "teoria" da "carência cultural" (ou "privação cultural") e à sua contrapartida: a educação compensatória. ${ }^{18} \mathrm{Em}$ meados dos anos 80 , essa crítica é feita, por exemplo, por Maria Helena Souza Patto (1985), que coloca a psicologia na origem dessa perspectiva, lembrando que essa "teoria" começa a ser delineada nos Estados Unidos entre fins dos anos 50 e inícios da década seguinte, quando procura-se explicar o fracasso escolar de "minorias sociais" ou "minorias raciais" cujo nível sócio-econômico era o mais baixo, como negros e porto-riquenhos. Com base em "pesquisas realizadas sobretudo no âmbito da vida familiar", conclui-se então que as crianças que pertenciam a essas minorias "iam mal na escola porque eram portadoras de inúmeras deficiências nas várias áreas do seu desenvolvimento biopsicossocial". Para Patto, nesse momento "a pesquisa

\footnotetext{
${ }^{17}$ Pedagogia dos conteúdos é uma das expressão comumente utilizada para nomear o discurso pedagógico que se configura a partir das posições defendidas por Dermeval Saviani no início dos anos 80, em artigos inicialmente publicados na revista $A N D E$ e depois reunidos no seu conhecido livro Escola e Democracia.

${ }^{18}$ Essa perspectiva foi muito criticada a partir do final da década de 70 , em especial nas discussões relativas à função da pré-escola, resultando em deslocamentos importantes já no início dos anos 80 nos discursos oficiais sobre esse nível do ensino. Por exemplo, em documentos elaborados pelo MEC (Abramovay e Kramer, 1988; Campos, 1989, p. 12).
} 
educacional contribuiu para a veiculação de uma imagem negativa da criança de 'classe baixa': ela seria portadora de inúmeras deficiências e problemas de desenvolvimento" (p. 13). "Essas deficiências a levariam a não ter a prontidão necessária à alfabetização no momento de ingresso na escola" e também "a se sair mal nos testes de inteligência" (p. 14). Além de localizarem "as causas dos problemas de aprendizagem escolar" nas próprias crianças, essas pesquisas asseveravam ainda que elas eram deficientes porque as suas famílias e seus ambientes familiares eram deficientes, não havendo nessa literatura uma perspectiva crítica sobre a incidência das dimensões econômica, política, social ou cultural (ibidem). Enfim, o que Patto questiona é a "teoria" que explica o insucesso escolar instaurando um déficit, uma carência ou insuficiência na criança e na família de um determinado setor social - as classes populares, os pobres. Posteriormente, na década de 70 , essa "visão" penetrou no Brasil e, conforme constata a autora, "ainda prevalece nas explicações do fracasso escolar", tanto nas pesquisas quanto entre os educadores, aos quais refere-se também numa entrevista concedida à revista Nova Escola: "esse tipo de psicologia educacional (...) referenda cientificamente, com toda a autoridade do discurso científico, preconceitos e estereótipos sociais. E a professora acredita neles". ${ }^{19}$ Quanto aos seus efeitos nas pesquisas, em outro artigo Patto assinala que "na vigência da teoria da deficiência cultural pouca ou nenhuma atenção se deu à participação de fatores intra-escolares" (1988, p. 76).

Embora os discursos educacionais dos anos 80 reconheçam que o desempenho escolar das crianças sofre a interferência negativa do que concebem como realidade exterior à escola - avaliando que existem determinantes sociais, culturais e econômicos que incidem sobre a escola, a criança e sua família -, cada vez mais esses discursos tendem a situar o problema do fracasso escolar no âmbito do sistema de ensino, tendo como primeira referência a rede pública. E o acento recai sobre a escola, é nela que a falta se instala. Ademais, o principal imputado tende a ficar sob a órbita do significante escola tradicional, mesmo com a inversão que o discurso próprio da pedagogia dos conteúdos tende a operar. No interior da escola, as causas, as responsabilidades, as razões do fracasso recaem

\footnotetext{
${ }^{19}$ Cf. "Como se escreve (por linhas tortas) o fracasso escolar de uma criança", Nova Escola, $\mathrm{n}^{\circ} 17$, nov./1987, pp. 13-4.
} 
sobre vários pontos, afunilando-se em certo momento na figura do professor, em particular com o construtivismo.

Esse deslocamento em direção à figura do professor pode ser apreendido percorrendo-se as matérias dos anos 80 da revista Nova Escola, mas também é indicado e reafirmado em textos de natureza teórica, como o de Patto (1985)..$^{20}$ Para a autora, no que ela concebe como o "terceiro momento da teoria e da pesquisa sobre as causas do fracasso escolar", ou seja, em meados dos anos 80 :

(...) o que se está procurando verificar é a contribuição das próprias práticas escolares na produção do fracasso escolar das crianças das escolas públicas nas regiões pauperizadas das cidades.

Atualmente as causas (...) estão sendo buscadas em instâncias do processo educativo, desde a política e a legislação educacional, a situação do professorado, a formação e a valorização profissional do professor, suas condições de trabalho (...) Dá-se, portanto, uma mudança de foco. Se este num determinado momento foi a criança e tentou-se buscar nela, através de uma abordagem medicalizada e psicologizada, a fonte da dificuldade, agora o centro da análise é fundamentalmente o processo de produção do fracasso escolar dentro da instituição-escola.

(...)

Neste momento da análise, o tema da qualidade da relação professor-aluno assume uma importância que não tinha anteriormente. Não se trata, contudo, de encontrar um novo réu: se antes o culpado era a criança e a família, agora ele não pode ser o professor. (p. 15)

Patto assinala uma mudança de foco e, se nos deixarmos levar pelo movimento do seu próprio discurso, pode-se dizer que a autora prefigura esse afunilamento do problema na relação professor-aluno e em particular no professor. Daí a advertência no sentido de não transformá-lo em réu. Enfim, ao longo dos anos 80, as articulações discursivas que crescentemente se afirmam e expandem tendem a situar no interior da escola, em particular no âmbito da atuação do professor, tudo o que é da ordem de uma falta ou de uma falha, que deve ser remediada para acabar com o fracasso escolar. É o que também fazem Ferreiro e Teberosky, mas sem deixar de referir-se ao que concebem como "fatores exógenos à instituição escolar" e que incidem negativamente sobre o desempenho das crianças de "classe baixa".

\footnotetext{
${ }^{20}$ Na revista Nova Escola, esse deslocamento ganha relevância em novembro/87. A manchete de capa dessa edição é "O poder do professor" e vem acompanhada deste subtítulo: "Ele constrói o sucesso (ou fracasso) de um aluno". A reportagem relativa a essa manchete é a mesma que reproduz algumas falas de Patto, como o trecho que já foi citado. Cf. "Como se escreve (por linhas tortas) o fracasso escolar de uma criança", Nova Escola, n 17, nov./1987.
} 
No Brasil, esse olhar que procura as causas do insucesso escolar dentro da escola, focalizando o que ocorre na sala de aula, vinha sendo sedimentado há décadas, como ainda nos lembra Patto, quando se refere aos escritos dos escolanovistas. Neles já existia "a atenção à participação da própria escola nos resultados por ela obtidos" (1988, p. 75). Nesses escritos, em particular nos que encontra na Revista Brasileira de Estudos Pedagógicos (entre 1944-1984), Patto mostra a presença simultânea de um outro viés, que sobrepuja o papel atribuído ao processo de ensino no sucesso escolar, ao enfatizar o valor explicativo dos "fatores sociais", das características "localizadas no aluno e em seu ambiente familiar e cultural", num discurso onde abundam os estereótipos sociais e os preconceitos (p. 74). Esse discurso, que ela chama de fraturado e que "predominou no período em que vigoraram as idéias escolanovistas", a autora considera que ainda está presente nas pesquisas da década de 80, cuja pressuposição básica continuaria sendo a deficiência das crianças pobres, relacionada com as suas condições de vida (p. 76).

Nessas pesquisas, Patto também detecta uma tendência que se afirma no Brasil nessa mesma década de 80 , relativa ao "segundo momento da produção científica" sobre o fracasso escolar (1985, pp. 14-5): a "teoria da diferença cultural". A criança pobre não mais seria carente ou deficiente, mas diferente, e à escola caberia adequar-se à realidade dessa criança. Ou seja, a deficiência foi trocada pela diferença e "a responsabilidade da escola pelo fracasso ficou limitada à sua inadequação à clientela" (1988, p. 76). Para Patto, "ao invés da tendência a atribuir à clientela a responsabilidade pelo fracasso escolar ter sido ultrapassada, ela foi apenas somada à responsabilização do sistema educacional" (ibidem). Essa idéia de adequar ou adaptar a escola, a proposta pedagógica, os métodos ou a ação do professor aos alunos, à clientela, à comunidade ou à chamada realidade será recorrente na década de 80 , prolongando-se na década seguinte, como pode ser constatado percorrendo-se as matérias da revista Nova Escola. No caso do discurso construtivista, o significante adequação deverá constituir um de seus pontos de ancoragem. ${ }^{21}$

\footnotetext{
${ }^{21}$ Esse pretendido ajuste ou adequação será insistentemente criticado por Lajonquière, na segunda metade da década de 90 (1997, p. 36, 1999, p. 56).
} 


\section{Um outro caminho}

Em relação aos deslocamentos discursivos próprios do final dos anos $70 \mathrm{e}$ início dos 80 , em especial a progressiva localização das causas do fracasso escolar no interior da escola e a crescente confiança na transformação da escola pública, deve ser considerado o importante (re)ordenamento discursivo que se processa em virtude do ponto de basta que os textos de Dermeval Saviani criam, quando da sua classificação dos discursos educacionais no início dos anos 80 . Uma classificação em seguida sustentada e desdobrada em "tendências pedagógicas" por José Carlos Libâneo (1982). ${ }^{22}$

No livro de Saviani que reúne esses textos, o seu ponto de partida é justamente o que o significante fracasso escolar demarca, aí delimitado em outros termos: "o problema da marginalidade". Como Ferreiro e Teberosky, Saviani igualmente apresenta os seus dados, apontando o problema da deserção na América Latina: em 1970, desertavam cerca de 50\% dos alunos das escolas primárias da maioria dos países latinoamaricanos, em condições de semianalfabetismo ou de analfabetismo potencial, sem se levar em conta os que "sequer têm acesso à escola". Em face dessa constatação, ele indaga: "Como interpretar esse dado? Como explicá-lo? Como as teorias da educação se posicionam diante dessa situação?" (1984, p. 7). Refere-se então, de um lado, ao que ele chama de teorias não-críticas (a pedagogia tradicional, a pedagogia nova e a pedagogia tecnicista), que são as que "encaram a educação como autônoma e buscam compreendê-la a partir dela mesma", concebendo-a como "um instrumento de equalização social, portanto, de superação da marginalidade"; de outro, as teorias crítico-reprodutivistas, que "se empenham em compreender a educação remetendo-a sempre a seus condicionantes objetivos, isto é, aos determinantes sociais, vale dizer, à estrutura sócio-econômica", sendo a educação "um instrumento de discriminação social, logo, um fator de marginalização" (pp. 7 e 9).

Ambas teorias são objeto de crítica. As primeiras porque ignoram os condicionantes objetivos e acreditam ingenuamente no poder equalizador da

\footnotetext{
22 Os textos de Saviani acima referidos encontram-se reunidos no livro Escola e Democracia, publicado em 1983, com artigos que já haviam sido publicados em 1981 e 1982, excetuando apenas um texto escrito para esse livro (Saviani, 1984, p. 5).
} 
escola, que a todos garantiria igualdade de oportunidades e possibilidades de sucesso; as últimas porque "chegam invariavelmente à conclusão de que a função própria da educação consiste na reprodução da sociedade em que ela se insere", isto é, o papel da escola é "reproduzir a sociedade de classes e reforçar o modo de produção capitalista" (pp. 19-20). Para Saviani, as teorias crítico-reprodutivistas concebem a escola como uma instituição a serviço do status quo, inserida numa sociedade que a determina inteiramente, de maneira que a escola não pode ser transformada sem antes mudar estruturalmente a sociedade. Em outras palavras, trata-se de uma perspectiva onde o que a escola é e os efeitos da escolarização não são mais do que o resultado de uma lógica inerente à sociedade de classes, à sociedade capitalista, tornando inútil qualquer tentativa no sentido de transformar a instituição escolar, cuja função precípua seria então a reprodução da sociedade de classes e das relações de dominação, em particular pela via da inculcação da ideologia dominante. ${ }^{23}$

Através do (re)ordenamento discursivo que se processa atrelado ao discurso de Saviani, presente em textos que tiveram grande repercussão no meio acadêmico, os discursos agrupados sob o nome de teorias crítico-reprodutivistas e a crítica a eles endereçada parecem ter adquirido maior visibilidade e unidade, tornando essa crítica muito mais efetiva. Se hoje somos tentados a ver nas teorias que ele arrola e em outros discursos semelhantes um único discurso, em parte é um efeito desse (re)ordenamento e dessa operação que os une para criticá-los. Digamos que esse é apenas um dos efeitos do ponto de basta que se constitui com os textos de Saviani, que são os que no início delimitam o que ele chama de pedagogia revolucionária, posteriormente denominada pedagogia crítico-social dos conteúdos ou simplesmente pedagogia dos conteúdos. ${ }^{24}$ Um outro efeito,

\footnotetext{
${ }^{23}$ As principais teorias que para Saviani expressam essa tendência são: "a) Teoria do sistema de ensino enquanto violência simbólica (Bourdieu-Passeron); b) Teoria de escola enquanto aparelho ideológico de Estado (Althusser); c) Teoria da escola dualista (Baudelot-Establet)" (1984, p. 69). No livro Escola e Democracia, Saviani também critica a educação compensatória, que considera "uma resposta não-crítica às dificuldades educacionais postas em evidência pelas teorias críticoreprodutivistas" (p. 37).

${ }^{24}$ A expressão pedagogia dos conteúdos é utilizada, por exemplo, por Libâneo (1982, p. 18), que também emprega pedagogia crítico-social dos conteúdos (Libâneo, 1989). Há também outros nomes que situam o mesmo discurso, como concepção histórico-crítica (Ghiraldelli, 1990, p. 204). A formulação desse discurso não diz respeito apenas a Dermeval Saviani. Uma importante fonte teórica citada em vários escritos que definem a pedagogia dos conteúdos é a obra de George Snyders, que é destacada pelo próprio Saviani e por Libâneo. Poder-se-ia dizer, é claro, que a penetração das idéias de Snyders no Brasil foi o que afinal provocou o (re)ordenamento discursivo
} 
inseparável do anterior e bem mais significativo, concerne à "revolução" ou giro discursivo que esse novo ponto de basta produz no campo dos discursos críticos, abalando a hegemonia dos discursos relativos às várias formas de educação alternativa. Com esse giro, um "outro caminho" começa a ser definido, bem diverso dos circuitos que a palavra alternativa criava.

\subsection{Circuitos da palavra alternativa}

$\mathrm{O}$ (re)ordenamento discursivo que se opera a partir do ponto de basta cujo significante-mestre é pedagogia dos conteúdos atinge todas as formas de crítica dirigidas à escola pública que tendem a negar qualquer possibilidade de mudança, que avaliam ser nela impossível sustentar uma ação educativa numa perspectiva que possa ser chamada mesmo de crítica, comprometida com a mudança social e voltada efetivamente para os setores populares. Uma avaliação feita em função de um poder estatal que não é bem visto, seja porque é concebido como um poder exercido pela classe dominante através do Estado, seja porque concerne aos mecanismos próprios da burocracia estatal, das amarras institucionais características do que se encontra diretamente subordinado ao Estado. Portanto, um poder que extrapola os seus protagonistas, subordinando-os ademais à sua lógica. Essas críticas à escola pública são produzidas ou encontram ressonância no campo da educação alternativa, tanto nas experiências que se desenrolam no âmbito da chamada educação popular, quanto nas que envolvem um setor das camadas médias. E podem ser encontradas em alguns textos publicados no início dos anos 80, como Cuidado, escola! (1981). Nesse livro, por exemplo, argumentase em favor das "pedagogias alternativas", tendendo-se a negar qualquer possibilidade de mudança significativa no "sistema educativo oficial". Além disso, entende-se que qualquer escola encontra-se fortemente limitada no que se refere ao seu raio de ação: "a escola não passa de uma peça a mais da engrenagem"

próprio da costura que então é feita. É o que sugere Patto, quando se refere à ruptura teórica inerente ao modo como a escola começou a ser pensada, isto é, determinada pelos condicionantes sociais e econômicos, mas contando também com um certo espaço próprio, com uma relativa autonomia: "Na ruptura teórica que subjaz a essa ruptura política, as idéias de George Snyders desempenharam um papel decisivo, abrindo espaço para a introdução das idéias de Gramsci nos meios acadêmicos" (1988, p. 76). Sem desconsiderar esse fato, aqui, porém, considera-se que coube um papel decisivo aos escritos de Saviani, que foram amplamente discutidos em inúmeros espaços, inclusive fora da universidade. O seu impacto pode ser avaliado pela ampla divulgação que teve o seu livro Escola e Democracia, que, como constata Ghiraldelli (1990, p. 205), "transformou-se em best-seller pedagógico em questão de meses". 
que gera a desigualdade, "uma peça entre as outras", de modo que "a raiz do problema educativo está fora da escola". Por isso, avalia-se também que não existe qualquer possibilidade de generalização das experiências educacionais alternativas enquanto não mudar a sociedade como um todo:

Mas a raiz do problema educativo está fora da escola. A escola inerente ao modo industrial de produção não faz senão prolongar e reforçar - ao invés de contrabalançar e de corrigir — a ação desintegradora, infantilizante e domesticadora da sociedade de consumo e do Estado.

Por isso mesmo é que, a nosso ver, uma outra educação só será viável em larga escala quando a experiência quotidiana de cada cidadão, de cada comunidade ou de cada grupo social - em sua vida e em seu trabalho, em seu modo de comportamento e em suas relações com os outros - se transformar em fonte de questionamento, de criatividade, de participação e, portanto, de conhecimento. (...) Somente uma outra maneira de agir e de pensar pode levar-nos a viver uma outra educação que não seja mais o monopólio da instituição escolar e de seus professores, assumida por todos os membros de cada comunidade e associada a todas as dimensões da vida quotidiana de seus membros. (p. 116)

A preocupação presente nesse texto do IDAC, com o que ocorre na escola e fora dela, com uma transformação que deveria atingir tanto as instituições e práticas educacionais quanto o seu entorno, a começar pelo plano da experiência ou da vida cotidiana, diz respeito ao perfil que buscava-se imprimir às iniciativas educacionais do campo alternativo, seja nas camadas médias ou nos setores populares.

Entre as camadas médias, no caso por exemplo das escolas privadas que na cidade de São Paulo eram chamadas de alternativas, realizavam-se experiências onde o tipo de transformações em jogo envolvia, mais do que as crianças, os próprios adultos (educadores e pais de alunos). Nessas iniciativas, a criação de um estilo de vida pautado por outros valores, diversos dos que então predominavam, era o que havia de mais essencial. Além disso, a idéia de uma "vida alternativa", de um cotidiano regido por outros valores, era solidária da criação de uma outra perspectiva educacional, tanto no âmbito familiar quanto na escola .

Os discursos próprios desse lugar social, em particular os que perpassavam o cotidiano, aí incluídos os de natureza educacional ou pedagógica, 
configuravam e ao mesmo tempo nutriam-se de tudo o que provinha do difuso campo da contracultura e de determinados discursos de esquerda, em particular os que remetiam à tradição libertária, então revitalizada pelos jovens universitários. Essas referências, relativas aos campos cultural e político, eram as que primeiramente definiam o lugar do principal significante-mestre desse discurso, o significante característico do seu ponto de arremate: alternativa. É claro que o discurso educacional alternativo nutria-se ainda de outras fontes, como a Psicologia, de forte presença nas experiências educacionais préescolares. O que dela procedia, entretanto, era sobrepujado por tudo o que o significante alternativa em si condensava, muito embora isso pudesse não transparecer no discurso mais elaborado ou no discurso teórico. Em outras palavras, tanto a psicologia quanto o que era da ordem do conhecimento e da ciência, tendiam a ficar subordinados à ordem de um saber inseparável desse estilo de vida que então estava sendo coletivamente delineado. Um saber e um estilo que em grande parte permaneciam em aberto, com os seus contornos pouco definidos, se aí não considerarmos, é claro, os momentos em que essas iniciativas caíram no mero registro ideológico, no registro característico do imaginário desenhado pelas articulações significantes que procediam dos discursos contraculturais e de esquerda. ${ }^{25}$

Nas iniciativas do campo popular articulava-se uma perspectiva parcialmente semelhante, com as marcas próprias dos seus principais protagonistas: os setores populares. E aqui é preciso atentar para as diferenças relativas às condições de vida dos setores sociais envolvidos nas experiências e projetos alternativos. À diferença das camadas médias, entre os setores populares as preocupações principais diziam respeito à inexistência de certas condições de vida consideradas mínimas, envolvendo a moradia, água e esgoto, coleta de lixo, centros de saúde, educação, entre outras que eram típicas dos que habitavam a periferia dos grandes centros urbanos. São essas as preocupações que estão na raiz das reivindicações de muitas das organizações e movimentos sociais populares surgidos em fins dos anos 70. Essas reivindicações, além de fomentarem o questionamento generalizado do regime militar, estão na origem de

\footnotetext{
${ }^{25} \mathrm{Em}$ relação ao perfil das escolas alternativas surgidas na cidade de São Paulo, veja-se o item "Um passado equivocado", no primeiro capítulo deste trabalho, e a minha dissertação de mestrado (Revah, 1994).
} 
uma diversidade de espaços e atividades que surgiram em face da ausência do Estado, adquirindo então um caráter alternativo. Esse caráter, vale ressalvar, não decorria apenas dessa circunstância, pois muitas iniciativas configuraram-se com o intuito de ficar mesmo à margem do Estado, resistindo à sua presença e a tudo o que ele representava, especialmente sob o governo militar.

Esse é o caso de muitos núcleos de educação popular voltados para a alfabetização de adultos que surgiram no início dos anos 70, durante o governo Médici, num clima de medo, censura e forte repressão política. Nesses núcleos foi retomada a tradição iniciada nos anos 60 , em particular o chamado método Paulo Freire, que durante a ditadura estava proibido.

Uma outra forma de educação alternativa, que se confundia com a anterior, correspondia, aí sim, às iniciativas que surgiram devido à falta de instituições educacionais públicas, principalmente daquelas voltadas para o atendimento de crianças pequenas, como creches e pré-escolas. Várias dessas iniciativas encontravam-se vinculadas aos movimentos de luta por creches que se configuraram em fins da década de 70, tendo como principais protagonistas mulheres dos setores populares, donas-de-casa e mães que se organizaram em movimentos para reivindicar do Estado esse atendimento. Em várias cidades, principalmente em algumas capitais do Norte e Nordeste e no Rio de Janeiro, com o passar dos anos configurou-se uma ampla rede de creches e pré-escolas como alternativa à ausência do Estado. Eram creches ou escolas chamadas de comunitárias, com um tipo de atendimento à criança pequena feito, em geral, por educadoras leigas, por mulheres mais ou menos envolvidas com as mobilizações e movimentos de reivindicação do bairro. Essas escolas, onde também eram promovidos cursos de alfabetização de adultos, posteriormente começaram a receber recursos públicos por meio de diversos convênios com o Estado, contribuindo para configurar o que nos anos 80 começa a ser concebido como um atendimento público não-estatal.

Quanto ao perfil das instituições denominadas comunitárias é necessário frisar que era por demais variável. Havia aquelas que nasceram fortemente atreladas às organizações e movimentos populares e que ao longo dos anos, particularmente na década de 80, contaram com o apoio de especialistas governamentais ou de Organizações Não-Governamentais para formar os seus 
educadores e para discutir questões relacionadas com a gestão da instituição. Num ambiente politizado, com uma gestão institucional que pretendia ser democrática, que abria o seu espaço para a participação da chamada comunidade, essas escolas comunitárias desenvolviam um trabalho educacional inspirado nos princípios consagrados na chamada educação popular. Desde o início, porém, as escolas comunitárias e as várias formas de educação alternativa que surgiram nos setores populares tiveram de enfrentar inúmeros problemas relacionados com as suas condições de vida, problemas que incidiram negativamente sobre a qualidade do trabalho educacional ou pedagógico, como "a precariedade das instalações físicas e das condições de higiene, a superlotação das salas, a falta de materiais didáticos e a não especialização dos agentes que trabalham como educadores" (Sposito e Ribeiro, 1989, p. 18). Ademais, por vezes envolviam um tipo de gestão institucional verticalizado e uma perspectiva educacional distante dos princípios da educação popular. ${ }^{26}$

Além dessas iniciativas, devem ser consideradas todas as formas de educação popular não relacionadas com um determinado nível do ensino ou com qualquer aprendizagem específica. De educação popular era também chamado o trabalho desenvolvido nos grupos que discutiam questões relacionadas com os problemas de seu bairro, envolvendo, por exemplo, as Comunidades Eclesiais de Base ou um grupo de moradores ou vizinhos que se mobilizava para resolver determinado problema. ${ }^{27}$

Segundo o que se evidencia em muitos dos discursos da educação popular dos anos 70 e 80, o educador devia trabalhar no sentido de afirmar uma "cultura popular" ou um "saber popular" de caráter "crítico" e com força suficiente para provocar transformações na "realidade" opressiva imposta pelas classes dominantes às classes populares, pela burguesia à classe trabalhadora, pelos opressores aos oprimidos, em conformidade com um discurso ordenado por essas oposições. O importante era que os educandos adquirissem "consciência" da sua realidade, da situação que os condicionava e oprimia. Uma consciência portanto

\footnotetext{
${ }^{26}$ O que aí está sendo chamado de educação popular corresponde à tradição que remonta ao início dos anos 60 e que se desdobra na década seguinte, tendo como principal fonte teórica inspiradora a obra de Paulo Freire.

${ }^{27}$ As várias formas de educação alternativa aqui apresentadas não são as únicas. Elas foram destacas pela sua relevância e apenas com o objetivo de situar o que neste trabalho está sendo considerado o campo da educação alternativa e dos discursos que o configuravam.
} 
crítica. A conscientização, inseparável do plano da ação efetiva, era considerada essencial para que as classes populares efetivamente se envolvessem na luta pela transformação da situação que as oprimia. Em muitos desses discursos a questão do poder era alçada a um primeiro plano, tendo em vista algo semelhante ao que se enuncia no texto já referido do IDAC: um "poder de ação criadora e autônoma", que deveria nascer junto com esse saber crítico, com esse saber gestado nos setores populares no âmbito das suas lutas e das várias formas de organização popular. As críticas à escola oficial eram comuns e dependiam da modalidade ou nível do ensino envolvido. Em muitas creches e escolas comunitárias denunciava-se, por exemplo, "o tratamento preconceituoso das crianças mais carentes, a incapacidade de compreendê-las, a disparidade entre os conteúdos e a visão de mundo veiculada pela escola e a realidade vivida" pelas crianças dos setores populares (Sposito e Ribeiro, 1989, p. 19). Criticava-se, enfim, o caráter excludente e discriminatório da escola pública, que não estaria presente nas escolas comunitárias, dado que nelas existiria uma identificação cultural entre os educadores e as crianças, além do forte envolvimento pessoal e político de seus educadores (ibidem).

Nesse discurso alternativo-popular, a obra de Paulo Freire constituía a sua principal fonte teórica. Dela provinham importantes articulações discursivas, que podem ser encontradas em seus escritos dos anos 60, como Pedagogia do oprimido, considerada a sua principal obra teórica.

Nesse livro são diferenciadas duas perspectivas educacionais, vez por outra lembradas nos discursos da educação popular dos anos 70 e 80: a educação bancária, que serve à dominação, e a educação problematizadora, que está a serviço da libertação dos oprimidos. A primeira, identificada com a chamada educação tradicional, é concebida como uma forma de educação na qual o educando torna-se um mero recipiente, um simples depósito de conteúdos constituídos por palavras ocas, sem força transformadora. As posições do educador e do educando são fixas, invariáveis; o primeiro será sempre aquele que sabe e o último aquele que nada sabe, aquele que docilmente guarda os conteúdos, memorizando-os mecanicamente. Segundo Freire, "A rigidez destas posições nega a educação e o conhecimento como processos de busca" (Freire, 1980, p. 67). 
A educação problematizadora é uma educação voltada para a libertação, ou seja, para a superação do antagonismo que é próprio da sociedade de classes, da sociedade dividida em opressores e oprimidos. Superar esse antagonismo, que está na base da opressão, é a visada última da pedagogia do oprimido. Esse é o seu sentido político. Um sentido que é próprio da ação educativa que contribui para dissolver a cultura dominante, que segundo Freire é o que afinal mantém as estruturas sociais em que essa mesma cultura se forma (1980, pp. 213-4). Essa "cultura alienada e alienante", que se impõe aos oprimidos e os invade, neles hospedando o próprio opressor, é precisamente o que a educação deve problematizar. A ação educativa é na verdade uma ação cultural, ou seja, uma ação que incide na estrutura social, podendo estar a serviço da dominação ou da libertação dos homens. Quando pela educação problematiza-se a cultura, abre-se a possibilidade de os oprimidos tomarem consciência da sua situação. Dessa consciência crítica, inseparável do plano das ações coletivas, resulta o envolvimento efetivo na luta pela transformação da sociedade, uma transformação simultaneamente política e cultural e que atinge o homem como um todo, humanizando-o.

Segundo Paulo Freire, a humanização do homem é gerada em relações horizontais e dialógicas, relações onde prima a comunicação mediatizada pela realidade, pelo objeto cognoscível. Essas relações são características da chamada educação problematizadora, que é uma educação onde "ninguém educa ninguém" porque todos se educam - e aqui Freire tem em vista, basicamente, as relações que se estabelecem entre adultos e não entre adultos e crianças. É também uma educação para a liberdade, porque ela supõe e implica a idéia de um homem livre, um homem que segundo Freire acolhe a dúvida. Esse é o tipo de homem que é capaz de atingir o que está na raiz da opressão, ou seja, ele próprio, a sua cultura: a cultura que ele hospeda e que, sem se aperceber disso, considera sua. Esse homem radical, que é o autenticamente revolucionário, é diferente do sectário, que pode ser tanto de direita quanto de esquerda - homens esses que segundo Freire sofrem da falta de dúvida (1980, p. 24).

Por meio desse tipo de articulação discursiva, acima apenas delineada, Freire cria uma pedagogia cuja costura é feita entrelaçando o significante educação com os significantes que davam o tom nas experiências de educação 
popular em que ele participou e que proliferaram nos movimentos educativos do início dos anos 60, anteriores ao golpe militar: os significantes cultura e política relativos a duas dimensões que continuaram fortemente entrelaçadas até fins de 1968, pelo menos no âmbito das manifestações, expressões e movimentos que tinham como público e protagonistas as camadas médias e os jovens universitários, cobrando vida novamente na década seguinte no campo alternativo. $\mathrm{Na}$ articulação significante própria desse entrelaçamento, nela aninhado, encontra-se o que poderia ser considerado o cerne do chamado método Paulo Freire: a palavra, ou melhor, determinadas palavras.

A dimensão da palavra, indissociável da ação, constitui na obra de Paulo Freire um elemento fundamental. O homem radical é, justamente, aquele que pronuncia a palavra verdadeira, a palavra que transforma, aquela que é simultaneamente ação e reflexão (Freire, 1980, p. 210). O educador crítico é o educador que mantém um compromisso com essa palavra. Portanto, um compromisso com a transformação da realidade opressiva. Essa palavra, como autêntica práxis, somente surge em comunhão, no encontro com outros homens empenhados na luta por um mundo sem opressão. Além disso, é uma palavra gestada junto aos dominados, que tem de partir dos "condenados da terra', dos oprimidos, dos esfarrapados do mundo e dos que com êles realmente se solidarizem" (p. 32).

O primeiro passo no método Paulo Freire é precisamente um passo dado em direção a essa palavra, a princípio uma "palavra geradora", retirada do universo vocabular dos educandos por meio da pesquisa que "agentes" ou "animadores" devem realizar na comunidade de origem dos alfabetizandos, de preferência convivendo com ela, ouvindo a suas falas, vendo como é o seu dia-adia, as suas necessidades e preocupações. Com a escuta aguçada nesse convívio, para iniciar o trabalho de alfabetização devem ser escolhidas determinadas palavras: é preciso "descobrir as palavras mais carregadas de emoção, mais carregadas de sensibilidade, mais ligadas à problemática da área"; as palavras geradoras devem ter "uma indiscutível força e um peso, uma significação viva dentro da área". Segundo Freire, o "critério da força significativa da palavra a gente pode perceber através de uma certa repetição da mesma palavra" (Freire e Beto, 1988, p. 19). Essas palavras geradoras, afora a sua 
"riqueza fonética" e a possibilidade que oferecem aos alfabetizandos de ir vencendo certas dificuldades (como a leitura e emprego de dígrafos), destacamse pela sua "riqueza temática, isto é, a variedade de temas que a elas estão referidos. Temas que, ligados à realidade local dos alfabetizandos, tornam possível a análise de aspectos da realidade nacional" (Freire, 1984, p. 144).

No método Paulo Freire, à palavra geradora é associada a "codificação" que é "a representação de um aspecto da realidade" (fotografia, desenho, etc.) e um elenco de temas. A discussão e o debate em torno das palavras geradoras e da codificação e os temas geradores, vinculados a essas palavras pelos mesmos alfabetizandos, é o que dá lugar à "leitura da realidade", ao início da sua compreensão crítica. Esse processo envolve o que Freire chama de "decodificação", implicando um maior conhecimento da realidade em que todos estão inseridos, um conhecimento ou um saber de caráter crítico. Nesse mesmo processo, através da comunicação e do diálogo que animador e alfabetizandos estabelecem, todos se educam, ou seja, todos mudam as suas "posições" no mundo. ${ }^{28}$ Isso implica, além de uma maior tomada de consciência sobre a realidade e sobre os problemas que afetam a comunidade, a organização e planificação de ações concretas, de interesse coletivo. Esses dois planos sempre devem estar presentes, eles concernem à dupla dimensão da palavra que Freire destaca: reflexão e ação. Enfim, é desse modo que Paulo Freire entende a alfabetização ou a educação de adultos, como uma ação centrada no uso da palavra, da palavra situada no plano da ação política e cultural.

Aproximando as conceitualizações de Paulo Freire do que é proposto neste estudo, pode-se dizer que as palavras geradoras são significantes-mestres dos discursos que perpassam o cotidiano de determinado grupo ou setor social, são pontos significantes que neles ganham ressonância, por isso retêm - e isto o que explicitamente se busca - o que nesses grupos ou setores há de singular, mesmo que às vezes possam ganhar ressonância nacional, como afirma Freire quando se refere, por exemplo, à palavra greve, que em determinado momento foi "uma palavra geradora nacional" (Freire e Beto, 1988, p. 20). É justamente nesses

\footnotetext{
${ }^{28}$ Para Freire, esse processo de debates e discussões não se restringem à alfabetização, podem ocorrer sem que seja desencadeado qualquer trabalho de alfabetização.
} 
pontos que é necessário penetrar. Neles e através deles, por meio da análise, debate e discussão das palavras e temas geradores - que diga-se de passagem não prescindem do saber dos especialistas, do saber disciplinar gerado no âmbito da ciência ${ }^{29}$ —, busca-se produzir deslocamentos discursivos e de posição subjetiva, que ocorrem na medida em que as séries discursivas amarradas nesses significantes-mestres vão sendo desatadas e costuradas de uma outra forma e com outros significantes. O que sobrevém desse processo é o que sobretudo interessa, o saber vem a posteriori, ele é produzido après-coup. No início todos encontram-se mais ou menos na ignorância e sem saber ao certo qual o sentido ou a "certeza" que poderá emergir dos debates e reflexões cujo norte é dado pelos pontos de ressonância dos discursos da comunidade. O saber crítico nasce nessa relação com os outros, com o Outro, este sendo demarcado com significantes como povo e comunidade.

Nessa ordem da palavra, da "palavra verdadeira", Freire situa o "saber verdadeiro", que é um saber ligado à ação e capaz de dissolver a cultura dominante, ou seja, capaz de transformar e libertar os homens das relações autoritárias, hierarquizadas e de opressão que vigoram na sociedade de classes. Assim considerado, sob o viés da libertação, o lugar do saber sofre um deslocamento importante: enquanto as orientações que caracterizam o método tendem a situá-lo como algo aberto, que acolhe a dúvida, o inesperado e o novo, o evento totalizador que estabelece o seu norte o transforma num saber já previamente enquadrado, tanto mais quanto maior a rede imaginária ${ }^{30}$ que define o seu sentido, ou seja, o sentido da libertação. Nessa diferença pode ser situado o que é da ordem dos limites e da ambigüidade da proposta freiriana, ou então, dos lugares onde o saber se configura nesse discurso.

Nos anos 70, mas também na década de 80 , a fonte primeira do "saber verdadeiro", do saber popular e crítico, é situada nas organizações e movimentos sociais populares desse período e na chamada comunidade. Daí os significantesmestres que definem o ponto de arremate dos discursos educacionais desse campo alternativo, como escolas comunitárias e educação popular, este último

\footnotetext{
${ }^{29}$ Paulo Freire trata sobre esse ponto em Pedagogia do oprimido, quando se refere aos temas "dobradiça".

${ }^{30} \mathrm{O}$ termo acima denota o que Lacan concebe como registro do imaginário.
} 
prolongando a tradição dos movimentos educativos do início dos anos 60 . Neles embutidos, significantes como comunidade, popular, povo, movimentos populares e movimentos sociais servem para delimitar o lugar onde busca-se gestar e alicerçar o saber que transforma, o saber crítico e popular, mesmo quando esse discurso penetra no âmbito da escola pública, onde a principal referência tende a ser a chamada comunidade. Daí o insistente lema da integração escolacomunidade que percorre a década de 80 . O surgimento de uma outra escola pública, de uma outra educação é considerado inseparável da relação com a comunidade e de transformações que nela também devem ocorrer. $\mathrm{Na}$ comunidade, onde tende a ser incluída a própria escola, é situado em última instância o que é da ordem de um saber capaz de mudar a escola pública, um saber que deve ser produzido coletivamente, sempre tendo por base relações democráticas.

O saber popular considerado crítico em grande parte correspondia ao que era gestado no plano onde emergiam e para o qual remetiam as questões então essenciais, ou seja, o cotidiano, que parece ter sido tão valorizado quanto no setor das camadas médias do campo alternativo. Essa valorização do cotidiano popular e os novos sentidos que dele emergem são destacados em vários trabalhos, como é o caso do estudo feito por Eder Sader sobre os movimentos sociais populares que surgiram em São Paulo na década de 70. A vitalidade desses movimentos sociais é relacionada por Sader com o sentido que o cotidiano popular então adquiriu, um cotidiano composto pelas "múltiplas formas de experiência da condição proletária":

(...) é certo que a vitalidade dos movimentos sociais gestados nos anos 70 está ligada ao fato de terem tomado e desdobrado as questões postas por esse cotidiano. As experiências da "voragem do progresso" com a remodelação incessante da paisagem urbana e as mudanças repetidas de casas e trajetos, as longas distâncias, a casa própria como sonho e/ou como realidade, o acesso a novos bens de consumo e a linguagem da televisão, o ritmo febril de cada dia -; as experiências da aculturação dos migrantes na selva urbana e da mobilização das relações informais para enfrentar os desafios; as experiências do desemprego e do despotismo fabril, das diferenças de exploração entre profissionais e peões, jovens e velhos, homens e mulheres, já vividas carregadas dos significados culturais instituídos, foram reelaboradas através dos movimentos sociais. (Sader, 1988, p. 142) 
Esse cotidiano popular, cujas várias facetas são indissociáveis do tipo de modernização impingida à sociedade durante o regime militar, foi objeto de reelaboração pelos movimentos sociais populares. Nesses movimentos, o cotidiano deixou de ser apenas o lugar da vida repetida, do conformismo ou da "reiteração acrítica de uma opressão silenciosa", como sugere Sader (1988, p. 141). Com eles, o cotidiano tornou-se um espaço de lutas e resistências, onde pequenas transformações foram adquirindo uma dimensão política, num sentido do político que foi alargado e transfigurado, se o compararmos com o que era próprio dos discursos que Sader chama de "matrizes discursivas da contestação", contrapostas por ele à "matriz dominante", relativa aos "discursos da ordem" (ibidem, pp. 144 e 194). ${ }^{31}$

Nos discursos da contestação, Sader identifica três matrizes discursivas que são misturadas e transformadas no âmbito dos movimentos sociais populares e no processo de reelaboração de seu cotidiano: a matriz discursiva da teologia da libertação, a matriz marxista e a matriz sindical. Essas três matrizes são primeiramente referidas a três instituições em crise: a Igreja Católica, os grupos de esquerda, cuja origem remete às organizações da "esquerda revolucionária" que surgem nos anos 60 , e os sindicatos dos trabalhadores qualificados. Segundo Sader, da reelaboração discursiva que se processa a partir desses discursos da contestação, no seio do movimentos sociais, resultam outros discursos, bem como uma "nova configuração das classes populares", com todo um conjunto de novos atores sociais e formas de organização popular, como os clubes de mães, o Movimento do Custo de Vida, as comissões de saúde e o movimento de saúde da periferia Leste da cidade de São Paulo e "o novo sindicalismo", que emerge das lutas dos metalúrgicos do $\mathrm{ABC}$ paulista e que está na base da nova força políticopartidária que surge no início da década seguinte — o Partido dos Trabalhadores. Essa lista, sob uma perspectiva mais ampla, que inclua outros setores e atores sociais, ainda pode ser ampliada com os movimentos e grupos que giravam em torno de temas e questões de uma outra natureza e cuja procedência não pode ser situada com as matrizes discursivas destacas por Sader, como é o caso dos grupos de homossexuais, das feministas e do movimento negro.

\footnotetext{
${ }^{31}$ Aqui vale ressalvar que o modo como Sader concebe o discurso ou o que ele chama de matriz discursiva é diferente do que neste estudo é chamado de discurso ou de matriz simbólica.
} 
Nesse processo de reelaboração discursiva constitui-se o discurso característico do cristianismo das comunidades de base, de forte presença nas organizações e movimentos populares que contaram com o apoio de agentes pastorais. No campo da educação alternativa, a presença desse discurso e o papel preponderante da Igreja Católica ficam em evidência no próprio ponto de arremate dos discursos educacionais, no significante escolas comunitárias. Quem principalmente pautava o que era chamado de comunitário ou concebido como vida comunitária era, precisamente, a Igreja Católica. E aqui é importante lembrar que, nos anos 70, essa instituição estava passando por transformações significativas, relacionadas com o que o significante comunidade costumava delimitar.

Essas transformações datam dos anos 60, quando ocorre o Concílio Vaticano II (entre 1962 e 1965) e a Conferência Geral do Episcopado na cidade colombiana de Medellín (1968), que reorienta a ação da Igreja na América Latina. $\mathrm{Na}$ conferência de bispos de Medellín, além de a Igreja reafirmar o papel da "família cristã" e a importância de determinados valores morais, denuncia com ênfase as estruturas sociais que no capitalismo geram desigualdade, exploração e miséria (Sader, 1988, p. 154). A luta contra essas estruturas injustas não é aí concebida de modo individual, mas sim em comunhão, por meio da constituição de comunidades onde devem ser fomentadas a solidariedade e a participação ativa e consciente (ibidem, p. 155). Em função dessa orientação, a Igreja promove a formação de Comunidades Eclesiais de Base, CEBs, as quais multiplicam-se no Brasil aos milhares, primeira e principalmente na zona rural, mas também na periferia dos grandes centros urbanos. ${ }^{32}$ As CEBs adquirem uma forma de organização flexível e são concebidas como comunidades de iguais. Ademais, constituem espaços relativamente autônomos, onde seus membros decidem as suas ações, é claro, sob a influência dos preceitos da Igreja, que na época incluía os setores onde encontrava eco a Teologia da Libertação, esta servindo de referência importante nas falas pastorais (ibidem, p. 160). Nesses espaços, que contam com a presença de agentes pastorais e de inúmeros leigos, dos bairros onde surgem essas comunidades de base, vai-se configurando um outro discurso,

\footnotetext{
${ }^{32}$ Calcula-se que em 1981 havia cerca de 80 mil comunidades de base em todo o Brasil, embora os números sejam imprecisos (Sader, 1988, pp. 155-6).
} 
diretamente relacionado com os problemas cotidianos das camadas populares. $E$ esse cotidiano, nesses espaços, é reelaborado coletivamente, embora não apenas neles, pois as CEBs envolveram-se em iniciativas coletivas que extrapolaram o âmbito estritamente religioso.

Nesse novo discurso comparece o tema da libertação, que certamente se misturou e confundiu com as articulações discursivas próprias da obra de Paulo Freire, pelo menos no âmbito das iniciativas voltadas para a educação popular. Com o termo libertação, porém, não estamos só diante de um tema, pois nos discursos pastorais constitui um forte ponto de ressonância. E mais do que isso, ao que tudo indica é o significante em torno do qual operou-se o importante (re)ordenamento discursivo que alterou a "postura da Igreja", como pode ser inferido da análise de Sader:

Este reconhecimento do povo (mais freqüentemente enunciados como os pobres, os excluídos, os oprimidos), como portador das mensagens de Deus, implica efetivamente uma alteração na postura da Igreja (...) uma atenção especial voltada para os "deserdados" não chega a constituir novidade na prática da Igreja. Novo seria aquilo que Leonardo Boff caracterizou como passagem de uma estratégia da caridade para outra da libertação (...) a estratégia da libertação começa por ver nos pobres uma experiência de encontro com Deus e a possibilidade de serem sujeitos conscientes de sua própria libertação. (Sader, 1988, pp. 163-4)

Isso que não poucas vezes afigurava um caminho ou uma caminhada, com esse mesmo significante comparecendo aí para situar o que era da ordem de uma trajetória em direção à libertação, inspirava-se inicialmente no que havia sido ressaltado pela Igreja em Medellin. No decorrer da década de 70, entretanto, essa caminhada da libertação vai adquirindo os contornos próprios do percurso que as organizações e movimentos sociais populares realizam, em função das suas reivindicações e de acordo com os embates que precisam travar, em geral com alguma autoridade ou representante do Estado. Nesses embates, condicionados pelas restrições impostas pela ditadura militar, adquirem valor os problemas do cotidiano, as próprias ações e a autonomia dos movimentos, que em geral não chegam até as autoridades pedindo um favor e sim reivindicando um direito. Por essa via, como indica Sader, além de ser alargado o espaço da política, foram inventadas novas formas de política, num processo em que as formas tradicionais de fazer política foram rejeitadas, chegando-se mesmo a desconfiar do discurso político. E aí vale lembrar que, em geral, as novas organizações e movimentos 
sociais não se encontravam referidos a qualquer estratégia revolucionária, nem a qualquer organização política que pudesse ultrapassá-los e definir o que eles eram. A política foi reinventada, segundo Sader (1988, p. 20), "politizando as questões do cotidiano dos lugares de trabalho e de moradia", com cada organização e movimento definindo-se mesmo no percurso.

Isso não significa que as iniciativas do campo popular não ficassem encerradas, em vários momentos, no universo "fechado" criado pelas palavras de ordem oriundas dos discursos já referidos, tornando o saber popular um saber inscrito num registro dominado pelo imaginário ${ }^{33}$, à semelhança do que ocorreu nas experiências alternativas desenvolvidas nas camadas médias. É o que pode ser inferido desta observação de Sader, sobre as discussões realizadas no âmbito das comunidades de base:

Quando observamos o modo de elaboração da realidade usado nas comunidades de base, é difícil não se impressionar com um certo "populismo teórico" com que se pretende valorizar o "saber popular". De um lado, pretende-se que da simples troca de informações e conhecimentos chegue-se à "realidade objetiva". De outro, pressupõe-se a existência dessa "realidade objetiva" como um dado irretorquível e sem ambigüidades. (Sader, 1988, p. 160)

É claro que os discursos do campo popular, especificamente os discursos educacionais alternativos, não tomavam essa única configuração - e é bem duvidoso que fosse a predominante. É o que pode ser inferido do que o próprio Sader sugere na continuidade desse mesmo texto:

Mas o fato é que - por mais ingênuo que seja — a prática desse confronto de informações, avaliações e propostas está ligada a ações que visam mudar a realidade tratada e produz nos participantes uma dimensão crítica e uma capacitação transformadora. (ibidem)

Um exemplo do que essa transformação significou, não apenas do ponto de vista político, mas também cultural, diz respeito à atuação das mulheres dos setores populares. A sua participação nas organizações e movimentos populares as colocou, pela primeira vez, em face do espaço público, da política e de questões antes impensadas. Essas mulheres, nesse período, levaram para o

\footnotetext{
${ }^{33}$ Esse termo denota o que Lacan concebe como registro do imaginário.
} 
espaço público questões do seu cotidiano, como o problema da educação dos filhos e o seu lugar na família, então questionados e repensados.

Nesse processo de reelaboração das experiências e discursos relacionados com as lutas dos setores populares, além dos militantes católicos ligados às CEBs ou às pastorais - que nem sempre estiveram presentes nas mobilizações ou na origem das organizações populares —, é preciso considerar outros atores, já parcialmente referidos, como intelectuais e militantes ou ex-militantes de esquerda, profissionais que atuavam em determinada área (como saúde ou educação) e estudantes universitários, dentre eles os que eram sensíveis à temática e preocupações próprias do campo alternativo que um setor das camadas médias delimitava. Dessa mistura, relativa a setores e atores sociais diversos, resultou o fermento próprio dos anos 70 , quando as transformações que se operaram no âmbito do cotidiano tiveram forte impacto no terreno político, social e cultural. Um fermento que resultou da confluência de universos discursivos por vezes bem dissonantes e cujas diferenças podem ser facilmente acentuadas pela simples contraposição de alguns termos, como Igreja e feminismo ou Igreja e contracultura.

Essas diferenças correspondem às que era possível notar no universo educacional alternativo e eram, é verdade, significativas, apesar dessa diversidade de discursos educacionais serem aqui considerados como articulações significantes da mesma matriz simbólica, do mesmo discurso. Essas diferenças podem ser pensadas no eixo dos nomes utilizados para reconhecer as várias formas de educação alternativa, ou seja, no eixo dos significantes-mestres que definem o ponto de arremate desse discurso. Ao que tudo indica, os significantes educação popular, escola comunitária ou escola da comunidade dificilmente eram utilizados para reconhecer qualquer instituição ou experiência educacional que se desenrolasse entre as camadas médias, onde além do termo alternativa (escolas alternativas) era possível encontrar outros termos de circulação mais ou menos restrita, como escolas experimentais ou renovadas este último servindo sobretudo para situar experiências e discursos que dificilmente eram considerados alternativos. $O$ inverso, porém, não ocorria, pois o significante alternativa era por vezes utilizado no campo popular, ao que parece principalmente por estudantes e intelectuais oriundos das camadas médias, como 
os "agentes" ou "assessores" vinculados, por exemplo, às instituições que no fins dos anos 80 começaram a ser chamadas de Organizações Não Governamentais (ONGs). Essas diferenças, além de relativas a setores sociais distintos, correspondem a diferenças nos pontos de ressonância. Por isso, embora o discurso educacional alternativo seja aqui muitas vezes considerado como um único discurso, porque vários pontos de ressonância são compartilhados, poderse-ia pensar em dois discursos, sem considerar o fato de que sempre seria possível dividi-los novamente. Afinal, os discursos contêm também as marcas próprias dos inúmeros lugares institucionais onde são gestados, afora o que é da ordem estritamente singular, porque relativo aos sujeitos que os produzem.

Mas fiquemos apenas nesses supostos dois discursos. A sua separação, sob um certo ponto de vista, que é precisamente o deste estudo, sempre será bem problemática, dado que há um forte ponto de enlace entre ambos, um ponto por demais importante, pois o significante alternativa está exatamente no ponto de arremate desses discursos, que é o que mais vale no embate com outros discursos. Digamos que esse significante, nesse ponto, é o que cria a unidade necessária nesse terreno, que é o terreno político. Separar o que aí foi soldado implica desfazer a unidade criada nas práticas discursivas próprias desses embates. Implica, ainda, apagar um importante nexo entre discursos relativos a lugares sociais distintos. Nesse caso está em jogo o apagamento do significantemestre alternativa, mas também de circuitos que essa palavra criou e reuniu. Essa operação de apagamento, de produção de uma forma de esquecimento, supõe que sejam interrompidas ou cortadas as várias séries significantes que fizeram da palavra alternativa ou das expressões escola alternativa e educação alternativa um significante-mestre. $E$ isso foi exatamente o que ocorreu na segunda metade dos anos 80, com conseqüências do ponto de vista histórico, na medida em que esse significante, transformado numa palavra como outra qualquer, está no cerne do recalque de um passado que cria parte dos sintomas construtivistas.

Ao longo da década de 70, as múltiplas lutas e discursos que tinham como referência o cotidiano, que reconfiguraram grupos e setores sociais, que redimensionaram o campo político e cultural, vão se somando e configurando o terreno da resistência à ditadura e das lutas pela democracia. O saber então valorizado nos discursos educacionais do campo alternativo inscreve-se nesse 
mesmo registro, com a democracia constituindo o grande eixo das transformações então visadas. E é nesse ponto de ressonância que também incide o discurso da pedagogia dos conteúdos, produzindo um giro discursivo que afeta o lugar do saber nos discursos educacionais considerados críticos, até esse momento basicamente concernentes ao universo dos discursos alternativos.

\subsection{Do saber da experiência ao saber pedagógico}

No livro Escola e Democracia, cujo título já evidencia onde o discurso de Saviani pretende ficar amarrado, são criticadas e rearticuladas as relações estabelecidas entre educação e política que o autor julga serem próprias do que predomina no campo dos discursos educacionais críticos. Essa temática é desenvolvida no texto "Onze teses sobre educação e política" e o seu ponto de partida é o "slogan" que de "uns tempos para cá se tornou lugar comum": a afirmação de que "a educação é um ato político" (1984, p. 85). A sua intenção é desfazer a identidade aí suposta, sem desconsiderar o fato de que educação e política são inseparáveis e de que esse "slogan", em seu momento, cumpriu um papel importante, pois possibilitou que a educação, de "fenômeno estritamente técnico-pedagógico", passasse a ser vista em sua dimensão política. Segundo Saviani, ao cair no pólo oposto, no "pólo político", a educação perdeu a sua especificidade — e aqui ele tem em vista, basicamente, a educação escolar.

Nesse texto, dedica-se então a sublinhar as diferenças entre educação e política: enquanto na educação é estabelecida uma relação entre não antagônicos, na política a relação se trava entre antagônicos; a primeira é uma relação de hegemonia alicerçada na persuasão (consenso, compreensão) e o seu objetivo é convencer, a segunda é uma relação de dominação baseada na dissuasão (dissenso, repressão) e o seu objetivo é vencer (Saviani, 1984, pp. 8693). Essa diferenciação está presente nesta apreciação de Saviani:

(...) em política, seria ingenuidade acreditar que o adversário está na posição oposta porque está equivocado; porque não compreendeu o seu erro e a validade da proposta contrária (...) ele pode ser vencido, mas não convencido.

Parece claro que em educação o comportamento é claramente diferente do acima descrito. Um professor, por exemplo, acredita que, se ele fundamentar adequadamente os assuntos em torno dos quais se trava sua relação com os alunos; se ele os expuser de modo claro, se suas posições forem consistentes e os alunos chegarem ao entendimento de 
seu significado, eles tenderão a concordar com ele. Se isso não ocorrer, é normal atribuir o desentendimento a uma insuficiente compreensão, a algum tipo de equívoco. (Saviani, 1984, p. 87)

Nessa diferenciação já se anuncia certo viés próprio do giro discursivo que a pedagogia dos conteúdos produz, sendo posteriormente acentuado e completado pelo construtivismo, mais precisamente com os significantes-mestres que definem um de seus pontos de ressonância: o ponto dos "desvios, confusões, equívocos ..." ${ }^{34}$ Naquela apreciação, porém, esse viés não pode ser mais do que entrevisto, porque fica circunscrito à relação educativa. Mas nota-se com nitidez num texto anterior de Saviani, como bem evidencia Libâneo (1989, p. 20), ao retomar e reforçar as suas idéias: "Em artigo publicado em 1981, Saviani descreveu com muita propriedade certas confusões que se emaranham na cabeça dos professores". ${ }^{35}$ Em que consiste essa confusão é esclarecido por meio desta citação do texto de Saviani:

“(...) Aí está o quadro contraditório em que se encontra o professor: sua cabeça é escolanovista, a realidade é tradicional; (...) rejeita o tecnicismo porque sente-se violentado pela ideologia oficial; não aceita a linha crítica porque não quer receber a denominação de agente repressor". (ibidem)

O professor confuso, que fica enredado nas diversas tendências que Saviani e Libâneo procuram depurar, apresentando-as de uma forma clara e distinta, já se encontra próximo do lugar que o construtivismo lhe destinará. Digamos que o terreno já está sendo preparado, não apenas para o professor, mas antes para a emergência de um novo discurso, que não é propriamente o novo que a pedagogia dos conteúdos representa.

A pedagogia crítico-social dos conteúdos pretende restituir à educação escolar a sua especificidade, que é a socialização dos conhecimentos acumulados pela humanidade, os chamados conteúdos, pois é desse modo que a escola cumpre a sua função política. Em outras palavras, a educação escolar somente cumpre a sua função política na medida em que mantém a sua especificidade, que é "o pedagógico" ou o ensino, este concebido como transmissão do conhecimento, sempre sob a perspectiva de uma assimilação

\footnotetext{
${ }^{34}$ A esse propósito, veja-se o primeiro capítulo deste trabalho.

${ }^{35}$ O livro Democratização da escola pública, de Libâneo, foi escrito na primeira metade da década de 80. A citação de Saviani por ele reproduzida foi retirada do texto "Tendências pedagógicas contemporâneas", que Libâneo não apresenta com os dados bibliográficos completos.
} 
crítica. $^{36}$ Se essa especificidade for dissolvida, se a escola não cumprir com a sua função histórica, então igualmente dilui-se a sua função política.

Essa função política, portanto, não se efetiva de modo direto e imediato, mas sim de maneira indireta e mediata: a educação é "uma atividade mediadora no seio da prática social global" (Saviani, 1984, p. 77) — "atividade mediadora entre o individual e o social, entre o aluno e o mundo social adulto, entre o aluno e a cultura social acumulada" (Libâneo, 1989, p. 119). Segundo Saviani (1984, p. 81), o "processo educativo é passagem da desigualdade à igualdade": no ponto de partida temos uma desigualdade real, mas essa desigualdade pode ser convertida em igualdade pela mediação da educação, embora não isoladamente, pois também é necessário o concurso de outras mediações que fazem parte da prática social global. Quer dizer, a "democracia é uma conquista": no ponto de partida só pode ser concebida como uma possibilidade, tornada realidade apenas no ponto de chegada (ibibem). Por isso a educação escolar deve ser avaliada em razão de seus efeitos na prática social global e não apenas por meio de um critério interno à prática pedagógica. Essa dimensão estritamente educacional deve ser extrapolada, pois o que conta são os "efeitos que se prolongam para além dela e que persistem mesmo após a cessação da ação pedagógica” (p. 80). Isso significa que o grau de democratização alcançado no interior das escolas deve ser aferido considerando-se o impacto das práticas pedagógicas em termos de elevação cultural das classes populares e da sua instrumentalização para a luta e a transformação da sociedade de classes, tendo em vista a sua libertação e, em última instância, a plenitude humana, que "está condicionada à superação dos antagonismos sociais" (p. 91).

Confundir educação e política, torná-las idênticas (Saviani, 1984), "sobrepor às questões pedagógico-didáticas os aspectos sociopolíticos", "Permanecer somente nos aspectos extra-escolares para defender os interesses populares, sem chegar ao interior da escola" (Libâneo, 1989, pp. 115 e 119), atribuir à escola a formação da consciência revolucionária e não atentar para a transmissão e apropriação do conhecimento (Mello, 1981, p. 89) - eis aí algumas das críticas que têm por base a rearticulação entre educação e política produzida por esse

\footnotetext{
${ }^{36}$ Sobre a especificidade da educação escolar, além de Saviani (1984), veja-se Libâneo (1989).
} 
novo discurso pedagógico. Nessa rearticulação está em jogo o significante-mestre que nos anos 70 e início dos 80 ressoava em todos os discursos de oposição ao regime militar: democracia. Um significante de presença obrigatória no campo dos discursos educacionais críticos e imprescindível em qualquer operação discursiva que ali pretendesse encontrar alguma ressonância, como bem evidenciam os títulos dos livros onde Saviani e Libâneo reuniram os seus principais textos sobre a pedagogia dos conteúdos: Escola e Democracia e Democratização da Escola Pública. Em outras palavras, o significante democracia constitui nesse discurso um ponto de ancoragem, um ponto onde se afirma e a partir do qual projeta a sua bateria significante.

A amarração do novo discurso nesse ponto de ressonância do campo político é feita através do próprio nome, ou seja, dos significantes que definem o seu ponto de arremate: pedagogia e conteúdos. Esses são precisamente os significantes que estabelecem o que deve ser entendido como sendo específico da educação escolar. Com eles, realiza-se uma dupla operação discursiva. De uma parte, enraíza-se o novo discurso no campo dos discursos críticos, com o nexo que aí é relevante, ou seja, a política, na medida em que a função política da educação, estreitamente vinculada à perspectiva de uma sociedade democrática, sobrevém com aqueles dois significantes. De outra, produz-se a torção que nos discursos críticos coloca o pedagógico no lugar do ideal, com as séries discursivas que nesse ponto vão sendo amarradas.

Essa dupla operação discursiva pode ainda ser pensada de outro modo: ela atinge a articulação significante que nos discursos educacionais entrelaçava educação, cultura e política, tendendo a desfazer a costura que desde o início dos anos 60 vinha sendo (re)feita em inúmeros discursos e experiências educacionais. Em outros termos, a ação educativa é separada da ação política ou pelo menos é estabelecida uma considerável distância entre ambas. Ademais, a dimensão cultural tende a ser reduzida à sua versão escolar: o conhecimento ou o saber sistematizado que deve ser transmitido na escola. Ou seja, a ação educativa deixa de ser uma ação cultural, no sentido amplo da palavra, para se tornar uma ação relativa a uma dimensão bem específica da cultura. Essa dupla operação discursiva separa o que até esse momento, no início dos anos 80 , vinha sendo fortemente vinculado. A ação educativa ganha agora um sentido depurado do tom 
que os significantes cultura e política costumavam the imprimir. Fica, digamos assim, o sentido pedagógico da ação educativa, pelo menos esse é o plano que ganha relevância, sobrepujando todos os outros.

Os principais alvos da argumentação que rearticula a relação entre educação, cultura e política e das críticas que ela sustenta são, é obvio, as práticas e discursos educacionais alternativos, muito embora 0 seu reconhecimento nos textos de Saviani e Libâneo exija algum esforço por parte do leitor, pois deve ser feito através das categorias que esses autores utilizam. Libâneo, por exemplo, a eles alude quando faz referência à pedagogia libertadora e à pedagogia libertária, que do ponto de vista da prática escolar considera semelhantes em muitos aspectos (1989, p. 70). Fala igualmente da "educação popular", ora identificando-a com a pedagogia libertadora, ora abrangendo ambas pedagogias (libertadora e libertária), operando assim um deslizamento que indica a dificuldade encontrada para separá-las (pp. 16 e 69). Menciona também as escolas "experimentais" e as "escolas comunitárias", que vincula à "tendência liberal renovada progressivista", assim situando-as fora do campo dos discursos educacionais críticos, ou melhor, das pedagogias progressistas, na terminologia que ele utiliza (p. 27). Em nenhum momento, porém, tanto Libâneo quanto Saviani utilizam o adjetivo alternativa, que era o significante que em não poucas falas costumava soldar as práticas e discursos alvos das críticas mais contundentes, ao menos das que eles faziam tendo em vista o campo dos discursos críticos, que era precisamente onde eles buscavam encravar e tornar hegemônica a sua própria alternativa.

Além de relacionada com uma disputa que deve ser situada no terreno ideológico e político, essa operação discursiva que apaga uma marca gerada nas práticas discursivas próprias desse período, da década de 70 e parte da década seguinte, igualmente apaga todo um conjunto de traços que singularizam as experiências e discursos educacionais alternativos. Ao serem primordialmente referidos a tradições anteriores e a categorias que tendem a abstrair qualquer traço de singularidade, que ignoram ademais qualquer transformação no âmbito do cotidiano escolar - e por tudo isso bem cabe a esses autores o título de abstracionistas (Azanha, 1990) —, as experiências e discursos educacionais alternativos deixam de ser avaliados no plano onde se produzem as 
transformações mais significativas. Ou então, essas transformações são avaliadas tão-somente a partir das categorias que o discurso da pedagogia dos conteúdos a elas sobrepõe, obscurecendo e anulando determinadas dimensões e aspectos realçados nas práticas discursivas do cotidiano escolar, as quais, é claro, para esse novo discurso não eram relevantes, posto que o principal concernia à "especificidade" da educação escolar. É por isso que nessas reflexões de Saviani e Libâneo não existe, por exemplo, qualquer referência às transformações culturais que estavam se processando no âmbito da vida cotidiana e que também incidiram sobre as práticas educativas e o dia-a-dia das instituições educacionais. É verdade que na maioria das escolas, nessa época, tudo isso era provavelmente muito incipiente. Mas, mesmo assim, seguindo-se o fio das suas reflexões, parece até que nada estivesse ocorrendo nesse plano. $O$ mesmo pode ser dito em relação à política, que continuou sendo pensada com as categorias de outrora, passando-se ao largo de questões de ordem micropolítica e do alargamento que esse campo vinha sofrendo. Na verdade, tudo o que era dessa ordem e do âmbito das transformações ocorridas no cotidiano, além de ficar obscurecido ou mesmo desaparecer do discurso desses autores, tende a ser banalizado, porque reduzido a determinadas caricaturas, como o chamado democratismo (Libâneo, 1989, pp. 49-51). Apesar disso, é necessário reconhecer que essas caricaturas não deixaram de evidenciar limites e problemas próprios dessas práticas e discursos alternativos, cumprindo por isso um papel crítico importante e com efeitos duradouros sobre esse campo.

Em face do que era hegemônico no campo dos discursos educacionais críticos, ou seja, diante do predomínio das práticas e discursos alternativos, a pedagogia dos conteúdos é apresentada como sendo "um outro caminho":

Até bem pouco tempo, os educadores empenhados no ensino voltado para os interesses populares dispunham apenas de propostas pedagógicas da "educação popular" (pedagogia libertária e pedagogia libertadora), assentadas na valorização dos processos em detrimento dos produtos da aprendizagem, na não-diretividade, na dissolução do especificamente pedagógico no sociopolítico e no ceticismo. A pedagogia crítico-social dos conteúdos (...) é um outro caminho para os que encaram a escola pública como difusão de conhecimento, que confiam na possibilidade de uma sistematização do saber e sua crítica, na valorização do pedagógico sem perder a vinculação com o todo social. (1989, pp. 167) 
Na perspectiva traçada por esse novo discurso, para democratizar a escola pública "é imperioso buscar uma pedagogia e uma didática" (Libâneo, 1989, p. 12), é urgente definir um novo "modelo pedagógico", que seja "mais adequado" a uma escola comprometida com a maioria das crianças brasileiras - um novo modelo para "uma nova escola, mais democrática e popular". ${ }^{37}$ Para enveredar por esse "caminho", que nesse discurso também adquire o sentido de um caminho em direção à libertação, o que aí torna-se prioritário, o passo que deve anteceder qualquer outro, é a realização de "uma reflexão criteriosa sobre a teoria educacional brasileira", sobre os fundamentos teóricos da prática pedagógica, não exatamente para provocar uma ruptura e sim para produzir uma "síntese superadora". ${ }^{38}$ Dela espera-se que resulte, em última instância, uma Nova Escola.

Quem primeiro estabelece os marcos da nova pedagogia é Saviani, tendo como guia a ciência, ou melhor, a "concepção dialética de ciência" explicitada por Marx (Saviani, 1984, p. 77). Antes disso, entretanto, formula algumas teses polêmicas o bastante para alcançar os objetivos que explícita ou implicitamente norteiam os seus escritos: alterar o lugar definido pelos significantes-mestres Escola Tradicional e Escola Nova e cavar um lugar para o seu próprio discurso, em especial no campo dos discursos considerados críticos. As teses que o próprio Saviani considera polêmicas - e cujo objetivo explícito é abalar o que, segundo ele, havia-se convertido "em senso comum para os educadores", isto é, "o ideário escolanovista" - invertem "a forma dominante de conceber a educação": a tendência "a considerar a pedagogia nova como portadora de todas as virtudes e de nenhum vício atribuindo, inversamente, à pedagogia tradicional todos os vícios e nenhuma virtude" (p. 62). Saviani estabelece ainda uma linha de continuidade histórica que afeta o lugar dos discursos educacionais alternativos, pois todos ficam mais ou menos vinculados ao movimento da Escola Nova, então tornada a grande vilã, a grande responsável pelos males que afligem a escola, sobretudo aquele que afigura o pior de todos: o "aligeiramento do ensino".

\footnotetext{
37 Os últimos trechos citados, escritos por Teresa Roserley (Rose) Neubauer da Silva, correspondem à apresentação do livro Democratização da escola pública, de Libâneo (p. 8). O destaque em itálico é meu.

${ }^{38}$ Ibidem.
} 
A controvérsia que essa operação discursiva efetivamente gerou insere-se num movimento mais amplo, nutrido por inúmeras falas e cujo sentido foi o (re)ordenamento das articulações discursivas vinculadas ao significante-mestre escola tradicional, tendo como efeito a sua parcial e súbita valorização. Essa valorização, entretanto, foi efêmera e não chegou a alterar de modo substancial o lugar que esse significante-mestre tende a ocupar na maioria dos discursos educacionais, alinhando-se do lado do fracasso escolar. E aqui vale lembrar que a intenção de Saviani não era a de transformar a escola tradicional numa espécie de ideal. Antes, como ele mesmo afirmava, pretendia curvar a vara para o outro lado, para ver se desse modo chegava-se a um ponto de equilíbrio. ${ }^{39}$

O ponto de equilíbrio por ele encontrado, a sua "novidade radical", a sua "proposta radicalmente nova", guiada pelo "critério de cientificidade" que retirou do "método da economia política" de Marx, é uma pedagogia cujo método de ensino consiste em cinco passos - um método assim apresentado para facilitar o seu entendimento e a sua comparação com os métodos que seriam próprios da pedagogia tradicional (Herbart) e da pedagogia nova (Dewey), também apresentados pelo autor mediante a discriminação de cinco passos (1984, pp. 6284). O seu método, que "mantém continuamente presente a vinculação entre educação e sociedade" (1984, p. 73), toma como ponto de partida do ensino a prática social, que do ponto de vista do aluno apresenta-se de modo sincrético, ou seja, como um todo caótico, como uma experiência parcial, confusa e fragmentada. Esse ponto de partida é também o ponto de chegada, pois o último passo reconduz o aluno à prática social, envolvendo porém uma compreensão mais orgânica, clara e unificada. É o momento da síntese. Essa passagem da síncrese ("visão do todo caótico") à síntese ("uma rica totalidade de determinações e de relações numerosas"), pela "mediação da análise", constitui para Saviani "um orientação segura tanto para o processo de descoberta de novos conhecimentos (o método científico) como para o processo de transmissãoassimilação de conhecimentos (o método de ensino)" (p. 77). ${ }^{40}$

Apesar da crítica endereçada aos escolanovistas, por causa da sua ênfase nos "processos" ou nos "métodos", a deriva própria desse novo discurso

\footnotetext{
${ }^{39}$ Sobre a teoria da curvatura da vara, veja-se o próprio Saviani (1984, pp. 40-84).

${ }^{40}$ Sobre essa passagem da síncrese à síntese, veja-se também Libâneo (1989, pp. 38-44).
} 
pedagógico torna o "como trabalhar" ou a questão metodológica ou didática o seu "núcleo central", mesmo que isso seja equacionado tendo em vista os tais conteúdos, que diga-se de passagem são sempre definidos de uma maneira bem genérica. Além de ficar evidente na reflexão de Saviani, essa preocupação é claramente destacada por Libâneo:

O núcleo central das preocupações da pedagogia dos conteúdos é: como trabalhar, pedagogicamente, com as matérias de estudo, a partir da experiência social concreta, trazida pelo aluno de seu meio social de origem? Ou seja, quais as ações pedagógicas concretas, através das quais se efetua a mediação entre o saber escolar e as condições concretas de existência dos alunos? Nesse caso, a definição de uma teoria pedagógica e a formulação de princípios didáticos norteadores para auxiliar os professores e enfrentar as situações didáticas específicas são fundamentais. (1989, p. 120)

Em relação a essa dimensão do "como", uma das questões mais debatidas concerne ao significante-mestre autoritarismo e ao que se concebe como uma escola democrática, envolvendo desse modo pontos de ressonância próprios do discurso político. Em torno disso, por exemplo, gira o artigo de Guiomar Namo de Mello intitulado "Ensino de $1^{\circ}$ Grau: direção ou espontaneísmo?", publicado em 1981. Nesse texto, a autora começa destacando dois "erros" que "costumamos cometer" quando "denunciamos o autoritarismo nas relações professor-aluno". O primeiro é "autonomizar a prática escolar": "Quando esse erro acontece, é quase automático concluir que se democratizarmos as relações professor-aluno este último viverá uma experiência democrática que poderá ser transferida para a sociedade como um todo" (p. 87). Porém, argumenta Mello, "não se constrói a democracia num movimento que vai da escola para o social": "por mais que as relações professor-aluno sejam despidas de autoritarismo, os sujeitos aí envolvidos terão uma posição social definida antes da escola e para além dela". Essa transferência, portanto, "será necessariamente mediada por essa posição" (ibidem).

O segundo erro destacado por Mello reafirma o que Saviani e Libâneo constantemente destacam: o erro de "secundarizar o conteúdo, por privilegiarmos a forma pela qual o ensino se realiza", assim perdendo de vista o que é inerente à escola. Ao desenvolver esse ponto volta-se contra os "métodos chamados democráticos de ensino", que prefere chamar de espontaneístas, e enumera as suas "premissas principais": 
- toda aprendizagem é uma descoberta do novo; a criança precisa viver o processo da descoberta para que aprenda e para que o aprendido tenha significado;

- nesse processo de descoberta ela tem condições de ir sozinha, porque toda criança é criativa, pode estabelecer seus próprios objetivos e formas de aprender;

- o professor é apenas um facilitador, já que ninguém ensina ninguém: a verdadeira aprendizagem é a que vem de dentro;

- para que a aprendizagem seja espontânea, deve realizar-se num clima não ameaçador, num clima em que a criança se sinta livre para percorrer seu próprio trajeto, para errar e acertar. (p. 88)

Para Mello, esses "métodos não-diretivos" privilegiam os já privilegiados, que freqüentam as escolas particulares. Eles não são democráticos para a maioria das crianças, na medida em que deixam de lado o que segundo Snyders constitui o elemento dominante de toda pedagogia: o saber ensinado. Se for considerado esse elemento, "a questão do autoritarismo nas relações professor-aluno se coloca em novo prisma, isto é, passa a dizer respeito não só ao como, mas ao que e ao quanto se ensina" (p. 88). Na sua argumentação, então, essa questão "se redefine. O autoritarismo acontece sim, mas quando se nega, se facilita ou se barateia o saber, reservando o 'caviar' do conhecimento para os privilegiados" ( $p$. 90). Para combater esse autoritarismo, Mello destaca duas frentes de luta: "generalizar a escola para todos" e "buscar formas pelas quais todos aprendem, e do melhor modo, aquilo que até agora foi privilégio de poucos" (ibidem). E aqui ela retorna ao "como", muito embora a sua crítica não fique circunscrita à dimensão da relação professor-aluno. O autoritarismo é definido recorrendo-se a um âmbito bem mais amplo, pois revela-se "em todas as estratégias de que a classe dominante lança mão para impedir o acesso ao saber escolar“ (p. 90). Por exemplo, "quando, na escola da periferia pobre, o período de aula é encurtado, são colocados professores mais despreparados, aumenta-se o número de feriados (...)" (ibidem).

Ainda nesse plano do "como", Mello critica "a idéia de que a relação professor-aluno deve ser carinhosa, amorosa e, semelhante à do brinquedo, uma relação entre iguais". E complementa: "Como não há forma de não ser diretivo no processo de ensino, dissimula-se a direção sob a capa do sentimento" (p. 91). Na argumentação da autora, mas também no discurso da pedagogia dos conteúdos, o que ganha relevância é o professor que direciona o processo de ensinoaprendizagem, o professor que "intervém" e não o professor "espontaneísta", que 
fica claramente vinculado às experiências educacionais do campo alternativo. Nessa mesma direção deverá caminhar, posteriormente, o discurso pedagógico construtivista, debatendo-se entre e com esses significantes que definem o lugar do professor, e que já encontravam algum eco nos discursos educacionais quando da entrada em cena do construtivismo, na segunda metade da década de 80 .

Para criticar essas idéias, consideradas hegemônicas entre professores e demais profissionais da educação, tanto Mello quanto Saviani e Libâneo tendem a mobilizar termos amarrados ao significante-mestre escola tradicional e cuja utilização costumava gerar ardorosas polêmicas. ${ }^{41} \mathrm{Um}$ deles é o significante disciplina, que nos discursos alternativos constituía uma espécie de palavra proibida. Ele é utilizado para fazer referência à apropriação do saber, que, conforme é ressaltado, exige "esforço, trabalho e disciplina", ainda mais nas classes populares:

Não se pode tratar apenas de pensar na educação e na escola alternativas, deixando de lado a questão de que as crianças das classes populares precisarão sobreviver nessa escola que temos, para se apropriarem dela. Para isso, precisarão, mais que as privilegiadas, de trabalho, disciplina e esforço. (Mello, 1981, p. 89) ${ }^{42}$

$\mathrm{Na}$ avaliação de Mello, numa escola que seja mesmo democrática, essas crianças precisarão na verdade de uma outra pedagogia, cujas premissas ela também procura "esquematizar" (p. 88), à semelhança de Saviani e Libâneo. Como eles, as suas críticas são igualmente endereçadas a esse amplo campo que se estende do alternativo-popular ao alternativo-renovado, se utilizarmos a última denominação para situar o que costumava preponderar entre as camadas médias, confundindo-se, no limite, com práticas e discursos educacionais nos quais desapareciam as questões próprias do campo alternativo - por isso o termo renovado. São criticas que têm um forte impacto sobre esse campo, muito

\footnotetext{
${ }^{41}$ É o que pode ser constatado nesta apreciação de Maria Malta Campos, no editorial que ela escreve para a revista Cadernos de Pesquisa de fevereiro de 1981, que assim começa: "Disciplina e conteúdo. Quem já trabalhou em escolas renovadas ou experimentais sabe que estes dois temas são constantemente levantados para discussão em reuniões com pais, professores e orientadores. Entretanto, a discussão da problemática que se esconde por trás dessas duas palavras - as quais, diga-se de passagem, costumam causar reações explosivas e nada racionais, sempre que surgem em reuniões escolares - raramente tem sido ligadas à reflexão mais geral sobre a democratização do ensino.", p. 2.

${ }^{42} \mathrm{O}$ destaque em itálico é meu.
} 
embora não fossem novas, pois algumas delas já vinham sendo delineadas no seu interior. ${ }^{43}$ Esse impacto pode ser avaliado tendo em vista os rumos que o debate educacional tomou e as alterações que ocorreram nos discursos educacionais alternativos, que a princípio podem ser considerados separadamente.

Envolvendo os defensores da chamada educação popular, gerou-se um debate que se prolongou na segunda metade da década de $80 .{ }^{44}$ Esse debate parece ter levado a reavaliar o valor e o sentido da dimensão política da educação em face do lugar atribuído a questões consideradas de ordem pedagógica, sobretudo as relativas à educação escolar. ${ }^{45}$ Além disso, nos discursos da educação popular surge com alguma relevância a referência aos conteúdos ou ao "saber sistematizado", que havia sido enfatizado pelo discurso da pedagogia dos conteúdos. ${ }^{46}$

Alguns dos efeitos desse debate podem ser pensados tomando como referência a fala de Paulo Freire, na entrevista que ele deu à revista Nova Escola quando se tornou secretário da Educação do município de São Paulo, em 1989. ${ }^{47}$ "Por uma escola séria e alegre" é o título dessa matéria, aí já transparecendo certas preocupações presentes na sua fala. Já no início da entrevista, Freire lembra o caráter político e ideológico da educação, destacando que a questão, em relação às políticas educacionais de um partido, é que política é essa: "a favor de que e de quem, contra que e contra quem se realiza" (p. 22). Ser conservador ou

\footnotetext{
${ }^{43}$ A esse propósito, veja-se o capítulo "Limites", em Revah (1994).

${ }^{44}$ Um exemplo é o debate que envolveu Paolo Nosella (1986) e Paulo Ghiraldelli Jr. (1986).

${ }^{45}$ A expressão projeto político-pedagógico, de uso freqüente nas administrações petistas e que destaca dois significantes que estavam no centro da polêmica acima referida, é uma expressão que em si mesma parece reter as preocupações que esse debate gerou, sem que houvesse um retrocesso na valorização da dimensão política da educação, tão enfatizada por Paulo Freire e os discursos da educação popular. Essa expressão significante tende a instituir ou reestabelecer um certo equilíbrio entre as duas dimensões implicadas no uso daqueles dois significantes-mestres.

${ }^{46} \mathrm{Um}$ exemplo desse percurso pode ser observado numa das publicações da Associação Movimento de Educação Integral (AMEPPE, 1989), que reúne textos de diferentes anos (de 1986 a 1988) sobre diversas questões envolvidas na atuação da sua equipe de educadores junto a creches comunitárias e movimentos populares de Belo Horizonte. No último texto, intitulado "Metodologia: a prática social como ponto de partida", no item "A elaboração da proposta pedagógica", além do "saber popular" é mencionado o "saber sistematizado", sem ser vinculado, porém, às reflexões dos autores que nutrem o discurso da pedagogia dos conteúdos. Mas não há como não encontrar ecos desse discurso nestas poucas linhas: "Sem termos o 'saber popular' apenas como 'ponto de partida' e não considerando o 'saber sistematizado' como 'ponto de chegada', mas ambos como construção histórica que estão numa relação constante (...)", p. 44.

${ }^{47}$ Cf. "Por uma escola séria e alegre", Nova Escola, n 30, maio./89, pp. 22-5.
} 
ser progressista, eis o contraste que define o que é fundamental nessa política e em um partido, mas também em um educador e na sua prática pedagógica. Um educador pode ser conservador ou progressista, mas "ambos têm que ensinar e saber o que ensinar" (p. 23). Sob uma perspectiva progressista, uma "leitura crítica" da realidade é tão importante quanto o "ensino dos conteúdos", conforme pode ser inferido da argumentação de Freire:

Para o educador progressista coerente, o necessário ensino dos conteúdos estará sempre associado a uma "leitura crítica" da realidade. Ensina-se a pensar certo através do ensino dos conteúdos. (ibidem)

O que nesse momento está em pauta é tudo o que o significante escola arrasta, como já pode ser antevisto no título dessa matéria. Antes do que pensar na educação popular, é preciso pensar e criar uma "escola popular". Falar dessa escola, colocar no horizonte esse significante-mestre é o que importa. Para definir seu lugar, Freire usa esta articulação significante: "uma escola competente, democrática, séria e alegre" (p. 24). "Mudar a cara da escola" significa torná-la, ao mesmo tempo, uma escola séria, porque se dedica ao ensino de forma competente, e alegre, porque nela se ensina e se aprende com alegria: "sonhamos com uma escola que, sendo séria, jamais vire sisuda"; trata-se de "não aceitar que ensinar e aprender são práticas necessariamente enfadonhas e tristes" (p. 25). Nessa escola popular e democrática, com "uma prática educativa crítica, provocadora da curiosidade, da pergunta, do risco intelectual” (p. 24), o diálogo é um elemento central: o diálogo "entre grupos populares e educadores, entre grupos populares, educadores da rede e os cientistas que nos assessoram" (p. 24).

A articulação significante que define o lugar da escola mantém um forte vínculo com o campo político e com significantes que adentram no terreno que era característico da educação alternativa (democracia, crítica, popular, alegre, criativa, etc.). Ademais, essas escolas públicas que Freire quer transformar em "centros de criatividade" apresentam uma outra face igualmente importante: são sérias, competentes e não descuidam dos "conteúdos programáticos". Aí estão, em suma, as marcas que o debate antes referido deixou: na emergência dessa face que a argumentação de Freire procura evidenciar e na ênfase posta nesses significantes que a definem. 
O discurso da educação popular, com as mudanças que ocorreram ao longo das últimas décadas e que aqui não foram suficientemente pesquisadas, manteve alguma presença na década de 90 , não mais através do significantemestre alternativa, cuja utilização nesse campo parece ter se exaurido. Mas sim através dos outros significantes de seu ponto de arremate, como o significantemestre educação popular. Este, aliás, encontra-se alicerçado numa longa e sólida tradição, relativa à história de inúmeros movimentos e organizações populares e a iniciativas oficiais que tiveram lugar na década de 80 , sem contar as suas raízes na extensa e mundialmente conhecida obra de Paulo Freire e nos escritos de outros intelectuais que nutriram essa mesma tradição. É um discurso bem fincado na história da educação brasileira.

Não é o que ocorreu com o discurso educacional alternativo próprio de um setor das camadas médias, que literalmente perdeu o rumo, ou seja, perdeu o seu significante-mestre. ${ }^{48} \mathrm{Um}$ bom exemplo do que isso significou diz respeito ao passado das escolas alternativas da cidade de São Paulo, que praticamente desapareceu, pelo menos o passado que permitia concebê-las nos termos que o próprio nome estabelecia. Do alternativo-renovado, pode-se dizer que sobrou apenas o último significante, pois essas experiências educacionais até hoje tendem a ser vistas como um desdobramento do ideário do movimento da Escola Nova, ancoradas sobretudo na psicologia e nas concepções piagetianas, sendo eventualmente mencionada a presença das idéias de Paulo Freire, no início das suas trajetórias. ${ }^{49}$ Ao longo da década de 80 , vários significantes mobilizados pelo discurso da pedagogia dos conteúdos começaram a afluir em direção a esse ponto inicial concomitante ao tom pejorativo que o significante-mestre alternativa começou a adquirir. Um deles torna-se particularmente importante: o significante espontaneísmo, usado no título do artigo de Mello já analisado (1981). Esse, justamente, é o significante que tende a caracterizar o primeiro momento do construtivismo no Brasil, situado em não poucas falas no período em que surgiram e proliferaram as práticas e discursos educacionais alternativos. Ou seja, esse

\footnotetext{
${ }^{48}$ Ao que parece, as poucas escolas que se inspiram no conjunto de idéias e princípios desenvolvidos por Rudolf Steiner ou na chamada antroposofia são as únicas da rede particular de ensino que continuaram sendo reconhecidas através do significante-mestre alternativa. Na revista Nova Escola, uma das raras ocasiões em que isso ocorre concerne justamente a uma matéria sobre esse tipo de perspectiva pedagógica, chamada também de pedagogia Waldorf. Cf. "Pedagogia Waldorf. De sete em sete anos", nov./94, n 80, pp. 38-41.

${ }^{49}$ A esse respeito, veja-se o item "Um passado equivocado", no primeiro capítulo deste trabalho.
} 
momento inicial, esse passado alternativo, também é sobrepujado pelo discurso pedagógico construtivista, que é um discurso que se configura posteriormente, impondo-se aos outros ao longo das décadas de 80 e 90.

À diferença do discurso da educação popular, o discurso educacional alternativo característico das camadas médias constituía não mais do que um esboço do ponto de vista teórico. ${ }^{50}$ No âmbito da pré-escola, que é o nível onde provavelmente adquiriu um estofo mais consistente, o discurso mais elaborado evidencia a presença de inúmeras categorias emprestadas da psicologia. Entretanto, nas centenas de relatórios produzidos para narrar as atividades desenvolvidas com as crianças, aparecem termos que buscam dar conta de questões suscitadas pela própria experiência e que nem sempre podem ser reduzidos a simples derivações de conceitos procedentes da reflexão de determinado autor, teoria ou campo disciplinar. Antes trata-se de significantes lançados em discussões coletivas e escritos com os quais procurava-se ordenar a experiência de um outro modo, se comparado com o que predominava nas práticas educativas pré-escolares, em geral qualificadas de tradicionais. Esses significantes surgiram em discussões nas quais não se pretendia que o discurso ficasse amarrado a qualquer teoria, tampouco existindo a intenção de considerar apenas o que adquiria o status de um conhecimento científico. Antes do que concepções incontestes ou científicas, das quais aliás tendia-se a desconfiar, o que então valorizava-se era a possibilidade de pensar uma mesma questão a partir de vários pontos de vista, mesmo que isso não permitisse chegar a qualquer conclusão. A diversidade de teorias, as contradições que entre elas existiam, as dúvidas que o seu confronto gerava, a imprecisão e a ambigüidade do discurso que com elas simultaneamente operava não constituíam propriamente um problema. Ao contrário, isso tudo tendia a ser visto como fator de enriquecimento da própria experiência. Esta era a principal referência das reflexões então desenvolvidas, à semelhança do que Paulo Freire sugeria e fazia: "pensar sempre a prática" (Freire e Beto, 1988, p. 9).

\footnotetext{
${ }^{50}$ A principal fonte dessa apreciação é a pesquisa que realizei para a minha dissertação de mestrado, sobre as escolas privadas que na cidade de São Paulo eram chamadas de alternativas (Revah, 1994).
} 
Um bom exemplo do que se configurou em processos como o acima referido é o significante limites, que começou a ser utilizado como uma categoria que permitia situar questões mais ou menos próximas do que a palavra disciplina demarcava na maioria das escolas. Com o passar dos anos, essa categoria adquiriu uma certa densidade, ao ponto de constituir um tema importante, como é possível observar acompanhando o percurso dos relatórios elaborados para serem lidos pelos pais de alunos. E mais, limites tornou-se o significante por meio do qual questões de natureza moral ou ética, relativas sobretudo à relação adultocriança, começaram a ser pensadas de um outro modo, se for tomado como referência o que costumava predominar na maioria das pré-escolas. Uma diversidade de práticas pedagógicas, bem como outras categorias e temas referidos a essas práticas, configuraram-se do mesmo modo e em experiências desse tipo, onde as críticas de natureza cultural foram particularmente intensas. Obviamente, esses temas e categorias podem ser vinculados a tradições anteriores ou a determinados autores, mesmo que seja de maneira indireta, mas aí teríamos que deixar de lado o particular impulso que eles ganharam nesse tipo de experiências educacionais, sem contar os traços que os singularizam. ${ }^{51} \mathrm{E}$ aqui vale ressalvar que essas experiências não se desenrolaram apenas na cidade de São Paulo ou no Brasil, pois concernem ao amplo espectro de experiências educativas que nutriram e desdobraram as questões próprias das transformações culturais das últimas décadas, tendo como marco consagrado os chamados "anos

\footnotetext{
${ }^{51}$ Veja-se, por exemplo, o caso dos seguintes temas ou categorias: grupo, sociabilidade, socialização. Se é verdade que a psicologia incidia sobre as reflexões que definiam o valor e o sentido do grupo e das questões que envolviam o processo de socialização da criança pequena, não é menos certo que a dimensão coletiva era particularmente alavancada pelo seu valor no âmbito do discurso político, de onde também procediam as articulações discursivas que definiam o seu sentido. O mesmo vale para outros temas e categorias que, a princípio, sem muita dificuldade e de modo retrospectivo, podem ser imediatamente vinculados à psicologia (como o brincar ou o jogo simbólico), mas que um olhar orientado pelos significantes-mestres dos discursos da época revela quanto o seu valor e sentido eram sobrepujados - principalmente no plano das práticas educativas cotidianas - pelos questionamentos de natureza contracultural, imbricados com as temáticas da esquerda. Limites, sociabilização/socialização, autonomia/independência, sexualidade, adaptação (sobre o processo de adaptação da criança pequena à instituição educativa, quando do seu ingresso), roda (de histórias, de conversa, etc.), faz de conta/jogo simbólico/brincar são algumas das categorias e temas que ganharam densidade em relatos de experiência de professores das escolas alternativas da cidade de São Paulo, muitos deles vinculados, de modo explícito ou implícito, a determinados autores e tradições, mas também desdobrados de uma forma singular, característica desse tipo de experiências educacionais. Concomitante ao delineamento dessas categorias e temas, ganharam forma todo um conjunto de práticas escolares, dentre elas a produção periódica e sistemática, por todos os professores de uma mesma escola, de observações, registros e relatórios sobre as experiências desenvolvidas junto às crianças. A respeito dessas práticas, veja-se a minha dissertação de mestrado (Revah, 1994).
} 
60 ", em particular entre os que inicialmente promoveram essas mudanças, ou seja, um setor das camadas médias.

Sobre aquele impulso e a presença dessas categorias e temas nos discursos educacionais da década de 80 e 90, bons exemplos podem ser encontrados em materiais utilizados na formação de professores de Educação Infanti ${ }^{52}$ ou em propostas pedagógicas ou curriculares voltadas para esse nível do ensino, dentre elas o Referencial Curricular para a Educação Infantil produzido durante o governo Fernando Henrique Cardoso. Em relação a tudo isso, o que aqui interessa ressaltar é que essas categorias e temas ficaram subsumidos no discurso pedagógico construtivista, no qual quase tudo começou a ser visto como se tivesse sido derivado de determinados princípios teóricos, procedentes sobretudo da obra de Piaget, não vendo-se qualquer relação com o amplo leque de temas que o questionamento do cotidiano e das instituições havia suscitado sob o norte que os discursos de esquerda e contraculturais então estabeleciam. Além disso, com o fim da ditadura militar e a democratização das instituições, as práticas e discursos alternativos gerados entre as camadas médias e no âmbito da rede particular de ensino emigraram em direção à rede pública, ficando esse processo completamente obscurecido.

Alguns conceitos e temas, é verdade, ficaram mais ou menos vinculados às transformações culturais das últimas décadas, sendo associados inclusive aos "anos 60", como a sexualidade, que adquiriu o status de um tema escolar, ficando igualmente vinculado ao campo da psicologia. Outros, entretanto, sofreram o apagamento próprio do que não chegou a adquirir a condição de um conceito teórico ou, pelo menos, de um elemento associado, em razão da sua relevância, ao tipo de experiências desenvolvido no campo alternativo, onde sob outras formas foram prolongados os questionamentos que caracterizaram os movimentos juvenis da década de 60. Esse é o caso do significante postura,

\footnotetext{
${ }^{52}$ A esse propósito, veja-se a publicação Professor da Pré-escola, vol. I e II, de 1990, produzida sob os auspícios da Fundação Roberto Marinho e do MEC para ser utilizada na capacitação de professores desse nível do ensino. Essa publicação vem acompanhada de duas fitas de vídeo intituladas Menino, quem foi teu mestre?, contendo 20 programas de TV realizados pela Fundação Roberto Marinho, com cenas de práticas educativas gravadas em várias escolas, dentre elas a Escola da Vila, da qual também procediam os dois "professores autores" dessa publicação. $\mathrm{Na}$ parte relativa aos "Pressupostos pedagógicos", as autoras argumentam em favor de uma pedagogia de orientação construtivista (Cavalcanti e Deheinzelin, vol. II, 1991, p. 157).
} 
relacionado com o lugar, o perfil ou a posição do educador, monitor ou professor. Com alguma presença no discurso da pedagogia dos conteúdos $^{53}$, esse significante ganha destaque no discurso pedagógico construtivista, sobretudo no plano do discurso cotidiano, do discurso menos elaborado do ponto de vista teórico. No significante postura, principalmente, parece ter ficado encerrada a multiplicidade de traços que singularizava as experiências educacionais do campo alternativo. Esses traços estavam menos nas palavras autorizadas do linguajar pedagógico do que nas palavras do cotidiano, nos atos, nos gestos, nas roupas, na forma de lidar com o corpo, com o espaço, com as crianças e em tudo o que era da ordem de um certo estilo de vida e da "nova sensibilidade" então almejada, pelo menos nas camadas médias. Embora isso não deixe de corresponder, com algumas diferenças importantes, ao que era próprio do alternativo-popular, onde o saber valorizado ancorava-se igualmente na experiência cotidiana e no que os significantes postura ou posição tendiam a demarcar, não sem ficarem subordinados e fortemente enlaçados ao que era próprio dos pontos de ressonância desse discurso (conscientização/consciência crítica, libertação, comunidade, etc.).

Tomando como eixo o significante postura, pode ser pensada a "revolução" ou giro discursivo que a pedagogia dos conteúdos tendeu a produzir no campo dos discursos críticos. Em geral, no universo alternativo, a postura correspondia a algo que as palavras mal conseguiam precisar, a um saber que era antes um semi-dizer do que qualquer coisa passível de ser formulada com clareza, um saber inseparável dos próprios atos, da própria prática, um saber enraizado na experiência, ou melhor, num tipo de experiência, que não ficava confinado no

\footnotetext{
${ }^{53}$ A esse respeito é interessante notar como esse significante não passa despercebido na classificação que Libâneo faz das tendências pedagógicas, no texto "Tendências pedagógicas na prática escolar" (1989). Nessas classificação, ele de certa forma homogeiniza essas tendências ao analisá-las sob as mesmas categorias, que são apresentadas como itens sob os quais caracteriza cada uma dessas tendências. Esses itens são os seguintes: papel da escola, conteúdos do ensino, métodos ou métodos de ensino, relacionamento ou relação professor-aluno, pressupostos de aprendizagem, manifestações na prática escolar. Libâneo introduz variações somente na "tendência progressista libertadora", na qual acrescenta o item "os passos da aprendizagem", na "tendência progressista libertária", que inclui o item "outras tendências pedagógicas correlatas", e na "tendência progressista 'crítico-social dos conteúdos", que é a tendência que ele defende, nela introduzindo o item "a postura da pedagogia "dos conteúdos"” (o destaque em itálico é meu). E aí, exatamente, no nível onde tudo fica homogeneizado, Libâneo introduz uma diferença que parece pequena, mas com um significante que demarca um lugar de não pouca relevância nos discursos educacionais críticos, que é justamente onde esse discurso busca penetrar. E aqui vale ressalvar que esse item não é destacado nesse mesmo artigo quando publicado da primeira vez, em 1982, na Revista da ANDE.
} 
âmbito das instituições educacionais. Daí o uso desse significante para fazer referência a um saber que extrapolava o campo educacional, adentrando no terreno valorizado nos discursos alternativos: o terreno político e cultural. Em outros termos, o que então ganhava relevância era a postura do educador, definida pelas suas posições políticas e pelos valores que seus atos e suas falas revelavam, principalmente nos detalhes e nas pequenas coisas do dia-a-dia; mas também, se pensarmos em certas falas que encontravam eco na educação popular, pela sua posição social, como atesta a preocupação de que os educadores fossem da própria comunidade. Enfim, o que o significante postura tendia a demarcar, com todos os traços que nele foram sendo costurados, constituía um dos lugares do saber valorizado no discurso educacional alternativo.

Esse saber alternativo e o tipo de experiência do qual resultava, com a multiplicidade de traços que os caracterizavam, em grande parte prolongam-se no campo das práticas e discursos construtivistas, mas sem serem reconhecidos como tais, isto é, como algo gerado em práticas educativas que ainda não eram construtivistas, mas sim alternativas. Para a produção desse apagamento, dessa forma de esquecimento, além da transfiguração produzida pela nova ordem discursiva que o construtivismo instaura, foi decisiva a disseminação ampla e mais ou menos rápida daquela multiplicidade de traços no âmbito da vida cotidiana e por meios os mais diversos. ${ }^{54}$ Por isso, aliás, a tal postura construtivista é frequentemente confundida ou identificada com o que é da ordem de uma postura de vida, ou então, de uma "posição no mundo", para usar uma expressão de Paulo Freire (Freire e Beto, 1988, p. 23). Tudo isso, enfim, foi fundamental na produção do amplo consenso que caracterizou os primeiros momentos do construtivismo, que chegou a reunir posições, idéias e teorias bem diversas.

No início da década de 80 , com a pedagogia dos conteúdos, o saber crítico considerado relevante no campo da educação fica sob uma nova injunção. O que adquire importância é o saber pedagógico, o saber didático, o saber escolar, em face do saber popular ou alternativo, do saber da experiência ou da vida que os significantes alternativa ou comunitária então definiam. Ademais, exige-se clareza,

\footnotetext{
${ }^{54}$ Em relação a essa disseminação e à produção dessa forma de esquecimento basta pensar no papel da mídia televisiva, que incorporou e redirecionou o que nos anos 70 e ainda no início da década de 80 tinha o sentido de uma crítica simultaneamente política e cultural. Um sentido que rapidamente desapareceu na deriva própria da indústria cultural.
} 
exige-se que as teorias e concepções implícitas nas práticas pedagógicas sejam explicitadas e distinguidas e não mais misturadas de uma forma indiscriminada e geradora de confusão, segundo o julgamento feito sob a nova ordem discursiva. É preciso, agora, reunir organicamente os elementos capazes de constituir uma pedagogia bem fundamentada, isto é, uma teoria da educação cientificamente fundamentada, que permita uma compreensão orgânica, clara e unificada da educação escolar. Um saber, portanto, distanciado do que considera-se próprio do ponto de partida de todo conhecimento: a experiência parcial, confusa e fragmentada, ou seja, o todo caótico, contraposto nesse discurso ao todo orgânico. Formula-se assim a pretensão de caminhar, no plano teórico e de um modo mais ou menos imediato, em direção a uma teoria que apresente as suas concepções e orientações de um modo claro, que permita aos professores agir coerentemente, com a teoria vinculada à prática, fornecendo-lhes sobretudo métodos de ensino que sejam eficazes, que possibilitem cumprir com a função histórica da escola pública. Por meio desse saber positivo, dessa teoria "orgânica", busca-se contribuir para chegar a um lugar igualmente "orgânico" e totalizador, à semelhança do que em muitos discursos do campo alternativo afigurava o final da "caminhada": a libertação, a plenitude humana, a sociedade que já superou os antagonismos próprios da sociedade de classes.

O ideal de um saber positivo e sistêmico e, por isso e apenas nessa medida, positivista, tributário ademais de uma tradição moderna que também nutriu o pensamento marxista, é o que nesse giro discursivo ou "revolução" pedagógica é reposto, justamente num período em que as experiências que se desenrolavam no campo alternativo começavam a esbarrar nos seus limites, com questões que multiplicavam as divergências e sepultavam qualquer ilusão de unidade. Nessa abertura, própria desse "momento dos limites" ${ }^{55}$ mas sujeita também à via que a pedagogia dos conteúdos repõe, configura-se posteriormente o discurso pedagógico construtivista, que completa o giro para que esse já anunciado saber positivo/saber pedagógico ocupe o lugar que no discurso é o dominante.

\footnotetext{
${ }^{55}$ Quanto às características desse momento, veja-se a minha dissertação de mestrado (Revah, 1994).
} 
O saber que a pedagogia dos conteúdos configura é, no momento inaugural, um saber gerado nos bancos acadêmicos, um saber, digamos assim, mal adquirido, sem lastro em experiências educacionais, mesmo que os argumentos sejam todos alicerçados recorrendo-se à história da educação brasileira. Trata-se de um saber sem o estofo da experiência, ao menos no início, mas que mesmo assim consegue tocar em pontos sensíveis dos discursos educacionais alternativos, redirecionando desse modo o campo dos discursos críticos. Pondo em primeiro plano a fundamentação teórica, o pedagógico, os conteúdos e a escola pública, ou seja, ancorado nesse lugar, esse discurso tende a orientar a suas baterias em direção da experiência. Esse movimento, porém, é subitamente sobrepujado pelo discurso pedagógico construtivista, cujas primeiras costuras são feitas com o nome Emilia Ferreiro. O novo discurso volta a reorganizar o campo dos discursos educacionais, mas com o olhar posto nesse "outro caminho" que a pedagogia dos conteúdos já havia indicado e sem desprezar o limite que, com ela, ficou em evidência - o limite definido pelo significante-mestre espontaneísmo. Tudo isso, ao menos, é próprio da vertente do discurso construtivista que se tornou dominante.

\section{O nome Emilia Ferreiro}

O nome Emilia Ferreiro surge no cenário brasileiro sob a marca da ciência, sob a marca da "revolução conceitual" que Ferreiro anuncia em seus artigos e livros. Uma revolução capaz de alterar profundamente a escola, conforme acreditam muitos dos que difundem as suas idéias:

As pesquisas de Emilia Ferreiro e colaboradores romperam o imobilismo lamuriento e acusatório e deflagraram um esforço coletivo de busca de novos caminhos (...) Suas idéias, quando levadas à prática, produzem mudanças tão profundas na própria natureza das relações do poder pedagógico que, sonho ou não, é inevitável acalentar a idéia de que esta revolução conceitual sobre a alfabetização acabe levando a mudanças profundas na própria estrutura escolar. ${ }^{56}$

E mais uma vez, concomitante ao anúncio do novo e da mudança, entra em cena o significante caminho/caminhada, já vastamente nutrido pelos discursos precedentes, em particular os da educação popular e os discursos pastorais. Esse

\footnotetext{
${ }^{56}$ Trecho retirado do prefácio escrito por Telma Weisz para o livro Reflexões sobre alfabetização, de Emilia Ferreiro, pp. 4 e 5. O destaque em itálico é meu.
} 
significante continua presente no construtivismo, no registro que é próprio do discurso religioso, como mostra Vieira (1995). Junto com o significante postura, ao qual fica particularmente amarrado, constitui um dos pontos de ancoragem do discurso construtivista, um ponto que o sustenta e projeta quando da sua emergência, contando para tanto com raízes já bem nutridas no campo alternativo.

Segundo Weisz, em face do fracasso escolar e do analfabetismo, "impôs-se a necessidade de mudanças radicais", isto antes das "idéias" de Ferreiro tornarem-se conhecidas. Essa "unanimidade nacional", porém, "converteu-se em uma caça aos culpados", pois faltavam os "instrumentos para repensar a prática falida". Esse é o momento do "imobilismo lamuriento e acusatório":

Ninguém escapou do banco dos réus: os alunos, por serem subnutridos, carentes, deficientes. A escola, por ser uma inexorável máquina de reprodução das relações de poder. O professor, por ser mal pago, mal formado, incompetente. (p. 4)

No terreno próprio desse "imobilismo" pode ser situado tudo o que nos discursos de meados dos anos 80 permanecia como que em suspenso, à espera de algo que pudesse indicar um "caminho" seguro. Um caminho capaz de apaziguar o dissenso que havia se instalado no campo dos discursos educacionais críticos. Um caminho que pudesse amarrar as articulações significantes que haviam ficado à deriva, flutuando, sem um ponto de arremate firme, que haviam perdido inclusive o seu norte, como era próprio do discurso alternativo das camadas médias, onde o significante alternativa havia se tornado por demais ambíguo, voltando-se inclusive contra aqueles que haviam-Ihe dado sentido e vida. ${ }^{57}$ Esse lugar tão desejado, já prefigurado pela pedagogia dos conteúdos, surge com nitidez com a pesquisa de Ferreiro e Teberosky, com as "suas idéias" cientificamente fundamentadas. Desta vez, idéias ancoradas num terreno que para muitos parecia sólido, sem as rachaduras e ambigüidades que então perpassavam os discursos educacionais, em particular os do campo alternativo, onde Weisz havia alicerçado boa parte do seu percurso profissional.

${ }^{57}$ A esse propósito, veja-se o capítulo "Limites”, em minha dissertação de mestrado (Revah, 1994). 
O lugar do "novo" que nesse momento é preenchido, com o ponto de basta que então se constitui, encontrava-se vago e era aguardado e antecipado em não poucos discursos. Lembremos, a esse propósito, que o fim da ditadura militar acenava exatamente nessa direção do novo, com a então chamada Nova República. Nesse mesmo período, ademais, é publicada a revista Nova Escola, que iria ter forte penetração entre os professores. No lugar do novo que ela demarca, essa publicação tende a repor, num lugar de prestígio, articulações discursivas corroídas nos debates e questionamentos suscitados pela pedagogia dos conteúdos, em particular as amarradas ao significante-mestre Escola Nova e boa parte do que encontrava eco no campo da educação alternativa, já bem disperso na segunda metade da década de 80 - antes nas camadas médias do que nos setores populares. Esse também foi o efeito sobre tudo o que foi ficando no encalço do nome e a figura de Emilia Ferreiro, como o lugar destinado à criança, um lugar revitalizado, por exemplo, no várias vezes lembrado deslocamento produzido pela investigação de Ferreiro e colaboradores: do "como se ensina" para o "como se aprende".

Apesar do renovado prestígio de parte do que havia sido tão acidamente criticado, parte essencial do discurso da pedagogia dos conteúdos ficou embutida no horizonte da "caminhada" que desde então foi sendo traçada, mesmo que isso não seja fácil de reconhecer, pois aí também houve algo que é da ordem de um recalque, ou seja, uma interrupção das séries significantes que possibilitariam esse reconhecimento. Essa "caminhada" alcança o seu ápice no momento em que o discurso construtivista torna-se o padrão almejado para todas as escolas do país, através dos Parâmetros Curriculares Nacionais ( $\mathrm{PCN}$ ), na segunda metade da década de 90. Justamente nesse período, Guiomar Namo de Mello torna-se a Diretora Executiva da Fundação Victor Civita, sendo apresentada no editorial da revista Nova Escola de abril/97, desde então passando a escrever vários desses editoriais. Sob a sua direção, a Nova Escola torna-se uma das grandes difusoras dos PCN, com suplementos específicos sobre as áreas do conhecimento apresentadas nessa proposta curricular construtivista. O "fim da caminhada", por assim dizer, cria esse encontro, na Nova Escola, com um dos principais intelectuais que haviam nutrido a chamada pedagogia dos conteúdos — de todos, talvez, o mais empenhado no tratamento das questões de ordem didática. Um encontro sedimentado por uma "caminhada" cujo rumo já havia sido antecipado 
pelos significantes que estabeleciam o seu norte, lançados principalmente pela pedagogia dos conteúdos. Esses significantes estiveram presentes desde o início na vertente do construtivismo que finalmente predominou. $E$ isso, até hoje, permanece na penumbra, com os PCN sendo associados primeiramente à psicologia e à reforma curricular espanhola.

Essa complexa operação discursiva, que (re)ordena e incorpora articulações significantes dos discursos precedentes, dando-lhes porém um novo sentido, é a que explica o amplo consenso que o novo discurso pedagógico rapidamente suscita, nele encerrando as asperezas da diversidade de vertentes que absorve e aglutina. Essa operação discursiva pode ser parcialmente apreendida acompanhando o percurso da revista Nova Escola, onde há inúmeras pistas sobre as costuras feitas com e através dos significantes-mestres que nesse novo discurso pedagógico constituem o seu ponto de arremate. Essa revista, aliás, inscreve-se num lugar mais do que apropriado para acompanhar a emergência desse novo discurso pedagógico: o lugar do novo. A Nova Escola situa-se exatamente nesse ponto, como quem aguarda algo capaz de preencher esse lugar, com matérias que vez por outra vislumbram "um novo caminho", sempre sob a marca do sucesso, de uma ação ou experiência avaliada positivamente, em geral desenvolvida nos setores populares ou na escola pública, pelo menos até o momento em que começa a se tornar freqüente a referência à escola particular, antes de terminar a primeira metade da década de 90 . Nesse lugar do novo deverá nascer a resposta para o que no decorrer da década de 80 tornar-se-á a principal demanda de todos os setores preocupados com a educação pública: a qualidade do ensino. É um lugar que a própria revista configura, na medida em que ela também define os contornos do que dele deverá emergir. Aí, exatamente, seguindo os rastos deixados nesse lugar e nessa revista, é possível acompanhar passo a passo como vão sendo feitas algumas das costuras do objeto que aqui interessa, o objeto que entra no circuito do desejo de inúmeros professores e profissionais da educação.

\subsection{Uma primeira inscrição}

Os primeiros indícios dessas costuras encontram-se numa reportagem publicada em setembro de 1986, intitulada "Com uma didática revolucionária, sucata e alegria é fácil alfabetizar crianças pobres" (as últimas três palavras são 
destacadas com letras bem maiores). ${ }^{58}$ A matéria é sobre as "classes experimentais do GEEMPA", o "Grupo de Estudos sobre Metodologia de Pesquisa e Ação da capital gaúcha", que é coordenado por Esther Pillar Grossi — alguns anos mais tarde chamada por essa mesma revista de "pioneira do construtivismo". No texto é apresentada a "proposta do GEEMPA", com descrições relativas a atividades desenvolvidas por professores e explicações que justificam esses encaminhamentos, por vezes por meio da "fala" da "pedagoga do GEEMPA", Esther Grossi, que aparece na foto que abre a matéria interagindo com algumas crianças. Nessa reportagem, destacados no título e subtítulo ("Um novo método de alfabetização para crianças de classes populares está revolucionando o ensino, na periferia de Porto Alegre, e levando $97 \%$ dos alunos à $2^{\text {a }}$ série"), encontram-se alguns dos lugares onde o novo discurso pedagógico está se inscrevendo e assim se configurando, conforme um percurso que aí já está sendo delineado e antecipado. Dentre os significantes que demarcam esses lugares, extraídos também do corpo da matéria, podem ser destacados os seguintes: alfabetização, didática/método/proposta, novo/revolução, sucesso/alto índice de aprovação, classes populares/crianças pobres/periferia. Outro lugar demarcado na mesma reportagem é o que inicialmente representa o pólo oposto dessa proposta: a escola tradicional, cuja didática é considerada "inadequada" para as crianças das classes populares. A adequação a essas crianças e à fase em que elas se encontram constitui, nessa matéria, uma das grandes chaves do sucesso da proposta, que apresenta ainda outras qualidades igualmente fundamentais, como a integração com outras áreas ("Matemática, Artes, Ciências Naturais e Sociais, Teatro, Educação Física, Música e Dança"), que "tem sido a maior responsável pelo alto índice de aprovação" (p. 43).

Quanto ao nome Emilia Ferreiro, ele sequer é mencionado, estando porém implícito, pelo menos para os leitores que já conheciam os seus escritos, pois vários aspectos dessa proposta didática evidenciam esse vínculo. A começar pelo nome atribuído ao método — "o método A Didática do Nível Pré-silábico" — e o reiterado uso da expressão fase ou nível pré-silábico, relativa à denominação

${ }^{58}$ Cf. Nova Escola, set./86, n 6, pp. 40-4. O primeiro exemplar dessa revista é de março de 1986. 
usada por Ferreiro e Teberosky para identificar determinadas escritas infantis. ${ }^{59}$ Essa categoria, nessa matéria, é também utilizada em referência a outras áreas, para situar o nível em que a criança se encontra, sendo assim estendido o seu alcance para além do campo da alfabetização, à semelhança do que ocorreu com boa parte do que foi sendo amarrado ao significante-mestre Emilia Ferreiro. $O$ lugar da criança/aluno, além de ser demarcado com o significante pré-silábico, é situado de modo a deixar em evidência o seu grande envolvimento, o seu papel ativo e a sua autonomia para realizar diversas atividades. Essas atividades não concernem apenas às áreas acima referidas, a abrangência da proposta é ainda mais ampla e parece estender-se em todas as direções, alcançando o recreio e a merenda: "Até a hora da merenda, para eles [os alunos], é um momento educativo" (p. 40).

Essa "proposta de ensino" ou essa "didática revolucionária" recebe nessa matéria uma marca que a diferencia de outras propostas, experiências e perspectivas apresentadas nessa mesma publicação, uma marca que de certo modo autoriza a sua generalização. Essa primeira inscrição surge no final da matéria, num trecho do texto destacado no seu único box: "Recentemente, a proposta de ensino do GEEMPA foi reconhecida como 'científica, diferente e capaz de ser generalizada'” (p. 44). Uma proposta, portanto, bem alicerçada, ou melhor, cientificamente fundamentada, que exige professores que estudem, que conheçam os seus fundamentos teóricos e científicos, conforme a exigência que mais tarde e de modo claro será feita ao professor construtivista. E aqui vale observar que essa é a primeira matéria da Nova Escola - pelo menos de todas as que foram pesquisadas - onde, de modo explícito, uma proposta recebe essa chancela, essa marca da ciência, dada não exatamente pela revista, mas pelo "coordenador de um grupo de pesquisas" da Fundação Ford. Enfim, na Nova Escola, essa pode ser considerada uma primeira inscrição - uma didática científica, um ideal fixado no horizonte do novo discurso desde os seus primórdios.

\footnotetext{
${ }^{59} \mathrm{O}$ nome que a revista atribui ao método corresponde ao da publicação homônima de Grossi
} (1994). 
Nessa matéria e até esse momento, o nome Emilia Ferreiro e o significante construtivismo não tinham sido utilizados nessa publicação. ${ }^{60}$ Quanto a Piaget, nessa matéria tampouco é mencionado. Ademais, praticamente não foi utilizado o substantivo construção ou o verbo construir (no infinitivo ou flexionado), cuja presença na revista multiplica-se nos anos subseqüentes, funcionando também como o nome Emilia Ferreiro, ou seja, como uma espécie de agulha com a qual serão costuradas articulações discursivas diversas. ${ }^{61} \mathrm{E}$ aqui, é claro, está se falando dos significantes construção/construir (com as suas variações) quando direta ou indiretamente vinculado aos significantes conhecimento ou aprendizagem, que é uma das trilhas que neste trabalho também interessa seguir.

\subsection{Discursos sem nome}

Os lugares onde o novo discurso inicialmente se inscreve e constitui fazem parte do terreno delimitado por outros discursos. Por isso, esses lugares funcionam - alguns mais outros menos, dependendo da sua penetração e força - como pontos de ancoragem do novo discurso, ou seja, como lugares a partir dos quais ele se afirma e projeta, não sem produzir alguma torção. Os significantes-mestres que definem esses lugares, portanto, vinculam discursos distintos, que não se estruturam a partir do mesmo ponto de arremate. Por vezes, ademais, esses significantes ligam discursos de natureza bem diversa, como é o caso do significante-mestre caminho, que, como já vimos, tem um lastro que vai do discurso religioso ao discurso político, com forte penetração no campo educacional. Cria-se assim um terreno comum, ambíguo e às vezes bem conflitivo, por isso exigindo que as divergências sejam acomodadas de alguma maneira. Com o construtivismo, a necessidade de acomodar as divergências surgiu quando surgiram as primeiras críticas. Um problema parcialmente contornado quando no novo discurso surgiu a dimensão temporal, isto é, quando a "caminhada" pôde ser delineada e foi criado um passado. Esse passado permitiu enquadrar, pelo menos em parte, o que até então escapava, na medida

\footnotetext{
${ }^{60}$ Para tanto foram conferidas as matérias que tratavam de aspectos relacionados com o ensino $e$ a aprendizagem da língua escrita e aquelas cujos títulos ou temas sugeriam o possível uso daqueles significantes-mestres. Certos tipos de textos não foram pesquisados de modo sistemático, como as cartas dos leitores, os informes publicitários e a seção de livros sugeridos para leitura.

${ }^{61}$ No artigo analisado, o verbo construir é utilizado apenas uma única vez, na reprodução da fala de uma professora para seus alunos.
} 
em que os "desvios, confusões, equívocos ..." puderam ser remetidos para a "origem" - uma operação discursiva realizada na vertente do construtivismo que se tornou dominante.

Nas matérias dos primeiros anos da revista Nova Escola, reconhecer ou identificar os discursos educacionais e/ou pedagógicos por meio de um nome exige, por parte do leitor, alguma familiaridade com os discursos do período e certo esforço de interpretação, pois os significantes-mestres que são próprios de seus pontos de arremate não costumam ficar à vista. Isso ocorre, provavelmente, em razão da debilidade que é própria desses pontos nesse momento, pois ficaram menos densos, menos espessos e estão se diluindo, com seus significantesmestres sem força para aparecer e unir o que outrora mantinham vinculado. Nesse período, nas matérias da Nova Escola, é comum que sobressaiam as marcas próprias de determinada experiência, de certa proposta, do discurso de determinado professor, especialista, grupo ou autoridade vinculada a algum órgão público ou secretaria de educação municipal ou estadual. Essa dispersão é característica desse momento, quando uma diversidade de articulações significantes estão como que à deriva, sem pontos firmes que as vinculem e englobem, sem nomes que cumpram com a função que cria a unidade dos discursos que adquirem ressonância social, a função própria dos aqui chamados pontos de arremate. São, por assim dizer, discursos sem nome.

Nos textos da Nova Escola, às vezes essa unidade surge por causa da presença dos pontos de ressonância característicos de determinado discurso e porque os significantes-mestres do seu ponto de arremate vez por outra ficam à vista, como pode ser observado em várias matérias onde o discurso da educação popular pode ser facilmente reconhecido. ${ }^{62}$ Em outros casos, porém, em especial

\footnotetext{
${ }^{62}$ Veja-se, por exemplo, as seguintes matérias: "Escola Aberta de Calabar" ( ${ }^{\circ} 2$, abril/86, pp. 54 6), sobre a escola criada pela Associação de Moradores da favela do Calabar, em Salvador (Bahia); "Escola Comunitária. Um jeitinho carioca de driblar a falta de vagas" ( $\mathrm{n}^{\circ} 11$, abril/87, pp. 38-41), que é uma reportagem que constata a existência de "uma verdadeira rede paralela, com cerca de quinhentas escolas" (p. 39), no município do Rio de Janeiro - na capa da revista há uma chamada sobre essa matéria; "Ação comunitária. Uma rede voltada para a organização popular" ( ${ }^{\circ} 35$, nov./89, pp. 32-4), sobre as "escolas da comunidade" criadas em bairros periféricos de Recife (Pernambuco), que acabaram formando "uma ampla rede paralela de ensino comprometida com a educação popular - são escolas que, em 1980, "agruparam-se no Movimento das Escolas Comunitárias (...) Elas seguem a linha da educação libertadora, influenciada pela Teologia da Libertação da Igreja Católica e baseada na pedagogia de Paulo Freire adaptada para as crianças" (p. 32). Nessas e em outras matérias semelhantes não costuma faltar o significante-mestre comunidade ou comunitário para definir o seu sentido.
} 
nesse amplo campo do discurso alternativo-renovado característico das camadas médias, essa identificação torna-se bem mais difícil, entre outras coisas porque nele penetram articulações significantes novas, que tornam esse discurso um outro discurso. Um exemplo é a matéria da Nova Escola antes analisada, sobre a experiência do GEEMPA, onde já está sendo delineado um discurso que não corresponde a nenhum dos precedentes, por causa da torção produzida por algumas articulações discursivas e os seus significantes-mestres, como ciência e didática. Eles dão uma feição diferente à rede significante que esse discurso sobrepuja, por exemplo, do campo alternativo, sem contar o efeito que é próprio do tipo de articulação discursiva que define a perspectiva de alfabetização inspirada na investigação de Ferreiro e Teberosky. ${ }^{63}$ Algo semelhante ocorre em outras matérias com as articulações discursivas próprias da pedagogia dos conteúdos, que é um discurso ainda mais difícil de encontrar ou reconhecer, retornando de forma mais nítida em um ou outro eco produzido por determinado significante. Por exemplo, quando surge a preocupação com o "saber sistematizado".

Em meados dos anos 80, no campo da educação escolar não há um discurso hegemônico. As razões do fracasso escolar, bem como as possíveis soluções, são diversas, sendo destacadas em discursos igualmente diversos, muito embora isso mude conforme nos aproximamos do final dessa década. Essa diversidade pode ser observada nas matérias da Nova Escola do primeiro ano, às vezes numa única matéria. Veja-se, por exemplo, a reportagem que é manchete de capa de abril/86, intitulada "Reforma Silenciosa". ${ }^{64}$ Logo no início, no olho que segue ao título, alude-se aos professores "discretos e eficazes", "corajosos e criativos", "realistas e aplicados" que estão tentando "descobrir um novo caminho

\footnotetext{
${ }^{63}$ No caso da reportagem sobre a proposta do GEEMPA, o que nela é delineado pode ser situado, é claro, em linha de continuidade com a chamada Escola Nova ou com aquilo que nos discursos do período poderia ser identificado através do significante pedagogia renovada ou escola renovada. Mas isso implicaria deixar de lado a complexa operação discursiva já mencionada, que (re)ordena e incorpora séries significantes dos discursos críticos típicos dos anos 70 e início dos 80 , sem contar os efeitos produzidos pelas articulações discursivas características dos textos de Ferreiro. Em relação ao significante pedagogia ou escola renovada, nas matérias da Nova Escola desse período não costuma comparecer, apesar do viés que tende a predominar na sua linha editorial, que sem muito esforço pode ser considerado sob o influxo de tudo o que ficou associado à chamada Escola Nova, a qual é evocada de muitas formas, a começar pelo próprio nome da revista.

${ }^{64}$ Cf. Nova Escola, n² 2, abr./86, pp. 10-7.
} 
para a Educação de $1^{\circ}$ Grau". O que está em pauta é a "reforma silenciosa" realizada por educadores que, individualmente ou em pequenos grupos, não esperam "ordens superiores", nem leis ou decretos para agir e melhorar a educação pública. Tendo como pano de fundo a "falência" da escola pública, os altos índices de evasão e repetência, a reportagem elenca um conjunto de iniciativas desenvolvidas em dez Estados e que em alguma medida envolvem o poder público. As soluções implementadas e avaliadas positivamente são as mais variadas, em geral todas elas mantendo o mesmo grau de importância. Em outras palavras, há "caminhos", estes ainda não foram unificados ou reduzidos a um único caminho. Eis algumas dessas iniciativas:

- PR. Destaca-se uma escola estadual de Curitiba, cuja diretora afirma ter mexido em tudo: mudaram os currículos; substituíram as provas por uma avaliação diária, com implicações para o trabalho da professora (tudo o que o aluno faz é resumido e anotado por ela, que dá atenção aos trabalhos em classe e também às atitudes com os colegas, etc.); eliminaram o livro didático; em várias situações os alunos têm o poder de decisão. No Estado, o governador deu "carta branca às escolas", elas devem descobrir "seus jeitos de auto-avaliarem o trabalho que fazem" e colocar em prática as medidas que julgarem necessárias. (pp. 11-2)

- SC. A Secretaria estadual de Educação decidiu acabar com o Sistema de Avanço Progressivo (SAP), que existia desde 1970. O SAP implantou a "aprovação automática" na rede estadual de 1ํㅡrau. (p. 12)

- RS. Destaca-se o Projeto Estudos Contínuos nas Duas Séries Iniciais, implantado em 1980 pela Secretaria Estadual. Com esse projeto, ampliou-se o tempo de alfabetização das crianças. Elas somente são avaliadas após dois anos de estudos. Os professores foram treinados e assim "preparados para respeitar o nível de desenvolvimento e conhecimento de cada grupo de sua turma". (p. 13)

- $\quad$ SP. Em 1984, a Secretaria de Educação do Estado implantou o ciclo básico. Os alunos são distribuídos por classes de níveis de conhecimento diferentes e têm um "atendimento quase individualizado e uma avaliação praticamente 
diária". É prevista a possibilidade de aulas extras para a criança que precisar. (p. 13)

- RJ. Por iniciativa da Secretaria de Educação do município, houve um investimento maciço na reforma e construção de prédios, mudou-se a sistemática da merenda, foram promovidos cursos de reciclagem para professores, os currículos foram repensados, ocorreram mudanças significativas na alfabetização - antes de ingressarem na $1^{\circ}$ série, as crianças são matriculadas nas Classes de Alfabetização e os professores dessas classes recebem uma gratificação. (pp. 14-5)

O que nas matérias da Nova Escola dá alguma unidade a esse amplo leque de discursos, de diagnósticos e soluções para os problemas da educação pública ou da educação voltada para os setores populares - que é o que tende a ficar em foco nessa publicação, ao menos na década de 80 -, é a oposição a certo passado, relacionado com a ditadura militar, com o autoritarismo, com a burocracia e com todo um conjunto de valores então questionados. Tudo isso em geral fica sob a órbita de um significante-mestre: escola tradicional ou ensino tradicional, incluídas aí todas as equivalências que concernem ao mesmo ponto de arremate (metodologia tradicional, professores tradicionais, cartilhas tradicionais, etc.). Nesse período, além de identificar um discurso pedagógico, esse é o único significante-mestre que é amplamente reconhecido e que tem a consistência e a força necessárias para marcar presença nos mais variados discursos. É o significante-mestre do ponto de arremate de um discurso criado, na verdade, pelos seus críticos, com os lugares e os sentidos que eles definem. Cada vez mais, no decorrer da década de 80 , as práticas e discursos identificados por intermédio do significante-mestre escola tradicional ou seus equivalentes serão negativamente avaliados não mais pelos discursos alternativos ou alternativos-renovados, mas sim pelo discurso que então está se configurando e que em fins dessa década, com o significante construtivismo, encontrará o seu significante de arremate definitivo. Desse modo e à semelhança da função que cumpriu em outros discursos quando da sua emergência, escola tradicional ou ensino tradicional tornar-se-á um outro e forte ponto de ancoragem do discurso construtivista. 
Os significantes-mestres do ponto de basta que cria o novo discurso pedagógico, embora já existissem e operassem como tais, em meados da década de 80 tampouco costumavam ficar à vista. Esse ponto de basta configura-se, de início, com a divulgação da pesquisa de Ferreiro e Teberosky, com as costuras feitas principalmente com o nome da primeira. Nesse momento, esse ponto não constitui propriamente um ponto de ressonância, um lugar suficientemente denso e unificado que possibilite o seu reconhecimento social e garanta a sua presença nos discursos educacionais, pelos menos com alguma visibilidade. Digamos que ainda não havia adquirido a força e os contornos necessários para ser reconhecido como uma nova proposta, perspectiva ou tendência pedagógica. No melhor dos casos, constituía apenas um discurso restrito ao campo da alfabetização e assim começa a ser reconhecido, ou seja, como uma nova perspectiva ou proposta de alfabetização. Como discurso pedagógico de caráter mais amplo, com o nome construtivismo, somente deverá emergir em fins da década de 80, se tomarmos como referência o que pode ser observado seguindose o percurso dos discursos presentes na revista Nova Escola.

\subsection{O nome de uma psicóloga}

O nome Emilia Ferreiro é citado pela primeira vez um ano depois de publicada a reportagem já analisada, em setembro de 1987, não existindo até essa data qualquer outra matéria que tenha como referência implícita a pesquisa de Ferreiro e Teberosky, pelo menos dentre todas as que foram pesquisadas. A matéria onde aparece o nome de Ferreiro é destacada na capa da revisa com este sugestivo título: "Alfabetização. Um novo jeito de vencer esse bicho-papão". O que é expresso na capa é retomado e reforçado no editorial, onde o também chamado "monstro" multiplica-se nas figuras que logo no início são evocadas: "Bicho-papão, papa-gente, coco, cuca, papa-figo, tutu, bitu, boitatá, mumuca". Por meio dessas figuras é situado o que "costuma tirar o sono de tantos professores e educadores": a alfabetização. Nessa edição, a revista apresenta "uma experiência animadora":

Inspirada nas observações da psicóloga argentina Emilia Ferreiro, esse trabalho pede ousadia, imaginação, um ambiente estimulador e, principalmente, respeito ao processo de construção da escrita na criança. $E$ indica um novo caminho para enfrentar e, quem sabe, vencer esse monstro. (p. 3) 
Na matéria, intitulada "Há um novo caminho para ensinar a ler e escrever", são apresentados aspectos das experiências desenvolvidas por professoras da "E.E.P.G. Edmundo de Carvalho, a única escola experimental da rede pública estadual de São Paulo". ${ }^{65}$ Além disso, num dos box da matéria, com um texto relativamente longo (do tamanho de uma página) e sob o título "Por que esse é um bom caminho", a pedagoga Virgínia Balau "fundamenta o ambiente estimulador" necessário para alfabetizar (pp. 12-3). Dessa pedagoga foi aluna e nesse momento participava de grupos de estudos por ela orientados, a professora cuja prática é mais extensamente apresentada nessa matéria (p. 15). Com essa informação, assinala-se uma relação, uma hierarquia e um sentido que será predominante no construtivismo: de um lado, a teoria e o especialista, com a psicologia constituindo a sua principal referência no campo da ciência; de outro, o professor-estudante e a sua prática, subordinada e em falta.

Ao longo dessa reportagem, o nome Emilia Ferreiro novamente é mencionado, indicando-se que as "suas descobertas vêm propondo um novo enfoque" (p. 13). Além do "novo jeito", "novo caminho", "novo enfoque", fala-se das "novas posturas" que os professores estão adotando na sala de aula. ${ }^{66} \mathrm{Nessa}$ e em outras matérias posteriores ainda comparecem, como maior ou menor destaque, os significantes experiência e prática, com eles sendo também situado o registro do que é concebido como novo. Ademais, pelo menos nas duas primeiras reportagens, trata-se de uma escola ou classes consideradas experimentais. Nessa última matéria tampouco falta a contraposição ao tradicional — situado com os termos método, prática e visão pedagógica - e várias vezes é utilizado o significante construção, para fazer referência ao processo de construção do conhecimento, da escrita ou do aprendizado por parte da criança.

Dessa matéria em diante, o nome Emilia Ferreiro começa a aparecer com alguma frequência. Em 1987, entretanto, dentre as matérias pesquisadas somente é mencionada em mais uma reportagem, onde a alfabetização é relacionada com

\footnotetext{
${ }^{65}$ Cf. Nova Escola, n 15, set./87, pp. 10-5.

${ }^{66}$ Isso é destacado na avaliação feita por Maria Leila Alves, da Coordenadoria de Estudos e Normas Pedagógicas da Secretaria da Educação de São Paulo (CENP), num box intitulado "Vencendo limites e fronteiras". Nesse box são também mencionados aspectos do trabalho de alfabetização desenvolvido por uma professora da rede municipal de São Paulo que conheceu as descobertas de Emilia Ferreiro em um curso de atualização e que, na sua prática, "mistura as idéias de Emilia Ferreiro a práticas pedagógicas já conhecidas" (p. 14).
} 
a aprendizagem da matemática. ${ }^{67}$ Nessa matéria, ao serem destacados aspectos de experiências desenvolvidas em escolas públicas de Porto Alegre, menciona-se a "proposta do GEEMPA" e a pesquisa que as suas educadoras desenvolveram, "fundamentadas em Piaget, Emilia Ferreiro e Sara Paim", não existindo maiores esclarecimentos sobre as contribuições de cada um desses autores. Trata ainda de iniciativas desenvolvidas junto à rede pública em São Paulo e Recife, nesta última tendo a "teoria de Piaget" como referência. Novamente aparece a contraposição ao tradicional (os professores tradicionais, a alfabetização tradicional) e fala-se da capacidade construtiva da criança e que ela constrói o seu conhecimento da matemática.

Aqui vale observar que, tanto o nome Piaget quanto os significantes construção/construir (com as suas variações), direta ou indiretamente vinculados aos significantes conhecimento ou aprendizagem, já tinham sido utilizados em números anteriores da revista, mas não de maneira freqüente. O seu uso, até esse momento, parece ter ficado restrito a matérias sobre o ensino e a aprendizagem da matemática, onde inclusive usa-se o conceito de erros construtivos. ${ }^{68}$ Isso pode ser tomado como um indicador de que, nesse período inicial, dificilmente algum dos jornalistas que participava da produção da revista Nova Escola, bem como a maioria dos professores e profissionais da educação, sentiam-se impelidos a usar a expressão construção do conhecimento ou qualquer outra semelhante ao tratar de temas mais ou menos relacionados com o ensino e a aprendizagem. Posteriormente, tornou-se difícil falar em outros termos sobre esses mesmos assuntos, pelo menos para quem pretendesse entrar no circuito das falas autorizadas, das falas legitimadas por um saber que se tornou hegemônico e que em meados da década de 80 ainda estava dando os seus primeiros passos.

\subsection{Começam as confusões e equívocos}

Nas matérias de 1988 que foram pesquisadas, o nome Emilia Ferreiro é citado em três, ficando porém implícito em outras. A primeira é do mês de junho e

\footnotetext{
${ }^{67}$ Cf. "Alfabetização. Que tal você começar pela matemática?", Nova Escola, n 17, nov./87, pp. 36-40.

${ }^{68}$ Veja-se, por exemplo, "O aluno aprende. É só você parar de ensinar", sobre a aprendizagem da matemática, Nova Escola, n 12, maio/87, pp. 30-3.
} 
é o destaque de capa, com o seguinte título: "Pais $\mathrm{x}$ professores. A difícil convivência na hora da alfabetização". No editorial retoma-se o que foi destacado na manchete de capa e menciona-se a "confusão de papéis" que ocorre na "fase da alfabetização", que é o tema central da matéria. Nesta, já no primeiro parágrafo, afirma-se: "a prática vem comprovando que há muitos equívocos a respeito do papel de cada um na alfabetização, tanto do lado dos pais quanto do lado da escola, especificamente do professor" (p. 12). A matéria pretende, justamente, desfazer essas "confusões e equívocos", que pela primeira vez são mencionados numa matéria onde faz-se referência a Emilia Ferreiro, não sendo comum ou relevante esse tipo de constatação nos números anteriores da revista. No próprio título fica evidente qual é o seu principal objetivo: "Pais x professores. O papel de cada um na alfabetização". ${ }^{69}$ Para deixar claro qual é o "papel" ou "função" de cada um, são apresentados os pontos de vista de pais, professores e outros profissionais da educação, dentre eles alguns já consultados em matérias anteriores sobre a "nova proposta", como Esther Grossi (GEEMPA), Maria Leila Alves (CENP) e Virgínia Balau. Os aspectos do processo de alfabetização que servem de referência para desfazer as "confusões e equívocos" concernem basicamente ao que direta ou indiretamente é vinculado à "nova proposta de alfabetização". Esta, contraposta à alfabetização tradicional, pela primeira vez é situada através de uma indicação bibliográfica (Psicogênese da língua escrita), sendo aí mencionado um nome até então ausente: Ana Teberosky. Já nesse momento é possível notar que a "nova proposta", baseada nas "pesquisas" de Ferreiro e Teberosky (p. 16), está sendo transformada no padrão que será largamente utilizado para julgar as mais diversas experiências e propostas de alfabetização, como pode ser mais facilmente constatado em outras matérias do mesmo ano.

Nessa matéria, a família e os pais - que na verdade são basicamente as mães, dado que são delas os únicos depoimentos — não surgem sob a forma da comunidade, como é comum nos discursos da educação popular presentes em várias matérias da Nova Escola. Sob o recorte típico do discurso das camadas médias - isto é, pais, em vez de comunidade —, as mães que não "entenderam" ou "compreenderam" qual deve ser o seu papel tendem a ser caracterizadas como

${ }^{69}$ Cf. Nova Escola, n²2, junho/88, p. 12. 
pessoas ansiosas, que por vezes sentem-se culpadas, querendo cumprir um papel para o qual não foram preparadas e que não é o delas, quando procuram ensinar a ler e escrever aos próprios filhos. A causa dessa "confusão" ou "equívoco" em grande parte é explicada colocando-se no centro a escola, especialmente o professor, que não estaria conseguindo cumprir o "seu papel" ou as "suas responsabilidades":

Profissionais mal preparados para a tarefa difícil da alfabetização, escolas sem recursos e com classes heterogêneas, ausência de discussão entre o corpo docente e, às vezes, falta absoluta de orientação pedagógica praticamente obrigam 0 professor ao jogo de empurrar suas responsabilidades para a família. (p. 14)

Nessa reportagem, chama-se à escola para que assuma "plenamente sua responsabilidade de ensinar" (p. 15) e logo no início, no subtítulo, adverte-se "os professores que transferem para a família a tarefa de ensinar" (p. 12). A "alfabetização é um trabalho técnico", lembra Esther Grossi (p. 15). O professor deve estar preparado para desenvolvê-lo. Além disso, "É como profissional que o professor se impõe". Ele deve ser reconhecido enquanto profissional e a "família como um núcleo de apoio — e não de substituição — da escola. Quem comanda o processo é e deve ser o professor", o que não significa que prescinda do auxílio dos pais, conforme se adverte em seguida (ibidem).

Esse apelo, demanda ou exigência feita ao professor, para que seja profissional, está presente desde os primeiros números da Nova Escola, em matérias não relacionadas com a nova proposta de alfabetização. Por vezes, contrapondo-se a discursos presentes nessa mesma publicação, em que a educação é definida como um ato de amor, que enfatizam o papel da afetividade no ensino ou que destacam a importância da vocação para ser professor. ${ }^{70}$ São tensões que perpassam as falas do período e também o discurso pedagógico que está se configurando, e às vezes adquirem a forma de uma oposição entre psicologia e pedagogia, esta última sendo associada ao professor cujo lugar é demarcado com o significante profissional, conforme pode ser observado em

${ }^{70}$ Cf. "Ensinar é um ato de amor", mar./86, n 1, pp. 22-3; "Uma escola, um ato de amor", nov./86, $\mathrm{n}^{\circ}$ 8, pp. 28-30. 
matérias do primeiro ano dessa publicação. ${ }^{71}$ Posteriormente, esse contraste desaparece, mas não a tensão que ele supõe e que concerne ao professor cujo lugar é também definido pelo significante crítico. Essa tensão, nos anos subseqüentes, tende a se resolver em favor da afirmação de um professor que deve ser eficiente, que precisa atuar como um profissional, com uma prática teoricamente fundamentada. Tudo isso visto como essencial para que cumpra o seu papel, no construtivismo primeiramente relacionado com a construção de conhecimentos por parte da criança. Por isso, aliás, em fins dos anos 80 surgem falas que tendem a realçar a dimensão do afeto, da emoção, dos sentimentos, mas de um modo que deixa transparecer certa preocupação com a relevância que teriam adquirido os aspectos considerados de ordem cognitiva ou relacionados com a construção de conhecimentos, em particular na alfabetização. ${ }^{72}$ Essas tensões, bem como o valor atribuído à aquisição de conhecimentos e aos conteúdos tipicamente escolares, situam-se em linha de continuidade com os debates do início da década de 80 , provocados sobretudo pelos defensores da pedagogia dos conteúdos.

Ainda em relação à matéria da Nova Escola antes analisada, nela também destaca-se que cabe ao professor fazer um trabalho com os pais, principalmente para esclarecer qual o lugar de cada um nesse difícil momento da alfabetização. O professor tem de "sossegar os pais" e "conseguir que eles não interfiram no seu trabalho" ${ }^{73}$ Para tanto, várias práticas são arroladas e assim sugeridas, tais como: esclarecer, na primeira reunião do ano, que "o nosso trabalho de alfabetização é diferente: sem cartilha, sem lições de casa com base em cópias e ditados, mas com incentivo ao texto espontâneo da criança, à sua curiosidade sobre leitura e escrita"; fazer reuniões nas quais se explica que "as crianças cumprem etapas", que "não adianta ter pressa nem tentar ajudar na lição de casa"; entrevistas individuais para esclarecer dúvidas (p. 17). O que se busca é que os pais "entendam" que há outras formas de ajudar, que não consistem em ensinar a ler e escrever. O que importa é que, em casa, os pais criem "um clima favorável à

\footnotetext{
${ }^{71}$ Sobre essa oposição ou essas tensões, em geral entremeadas nas falas, veja-se: "Não sei o que fazer com essa criança", mar./86, n 1, pp. 50-1; "Drogas. Essa briga a escola pode ganhar", abr./86, n 3, pp. 52-5; "O $1 \circ$ Grau ainda desafia a capacidade do MEC", dez./86, n 9, pp. 48-60.

${ }^{72}$ Cf. "O que o professor eficiente tem de especial", n 31, jun/89, pp. 28-9; "Sem afeto, não há alfabetização", n 32, ago/89, pp. 22-4.

${ }^{73}$ Cf. "Pais x professores. O papel de cada um na alfabetização", jun./88, n 22, p. 15.
} 
alfabetização", que substituam "atitudes de controle sobre o aprendizado do filho por gestos de carinho e camaradagem" (pp. 16-7). A "nova proposta" exige todo um trabalho voltado para a família, que não mais está em "perfeito acordo" com a escola, como na "forma tradicional de alfabetização" (p. 16).

O que nesse discurso vai sendo demarcado como lugar da família ou dos pais começa a ficar bem distante do que o significante comunidade situava nos discursos da educação popular, mas também do que o próprio significante pais ou família delimitava no discurso educacional alternativo das camadas médias. Há uma mudança significativa em relação ao lugar onde, acreditava-se, poderia surgir um saber relevante no que se refere à educação - com o construtivismo, na verdade, um lugar antes vinculado aos significantes ensino-aprendizagem e escola do que ao significante educação.

O que no campo alternativo e nas camadas médias via-se como algo gestado coletivamente, sem divisões nítidas entre pais e educadores/monitores/professores — pelo menos quanto ao saber que todos procuravam produzir, num período em que as antigas referências haviam sido fortemente questionadas e não havia propriamente o que pôr no seu lugar torna-se um saber que, cada vez mais, começa a fazer parte do domínio exclusivo dos novos especialistas, de acordo com a transfiguração perceptível na maioria dos educadores que participavam dessas experiencias, conforme ocorre a sua "modernização" e a entrada em cena do construtivismo. Afirma-se aí uma hierarquia, pouco relevante ou mesmo inexistente no começo dessas experiências alternativas que se desenrolavam no âmbito das escolas particulares. No seu topo ficam esses profissionais, com uma experiência alicerçada no campo alternativo e com a legitimidade e a força que o novo discurso "científico" fornece. Condições essas propícias para os que procuraram ampliar a sua atuação, por meio de cursos e assessorias, em instâncias diversas da rede de ensino público, escolas privadas e outras instituições educacionais, num período em que crescentemente se disseminam todo um conjunto de valores acalentados nesses setores médios. ${ }^{74}$ Concomitante ao estabelecimento dessa hierarquia, não raro essas escolas

\footnotetext{
${ }^{74}$ A referência principal dessa argumentação é a trajetória das escolas alternativas da cidade de São Paulo (Revah, 1994).
} 
procuraram pautar a atuação dos pais de um modo mais incisivo, mantendo-os ademais a uma certa distância, julgada necessária para que não interferissem no trabalho cujo domínio, enfatiza-se então, cabia ao professor. O que aí está em jogo é a especificidade da educação escolar e de um profissional que procura um lugar diferenciado em face da família. Mas também o lugar do saber no que se refere à educação - um lugar que daí em mais tende a ser configurado pelos novos especialistas e o seu discurso científico. E aí encontram-se implicadas, é claro, determinadas relações de poder, envolvendo escola/profissionais da educação, de um lado, e casa/família/pais, de outro.

Em relação ao alternativo-popular, o lugar do saber sofre também um deslocamento. Em face do novo discurso, o saber valorizado, o saber da comunidade, que se estendia em direção às organizações e movimentos populares, tende a se esvair, perdendo assim o seu antigo potencial. Sobrepondose à comunidade, à sua experiência, surge um lugar sob a marca da falta, próximo do que historicamente a escola consagrou como lugar da família, sobretudo nos setores populares. Uma falta que em geral não é vista como estando num registro próximo do que recebia o qualificativo de tradicional ou do que desde a década de 70 vinha sendo tão criticado: a teoria da carência ou privação cultural. ${ }^{75} \mathrm{~A}$ falta, a "ausência", agora ganha um sentido que justifica e alicerça a nova proposta de alfabetização, como já é possível observar na argumentação de Esther Grossi, na primeira reportagem em que esse discurso ganha os seus primeiros contornos:

\begin{abstract}
"Nas famílias de classes populares (...) há uma ausência quase completa de experiências com materiais de leitura e com o próprio ato de ler e escrever. Isso impede que essas crianças avancem, dos 2 aos 6 anos, no mesmo ritmo que crianças de classes favorecidas". ${ }^{76}$
\end{abstract}

Essa "ausência", isso que é da ordem de uma falta, de uma carência — que é o que nessa argumentação em grande parte sustenta a idéia de que a "proposta do GEEMPA" é adequada às classes populares —-, não se configura exatamente nos mesmos registros anteriores, há um deslocamento, na medida em que, a princípio, evita-se culpabilizar as famílias, tendendo-se a colocar toda a responsabilidade na escola, especialmente no professor. Além disso, e nisto

\footnotetext{
${ }^{75}$ Uma exceção é a reflexão de Patto já comentada, quando se refere à "teoria da diferença cultural" $(1985,1988)$.

${ }^{76}$ Cf. "Com uma didática revolucionária, sucata e alegria é fácil alfabetizar crianças pobres", Nova Escola, n 6 , set./86, p. 41.
} 
talvez resida a principal diferença, o lugar da criança é sempre preservado. $E$ mais do que isso, tudo o que a criança produz, o que ela apresenta, o que é da ordem do seu saber, do saber que ela consegue "construir", adquire um valor positivo. Em outras palavras, o que a criança evidencia em termos de "construção de conhecimento", seja sob qual forma for, é extremamente valorizado e, inclusive, tende a pautar a atuação do professor.

Apesar disso, existe na "nova proposta" algo que é da ordem de uma compensação das "carências", nesse caso de experiências que as crianças não puderam ter em suas casas, com as suas famílias. Ademais, nesse lugar das famílias, acaba se configurando uma falta que é de uma outra ordem e cujo efeito é semelhante ao que aqueles discursos tão criticados produziam. Por isso, mais adiante, configurar-se-á com alguma força o tema da "resistência" dos pais às mudanças, com esse significante sendo utilizado também - e muito - para demarcar o lugar dos professores. Ou seja, a princípio procura-se não culpabilizar os pais ou as famílias, mas, se a "nova proposta" não for aceita ou se os resultados relativos à sua implementação não forem os esperados, cai-se com facilidade naquele outro registro, onde pais ou professores surgem como culpados ou como carentes de um saber que a escola ou os especialistas de algum modo precisam fornecer, para vencer as "resistências" e para que todos atuem "adequadamente". E quando isso ocorre, quando a culpa ou a carência retornam sob essa forma, tende a passar despercebida a familiaridade aí existente, entre o novo discurso pedagógico e discursos anteriores. Nesse ponto da "resistência" houve, na verdade, um recalque, necessário para afastar parentescos indesejados.

\section{5. (Re)ordenando discursos e nomes}

Numa outra matéria de 1988, sobre o trabalho de alfabetização desenvolvido por uma professora de uma escola estadual de Porto Alegre, destaca-se que "ela aboliu a cartilha" e adotou um livro de poesias de Mário Quintana. ${ }^{77}$ Ao indicar as leituras que havia feito — "buscando encontrar meu próprio caminho" _ , menciona Piaget, Emilia Ferreiro e Paulo Freire, que pela primeira vez surge nessa particular conjunção. Apesar da professora assinalar

${ }^{77}$ Cf. "Com P se escreve poesia ....", n²4, set./88, pp. 42-4. 
que está procurando o seu "próprio caminho" - uma afirmação que daí em mais será bem comum no âmbito do novo discurso - vários lugares voltam a aparecer, repetem-se, a começar pelos nomes próprios do ponto de arremate desse discurso (Emilia Ferreiro e Piaget) e a referência ao tradicional ou, mais exatamente, às "cartilhas tradicionais, cheias de textos impostos e monótonos para as crianças" (ibidem). Em relação às pesquisas de Emilia Ferreiro e ao processo de alfabetização, a professora afirma que é "uma fase que só recentemente vem sendo estudada, do ponto de vista científico" (p. 43). Ademais, tende a demarcar o lugar dos pais de uma forma semelhante à matéria antes referida:

Para a professora, há dois pontos básicos no relacionamento com os pais. O primeiro é fazer com que compreendam e aceitem sua proposta de alfabetização. "Para isso, faço reuniões mensais onde dou praticamente uma aula para cada pai compreender o que se passa com sua criança. Atualmente eles não estão mais tão ansiosos (...)

Desafio - O segundo ponto básico é tentar aproximar os pais dos interesses dos seus filhos.

Segundo a professora, os pais têm cooperado e até lido livros que ela indicou, como Pedagogia do oprimido, de Paulo Freire. E aqui vemos em que tipo de articulação discursiva vai sendo inserido o nome de Paulo Freire e a sua obra, nesse caso no âmbito do "relacionamento com os pais" e de um modo bem diverso do que esse autor costumava destacar em face da "comunidade". A aproximação com esse nome e também com articulações significantes próprias do alternativo-popular continuará a ocorrer em outras matérias, de início com o nome Paulo Freire bastante presente, mas desaparecendo posteriormente, em meados da década de $90 .^{78}$

Uma outra matéria de 1988, a última onde Ferreiro é citada, é sobre a reforma curricular prevista para ser implementada, no ano seguinte, no município do Rio de Janeiro, como um segundo passo "em busca da democratização do ensino". ${ }^{79}$ Nessa matéria, Emilia Ferreiro é o único nome próprio que remete para

\footnotetext{
${ }^{78}$ A referência feita a Paulo Freire, bem como a sua absorção no âmbito do discurso construtivista, já foram assinaladas por Vieira $(1995$, p. 31), que também destaca a ocorrência de algo semelhante com outros autores, não tão presentes nessas matérias da Nova Escola quanto Paulo Freire.

${ }^{79} \mathrm{O}$ "primeiro passo" teria sido "a realização de eleições diretas para escolha de diretores", no ano anterior. Segundo a fala atribuída ao secretário municipal da Educação: "Será uma mexida nos
} 
um certo referencial teórico, que aí está implícito. Ademais, seu nome fica associado aos vários significantes que nela comparecem, dentre eles alguns dos que ficarão particularmente amarrados ao significante-mestre construtivismo, como reforma curricular, postura atual e democrática e qualidade de ensino.

Ainda em 1988, encontram-se algumas matérias onde o nome Emilia Ferreiro não é utilizado, mas que não deixam de evocá-lo, ao repetir os lugares que já nesse momento podiam ser reconhecidos como sendo próprios da "nova proposta de alfabetização". Dentre elas, há uma sobre um "projeto" voltado para a alfabetização que estava sendo implementado na capital do Acre, em quatro escolas públicas da rede estadual, com o intuito de combater os altos índices de evasão e repetência. ${ }^{80}$ Alguns dos aspectos do projeto destacados na reportagem deixam em evidência, não a familiaridade com a perspectiva de alfabetização atrelada ao nome Emilia Ferreiro, mas o contrário: uma perspectiva que no âmbito do novo discurso pedagógico será alvo de crítica, como de fato ocorre nessa matéria.

O projeto toma como referência básica o "conceito de prontidão para a alfabetização", implicando na divisão de cada turma em níveis, de acordo com o domínio demonstrado pelas crianças em relação às "habilidades do período preparatório" (discriminação visual ou auditiva, coordenação motora, lateralidade, etc.). O objetivo é formar grupos homogêneos, pois entende-se que desse modo o trabalho "rende muito mais e é mais gratificante" (p. 59). Embora sejam mencionadas algumas dificuldades enfrentadas pela equipe que elaborou e implantou o projeto, ressalta-se o empenho e o entusiasmo dos educadores envolvidos. Uma dimensão que é destacada no box que acompanha a matéria, não sem colocar em xeque "o método" utilizado, como já se antecipa no seu título: "O empenho conta mais que o método". Este é avaliado tendo em vista as "novas propostas de alfabetização", especialmente uma delas, "denominada construtiva",

conceitos de saber, tendo como base uma postura atual e democrática e visando sobretudo a melhoria da qualidade de ensino" (ibidem). Na matéria, assinala-se que o documento inicial da Secretaria, ainda em discussão, apresenta "um mapa com os conteúdos mínimos para cada série"; são destacadas algumas áreas e aspectos relativos ao enfoque adotado, como "o ensino a partir do cotidiano da criança", em História e Geografia; e, em relação à alfabetização, menciona-se "a professora argentina Emilia Ferreiro" e as suas pesquisas, indicando-se que a proposta curricular nessa área "apresenta novas formas de ensino que respeitam o conhecimento adquirido pelo aluno fora da escola e as hipóteses que ele formula sobre a leitura e a escrita" (ibidem). Cf. "A reforma chega às escolas do Rio", $n^{\circ} 26$, nov./88, pp. 56-7.

${ }^{80}$ Cf. "Acre luta contra a evasão e a repetência", $n^{\circ} 25$, out./88, pp. 58-9. 
que "é aceita hoje por muitos educadores e já começa a ser adotada por várias entidades de ensino" (ibidem). A proposta "construtiva", que é brevemente caracterizada e implicitamente vinculada ao nome Emilia Ferreiro, é utilizada como padrão ou critério para avaliar o projeto de alfabetização apresentado na reportagem. Além disso, pela primeira vez na revista Nova Escola, usa-se um significante semelhante ao que deverá ser largamente empregado para reconhecer a "nova proposta", que nos anos subseqüentes deixará de ser apenas uma proposta de alfabetização.

O uso do significante "construtiva", no lugar de construtivista, como será comum nessa revista a partir de 1989, antes do que uma falha ou um erro parece indicar que, nesse momento, o significante-mestre construtivismo e seus derivados (como proposta construtivista) não eram utilizados com muita freqüência ou, pelo menos, não eram suficientemente conhecidos ou familiares para os jornalistas que produziam a Nova Escola. ${ }^{81}$ Ademais, talvez seja indicativo da busca de um nome mais abrangente para uma proposta que, além de começar a extrapolar de modo mais nítido o campo da alfabetização, já era reconhecida em instâncias diversas em todo o país.

Sobre a emergência do significante-mestre construtivismo, que afinal se impõe como nome do novo discurso pedagógico e que na revista Nova Escola já é possível vislumbrar em fins de 1988, deve ser considerado o papel dos significantes construção/construir (com as suas variações). Com eles vai sendo realizada uma costura que também vincula discursos que extrapolam o campo da alfabetização, discursos esses onde o nome Emilia Ferreiro não aparece, mas que de qualquer modo já estão sendo (re)ordenados sob o influxo desses significantes. Vejamos então alguns exemplos.

Nos primeiros anos da revista Nova Escola, se não considerarmos as matérias que tratam da aprendizagem da matemática ou da alfabetização, são poucas as que utilizam os significantes construção/construir para fazer referência

\footnotetext{
${ }^{81} \mathrm{O}$ uso do significante construtivista referido à nova perspectiva de alfabetização já pode ser encontrado em textos de meados da década de 80, como é o caso de um artigo escrito por Telma Weisz (1985) para uma publicação do Projeto Ipê, onde a autora afirma: "foi precisamente esse posicionamento teórico - construtivista/interacionista - que permitiu que Emilia Ferreiro e Ana Teberosky fizessem descobertas que são verdadeiros `ovos de colombo'” (p. 27).
} 
ao processo de aprendizagem da criança ou à aquisição de conhecimentos. Dentre elas, há uma sobre o ensino de História, em novembro/87. ${ }^{82} \mathrm{~A}$ reportagem refere-se ao trabalho desenvolvido no $1^{\circ}$ Grau por um grupo de professoras paulistas, a maioria da rede pública de ensino. Elas estavam implantando "um novo método de ensino de História". Na definição do método, a contraposição ao ensino tradicional é fundamental. Com o "método tradicional", os alunos "seguiam mecanicamente o livro didático, decorando datas, causas e conseqüências dos fatos históricos" (ibidem). Com o "novo método" de ensino, tanto as professoras quanto os alunos livraram-se dos livros didáticos, que em sua maioria "ditam o programa, são cansativos, desestimulantes e limitadores, representam a versão da classe dominante na História e apresentam essa versão como a verdadeira e a definitiva" (pp. 42-3). Quanto ao trabalho desenvolvido pelas professoras, eis algumas características:

São sete professoras que não seguem, como nos livros, os fatos cronologicamente, não partem desses fatos para iniciar o ensino e não usam um material único de pesquisa. Partem dos problemas concretos do presente, da realidade dos alunos, da escola, da comunidade. As crianças, com a ajuda dos professores, textos, pesquisas e debates, recuperam certos momentos e objetos do passado. O resultado: alunos críticos, que aprendem sem a necessidade da amaldiçoada "decoreba". (p. 42)

Ao longo da reportagem são delineados aspectos particulares do trabalho desenvolvido por cada uma das professoras, indicando-se os temas dos quais os alunos partiram ou que nesse momento estavam pesquisando, bem como as noções básicas que as professoras pretendiam desenvolver. ${ }^{83} \mathrm{O}$ "novo método", de acordo com a reportagem, "tem como base a proposta curricular lançada pela Equipe Técnica de História da Coordenadoria de Estudos e Normas Pedagógicas (CENP), da Secretaria de Educação de São Paulo" (p. 42). A também chamada "nova proposta" é delineada e destacada num box, do tamanho de uma página, intitulado "Construir o conhecimento". No box informa-se que a "nova proposta"

${ }^{82}$ Cf. "Nos temas do presente, o início da aprendizagem", Nova Escola, n 17, novembro/87, pp. 42-6.

${ }^{83}$ Eis alguns desses temas: a formação e trajetória da Sociedade amigos do Bairro de Rio Pequeno; as histórias das famílias; "provérbios, contos e lendas populares"; "o mercado de trabalho no bairro do Butantã". Quanto às "noções básicas", são mencionadas as seguintes: "tempo e espaço, diferença e semelhança, permanência e mudança, relações sociais, documentos e produção da História" (p. 43). 
vinha sendo elaborada há três anos, sendo colocada em discussão em toda a rede, em julho desse ano. Na caracterização da proposta, que sugere temas, noções e questões para serem desenvolvidas nas diferentes séries, repete-se basicamente o que acima foi apontado. Mas há uma diferença básica, implicada no título do box e ressaltada no seu interior:

(...) a nova proposta apresenta uma concepção diferente de ensino: a construção do conhecimento pelo aluno. "A forma tradicional de ensino, com base no livro didático, parte de um saber como verdade pronta e coloca o aluno como um ser vazio, sem qualquer conhecimento", explica [um membro da equipe da CENP]. Por isso, o ensino proposto parte da realidade da criança, do que ela já conhece. A partir do aprofundamento da problemática atual, ela pode recuar a qualquer momento histórico. ( $p$. 44)

No texto do box opera-se um deslocamento que coloca o significante construção do conhecimento num primeiro plano. Nesse deslocamento prenunciase o que deverá ocorrer com o significante "realidade", de forte ressonância no discurso da educação popular e muito presente nas matérias da Nova Escola desse primeiro período. A realidade da criança, que antes de mais nada concerne à realidade da sua comunidade, do seu bairro e da cultura da qual faz parte, tornar-se-á com o passar dos anos uma outra realidade, na medida em que é sobrepujada pelo significante construção/construir e toda a rede discursiva que procede da psicologia. Nos discursos da educação popular, a realidade da criança em muito extrapola a própria criança, para situar diretamente o contexto em que ela vive. Com o construtivismo, no entanto, nas matérias da Nova Escola de meados da década de 90, esse contexto praticamente desaparece. E mais, com a hegemonia do novo discurso e o giro discursivo que ele produz, todo e qualquer contexto das experiências que servem de referência às matérias da revista também se esvai. O que sobra é a sala de aula, os materiais didáticos, os conteúdos que o professor tem de trabalhar e sobretudo as técnicas de ensino, os métodos e tudo o que é da ordem do "como" ensinar, então depurado de qualquer traço de singularidade. Isso é o que tende a ocorrer no período em que o construtivismo tem o seus "pontos básicos trocados em miúdos", conforme anuncia a manchete de capa da Nova Escola de março/95.

Uma outra matéria da Nova Escola onde os significantes construção/construir aparecem encontra-se no exemplar do mês de março/88. É uma reportagem sobre o ensino de Geografia, intitulada "É melhor ensinar a 
pescar do que dar o peixe". 84 "Em vez de oferecer verdades prontas, uma escola paulista leva seus alunos a construir o conhecimento", complementa-se no subtítulo da matéria. Nela, descreve-se o trabalho que vem sendo realizado por três professores, de $5^{\text {a }}$ a $8^{\text {a }}$ série, de uma escola estadual da periferia de São Paulo. Os professores desenvolveram uma "nova postura de ensino", uma "nova proposta", que leva em conta o cotidiano das crianças "mas também todos os conteúdos de Geografia":

"Procuramos mostrar o mundo a partir do bairro, do dia-a-dia, passando noções de Geografia física, política e econômica. Nada de forma estanque. Tudo tendo o homem como centro" (...)

(...) "ensinar a pescar" é fazer a criança desenvolver o espírito crítico, ser o sujeito do aprendizado e construir o conhecimento a partir de sua própria realidade.

Entre os aspectos relacionados com os "resultados positivos" do trabalho são mencionados o "estabelecimento de uma relação menos autoritária com o aluno, que não fica apenas calado e ouvindo" e o fato dos professores trabalharem com os conteúdos de "forma interdisciplinar". À semelhança da reportagem sobre o ensino de História, aqui também relaciona-se a experiência desses professores com a "nova proposta curricular de Geografia" da CENP, afirmando-se que essa experiência foi "um dos pontos de referência" usados para a elaboração dessa proposta (p. 27). Enfim, esses são alguns exemplos relativos a uma costura que já vinha sendo feita com os significantes construção/construir e que precede e sustenta o que em 1989 deverá ficar num primeiro plano.

1989 é um ano crucial, se tomarmos como referência a revista Nova Escola. O nome Emilia Ferreiro é citado em pelo menos uma matéria de todos os números da revista. Ademais, o nome e a imagem de Ferreiro chegam à capa dessa publicação e pela primeira vez é usado o significante-mestre construtivismo e seus derivados, como proposta ou teoria construtivista. O mais importante, porém, são os efeitos que essa emergência produz. Vejamos.

No primeiro número de 1989, a capa da revista apresenta uma pequena foto de Emilia Ferreiro - a primeira figura pública ou "autoridade" relacionada

${ }^{84}$ Cf. Nova Escola, n 19, março/88, pp. 26-7. 
com a educação que tem o privilégio de aparecer na capa, desde o início dessa publicação, em março de 1986. Acima dela, da imagem de seu rosto, encontra-se uma professora com um avental branco, ao que parece lendo uma história para os seus atentos alunos, não na sala de aula, mas sobre um gramado, ao ar livre, num ambiente "natural". As crianças, algumas em pé, outras sentadas, não usam uniforme nem qualquer coisa que permita reconhecê-las como alunos. Uma certa informalidade, em face do que poderia ser entendido como típico de uma escola, parece dominar a imagem. O título da capa é "Revolução na alfabetização", sendo complementado com este subtítulo: "Idéias de Emilia Ferreiro mudam a postura do professor". Uma frase cujo sentido tende a ser reforçado e ampliado pela particular disposição das fotos e do que nelas aparece, como se as idéias de Ferreiro tivessem encontrado a sua concretude bem ali, na "postura" da professora cuja foto fica, justamente, acima da imagem da pesquisadora:

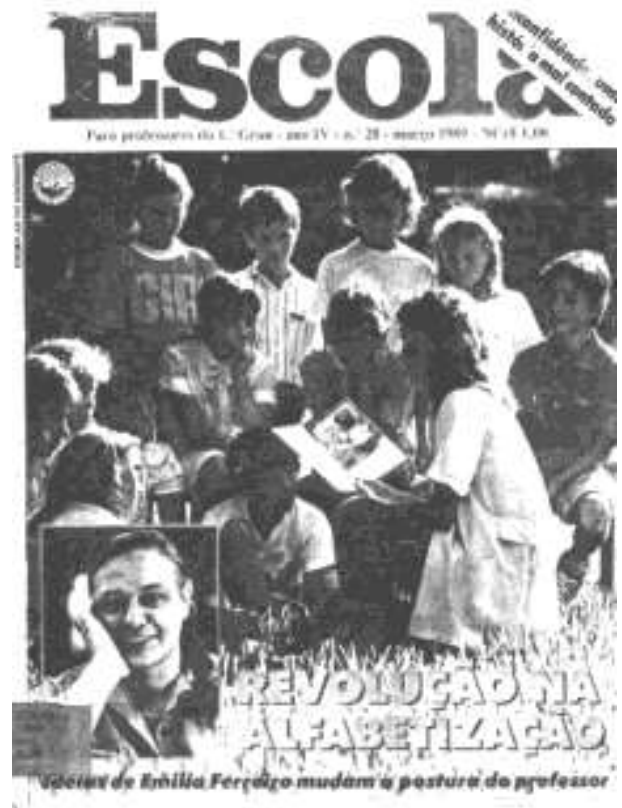

A frase do subtítulo situa com nitidez e ela própria engendra certo tipo de "revolução" ou giro discursivo produzido pelo novo discurso pedagógico. No centro dessa "revolução" está em jogo uma mudança de "postura" do professor, que na revista, até então, vinha sendo atribuída a diversas circunstâncias e experiências, sem que existisse um vínculo claro com determinado discurso. De agora em mais, com a repetida costura do ponto de basta que cria o novo discurso, com esse basteamento que traz à tona e começa a operar com o significante-mestre construtivismo, as mudanças de postura que vinham ganhando um sentido positivo tendem a ficar referidas e subordinadas a um único ponto, a princípio 
relativo ao nome Emilia Ferreiro e à sua imagem: a de uma psicóloga argentina, exilada, "Doutora em Psicologia pela Universidade de Genebra, com tese orientada por Jean Piaget, de quem foi colaboradora", que "realizou um trabalho de investigação a respeito do processo de alfabetização, buscando compreender melhor o fracasso escolar nas séries iniciais", conforme informa-se no box colocado no final da matéria que corresponde ao único destaque de capa. ${ }^{85}$ Ademais, uma pesquisadora que "Faz questão de não personalizar qualquer trabalho de alfabetização e de deixar claro que não criou nenhum método nem sequer uma proposta de alfabetização", mas que acompanha de perto "os novos rumos que a alfabetização vem tomando, como prática pedagógica e como compromisso político, junto a classes populares de países da América Latina" (p. 18). Em relação ao seu trabalho, "vem sendo bastante cautelosa" na sua divulgação, "principalmente para que os professores não passem a entender e aplicar suas idéias de forma distorcida" (ibidem). Idéias essas que, segundo destaca-se no subtítulo da matéria, "dão fundamentação teórica à alfabetização e promovem uma verdadeira democratização do ensino" (p. 12).

Com essa caracterização, reforçada e ampliada por outros aspectos mencionados ao longo da reportagem, o novo discurso pedagógico mantém-se ancorado nos pontos de ressonância necessários para sustentar-se e ganhar uma projeção ainda maior. Pontos de ressonância que são próprios de outros discursos e que o construtivismo desloca e (re)ordena, transformando-os em seus pontos de ancoragem, como é o caso dos seguintes: fracasso escolar, analfabetismo, qualidade de ensino, democracia, classes populares/pobres, novo/revolução/mudança, fundamentação teórica/ciência, postura.

Essa lista pode ser ampliada com os pontos cujas costuras ainda são incipientes, mas que no âmbito da rede que está se configurando serão essenciais, como o que corresponde à referida preocupação de Ferreiro com a "distorção" que poderia ocorrer em relação ao entendimento e aplicação das suas "idéias". Afinal, a "revolução conceitual" somente poderá produzir efeitos democratizantes, será realmente "uma revolução na ótica do que é ensinar e aprender" se, primeiramente, os professores compreenderem a teoria. Esse é o

\footnotetext{
${ }^{85}$ Cf. "Uma revolução na ótica do que é ensinar e aprender", n 28, março/89, pp. 12-8.
} 
primeiro e fundamental passo: "muito estudo e reflexão para mudar a ótica", como é destacado num dos subtítulos que divide o corpo da matéria (p. 17). Para tanto pode ajudar a bibliografia mínima sugerida no final da reportagem, composta por três livros escritos por Ferreiro, um deles junto com Ana Teberosky, que também é citada no box já mencionado e intitulado "Quem é Emilia Ferreiro" (p. 18).

Nessa reportagem, a postura configura-se como um lugar que deriva de certas "idéias", ou melhor, da "revolução conceitual" que Emilia Ferreiro produz, tendo por base a "teoria construtivista". A "revolução conceitual", ainda não adjetivada desse modo nessa revista, precede e determina a mudança de postura. Todavia, em outras matérias anteriores sobre temas diversos, não relacionados com a "nova proposta de alfabetização", o significante postura dizia respeito a uma outra configuração discursiva. A postura encontrava o seu sentido em articulações discursivas onde não existia aquela hierarquia (teoria-prática, teoriapostura), nem o déficit que daí em mais deverá acompanhar o que é situado no âmbito da prática e da postura, sob a forma que é própria nesse tipo de discurso, a dos "desvios, confusões, equívocos ...". Além do mais, nessas matérias anteriores, as várias significações instituídas com o significante postura costumavam adentrar no terreno dos questionamentos políticos e culturais, ao passo que com o construtivismo deverá ser cada vez mais um campo dominado pelas preocupações didáticas e metodológicas, tendo em vista a eficácia da ação pedagógica. $O$ que não quer dizer que no construtivismo a dimensão própria do questionamento político e cultural tenha desaparecido. Digamos que ela subsiste, subordinada e crescentemente sobrepujada por aquela renovada hierarquia, que não exclui a política, principalmente porque ela institui uma outra política, uma outra relação de poder. Em outras palavras, a ênfase na postura do professor, no seu posicionamento contra o autoritarismo, a burocracia, as atitudes repressivas ou inibidores das falas e ações dos alunos e a favor de relações democráticas, de um espaço de diálogo e de maior liberdade para os alunos, com a preocupação de neles igualmente desenvolver uma postura ou visão crítica, tudo isso continua, mas entra no circuito que a nova rede discursiva cria. Uma rede cada vez mais distante, por exemplo, do que os discursos educacionais alternativos configuravam. 
Nesses discursos alternativos — lembremos de Paulo Freire —, uma mudança de "posição no mundo" gestava-se no interior de uma ordem instaurada pela palavra, a palavra comum, compartilhada, coletiva. As teorias e a ciência tinham o seu lugar, mas subordinado à ordem da palavra verdadeira, uma palavra simultaneamente política e cultural e que encontrava eco na comunidade, no povo, na sua experiência, nas suas ações e reflexões. A ação-reflexão própria da ordem da palavra, tal como entendida por Freire, mas que também encontrava a sua significação em inúmeras experiências e discursos do campo alternativo, fica cada vez mais distante do universo discursivo que está se configurando com o construtivismo. A postura do educador ou professor construtivista tenderá a ser vista antes como o resultado da compreensão de determinada teoria científica do que algo oriundo de uma experiência atravessada pela ordem da palavra, daquela palavra, da que nascia sob o influxo dos questionamentos de natureza política e cultural e que, ademais, não ficava subordinada a hierarquias pré-estabelecidas entre teoria e prática, entre ciência e outros discursos sem essa chancela. No discurso da educação popular dos anos 70 e 80, uma consciência crítica, uma posição crítica ou uma teoria crítica tinham de nascer nesse terreno, tendo por base aquele tipo de experiências.

Nessa matéria da Nova Escola onde pela primeira vez comparece o significante construtivismo, recolhem-se elementos até então dispersos em matérias anteriores, como é o caso do significante postura. Esses "significantes flutuantes" vinham aparecendo em articulações diversas, geralmente em discursos sem um ponto de arremate à vista. Nessa matéria, porém, são enlaçados pelo significante-mestre que nesse momento emerge, sob a hierarquia que então fica bem estabelecia - com as "idéias" de Emilia Ferreiro mudando a postura do professor. Esses "significantes flutuantes" são amarrados pelo laço que aí é criado, pelo ponto de basta feito com essa agulha, com o significante-mestre construtivismo, ainda subordinado ao nome Emilia Ferreiro. Nesse laço não deve ser desprezado o papel da imagem da capa da revista. O ambiente "natural", a informalidade própria da cena, com os alunos mostrando-se interessados e atentos à leitura feita pela professora, são elementos que evocam inúmeras fotos presentes na revista desde o seu início. Os inúmeros laços que vinham sendo criados com essas e outras imagens - muitas delas presentes nas matérias sobre a "nova proposta" de alfabetização - e com a rede de enunciados que 
nelas conflui, são também afetados pelo ponto de basta que então se constitui, com o grande laço que nesse momento é feito.

Esse laço retroage vinculando e unificando a dispersão precedente e é repetido e reforçado em matérias posteriores. Com ele, por meio dessa operação discursiva, tende-se a transformar toda e qualquer postura do professor cuja atuação é avaliada positivamente, seja ela relativa ao passado recente ou ao futuro próximo, numa postura característica do professor construtivista. E aí é produzida certa inversão. O que se concebe como uma "nova postura" em boa medida já existia, com todo um conjunto de traços que vinham sendo amarrados ao significante postura em discursos, experiências educacionais e por educadores sensíveis aos questionamentos de natureza política e cultural, os questionamentos que arrefeceram e perderam o seu antigo valor na segunda metade da década de 80, em consonância com a inflexão perceptível nos discursos do campo alternativo. A "nova postura", redimensionada em razão dessa inflexão, foi o que em grande parte criou o terreno propício para a receptividade das "idéias" de Ferreiro. A mudança de postura precedeu a entrada em cena das suas "idéias" e não o contrário. Tudo o que essa mudança supõe, com as inúmeras e pequenas transformações nela envolvidas, criou as condições necessárias para que ocorra essa emergência, possibilitou essa operação de basteamento, com o recalque aí implicado. Em outras palavras, as "idéias" de Ferreiro encontraram acolhida entre os educadores brasileiros graças a uma mudança de postura que já vinha se desenrolando. É claro que essas "idéias" introduziram certa torção, elas produziram alguns deslocamentos discursivos importantes, mas o fundamental neste caso é que elas encontraram eco porque entraram em sintonia com a multiplicidade de traços que já definiam a "nova postura", daí em mais uma postura do professor construtivista. Um professor criado pelo ponto de basta que então se constitui, em razão do corte e do efeito retroativo que é próprio dessa operação discursiva. Ele é criado com os traços que já vinham demarcando o seu lugar, mas que unificados pelo novo significantemestre ganharão um novo sentido. Essa unificação e esse novo sentido ainda deverão ser melhor estabelecidos, em particular no momento em que é finalizada a moldura do novo discurso, a moldura ou suporte que permitirá conceber o construtivismo como eqüidistante de dois extremos igualmente recusados: a escola tradicional e o espontaneísmo. 
Justo nessa matéria surge de forma nítida a dimensão temporal, isto é, a "nova proposta de alfabetização" começa a ter uma história, não ficando referida somente a uma investigação ou teoria sobre como as crianças aprendem a ler e escrever. É verdade que essa dimensão já estava presente em matérias anteriores, sobre determinada experiência ou sobre o trabalho desenvolvido pelo GEEMPA, por exemplo. Mas agora ganha um lastro mais consistente e comum a várias iniciativas, a várias "experiências alternativas de alfabetização que vêm acontecendo em nossa rede pública" (p. 13) e que nessa longa reportagem procura-se caracterizar. Além do mais, a história que desde então fica sob a órbita do novo significante-mestre (construtivismo), torna-se uma história que adquire uma dimensão nacional, pois são apresentados depoimentos de professoras de várias capitais e brevemente traçadas as trajetórias das iniciativas voltadas para "A capacitação dos professores nos Estados", conforme anuncia o título de um extenso box sobre esse assunto (pp. 14-6). Além do trabalho desenvolvido na rede pública de importantes capitais e Estados (Rio Grande do Sul, São Paulo, Rio de Janeiro, Minas Gerais, Bahia e Pernambuco), são citados os nomes de alguns órgãos, grupos e pessoas, vários deles já mencionados em reportagens anteriores, como CENP, GEEMPA, Esther Grossi e Telma Weisz.

Nessa reportagem, o "caminho" construtivista apresenta os seus primeiros contornos, esboçados principalmente nos depoimentos atribuídos às professoras que mudaram a sua "postura". Elas lembram, por exemplo, como foi "cansativo e angustiante ter que repensar e criticar todo o trabalho que fazíamos até então", a descrença na possibilidade de construir uma "nova proposta de alfabetização", as muitas dúvidas, o temor, a insegurança, a ansiedade. "A passagem do velho para o novo", das "posturas antigas" para a "nova postura" é concebida como "um processo lento, que exige uma maturação gradativa" (p. 17), é trabalhoso e difícil. Ademais, exige estudar mesmo, buscar fundamentação, compreender a teoria e superar a dificuldade de passar da teoria à prática. Uma compreensão que envolve, sobretudo, descobrir "como as crianças pensam" (p. 14), "entender como a criança constrói seu conhecimento" (p. 17). Afinal, quem dá "a receita de como trabalhar" são as próprias crianças, "é o aluno quem mostra os caminhos" (p. 13). Uma conclusão que, de acordo com o que é sugerido nessa mesma matéria, encontra respaldo no que Emilia Ferreiro "descobriu": 
Em suas pesquisas, ela descobriu o que vem sendo considerado o "ovo de Colombo" por educadores de vários países da América Latina: ao contrário do que se pensava, não é o professor quem ensina a ler e escrever, mas é a criança que constrói seu próprio processo de leitura e de escrita. (pp. 12 3)

Para começar a mudar, "a chave" é "acreditar que a criança aprende", que ela "é autônoma e capaz de aprender por sua própria iniciativa". Portanto, aceitar o novo lugar, assumir a "nova postura" exige muito do professor, principalmente do professor que trabalha numa perspectiva tradicional, segundo a qual ele "ensina tudo" e "a criança é uma tábula rasa, que chega à escola para aprender do jeito que o professor ensina" (p. 13). Além de "humildade", necessária "para acreditar que não é o professor quem ensina" (p. 17), os professores que estão buscando "alternativas educacionais" para o fracasso escolar apresentam outras qualidades: são "inquietos, cheios de vontade de acertar e de superar a exaustiva sensação de fracasso diante de crianças que repetem ou saem da escola sem aprender a ler e escrever" (p. 12).

Os professores são, em suma, os principais protagonistas das transformações almejadas, mas também os principais responsáveis. Sobre eles já começa a cair todo o peso dessa responsabilidade. Por isso, dentre as questões arroladas nessa matéria e que "põem em dúvida a garantia de um trabalho contínuo e de qualidade, dentro dessa nova ótica", a principal delas, aquela de maior destaque diz respeito à "resistência" dos professores. Ou seja, eles podem mudar a qualidade do ensino, acabar com o fracasso escolar, mas também constituem o principal empecilho, o maior obstáculo para a implementação da "nova proposta". O "caminho", portanto, é difícil e a responsabilidade dos professores imensa. Entretanto, uma vez que eles acertam, que transformam as suas concepções e práticas, a recompensa é certa: o entusiasmo com a sua nova postura, os "ótimos resultados práticos" (p. 15), a significativa mudança nos próprios alunos, que se envolvem nas atividades, ficam mais soltos e aprendem. ${ }^{86}$

O lugar do professor acima definido, com o ensino não sendo considerado uma das suas atribuições, situa-se em linha de continuidade com o teor de outras

\footnotetext{
${ }^{86}$ Os traços desse "caminho" construtivista, acima relacionados com a "postura" do professor, são basicamente os que Vieira (1995) ressalta quando assinala o seu parentesco com a conversão religiosa.
} 
matérias presentes na Nova Escola desde o seu início, em 1986. Mas esse viés convive, inclusive nessa mesma reportagem, com afirmações que atenuam ou matizam o esvaziamento que a exclusão do significante ensinar/ensino produz. Por exemplo, quando se afirma que "O papel do professor na classe é fundamental. Ele é o informante e deve saber reconhecer e valorizar a escrita do aluno" (p. 13). Todavia, essas e outras articulações discursivas não serão suficientes para reverter as críticas que começarão a surgir tendo em vista o modo como esse lugar é demarcado, não apenas nessa revista, mas nesse discurso, que ainda está se configurando. Desse lugar, amarrando todos os traços indesejados, deverá (re)emergir com força o significante-mestre espontaneísmo, como uma crítica, mas também como uma forma de sustá-la, pois com esse significante procurar-se-á definir um lugar preciso para boa parte do que nesse discurso fracassa ou escapa.

Na Nova Escola, o significante espontaneísmo não deverá comparecer tão cedo. Somente (re)surge, definindo desse modo o suporte do discurso construtivista, quando suficientemente consolidado o principal significante-mestre do ponto de arremate desse discurso, ou seja, quando o nome construtivismo é transformado na manchete de capa dessa publicação. Isso ocorre em maio de 1991. O objetivo dessa matéria, que é o destaque de capa e que pela primeira vez na revista Nova Escola utiliza o significante espontaneísmo (pelo menos se consideradas todas as que foram pesquisadas), é fazer um "balanço" dos "Dez anos de contrutivismo no Brasil". ${ }^{87}$ Nesse momento, nessa publicação, é feita a amarração necessária para sustentar o discurso construtivista no lugar onde por vários anos deverá se manter, pois a sua hegemonia é discursivamente garantida por esse suporte, ou melhor, é garantida por meio do que esse suporte encerra e dificilmente deixa à vista.

O "caminho" construtivista não concerne apenas à postura do professor. $\mathrm{Na}$ reconstrução histórica feita nessa primeira matéria de 1989, o recuo chega aos "anos 60":

${ }^{87}$ Cf. "Dez anos de construtivismo no Brasil", n 48, maio/91, pp. 10-8. Antes dessa data, o significante espontaneísmo não foi encontrado em nenhuma matéria da revista, dentre todas as que foram pesquisadas. 
Abalando os métodos tradicionais, nos anos 60 surgiram as idéias de Paulo Freire, levando professores de todos os cantos do país a questionar o conteúdo das cartilhas e a valorizar as palavras dos alunos. Porém, nestes anos 80 , é bem mais que um abalo o que a história da alfabetização vem sofrendo entre nós: em maior ou menor grau, aqui e ali, práticas de fôlego, com base nas idéias e nas descobertas de uma argentina chamada Emilia Ferreiro, estão conseguindo derrubar muitas das velhas certezas dos métodos tradicionais de alfabetização. (p. 12)

Nessa "história da alfabetização", passa-se das "idéias" de Paulo Freire, nos "anos 60", às "idéias" de Emilia Ferreiro, nos "anos 80", como determinantes das significativas mudanças ocorridas no campo da alfabetização, sublinhando-se aí o forte impacto sobre os "métodos tradicionais". Esse é o ponto que vincula, de modo explícito, os dois nomes e períodos, sendo basicamente diferenciados porque com Ferreiro "é bem mais que um abalo". O estabelecimento dessa ordem, dessa hierarquia, relativa à relevância de Ferreiro em face do impacto das "idéias" de Paulo Freire, corresponde à subordinação do último à ordem discursiva própria do construtivismo. Mas corresponde também à inclusão, no âmbito do novo discurso, de articulações discursivas procedentes dos discursos educacionais alternativos dos anos 70 e início dos 80 , os quais prolongaram questões, temas e preocupações que surgiram ou ganharam relevância nos "anos $60 "$.

O sentido desse (re)ordenamento dos discursos precedentes é reforçado nas capas da revista desse mesmo ano, no qual também aparecem Paulo Freire e Marta Suplicy, em números diferentes, numa pequena foto acompanhada do nome ${ }^{88}$ Ambos nomes e imagens dividem a atenção do leitor com a matéria que é o destaque de capa. ${ }^{89}$ Sem muito esforço, esses dois nomes poderiam ser associados aos "anos 60": Paulo Freire, por meio de vínculos óbvios e já explicitados na própria revista; Marta Suplicy, por uma via indireta, mas não por

\footnotetext{
${ }^{88}$ No terceiro número da Nova Escola, em abril de 1986, Paulo Freire já havia sido destacado, com a sua foto e nome colocados no sumário, com o objetivo de chamar a atenção do leitor sobre uma entrevista feita com Freire, onde basicamente fala sobre as cartilhas.

${ }^{89}$ Paulo Freire, cuja foto é colocada no número do mês de maio $\left(n^{\circ} 30\right)$, havia se tornado secretário da Educação do município de São Paulo em janeiro desse ano, a matéria consistindo numa entrevista com ele. Quanto ao destaque de capa desse número, consiste numa matéria cujo objetivo é fazer "Um balanço da luta contra a evasão e a repetência na primeira série", conforme se afirma no seu título. O que nela está em foco é a implantação do ciclo básico e a "adoção de novas propostas pedagógicas" (p. 12), dentre elas a "nova proposta de alfabetização, baseada nas idéias de Emilia Ferreiro" (p. 16). Quanto a Marta Suplicy, cuja foto está na capa do mês de novembro ( $\left.n^{\circ} 35\right)$, a matéria também consiste numa entrevista, onde é destacada a implantação de um projeto de orientação sexual nas escolas municipais da cidade de São Paulo. Cf. "Para falar de sexo é preciso saber ouvir", pp. 22-5.
} 
isso arbitrária, afinal, o que com ela está em jogo é o "sexo na escola", conforme a expressão presente na capa da revista - um tema amarrado àquele ponto de ressonância ("anos 60") por meio de uma infinidade de laços. ${ }^{90}$ Se ficarmos com esses laços e com tudo o que eles supõem, a presença dessas fotos adquire um outro sentido. Em face dos "anos 60", da "revolução" política, social e cultural então almejada pelos jovens estudantes, para os novos tempos temos a pesquisadora que provoca uma "revolução conceitual". Uma pesquisadora cuja imagem precede a de Paulo Freire (um nome equivalente ao significante-mestre educação popular e estreitamente vinculado aos questionamentos políticos e sociais próprios desse campo discursivo) e que ofusca a imagem de Marta Suplicy (vinculada a uma temática fortemente associada às transformações culturais das últimas décadas). A foto de Marta Suplicy surge logo após a apoteótica foto de Emilia Ferreiro na capa de outubro, relativa a uma matéria não menos mitificadora, como a análise de Vieira sublinha (1995). Eis as imagens das capas desses números:

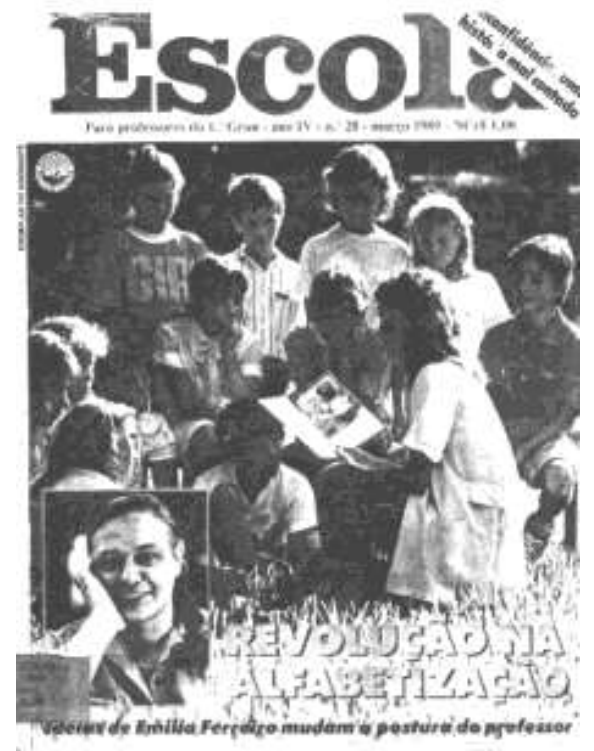

março/89

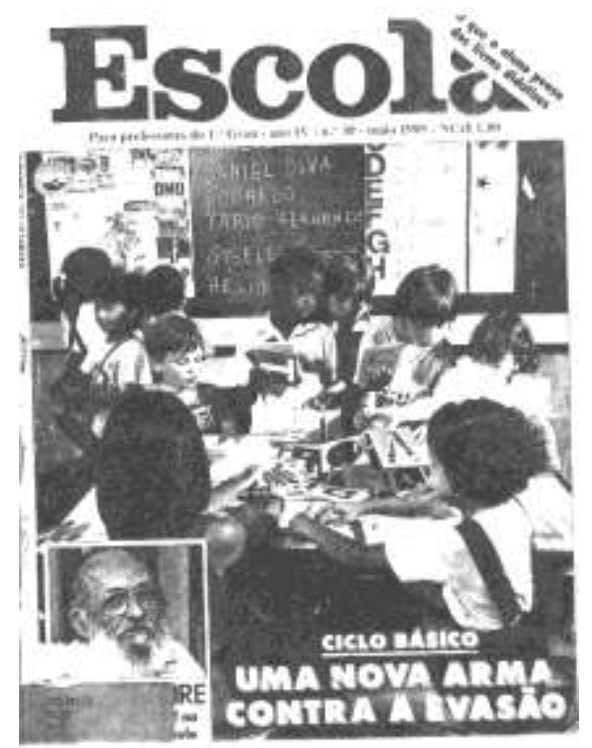

maio/89

\footnotetext{
${ }^{90}$ Aqui também deve ser considerado o vínculo estabelecido pela própria revista entre Marta Suplicy e Paulo Freire, pois na entrevista da primeira faz-se referência ao projeto de orientação sexual que Marta Suplicy e sua equipe estavam desenvolvendo nas escolas do município de São Paulo, em virtude do convite feito por Paulo Freire.
} 


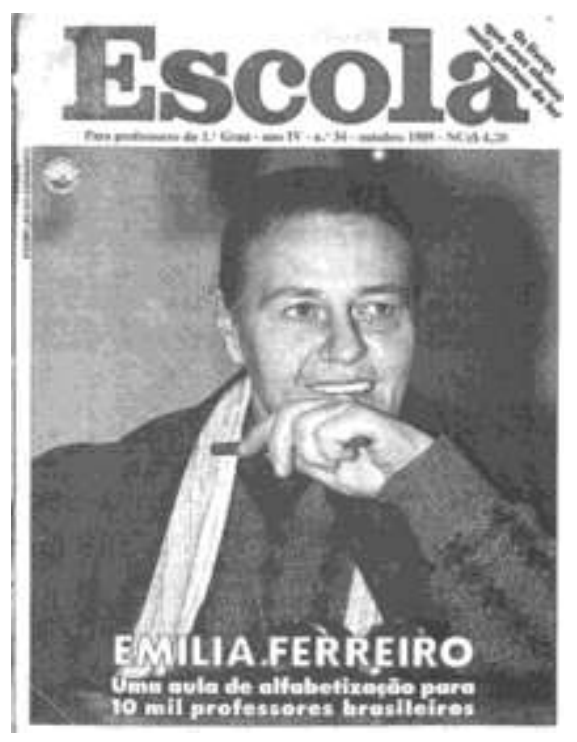

outubro/89

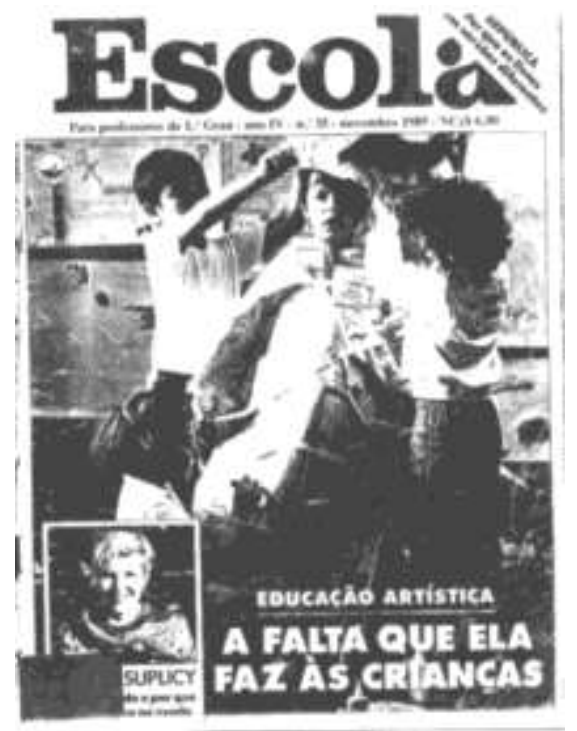

novembro/89

Emilia Ferreiro/Paulo Freire/Marta Suplicy é uma série significante que corresponde ao (re)ordenamento discursivo e à intensidade do recalque que o discurso construtivista produziu, pelo menos em relação aos discursos educacionais alternativos: Paulo Freire e o discurso da educação popular continuaram em cena, mas foram parcialmente absorvidos pela ordem discursiva do construtivismo; o discurso educacional alternativo das camadas médias, em boa parte ancorado na psicologia (como a temática da "sexóloga") e mais voltado que o anterior para os questionamentos de natureza cultural, em particular no que se refere a determinadas temáticas, foi inteiramente absorvido, desaparecendo como discurso passível de ser reconhecido nos termos em que surgiu. ${ }^{91}$ Aquela série significante situa também o lugar reservado às experiências educacionais alternativas em certa vertente do construtivismo: o lugar da "origem" ${ }^{92}$

\footnotetext{
${ }^{91}$ As aproximações e vínculos estabelecidos entre os significantes acima destacados, com os sentidos que desse modo foram construídos, concernem também às escolhas feitas pelos autores da Nova Escola. Em relação a essas escolhas vale destacar um aspecto aparentemente secundário, mas relevante se vinculado a esses sentidos. Trata-se do perfil e a trajetória profissional dos jornalistas que produziam a revista nesse período, segundo o que consta em documento interno escrito em 1992 por um dos redatores da revista e que foi reproduzido por Vieira (1995, pp. 22-5). Nesse documento afirma-se que, da equipe inicial, continuavam a diretora de redação e o editor de arte. Quanto aos demais, "estão no mínimo há três anos na equipe e possuem larga experiência profissional, com passagens nos principais órgãos de imprensa (...) e alguns com importantes contribuições no surgimento da imprensa alternativa e na renovação da imprensa sindical nas décadas passadas" (p. 25) — o destaque em itálico é meu. A propósito de tudo isso, também cabe apontar que a trajetória dos discursos da revista Nova Escola em muito acompanha o que se observa nos discursos da vertente do construtivismo que se tornou dominante, com fortes raízes no campo alternativo. E aí igualmente vale lembrar das profissionais que a revista chama de pioneiras do construtivismo, cujos vínculos com esse campo já foram apontados.

92 Veja-se, no primeiro capítulo deste trabalho, o item "Um passado equivocado".
} 
Sobre essa série significante, com aqueles três nomes próprios, pode-se dizer também que ela corresponde a certo vínculo que pode ser estabelecido entre as fotos presentes nas capas de março, maio e novembro de 1989, todas dispostas no mesmo extremo da capa e com o mesmo tamanho, ou melhor, com o mesmo valor, em particular as fotos de Paulo Freire e Marta Suplicy, ambas não vinculados ao tema destacado na manchete de capa. Os três nomes, as três fotos, ocupando o mesmo lugar na capa e na mesma proporção, fazem parte da mesma trilha, uma trilha que vinha sendo criada pelos discursos educacionais. Dela, da infinidade de palavras e enunciados que a nutrem, destaca-se e alcança um primeiro plano, tornando-se a manchete de capa, um único nome e uma imagem cujas proporções falam por si sobre o seu valor. Esse significante-mestre, o nome Emilia Ferreiro, é o Um que se destaca e que (re)ordena tudo o que é da ordem dessa trilha. O Um que em si mesmo a contém, o Um do Todo que essa trilha constitui, o Um do Outro. Nesse caso, trata-se de Um significante-mestre $\left(S_{1}\right)$ que antes de emergir já se encontrava atrelado a um saber científico $\left(S_{2}\right)$ que há tempos vinha sendo assimilado pelos discursos pedagógicos. Ambos, o $S_{2}$ que o precede e o $S_{1}$ que dele se destaca, participam do (re)ordenamento que então se produz, criando a rede de saber que é própria desse "caminho". Essa rede de saber (um $\mathrm{S}_{2}$ diferente do primeiro) resulta de um (re)ordenamento que incorpora aquele saber científico e que em boa parte subordina-se a seus ditames. É isso que também é (re)produzido por meio das capas da Nova Escola antes destacadas. Com elas é (re)feito o corte que cria uma nova trilha, um "novo caminho", um "caminho" cujas margens ainda deverão ser ampliadas e melhor definidas com o significante-mestre construtivismo.

Antes de ser transformado na manchete de capa, em outubro/89, o nome Emilia Ferreiro vinha sendo mencionado e assim alavancado em diversas matérias, em algumas delas sendo também mencionados Paulo Freire e/ou Piaget. Nessas matérias, além de serem rafirmados lugares já demarcados anteriormente, o nome Emilia Ferreiro fica cada vez mais vinculado às políticas implementadas pelas Secretarias da Educação de diversos Estados e municípios, bem como às várias transformações que elas induzem nas redes de ensino público. É o que em parte pode ser observado na matéria já analisada, de março/89, e numa reportagem de maio/89, intitulada "Um balanço da luta contra a evasão e a repetência na primeira série", onde se faz referência às políticas 
públicas implementadas em oito Estados. ${ }^{93} \mathrm{~A}$ reportagem, que é o destaque de capa dessa edição, aborda basicamente a implantação do ciclo básico e a "adoção de novas propostas pedagógicas", relacionadas na verdade com a alfabetização e o nome Emilia Ferreiro. Mas ela também trata de outros assuntos, alguns não mais do que mencionados, como a implementação da jornada única, o novo processo de avaliação, a capacitação dos professores e as condições físicas da rede. Nessa e em outras matérias, as mudanças que ocorrem no sistema público de ensino começam a confundir-se com a implantação da "nova proposta" de alfabetização, esta ficando quase que automaticamente vinculada a toda e qualquer transformação significativa e bem sucedida no âmbito escolar, principalmente quando está em jogo a qualidade do ensino. Essa confluência vai engrossando o curso da "nova proposta", com o nome Emilia Ferreiro arrastando consigo e (re)ordenando temas e articulações significantes diversas, como as que giram em torno do significante resistência. Esse significante já havia sido empregado em matérias anteriores não relacionadas com a "nova proposta" de alfabetização ${ }^{94} \mathrm{e}$, na matéria acima referida, é utilizado para lembrar das críticas e resistência dos professores, dos entraves e polêmicas surgidos quando da implantação do "novo projeto", envolvendo o ciclo básico e a "nova metodologia" de alfabetização - ambos estreitamente ligados, pois o sucesso do primeiro é relacionado com o sucesso da "nova metodologia". ${ }^{95}$ Essa é uma das formas pelas quais a "caminhada" ou o "novo caminho" vai sendo alargado, mantendo o vínculo com o nome Emilia Ferreiro e simultaneamente deixando de ficar circunscrito à alfabetização, na medida em que incorpora outros elementos, temas e problemas.

Em 1989, em virtude do caudal discursivo que aflui ao curso da "nova proposta", esta vai se tornando representativa do novo e da mudança. Um caudal que extravasa o campo da alfabetização e o nome Emilia Ferreiro, mas que o novo significante-mestre construtivismo, que emerge nesse mesmo ano, é chamado a conter e delimitar dentro de um território mais amplo. O novo significante-mestre torna-se indispensável para alargar e aprofundar o

\footnotetext{
${ }^{93}$ Cf. Nova Escola, n 30, maio/89, pp. 12-9.

${ }^{94}$ Veja-se, por exemplo, "Ciclo Básico. Uma arma contra a repetência", onde menciona-se a "resistência dos próprios professores em aceitar o novo", Nova Escola, n 11, abril/87, pp. 24-5.

${ }^{95}$ A implantação do ciclo básico (CB) nem sempre coincidiu com a introdução da "nova proposta" de alfabetização. Em vários Estados, o CB já tinha sido implantado há alguns anos.
} 
(re)ordenamento discursivo que vinha sendo realizado com o nome Emilia Ferreiro, do qual ainda não prescinde, pois, nas poucas matérias de 1989 em que o significante construtivismo ou seus derivados são utilizados, o nome da psicóloga argentina não deixa de comparecer. ${ }^{96}$ Essa falta de autonomia corresponde a um discurso cujas costuras mal haviam penetrado em outros campos além da alfabetização. De modo que a matriz simbólica construtivista, nesse momento, ainda não estava pronta, pelo menos se consideramos o que se observa na revista Nova Escola.

De 1989 em diante, os leitores da Nova Escola deverão esperar um longo período para ver destacada em sua capa uma "autoridade" que possa orientá-los, que adquira a mesma relevância das personalidades até então selecionadas. Isso voltará a ocorrer dois anos depois, em maio de 1992, quando novamente aparecerá na capa da revista a foto de uma figura pública relacionada com o construtivismo, a de Esther Grossi, já bem conhecida pelos leitores. A sua imagem e o seu nome interrompem o longo "silêncio" que se seguiu ao (re)ordenamento discursivo ocorrido em 1989. Um "silêncio" que sofreu uma única interrupção, não de um nome próprio, mas do significante-mestre construtivismo, transformado na manchete de capa em maio de 1991, na primeira ocasião em que isso ocorre com um nome empregado para reconhecer uma teoria, uma proposta ou linha pedagógica.

\section{De novo, a ciência}

Em outubro de 1989, quando a imagem da chamada "grande mestra da teoria construtivista da alfabetização" preenche toda a capa da revista, com o seu nome transformado em manchete, pela primeira vez na revista Nova Escola é mencionada e delineada a "revolução conceitual" que Ferreiro anuncia em seus escritos e falas. Nessa edição, contendo uma entrevista com ela e uma reportagem sobre a "aula inédita" que a psicolingüista deu para dez mil educadores, são alinhavadas algumas questões de ordem teórica, mas de um modo um tanto ligeiro e às vezes por meio de explicações que não correspondem

\footnotetext{
${ }^{96}$ O significante construtivismo e seus derivados, como proposta ou teoria construtivista, foram encontrados em matérias relativas aos exemplares de março, agosto, outubro e dezembro de 1989.
} 
às formulações de Ferreiro. ${ }^{97}$ De qualquer modo, os elementos básicos dessa "revolução conceitual" são aí esboçados. Se considerarmos os escritos de Ferreiro a esse respeito, esses elementos podem ser reduzidos a três: o objeto de conhecimento (a língua escrita), quem aprende (a criança/aluno) e quem ensina (o professor).

Boa parte das idéias apresentadas nessa reportagem pode ser encontrada no artigo de Ferreiro "A representação da linguagem e o processo de alfabetização", publicado no Brasil em $1985 .{ }^{98}$ Nesse texto, a autora refere-se explicitamente à "revolução conceitual" e destaca de modo nítido aqueles três elementos, muito embora a sua análise tome como eixo apenas um deles: o objeto de conhecimento envolvido na alfabetização. Esse objeto, alerta a autora, intervém no processo de aprendizagem:

(...) não como uma entidade única, mas como uma tríade: temos, por um lado, o sistema de representação alfabética da linguagem, com suas características específicas; por outro lado, as concepções que tanto os que aprendem (as crianças) como os que ensinam (os professores) têm sobre esse objeto. (Ferreiro, 1993, p. 9)

O artigo é dividido em três partes principais e em cada uma delas a autora põe em foco um desses elementos. Na primeira, Ferreiro explica a diferença entre conceber a língua escrita como um sistema de representação da linguagem e um código de transcrição gráfica das unidades sonoras. Com essa demarcação, deixa em evidência algumas das conseqüências da assunção de uma ou outra concepção para as práticas pedagógicas. Quando a língua escrita é concebida como um código de transcrição, a aprendizagem da escrita torna-se semelhante à aquisição de uma técnica e coloca-se em primeiro plano a discriminação perceptiva (visual e auditiva), como ocorre nas práticas de alfabetização tradicionais. Entretanto, se for corretamente concebida, isto é, como um sistema de representação da linguagem, a aprendizagem da escrita converte-se na apropriação de um novo objeto de conhecimento, ou seja, é uma aprendizagem conceitual (Ferreiro, 1993, pp. 10-6). No caso, trata-se de compreender como um sistema de escrita funciona. Um problema que basicamente exige encontrar

\footnotetext{
${ }^{97}$ Cf. "Emilia Ferreiro. Uma aula inédita para 10 mil professores" (pp. 12-7) e a entrevista intitulada "Meu trabalho não é um método" (pp. 18-9), Nova Escola, n 34.

${ }^{98}$ Cf. Cadernos de Pesquisa, n 52, pp. 7-17, fev./85. Esse mesmo texto abre o livro de Ferreiro Reflexões sobre alfabetização (1993).
} 
respostas para duas questões: qual a natureza do objeto representado na escrita e de que modo esse objeto é representado. Para tanto, a criança precisa reinventar ou reconstruir um sistema de escrita que já existe e cujo funcionamento pode observar nos atos de leitura e escrita e nas diversas situações em que a língua escrita é utilizada.

O segundo elemento da "revolução conceitual" concerne à criança e ao seu processo de aprendizagem, que constitui o cerne da investigação que Ferreiro e Teberosky realizaram e divulgaram em Psicogênese da língua escrita. Ferreiro lembra que as crianças criam idéias que não coincidem com as do adulto, mas que constituem um saber, mesmo que seja diferente ou errado se comparado com o saber socialmente válido (1993, p. 17). Refere-se então à evolução das idéias infantis, tomando como referência as produções escritas, que nesse texto são ordenadas em três grandes períodos (ibidem, p.19). Em cada período são destacadas as hipóteses principais, várias delas mencionadas naquela matéria da Nova Escola (quantidade mínima de caracteres, variação entre as grafias de uma mesma escrita, hipótese silábica, etc.).

Por último, Ferreiro analisa e discute algumas concepções e práticas docentes. Começa fazendo referência à tradicional polêmica em torno dos métodos de alfabetização, observando que não se trata de criar um novo método, mas sim de considerar o que todas as discussões sobre as práticas de alfabetização até então ignoraram: as concepções das crianças sobre o sistema de escrita. ${ }^{99}$ Considerá-las é essencial para poder "imaginar um tipo de intervenção adequada à natureza do processo real de aprendizagem" (1993, p. 30). Ferreiro aí critica a imagem empobrecida que temos da criança, quando a reduzimos a "uma tábua rasa onde se inscrevem as letras e as palavras segundo determinado método" (p. 29), quando a "reduzimos a um par de olhos, um par de ouvidos, uma mão que pega um instrumento para marcar e um aparelho fonador que emite sons" (p. 40). Por trás disso, no entanto, está o sujeito cognoscente que Piaget nos ensinou a ver: "alguém que pensa, que constrói interpretações, que age sobre o real para fazê-lo seu" (p. 41). Ao referir-se às concepções

\footnotetext{
99 Em várias oportunidades, Ferreiro faz questão de ressaltar que não criou nenhum método, inclusive na entrevista dada à revista Nova Escola, em outubro/89, cujo título ressalta justamente isso: "Meu trabalho não é um método".
} 
subjacentes à prática docente, Ferreiro alude também à imagem empobrecida que temos da língua escrita, pois esse objeto de uso social, que tem uma existência social, costuma ser transformado num insípido objeto escolar.

Todas essas questões atingem direta e primeiramente o professor, do qual exige-se que redefina o seu papel tendo em vista a realização de "um tipo de intervenção adequada". Para isso deve considerar o objeto de conhecimento e sobretudo o processo de aprendizagem da criança, de modo a não empobrecê-los e a garantir que a apropriação desse objeto de conhecimento ocorra. Além disso, o professor deve manter-se distante tanto das concepções e práticas consideradas tradicionais, quanto da idéia de que ele "deveria se limitar a ser simples espectador de um processo espontâneo" (p. 39). ${ }^{100}$ Ou seja, Ferreiro recusa o que no discurso pedagógico construtivista constitui os extremos que balizam a atuação do professor, as regiões do discurso e das práticas pedagógicas que ficam interditadas. Esses limites também são lembrados na entrevista dada por Emilia Ferreiro à revista Nova Escola, em outubro/89. Nessa entrevista refere-se à apropriação tradicional do seu trabalho e ao que nessa mesma publicação, alguns anos mais tarde, será chamado de espontaneísmo:

Antes de mais nada quero fazer um esclarecimento: tenho visto, em alguns contextos, utilizarem as denominações pré-silábico, silábico ou silábicoalfabético, como se fossem novas etiquetas para velhas categorias. De tal maneira que pré-silábico quer dizer imaturo, sem a prontidão necessária; silábico quer dizer "está pronto"; silábico-alfabético quer dizer "pode ser promovido". Eu quero alertar contra esse tipo de interpretação. Se trocarmos os nomes, mas seguirmos com as mesmas concepções, não mudamos nada. ${ }^{101}$

Não se trata, de modo algum, de dizer que as crianças se alfabetizam sozinhas. Trata-se, isto sim, de compreender o processo que elas estão vivendo, a cada momento, para poder intervir mais eficazmente $(. . .)^{102}$

Alguns professores se angustiam, pensando que a partir deste momento já não vão fazer mais nada. Se não vão dar aula, o que vão fazer? Quando intervir? Têm que esperar de braços cruzados que as crianças progridam? E aí vem um equívoco $(. . .)^{103}$

\footnotetext{
${ }^{100}$ Esses dois extremos são igualmente lembrados e recusados na matéria da Nova Escola já referida, de outubro/89.

101 Cf. "Meu trabalho não é um método", Nova Escola, n 34, outubro/89, p. 18-9.

102 Cf. "Emilia Ferreiro. Uma aula inédita para 10 mil professores", Nova Escola, n 34, outubro/89, p. 13.

${ }^{103}$ Cf. "Meu trabalho não é um método", Nova Escola, n 34, outubro/89, p. 19.
} 
Esses e outros "desvios, confusões, equívocos ..." delineados nas matérias da Nova Escola e que fazem parte do novo discurso pedagógico surgem sob a ordem da "revolução conceitual" anunciada e criada por Emilia Ferreiro e seus colaboradores. Mas essa "revolução", que tem na obra de Piaget a sua primeira fonte teórica, concerne apenas a uma parte, certamente fundamental, do (re)ordenamento discursivo que se processa tendo como principal significantemestre o nome Emilia Ferreiro. Mesmo em relação ao marco teórico dessa "revolução conceitual", vale lembrar que ele não diz respeito unicamente à teoria psicogenética piagetiana. Em Psicogênese da língua escrita, as próprias autoras referem-se à relevância da psicolingüística contemporânea, onde o modo de conceber os processos de aprendizagem da língua oral começou a coincidir, a partir dos anos 60, com as formulações piagetianas sobre a aquisição do conhecimento (Ferreiro e Teberosky, 1986, pp. 21-5). Esse "duplo marco conceitual" permitiu-lhes "encarar questões" que antes dessa investigação não haviam sido resolvidas, no que se refere à aquisição da língua escrita (ibidem, p.32).

Sem dúvida, sob esse "duplo marco conceitual", essa investigação trouxe inúmeros elementos novos sobre o processo de aprendizagem da língua escrita, o que em parte explica o seu enorme impacto no meio educacional, e não apenas no Brasil. Ademais, os seus resultados inspiraram efetivamente novas práticas de alfabetização, as quais começaram a ser desenvolvidas fora do Brasil pela mesma Ana Teberosky, que em seus trabalhos posteriores parece ter privilegiado as questões de ordem didática, com livros publicados a esse respeito $(1989,1992)$. As principais características dessas novas práticas da alfabetização podem ser parcialmente apreendidas seguindo-se as matérias da Nova Escola, aí incluídas as que já foram analisadas neste trabalho, embora não sob essa perspectiva e com o objetivo de realçar essas características. São práticas que surgem tendo em vista os trabalhos de Ferreiro e sua equipe, mas também são informadas por discursos que em muito extrapolam essa primeira fonte, sobretudo se considerarmos a amplitude do (re)ordenamento discursivo até aqui delineado e que prossegue sob a órbita do significante-mestre construtivismo. ${ }^{104}$

\footnotetext{
${ }^{104}$ Em relação às fontes teóricas que nutrem as novas práticas de alfabetização e o ensino da língua escrita, pode-se pensar na repercussão das reflexões produzidas no interior da lingüística, nos vários campos em que é subdivida, como a lingüística textual, cuja incidência sobre o ensino
} 
Com o impulso da "revolução conceitual", completa-se o giro que já vinha ocorrendo no campo dos discursos educacionais críticos e que muda o lugar do saber. O que se torna central é o conhecimento científico. De novo, portanto, a ciência. Um saber revitalizado pela nova rede conceitual dos trabalhos de Emilia Ferreiro e sua equipe e que volta a ocupar um lugar muito prestigiado. Em outras palavras, a ciência torna-se o saber dominante, o saber hegemônico no campo educacional.

Com isso, o saber exigido ao professor torna-se também um saber que fica sujeito a essa mesma ordem do discurso. Ademais, consolida-se a tendência de procurar e encontrar no professor tudo o que é da ordem de uma falta, vinculada sobretudo ao conhecimento que ele deveria ter da criança, do seu processo de aprendizagem, com o objetivo de realizar uma "intervenção adequada". Uma intervenção que igualmente implica uma metodologia, uma didática, uma proposta ou projeto pedagógico "adequados" às crianças, conforme o ditame que esse ponto de ressonância estabelece, estendendo-se em todas as direções. O saber exigido ao professor envolve ainda, em maior ou menor grau, dependendo da vertente do construtivismo em questão, os objetos de conhecimento que a criança precisa construir e que nesse período passam por importantes transformações, pelo menos em algumas áreas. ${ }^{105}$

da língua escrita parece ter sido bem significativa. Isso pode ser notado na centralidade outorgada ao texto, que é tomado como a unidade do ensino da língua escrita (e não mais as letras, os fonemas, as sílabas ou as orações), nas várias tentativas de definir uma tipologia textual para organizar o ensino e na crescente atenção a determinados aspectos ou dimensões do texto, como a relação texto/contexto (veja-se, por exemplo, Kaufman e Rodriguez, 1995). Outro exemplo é a repercussão das investigações que vão se avolumando na esteira do significante letramento, que começa a ser utilizado no Brasil em meados da década de 80 (Soares, 1998). Nessas pesquisas e em tudo que o vai sendo demarcado com o significante letramento ficam em evidência novas dimensões das práticas sociais de leitura e escrita, que são as que crescentemente servem de referência para as práticas escolares. Essa ampliação e as reflexões que ela suscita no âmbito do ensino da língua escrita nutrem, também, as novas práticas de alfabetização, existindo aí, na verdade, uma confluência com os pontos de vista defendidos por Emilia Ferreiro e sua equipe.

${ }^{105}$ Além do que já foi mencionado em relação à língua escrita, cujo ensino passa por significativas transformações envolvendo os primeiros níveis (Educação Infantil e primeiras séries do Ensino Fundamental), em outras áreas também ocorrem mudanças importantes, em relação aos conteúdos e também quanto à didática, notadamente na década de 90 . Por exemplo, em História, com a relevância que adquire a chamada história do cotidiano ou da vida cotidiana e, em Matemática, o trabalho nas primeiras séries com cálculo mental exato e estimado e o uso de diversas estratégias para realizar as operações elementares. Sem contar a interdisciplinaridade, uma temática de forte presença em diversas experiências e propostas apresentadas em matérias da revista Nova Escola. Na renovação dos conteúdos escolares, nesse período é forte a tendência que consiste em aproximar os conteúdos escolares das práticas sociais, uma tendência que é anterior ao discurso construtivista e constitui um ponto de coincidência entre os discursos educacionais alternativos e a pedagogia dos conteúdos. Ainda em relação aos conteúdos do 
Com a rede conceitual que sustenta e projeta o nome Emilia Ferreiro, também adquire relevância a criança piagetiana, "a criança que constrói seu próprio conhecimento". E mais do que isso, talvez pela primeira vez na história da educação escolar, a criança fica embutida no ponto de arremate de um discurso pedagógico, no próprio nome, pois o nome não constitui tão-somente uma referência à obra de Piaget, ele concerne principalmente ao construtivismo "da" criança. $^{106}$ Com tudo isso, ganha maior projeção a psicologia, em particular a psicologia da criança, como pode ser parcialmente observado nas matérias da Nova Escola, com Piaget tornando-se a manchete de capa em agosto de 1996, no momento em que o construtivismo torna-se o padrão nacional, com os Parâmetros Curriculares Nacionais. Eis aí parte do "caminho" que continuaremos percorrendo no próximo capítulo, já sob o comando do significante-mestre construtivismo.

ensino, a sua relevância nas reformas curriculares que se desenrolaram na década de $80 \mathrm{em}$ grande parte pode ser creditada aos efeitos do discurso da pedagogia dos conteúdos. A esse respeito, veja-se: Sá Barreto, 1998, pp. 7-11. Nas experiências escolares surgem também outras formas de distribuir o tempo, apresentar os conteúdos e organizar as atividades escolares, sendo essas mudanças objeto de reflexão e sistematização no campo da didática. Dentre os autores que fazem essa reflexão e que discutem as diferenças em relação às práticas pedagógicas consideradas tradicionais, para então propor uma outra forma de gestão do "tempo de didático" e de organização das atividades que pretende preservar a complexidade inerente aos objetos de conhecimento envolvidos no ensino, vale destacar Delia Lerner (2002), a especialista em didática que participou da elaboração dos Parâmetros Curriculares Nacionais como "consultora". Todas essas mudanças foram objeto de apropriação durante a elaboração dos PCN.

${ }^{106}$ Os significantes-mestres escola ativa e métodos ativos, muito utilizados por Piaget, de certo modo também traziam embutidos a criança, na mesma medida em que a ela se alude por meio do significante ativa. 


\section{Construtivismo: um saber positivo}

Com a crescente utilização do significante-mestre construtivismo, entre o final da década de 80 e o início da década seguinte completa-se o giro discursivo que transforma o conhecimento científico no saber dominante, no saber hegemônico no campo educacional, afetando sobretudo o campo dos discursos críticos. Algo que a rigor já vinha ocorrendo em razão da inflexão produzida pelo discurso da pedagogia dos conteúdos. Nesse giro, ao invés de "uma mudança total", repõem-se certas coisas em certos lugares. ${ }^{1}$ Em outras palavras, com o construtivismo, o saber hegemônico fica sob a configuração que é própria do discurso científico - que é o que Lacan chama de discurso Universitário -, e aí tende a cristalizar-se, não sem o concurso do novo ponto de basta que sobrepuja todo esse campo discursivo na primeira metade dos anos 90.

Trata-se nesse caso do viés que se afirma com a rede discursiva amarrada aos significantes-mestres que nesse período encontram forte eco nos campos político e econômico, tais como: moderno, futuro, globalização, mercado, economia, desenvolvimento, revolução tecnológica. Todos eles significantesmestres equivalentes quando se infiltram no discurso pedagógico, pois tendem a produzir a mesma torção, os mesmos efeitos. Dentre eles, o mais importante talvez seja o de ter contribuído para transformar o construtivismo num saber positivo, na sua pior versão, se considerados seus efeitos deletérios para a educação e o ensino, pois em meados da década de 90 o construtivismo é quase que reduzido a um saber técnico, em face do qual o professor e o que há de singular em sua experiência e sua prática tendem a desaparecer. Como saber positivo, mas não reduzido a um saber meramente técnico, o construtivismo adquire um outro estofo quando da divulgação dos Parâmetros Curriculares Nacionais (PCN), na segunda metade da década de 90. Neste capítulo chegaremos até esse ponto.

\footnotetext{
1 "Mudança total" é uma das expressões usadas na revista Nova Escola para caracterizar a "revolução conceitual" produzida por Emilia Ferreiro. Cf. "Emilia Ferreiro. Uma aula inédita para 10 mil professores", Nova Escola, n³4, out./89, p. 13.
} 


\section{0 construtivismo é o caminho}

Na revista Nova Escola, o (re)ordenamento discursivo que vinha se processando em virtude das costuras feitas com o nome Emilia Ferreiro tem um primeiro ponto de inflexão em 1989 e prossegue nos anos subseqüentes, mas sob o comando do significante-mestre que emerge nesse mesmo ano. Com ele, com o significante construtivismo, de início fortemente vinculado à alfabetização e ao nome Emilia Ferreiro, alargam-se crescentemente as fronteiras desse discurso, conforme é possível notar seguindo-se a trilha do novo nome. Mas, o mais importante é que efetivamente se configura um novo discurso pedagógico, uma nova matriz simbólica, própria do que depois é chamado de "caminho construtivista". O que aqui será analisado e discutido é precisamente a conclusão dessa matriz simbólica e o alargamento desse "caminho".

\subsection{Nomes próprios}

De 1990 em diante, o significante-mestre construtivismo é utilizado em pelo menos uma matéria da maioria dos números da revista Nova Escola de um mesmo ano, até 1997/98, quando o seu uso torna-se menos freqüente, concomitante à divulgação dos Parâmetros Curriculares Nacionais e à utilização desse novo significante-mestre nessa revista. Já a partir de 1990, o significante construtivismo começa a ser utilizado em matérias onde o nome Emilia Ferreiro não comparece e crescentemente parece ficar implícito numa diversidade de textos. Além disso, começa a ser utilizado para situar o trabalho desenvolvido em outras áreas que não a alfabetização ou o ensino da língua escrita, sendo também ampliado o leque de autores, pesquisadores ou pensadores aos quais é vinculado. Paulo Freire continua bem presente nas matérias da revista, embora menos que o nome Emilia Ferreiro e por vezes compondo a tríade já assinalada: Piaget/Emilia Ferreiro/Paulo Freire. Ao que tudo indica, nesse ano de 1990 pela primeira vez faz-se referência a Vigotsky, que é o autor destacado por algumas escolas, professores e outros profissionais da educação que procuram diferenciar e afirmar determinada vertente do construtivismo, com um outro significantemestre no seu ponto de arremate, como sócio-construtivismo ou sóciointeracionismo, além daquele nome próprio. Um nome que voltará a aparecer nos anos subseqüentes, sem nunca alcançar a relevância do significante-mestre Piaget, cuja presença tende a se ampliar conforme nos aproximamos do final da 
primeira metade dessa década. Uma escalada que é simultânea à diminuição da presença do nome Emilia Ferreiro, mas sobretudo do nome Paulo Freire, que em meados da década de 90 praticamente desaparece. Junto com ele, em particular em 1995/96, quando na Nova Escola o discurso pedagógico adquire um claro viés tecnicista, igualmente tendem a desaparecer os significantes comunidade/comunitário e principalmente o significante popular, todos eles utilizados com relativa freqüência antes desse período, em expressões as mais diversas (escola comunitária, ação comunitária, comunidade escolar, participação da comunidade, classes populares, camadas populares, movimentos populares, educação popular, escola popular, cultura popular, etc.). Nessa fase tecnicista, o uso do nome Piaget também diminui, muito embora o epistemólogo suíço seja transformado na manchete de capa em agosto de 1996, nunca antes tendo adquirido tamanha relevância. ${ }^{2}$

O uso do significante construtivismo num sentido mais amplo, para além do campo da alfabetização, já ocorre em 1989, conforme é possível notar numa reportagem de outubro intitulada "Um município mineiro muda a face do ensino no campo". ${ }^{3}$ No olho que abre a reportagem, faz-se referência à substituição de classes multisseriadas por escolas que "adotam proposta construtivista de ensino". No corpo da matéria, usa-se novamente esse significante-mestre num sentido amplo:

O modelo pedagógico hoje adotado é baseado nas teorias construtivistas, segundo as quais quem constrói o conhecimento é o próprio aluno, passando o professor a ter o importante papel de mediador desse processo. Os supervisores de ensino foram os primeiros a ter contato com as teorias de educadores como Piaget, Freinet e Emilia Ferreiro, através de seminários, cursos e leitura. (p. 24)

Repare-se que nesse texto já se fala em teorias, no plural, sugerindo-se a existência de diferenças no interior do construtivismo, nesse caso teóricas. Essas e outras diferenças deverão ser também indicadas em matérias dos anos seguintes, mantendo-se porém o mesmo pano de fundo piagetiano: "a criança que constrói seu próprio conhecimento". Ademais, Piaget tornar-se-á uma espécie de fundador do que é concebido como uma nova proposta ou linha pedagógica, com

\footnotetext{
${ }^{2}$ A maior ou menor presença desses significantes-mestres foi estimada tomando como base a quantidade de matérias pesquisadas em que foram mencionados.

${ }^{3}$ Cf. Nova Escola, n 34 , out./89, pp. 22-6.
} 
a psicologia consensualmente reconhecida como o seu substrato teórico primordial. Nessa matéria de 1989, ainda são centrais as questões relacionadas com a alfabetização. Entretanto, o "modelo pedagógico" construtivista já inclui implicitamente o trabalho desenvolvido em outras áreas, com outros conteúdos, como é indicado no relato de uma professora de $4^{\circ}$ série que, com "os temas geradores", trabalha "conteúdos de Português, Matemática e Estudos Sociais" (p. 26).

A incorporação de autores e concepções teóricas as mais diversas dentro do construtivismo continua ocorrendo ao longo da década de 90, não apenas nessa revista ou no Brasil. ${ }^{4} \mathrm{Na}$ Nova Escola vale destacar o ano de 1994, quando os nomes de determinadas concepções e teóricos ou pensadores relacionados com a educação são mencionados em sua capa, em diferentes números. São eles: Freinet (abril), Piaget (junho), Montessori (outubro), "Waldorf, a pedagogia antroposófica" (em novembro) e Vigotsky (dezembro). Nas matérias que correspondem a essas chamadas de capa são brevemente apresentados alguns elementos das concepções teóricas implicadas em cada caso e experiências educacionais que nelas se inspiram, com pequenos relatos e comentários sobre o que é feito em sala de aula. Essa diversidade de autores, concepções e práticas educacionais poderia indicar que a Nova Escola começou a remar contra a maré, num período de nítida hegemonia do construtivismo. Essa impressão, porém, logo se vê dissipada quando analisamos essas mesmas matérias. ${ }^{5}$ Vejamos.

\footnotetext{
${ }^{4}$ Já no início da década de 90 essa incorporação encontrava-se bem avançada, conforme pode ser constatado em outras publicações e livros desse período, como Paixão de aprender (Grossi e Bordin) e Construtivismo pós-piagetiano (idem), o primeiro publicado em 1992 e o segundo em 1993. Esse fato é constatado ainda em outros países, como a Espanha, onde o construtivismo também se tornou objeto de intensas polêmicas. Juan Delval (1998), por exemplo, refere-se a esse fato com certa preocupação: "O construtivismo estende-se como uma mancha de óleo sobre todas as publicações pedagógicas, e por isso, hoje em dia, todo o mundo se proclama construtivista sem realmente o ser" (p. 15). Outro autor espanhol preocupado com essa mesma questão é César Coll, do qual pode ser lembrado o título de um de seus textos: "Construtivismo e educação escolar: nem sempre falamos da mesma coisa e nem sempre o fazemos da mesma perspectiva epistemológica" (1998).
}

${ }^{5}$ No meio acadêmico e em algumas publicações, como Educação \& Realidade, as críticas ao construtivismo tornaram-se particularmente intensas desde 1993. Na Nova Escola não há mais do que pequenos sinais desses questionamentos e estes não chegam a alterar o prestigio alcançado por esse significante-mestre. Isso ocorre, por exemplo, quando surgem falas que recusam que o construtivismo seja um simples modismo, que rejeitam o seu uso como um rótulo ou constatam que "quem quer se apresentar como moderno se diz construtivista" (Cf. "As agruras do caminho construtivista", $n^{\circ} 65$, abr./93, p. 9). O súbito destaque dado pela Nova Escola a tantos autores e teorias num único ano, em 1994, talvez responda à intenção de afirmar a imagem de uma 
Piaget e Vigotsky são, obviamente, vinculados ao construtivismo. O primeiro é objeto de uma matéria com este título: "Como a criança aprende segundo Piaget". ${ }^{6}$ No início, no olho da matéria, em grande parte repete-se o que já tinha se tornado um lugar comum:

Para o pesquisador suíço, que descobriu a possibilidade de trabalhar a partir do erro, todo conhecimento é construído (...) Da sua teoria, conhecida pelo imponente nome de epistemologia genética, partiram as teses construtivistas de nossos dias e as práticas escolares que respeitam o universo do aluno (p. 20).

Das cinco matérias antes referidas, essa é a única onde surge a preocupação com os "equívocos" relativos à assimilação das concepções do autor então destacado ou, mais precisamente, com "uma simplificação equivocada de suas teorias", das teorias piagetianas (p. 21).

Na matéria sobre Vigotsky, o que antes de mais nada é destacado é a dimensão social que as suas concepções teriam introduzido no ensino, como é sugerido no olho da reportagem: "As idéias do pensador bielo-russo dão uma pitada social às linhas construtivistas adotadas por educadores brasileiros" (p. 44). ${ }^{7}$ O "social" é, justamente, o que busca-se evidenciar quando é utilizado o significante interação ou interação social, de presença quase que obrigatória toda vez que se fala desse autor ou da "linha construtivista" nele inspirada, que nessa matéria é chamada de construtivismo interacionista social ou sócio-construtivismo. Outra dimensão que adquire um certo destaque é o afeto, os sentimentos, que Vigotsky teria mantido vinculados à "construção coletiva do saber" (p. 45).

Quando o "pensador bielo-russo" é incluído no construtivismo, não raro cumpre com a função de preencher as lacunas que Piaget teria deixado, desse modo servindo para afastar determinadas críticas e alargar as fronteiras do construtivismo. Nessa mesma matéria algumas dessas críticas são esboçadas pelas profissionais entrevistadas, não necessariamente fazendo menção explícita das concepções piagetianas. Por exemplo, em tom crítico elas lembram que há "outras teorias de aprendizagem" em que "o conhecimento é apoiado num

publicação pluralista, aberta a várias tendências educacionais. E assim fazer face àquelas críticas, que desde então começam a se avolumar, atingindo inclusive essa publicação.

${ }^{6}$ Cf. Nova Escola, n 76, junho/94, pp. 20-5.

${ }^{7}$ Cf. "Vygotsky com molho tropical", Nova Escola, n 81, dez./94, pp. 44-6. 
processo individual e psicologizante" (p. 45); referem-se também às práticas em que o professor só fica acompanhando o que a criança sabe, não assumindo o papel de mediador, como teria sugerido Vigotsky. ${ }^{8}$

Nessa reportagem, em síntese, são destacados três pontos sensíveis, mas também falhos, pelo menos segundo a avaliação que muitos educadores costumam fazer sobre o construtivismo de viés piagetiano: o social, os afetos/sentimentos e o professor mediador, que é um professor que interfere algo que é necessário lembrar para afastar o "equívoco" que costuma inquietar muitos construtivistas: o espontaneísmo. ${ }^{9}$

Quanto a Freinet, o que aqui interessa destacar é o relevo dado a determinadas dimensões da sua obra que contribuem para situá-lo no interior do construtivismo. É o caso do que é afirmado na primeira linha do olho da matéria dedicada à sua obra: "Para Célestin Freinet a criança constrói seu conhecimento no fazer e refazer de atividades que não devem ser apenas brincadeiras vazias, mas trabalho". ${ }^{10}$ Com "a criança constrói seu conhecimento", Freinet é logo introduzido no registro do construtivismo, mas deixando-se uma marca que posteriormente a ele é atribuída: o significante trabalho. No começo da matéria também é assinalada a sua proximidade com as concepções de Piaget e até com as conclusões a que chegou Emilia Ferreiro (pp. 24-5). Essas são marcas que logo no início são lembradas, mas que tendem a se esvair ao longo do texto,

\footnotetext{
${ }^{8}$ A fala que toca nesse ponto, de uma "coordenadora de ensino", é esta: "enquanto estávamos trabalhando só com Piaget, a preocupação era identificar o nível de desenvolvimento da criança e trabalhar de acordo com essa estrutura de pensamento possível (...) Hoje acreditamos que a criança é capaz de ir além dessa estrutura, se o professor interferir, ajudar, colaborar, em vez de deixá-la trabalhar sozinha e só ficar acompanhando o que ela sabe" (p. 46).

${ }^{9}$ Os "equívocos", embora não sejam mencionados nessa matéria, também perseguiram a obra teórica de Vigotsky, ou melhor, os construtivistas, em geral preocupados com essa questão. A esse respeito, veja-se "Vygotsky: alguns equívocos na interpretação de seu pensamento", de Oliveira (1992). Nesse artigo, a preocupação principal da autora é com a apropriação tradicional das concepções de Vygotsky. É o que pode ser observado nestes trechos de seu texto: "A interpretação (inadequada) de verbal como verbalista levaria, assim, à atribuição a Vygotsky da postulação de uma volta ao chamado ensino tradicional (...) outro equívoco na compreensão do pensamento de Vygotsky: sua idéia de que a intervenção de outras pessoas é fundamental (...) é compreendida como uma proposta pedagógica intervencionista, de caráter autoritário, o que, novamente, conduziria à postulação de um ensino de tipo 'tradicional'"' (p. 68). Como se vê, o que nesses trechos é salientado concerne a um suposto mal uso das concepções de Vygotsky. Um mal uso da obra de um autor que por vezes é esgrimido como uma espécie de antídoto contra o espontaneísmo, mas que cria outros problemas, na mesma medida em que atrai o outro extremo repelido pelo discurso construtivista.

${ }^{10}$ Cf. "Como a criança aprende segundo Freinet", Nova Escola, n 74, abr./94, pp. 24-8.
} 
quando vão emergindo outras, menos vinculadas às que surgem nessa primeira parte. Por exemplo, quando se fala do "cerne da sua pedagogia - a atividade. A raiz da futura Pedagogia do trabalho" (p. 26). E por essa via, estabelecida pelo significante trabalho, que já havia sido mencionado no olho, chega-se ao que é chamado de "ponto de partida marxista" de Freinet, lembrado num dos box da reportagem (ibidem).

Tudo isso corresponde a uma das formas de subordinar uma obra a outra, um autor a outro autor. Nesse caso, Freinet em relação a Piaget e o construtivismo. Algo que também pode ser vislumbrado na referida matéria sobre Piaget e a sua obra, quando se afirma que "Nessa fonte [em Piaget] se inspiraram desde Freinet até Emilia Ferreiro". ${ }^{11} \mathrm{O}$ que aqui está em causa não é o fato de Freinet ter se inspirado ou não em Piaget e em que grau, se foi muito ou se foi pouco, mas os múltiplos mecanismos discursivos que nesse período aproximam Piaget e Freinet e subordinam o último, mas também outros autores e teorias, à nova ordem discursiva.

A subordinação a essa nova ordem discursiva igualmente ocorre quando Piaget ou o discurso construtivista surgem como padrão avaliativo, como é o caso da matéria sobre Montessori, celebrada na capa da revista com esta chamada: "Teoria e método de aprendizagem segundo a grande mestra". Na matéria, entretanto, o "método" da grande mestra fica sob a injunção do novo discurso, no box intitulado "Um método criticado mas ainda útil". 12 "Contemporânea de Piaget", mas com "uma concepção de aprendizagem própria da época, empirista e inatista", Maria Montessori estava num "caminho" que não é o de "nossos dias". Segunda a matéria, "A educação nos nossos dias, ao contrário, caminha na trilha interacionista" (ibidem). Nessa trilha, pelo que pode ser inferido dos laços criados nesse texto, encontram-se Piaget e Freinet, os dois autores mencionados no box. Neste, além de serem sintetizadas "as diferenças entre o que Montessori defendia e o que é aceito hoje", são esclarecidos os pontos críticos da sua teoria, chamados também de "grandes equívocos" (pp. 28-9).

Quanto à antroposofia ou "pedagogia Waldorf", essa "mistura de ciência e

\footnotetext{
${ }^{11}$ Cf. "Como a criança aprende segundo Piaget", Nova Escola, n 76, junho/94, p. 21.

${ }^{12}$ Cf. "Como a criança aprende, segundo Montessori", Nova Escola, n 79, out./94, p. 28.
} 
espiritualismo" criada por Rudolf Steiner, a matéria informa que se trata de um "conjunto de idéias ainda hoje seguidas em bolsões alternativos e que se infiltrou em ramos do conhecimento como a medicina, a agricultura, a educação, a arquitetura". ${ }^{13}$ Das cinco matérias que aqui estão sendo consideradas, essa é a única onde não é estabelecido qualquer vínculo explícito com Piaget ou com o construtivismo. Algo que certamente dificulta a sua localização por parte do leitor. Onde situar essa "'ciência espiritual' conhecida por antroposofia, se é que se pode conceber cientificamente uma ciência espiritual" (ibidem)? Digamos que ela está numa espécie de limbo, se nos deixarmos guiar pelo sentido que por vezes surge com a súbita e extemporânea aparição do significante alternativa. E talvez nada melhor para situar esse lugar, conforme se configura nessa matéria, do que recorrer aos significados da palavra "bolsão", pelo menos alguns dos registrados no dicionário Aurélio:

3. Aquilo que, por determinadas circunstâncias, se encontra isolado do todo a que pertence e envolvido por elementos antagônicos, ou hostis.

4. Aquilo que se destaca do todo em que está inserido, por ter características opostas.

Se tomarmos como eixo o significante construtivismo, com tudo o que ele condensa e considerando o que até agora foi destacado nas cinco matérias brevemente analisadas, seria possível estabelecer algumas relações. Piaget, Vigotsky e Freinet estão no mesmo "caminho". Montessori está numa outra trilha, que não seria arbitrário chamar de tradicional, considerando o que a matéria destaca, sobretudo a sua concepção empirista e inatista. Quanto à "pedagogia antroposófica", numa primeira avaliação pode se dizer que fica num lugar um tanto impreciso, se a nossa intenção for encontrar algum nexo com o discurso pedagógico que nesse momento já é hegemônico. Mas, como esse lugar concerne a um "bolsão", pode ser situado em oposição ao que em "nossos dias" prevalece. À primeira vista, portanto, essa "ciência alternativa" não está no mesmo "caminho" do construtivismo. Porém, também é possível afirmar o contrário, que está sim, mas em determinado ponto do passado desse mesmo "caminho" e em oposição ao presente, ou seja, nesse nebuloso e amplo lugar que no discurso construtivista afigura a sua "origem", ao menos na vertente que se tornou dominante. "Origem" recusada e pólo de oposição necessário para definir a

\footnotetext{
${ }^{13}$ Cf. "Pedagogia Waldorf. De sete em sete anos", Nova Escola, n 80, nov./94, p. 38. O destaque em itálico é meu.
} 
direção e o sentido de certas trajetórias profissionais e institucionais. ${ }^{14} \mathrm{Em}$ outras palavras, o lugar de tudo o que em certo período, na década de 70 e parte da década seguinte, era abraçado pela palavra alternativa, como a chamada educação popular e Paulo Freire. Este, um nome próprio que praticamente desaparece da revista nos anos seguintes e que concerne a uma ausência que também define esse lugar impreciso.

Enfim, os lugares que nessas cinco matérias são criados, com os autores, concepções e experiências nelas destacados, encontram-se relacionados e distribuídos de um modo que muito deve ao suporte que é próprio do "caminho construtivista", como ainda é possível observar em outras tantas matérias da Nova Escola.

\subsection{Linhas, propostas, projetos ...}

Desde o final da década de 80 , as transformações que vinham se desenrolando em diversas áreas do currículo escolar, envolvendo determinados conteúdos e questões de ordem didática, cada vez mais ficam sob a órbita do novo discurso pedagógico. O significante-mestre construtivismo tudo tende a sobrelevar e incluir, mesmo as perspectivas ou correntes que são próprias de determinada disciplina. É o que pode ser observado, por exemplo, no ensino de História, que constitui o tema de uma ampla reportagem que é o destaque de capa da revista Nova Escola do mês de novembro/91, intitulada "História. O bonde que a escola perdeu". Logo no início é caracterizado o que predomina no ensino dessa disciplina:

Desinteressante, precário, decadente, confuso, burocratizado e repetitivo - são inúmeros os adjetivos para caracterizar o atual quadro do ensino de uma disciplina que não atrai mais alunos (...) o ensino ficou estagnado na História positivista, idealista, factual - aquela das datas, nomes e heróis - , que servia bem à clientela de classe média dos anos 50 , mas que faz dormir crianças nos anos 80/90 de qualquer classe social.

Em seguida, a situação do ensino relativo a essa disciplina é parcialmente vinculado à "repressão às mudanças durante os 20 anos de ditadura militar". Uma situação que começou a mudar "há alguns anos", em razão de iniciativas

\footnotetext{
${ }^{14}$ A esse respeito, veja-se o capítulo "Um passado equivocado", na primeira parte deste trabalho.
} 
individuais e de grupos que estão "abrindo novos caminhos para o ensino. Caminhos que, em alguns locais, começam a ser incorporados por governos mais progressistas" (p. 10). Dentre eles, o primeiro a ser mencionado é o da prefeitura de São Paulo, que está implantando "uma nova proposta curricular inspirada no construtivismo" (p. 11). No decorrer da reportagem são apresentadas as opiniões e falas de especialistas e professores dessa disciplina, bem como de alguns alunos. Entre outras coisas, criticam-se os livros didáticos tradicionais, a ênfase na memorização de datas e nomes e a distância do que se ensina em face da realidade dos alunos. Várias concepções de história ou linhas de trabalho são destacadas num box e brevemente caracterizadas - História Idealista, História Positivista, História Narrativa, História Marxista, História das Mentalidades e História Temática (pp. 14-5). Em relação à proposta desenvolvida no município de São Paulo, que não constitui o único exemplo apresentado na reportagem, destaca-se que em "100 escolas" está sendo implantado o "sistema de interdisciplinaridade" (p. 17). Nesse sistema, o conteúdo das aulas é dado por um tema escolhido pela comunidade de cada escola. Esse tema serve de eixo para todas as disciplinas, aí incluída História, voltada basicamente para o "cotidiano":

"(...) A idéia era que cada aluno percebesse como esse cotidiano é um espaço de múltiplos projetos, lutas e disputas entre os homens, passando pela discussão sobre as formas de poder", explica Marcos Antônio da Silva [assessor da prefeitura]. "Era deixar de lado os grandes acontecimentos, deslocando para o homem que faz o seu dia-a-dia, dando condições para o aluno se situar na História como agente possível", acrescenta o professor paulista, defendendo o caráter construtivista do projeto. (p. 18)

O tipo de abordagem da História que aí é proposto confunde-se com o construtivismo, ou melhor, "o caráter construtivista do projeto" é definido por meio de um tipo de articulação discursiva que igualmente corresponde ao que na reportagem é chamado de História das Mentalidades ou História do Cotidiano esta última concebida como parte da primeira (ibidem). Além disso, como ocorre em outras matérias, todas essas articulações discursivas que são próprias da educação popular ou do discurso alternativo-popular tendem a ser incorporadas ao novo discurso pedagógico. Nesse caso, com evidente destaque para o significante cotidiano e tudo o que ele condensa, de não pouca relevância no campo alternativo. $\mathrm{E}$ aí também é preciso considerar o significante interdisciplinaridade, de uso freqüente na revista Nova Escola e que também 
define o caráter do "projeto" desenvolvido na rede paulistana durante a gestão da prefeita Luíza Erundina. Esse significante-mestre, ao ser incorporado no âmbito do novo discurso pedagógico, é transformado em um de seus pontos de ressonância. Junto com ele, ademais, é igualmente sobrepujada toda a rede discursiva que procede da educação popular e que se encontra amarrada ao significante interdisciplinaridade, como se observa com nitidez numa reportagem de abril/92.

O título dessa reportagem, precedida pelo nome da seção (Interdisciplinaridade), é este: "Uma escola que não tem medo de discutir a realidade". Um título assim complementado: "Cresce na rede municipal a adesão à interdisciplinaridade, num projeto que visa integrar escola e comunidade e criar o aluno atuante" (p. 26). Embora toda a matéria gire em torno do significante interdisciplinaridade, pois quase tudo o que é relatado conflui nesse ponto, o teor do "projeto" é também definido recorrendo-se ao significante-mestre construtivismo. ${ }^{15}$ Este é utilizado em um único parágrafo, para lembrar que a reelaboração dos currículos feita nas escolas leva em conta, "como prega o construtivismo, o conhecimento dos alunos". Mas a sua função primeira não é essa. Antes de mais nada esse significante constitui uma espécie de etiqueta com a qual tudo o que no texto é reportado é implicitamente abraçado, assim ficando virtualmente sujeito à nova ordem discursiva, em particular certos nomes e o que eles condensam:

A idéia dessa escola nova, mais democrática, tomou corpo com a posse da prefeita Luíza Erundina, do Partido dos Trabalhadores (PT), em 1989: a Secretaria Municipal da Educação resolveu implantar o construtivismo na rede pública, com base nas teorias de Paulo Freire (então secretário da Educação), Emilia Ferreiro e outros educadores. (ibidem)

Essa "escola nova, mais democrática" é brevemente caracterizada no parágrafo anterior, que é o que abre a reportagem:

Uma escola que esteja integrada à vida do seu bairro, que trate os conflitos sociais como objeto de aprendizagem e forme indivíduos com

\footnotetext{
${ }^{15} \mathrm{O}$ uso do significante projeto, à semelhança do que ocorre em outras matérias da Nova Escola da década de 90 , supõe a existência de um território já demarcado, uma espécie de suporte mais largo que o ultrapassa e contém, relativo à nova proposta ou linha pedagógica evocada por meio do significante construtivismo.
} 
uma visão crítica da realidade, capazes de interferir nela e transformá-la esse projeto ambicioso, até mesmo revolucionário, vem sendo experimentado desde 1990 em escolas da rede municipal de São Paulo (SP). O meio para atingir seus objetivos principais é a interdisciplinaridade, que no jargão dos professores passou a ser chamada simplesmente de inter, palavra curtinha cada vez mais presente na vida escolar. (ibidem)

Ao longo da reportagem, o teor desse "projeto revolucionário" continua a ser definido com todo um conjunto de articulações discursivas próprias da educação popular, tal como já se evidencia no título, subtítulo e primeiro parágrafo dessa matéria. O trabalho que as escolas e os professores desenvolvem é realizado em torno de temas geradores, sobre os quais todas as disciplinas trabalham de maneira integrada. Esses temas comuns são extraídos "do mundo real, do cotidiano dos alunos", constituem "problemas prementes da comunidade", temas escolhidos depois de pesquisada a "realidade social, econômica e cultural do bairro" (ibidem). Pretende-se assim que a escola passe a "encarar o conhecimento como matéria viva, em constante transformação, num enfoque oposto ao da escola com que nos acostumamos a conviver" (ibidem). Ou seja, a escola tradicional: uma escola despreocupada com a realidade, que se isola da comunidade. Segundo a reportagem, com a "experiência da interdisciplinaridade", desenvolvida pelas escolas e professores que aderiram ao projeto, "uma escola nova está surgindo. Uma escola integrada à maioria da comunidade, e uma comunidade participante da vida escolar" (p. 29).

Realizar essa experiência, no entanto, com tudo o que ela supõe, "não é uma empreitada fácil":

Exige dos professores interesse, participação e dedicação redobrados na vida escolar e comunitária, além da disposição de abandonar o trabalho isolado e adotar o planejamento conjunto. Ou seja, mudar radicalmente a postura que sempre tiveram e adotar outra, em que prevalece o diálogo tanto com colegas quanto com alunos e pais. (pp. 267)

A mudança radical de postura é acima assinalada e demarcada com o significante diálogo. Além disso, tanto nesse trecho, quanto no decorrer da matéria, a dimensão coletiva do trabalho é realçada: as discussões coletivas, as reuniões, o trabalho em grupo. E um dos efeitos de tudo isso sobre os professores é destacado no final da reportagem, por meio da fala de um professor: o ressurgimento de "um sentimento morto há muito tempo na escola, o 
companheirismo". Quanto aos alunos, entre outras coisas afirma-se que já estão adquirindo um olhar crítico sobre o que é estudado, enriquecem o seu conhecimento com os recursos utilizados (como o trabalho em grupo, o contato com a comunidade, o diálogo) e hoje são muito mais atuantes, participantes e criativos (p. 27).

Para superar os erros ou dificuldades que fazem "parte do processo de adaptação dos professores, presos ainda ao método tradicional de ensino" (p. 28), o plano da experiência, das próprias vivências e das práticas escolares constitui um elemento fundamental:

"Por falta de vivência na inter, cometemos alguns erros", reconhece Nanci Nunes, coordenadora pedagógica (...) "Ficamos mais de um semestre, em 1990, ouvindo o relato dos alunos (...) Mas já conseguimos acertar o passo, e nosso erro acabou tendo um aspecto positivo: além de termos conhecimento profundo dos nossos alunos, mostramos para as escolas que iniciaram o processo no ano passado o que não deve ser feito", afirma Nanci. (p. 27)

"Eu faço uma integração de disciplinas. Preciso de mais leitura, mais vivência, para chegar à inter". Para ela [professora] e várias de suas colegas, a maneira de planejar o ensino é um entrave para a verdadeira interdisciplinaridade. (p. 28)

"Essa é nossa maior dificuldade: garantir o trabalho coletivo. É ela que emperra um pouco o nosso trabalho", afirma Marilu Fraga [assessora do NAE-4]. (p. 29)

As dificuldades ou erros que são destacados nessa reportagem não decorrem da incompreensão de uma teoria, da sua distorção, da falta de fundamentação, da ausência de uma base científica para a prática pedagógica ou de uma postura que não corresponde a determinada teoria, como é próprio do discurso construtivista. Eles estão inscritos na prática, mas a sua correção, o que deve ser feito para superar as dificuldades, as mudanças necessárias para atingir a meta estabelecida pelo significante "inter", o saber que tudo isso exige, remete em grande medida para o mesmo registro da experiência, da prática pedagógica, das vivências individuais e coletivas. Os entraves, as dificuldades, os problemas relativos a determinada experiência constituem referências fundamentais para orientar outras experiências, desenvolvidas por outros professores e escolas. Daí o valor dos "cadernos com os relatos das práticas pedagógicas adotadas na rede", que, segundo informa-se na matéria, seriam divulgados nesse mesmo ano. Com 
esses relatos, pretende-se mostrar que é possível "seguir caminhos diferentes para atingir o mesmo objetivo" (p. 27). Nesse caso, a "inter" — um significantemestre que surge associado ao significante-mestre construtivismo. Este, nessa e em outras matérias, comparecer para cumprir esta função: assinalar e antecipar um domínio que ainda não conquistou.

Tomando como referência a revista Nova Escola, pode-se dizer que até fins da primeira metade da década de 90 o construtivismo incorpora e sobrepuja boa parte da rede significante que é própria do discurso da educação popular. Mas isso deve ser entendido, primeiramente, como uma visão retrospectiva, que não evidencia boa parte dos embates implicados nesse processo - embates, aliás, difíceis de perceber percorrendo-se apenas os textos da Nova Escola. Ou seja, a apropriação progressiva das articulações discursivas que são próprias da educação popular e o seu (re)ordenamento ocorrem tão-somente se olharmos esse processo retrospectivamente, sob a perspectiva do discurso que acabou se impondo. Várias reportagens relacionadas com a alfabetização e que mencionam Emilia Ferreiro e Paulo Freire, autores cujas reflexões podem ser facilmente aproximadas em vários pontos, apresentam um discurso que está muito mais próximo da educação popular do que do construtivismo. Um exemplo é a reportagem antes analisada. Mas existem outras, nas quais o nome Emilia Ferreiro e o que ele condensa ficam sob o influxo dos pontos de ressonância do discurso da educação popular. ${ }^{16}$ Portanto, o último tende a absorver e (re)ordenar as articulações discursivas amarradas ao significante-mestre Emilia Ferreiro e não o contrário. Não enxergar isso ou chamar todo e qualquer discurso de construtivista, como de fato começou a ocorrer, é apenas um dos efeitos produzidos pelo "caminho construtivista", ou melhor, pelos mecanismos discursivos que nele ficaram encerrados e que obscureceram os conflitos e embates que resultaram na hegemonia desse discurso.

No início dos anos 90, as principais costuras do novo discurso pedagógico já haviam sido concluídas, a matriz simbólica construtivista já estava pronta e continuava a se expandir e consolidar. O que nessa matriz é essencial é o que

\footnotetext{
${ }^{16}$ Veja-se, por exemplo, uma reportagem sobre alfabetização de adultos que é o destaque de capa da Nova Escola com a seguinte manchete: "Alfabetização. O segredo do sucesso dos movimentos populares". O título da matéria é "Quem disse que 'papagaio velho não aprende a falar'?", n 40, junho/90, pp. 10-7.
} 
define os seus pontos de fuga, os limites do discurso que estabelecem o que é da ordem de um fracasso, de uma falha. Em nosso caso, relativa à ação educativa. Um desses limites é estabelecido pelo significante escola tradicional e seus equivalentes, de forte presença nos discursos pedagógicos do período aqui considerado. O outro, que é próprio da vertente construtivista que se tornou dominante, surge na revista Nova Escola sem muita força e assim permanece, se consideramos a quantidade de matérias em que aparece, por demais raras. Com efeito, o significante espontaneísmo e seus derivados (prática, método ou ensino espontaneísta) dificilmente são utilizados na Nova Escola. Mas eles surgem ou estão presentes em alguns momentos cruciais: quando é necessário estabelecer uma ordem que, sem eles ou sem o que eles supõem, não existiria. ${ }^{17}$

Ao que tudo indica, a primeira matéria onde esse significante comparece, como se tivesse sido chamado para essa particular ocasião, concerne ao momento em que o significante-mestre construtivismo é transformado na manchete de capa da Nova Escola, em maio/91. ${ }^{18}$ Essa é a primeira oportunidade em que, nessa publicação, um nome atribuído a uma teoria, proposta ou linha pedagógica ganha tamanha relevância. Nesse momento é feito um "balanço" do "caminho" até então percorrido, relativo aos "dez anos de construtivismo no Brasil", os "anos que abalaram nossas crenças", de acordo com o enunciado que complementa a manchete de capa. Nessa matéria menciona-se Piaget, Emilia Ferreiro, Paulo Freire e Vigotsky e as chamadas "pioneiras" do construtivismo (Madalena Freire, Telma Weisz e Esther Grossi). Um dos box da matéria é reservado para falar da Escola da Vila, que no discurso da revista constitui uma espécie de pioneira e paradigma de escola construtivista. Para a capa dessa edição foi escolhida uma imagem que corresponde ao que parece estar no âmago do significante construtivismo: a criança. Mas não se trata de qualquer criança. A que fica num primeiro plano, por trás daquele significante sobreposto à imagem, é uma criança que estuda numa escola particular ou, mais exatamente, na escolaparadigma, como a própria revista informa - "Capa: crianças da Escola da Vila" (p. 3). Essas são, em suma, algumas das confluências criadas pelo ponto de

\footnotetext{
${ }^{17}$ Dentre as matérias da Nova Escola que foram pesquisadas, entre 1986 e 1998, o significante espontaneísmo ou seus derivados foram encontrados em seis matérias: uma em 1991 e 1992 e duas em 1993 e 1995.

${ }^{18}$ Cf. "Dez anos de construtivismo no Brasil", Nova Escola, n 48, maio/91,pp. 10-8.
} 
basta que se constitui com o significante-mestre construtivismo, no momento em que esse significante alcança um primeiro plano acompanhado desta imagem:

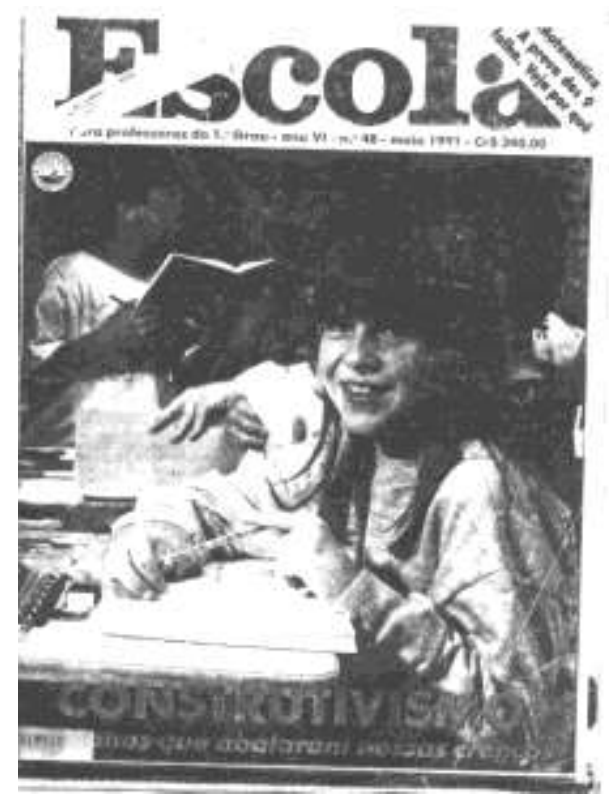

Ao longo dessa extensa reportagem procura-se mostrar como o construtivismo se "propagou" no Brasil, entendido basicamente como uma proposta de alfabetização baseada nas "idéias" de Emilia Ferreiro, por vezes adquirindo um sentido mais amplo. Por exemplo, quando se fala em linha de ensino, linha pedagógica ou proposta educacional, as quais concebe-se como derivadas da teoria ou das teorias construtivistas, à semelhança da postura, comportamentos, práticas e experiências desenvolvidas pelo professor construtivista. Tudo isso não apenas deriva, mas também é visto como mais ou menos adequado à ordem teórica suposta cada vez que é usada a palavra construtivismo, de acordo com a hierarquia que esse significante (re)estabelece e que nessa matéria é também lembrada e destacada logo nas primeiras linhas. ${ }^{19} \mathrm{E}$ aí figura em primeiro lugar a "teoria da psicogênese da língua escrita", "elaborada e comprovada por Emilia Ferreiro", uma teoria "segundo a qual a criança constrói seu próprio processo de leitura e de escrita" (p. 10).

\footnotetext{
${ }^{19}$ Essa hierarquia é logo anunciada e estabelecida no olho que sucede ao título, com um tipo de articulação discursiva conhecido pelos leitores da revista: "as idéias de Emilia Ferreiro mexeram com muitas cabeças e mudaram completamente a linha de ensino de muitas escolas em todo 0 país". Além disso, essa hierarquia é reforçada no primeiro box existente nessa matéria, na primeira página e com este título: "Uma teoria que mexeu com as cabeças" (p. 10).
} 
A "propagação" do construtivismo é assinalada recorrendo-se às trajetórias de professores, de escolas públicas e privadas e redes de ensino municipais e estaduais de diversas regiões do país. Entre outras coisas, menciona-se o papel dos cursos de capacitação, treinamento ou reciclagem na linha construtivista, a participação dos professores em congressos, o contato com a teoria através de livros, as assessorias das universidades e de especialistas, a divulgação de relatos de experiências construtivistas, os grupos de estudo, discussão e reflexão, não apenas sobre questões de ordem teórica. Esta, porém, é a ordem que adquire maior relevância.

No balanço que é feito dessa "propagação" procura-se salientar que há uma "diversidade de caminhos" e que existe "um construtivismo com diferentes faces" (p. 14). Em Pernambuco, por exemplo, no âmbito da rede estadual, "os professores trabalham com o que chamam de sócio-construtivismo", pois julgam que a teoria piagetiana "não considerou as interferências das diferenças sociais sobre o processo de construção do conhecimento". Eles consideram "o homem em seu contexto social, interagindo em seu meio", valendo-se sobretudo dos "textos soviéticos de Luria, Leontiev e Vigotsky" (p. 14). Em Santa Catarina, o construtivismo foi inicialmente adotado na rede e depois abandonado - o único caso mencionado na matéria - "para trabalhar numa linha mais voltada para o coletivo", pois considera-se "o construtivismo individualista, já que se concentra no processo de cada criança, muito preso a etapas" (ibidem). No Rio Grande do Sul, como "alternativa para os pobres"20, temos "o exemplo mais marcante de participação do Estado na propagação do construtivismo" (p. 12). Esse é um dos estados onde "o construtivismo está mais solidamente instalado" e "uma nova questão vem sendo colocada: a adoção das idéias emilistas pelas demais séries do $1^{\circ}$ Grau" (p. 18). Nesse e em outros exemplos, quantifica-se essa expansão: em Porto Alegre, "65\% das 34 escolas são construtivistas" (p. 13). Ademais, chega a ser antecipada a sua generalização: "Até 1992, segundo previsão da secretária da Educação Esther Grossi, toda a rede estará trabalhando na mesma linha" (ibidem). Mostrar essa "diversidade de caminhos", fazer esse mapeamento, envolve também comparar a rede pública e privada: "a adesão à teoria de Emilia Ferreiro é um fenômeno característico da rede pública de ensino", existindo porém

\footnotetext{
${ }^{20}$ Esse é o intertítulo que precede a descrição do "caminho" seguido pelo construtivismo nesse estado.
} 
"honrosas exceções" na rede particular — a "Escola da Vila, em São Paulo, e a Balão Vermelho, em Belo Horizonte" (pp. 13-14).

Nessas diversas trajetórias pontua-se brevemente quando o construtivismo teria começado, de que modo, algumas peculiaridades do percurso realizado e quais os entraves, problemas ou dificuldades que surgiram durante a sua implantação. Sobre esse último ponto, vários aspectos são mencionados (falta de material didático, de apoio oficial, obstáculos administrativos, etc.), mas o principal diz respeito ao professor, a começar pelo seu desconhecimento da teoria. Daí a relevância dos cursos de capacitação, sobre os quais também são sumariamente descritos os "caminhos" percorridos. Esses cursos são essenciais para afastar os "riscos de desvios":

Justamente por causa dos riscos de desvios, as propostas construtivistas vêm acompanhadas, em geral, de uma preocupação maior com a capacitação dos professores. (p. 15)

Nos cursos de capacitação pode também ser vencida a "resistência" dos professores que não "aderem" ao construtivismo, às vezes porque "é muito mais uma falta de compreensão do que seja essa filosofia do que uma resistência por incredulidade"21. Com essa adesão, porém, começam outros problemas, pois devem ser enfrentadas "as armadilhas dos vícios do sistema tradicional do ensino" (p. 17). Ou seja, esses professores dizem que são construtivistas mas a sua prática é tradicional, conforme procura-se esclarecer por meio de alguns exemplos.

A escola ou ensino tradicional, lembrado em vários momentos, não constitui o único risco, o único empecilho. Existe um outro que nessa matéria merece um destaque especial, no box reservado à Escola da Vila, que já "chegou a cometer enganos", conforme antecipa o título. Consiste em imaginar que a criança "poderia aprender sem a intervenção explícita do professor" (p. 16). Esse engano diz respeito aos primeiros anos da Escola da Vila, mas também remete para o que afigura os primórdios do construtivismo ou das experiências construtivistas no

${ }^{21}$ Explicação de "Teresinha Pessoa Tavares, do centro de Educação Bernardo Van Leer, do Recife", p. 17. 
Brasil. $^{22}$ De lá para cá, porém, ocorreram avanços, conforme é sugerido na reconstrução da trajetória dessa escola paulistana:

Essa tomada de consciência e a mudança de atitude foram um lento processo e a escola levou algum tempo para reconhecer o papel mediador do professor. Hoje o professor intervém constantemente no processo de aprendizagem. (pp. 16-7)

O "engano" que é próprio desse ponto onde todos os "começos" parecem encontrar-se, no qual localiza-se a "origem" do construtivismo e que costuma retornar toda vez que um professor começa a trilhar esse "caminho", é destacado e lembrado já no início da reportagem, no olho que sucede ao título:

As experiências construtivistas servem para mostrar que não existem fórmulas mágicas. E fica claro que, para se obter bons resultados, não basta deixar os alunos soltos na sala de aula. Antes de mais nada, a prática tem demonstrado que é preciso investir na formação do professor.(p. 10) $)^{23}$

O "engano" implícito na advertência feita nesse texto pode se dizer que aflui "naturalmente" em direção ao significante espontaneísmo, utilizado nessa reportagem uma única vez, na última página:

O professor também tem dificuldade em lidar com a criança na classe como parte de um grupo mas guardando as características individuais. Ele passa, então, a apenas observar, sem interferir no aprendizado, caindo no espontaneísmo, onde cada criança faz o que quer.

Em face do modelo tradicional e o espontaneísmo - dois extremos que em geral permanecem implícitos nas falas -, o professor deve procurar "o ponto de equilíbrio", lembrado na seqüência desse mesmo trecho do texto, embora não seja situado exatamente da forma que aqui está sendo sugerida:

"O mais complicado para os professores é se situar ora como aquele que aprende, ora como aquele que ajuda a sistematizar o conteúdo, introduzindo novos conhecimentos. E demora até ele encontrar o ponto de equilíbrio", acrescenta Rosely [supervisora pedagógica de uma escola municipal de Belo Horizonte].

Esse é o principal desafio para o professor construtivista: aprender a situarse no "ponto de equilíbrio", afastando-se igualmente dos extremos que são

\footnotetext{
${ }^{22}$ A esse propósito, veja-se o item "Um passado equivocado", no primeiro capítulo deste trabalho.

${ }^{23} \mathrm{O}$ destaque em itálico é meu.
} 
próprios dos "desvios, confusões, equívocos ...". Os esforços do professor para tentar mudar, as dificuldades que deve superar nesse difícil "caminho", as suas angústias, insegurança, medos, tudo o que explícita ou implicitamente é relacionado com a sua mudança de postura - e que nessa matéria também é lembrada — diz respeito a esse lugar, àquele "ponto de equilíbrio", mas sobretudo ao que o cerca. Esse sim, um lugar de fantasmas - o lugar dos "erros" que costumam acossar o professor que quer se tornar um construtivista.

Situação bem diversa é a do aluno/criança, não mais sujeito ao lugar que Ihe era reservado nos discursos pedagógicos considerados tradicionais. As posições inverteram-se: os alunos não mais - ou pelo menos assim deveria ser — inibem-se ou sentem-se "perseguidos pelo fantasma do erro":

"Sentimos que nossos alunos estavam tendo uma relação mais gostosa com a leitura e a escrita. Eles não eram mais perseguidos pelo fantasma do erro. Escrever e ler não era sofrido. Tudo parecia natural para as crianças", conta lêda Maria Luz Brito, da Escola Barão Vermelho, de Minas. (p. 18)

Nessa matéria da Nova Escola, a nova linha ou proposta pedagógica desdobra-se numa "diversidade de caminhos", mas simultaneamente essa diversidade é contida dentro desse largo e único "caminho" pressuposto toda vez que se fala em construtivismo. Nesse momento, muitos educadores já parecem estar certos de uma coisa, explícita na fala de uma professora: "Sabemos que o construtivismo é o caminho. Mas falta muito para alcançar o fim. Nós ainda estamos despreparadas (...)" (p. 17). Essa certeza alastra-se durante a primeira metade da década de 90, pressupondo um "caminho" que em maio/1991 já evidencia os seus pontos cardeais, os pontos que o transformam num caminho evolutivo, a começar pelo momento em que ocorrem os "enganos", e que já pode ser nitidamente fixado com o significante espontaneísmo. Um momento que por vezes se confunde com o outro extremo que define a moldura do discurso construtivista - a escola tradicional.

Nessa reportagem temos também os exemplos que servem para o leitor saber em que ponto da "caminhada" se encontra: mais ou menos avançado em relação à "origem". Para isso contribuem as "pioneiras" e a escola-paradigma, que pela primeira vez recebem essa distinção. Elas tornam concreta essa trajetória, 
bem com a realização do ideal que se aninha em inúmeras falas: aplicar o construtivismo corretamente. Um ideal concretizado pela escola-paradigma outrora uma "escola alternativa" — e pelas "pioneiras" — das três mencionadas, duas com a sua trajetória profissional vinculada à Escola da Vila. ${ }^{24}$

Essa é a escola-exemplar, o exemplo que nessa reportagem fica com o significante paradigma. Com ela e dessa forma, o que tende a ficar no lugar do ideal, do ideal imaginário, mas que também diz respeito à "origem", concerne a uma escola privada. ${ }^{25}$ É um ideal, portanto, gerado na rede particular de ensino e que tende a pautar o ensino público, com tudo o que configura esse lugar, como a criança da capa da Nova Escola e a temporalidade evolutiva já referida, com as duas bordas que a delimitam — os "enganos" e o ideal parcialmente realizado. Uma temporalidade que no concorrido mercado das escolas privadas cumpre uma função vital, na medida em que (re)cria uma ordem que orienta os que nele se encontram, a começar por aquilo que está no cerne de qualquer mercado: o dinheiro. Ou seja, essa temporalidade evolutiva (re)cria a ordem de circulação do capital no interior desse mercado, com efeitos que muito extrapolam esse âmbito. Essa circulação, esse circuito, é também uma obra do significante construtivismo. ${ }^{26}$

Sob essa temporalidade evolutiva, a incipiente proliferação de linhas, propostas, projetos, práticas, experiências e posturas consideradas construtivistas sofre o seu primeiro enquadramento temporal. Um enquadramento realizado quando o significante-mestre construtivismo alcança um primeiro plano, com a amarração que nesse momento é feita. Esse ponto de basta é precedido por uma infinidade de pequenas costuras que agora ficam sob a ordem que é própria

\footnotetext{
${ }^{24}$ Essas duas "pioneiras" são Telma Weisz e Madalena Freire, cujos vínculos com a história da Escola da Vila não são mencionados na reportagem.

${ }^{25} \mathrm{O}$ termo imaginário acima utilizado denota o que Lacan chama de registro do imaginário.

${ }^{26} \mathrm{Em}$ relação a essa temporalidade evolutiva, com a sua particular "origem", uma investigação sobre a sua procedência provavelmente revelaria o que emigrou da rede particular de ensino para a rede pública, a começar por essa mesma temporalidade. Para tanto bastaria seguir a trilha do significante espontaneísmo, por onde certamente chegaríamos até o campo dos discursos e experiências alternativas, em particular do alternativo-renovado, que é aonde esse significantemestre ficou particularmente aderido. Um significante de uso freqüente em determinado circuito de escolas particulares paulistanas e de forte ressonância na Escola da Vila, inclusive na época em que foi feita aquela reportagem da revista Nova Escola. Isso foi verificado na pesquisa realizada para a minha dissertação de mestrado (Revah, 1994). Na ocasião, entre 1990 e 1991, entrevistei quatro educadoras vinculadas à história da Escola da Vila. Todas elas usaram o significante espontaneísmo para referir-se aos primeiros momentos dessa história.
} 
desse tipo de enquadramento que define a matriz simbólica construtivista. $O$ acabamento dessa matriz é o principal efeito da operação de costura realizada nesse momento, ou melhor, nos vários momentos que nesse período podem ser detectados e destacados, se fosse possível considerar a infinidade de discursos e falas do período compreendido entre a segunda metade dos anos 80 e início da década seguinte. Esse é o período em que efetivamente emerge um novo discurso pedagógico, mesmo que seja sob a forma que é própria de uma velha configuração discursiva, como é o caso da ciência.

Essa operação discursiva produz efeitos retroativos e prospectivos, pois aquele enquadramento tende a ordenar todos os discursos, do passado e do futuro. Para tanto parece ter sido fundamental a (re)utilização do significante espontaneísmo, que já tinha adquirido alguma notoriedade no início dos anos 80 com o discurso da pedagogia dos conteúdos. Um significante que, a rigor, sempre esteve presente, tendo encontrado eco apenas entre alguns educadores, em alguns âmbitos, sendo que na Nova Escola comparece pela primeira vez, ao que tudo indica, em 1991. Amarrado ao significante-mestre construtivismo, o significante espontaneísmo define um dos pontos de ressonância do novo discurso, pelo menos da corrente construtivista que se tornou hegemônica. $E$ desse modo compõe e fecha a estrutura significante do suporte que define o lugar do discurso pedagógico construtivista. Além disso, com o ponto que esse significante define, certas articulações discursivas de forte presença nessa revista tendem a confluir em sua direção, ou seja, em direção à "origem" do construtivismo. Não exatamente de modo explícito, mas antes em razão das confluências que esse discurso cria quando o significante espontaneísmo aparece. Em outras palavras, no momento em que a matriz simbólica construtivista é concluída, os discursos precedentes ficam sob a moldura que é própria daquela temporalidade evolutiva. Esses discursos, essas múltiplas articulações discursivas, ganham assim um novo sentido, que igualmente deverá ser o destino de muitas falas ainda não realizadas. Essas falas já encontram o seu lugar previamente demarcado, como é o caso das que são "naturalmente" atraídas por essa espécie de buraco que afigura a "origem" do "caminho construtivista". 
Em relação à revista Nova Escola, aqui vale lembrar que ela está sendo tomada como uma espécie de guia. Um guia utilizado para nos aproximarmos dos momentos em que são feitos os nós fundamentais que criam o novo discurso, pelo menos se entendido nos termos concebidos por este trabalho. Em que momento esse discurso emerge? É obvio que essa questão está sendo respondida no interior da trama que aqui foi criada, ao tomar como principal referência um único significante (construtivismo) e a sua repetida presença nos discursos educacionais e/ou pedagógicos. Isso é parte do viés desta análise, do que nela há de parcial e arbitrário. Um arbitrário que, no entanto, é inseparável do discurso que está sendo analisado, permitindo-nos assim, a partir do que aqui mesmo foi instituído, percorrer algumas das costuras e contornos criados com e pelo significante-mestre construtivismo. Agora, é possível fixar a data dessa emergência? Em maio de 1991? É claro que essa data é uma referência importante, mas antes de mais nada no âmbito da revista Nova Escola. A matéria destacada nessa edição, a bem da verdade, é apenas um exemplo que situa num plano imaginário um fato do discurso do qual podemos tão-somente nos aproximar, chegando talvez bem perto de seus limites, mas sem que seja possível chegar ao "ponto". Este nos escapa. Além disso, antes do que corresponder a um momento passível de ser situado numa linha cronológica, diz respeito a um processo que envolve vários momentos, vários pontos de basta. $\mathrm{O}$ modo como esses pontos se constituem é o que sobretudo interessa. De qualquer forma, no Brasil, aquele "ponto" de emergência relacionado com o uso do significantemestre construtivismo e seus derivados poderia ser situado bem antes, no mínimo em meados da década de 80 . Nessa data, os três pontos de estrutura da matriz simbólica construtivista já haviam sido claramente situados e definidos, como se observa em artigo de Carraher e Carraher (1986). Mas, certamente, nesse momento o significante-mestre construtivismo ainda não havia encontrado muito eco. Tomando a revista Nova Escola como referência, esse significante-mestre consegue sobrelevar o nome Emilia Ferreiro apenas no início da década de 90, quando se torna a manchete de capa. Ou seja, nesse instante ele claramente se destaca da rede discursiva da qual fazia parte e se torna o que na verdade já era, mas sem tanta evidência e relevância: o Um dessa mesma rede, o Um que a representa e contém, o Um do Outro, que assim como o nome Emilia Ferreiro podemos chamar de $S_{1}$. 


\subsection{O bom professor}

Na revista Nova Escola, se consideradas apenas as matérias pesquisadas, a segunda ocasião em que o significante espontaneísmo é empregado é no mês de setembro/92. Trata-se de uma reportagem onde o "como" trabalhar ou lidar com o "erro" dos alunos é a temática central, envolvendo questões de ordem didática ou metodológica, no caso relacionadas com o ensino da língua escrita. Ela é o destaque de capa com esta manchete: "Como lidar com o erro". A resposta encontra-se na única foto da capa, ou melhor, ela indica onde pode ser procurada: na Escola da Vila, pois a foto foi feita nessa escola, com a sua "coordenadora" numa sala de aula, como se fosse uma professora: ${ }^{27}$

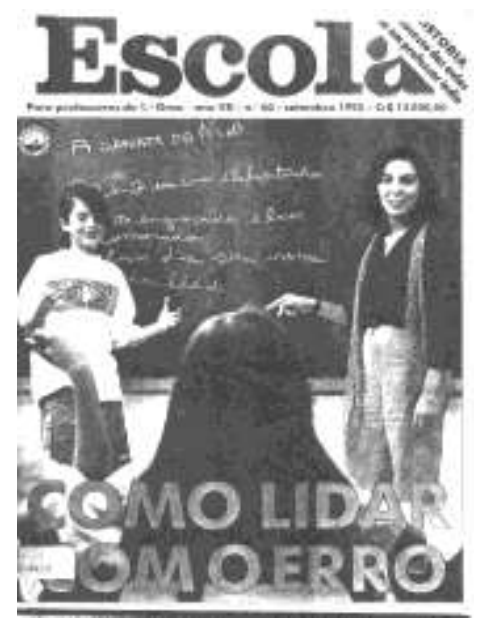

A questão central da reportagem são os erros de ortografia, mas a alfabetização e as "idéias construtivistas de ensino" de Emilia Ferreiro continuam como referências fundamentais (p. 14). A esse propósito vale apontar que, nesse início da década de 90, já existiam experiências escolares mais ou menos consolidadas no que se refere à "nova proposta" de alfabetização. Esta, cada vez mais, torna-se apenas uma parte, certamente importante, do que o construtivismo abrange. Nesse período, ademais, percebe-se que em várias publicações as experiências e práticas de alfabetização qualificadas de construtivistas costumam ser descritas recorrendo-se aos mesmos princípios e categorias. Na revista Nova Escola, por exemplo, fala-se do "ambiente alfabetizador", o trabalho com "grupos heterogêneos" (sendo que antes do construtivismo a norma era formar e trabalhar

\footnotetext{
${ }^{27}$ Parte dessa informação está nos créditos da foto de capa (p. 3) e a outra parte na própria matéria, onde também há uma pequena foto de Sônia Barreira, coordenadora da Escola da Vila ( $p$. 17). Cf. "Como trabalhar o erro", Nova Escola, $n^{\circ}$ 60, set./92.
} 
com grupos homogêneos), o texto como primeira referência para o trabalho de alfabetização, o uso de diversos tipos de textos (os nomes das crianças, listas de animais, rótulos de embalagens, contos, cartazes, etc.), recusa-se em geral o uso de qualquer cartilha ou livro didático, valoriza-se os "conhecimentos prévios" das crianças (relativos às sempre lembradas "hipóteses": pré-silábica, silábica, etc.) e alude-se a outros tantos elementos que criam determinados lugares, comuns a diversas experiências e discursos. Esses lugares, vários deles inexistentes antes de surgirem essas novas práticas de alfabetização, acabam definindo os contornos mais ou menos difusos de uma didática, uma metodologia, um tipo de prática de alfabetização construtivista, própria do professor que também começa a ser chamado de construtivista e que deverá ocupar o lugar do "bom professor".

Nessa reportagem sobre os erros ortográficos, de início afirma-se que não há consenso entre os educadores sobre como essa questão deve ser trabalhada e as principais posições são assim resumidas, no olho que antecede o corpo da matéria:

De um lado há quem defenda que o erro é absolutamente prejudicial e precisa ser, de algum modo, punido. De outro, estão os que o vêem como parte natural e insubstituível do processo de construção do conhecimento. Por trás de cada uma dessas maneiras de ver o erro ortográfico aninha-se uma concepção diferente do papel que a escola deve desempenhar: repassar conhecimentos ou ajudar a formar gente capaz de enfrentar desafios? (p. 10)

É claro que a primeira posição é relacionada com uma postura, modelo, metodologia ou educação tradicional, com a escola conservadora e autoritária. A reportagem é iniciada, justamente, trazendo à tona lembranças relativas a essa escola, na versão dos anos 50:

A palmatória, o croque na cabeça, folhas e mais folhas com a mesma palavra escrita uma centena de vezes e, para coroar, a dor aguda que sentia depois de alguns minutos ajoelhada sobre grãos de milho. E ainda, a chacota constante dos colegas ampliando um sentimento de inferioridade, carregado por toda a infância e parte da vida adulta. (p. 10) ${ }^{28}$

Esse modelo, lembra-se na reportagem, não continua exatamente igual, ocorreram "mudança sociais, econômicas e políticas" que pressionaram a escola,

\footnotetext{
28 "Essas são as primeiras imagens que vêm à cabeça da professora Janice Cavalher Wambier quando ela começa a falar da primeira escola que freqüentou" (p. 10).
} 
de modo que ela "não pode mais usar à vontade as velhas fórmulas". Entretanto, "como não abandonou a idéia básica do erro como fonte de culpa, sempre encontrava novas fórmulas de humilhar ou pressionar a criança" (p. 11). ${ }^{29} \mathrm{~A}$ seguir, são destacadas algumas dessas "novas fórmulas" e as suas implicações negativas para o ensino, relacionadas com uma "visão de ensino que enxerga o conhecimento como algo pronto e acabado e a criança como um armário cheio de gavetas vazias que precisam ser preenchidas, uma a uma" (ibidem). Essa visão de ensino, essa escola e professor que "não podem ou não sabem conviver com o erro são responsáveis pela evasão escolar" (ibidem). Quanto aos alunos:

(...) que resistem e permanecem nos bancos escolares, a perspectiva não é mais rósea: alguns passam a carregar um sentimento de inadequação e derrota (...) Outros, mais seguros de si ou maleáveis, vão se ajeitando e aprendendo que o melhor é questionar pouco e ousar menos ainda. (pp. 11-2)

A via para evitar tudo isso, surge na perspectiva que fica sob a égide do significante construtivismo e que corresponde à segundo posição explicitada no olho que precede o corpo da matéria. Para delineá-la foram consultados alguns professores e especialistas. O primeiro a ser mencionado é o professor Wanderley Geraldi, da Universidade de Campinas (SP):

Para o professor, diferente do que informam os métodos mais tradicionais, a escola primeiro precisa deixar a criança exercitar suas dúvidas, cometer toda sorte de erros, para só depois — sabendo quais são os tipos de dificuldades dos alunos - iniciar as interferências necessárias. Mas é justamente nesse ponto - o de saber quando e como interferir que os mestres se defrontam com mais um problema. (p. 12)

O problema que a seguir vai ser explicitado surge no ponto que no construtivismo representa o início da "caminhada", quando o professor tradicional está ensaiando os seus primeiros passos numa outra direção:

São muitos os que, ainda presos à idéia de que seu papel é ensinar o certo e coibir o errado, recusam-se a punir o aluno que erra, por não considerarem essa uma boa atitude ou por não acreditarem que as punições dêem bons resultados. Como conseqüência, esses professores acabam paralisados, sem conseguir elaborar uma nova conduta que pudesse representar um passo adiante no velho processo. (ibidem)

\footnotetext{
${ }^{29}$ A reportagem baseia-se, segundo o que nela é explicitado, nas considerações do professor Cipriano Luckesi.
} 
Ficar "paralisado" implica, precisamente, cair no outro extremo, criticado e recusado no interior do construtivismo. Esse outro extremo é estabelecido com o significante que melhor o define apenas na última página da reportagem:

Segundo ela [Magda Soares] também no construtivismo existe o risco de o aprendizado cair no espontaneísmo, que não é nada construtivo. "Deixar a criança errar e errar até que aprenda é um equívoco e uma irresponsabilidade (...)". (p. 17)

O extremo definido com e pelo significante espontaneísmo confunde-se com o outro extremo no buraco que é próprio dos "erros", nesse caso do professor. Pelo menos até o momento em que ele consegue distanciar-se dessa dupla fronteira (prática tradicional/prática espontaneísta) e encontrar "o ponto de equilíbrio", conhecido tão-somente pelos professores que, esses sim, podem ser chamados de construtivistas, os professores que já conseguem saber "quando e como interferir". São os professores que não estão mais confusos "sobre o caminho a seguir" e que conseguem intervir adequadamente. ${ }^{30}$ Para isso é necessário que saibam em que nível as crianças estão, quais são as suas hipóteses e que, ademais, forneçam elementos para que elas avancem e se aproximem do que é considerado correto. É importante também que o professor saiba discriminar os erros construtivos de outros tipos de erro; por falta de atenção, por exemplo. E mais, "ao contrário do que ensina a Educação tradicional, o erro deve ser trabalhado e não evitado, pois ele norteia a prática de sala de aula" (p. 14). Enfim, conhecer os processos construtivos da criança, as idéias que ela cria, os tipos de erro que ela comete é fundamental para o professor orientar a sua ação, de modo a ajustá-la ao que a criança ou aluno supostamente precisa.

Nessa reportagem são brevemente apresentadas situações ocorridas em sala de aula ou estratégias desenvolvidas para trabalhar o erro, dentre elas as que a revista aprova. E aí o destaque é a Escola da Vila, se consideramos que um dos três box existentes na matéria é destinado a essa escola, basicamente para exemplificar como trabalham com os erros ortográficos. Nesse box, intitulado "As hipóteses dos construtivistas para testar o erro", é mencionado o seu Centro de

\footnotetext{
${ }^{30}$ Nessa reportagem, uma das práticas brevemente descritas é a de uma professora que ainda se mostra "confusa sobre o caminho a seguir", quando desenvolve o seu trabalho em sala de aula ( $p$. 13).
} 
Estudos e um curso nele promovido sobre ortografia. A esse respeito, afirma-se 0 seguinte:

Muitas das reflexões e procedimentos metodológicos postos em discussão foram gerados, segundo a coordenadora Sônia Barreira, na prática das salas de aula da escola e no momento, depois de mais de 10 anos de experiência construtivista, fazem parte do cotidiano de seus professores e alunos. (p. 16)

O que acima sobressai é o plano da experiência. Nesse caso a experiência de quem, supõe-se, já assimilou determinado corpo teórico evocado pelo significante construtivismo, ou seja, de quem já sabe "pôr o construtivismo em prática". ${ }^{31}$ Além disso, essa "escola construtivista" já ultrapassou as fronteiras do terreno que é próprio dos "desvios, confusões, equívocos ...", que não deixam de ser evocados quando se faz referência ao momento em que se "exortava as crianças a escreverem 'do seu jeito'" (p. 16). Um momento já superado, pois, posteriormente, devido a que os alunos chegavam "à $3^{\text {a }}$ ou 4 série com muitas dúvidas ortográficas", começaram a se inquietar e a entender "uma das origens da displicência dos alunos": "do seu jeito' era entendido como "de qualquer jeito" (ibidem).

Além desse box, destinado a uma escola que quase não evidencia nenhum sinal do seu passado alternativo, há um outro que não deixa de evocá-lo de uma forma mais nítida, pelo menos o amplo campo do alternativo-popular, pois o que nele está em foco são "as escolas comunitárias de $1^{\circ}$ Grau de Salvador (BA)" (p. 12). Essas escolas não são consideradas construtivistas, nem poderiam sê-lo, pois adotam "um método de alfabetização considerado ultrapassado" (ibidem). Digamos que "as escolas comunitárias" ainda estão na "origem" de um "caminho" que ainda não fizeram, mas já estão na direção certa, conforme sugerem o título do box ("Respeito ao aluno diminui a evasão") e outros elementos que o texto valoriza ("clima de respeito e cumplicidade", o "processo de aprendizagem é lúdico", etc.). ${ }^{32}$

\footnotetext{
${ }^{31}$ Expressão usada em "Dez anos de construtivismo no Brasil", Nova Escola, n 48, maio/91, p. 10. ${ }^{32}$ Ao longo dessa reportagem, o trabalho com a ortografia é situado dentro de uma perspectiva mais ampla, como indica o título do terceiro box e que acima não foi mencionado: "Saber escrever é mais que saber ortografia". O uso competente da língua portuguesa, o texto (bons textos, que sejam significativos, etc.), as várias dimensões ou aspectos implicados na produção de um texto escrito (a ortografia sendo apenas um), a prática de revisão de textos, o uso de rascunhos e que "a capacidade de produzir bons textos deve estar acima de qualquer outra meta" (fala da
} 
Superpondo o perfil das escolas e práticas pedagógicas referidas ao longo da reportagem, o "caminho construtivista" surge sob a mesma moldura já referida, com os dois territórios que tendem a ser interditados pela vertente construtivista que se tornou dominante. Essa moldura, junto com a temporalidade evolutiva que a caracteriza, volta a ficar explícita no ano seguinte com os significantes-mestres que definem esses extremos. Trata-se de numa matéria onde finalmente é preenchido o lugar que na revista Nova Escola havia sido simbolicamente antecipado em 1988.

Nesse ano, essa antecipação ocorre de uma forma que é própria desse período, quando nenhum discurso educacional mostrava-se hegemônico e o significante construtivismo ainda não havia emergido nessa publicação. O que nesse ano é antecipado surge sob a forma que é própria do que é desconhecido, do que não apresenta contornos definidos, do que é mesmo um lugar vazio; mas que, ao mesmo tempo, é conclamado em todos os discursos educacionais: o "bom professor" — um significante para um lugar vazio. Em 1993, esse lugar é preenchido por uma imagem que nele se encaixa com perfeição, porque ela própria, junto com todos os enunciados que nela confluem, é a que define os seus contornos. Trata-se da imagem nítida e concreta de "uma construtivista": a professora Bernadete, cuja foto está na capa da Nova Escola de abril/93. Como nota Vieira (1995, p. 49), ela aparece "com seus alunos, com ar de vitoriosa, de quem obteve sucesso". Eis as capas desses números:
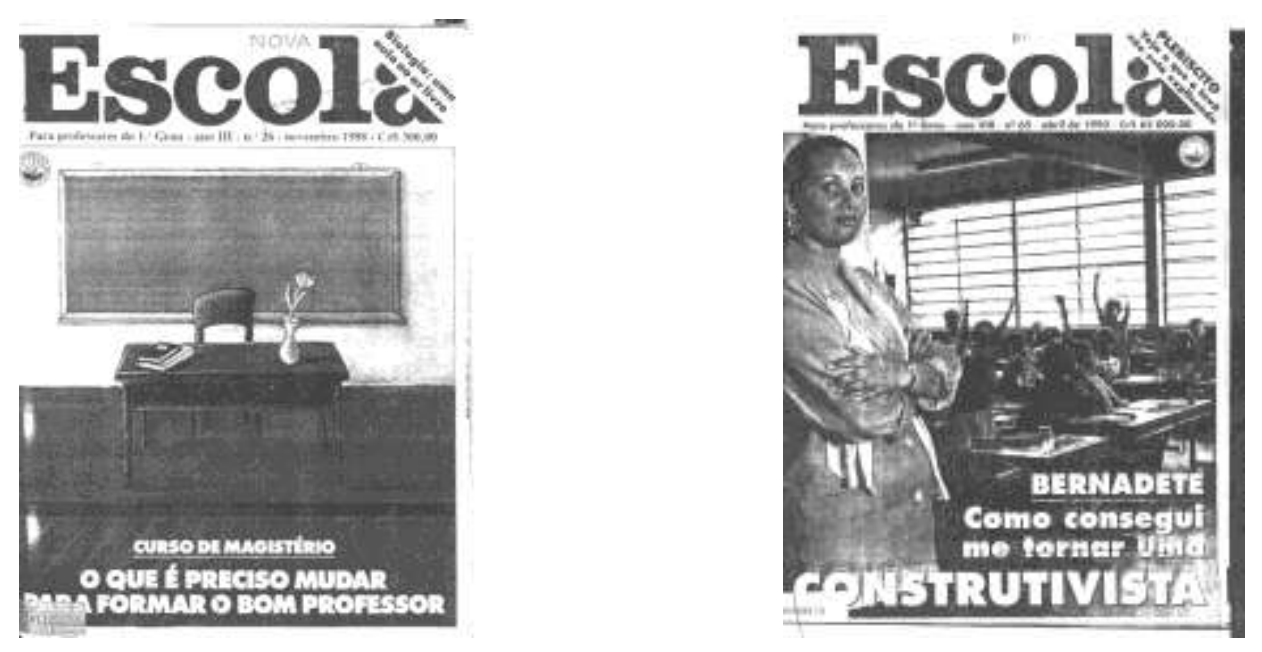

coordenadora da Escola da Vila, p. 17) são alguns dos pontos destacados na reportagem. Esses e outros elementos presentes nessa e em outras matérias da revista Nova Escola constituem boa parte do que, alguns anos mais tarde, será apresentado de forma unificada nos Parâmetros Curriculares Nacionais de Língua Portuguesa. 
Em 1988 falta o professor, ou melhor, "o bom professor". Tudo o mais parece estar disposto para que ele apareça, com os olhares de todos postos no lugar em que sobressai a sua ausência, ou seja, o lugar da sala de aula. À sua disposição tem uma lousa, uma escrivaninha sobre o velho estrado, que o coloca num nível acima dos alunos, uma cadeira, talvez alguns livros e até mesmo um vaso com uma flor. Tudo como antigamente, poder-se-ia pensar. Por isso a imagem talvez sugira uma outra coisa: "o que é preciso mudar" para que "o bom professor" apareça, pois com esses elementos, com essa escola tradicional, com a formação que o professor recebe para nela atuar, jamais será possível que esse professor tão aguardado apareça. É necessário um novo professor para uma Nova Escola, a escola cujos contornos estão sendo definidos pela própria revista. A reformulação dos cursos de formação de professores é um passo importante nessa direção cuja meta é a qualidade do ensino, conforme é sugerido na reportagem relativa ao destaque de capa. ${ }^{33}$

Já no ano seguinte, em 1989, os contornos do "bom professor" começam a ficar mais nítidos. Justamente no ano em que emerge o significante construtivismo e a mudança de postura dos professores é atribuída às "idéias" de Emilia Ferreiro. Em duas matérias desse ano, nas quais o nome Emilia Ferreiro comparece, o que adquire maior relevância é precisamente o "bom professor", o professor eficiente ou eficaz, primeiramente relacionado com a alfabetização. ${ }^{34} \mathrm{~A}$ primeira dessas matérias ganha inclusive uma pequena chamada na capa da revista: "Pesquisa revela perfil do professor eficiente". Nessas matérias, mas também numa outra do mês de setembro onde o nome Emilia Ferreiro é citado ${ }^{35}$, determinadas articulações discursivas próprias da psicologia tornam-se nítidas. $O$ que nelas tende a ser ressaltado é tudo o que é da ordem do afeto, das emoções, dos sentimentos, como se desse modo estivesse sendo compensada essa dimensão do desenvolvimento infantil, até então pouco destacada nas matérias sobre a "nova proposta" de alfabetização:

Porque, como toda aprendizagem, a alfabetização não se dá apenas no plano cognitivo. Além da inteligência, a aprendizagem envolve aspectos

\footnotetext{
${ }^{33}$ Cf. "Uma fábrica sem controle de qualidade", Nova Escola, n 26, nov./88, pp. 12-22.

${ }^{34}$ Cf. "O que o professor eficiente tem de especial", $n^{\circ} 31$, junho/89, pp. 28-9; "Sem afeto, não há alfabetização", n 32 , ago/89, p. 22-4.

${ }^{35}$ Cf. "A criança se constrói na pré-escola", n³3, set/89, pp. 24-5.
} 
orgânicos, corporais, afetivos e emocionais. Para que a aprendizagem ocorra é necessário que essas funções estejam em harmonia.36

O "bom professor" deve cuidar para que todas os aspectos ou funções implicadas na aprendizagem e no desenvolvimento da criança estejam em harmonia, devendo atentar sobretudo para os dois planos que no campo da psicologia costuma-se destacar e diferenciar: o cognitivo e o emocional/afetivo. Além do mais, o professor precisa "conhecer Psicologia do Desenvolvimento" ${ }^{37}$. Essa e outras exigências feitas ao professor - como respeitar o ritmo de cada criança e a sua forma natural de aprender, tornar a aprendizagem prazerosa, sempre considerando os seus gostos e interesses - na revista Nova Escola não eram novas. Entretanto, nesse ano, várias dessas exigências são feitas de modo mais claro sob aquele tipo de recorte (cognitivo/afetivo) e em matérias onde é citada Emilia Ferreiro. Além disso, essas exigências ficam nitidamente vinculadas ao perfil e à ação do professor qualificado de eficiente ou eficaz. São exigências que deverão confluir na definição do "ponto de equilíbrio" do professor construtivista, que na maioria dos casos é uma professora, pois trata-se basicamente de mulheres. Um professor/professora que aí já está sendo produzido quando the são endereçadas determinadas demandas, como conhecer a psicologia da criança e trabalhar tendo em vista o equilíbrio das várias dimensões do desenvolvimento infantil.

Nesses primeiros momentos, o professor não se encontrava sob a moldura que é própria do novo discurso pedagógico. Ao contrário da professora Bernadete, que surge sob esse enquadramento, representando nada menos do que a figura principal da Nova Escola. Ou seja: o objeto que preenche o vazio que a própria revista evidenciou, mas que também configurou, e que circulava ordenando boa parte dos discursos pedagógicos. Na rota desse vazio parece ter penetrado a palavra construtivismo, assim definindo um circuito onde todos os professores foram incluídos, com essa palavra sendo transformada no significante-mestre que daí em mais fixou a suas posições, isto é, o que eles eram, o que eles faziam e o

\footnotetext{
${ }^{36} \mathrm{O}$ texto acima citado é um trecho da entrevista dada por Marizinha Pimentel - "mistura de professora, pedagoga e psicóloga" - à revista Nova Escola. A matéria reduz-se à entrevista. Cf. "Sem afeto, não há alfabetização", n 32, ago/89, p. 22.

${ }^{37}$ Cf. "A criança se constrói na pré-escola", n³3, set/89, p. 25.
} 
que eles pensavam. Em outros termos, desse circuito onde circulava a falta emergiu o que faltava: a figura do professor construtivista.

Ao longo da década de 90, o professor tende a oscilar entre essas posições: entre afigurar a falta, como vazio, e "o que" faltava. Nesse intervalo, entre essas posições, foi criado o "caminho construtivista" ou, mais exatamente, o circuito do desejo de inúmeros professores. Esse circuito nasce com e sob essa ambivalência e em grande parte a mantém, porque dela própria se nutre. Essa ambivalência, essa oscilação entre os "erros" e o ideal, entre não ser nada e ser o que todos consideram essencial ("o bom professor") não concerne apenas ao registro que é próprio dos discursos brasileiros. António Nóvoa, por exemplo, refere-se à mesma questão:

Por um lado, os professores são olhados com desconfiança, acusados de serem profissionais medíocres e de terem uma formação deficiente; por outro lado, são bombardeados com uma retórica cada vez mais abundante que os considera elementos essenciais para a melhoria da qualidade do ensino e para o progresso social e cultural. (1999, pp. 134)

No Brasil, essa ambivalência tornou-se particularmente intensa, talvez tão intensa quanto o "abalo sísmico" (Corazza, 1994, p. 123) que o construtivismo parece ter provocado. É uma ambivalência nutrida por abismos históricos, por demandas que com o construtivismo recaem sobre o professor. Deste, exige-se que na sala de aula desate os grandes e históricos nós da educação pública, como é o caso do analfabetismo, que é o que se promete resolver com a chamada "nova proposta" de alfabetização.

Para evidenciar a magnitude desse contraste, dessa ambivalência que a posição do professor deve suportar, podemos colocar lado a lado duas capas da Nova Escola, duas capas que evidenciam esse contraste e que ao mesmo tempo confluem para configurar essa particular posição. A primeira é de março/90 e põe em destaque o "Analfabetismo. A vergonha nacional". A outra é de maio/92 e apresenta a imagem da conhecida "educadora gaúcha Esther Pillar Grossi", que "não tem a menor dúvida: o construtivismo pode, em pouco tempo, mudar o 
Brasil". ${ }^{38}$ Afinal, "Em matéria de alfabetização damos banho no Primeiro Mundo". Eis as imagens dessas duas capas:
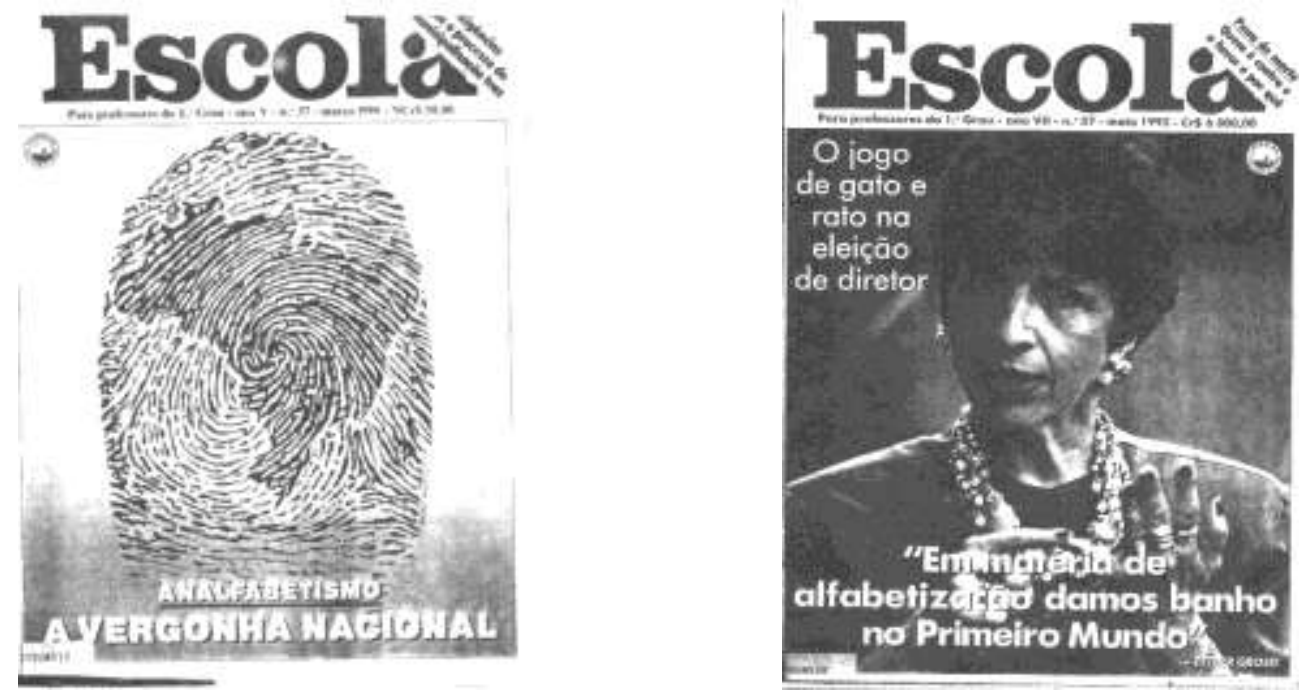

O "caminho construtivista" é estendido entre esses dois pontos: entre o abismo de um território sem as "primeiras letras" e um lugar que "em matéria de alfabetização" supera o que o Primeiro Mundo oferece, como se estivéssemos "além" dele. "As agruras do caminho construtivista" muito devem ao que se aninha nessas duas bordas, muito devem a "isso" que é criado sob a forma da "origem" e dos ideais. Vejamos agora em que consiste esse "caminho" em que o professor é o principal protagonista.

A reportagem em que a professora Bernadete é o destaque de capa já foi objeto de análise minuciosa por parte de Martha Vieira (1995). Da sua análise, bem como da própria matéria, serão retomados alguns pontos. Intitulada "As agruras do caminho construtivista", nessa reportagem são destacados alguns momentos e aspectos relativos à "radical mudança de postura" ${ }^{39}$ que todo professor teria de enfrentar para se tornar um construtivista, à semelhança da "professora-modelo" Bernadete. ${ }^{40}$ Essa mudança é descrita tendo como referência a experiência de três professoras e as práticas de alfabetização. Cada uma dessas professoras encontra-se num ponto dessa trajetória.

\footnotetext{
${ }^{38} \mathrm{O}$ trecho acima é do olho que sucede ao título da entrevista de Esther Grossi. Cf. "Em matéria de alfabetização damos banho no Primeiro Mundo", n 57, maio/92, p. 20.

${ }^{39}$ Expressão atribuída a Maria Leila Alves, da FDE. Cf. "As agruras do caminho construtivista", Nova Escola, n 65, abr./93, p. 8.

40 "Professora-modelo" é uma expressão usada por Vieira (1995, p. 52).
} 
Yolanda é a mais velha, com cerca de 50 anos, dos quais 23 trabalhou "usando métodos tradicionais" na alfabetização. Segundo a reportagem, ela "conta os medos que teve de superar em sua caminhada". ${ }^{41} \mathrm{O}$ que ela percorreu, porém, parece ter sido bem pouco, embora fundamental, pois precisou vencer o medo, as dúvidas, deixar de resistir e mudar de trilha, fazendo a ruptura necessária para começar, segundo ela, "esse caminho alternativo" (p. 14). De acordo com essa professora, que "viu e foi obrigada a crer nas virtudes de uma nova prática", "ainda hoje" está no "começo do caminho", um começo que nesse caso significa estar bem próximo do tradicional, conforme pode ser inferido do que é afirmado na matéria e do que as fotos sugerem (pp. 13-4).

Ana, 29 anos, "ainda caloura na estrada construtivista", parece estar um pouco à frente de Yolanda. Ela estava introduzindo o trabalho lentamente, ia observando os resultados e misturando "coisas do construtivismo com métodos tradicionais" (p. 12). "Não sei se posso dizer que já sou uma professora construtivista", afirma a professora, que também manifesta ter muitas dúvidas e acha todo esse processo cansativo e desgastante. Mas, ao mesmo tempo, "muito prazeroso também, porque você orienta a criança e ela sai fazendo, pensando. Além disso, muda você mesma. Eu estou mais crítica em relação à sociedade" ( $p$. 13). Conforme informa a matéria, Ana está exatamente nesta fase: "Um período difícil, em que a professora já não acompanha a cartilha, mas não tem segurança para agir de outro modo" (p. 9). Ela está "Tateando. Nem sequer se define como construtivista. 'O que é ótimo', segundo Marília Duran. 'Sinal de que ela fez um bom curso e sabe que está vivendo um processo"' (ibidem). Logo após essa fala, na qual Ana é apresentada como alguém que está tateando, que "não sabe nem reutilizar o que já sabia", comparece o significante espontaneísmo, como se essa professora o tivesse atraído ou convocado:

Parte da insegurança inicial das professoras que resolvem experimentar a mudança está numa visão equivocada que associa construtivismo a espontaneísmo. "As pessoas pensam que não há necessidade de planejamento. Que é só deixar a criança fazer o que ela quiser. Que não se ensina mais nada. Isso é um erro. Você tem de planejar, sim, tem de saber o que vai dar, os objetivos a serem atingidos, as atividades adequadas a esses objetivos. A psicologia apenas explica como se dá o processo. Não substitui o ensino", analisa Marília Duran.

\footnotetext{
${ }^{41}$ Cf. "As agruras do caminho construtivista", Nova Escola, n 65, abr./93, p. 13.
} 
Para ela, esse equívoco aconteceu porque no começo não havia nada publicado a respeito. "Era um aprendizado ali, na raça. Hoje temos várias publicações (...)

A existência dessas fontes de informação não impede, no entanto, que muitos façam delas mau uso. (p. 9)

Nesse texto, a rede discursiva amarrada ao significante-mestre espontaneísmo é ampliada um pouco mais, na medida em que se faz referência ao planejamento, aos objetivos, às "atividades adequadas" e a um lugar atribuído à psicologia que não the corresponderia: substituir o ensino. É uma fala que se situa em linha de continuidade com a defesa do professor que intervém e que tem de saber intervir adequadamente. Uma fala também que converge com outras que sublinham o valor do pedagógico, das questões didáticas, da metodologia e que vez por outra evidenciam certa tensão em face da psicologia. Tudo isso conflui para o que está no centro dessa reportagem: a postura do professor construtivista e a mudança implicada para alcançar o que podemos continuar chamando de "ponto de equilíbrio".

Das três professoras, Bernadete é a mais jovem e a única que chegou ao "fim do caminho". Ademais, é "a professora que virou tese", um enunciado que até mesmo poderia ser tomado ao pé da letra (p. 8). Afinal, ela encarna o construtivismo, a teoria que efetivamente encontrou uma prática adequada, realizando-se assim o ideal de uma ação educativa coerente, com a teoria vinculada à prática. Em outros termos, foi soldada a fissura que divide a matriz simbólica do discurso construtivista, que divide o seu significante-mestre, na medida em que o mesmo significante remete para a teoria e para a sua aplicação, esta em geral sujeita à ordem dos "desvios, confusões, equívocos ...". Por isso, o que Bernadete encarna concerne na verdade à concretização dessa sutura que liga teoria e prática.

A professora Bernadete é apresentada quase que como um produto do trabalho feito pela sua "fada-madrinha", Emilia Cipriano, que fez a sua "tese de mestrado" tendo como tema "a trajetória no caminho construtivista" da Bernadete (p. 9). E mais, durante dois anos, a acompanhou "em seus esforços para colocar na prática o que havia aprendido sobre o construtivismo em cursos de capacitação e na leitura dos livros recomendados nesses cursos" (p. 10). Bernadete é caracterizada como uma "professora dedicada e amorosa. Prisioneira 
do despreparo mas disposta a romper com as amarras e tentar o novo, discutindo e se rediscutindo a cada passo" (ibidem). Além disso, quando Emilia a encontrou, "ainda não cristalizara vícios, no se julgava dona da verdade, não se tornara apática" (ibidem). Emilia constitui uma espécie de assessora ou supervisora do trabalho da Bernadete, uma acompanhante imprescindível, pois "a viagem construtivista precisa de acompanhantes" (p. 11). Juntas, Emilia e Bernadete analisaram o trabalho feito com as crianças, definiram as atividades, realizaram leituras e discussões e desse modo, cada dia mais, "Bernadete podia confrontar o que lia com o que vivia na sala de aula" (ibidem). Mas isso não é tudo: "No contato que tiveram ao longo desses dois anos, Bernadete abriu para Emilia seus cadernos de anotações, sua mente e também o coração" (ibidem).

A hierarquia que a reportagem estabelece entre as três professoras, bem como o lugar destinado a cada uma delas, são também definidos pelas fotos. A esse propósito, vale a pena retomar as fotos que abrem a reportagem e que são colocadas lado a lado, com a professora Bernadete na primeira foto, seguida de Ana e, por último, Yolanda:
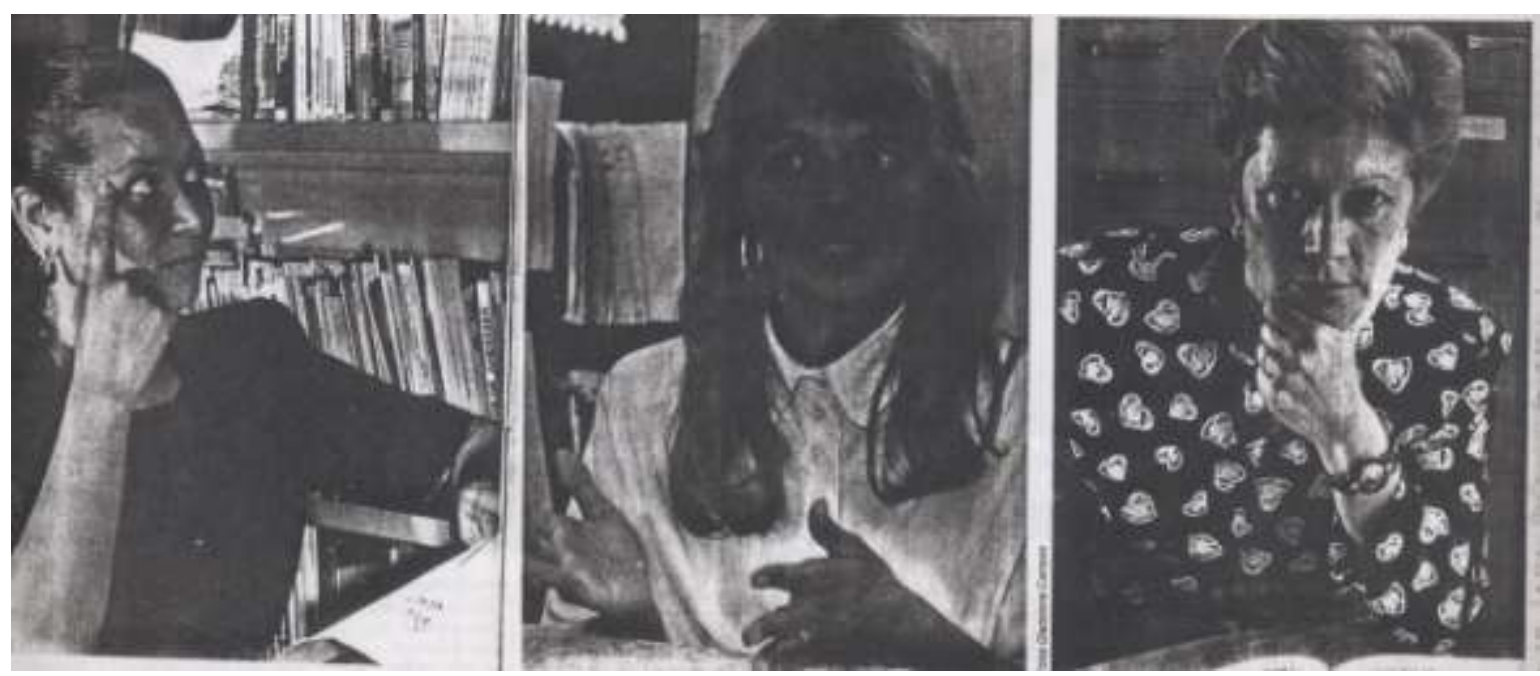

Os livros colocados no fundo da primeira foto correspondem a um elemento que obviamente é relevante no caso da Bernadete, a professora que leu, estudou, discutiu e que supostamente conseguiu assimilar a teoria ou parte dela, mas o suficiente como para ser considerada uma professora construtivista. No foto de Ana, que é a que fica entre a de Bernadete e Yolanda, é possível observar algumas estantes que ocupam parte do fundo da foto, do lado esquerdo. 
Aparentemente, nessas estantes foram colocadas algumas folhas ou um folheto, talvez alguns livros ou revistas. Digamos que por trás da sua imagem, a teoria apenas se insinua, ao contrário do que sugere a foto com a imagem da Bernadete, fortemente "sustentada" por várias prateleiras repletas de livros. Bernadete, aliás, apóia-se mesmo na estante e em uma de suas mãos segura uma folha de papel, como aponta Vieira (1995, p. 51). Além disso, "com ar pensativo"42, Bernadete está fazendo um sugestivo gesto com o dedo indicador, como para lembrar que ela é a professora que pensa, que reflete, que conhece a teoria, que está bem ali, na sua cabeça, mas também nesse ponto virtual aonde seus olhos se dirigem, ou seja, nessas prateleiras repletas de livros que se prolongam para além do que a foto mostra. A disposição dessas duas fotos, da Bernadete e da Ana, também sugere uma certa continuidade entre ambas, com as prateleiras que sustentam Bernadete como que prolongando-se por trás da imagem da sua colega, que ainda está no início da "caminhada". É para essa direção que aponta o olhar da Bernadete, com seu gesto por demais sugestivo.

E Yolanda? Na sua foto não apenas não há livros como há um sugestivo conjunto de gavetas, bem atrás da sua cabeça. Por que essas gavetas? O que elas sugerem? Digamos que as gavetas estão no lugar dos livros da Bernadete, que é a "professora-modelo". Relacionando-as com o perfil que a reportagem traça da professora Yolanda e com o que o fundo das outras fotos sugerem, não seria arbitrário lembrar das articulações discursivas que o significante "gaveta" conclama quando utilizado pelos críticos do ensino tradicional. Seguindo essa via, poder-se-ia dizer que essas gavetas estão como que insinuando, talvez, como essa professora pensa ou, então, como concebe a mente ou o intelecto da criança, ou seja, como "um armário cheio de gavetas vazias que precisam ser preenchidas, uma a uma", de acordo com o enunciado aqui já reproduzido e que concerne a um tipo de crítica vez por outra dirigido ao ensino tradicional. ${ }^{43}$

\footnotetext{
42 Ibidem.

${ }^{43}$ Cf. "Como trabalhar o erro", Nova Escola, n 60, set./92, p. 11. Na análise das fotos foram aproveitados alguns elementos já destacados por Martha Viera. Ela menciona a presença dos livros no caso da imagem da Bernadete e as sua ausência no fundo das outras duas, além da hierarquia que as fotos sugerem (1995, p. 51).
} 
As outras fotos contribuem para reafirmar a mesma hierarquia, ${ }^{44}$ acrescida pelas profissionais que parecem estar um ou vários degraus acima dessas professoras, como "a fada-madrinha da Bernadete" e algumas das responsáveis pela "implantação do construtivismo na rede paulistana", dentre elas Telma Weisz. Em face dessas profissionais ou especialistas, o "fim do caminho" da Bernadete parece constituir apenas um primeiro nível, aquele que concerne à prática pedagógica ou à efetivação da teoria. ${ }^{45}$

De tudo isso, das convergências que os enunciados e as imagens criam, aqui importa reter a temporalidade evolutiva que novamente comparece nessa reportagem. Agora para definir a trajetória da professora que se torna uma construtivista. Essa trajetória implica várias dimensões e aspectos e pode ser caracterizada de diversos modos. A própria matéria enumera as várias "lições" que Bernadete aprendeu, seus "movimentos de mudança de postura" e os "obstáculos" que teve de enfrentar e vencer. Sublinha, ademais, que Bernadete "percorreu todos os passos", que também são listados. Vieira (1995), baseada no que a reportagem destaca, discrimina e caracteriza a seu modo algumas etapas desse "caminho construtivista" e mostra a sua semelhança com a "conversão religiosa". Esses momentos também podem ser situados pondo no centro da análise os lugares relativos aos pontos de ressonância que estruturam e sustentam o novo discurso pedagógico. E que, como veremos, podem ser aproximados das etapas discriminadas por Vieira e dos lugares que a reportagem tende a destinar a cada professora.

Yolanda está mais próxima de uma professora tradicional e do início da "caminhada", que corresponde à etapa que Vieira caracteriza como de "descrença e resistência" (1995, p. 47). Ana já avançou nesse "caminho construtivista", mas não muito e o seu perfil tende a confundir-se, em alguns pontos, com o perfil da Yolanda. Além disso, a "fase" em que Ana se encontra tende a ficar implicitamente

\footnotetext{
${ }^{44}$ Essa hierarquia é confirmada por outras duas fotos e pela ausência de uma terceira. De um lado, as fotos de "Bernadete e Ana Menezes, com seus alunos, em sala de aula, 'colocando em prática' o 'construtivismo'" (Vieira, 1995, p. 52); de outro, a inexistência de uma outra foto com a professora Yolanda. A sua prática, como indica Vieira, "ainda não merece ser fotografada e destacada como modelo" (ibidem).

${ }^{45} \mathrm{Na}$ revista Nova Escola, essa hierarquia chega mesmo a se tornar mundial, com as suas "autoridades" devidamente hierarquizadas: "A psicóloga argentina Liliana Tolchisky ocupa o terceiro lugar na hierarquia mundial do construtivismo, abaixo de Emilia Ferreiro e Ana Teberosky". Cf. "Progresso com os números", n 87 , set./95, p. 56.
} 
vinculada aos professores que, tendo uma "visão equivocada", associam construtivismo a espontaneísmo. Ana, que poderíamos chamar de professora espontaneísta, se aí acentuarmos alguns elementos que nela tendem a convergir, pode ser situada na segunda etapa das três que Vieira discrimina ao assemelhar o "caminho construtivista" à "conversão religiosa": a fase das "dúvidas, dificuldades e críticas dos que não optaram pelo mesmo 'caminho'" (ibidem). E, finalmente, a professora construtivista, que passou por todas as etapas e cujo último passo é este: "a conversão total e a certeza da escolha" (ibidem). Essas três etapas também são referidas por Vieira de um outro modo. Antes: "dúvidas, resistência e descrença". Durante: "insegurança, dificuldades e obstáculos". Depois: "prazeres e compensações" (1995, p. 46).

Os lugares que a reportagem configura para as três professoras tendem a ficar sob a esfera de influência dos três pontos de estrutura do novo discurso pedagógico: construtivismo, espontaneísmo e escola tradicional, havendo aí uma correspondência termo a termo entre cada professora e cada um desses pontos de ressonância. Quanto à análise de Vieira, pode ser afirmado a mesma coisa em relação às etapas que ela discrimina, sobretudo as que foram apresentadas por último. Ainda sobre a minuciosa análise de Vieira, é curioso que não tenha feito qualquer menção ao trecho da matéria onde se faz uma advertência sobre o equívoco de associar o construtivismo ao espontaneísmo. A autora apenas ressalta "a dicotomia BEM/MAL" operada na matéria ao classificar a prática pedagógica em tradicional e construtivista, aproximando essa operação discursiva do discurso religioso (1995, p. 48). O significante que na sua análise the escapa, junto com o lugar que ele demarca, coincide com o ponto por onde o discurso construtivista parece "pegar" a própria autora, que no fim da sua análise critica o professor que tem uma prática espontaneísta (ibidem, p. 54). Digamos que Vieira tende a situar-se no lugar que é próprio da vertente dominante do novo discurso, com seus três pilares. Os três pilares que sustentam e ordenam todos os discursos educacionais e/ou pedagógicos sob a hegemonia do discurso construtivista, inclusive este trabalho, pelo menos em parte. Afinal, o que aqui está sendo analisado é precisamente esse discurso.

Na mudança de postura necessária para ser um "bom professor", para ser um "professor construtivista", para ter uma "prática eficiente", ainda é necessário 
destacar alguns elementos que na reportagem acima analisada são fundamentais e que justificam a aproximação que Vieira faz com o discurso religioso. Esses elementos ficam mais nítidos na trajetória da professora Bernadete e concernem à sua "profunda transformação", ao "caminho sem volta" que teve de percorrer. Um caminho "longo, pedregoso", mas no qual "as agruras são compensadas": "conseguir chegar ao fim do caminho é, para um professor construtivista, uma recompensa forte e emocionante". 46

A "radical mudança de postura" da professora Bernadete e tudo o que esse processo implicou é destacado no primeiro e maior box da reportagem, intitulado "Bernadete, suas angústias, por ela mesma". Nesse box são apresentadas as anotações das "suas angústias", feitas por ela "durante todo o processo de descoberta do que seria uma prática construtivista" (p. 10). Eis alguns trechos:

"Estou sofrendo muito. Nunca imaginei que seria assim. Minha cabeça dói muito, às vezes chega a me impedir de estudar, de refletir mais profundamente a minha prática e as leituras que tenho que fazer (...)"

"(...) E achava que estava sendo construtivista. O pior era isso. Tinha medo, mas me tornei corajosa. A prova é estar aqui agora, contando tudo isso. A princípio eu era incrédula (...) Não conseguia ver as crianças como indivíduos, a diversidade de idéias, não sabia que poderia trabalhar com isso. Não sabia ouvir a fala da criança. (...)"

"(...) As crianças descobriam, eu descobria as crianças e descobria a mim mesma. A angústia andava comigo o tempo todo. $\mathrm{E}$ era bom, porque essa angústia, na realidade, era o conflito que eu estava vivendo. $E$ ia mudando inclusive minha aparência física. Melhorando, segundo colegas. Elas dizem que mudou primeiro o olhar. (...)

"Hoje eu sei que estou mais solta, sempre querendo fazer. Até na minha questão pessoal, amorosa, mudou muito. (...)

"(...) Este caminho não tem volta. A minha visão do mundo, hoje, é outra". (pp. 10-1)

O que a professora Bernadete fala, o que a própria matéria destaca e cria ao delinear as trajetórias das três professoras, certamente pode ser aproximado da "conversão religiosa". Esse viés religioso advém sobretudo com o significante "caminho", que, como já vimos no capítulo anterior, foi bem nutrido pelos discursos pastorais. Sem contar o sentido religioso presente "no discurso da educação de um modo geral", como lembra Vieira, com a "visão do trabalho do professor como 'missão', como 'apostolado'" (1995, p. 54). Entretanto, também é

\footnotetext{
${ }^{46}$ Cf. "As agruras do caminho construtivista", Nova Escola, n 65, abr./93, pp. 8 e 14.
} 
possível fazer uma outra leitura, uma leitura que não banalize ou desqualifique as várias falas que constroem esse texto. Como ocorre quando se considera que esse tipo de falas baseia-se tão-somente em slogans e que, ademais, deforma ou distorce o construtivismo, como argumenta Vieira em alguns momentos, em prol da ciência e de um suposto construtivismo não deformado ou distorcido. ${ }^{47}$

Para começar, poderíamos partir da seguinte pergunta: o que é que está em jogo nessa mudança que seria própria do "caminho construtivista"? O que está jogo nesse "caminho" certamente envolve uma mudança na posição subjetiva, que atinge o ser professora, mas sobretudo o ser do sujeito, o seu desejo. Daí a angústia, tanta angústia, dor de cabeça e sofrimento. Muda a "aparência física", o olhar, a "questão pessoal, amorosa", a sua "visão do mundo". E esse "caminho não tem volta".

Afinal, como é esse "caminho"? Por onde ele conduz? O que ele promete? Aqui também podemos dar várias respostas, ler o mesmo texto de várias formas. Uma via possível é pensar esse "caminho" a partir da ambivalência já referida em relação à posição do professor. Em sua direção, como vimos, tendem a convergir abismos históricos (fracasso escolar, analfabetismo, pobreza, etc.), nele sendo articulada a gigantesca promessa de resolvê-los. O "caminho construtivista", apesar do caráter processual que a mudança de postura supõe em algumas falas, encontra-se sujeito ao que é da ordem desses extremos, ou melhor, da forte diferença de potencial que entre eles existe: entre o lugar dos "desvios, confusões e equívocos ..." (as posições iniciais de Yolanda e Ana) e a encarnação do ideal (a professora Bernadete). Sob essa forte tensão encontra-se o professor que quer se tornar um construtivista.

É possível também fazer uma outra leitura, como a que agora realizaremos, mas sempre mantendo o vínculo que nesta tese é essencial, ou seja, o vínculo com os pontos de ressonância do discurso construtivista. Eles são a nossa estrela-guia. Por isso, quem deverá orientar-nos para continuar interrogando esse "caminho" é a criança, que tanto aparece na fala da professora Bernadete e em alguns momentos da reportagem.

${ }^{47}$ A esse propósito, veja-se o primeiro capítulo deste trabalho. 
Para percorrer a "estrada do construtivismo", Bernadete precisou se aproximar da criança, ir em sua direção, até mesmo assemelhar-se com ela, encontrar a criança em si própria, no seu ser: "eu descobria as crianças e descobria a mim mesma". O novo que a Bernadete procurava, mas que também concerne ao lugar que o construtivismo configura e ocupa, está nessa criança, é essa criança. Bernadete, segundo a reportagem, "Construía o novo, que na verdade era olhar e ver a criança" (p. 12). Ela própria passou por esse lugar para se transformar, para transformar a sua prática. $O$ "seu primeiro movimento de mudança de postura" foi justamente "deslocar o como se ensina para o como se aprende" (p. 11). A sua mudança de postura implica e é simultâneo a esse olhar dirigido em direção à criança, não apenas os seus alunos, mas ela própria, como criança. Bernadete fica "mais solta, sempre querendo fazer", passando também a construir e reconstruir seus conhecimentos. De certo modo, a professora construtivista torna-se semelhante à criança construtivista. Uma criança que não tem medo de errar, como parece ser o caso da Bernadete, que se tornou corajosa, talvez porque também perdeu o medo de "errar". Ou seja, ela finalmente delimitou o seu lugar, com a moldura apropriada, a mesma que a da sua "fadamadrinha" Emilia Cipriano.

Por essa via, aproximando-se da criança, Bernadete chegou ao "fim do caminho", um caminho que acena com esse feliz (re)encontro do professor com seu aluno, do adulto com a (sua) criança, da mulher com a (sua) criança. Essa é uma das promessas que tanto seduz, a mais exposta e talvez a menos visível, mas não por isso irrelevante, muito pelo contrário.

Esse (re)encontro parece produzir, de fato, "profundas transformações" ${ }^{48}$, mesmo que tenha ocorrido por alguns instantes. E tudo indica que a "felicidade" da Bernadete e das outras professoras advém desse (re)encontro e seus efeitos, sobre elas próprias, as suas práticas em sala de aula e seus alunos, que também se transformaram. Um (re)encontro que, podemos supor, prolonga-se no dia-a-dia da sala de aula: "as agruras são compensadas pela felicidade de estar caminhando junto com seus alunos" (p. 8). Esse é o "fim da caminhada" feita pela professora que se tornou "uma construtivista", uma professora que já pode

\footnotetext{
${ }^{48}$ É desse modo que a reportagem se refere às transformações ocorridas nas professoras que mudaram de postura.
} 
caminhar sozinha. Afinal, já está junto com seus alunos, junto com aqueles que de certo modo são seus guias: "'Descobrimos que já não éramos tão necessários. Ela caminhava sozinha. Ela e seus alunos"'. Isso é afirmado na última frase da matéria, que reproduz a fala de Emilia Cipriano, a sua "fada-madrinha", ${ }^{49}$ a fada que realizou o desejo da Bernadete e, certamente, o dela própria.

Tudo o que envolve essa mudança de postura e que passa pelo significante criança em muito extrapola a educação e a escola. No discurso construtivista, porém, os sentidos e a amplitude dessa mudança tendem a ficar encerrados no circuito definido pelo seu significante de arremate, que tudo faz confluir em si próprio. Na revista Nova Escola, isso ocorreu no momento em que emergiu o significante construtivismo, quando as mudanças de postura começaram a ser atribuídas às "idéias" de Emilia Ferreiro. ${ }^{50}$ Desse modo, por meio da inversão implicada nessa operação discursiva, foi criado um amplo terreno de ancoragem para o discurso que então estava se configurando. Assim foi também produzido um forte obscurecimento dos sentidos e da amplitude das transformações culturais que vinham se processando com intensidade desde a década de 70 e conservando certo sentido político ainda nos anos 80 . Um apagamento que é simultâneo ao desaparecimento do significante de arremate alternativa.

O "marco inaugural" dessas transformações concerne aos "anos 60". Mas, obviamente, é possível recuar indefinidamente; se desprezarmos, é claro, o forte questionamento das instituições que ocorre nessa década, em vários países simultaneamente, bem como os nós ou pontos de basta que então ou desde então são (re)produzidos em inúmeras falas, como "anos 60" e "1968". Em outras palavras, a "radical mudança de postura" concerne a certas dimensões e valores da cultura contemporânea relacionados com as transformações culturais implicadas nesses pontos de ressonância, consideradas aí as inflexões que ocorreram desde aquele período. Se hoje é possível dizer que a escola não é mais a mesma, se comparada com a escola de algumas décadas atrás; ou então, se é válido afirmar que ela está passando por profundas transformações, a ponto de estar surgindo uma Nova Escola Moderna; tudo isso decorre primeiramente desse conjunto de transformações de ordem cultural - não desvinculadas de

\footnotetext{
${ }^{49}$ Esse é o qualificativo que a própria reportagem usa ao falar de Emilia Cipriano (p. 14).

${ }^{50}$ A esse respeito, veja-se o capítulo anterior.
} 
outras (sociais, políticas, econômicas) - e não exatamente dos efeitos da rede conceitual que o discurso construtivista, em suas várias versões acadêmicas, costuma definir e utilizar. Dito de um outro modo, mas agora pondo no centro o professor: se "o professor construtivista tem uma outra razão de viver", como afirma Esther Grossi, ${ }^{51}$ não é propriamente uma decorrência da "teoria revolucionária" que o significante construtivismo evoca - uma teoria que em certas falas é considerada "revolucionária" porque "dá voz sobretudo às crianças mudas e tímidas das classes pobres do Terceiro Mundo". ${ }^{52}$ A procedência ou "origem" dessa "outra razão de viver" deve ser procurada em outro lugar. Essa "outra razão" e esse outro lugar concernem a uma mudança de "posição no mundo" relacionada primeiramente com tudo o que o significante construtivismo sobrepuja e não costuma deixar à vista, porque escoa pelas regiões que ficaram interditadas e esquecidas.

A criança está no coração dos discursos modernos. Conhecer, caracterizar e valorizar o universo infantil, reencontrar a criança que supostamente está em cada adulto, enfim, aproximar-se da criança é um empreendimento que tem um lastro de décadas e até mesmo séculos. Além disso, configura-se de diversas maneiras, em várias teorias, discursos e movimentos que tiveram impacto no campo educacional. O discurso pedagógico construtivista situa-se, obviamente, em linha de continuidade com tudo isso. Na revista Nova Escola, no período anterior à emergência do discurso construtivista, essa aproximação em direção à criança é freqüentemente evidenciada e valorizada, por vezes sendo clara e expressamente relacionada com a mudança de postura do professor e também dos pais. Em algumas reportagens sobre cursos de treinamento e capacitação de professores, por exemplo, a mudança de postura implica e supõe que o professor tenha de liberar "a criança que cada um de nós tem dentro de si", como se afirma numa reportagem. ${ }^{53}$ Uma mudança que passa pelo corpo, como Bernadete deixou registrado em suas anotações e como fica em evidência em outras matérias da Nova Escola. Por exemplo, em fotos como esta:

\footnotetext{
${ }^{51} \mathrm{Cf}$. "O papel do professor que trabalha o interesse e o prazer", Nova Escola, n 56, abr./92, p. 48.

${ }^{52}$ Cf. "As agruras do caminho construtivista", n 65, abr./93, p. 8.

${ }^{53}$ Cf. "Oficinas de leitura mudam a prática de educadores populares", Nova Escola, $n^{\circ} 71$, nov./93, p. 44.
} 


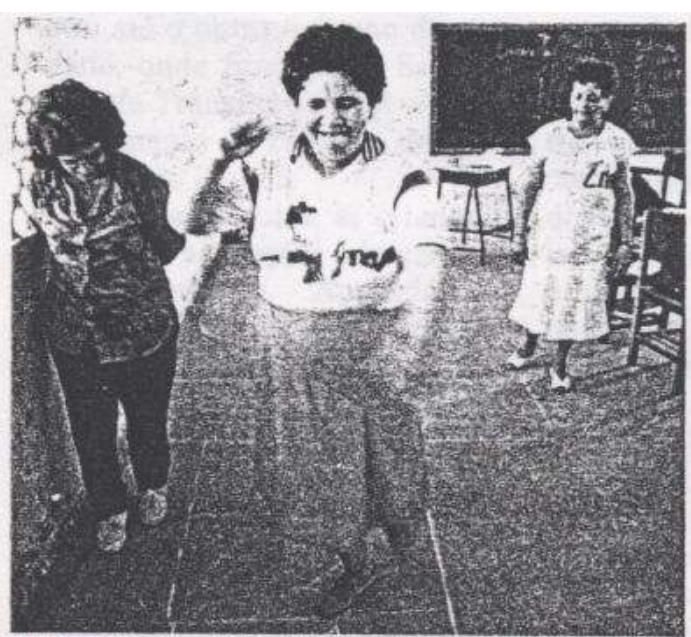

No jogo da amarelinha, ela aprende que reciclagem pode...

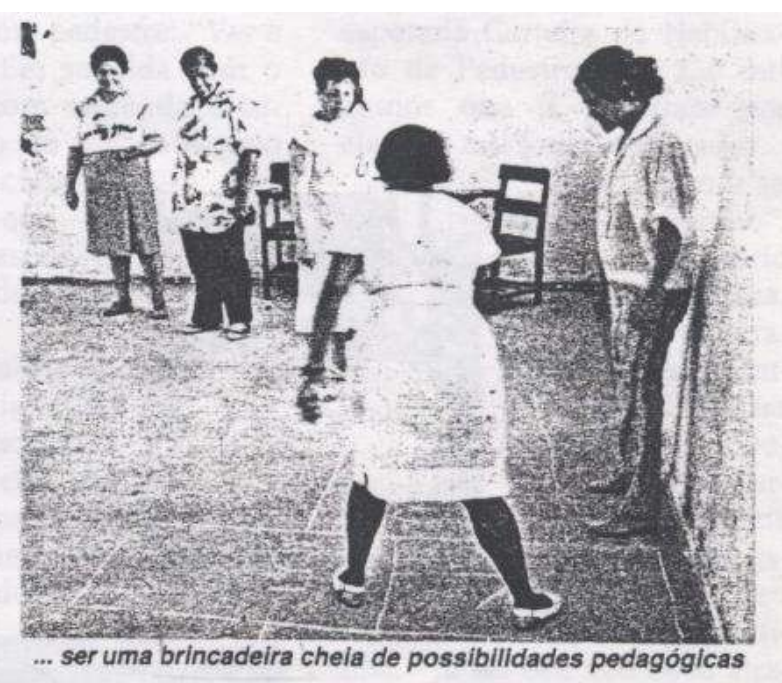

Essas fotos são de uma reportagem de agosto/87, sobre um projeto de treinamento ou reciclagem de professores que começavam "a integrar-se ao Ciclo de Alfabetização" implantado pela prefeitura de Recife nas escolas municipais. ${ }^{54}$ Em relação a esse projeto, nenhuma teoria ou autor é mencionado, não há qualquer referência teórica. Mencioná-las, nesse período, não era importante. As "senhoras" ou professoras que aparecem nas fotos participavam desse projeto de treinamento comparecendo às reuniões "para dançar, cantar, pular amarelinha, brincar com tampinhas de garrafa ou jogar prosaicas bolinhas de gude. Parece até um grupo de crianças" (p. 56). Esse tipo de treinamento é justificado porque as brincadeiras "são uma maneira de levar o professor a conhecer, na prática, o tipo de atividade que ele apresentará a seus alunos na semana seguinte" (p. 56). Mas o que aí também parece estar em causa é a postura dessas "senhoras", das quais talvez espera-se que fiquem mais soltas, descontraídas, flexíveis e com um bom "jogo de cintura".

Esses são alguns dos elementos que desde os primeiros números da Nova Escola definem a postura dos professores e que surgem em diversas matérias, aí incluídas as fotos. Nestas, os professores, em geral professoras, costumam aparecer misturadas às crianças, num "clima" que parece descontraído, num espaço físico que deixa transparecer certo desordem, com as carteiras agrupadas de diferentes maneiras, com crianças que se mostram participativas, falantes, em pé, sentadas, andando. Tudo de uma forma "natural", em atividades realizadas

${ }^{54}$ Cf. "Professores estimulados melhoram o ciclo básico", Nova Escola, n 14, ago./87, pp. 56-60. 
com prazer e sem constrangimentos, conforme costuma ser sugerido ou insinuado no corpo das matérias ou nas legendas das fotos.

Por meio desse movimento de aproximação do adulto em direção ao universo infantil é definida boa parte dos traços da postura do professor construtivista. Traços que vinham sendo delineados antes de emergir o novo discurso, que é o que afinal os absorve e lhes dá um novo sentido: o do "caminho construtivista". Se recuarmos no tempo, seguindo a trilha do significante postura, com certeza depararíamos com esse amplo leque de discursos e práticas educacionais onde se imbricavam os mais diversos questionamentos de natureza política, cultural e social. A criança que comparece nesses discursos certamente não é a mesma que os construtivistas procuram e isso concerne à torção que o novo discurso introduz. No construtivismo, aproximar-se da criança ou conhecer a criança supõe e implica, primeiramente, conhecer a teoria ou teorias construtivistas. Ou seja, o adulto aproxima-se das crianças utilizando sobretudo o filtro e o "caminho" que a psicologia fornece. A criança é recortada com esse gume: conhecer a criança é conhecer a teoria, especialmente tudo o que se relaciona com "a criança que constrói seu próprio conhecimento", a começar pela psicologia genética - o principal substrato teórico e científico do construtivismo. Mas não é só isso, pois se assim o entendermos, teríamos que ignorar o amplo (re)ordenamento discursivo que ocorre sob a égide do significante construtivismo.

Na revista Nova Escola, a mudança de postura não é privativa do "caminho construtivista", ou seja, nem sempre fica encerrada na moldura que ele estabelece, até mesmo no início da década de 90. Há matérias, sobre temas diversos e com um discurso que está muito mais próximo da educação popular, que apresentam articulações discursivas semelhantes às que definem as transformações da professora Bernadete. É o caso de uma reportagem de novembro/92, intitulada "Quem foi que disse que democracia é fácil?". No olho que sucede ao título, o leitor já é alertado que "As tarefas são muitas, dão trabalho, exigem disposição e jogo de cintura" (p. 42). A questão principal da matéria é "como se constrói a democracia". Várias experiências são brevemente descritas. Uma delas, a primeira a ser destacada, é sobre uma escola municipal paulistana onde foi realizada uma agitada eleição do "novo coordenador pedagógico", com a participação dos professores, alunos e pais. Basicamente, a 
matéria refere-se ao processo de implantação dos Conselhos de escola ou Colegiados, como são chamados em Minas Gerais. Para tratar desse temática, a matéria recua até o final da década de 70 , quando na "esteira da luta mais geral da sociedade pela democratização", associações ou sindicatos de professores levantavam "a urgência da abertura da escola para a comunidade e a necessidade da democratização de suas relações e instâncias de poder" (p. 43). Junto com a democratização, na época também estava em pauta, lembra a reportagem:

(...) a conquista da autonomia da escola - através, entre outras coisas, da eleição dos diretores, do reavivamento dos grêmios estudantis e da formação dos Conselhos de escola - como algumas das condições fundamentais para a melhoria da qualidade de ensino.

Hoje, algumas dessas reivindicações estão se transformando em realidade em unidades escolares de redes municipais ou estaduais de ensino de vários Estados do país, conseguindo se firmar aos poucos e mudar a face dessas escolas. Engana-se, porém, quem pensa que vencer resistências, romper muros ou pôr abaixo portões cerrados são coisas tranqüilas ou lineares. Ao contrário, são tarefas trabalhosas e feitas de muitos avanços e recuos. (ibidem)

Como se observa nesse trecho, o início do "caminho" surge sob a mesma feição que é própria do discurso construtivista. $E$ isso continua a ser reforçado ao longo da reportagem. No processo da escola municipal já referida: "o caminho de construção de um Conselho atuante foi tortuoso e cercado de armadilhas". E em outras escolas da rede paulistana foi ainda mais difícil, pois "não conseguiram fazer deslanchar os Conselhos de escola" (ibidem). Entre outras coisas, menciona-se a resistência de diretores e professores, seus temores e idéias preconcebidas e a inexperiência de alunos e pais. Outras experiências são também mencionadas, como as desenvolvidas nas escolas da capital mineira, onde a secretária da Educação do município "reconhece que os Colegiados dão margem para que despontem as posturas mais democráticas e as mais autoritárias. 'Mas é nesse embate que as pessoas se educam', diz" (p. 46).

Nessa reportagem não existe qualquer referência explícita ao construtivismo, embora, é claro, poder-se-ia dizer que as experiências mencionadas e os projetos em curso, nas prefeituras citadas, já se encontravam sob o seu influxo. De qualquer modo, o que interessa ressaltar é a presença de articulações discursivas que definem transformações de diversas ordens e que, 
em outras reportagens, demarcam com nitidez o que passa a ser reconhecido como o "caminho construtivista", neste sendo encerrada toda e qualquer transformação que adquire um sentido positivo. No caso dessa reportagem, o que primeiramente encontra-se implicado é o significante-mestre democracia, com o significante postura constituindo um elemento secundário. ${ }^{55}$

Um outro exemplo é uma reportagem de novembro/93, com um discurso que ressalta elementos típicos da educação popular. Um discurso onde nem a ciência nem qualquer teoria ou autor são convocados para justificar ou legitimar as experiências que são apresentadas. ${ }^{56} \mathrm{~A}$ matéria trata de "uma rede de escolas informais" que atende "crianças pobres" de Vitória (ES) e de cidades do interior de Minas Gerais. Crianças em idade pré-escolar, que a cada dia ficam "na casa de algum membro da comunidade", e outras na faixa dos 7 aos 15 anos. São dois projetos desenvolvidos por "uma instituição não-governametal, o CPCD — Centro Popular de Cultura e Desenvolvimento". É especialmente destacada a experiência desenvolvida na cidade de São Francisco, em Minas, em parceria com o poder municipal, que paga os educadores. Ao longo da matéria, fala-se da participação da comunidade, o contraste em relação ao que é feito na rede oficial de ensino, a luta "contra os preconceitos que surgem, tanto por parte da escola regular como da comunidade" (p. 38), e a preocupação com a desnutrição, a saúde e a higiene das crianças, às quais procura-se passar algumas noções a esse respeito. 0 trabalho é feito de uma forma lúdica e alegre, com muitas brincadeiras utilizadas para que as crianças aprendam, com ênfase na dimensão coletiva, exercitando a socialização e a organização do grupo de crianças, que conversam, discutem, participam. "Todos falam, dentro de uma relação de igualdade e de democracia" (p. 34). A "cultura popular fornece os conteúdos trabalhados" (p. 35) e as crianças são também iniciadas no processo de alfabetização, que inclui elementos que podem ser considerados próprios das novas propostas de alfabetização, mesmo que não seja feita qualquer referência explícita a esse propósito.

\footnotetext{
55 A postura democrática e a democracia são pontos significantes do discurso construtivista que também alavancaram a sua emergência. Ademais, como veremos mais adiante em Becker (1993, 1994b), a postura democrática tende a se confundir com a postura construtivista. E é claro que aí o significante democracia e o que ele condensa são sobrepujados pelo construtivismo, que por essa via também nutre e fortalece o seu "ponto de equilíbrio".

${ }^{56}$ Cf. "São Francisco. As sementes plantadas às margens do rio", n 71, nov./93, pp. 32-8.
} 
Num dos box da reportagem, intitulado "Uma cuidadosa preparação dos educadores", destaca-se as mudanças pelas quais eles passaram em decorrência da sua participação nos projetos do CPCD — "uma experiência rica tanto para as crianças quanto para os educadores" (p. 36). Eis alguns trechos:

(...) Rosália Maria Alves de Oliveria, que trabalha no CPCD há dois anos e meio, conta que, quando entrou, a primeira coisa que the veio à cabeça foram as perguntas: "Cadê o giz?", "Cadê o quadro-negro?". Com o tempo, foi descobrindo que o professor tem de ser um provocador, alguém que incentive os alunos a pensar, falar e resolver as questões propostas. Ela diz: "Tudo isso mudou a minha cabeça e até a minha vida com os meus dois filhos. Antes eu achava que tinha que dar uns tapas para conseguir as coisas deles. Não sabia da importância da conversa. (...)

O que os educadores contam é que o processo de mudança tem sido difícil, doloroso até, mas também muito gratificante. Sônia Aparecida Alves de Araújo, quatro anos de magistério, lembra: "Eu dava aulas na roça e nunca tinha ouvido falar em educação popular. Quando comecei, ficava sem saber como agir com os meninos 'atentados'. Eu não podia dar castigo para eles e não sabia conversar. Foi muito difícil no início. Hoje, sinto que esse trabalho fez com que eu mudasse muito como pessoa". Outra educadora, Geane Gomes de Araújo, diz que o mais difícil para ela foi aprender a se relacionar com a comunidade. E Marciene Chaves Lima acrescenta que aprendeu, entre outras coisas, a questionar. "A gente cresce, porque o projeto provoca o tempo todo." (ibidem)

Como se vê acima, o que essas educadoras ou monitoras aprenderam concerne a diferentes lugares, em nenhum caso o essencial passa pelo conhecimento de determinada teoria e sequer é usado esse significante, mesmo quando no box se fala do "trabalho sistemático" promovido pelo CPCD para preparar as professoras. Elas fazem uma "reciclagem" duas vezes por ano, quando "discutem textos de educação e participam de palestras e atividades sobre saúde, alimentação, literatura infantil e alfabetização, por exemplo" (ibidem). As educadoras também se reúnem semanalmente para fazer avaliação e planejamento, participam de um seminário mensal, assistem filmes que procuram relacionar com o trabalho e fazem registros semanais anotando tudo aquilo que realizaram. Ademais, "Existe o Bornal do Livro. Uma vez por mês, as professoras recebem um bornal", isto é, uma bolsa contendo duas revistas (Nova Escola e Superinteressante) e um livro, "que pode ser tanto de literatura como de temas variados, como reforma agrária, educação etc." (p. 37). Depois, numa reunião, contam informalmente para as colegas o que leram e aprenderam. 
Embora sejam empregadas algumas das articulações discursivas próprias do "caminho construtivista", a transformação das educadoras delineada nessa reportagem não é encerrada no molde que é próprio desse caminho. As educadoras mudaram muito, não apenas no seu trabalho. Elas agora parecem situar-se de um outro modo, na sua própria vida. Uma das referências dessa mudança, antes implícita do que explícita, é a educação tradicional - um dos pontos de ressonância do novo discurso, mas também de outros. Para ser o "caminho construtivista", nessa mudança parecem faltar as costuras que são próprias dos outros dois pontos de estrutura, que são dois pontos que se recobrem: aquele que define a "origem" e aquele que estabelece o que é da ordem dos ideais, ou seja, "o ponto de equilíbrio".

\subsection{A vara no ponto de equilíbrio}

Construtivismo é o ponto de basta que cria o novo discurso pedagógico, a nova matriz simbólica. Esta, porém, para ser concluída também exige a (re)utilização do significante-mestre espontaneísmo e outros significantes equivalentes, necessários para definir o lugar do novo discurso pedagógico e a "origem" do "caminho construtivista". Uma vez estabelecida essa "origem" e por meio da ordenação temporal aí implicada é parcialmente enquadrada a crescente proliferação de teorias, autores, linhas, propostas, projetos, escolas, práticas, posturas e tudo o que fica ao abrigo do significante-mestre construtivismo. Esse enquadramento tende a ser reforçado e reatualizado toda vez que essa agulha é utilizada, mesmo que implicitamente. E dessa forma são também acentuados os seus efeitos. Um deles consiste em ter inscrito o fracasso escolar numa outra rota. Uma operação discursiva nutrida pelos que criticam o construtivismo, mas também pelos que assumem a sua defesa.

Isso, na verdade, já vinha ocorrendo pelo menos desde o início dos anos 80, mas sem qualquer relação com o "caminho construtivista", que sequer existia. Lembremos a esse propósito de Saviani (1984) e a sua pedagogia dos conteúdos, quando o "aligeiramento do ensino" é atribuído a tudo o que é situado em linha de continuidade com a chamada Escola Nova, como os discursos renovados e alternativos. E Guiomar Namo de Mello (1981), quando também critica os "métodos não diretivos" ou os métodos que ela prefere chamar de espontaneístas. Nesse momento, nesse discurso, o fracasso escolar já estava mudando de trilha, 
na mesma medida em que se avalia que as crianças fracassam porque a escola e os professores não ensinam, ou melhor, não transmitem os conhecimentos que a Escola Tradicional sempre teria colocado em primeiro lugar, os chamados conteúdos, o saber sistematizado e acumulado pela humanidade. Na pedagogia dos conteúdos assume-se a defesa da Escola Tradicional, mas apenas para curvar a vara para o outro lado, pois desse modo julga-se que pode ser alcançado "o ponto de equilíbrio", entre a Escola Tradicional e a Escola Nova, conforme é possível inferir da argumentação de Saviani quando se refere à "teoria da curvatura da vara" (1984, pp. 40-84).

Com o construtivismo, o significante-mestre espontaneísmo e seus equivalentes continuam circulando no discurso pedagógico, mas com a função de fazer escoar as críticas endereçadas ao construtivismo pelo furo que o novo ponto de arremate (re)cria. Nesse furo, definido pelo significante espontaneísmo, é acolhido o fracasso escolar, sem que isso altere o lugar da chamada escola tradicional, considerada ainda a principal responsável por esse histórico mal.

Com os três pontos de estrutura do novo discurso pedagógico são (re)criadas as duas linhas paralelas e opostas que Saviani havia destacado. Uma concerne à Escola Tradicional e a outra torna-se a linha do "caminho construtivista". No início desse "caminho" temos o construtivismo espontaneísta: uma interpretação "equivocada" das teorias construtivistas. No fim, o verdadeiro construtivismo, que no Brasil preenche um lugar prefigurado alguns anos antes pela pedagogia dos conteúdos, mas também por outros discursos de menor ressonância. ${ }^{57}$

Esses vários lugares por vezes são imaginariamente preenchidos, como já vimos no caso do "ponto de equilíbrio", com as especialistas "pioneiras", a escolaparadigma e a professora construtivista representada por Bernadete. ${ }^{58}$ Essa é uma das vias pelas quais o discurso construtivista se transforma num discurso transparente, um discurso cujos pontos de estrutura crescentemente se enrijecem, ficando claros, nítidos, positivos. ${ }^{59}$ Isso não ocorre apenas na revista Nova Escola,

\footnotetext{
${ }^{57}$ Em relação a esses discursos de menor ressonância, veja-se por exemplo a classificação apresentada por Nélio Parra (1980).

${ }^{58}$ Acima está sendo feita uma alusão ao que Lacan chama de registro do imaginário.

${ }^{59}$ Sobre o que está sendo chamado de discurso transparente, veja-se o capítulo II.
} 
a academia investe nessa mesma direção. No caso do professor, nos textos de Becker por exemplo, a multiplicidade de traços que define a sua postura e que extrapola os marcos do "caminho construtivista" em grande parte desaparece em face da rede epistemológica que esse autor mobiliza. Em nome da ciência, em nome de um saber positivo, Becker opera do mesmo modo que os discursos presentes nas páginas da Nova Escola e que muitos desqualificam porque seriam simples slogans ou palavras vazias que estão na moda, uma e outra vez repetidas sem que se saiba ao certo o seu significado. Esse saber positivo, esse saber científico, não raro esgrimido para combater o chamado "senso comum", participa com este último da mesma amarração, dos mesmos nós ou enlaces que projetam e sustentam o discurso construtivista. É o que agora veremos nos trabalhos de Fernando Becker, que constituem um bom exemplo sobre como é criado o suporte que discursivamente garante a hegemonia do novo discurso.

Aqui tomaremos como referência dois artigos de Becker publicados em 1993 e 1994. Neles trata basicamente da mesma questão, tendo como base a pesquisa que realizou junto a professores e professoras de todos os níveis de ensino. O que está em causa nessa pesquisa é a "epistemologia do professor, epistemologia quase totalmente inconsciente - epistemologia subjacente ao trabalho docente" (1993, p. 77). Para Becker, a "superação da escola atual, na direção de uma escola verdadeiramente democrática - escola para todos e competente na transmissão e na produção do conhecimento —-", implica necessariamente a crítica da "epistemologia do professor" (ibidem, p. 79). Uma afirmação que vem acompanhada deste esclarecimento: "Não estou afirmando que esta crítica é um caminho único, mas, que é um caminho necessário" (ibidem). Como veremos, esse "caminho necessário", por onde todos obrigatoriamente deveríamos passar, é o "caminho construtivista".

Segundo o autor, sob o ponto de vista das relações pedagógicas que se constituem nas práticas de sala de aula, é possível verificar que há "um movimento de polarização 'espontâneo'" que tende a valorizar o professor, o aluno ou as relações entre professor e aluno (1993). Esse "fenômeno de polarização" denuncia, segundo Becker, determinadas concepções pedagógicas que "fazem avançar, retardar ou até impedir o processo de construção do conhecimento" (ibidem). Feita essa constatação, ele empenha-se na caracterização das três 
pedagogias aí implicadas: uma centrada no professor, outra no aluno e outra na relação. Ou, respectivamente, pedagogia diretiva, pedagogia não-diretiva e pedagogia relacional, segundo a denominação que usa no seu segundo artigo (1994b). Cada uma dessas pedagogias é por sua vez relacionada com uma "fundamentação epistemológica" diferente, conforme pode ser observado em sua caracterização:

Assim, uma pedagogia centrada no professor tende a valorizar relações hierárquicas que, em nome da transmissão do conhecimento, acabam por produzir ditadores, por um lado, e indivíduos subservientes, anulados em sua capacidade criativa, por outro. Consideram o sujeito da aprendizagem, em cada novo nível, como tábula rasa. (...) Este modelo encontra apoio, na psicologia, no associacionismo, em geral, no behaviorismo e no neo-behaviorismo, de Watson e Skinner, em particular. Sua fundamentação epistemológica é fornecida pelo empirismo.

Uma pedagogia centrada no aluno pretende enfrentar os desmandos autoritários do modelo anterior, atribuindo ao aluno qualidades que ele não tem (...) Snyders, mostra o quão autoritária pode ser uma sala de aula em que vigora tal pedagogia (...) O suporte deste modelo é dado, na Psicologia, pela obra de Carl Rogers, pelos mentores da Escola Nova, e, por caminhos mais difíceis de mostrar, pela psicologia da Gestalt. Apesar das mesclas empiristas, como é o caso de Rogers, sua fundamentação epistemológica é dada pelo apriorismo — inatista ou maturacionista.

Uma pedagogia centrada na relação tende a desabsolutizar os pólos da relação pedagógica, dialetizando-os. Nenhum dos pólos dispõe de hegemonia prévia. O professor traz sua bagagem, o aluno também. São bagagens diferenciadas que entram em relação. Nada, a rigor, pode ser definido previamente devido à infinidade de níveis possíveis dessas diferentes bagagens. (...)

(...)

Nega-se, portanto, o autoritarismo do professor e o autoritarismo do aluno, simultaneamente. Trata-se de um modelo pedagógico que (...) resgata a importância dos pólos de relação pedagógica escolar (...) O suporte deste modelo encontra-se na Psicologia Genética de Piaget, na obra pedagógica de Paulo Freire, em pedagogias de fundamentação marxista: na psicologia do desenvolvimento de Vigotsky, em Gramsci, Wallon, etc. Sua fundamentação epistemológica encontra-se no interacionismo de tipo construtivista. (1993, p. 78)

Considerando a caracterização que Becker faz, baseado em "uma fundamentação teórico-epistemológica consistente", cada um desses lugares pode ser situado com os nomes que são próprios dos "slogans" que nesse mesmo período circulam entre os professores e outros profissionais da educação: escola tradicional, espontaneísmo e construtivismo. Esses três pontos de estrutura ganham em Becker "consistência teórica", à semelhança do que ocorre em outros 
trabalhos acadêmicos, de outros autores. Para tanto, nesse caso, esses pontos são amarrados às "categorias básicas da epistemologia, particularmente da epistemologia genética de Jean Piaget: empirismo, apriorismo, interacionismo" (1993, p. 80). Além disso, esses pontos de estrutura orientam a análise das práticas e concepções dos professores que Becker observou e entrevistou. Nessa análise ganham relevo as "posturas epistemológicas", que igualmente divide em três.

Em sua pesquisa, Becker constatou que "o empirismo é a forma que mais amplamente caracteriza a epistemologia do professor" (1993, p. 81). E mais: "todos os docentes são, pelo menos em algum grau, empiristas" (ibidem). E aí devem ser incluídos os docentes com posturas aprioristas e os que se aproximam de uma postura interacionista ou construtivista, pois eles tampouco "conseguem superar totalmente sua epistemologia empirista" (ibidem). Quer dizer, a sua conclusão é semelhante ao que quase todos os discursos pedagógicos acusam: os professores têm uma prática tradicional, o que predomina é o professor tradicional. Becker também detecta uma certa oscilação no professor, entre o empirismo dominante e o apriorismo, como se esses extremos por vezes se confundissem (p. 77). Ou seja, a postura tradicional e a postura espontaneísta às vezes se confundem no lugar que é próprio dos equívocos.

Segundo Becker, a "postura construtivista" dificilmente é encontrada. O professor só ensaia essa postura ao se defrontar com a sua prática pedagógica (1993, p. 77). Por isso, ao contrário do que prevalece, ele sugere este "caminho didático para a formação de professores: refletir, primeiramente, sobre a prática pedagógica da qual o docente é sujeito. Apenas, então, apropriar-se da teoria capaz de desmontar a prática conservadora" (p. 93). Entretanto, para transformar a postura pedagógica, antes de mais nada é necessário apelar para uma "instância crítica": a ciência. O prioritário é a "crítica epistemológica" (p. 92). É por essa via ou "caminho" que os professores podem encontrar "a" postura adequada.

Para realizar essa crítica e de acordo com o que "é próprio de um processo de superação", os modelos que Becker situa nos extremos devem ser negados, mas sem deixar de resgatar "a qualidade de um e de outro pólo da relação". (p. 78). Eis o que ele resgata: 
Resgata-se, do primeiro, a importância que se dá ao conteúdo, sistematizado pelas várias ciências ("acervo cultural da humanidade"), e a autoridade do saber do professor; do segundo, resgata-se a experiência de vida, o saber até agora construído e a capacidade de construir conhecimentos que a sala de aula tem por função ativar. (ibidem)

O que Becker articula nesse trecho, mas também ao longo dos dois artigos, mostra bem o vão onde o discurso construtivista procurou e conseguiu se instalar desde que começaram a ser feitas as suas primeiras costuras. O que ele situa de um lado e de outro corresponde aos "pólos da relação" (professor e aluno), mas também aos modelos que ele recusa ou "nega". Além disso, o que ele resgata mantém as suas próprias conexões, implícitas ou explícitas, com essa ampla rede discursiva que é própria dos debates do início da década de 80. Para puxar essa rede, para deixar à vista algumas das conexões que nesse e em outros discursos foram apagadas, é necessário realizar alguns deslocamentos e incluir alguns significantes ausentes na rede discursiva que Becker mobiliza, pois o que produz esse apagamento ou recalque são deslizamentos e substituições que ocorrem nas cadeias significantes implicadas nessa rede. Vejamos.

Para começar, o que Becker primeiro resgata é o que corresponde à rede discursiva amarrada ao significante-mestre escola tradicional, mas de acordo com o nó, tudo indica, que havia sido feito pelo discurso da pedagogia dos conteúdos. Não por acaso convoca os significantes conteúdo e autoridade, dois significantes esgrimidos nos debates do início da década de 80 para atingir os discursos educacionais que então eram hegemônicos: os discursos educacionais do campo alternativo. ${ }^{60}$ Digamos que com esses dois significantes, com o que eles arrastam e com o que Becker (re)articula, o seu discurso - um discurso construtivista -

\footnotetext{
${ }^{60}$ A preocupação com o "resgate" da autoridade do professor (em Becker, com um pequeno deslizamento: a autoridade "do saber" do professor), aliada à crítica ao autoritarismo, pode ser também encontrada na revista Nova Escola. Em dezembro/90, por exemplo, constitui o único destaque de capa. A matéria, intitulada "A confusão entre autoridade e autoritarismo ou a pedagogia do chinelo", deixa em evidência dois extremos. De um lado, tudo o que o significantemestre autoritarismo abraça e que tende a cair sob a órbita da escola tradicional, como os "colégios religiosos e militares que associam, como se fazia antigamente, a qualidade do ensino ao autoritarismo" (p. 18). Esse extremo é o principal alvo das críticas feitas nessa reportagem. De outro lado, temos o que poderia ser situado com o significante-mestre escolas alternativas, mas que na matéria é assim lembrado: "Na outra ponta está o universo das escolas particulares leigas, onde, passada a fase das experiências quase anarquistas dos anos 60/70, têm-se criado projetos pedagógico-disciplinares em que os alunos vivem com mais liberdade e responsabilidade" (ibidem). Ou seja, são as escolas que "caminharam" em direção ao "ponto de equilíbrio" e que nesse período já são chamadas de construtivistas, mesmo que a reportagem no use esse significante-mestre.
} 
aproxima-se do lugar idealizado por essas críticas. Ou seja, o lugar virtual antecipado pela tão falada "teoria da curvatura da vara" (Saviani, 1984, pp. 40-84). O nexo mais explícito entre a articulação discursiva criada por Becker e a pedagogia dos conteúdos talvez seja este nome: Snyders, que concerne à fonte teórica que inspirou boa parte das reflexões que nutriram a pedagogia dos conteúdos. De tudo isso, considerando essa articulação significante que Becker resgata, mas também os discursos educacionais nela implicados, podemos reter por enquanto os dois significantes-mestres dos pontos de arremate desses discursos: pedagogia dos conteúdos e escola tradicional.

Em segundo lugar, naquele mesmo trecho de seu artigo, Becker resgata a "experiência de vida". Ou seja, do lado do aluno, do lado desse modelo que ele relaciona com a Escola Nova e que corresponde ao "regime do laissez-faire" (1994b, p. 90), Becker recupera um significante que contém elementos de forte ressonância e penetração no campo alternativo, que nesse período já se encontrava em avançado processo de diluição. ${ }^{61}$ Sem contar 0 valor do significante "experiência de vida" no curso definido pelo significante Escola Nova, que é um curso sobre o qual incidiram os discursos educacionais alternativos. Além disso, Becker alude a um "saber" que fica sob a égide do significante "construção" ou "construção do conhecimento". Ou seja, ele convoca um significante embutido no ponto de arremate do discurso construtivista. Tendo em vista esses dois significantes que Becker convoca ("experiência de vida" e "construir conhecimentos") poderíamos fazer comparecer os dois nomes próprios que, mencionados por Becker nesse mesmo artigo, parecem mais diretamente relacionados com o que esses significantes evocam, ou seja, Paulo Freire e Piaget — os dois autores que em seus textos, vez por outra, Becker procura aproximar e destacar. Agora, se dessa rede significante recuperássemos tão somente os pontos de arremate dos discursos educacionais nela implicados, seria possível ficarmos com estes três: construtivismo, educação popular/educação alternativa e escola nova. Todos eles do "lado" ou extremo que o significante espontaneísmo fixa.

61 O valor atribuído ao plano da "experiência" ou "vida cotidiana", no campo alternativo, foi assinalado no capítulo III. 
A rede significante que Becker mobiliza tem por base, primeiramente, os dois pontos de arremate cuja configuração histórica pode ser situada nas primeiras décadas do século passado, mas que contemporaneamente sofreram um importante e parcial (re)ordenamento no início da década de 80 , com a pedagogia dos conteúdos. Esses pontos correspondem ao que os discursos educacionais tendem a representar por meio de duas linhas que correm paralelas e em oposição, relativas à Escola Tradicional e à Escola Nova. Uma oposição reavivada pela pedagogia dos conteúdos, em particular nos textos de Saviani, que cria um tipo de alinhamento que se prolonga em inúmeras análises, como a que Becker realiza. O último, porém, à semelhança de outros autores, acrescenta um elemento: o construtivismo, que pode ser situado em linha de continuidade com a Escola Nova. Situado desse modo, o construtivismo emerge como se fosse o fruto maduro de apenas uma dessas duas grandes fontes de discursos e práticas educacionais.

A Escola Nova constitui um ponto de ressonância que "naturalmente" atrai o construtivismo. Há uma infinidade de laços históricos que criam e sustentam essa aproximação, a começar pelos vínculos estabelecidos pelo próprio Piaget, um defensor dos "métodos ativos" e da "escola ativa". Becker, no entanto, desenvolve uma argumentação que investe na criação de um "terceiro lugar" que parece eqüidistante daqueles extremos, com os quais porém procura manter algum vínculo. Um vínculo estabelecido quando faz o "resgate de qualidade" de cada "pólo".

Ao definir esse "terceiro lugar", ao resgatar os "pólos" implicados nos dois modelos-limites, Becker faz confluir e superpõe diversos discursos, diversos pontos de arremate, recobrindo todos eles com 0 significante-mestre construtivismo. Para realizar essa costura, Becker convoca ainda o significante interacionismo, que nesse período permite recobrir algumas das falhas então atribuídas ao construtivismo. Interacionismo é um significante com o qual são evocados vários autores e teorias, abraçando desse modo inúmeros profissionais da educação, a começar por aqueles que criaram uma espécie de dissidência no interior do construtivismo, baseados na obra teórica de Vigotsky. Dentre esses autores, é necessário considerar todos os que são implicitamente convocados 
com o "etc" usado por Becker, ao falar do "suporte" de seu modelo. Um "etc" cujo sentido parece ser o de ampliar e manter em aberto o domínio do novo discurso.

As costuras que Becker realiza fazem parte da operação, seção ou corte que (re)cria o circuito do novo discurso, que (re)cria o que também pode ser chamado de "a metáfora do 'caminho construtivista'", se quisermos empregar os mesmos termos utilizados por Vieira (1995, p. 44). Essa operação de costura na verdade é uma metáfora, uma metáfora cujas condições de possibilidade foram criadas pelos discursos que a precederam. Esses discursos, em particular os vinculados com e pelo significante crítico, foram os que em última instância sustentaram a emergência do construtivismo, a sustentaram porque forneceram os seus pontos de ancoragem. E mais, nesse mesmo processo esses discursos críticos foram deslocados e substituídos por um discurso que se instalou no vácuo por eles criados, nos debates gerados no interior desse campo no período compreendido entre fins da década de 70 e início dos anos 80. Esse vácuo é preenchido, precisamente, pelo objeto ou objetos cujos contornos são definidos por meio do tipo de convergência e superposição que Becker e outros autores realizam. No caso de Becker, ele faz convergir significantes que, seguindo-se a trilha de onde procedem, por contigüidade, conduzem-nos até os dois discursos críticos em disputa naquele período: os discursos educacionais alternativos e a pedagogia dos conteúdos. São sobretudo esses os discursos ou os pontos de arremate que o significante construtivismo substitui e desloca, de um modo que os transforma no seu suporte. Nesse suporte devem ser incluídas as duas linhas opostas e paralelas que atravessam esses discursos críticos e participam das suas costuras, ou seja, a Escola Tradicional e a Escola Nova.

Essa complexa operação de costura, bem como os recalques que ela produz, podem ser pensados pondo em evidência o que Lacan concebe como as duas leis da linguagem que regem a ordem significante: a metonímia e a metáfora. Por meio desses dois mecanismos ou processos um significante é sempre elidido, portanto não está presente no enunciado, embora sim no que pode ser vislumbrado nas entrelinhas, nisso que podemos situar no plano da enunciação. Essa supressão ocorre de um modo diferente em cada caso.

Na metonímia, o significante ausente é representado no enunciado pelo significante que o deslocou de seu lugar na cadeia e que com ele mantém uma 
relação de contigüidade. Esse é o caso da expressão "trinta velas", que Lacan apresenta como exemplo (1957, p. 509) e que equivale a "trinta barcos". "Velas" está no lugar de "barcos", havendo entre os dois uma conexão por contigüidade, presente nesta expressão: "barco à vela". É isso que permite que um leitor entenda "trinta velas" como equivalente a "trinta barcos", apesar de não existirem barcos com uma vela. Ou seja, o referente não importa, o sentido vem dessa conexão que não está explícita. Nesse exemplo, o significante "barco", que é o significante deslocado, torna-se o significado de "velas", que é o significante que o representa. "De palavra em palavra", essa é a fórmula que Lacan apresenta para a metonímia.

Quanto à metáfora, a sua fórmula é "uma palavra por outra", implicando a substituição de um significante por outro. A metáfora cria um sentido ou um efeito de significação relacionado com essa substituição:

A centelha criadora da metáfora não brota da presentificação de duas imagens, isto é, de dois significantes igualmente atualizados. Ela brota entre dois significantes dos quais um substitui o outro, assumindo seu lugar na cadeia significante, enquanto o significante oculto permanece presente em sua conexão (metonímica) com o resto da cadeia. (Lacan, 1957, p. 510)

Voltemos agora para as convergências e superposições produzidas por Becker, pondo em foco primeiramente os significantes conteúdo e autoridade. Esses significantes encontram-se vinculados na série significante relativa a uma das linhas criadas pelos discursos pedagógicos. No caso, a linha que parte da Escola Tradicional e chega até a pedagogia dos conteúdos. No texto de Becker (1993), conteúdo e autoridade podem ser pensados como significantes metonimicamente relacionados com o significante professor, que é o que basicamente está em causa em sua argumentação. Mas não se trata de qualquer professor, pois nesse caso é o professor definido pelo significante-mestre onde essa série discursiva (conteúdo-autoridade-professor) tende a confluir, ou seja, o professor tradicional. Portanto, o que Becker pretende resgatar é o professor tradicional, mas na versão que resulta do (re)ordenamento produzido pela pedagogia dos conteúdos. Nesse caso, conteúdo e autoridade representam o significante professor tradicional, ausente no plano do enunciado; ou seja, o 
significante professor tradicional é o significado daqueles dois significantes. ${ }^{62}$ Esse significante deslocado pode ser considerado um "significante oculto", mas que certamente não está tão oculto quanto o nome do discurso que atualizou e valorizou o professor tradicional no início da década de 80 , ou seja, a pedagogia dos conteúdos. Esse discurso, aliás, parece guiar o professor Becker em vários momentos, em particular na sua pretensão de realizar mais uma "síntese superadora" dos modelos até então vigentes, uma síntese outrora buscada e realizada pelos intelectuais que formularam a pedagogia dos conteúdos. ${ }^{63}$

Tomando como base o discurso de Becker, análise semelhante pode ser feita em relação ao significante experiência de vida, mas ligando-o a outra linha que os discursos educacionais costumam traçar tendo como ponto de partida a Escola Nova e como ponto terminal o construtivismo.

Quando aqui se afirma que o ponto de basta que cria o novo discurso é uma metáfora, seguindo-se nesse caso as pistas que Lacan fornece, entende-se que há uma substituição de um significante por outro. E aqui o que interessa pôr em foco é o significante-mestre construtivismo. Este substitui, antes de mais nada, os significantes-mestres que definem os pontos de arremate dos dois discursos em confronto no início da década de 80 . O efeito de significação dessa metáfora, a sua "centelha criadora", deve ser procurada no que "brota" dessa e nessa substituição significante.

Em relação aos discursos educacionais alternativos, o efeito de sentido que é próprio dessa substituição é a criação da "origem" do construtivismo. É isso o que sobretudo "brota" da metáfora que cria o "caminho construtivista". Sem essa "origem", que "brota" do vão que surge entre um discurso e outro, entre um ponto de arremate e outro, não existiria esse "caminho". Esse é um dos principais efeitos do corte que é próprio dessa metáfora, do corte que suprime determinados

\footnotetext{
${ }^{62}$ Para tornar mais claro o que acima foi exposto, pode-se fazer uma equivalência termo a termo com o exemplo fornecido por Lacan e criar alguns enunciados próximos do que, supõe-se aqui, está implícito na argumentação de Becker:

- trinta velas $\equiv$ resgatar a importância dos conteúdos e a autoridade do saber do professor;

- barco à vela $\equiv$ o professor tradicional é o que valoriza os conteúdos e possui a autoridade que o saber lhe outorga;

- trinta barcos $\equiv$ resgatar o professor tradicional, na versão da pedagogia dos conteúdos.

63"Síntese superadora" é uma expressão utilizada na apresentação do livro de Libâneo Democratização da escola pública: a pedagogia crítico social dos conteúdos (1989, p. 8).
} 
significantes. Nesse caso, o que é elidido do discurso construtivista, o que não está explícito, são todos os significantes-mestres que concernem ao ponto de arremate dos discursos educacionais alternativos: escolas alternativas, educação alternativa, escolas comunitárias, educação popular, Paulo Freire. Esses são alguns dos "significantes ocultos" ou que tendem a ficar ocultos, sobretudo o significante alternativa. ${ }^{64}$ Ocultos aqui significa que esses significantes de arremate continuam implicitamente presentes, nas cadeias significantes que confluem em direção ao lugar que, em razão da substituição ocorrida, passa a ser definido pelo significante construtivismo. ${ }^{65}$

Esse lugar é também definido por um significante que já era fundamental nos discursos alternativos, em particular nos alternativos-renovados: o significante criança, que é um dos pontos de ressonância do discurso construtivista, um ponto essencial, pois fica embutido no ponto de arremate do novo discurso, que é aonde tudo conflui e a partir do qual tudo se ordena. Com essa "criança" e com o significante-mestre que nesse momento a define é produzido o golpe que substitui os significantes de arremate dos discursos alternativos pelo significante-mestre construtivismo. Essa operação envolveu ainda o acréscimo que é próprio de toda metáfora. No caso, a sua "centelha criadora" exigiu a convocação de um significante para definir a "origem", um significante que já circulava no discurso pedagógico: o significante espontaneísmo e outros equivalentes. Assim nasceu o "construtivismo espontaneísta". ${ }^{66}$

\footnotetext{
${ }^{64}$ O significante alternativa, na função que é própria do ponto de arremate, praticamente desaparece na segunda metade dos anos 80. Quanto aos outros significantes-mestres, se seguirmos o "caminho" da revista Nova Escola, igualmente tendem a desaparecer, de forma notável em 1995 e 1996. Isso já pode ser observado no momento em que o construtivismo começa a ser "trocado em miúdos", em março/95, quando não mais é lembrado o nome Paulo Freire, freqüentemente utilizado e incluído na ordem do novo discurso antes de iniciar-se essa nova fase da revista - uma fase que corresponde a certa inflexão do discurso construtivista. Cf. "O tira-teima do Construtivismo: 50 grandes e pequenas dúvidas esclarecidas", Nova Escola, n 82, março/95.

${ }^{65}$ Nos textos de Becker que foram analisados o nome Paulo Freire é mencionado, mas entra na série significante que aflui ao lugar definido pelo significante-mestre construtivismo.

66 "Construtivismo espontaneísta" é uma expressão que pode ser encontrada, por exemplo, na dissertação de mestrado de Ribeiro (1997), orientada pelo professor "construtivista" Dr. Lino de Macedo. Em seu trabalho, a autora investigou "a noção de professores sobre o construtivismo e a maneira como articulam tal teoria em uma prática pedagógica" (p. 144). Entre outras coisas, Ribeiro conclui que "A idéia de um 'construtivismo espontaneísta' apresenta-se como uma tendência muito marcante nas respostas dos professores" (p. 145).
} 
Como vimos, o significante-mestre construtivismo penetra também na rede discursiva que é própria da pedagogia dos conteúdos. ${ }^{67}$ Nesse caso, a metáfora construtivista envolveu a substituição do significante-mestre desse "outro caminho" que na primeira metade da década de 80 estava adquirindo os seus primeiros contornos. ${ }^{68}$ Ou seja, o significante substituído e que fica "oculto" é pedagogia dos conteúdos, muito embora continue presente, como já foi destacado na argumentação de Becker. Nessa substituição, pode-se dizer que o significante construtivismo assume o lugar que a pedagogia dos conteúdos pretendia preencher e que Saviani antecipou quando fez referência ao "além" da teoria da curvatura da vara - um significante, aliás, que bem exprime o que aí está em jogo e que corresponde ao aqui chamado "ponto de equilíbrio" ou "terceiro lugar". ${ }^{69}$ O significante construtivismo passa então a definir esse lugar, pelo menos nas falas que operam com esse significante-mestre e que se apropriam de elementos daquela rede discursiva.

Esses elementos, esses significantes que antes afluíam em direção ao significante-mestre pedagogia dos conteúdos, convergem agora para sustentar um novo ideal: "a criança que constrói seu próprio conhecimento", a criança piagetiana, a criança da psicologia e da ciência - eis aí uma outra "centelha criadora" da metáfora construtivista. Essa criança é a que define "o ponto de equilíbrio", ela indica e está no fim do "caminho". Ademais, ela vincula a "origem" e o "ponto de equilíbrio", a "origem" e os ideais, o "construtivismo espontaneísta" e

\footnotetext{
${ }^{67}$ Esse fato do discurso e seus efeitos parecem ter passado despercebidos nas análises sobre o construtivismo. Para tanto talvez tenha contribuído o uso cada vez mais raro do significante-mestre que permitia reconhecer aquele discurso, em particular nas publicações onde o construtivismo se tornou hegemônico. No caso da Nova Escola, vale apontar que essa publicação, no seu próprio nome (Nova Escola/Escola Nova), criou o anteparo necessário para manter a uma certa distância esses novos defensores da Escola Tradicional e as suas ácidas críticas à Escola Nova. Nesse anteparo, ademais, parece residir o que explica o uso tão raro do significante espontaneísmo nessa publicação. Bem diferente do que se observa em outros âmbitos, como aqueles aos quais os jornalistas da Nova Escola costumavam comparecer para procurar as "autoridades" do construtivismo. Esse fato singular, essa raridade, essa repetida ausência, talvez encontre a sua razão de ser no seu oposto: no uso mais ou menos freqüente do significante espontaneísmo, ou melhor, nos danos que essa utilização poderia provocar. Com efeito, empregar o significante espontaneísmo com alguma freqüência encerrava determinados riscos, na medida em que poderia suscitar a sua "natural" aderência ao nome da própria revista, na qual abundavam os discursos que facilmente poderiam atraí-lo.

${ }^{68}$ A esse respeito, veja-se o item "Um outro caminho", no capítulo III.

${ }^{69}$ Veja-se, de Saviani (1984), o capítulo "Escola e Democracia II: Para além da teoria da curvatura da vara".
} 
o "verdadeiro construtivismo". Ou seja, essa "criança" é o que primeiramente define o "caminho construtivista".

Esse "caminho" é feito na verdade de inúmeros circuitos, circuitos que o definem e que ele próprio define, na mesma medida em que lhes fornece a sua estrutura, isto é, uma rede simbólica constituída por determinados pontos de ressonância, dentre eles os que atraem e amarram todos os outros - os três pontos de estrutura. Essa estrutura, esse "caminho", mas também a infinidade de circuitos nele contidos, nasce sob o corte da metáfora construtivista, ou melhor, sob a Seção que cria a nova rede de saber que fica condensada no significantemestre construtivismo e que podemos chamar de $S_{2}$ : o Outro construtivista, o Outro que define o lugar do educador ou professor construtivista. Conforme já vimos, esse lugar, o lugar do Outro, surge quando Um significante-mestre se destaca para abraçar e (re)ordenar a rede toda, tornando-se o Um que representa essa totalidade, o Um do Outro, ou melhor, o $S_{1}$ do $S_{2}$. Ou ainda, se utilizarmos a notação que Lacan emprega: $S_{1} \rightarrow S_{2}$. E aqui vale esclarecer que esse $U m$ do Todo não é o mesmo, supõe-se aqui, que o Um desconhecido que marca o sujeito, o Um do traço unário, embora ambos sejam indissociáveis, pelo menos se pensarmos no sujeito capturado por essa rede. Um sujeito que (re)produz essa mesma rede, esse mesmo "caminho", mas numa posição singular, fazendo o seu próprio discurso, o seu próprio circuito, este sendo definido pelo que é da ordem de seu desejo, ou seja, do traço unário, do $S_{1}$.

Para a configuração desse "caminho" foi fundamental a pedagogia dos conteúdos, pelo menos no Brasil, pois é desse discurso que sobretudo procede a sua estrutura. Com a pedagogia dos conteúdos e em particular com a argumentação de Saviani, de grande impacto e influência no início dos anos 80 , ganham evidência e são atualizados os lugares relativos aos três pontos de estrutura do discurso pedagógico construtivista. Um discurso que ainda não existia, mas que emerge desse "terceiro lugar" que a pedagogia dos conteúdos começou a preencher e ocupar.

Esse "terceiro lugar", com a estrutura que assim o define, não foi criado pelo discurso da pedagogia dos conteúdos. Na verdade ele já existia, há décadas, mas como um lugar vazio ou insuficientemente demarcado, à espera talvez de um 
nome, ou de vários nomes, necessários para situar e definir os seus extremos. Para verificar isso, uma via que pode ser seguida consiste em recuar em direção à "origem" do construtivismo, pela linha que muitos traçam até a Escola Nova. Nesse lugar encontraremos, por exemplo, John Dewey, o intelectual que muitos consideram uma espécie de fundador do chamado movimento da Escola Nova. Vejamos o que ele afirma num artigo publicado originalmente no Brasil em 1930, no primeiro número da revista Escola Nova. Nesse texto, refere-se à oposição entre dois tipos de escola, recusando ambas:

"Direcção e controle" são as palavras mágicas de uma escola; "liberdade e iniciativa", as da outra. Proclamam-se a lei e a ordem como fundamento de uma; a espontaneidade é o que se busca na outra. Voltamse os carinhos aqui para o que é antigo, para a conservação do que o passado conquistou com esforço e labôr; novidade, mudança e progresso vencem acolá todas as affeições. Inercia e rotina por um lado, cháos e anarchia do outro, são as mutuas accusações condemnatorias. A escola que faz da criança o centro de tudo é accusada de desprezar a autoridade sagrada do dever; ella, por sua vez, ataca na sua oppositora a suppressão da individualidade atravez de um despotismo tyrannico.

Taes opposições raramente são levadas até as suas últimas conclusões lógicas. Ao bom-senso repugna o caracter extremo desses pontos de vista. Ficam elles para os theoristas, emquanto, praticamente, se adopta um ecletismo confuso e inconsistente. (Dewey, 1930, pp. 31-2)

O que Saviani apresenta no início da década de 80 está bem próximo da argumentação desenvolvida por Dewey nesse texto de 1930. À semelhança do que Dewey insinuava, Saviani procura também superar aquelas posições extremas. A diferença básica, poder-se-ia pensar, é que Saviani coloca a Escola Nova num desses extremos. Ele julga que a pedagogia nova se tornou a "portadora de todas as virtudes e de nenhum vício", sendo por isso necessário curvar a vara para o outro lado (1984, p. 62), em favor da Escola Tradicional - a portadora de "todos os vícios e nenhuma virtude" - e contra a Escola Nova, que ele transforma na grande vilã. A intenção de Saviani era "ultrapassar o momento da antítese na direção do momento da síntese" (ibidem, p. 64). Nessa "direção" ou nesse "momento" nasce a pedagogia dos conteúdos, com a qual vários intelectuais procuram ordenar o ecletismo e confusão dominante. Aliás, algo bem semelhante ao que Dewey constata cerca de 50 anos antes, não se referindo, é claro, ao Brasil. Nessa época, Dewey já formula esta demanda: "corrigir taes erros" (1930, p. 34), ou seja, os "erros" assinalados no texto acima citado e outros igualmente situados nos extremos. Por exemplo, "as depreciações extremas da 
criança" e "as exageradas idealizações sentimentais sobre a natureza" (ibidem). Enfim, aquele "terceiro lugar", com os extremos que o delimitam, vinha sendo configurado há décadas, mas de um modo um tanto impreciso, com uma demarcação pouco vigorosa ou incompleta. Pode-se dizer então que ainda não existia uma definição precisa, com nomes ou significantes-mestres que fixassem de modo inequívoco cada um desses lugares. Isso, precisamente, é o que a pedagogia dos conteúdos começou a efetivar, sendo sobrepujada pelo discurso construtivista.

Nessa mesma época, no Brasil, outros autores dedicaram-se à mesma tarefa, recuperando inclusive o nome de Dewey. Esse o caso de um texto escrito por Nélio Parra (1980), de menor ressonância se comparado com o impacto que a argumentação de Saviani teve no mesmo período. De qualquer modo, também poderia ser tomado como uma fonte do discurso construtivista, uma fonte até mesmo mais próxima desse discurso do que a pedagogia dos conteúdos, se aí consideramos a forma como são demarcados os lugares relativos aos três pontos de estrutura.

Parra destaca e caracteriza "três grandes correntes ideológicas no ensino atual", tomando como base a classificação feita por Kohlberg e Mayer num trabalho de 1972, intitulado "Rochelle Development as the aim of education". As "três ideologias" são o romanticismo, a transmissão cultural e o progressivismo. $\mathrm{Na}$ primeira é destacada a obra de Rogers, enquanto na segunda tendem a adquirir maior relevância as idéias do filósofo John Locke, o trabalho de Skinner e o movimento chamado de tecnologia da educação. À diferença da corrente romântica, na qual é sublinhado "o papel do indivíduo como um ser autônomo" ( $p$. 271), na segunda corrente é ressaltado, por exemplo, a importância decisiva do ambiente e a idéia de que o homem ao nascer é uma folha em branco ou uma tábula rasa (p. 272). Essas duas "correntes ideológicas", como já pode ser notado, são colocadas em oposição.

Em relação ao behaviorismo skinneriano, vale a pena destacar esta citação de Skinner reproduzida por Parra:

'"A escola da experiência não tem, na verdade, nada de escola, e não porque ninguém aprende nela, senão porque ninguém ensina. Ensinar 
é transmitir conhecimentos: quem é ensinado aprende mais depressa que aquele que não se lhe ensina'" (p. 274).

Obviamente, no texto acima reproduzido, o que está sendo criticado é o tipo de escola e de ensino situados no extremo oposto do que Skinner defende e que na classificação reproduzida por Parra concerne à corrente romântica, que facilmente poderia ser aproximada do chamado espontaneísmo e do campo que é próprio do alternativo-renovado. Quanto à ideologia da transmissão cultural, ela também pode ser facilmente vinculada à escola tradicional ou ao ensino tradicional, mesmo que Parra não utilize essas categorias. E aqui vale destacar como ele situa a chamada tecnologia da educação, que concerne ao que Saviani denomina pedagogia tecnicista. Enquanto o último tende a aproximá-la do movimento da Escola Nova, Parra opera implicitamente no sentido oposto, ou seja, aproxima o tecnicismo do ensino tradicional ou, para usar a sua terminologia, inclui a tecnologia da educação na ideologia da transmissão cultural. ${ }^{70}$ Essas diferenças fazem parte das disputas e tensões que atravessavam os discursos pedagógicos no início dos anos 80 .

Quanto à "terceira tendência educacional", Parra começa destacando "um de seus principais representes: John Dewey" (p. 280), em seguida definindo esse "terceiro lugar" como um lugar eqüidistante dos extremos:

O progressivismo rejeita a dicotomia: maturação ou ambiente. Para essa corrente, o ser humano ao nascer nem é tudo, como querem os românticos, nem é nada, como afirmam os defensores da transmissão cultural. Todo ser vivo, ao nascer, traz consigo uma "história evolucionária", uma bagagem genética, que lhe permite iniciar um relacionamento com o mundo de forma característica à sua espécie. ( $p$. 280)

Nessa "terceira" corrente, além de Dewey, são destacadas algumas das concepções desenvolvidas por Piaget. Ademais, Parra situa essa corrente em linha de continuidade com o movimento da "educação nova" ou "educação

\footnotetext{
70 Segundo Saviani (1984), ao findar a primeira metade do século XX, "o escolanovismo apresentava sinais visíveis de exaustão" (p. 15). Surgem então, de um lado, "tentativas de desenvolver uma espécie de 'Escola Nova Popular', cujos exemplos mais significativos são as pedagogias de Freinet e de Paulo Freire; de outro, "radicalizava-se a preocupação com os métodos pedagógicos presentes no escolanovismo que acaba por desembocar na eficiência instrumental. Articula-se aqui uma nova teoria educacional: a pedagogia tecnicista" (ibidem). Enfim, por meio dessas costuras Saviani coloca sob uma mesma raiz a educação popular e a "pedagogia tecnicista", ambas sendo assim aproximadas da "pedagogia nova".
} 
progressiva", relacionando esse movimento com vários outros nomes, como Montessori, Freinet e Makarenko. Enfim, como se observa no artigo de Parra, nele também encontram-se prefigurados os lugares que correspondem aos três pontos de estrutura do discurso pedagógico construtivista.

No Brasil, esses três pontos de estrutura já são claramente situados em discursos que utilizam o significante-mestre construtivismo ou seus derivados desde, pelo menos, meados da década de 80, como é possível notar em artigo de Carraher e Carraher (1986). Com efeito, nesse artigo, que trata basicamente sobre o ensino de Ciências e Estudos Sociais, os autores apresentam três modelos. E neles vemos repetir-se a mesma estrutura já referida. Nos extremos temos, de um lado, o chamado modelo tradicional e, de outro, um modelo apresentado com menor destaque, de forma sucinta e sem um nome. É o modelo que resulta de "uma reação freqüente contra o modelo tradicional do ensino":

Passa-se freqüentemente para o extremo oposto, nesses casos. Ao enfatizar a capacidade dos alunos de aprenderem sozinhos, de pensarem, de descobrirem, as críticas ao modelo tradicional passam rapidamente a manter que a criança aprende por si só (...) Segundo esse outro modelo, o conhecimento seria exclusivamente uma construção espontânea do aluno, algo que surge quando ele está pronto para aprender (...) (p. 138)

Em sua argumentação, os autores lembram que é "verdade que muitas coisas são aprendidas pela criança através da sua experiência no mundo" , mas alertam que a escola tem "o papel importante de introduzir a criança, de forma sistemática, no legado cultural rico de idéias, artefatos e técnicas que a sociedade desenvolveu através de séculos" (p. 139). E nesse ponto destacam que a escola atua como "uma instituição de intervenção no desenvolvimento intelectual da criança" (ibidem). ${ }^{71}$

O modelo que Carraher e Carraher expõem no final do artigo, mas que desde o início vai sendo delineado, é o chamado modelo social-construtivista, que é comparado com o modelo tradicional por meio dos mesmos itens (conhecimento, ensino, aprendizagem, atividades didáticas, avaliação, clima na sala de aula). Nessa exposição não é mencionado o nome Emilia Ferreiro nem é

\footnotetext{
${ }^{71}$ Nos trechos acima reproduzidos temos alguns significantes (todos eles destacados em itálico, apenas na citação) e uma argumentação que, assim como foi feito com o texto de Becker, não é difícil aproximar dos debates da primeira metade da década de 80 e dos discursos então em confronto.
} 
feita qualquer referência à alfabetização ou às pesquisas da psicóloga Argentina. Mas a fonte das idéias desenvolvidas nesse texto é a Psicologia Cognitiva ou Psicologia do Conhecimento, como os próprios autores lembram (p. 127).

A argumentação de Becker situa-se em linha de continuidade com tudo isso. Porém, ele vai bem mais longe, aprofundando e ampliando a mesma estrutura significante em todas as direções possíveis e tendo como fundo a epistemologia, que é um dos lugares onde inicialmente emerge essa moderna estrutura. Isso pode ser observado nestes quadros produzidos por Becker: ${ }^{72}$

QUADRO I
Comparaçżo dos modelos pedagúgico e epistemológlco
\begin{tabular}{|c|c|c|c|}
\hline \multicolumn{2}{|c|}{ EPISTEMOLOGIA } & \multicolumn{2}{|c|}{ PEDAGOGIA } \\
\hline Teoria & Modelo & Modelo & Tecria \\
\hline Empirismo & $\mathrm{S}-\mathrm{O}$ & $\mathrm{A}-\mathrm{P}$ & Diretivismo \\
Apriorismo & $\mathrm{S} \rightarrow \mathrm{O}$ & $\mathrm{A} \rightarrow \mathrm{P}$ & Náo-Diretivismo \\
Construtivismo & $\mathrm{S}-\mathrm{O}$ & $\mathrm{A}-\mathrm{P}$ & Ped. Relacional \\
\hline
\end{tabular}

QUADRO ॥

Comparą̧ăo dos modelos blológico, psicológico e sociológico

\begin{tabular}{|c|c|c|c|c|c|}
\hline \multicolumn{2}{|r|}{ Blologia } & \multicolumn{2}{|c|}{ Psicologia } & \multicolumn{2}{|c|}{ Soclologia } \\
\hline Modelo & Teoria & Modelo & Teoria & Modelo & Teoria \\
\hline Or $-M$ & Lamarckismo & $A-E$ & $\begin{array}{l}\text { Associac. } \\
\text { Behavior }\end{array}$ & 1 - Ms & Positivismo \\
\hline Or $\rightarrow M$ & Darwinismo/Néo-Darwinismo & $A \rightarrow E$ & $\begin{array}{c}\text { Gestalt } \\
\text { Carl Rogers }\end{array}$ & $1-M s$ & Idealismo \\
\hline Or $* M$ & Biologias Relacionais & $A-E$ & $\begin{array}{c}\text { Psicologia } \\
\text { Genética }\end{array}$ & I. Ms & Dialética \\
\hline
\end{tabular}

Nessa lógica cuja articulação básica envolve três elementos e que é nutrida por discursos de natureza diversa é igualmente encerrada a democracia, que era um dos pontos de ressonância que unia os discursos críticos no início da década de 80. No discurso construtivista, a postura democrática confunde-se com a postura construtivista. No caso da argumentação de Becker, a última constitui

\footnotetext{
${ }^{72}$ Cf. Becker, 1994a, pp. 94-5. No primeiro quadro, S significa sujeito, O objeto, A aluno e P professor.
} 
uma condição necessária da primeira, pois, para alcançar uma postura democrática, é necessário superar as epistemologias fixistas e ingênuas:

Uma postura docente democrática é incompatível com a permanência de posturas epistemológicas empirista ou apriorista. Note-se que não estou afirmando que a mera superação destas epistemologias fixistas gera, por si mesma, a postura democrática; afirmo, sim, que esta superação deva ser encarada como uma condição prévia da postura democrática. A postura educacional democrática implica, pois, a superação de tais modelos epistemológicos. Superação no sentido de que o conhecimento é uma construção que acontece na interação do organismo com o meio ambiente, do sujeito com o objeto, do indivíduo com a sociedade. Esta interação construtiva (...) (1993, p. 93)

Em Becker, como é próprio do discurso construtivista, tudo tende a confluir em direção ao "ponto de equilíbrio". No texto acima, a política e a democracia ficam sob a órbita do novo discurso e do novo significante-mestre, nesse caso do significante "interação construtiva". E por essa via ficam sujeitas ao que é da ordem da ciência, que Becker convoca para superar o senso-comum e avançar na construção da democracia. Uma construção que a todos exige percorrer o "caminho construtivista".

Nesse mesmo período em que Becker escreve esses artigos, as críticas ao construtivismo ganham evidência e atingem o que Becker vinha desenvolvendo, com a sua "epistemologia do professor". A sua classificação, assim como a sua tentativa de tudo abranger com as coordenadas que ele estabelece - e que são próprias da estrutura do discurso construtivista - constituem o alvo das críticas de Silva (1994). Críticas essas feitas em tom irônico a quem chama de "classificador morto e sem imaginação do pensamento e da ação adultas" (ibidem,p. 16):

Para Becker as pedagogias se dividem em diretivas, não diretivas e relacionais (leia-se "construtivistas" ou "piagetianas"). Correspondentemente, os professores, como o mundo, para Becker, se dividem em empiristas, aprioristas e construtivistas. (ibidem, p. 14)

O artigo de Silva é uma resposta a um artigo de Becker (1994a), que por sua vez responde a um artigo de Silva (1993), todos eles publicados na revista Educação \& Realidade. O primeiro texto de Silva, intitulado "Desconstruindo o construtivismo pedagógico", pode ser tomado como a amarração inicial de todo um conjunto de críticas que demarcam um novo lugar para o construtivismo: o de 
uma tendência que parece progressista mas que, na verdade, é regressiva, conservadora, como o autor sugere. Nesse artigo, logo no início, Silva constata que "o construtivismo tornou-se, de repente, dominante. Nem bem tínhamo-nos refeito da influência da agonizante 'pedagogia dos conteúdos' (...)" (p. 3). Sobre a última, entre outras coisas menciona o "seu relativo sucesso, ao fornecer uma certa direção para a prática pedagógica". E diz que esse "relativo sucesso" é "um indicador dessa necessidade que veio a ser preenchida, agora, pelo construtivismo". Ou seja, de certo modo ele está afirmando que o construtivismo instalou-se num lugar que a pedagogia dos conteúdos havia começado a preencher, como aqui se sustenta, embora não do mesmo modo. A predominância do construtivismo concerne precisamente a esse lugar. Nos termos de Silva, diz respeito à "dupla promessa" do novo discurso:

Parte da predominância atual do construtivismo deve-se, precisamente, à sua dupla promessa. De um lado, ele aparece como uma teoria educacional progressista, satisfazendo portanto aqueles critérios políticos exigidos por pessoas que, em geral, se classificam como de "esquerda". De outro, o construtivismo fornece uma direção relativamente clara para a prática pedagógica, além de ter como base uma teoria de aprendizagem e do desenvolvimento humano como forte prestígio científico. (ibidem, p. 4).

A primeira parte dessa promessa concerne ao semblante com que o construtivismo surge, na medida em que se faz passar por "um projeto educacional de esquerda" (ibidem, p. 9). A "falta" de formulação de tal projeto é o que Silva aponta como possível razão do construtivismo ter se "instalado tão decisiva e confortavelmente na cena educacional brasileira" (ibidem). Em outras palavras, o que Silva igualmente chama de "vácuo" é o que teria sido decisivo. Afinal, como aqui se sustenta, o construtivismo instalou-se precisamente no "vácuo" gerado pelos debates do início da década de 80 no campo dos discursos críticos. As principais críticas de Silva referem-se aos efeitos conservadores dessa predominância do construtivismo, "na medida, sobretudo, em que representa a volta do predomínio da Psicologia na Educação e na Pedagogia" (p. 4). O que não significa, conforme esclarece, que "os construtivistas sejam conservadores" (ibidem).

Para situar essa "volta", Silva recua até o início da escolarização de massa, para apontar o papel da Psicologia nesse momento. Caracteriza a Psicologia 
como uma ciência a serviço do controle e da produção de subjetividades e identidades. E, ao relacioná-la com a educação, ressalta 0 seu papel despolitizador. Entre outras coisas considera que a ênfase posta na Psicologia e nos seus "tributários" (Teoria do Currículo, Didática, Metodologia) teria implicado "numa operação de isolamento da educação de seu contexto social, de seus componentes políticos" (1993, pp. 4 e 5). Para Silva, a "psicologização da educação implica, necessariamente, na sua despolitização" (p. 5).

Os efeitos do predomínio do construtivismo e da Psicologia assinalados por Silva são diversos. Um deles diz respeito ao vínculo estabelecido entre construtivismo e democracia, que aqui já foi parcialmente comentado em relação à "postura" do professor, no artigo de Becker. Segundo Silva, "o construtivismo se apresenta como a possibilidade de instauração da democracia através da Pedagogia" (p. 5). E aqui Silva refere-se basicamente às crianças:

Segundo esta pretensão, o construtivismo traria embutido, ao favorecer relações de aprendizagem mais democráticas, um potencial radical, libertador, no sentido político. Crianças educadas sob o construtivismo tenderiam a favorecer em sua vida adulta - este é o raciocínio - relações mais democráticas, tenderiam a não aceitar facilmente, em sua vida política e de trabalho, relações autoritárias. É fácil ver a falta de fundamento de uma tal pretensão. (1993, p. 5)

Silva avalia que essa "posição está imbuída de conservadorismo, ao atribuir às relações de sala de aula propriedades que pertencem à esfera das relações econômicas e políticas mais amplas" (ibidem). ${ }^{73}$ Por essa via, acusa o autor, "a democracia e a política tornam-se sinônimos de relações interpessoais" (ibidem). Outra crítica de Silva é que o construtivismo, além de elidir aspectos políticos e sociais da educação, "quer fazer se passar por uma teoria social", "uma teoria abrangente de compreensão da educação e sua prática" (p. 7).

Tudo isso, em suma, diz respeito ao que Silva chama de "uma nova onda pedagógica", a qual, no entanto, não deve ser tomada apenas "como mais uma onda":

\footnotetext{
${ }^{73}$ Basicamente, esse é um dos argumentos que Guiomar Namo de Mello esgrimia em 1981 para criticar os discursos educacionais alternativos. A esse respeito, veja-se o artigo de Mello já comentado no capítulo III (1981).
} 
(...) precisamos ver o presente predomínio do construtivismo pedagógico não apenas como mais uma onda, como mais um inocente modismo, mas como uma prática discursiva que pode estar agindo regressivamente sobre todo nosso esforço para ver a educação institucionalizada como um campo político e social onde se travam batalhas decisivas pelo controle cultural e simbólico da sociedade. (p. 9)

A resposta de Becker a esse artigo de Silva veio sob a forma que é própria do discurso pedagógico construtivista, sobretudo pelo lugar onde tende a confinar a argumentação de Silva: o lugar dos "equívocos". Segundo Becker (1994a), Silva "toma a interpretação equivocada de alguns como marca negativa do construtivismo em sua totalidade" (p. 3). E mais, a própria interpretação de Silva deve ser remetida para o mesmo lugar, para o lugar dos "desvios, confusões, equívocos ...":

(...) a "desconstrução" de Silva sacrifica a dialética e alinha-se claramente à tese positivista (ou neo-positivista) da determinação unilateral do indivíduo pela totalidade social. Como já lembramos, a matriz epistemológica dessa postura filosófica é dada pelo empirismo (...) $\mathrm{Na}$ medida em que SILVA, por preconceito ou por outro motivo inconfesso, deixa de buscar a colaboração de uma psicologia crítica, passa, inevitavelmente, a operar sobre uma psicologia ingênua; na medida em que atropela, por motivos desconhecidos, uma epistemologia crítica, inevitavelmente, enfraquecerá seu arcabouço conceitual pelo recurso a epistemologias ingênuas (aprioristas ou empiristas). (Becker, 1994a, pp. 56)

Para Becker, em síntese, quem não adere ao "caminho construtivista" vai se somar, "inevitavelmente", a tudo o que reflui em direção aos dois pontos de estrutura que definem os limites do discurso construtivista. Os dois pontos que absorvem tudo o que é rejeitado, mas que também aninham o que esse discurso precisa para completar as suas falhas.

O ponto de basta ou amarração que é própria do artigo de Silva (1993), com o novo lugar que aí é demarcado, será uma e outra vez refeito em outras falas, em outros textos e por diversos autores, por vezes colocando em causa o significante-mestre moderno e o que ele condensa. Esse, precisamente, junto com seus equivalentes, é o significante-mestre que sobrepuja o discurso construtivista já nos primeiros anos da década de 90 . De modo que o construtivismo tende a ficar sob a sua órbita, ou melhor, sob a órbita de um novo discurso moderno, um 
discurso que aqui chamaremos de Novo Moderno. ${ }^{74}$ Este, aliás, é um significantemestre que nos debates educacionais surge em discursos que às vezes se opõem, neles configurando-se a mesma divisão desenhada por Silva em sua argumentação sobre o sentido do discurso construtivista (regressivo/conservador ou progressista), com o significante moderno e o discurso que ele define pendendo para um lado ou para o outro. Ou seja, de uma parte, o moderno como futuro e como destino, representando o que há de mais avançado, desenvolvido e progressista neste mundo globalizado; de outro, o moderno como passado, como retorno do que há de pior, um retorno que sustenta e revigora o mundo dominado pelo neoliberalismo.

Sob o ponto de basta que é próprio do Novo Moderno, mas com a divisão que os debates aí introduzem, ao longo da década de 90 crescem as críticas ao construtivismo, por vezes fazendo "ressuscitar" a defesa da escola tradicional e os questionamentos já conhecidos no âmbito da pedagogia dos conteúdos, em particular os que nutrem o significante-mestre espontaneísmo. ${ }^{75}$ Essas críticas, porém, não abalam a hegemonia do novo discurso, pelo menos não de modo imediato. Nesse período os seus pontos de estrutura encontravam-se bem assentados, sendo constantemente refeitos ao sabor dos movimentos que são próprios dessas críticas. Esses pontos parecem sofrer uma primeira e tímida diluição na segunda metade da década de 90 , quando o construtivismo alcança o ápice da sua hegemonia e começa a evidenciar os primeiros sinais de refluxo.

Os três pontos de estrutura que definem o lugar e o suporte do discurso pedagógico construtivista não concernem apenas ao discurso que se configura no Brasil. Um bom exemplo pode ser encontrado em César Coll, num dos textos em que busca delinear a sua "concepção construtivista de aprendizagem e do ensino" (1996). Nesse texto, intitulado "Um marco de referência psicológico para a educação escolar: a concepção construtivista da aprendizagem e do ensino", começa assinalando a relevância e pertinência das contribuições da Psicologia da Educação para a teoria e a prática educativas, lembrando também de seus limites,

\footnotetext{
${ }^{74}$ Novo Moderno é o significante utilizado na minha dissertação de mestrado para identificar esse mesmo discurso (Revah, 1994).

${ }^{75}$ A respeito dessas críticas, que nem sempre fazem referência explícita ao construtivismo, veja-se por exemplo Corazza (1996b), Lajonquière (1999) e Souza (1998). A minha própria dissertação de mestrado insere-se nesse mesmo movimento de crítica (ver o capítulo "O 'novo' moderno", Revah, 1994).
} 
em razão da "enorme complexidade dos fenômenos educativos" (p. 390). Além disso, constata que ainda não dispomos de uma teoria ou "explicação global coerente, suficientemente articulada, precisa e com sólidos apoios empíricos, das mudanças educativas" (ibidem). A sua exposição, justamente, busca avançar nesse sentido e para tanto logo destaca o princípio explicativo básico "mais amplamente compartilhado" por autores e pesquisadores que se situam em "enquadramentos teóricos distintos" (ibidem). Esse princípio é "o que se refere à importância da atividade construtiva do aluno na realização das aprendizagens escolares" (pp. 390-1). Em outras palavras, tendo a Psicologia da Educação como principal fonte no campo da ciência, Coll destaca como princípio unificador de várias posições teóricas a conhecida "criança que constrói seu próprio conhecimento". Essa "criança" é o que também está no centro de seu "esquema integrador".

A sua exposição, conforme esclarece, pretende "proporcionar um esquema de conjunto, elaborado a partir de uma série de tomadas de posição hierarquizadas sobre alguns aspectos cruciais dos processos escolares de ensino e aprendizagem" (1996, p. 391). Essa "série de posicionamentos 'em cascata"' constitui para Coll um "ingrediente básico da concepção construtivista" (ibidem). E mais, aludir a essa série de posicionamentos "não é um simples recurso estilístico a serviço da clareza expositiva, senão o expoente das precauções adotadas para minimizar os riscos" que ele assinala, tais como: "ecletismos fáceis, simplificadores e inevitavelmente deformantes da realidade, dos dogmatismos excludentes e os perigos do reducionismo psicológico" (pp. 391-2). O ponto de partida da sua reflexão e que pode ser considerado um "antídoto" contra esses riscos - segundo o termo que ele próprio emprega — é este:

Começaremos (...) com algumas reflexões gerais sobre a natureza social da educação escolar e sua função socializadora, o que fará com que nos pronunciemos sobre o controvertido tema das relações entre desenvolvimento e aprendizagem. Este pronunciamento e as conseqüências que dele derivem constitui a plataforma que utilizaremos, em um segundo momento, para abordar o tema da construção do conhecimento na escola (...) (ibidem)

De acordo com o que César Coll argumenta, o ponto de partida da sua reflexão - e que está no cume dessa série de posicionamentos hierarquizados é "a plataforma" que lhe permite sustentar a abordagem do tema que vem a 
seguir: a "construção do conhecimento". Essa "plataforma", como veremos, é a superfície-limite que em si encerra a "controvérsia" histórica entre as já referidas linhas paralelas e opostas que inúmeros discursos costumam desenhar. Coll, neste caso, equaciona essa controvérsia sob a oposição desenvolvimento/aprendizagem. Uma oposição que define a superfície primeira que sustenta o seu discurso, o avesso cujo direito concerne ao "terceiro elemento", ou melhor, ao "ponto de equilíbrio" onde o construtivismo nasce e se instala. Um ponto que já está presente na "plataforma" de Coll, mas cuja extensão exige os desdobramentos das reflexões que se prolongam nesse texto e em inúmeros outros.

No texto de Coll (1996), os dois limites ou extremos do discurso construtivista surgem de modo nítido depois que caracteriza alguns conflitos e as suas conseqüências. Conflitos esses relacionados com a configuração histórica das principais concepções ou propostas no âmbito da educação escolar, que são basicamente duas:

(...) o fato importante é que se produz a configuração das alternativas monolíticas, mutuamente excludentes e incompatíveis, que na realidade integram elementos não necessariamente excludentes e incompatíveis. Por um lado, a concepção da educação como fenômeno essencialmente social e socializador aparece estreitamente associada a propostas ambientalistas e receptivas da aprendizagem, que não deixam lugar algum à atividade construtiva do aluno. Por outro lado, as alternativas que correspondem a propostas mais construtivas e cognitivas da aprendizagem e que atribuem, em conseqüência, um papel-chave à atividade construtiva do aluno, surgem estreitamente associadas a uma concepção da educação escolar que tende a ignorar, e em certas ocasiões inclusive a negar, sua natureza social e sua função socializadora. (pp. 3934)

Essas "alternativas monolíticas" correspondem ao que pode ser situado em linha direta com a Escola Tradicional e a Escola Nova. Ou, nos termos de César Coll, de um lado temos as "propostas mais tradicionais e conservadoras", nas quais costuma-se destacar, por parte de quem as questiona, "o papel que desempenha a educação na reprodução e conservação dos valores e interesses dominantes e a concepção de um aluno puramente receptivo e passivo que lhes é própria" (p. 393). E, de outro, as propostas que tendem a "menosprezar (...) a educação escolar e a aprendizagem de conteúdos culturais específicos como fonte criadora de desenvolvimento" (ibidem). Nas últimas, Coll acusa que "a 
função reprodutora da educação" é identificada com "o fato em si da transmissão cultural, interditando o papel que desempenha a cultura e a educação como instrumentos de transmissão cultural" (ibidem). A sua principal preocupação nesse caso é com a separação aí implicada, entre desenvolvimento e aprendizagem. Uma separação cuja procedência ele remete às "manifestações de alguns dos movimentos pedagógicos renovadores do princípio do século" e que é reforçada posteriormente, pois:

(...) recebe um forte apoio, nos anos sessenta e setenta, graças à popularidade alcançada por algumas teorias estruturalistas e construtivistas do desenvolvimento, entre as quais destaca (sic), por seu rigor, amplitude e coerência, a elaborada por Piaget e seus colaboradores da escola de Genebra. A alternativa para a pedagogia tradicional é concretizada, então, em uma série de propostas de talhe construtivista e cognitivista que, ao mesmo tempo que atribuem ao aluno um papel ativo na aprendizagem e destacam a importância da exploração e da descoberta, concedem um papel secundário aos conteúdos do ensino e concebem o professor basicamente como um facilitador e orientador da aprendizagem (...) São propostas pedagógicas, em suma, cuja finalidade é promover o desenvolvimento dos alunos, porém um desenvolvimento entendido como processo relativamente independente da realização de aprendizagens específicas. (p. 393)

Uma vez definidos esses dois pontos de estrutura, Coll cria também um "terceiro lugar", resgatando aspectos positivos de ambas propostas. Das propostas tradicionais, ele tende a recuperar o que as "justificadas" denúncias das propostas "alternativas" levaram a interditar e menosprezar. Essas propostas "alternativas" relegaram basicamente os "conteúdos" e o papel do professor, pois valorizaram sobremaneira o que é da ordem do desenvolvimento e o papel do aluno, a quem atribuíram "a responsabilidade pelo desenvolvimento" (ibidem). Em outras palavras, da Escola Tradicional pode-se dizer que ele resgata os "conteúdos" e a "autoridade" do professor - se aí realizarmos um pequeno deslocamento, apenas para utilizar o significante convocado por Becker (1993) e que nesse lugar acomoda-se muito bem. Tudo isso concerne ao que se encontra amarrado ao significante aprendizagem, mas também ao significante ensino, ambos estreitamente relacionados com a preocupação de Coll em torno dos chamados "mecanismos de influência educativa".

Do lado da "alternativa para a pedagogia tradicional", Coll recupera sobretudo o significante desenvolvimento e "a atividade construtiva do aluno", ou 
seja, "a criança que constrói seu próprio conhecimento". Essa linha "alternativa", portanto, concerne à "origem" do construtivismo. Ou melhor, a "origem" desse Outro lugar que "surge" com seu "esquema de conjunto", um esquema que integra os dois pólos até então separados:

Surge, deste modo, um esquema de conjunto, no qual os processos de desenvolvimento e aprendizagem, longe de constituírem compartimentos estanques, mantém estreitas e complexas relações entre si (...) (p. 394).

Enfim, o que Coll apresenta tem por base as mesmas articulações significantes que definem outros tantos circuitos construtivistas. As suas "reflexões" preliminares definem, precisamente, as "coordenadas" de seu discurso, que são na verdade as do discurso construtivista. Um discurso com três pontos de estrutura: os pontos que permitem realizar, uma e outra vez, o mesmo "caminho", por circuitos diversos. Esse, pelo menos, é o sentido que aqui é dado às "reflexões" de Coll, considerando o que ele próprio manifesta a esse respeito:

As reflexões precedentes proporcionam as coordenadas nas quais deve situar-se, em nosso entendimento, a concepção construtivista da aprendizagem e do ensino, e sugerem uma série de posicionamentos de "primeiro nível", que são a referência imediata para abordar o tema da construção do conhecimento na escola. (ibidem)

Essas "coordenadas" concernem à sua "plataforma", à sua superfície-limite, a superfície que sustenta e projeta o discurso construtivista. Essa "plataforma" na verdade pode ser concebida como uma superfície ou tecido com duas faces, como se fosse uma fita. De um lado, os seus pontos de fuga, os seus pontos limítrofes, o avesso da realidade que o discurso construtivista cria, o avesso que a sustenta e que chega a se confundir com essa realidade, que é a do "caminho construtivista", com a sua "origem" e os ideais que nesse mesmo ponto se aninham. De outro, o ponto de arremate, já localizado por Coll em sua "plataforma", mas que é necessário desdobrar. Como? Circulando por essa superfície, em circuitos que sempre passam pelos mesmos pontos, à semelhança do percurso que uma fita de Moebius sugere. ${ }^{76}$ As duas faces dessa superfície constituem, justamente, frente e verso do mesmo caminho, do "caminho construtivista". Isto, é claro, se quisermos deslocar e inscrever a reflexão de Coll

\footnotetext{
${ }^{76}$ Sobre a fita de Moebius, veja-se o Apêndice.
} 
no registro que surge com o significante "caminho", que vez por outra comparece nos discursos construtivistas brasileiros. Um "caminho" sustentado pelas fronteiras ou limites criados pelos discursos educacionais no âmbito dos conflitos e disputas de ordem política e cultural do último século. Limites que muitos construtivistas querem tornar cristalinos, mas que assim cristalizam, enrijecem ou reificam; não apenas esses limites, mas também o saber que o seu discurso cria, sobretudo quando se vêem impelidos a responder às demandas do "futuro".

\section{Na direção do futuro}

Com o "caminho construtivista" definido e bem assentado, os questionamentos e críticas que ganham intensidade ainda na primeira metade da década de 90 não encontram espaço nas páginas da revista Nova Escola, que praticamente os exclui, quando não os enclausura dentro dos já referidos pontos limítrofes (escola tradicional/espontaneísmo). Isso não quer dizer que não acolha as inúmeras "dúvidas" que parecem aflorar em meados dessa década, talvez em decorrência do ponto de basta que criou um novo lugar para o construtivismo - o de uma tendência que parece progressista, mas que na verdade é regressiva e conservadora. Nas matérias da Nova Escola, essas dúvidas vez por outra são respondidas pela "respeitadas especialistas" que a revista consulta. Como ocorre nesse preciso momento, quando as dúvidas parecem transbordar o espaço que habitualmente Ihes é destinado em suas páginas. Isso é o que pode ser observado na edição em que o construtivismo é "trocado em miúdos", em março/95, na segunda e última ocasião em que esse significante-mestre é transformado na manchete de capa. Uma emergência que corresponde a uma nova inflexão do discurso construtivista, um novo corte, feito com o mesmo significante de arremate, mas não apenas com ele, como ainda veremos.

Nesse número, no editorial, é feita uma tímida alusão àquelas críticas:

Se há um assunto que mexe com o nosso leitor, é a nova linha pedagógica conhecida por construtivismo, tema sobre o qual NOVA ESCOLA mais recolhe manifestações — de nariz torcido algumas, de sincera admiração outras e de neutra curiosidade a maioria. A reportagem de capa desta edição é o resultado de um esforço concentrado da equipe da revista para saciar, ao menos em parte, essa formidável sede de informação. Começou por uma maratona de quinze horas de reuniões para selecionar as dúvidas mais comuns despertadas pelo construtivismo 
(chegamos, para nosso próprio espanto, a nove dezenas de indagações). (p. 3)

Depois dessa seleção, essas questões foram apresentadas a "cinco respeitadas autoridades brasileiras em construtivismo", a quem a revista agradece "pelo total de 47 horas gastas em esclarecê-las". Dentre essas "especialistas", algumas já haviam sido mencionadas em outras reportagens, como Esther Grossi, vinculada ao Geempa, e Sônia Barreira, diretora pedagógica da Escola da Vila. O próximo passo envolveu "o editor especial" da revista, que cuidou da delicada tarefa de fundir as respostas, nem sempre convergentes, e de baixá-las para o patamar mais razoável de 50 tópicos" (ibidem). Nesse "caminho" de crescente enxugamento e maximização do que foi levantado junto aos professores, mas também de busca de clareza, objetividade e "concretude", ainda faltava esta última etapa: "O desafio restante era encontrar uma apresentação visual concreta para um tema tão abstrato quanto o construtivismo" (ibidem). E quem "deu conta do recado" foi "o novo diretor de arte".

A "reportagem de capa" consiste na verdade em 50 perguntas, acompanhadas das respostas que buscam esclarecer as "grandes e pequenas dúvidas" do leitor. ${ }^{77}$ Respostas objetivas, breves, que não ultrapassam o tamanho de um parágrafo. São respostas onde todo e qualquer traço subjetivo, singular, foi apagado. Quem responde é "a" síntese feita pela revista, tendo por base a consulta feita às já referidas "cinco respeitadas especialistas", como volta a ser lembrado no olho que sucede ao título. As perguntas e as respostas foram devidamente organizadas e hierarquizadas, sendo precedidas pela questão que parece a mais essencial, se tomarmos como referência o que tende a mobilizar os defensores do construtivismo e também seus críticos: "O que é o construtivismo?". Uma pergunta respondida em um parágrafo, mas que podemos supor desdobrase em todos os demais.

Sobre a primeira pergunta, a revista informa que o construtivismo é "o nome pelo qual se tornou conhecida uma nova linha pedagógica que vem ganhando terreno nas salas de aula há pouco mais de uma década" (p. 8). Entretanto, "as maiores autoridades do construtivismo" ainda "não costumam

\footnotetext{
${ }^{77}$ Cf. "O tira-teima do Construtivismo: 50 grandes e pequenas dúvidas esclarecidas", Nova Escola, n० 82, março/95, p. 13.
} 
admitir que se trate de uma pedagogia ou método de ensino" (ibidem). No plano das práticas, salvo a alfabetização, ainda é necessário "amadurecimento e sistematização". Feitas essas ressalvas, logo depois alude-se às "linhas gerais" da "pedagogia construtivista", onde o leitor é informado que através do termo construtivismo procura-se indicar "que uma pessoa aprende melhor quando toma parte direta na construção do conhecimento que adquire" (ibidem). As práticas construtivistas, informa-se a seguir, têm por base os "estudos do psicólogo suíço Jean Piaget", de quem são também esboçadas algumas idéias. Mas Piaget não criou o construtivismo: "Nada mais falso (...) ele nunca se preocupou em formular uma pedagogia (...) Outros especialistas é que se valeram das suas descobertas para desenvolver propostas pedagógicas inovadoras" (p. 9). E nesse ponto é destacada "a psicóloga Emilia Ferreiro", que foi "quem adotou e tornou conhecida a expressão" construtivismo, assim "batizando" a sua própria teoria (ibidem). Mas ela tampouco é considerada a autora da pedagogia construtivista. Ela "se limitou a desenvolver uma teoria científica" (ibidem). Nessa parte, a trajetória do construtivismo é assim apresentada:

No começo, o nome construtivismo se aplicava só à teoria de Emilia. Com o tempo, passaram a ser chamadas de construtivistas as novas propostas pedagógicas inspiradas em sua teoria, a própria teoria de Piaget e até mesmo pedagogias anteriores, porém compatíveis, como a do educador soviético Lev Vygotsky (...) (p. 9)

Nessa reconstituição histórica, o que é apontado como referência básica e explícita do construtivismo concerne apenas à psicologia, com Piaget figurando no seu ápice. O nome Paulo Freire, que aparecia com relativa freqüência antes dessa nova fase da revista, sequer aparece. Em outras palavras, os pontos de ancoragem deixaram de cumprir a sua função, o novo discurso já é hegemônico e vários desses pontos desapareceram, enquanto outros continuaram sustentando esse discurso, que deles se apropriou e assim transformou em seus pontos de ressonância. Quanto à "teoria de Emilia", além de serem destacadas as conhecidas fases que a criança atravessa até se alfabetizar (pré-silábica, silábica, etc.), assinala-se que ela "abriu aos educadores a base científica para a formulação de novas propostas pedagógicas de alfabetização, sob medida para a lógica infantil" (p. 9). Desse ponto em diante, são brevemente tratados diversos assuntos, vários deles envolvendo questões relacionadas com a prática pedagógica e o papel do professor. 
Nessa longa série de perguntas e respostas, continua sendo (re)configurado o lugar que é próprio do discurso construtivista ou, mais exatamente, o "terceiro lugar", resguardado pelos seus pontos limítrofes. Estes surgem sob as suas formas típicas: escola tradicional/prática tradicional/ensino tradicional e prática espontaneísta. Também estão presentes as articulações discursivas que sustentam esses dois pontos significantes. Dentre elas podem ser destacadas duas, que correspondem aos olhos internos da matéria, que são quatro. O primeiro e o último correspondem a esses extremos, pelo menos se consideramos os significantes-mestres evocados pelas advertências feitas ao professor. No primeiro, ao professor que se aproxima do que é demarcado com o significante escola tradicional e seus equivalentes: "Nada de afogar o aluno com coisas prontas e acabadas. O caminho a ser trilhado é o da descoberta, da aventura do saber" (p. 10). O segundo com uma advertência para o professor que tende a cair no espontaneísmo: "Um professor flexível, mas pronto para intervir quando necessário: existem limites" (p. 13). Na mesma página em que é destacado esse último texto, menciona-se essa "prática espontaneísta", relativa à "fase inicial" do construtivismo, quando "o aluno era deixado muito solto, como se a professora não estivesse" (ibidem). "O superliberalismo pedagógico destoa das concepções do construtivismo", que também "pune alunos indisciplinados" (ibidem). Nessa última parte, concomitante a essa súbita emergência da "origem" do construtivismo, é novamente traçada a sua trajetória, repetindo-se parte do que havia sido afirmado no começo da matéria. ${ }^{78}$

Em relação aos outros dois olhos internos da matéria, os textos tendem a demarcar o lugar do ponto de arremate. Mas, num deles, também é apresentado este ditame: "Cooperação, em vez de competição: o conhecimento como o desafio pessoal de cada um" (p. 12). A restrição ou advertência aí implicada é curiosa, entre outras coisas porque pouco corresponde a certo viés que toma conta da revista, presente por exemplo no título escolhido para o editorial desse número: "A maratona do construtivismo" — um título que bem ilustra a torção sofrida pelo "caminho construtivista". Por enquanto, digamos apenas que se tornou uma longa, intensa e concorrida competição.

\footnotetext{
${ }^{78}$ Depois dessa matéria, o significante espontaneísmo foi encontrado apenas uma única vez, nesse mesmo ano, se consideradas as matérias pesquisadas até o fim de 1998. Cf. "Fachada antiga e alma nova", Nova Escola, n 83, abr./95.
} 
Quanto ao "ponto de equilíbrio" do discurso construtivista, ele continua sendo definido por meio das várias articulações discursivas que aqui já foram evidenciadas e mantendo-se distância em relação a certos significantes que continuam confluindo em direção aos pontos limítrofes. Isto último é o que ocorre quando é mencionada a "prontidão" na alfabetização ou as "cartilhas", que não por muito tempo continuarão confinadas nessa região do discurso - as "cartilhas construtivistas" já estão a caminho. Nessa matéria também parece existir a preocupação com o "resgate" de articulações discursivas ou de significantes que por muito tempo ficaram amarrados ao significante-mestre escola tradicional. Esse jogo de aproximação/distanciamento em face dos extremos constitui um dos mecanismos discursivos que define o lugar do construtivismo, como pode ser notado nestes trechos, onde o ensino tradicional parece constituir uma referência implícita:

- (...) embora o construtivismo enfatize o processo de aprendizagem, este não ocorre desligado do conteúdo (...) a aquisição de informações é fundamental. (p. 10)

- O construtivismo estimula a descoberta do conhecimento pelo aluno. Evita afogá-lo com informações prontas e acabadas, mas quando necessário não hesita em valer-se da memorização. (ibidem)

- Se o construtivismo admite que cada aluno tem o seu processo particular de aprendizagem, a professora deve conhecê-lo, acompanhá-lo e fazer as intervenções adequadas. Mas isso não quer dizer centralização total, ao contrário. (ibidem) ${ }^{79}$

Sempre de modo breve, a matéria toca em outros pontos sensíveis, como o ensino da tabuada e das regras gramaticais, o uso de fórmulas, a realização de provas, a reprovação e a correção dos erros do aluno. Quanto ao papel da professora, afirma-se que ela deve organizar "o trabalho didático-pedagógico de modo que o aluno seja o co-piloto de sua própria aprendizagem. A professora fica na posição de mediadora ou facilitadora desse processo" (p. 11). Também é mencionado o que é necessário para "ser uma boa professora construtivista", como "mentalidade aberta, atitude investigativa, desprendimento intelectual, senso crítico, sensibilidade às mudanças do mundo", iniciativa, flexibilidade (ibidem). Segundo a Nova Escola, a professora construtivista precisa de uma "orientadora

\footnotetext{
${ }^{79}$ Em itálico foram destacados os significantes e as articulações discursivas que sem grandes esforços podem ser concebidos nas séries que confluem em direção ao significante-mestre escola tradicional.
} 
pedagógica" para "servir de interlocutora com quem ela possa refletir sobre sua prática" (ibidem). Uma "interlocutora" que, implicitamente, é necessária para que a professora construtivista possa avançar nesse "caminho" que a conduz até o ideal da "boa professora". Para as que pretendem entrar nesse "caminho", a matéria adverte que não há propriamente cursos onde se ensine a ser construtivista, nem tampouco manuais "com tudo mastigado" que cumpram com essa finalidade. Tudo isso é importante, mas o fundamental é a prática:

O fundamental, de qualquer maneira, é a prática. Calcula-se que são necessários ao menos dois anos de prática em classe, reforçados por reuniões semanais com outros colegas, para tornar-se uma boa professora construtivista.

Esse plano da prática é o que se torna central, na própria revista. Tendo como foco as ações do professor com seus alunos, com a sua classe, em geral na sala de aula, a Nova Escola investe na divulgação de técnicas, métodos, exercícios, atividades, jogos, assim como materiais didáticos que professores e especialistas criam. Há também uma preocupação com os "conteúdos", em matérias que buscam informar o professor sobre determinados assuntos que ele pode trabalhar com seus alunos. Digamos que o que ganha relevância é "o quê" e o "como" ensinar. Tudo sob o espírito moderno que se impõe em meados da década de 90, com a crescente busca de objetividade, clareza, precisão, economia, rapidez e sentido prático, como já se observa no "tira-teima" do construtivismo, onde tudo é devidamente ordenado, numerado e quantificado "quinze horas de reuniões", "nove dezenas de indagações", "cinco respeitadas autoridades", "47 horas gastas" para esclarecer as questões, com a sua redução a exatos "50 tópicos". Esse espírito moderno assume uma forma "concreta" na imagem e na manchete escolhida para a capa dessa edição, de março/95. Nas capa, desta vez não temos a imagem ou o nome de uma psicóloga precedendo o significante construtivismo, como ocorreu com Emilia Ferreiro (em março e outubro de 1989); esse significante tampouco fica sob a guarda de uma criança (como na capa de maio/91) ou é vinculado à imagem de uma professora construtivista e ao "caminho" que ela realiza (como em abril/93, com a professora Bernadete). Agora, evoca-se uma outra coisa. O apelo não é mais pela via da imagem de uma psicóloga, de uma criança ou de uma professora com seus 
alunos, como é o caso das capas dos números acima lembrados. Do que é humano e está vivo, por assim dizer, restou apenas uma mão:

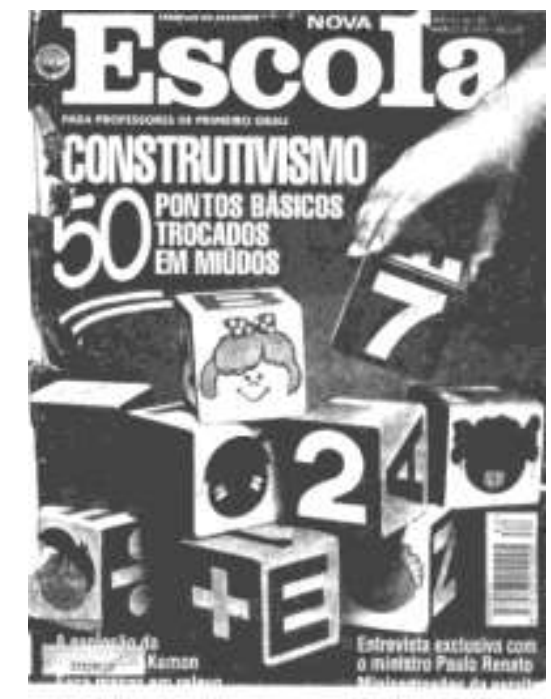

Com essa matéria que retalha o construtivismo em 50 itens, para depois trocá-los em "miúdos", pode-se dizer que entramos numa nova fase do discurso pedagógico, que já não precisa ser chamado de construtivista. Afinal, nesse momento o construtivismo é quase que onipresente, mesmo quando esse significante-mestre não aparece. A capa dessa edição já parece antecipar qual o sentido dessa nova fase, desse novo ponto de basta que convoca a imagem de alguns cubos. Estes estão dispostos à maneira de uma construção vertical e em suas faces foram estampados alguns números, letras, sinais de operações matemáticas e os desenhos estilizados de cinco rostos infantis, cujos traços denotam certa diversidade racial. Com essa imagem, com esses poucos elementos, a revista configura e antecipa parte do que deverá ficar num primeiro plano. O mais evidente é o "material didático" — os cubos com os quais podem ser trabalhados alguns "conteúdos" e que sugerem determinado tipo de "atividades" ou "jogos". A quem? Ao professor e sobretudo às crianças, que estão como que embutidas no material, como se dele dependessem. Digamos que elas vão para onde ele conduz. Uma inferência nada arbitrária se considerarmos que esse, precisamente, é parte do viés que se afirma e predomina nas matérias da Nova Escola nessa fase tecnicista, que basicamente concerne aos anos de 1995, 1996 e parte de 1997, quando esse viés começa a perder o seu vigor.

Para situar melhor os efeitos que são próprios dessa torção é necessário recuar alguns anos, até o momento em que se configura o ponto de basta que põe 
em cena o significante-mestre moderno e seus equivalentes nesse período (futuro, desenvolvimento, globalização, etc.). Da costura que é feita com essa agulha, resulta o espírito moderno que toma conta da Nova Escola, mas também do discurso construtivista, que é uma das forças que evoca e chama o significante moderno. Boa parte deste último item trata dessa dupla torção: a torção do Novo Moderno e a inflexão que tende a transformar o construtivismo num saber meramente técnico, pelo menos até entrada em cena dos PCN.

\subsection{O futuro ameaçado}

Se tomarmos como guia a revista Nova Escola, algumas das costuras que são próprias do Novo Moderno começam a ser ensaiadas em fins dos anos 80. Mas apenas na década seguinte produz-se o corte que cria o ideal do "novo cidadão". E aí podemos considerar crucial o ano de 1993, quando a estrutura do "caminho construtivista" já havia sido definida e essa nova demanda alcança um primeiro plano, assim sobrepujando os discursos educacionais. Essa nova demanda parece redobrar as exigências feitas ao professor, em especial ao professor da escola pública, a quem cabe trabalhar em prol desse "futuro" que já está no presente fazendo esta exigência: formar um tipo de pessoa e profissional pronto para participar e trabalhar no mundo moderno - um mundo globalizado, altamente competitivo e marcado pelo rápido desenvolvimento de novas tecnologias. A ambivalência que define o lugar do professor é nutrida e acentuada por essa nova demanda, que se soma às anteriores, não sem reordená-las e colocá-las sob a sua direção. Essa demanda nasce junto com a retomada da velha articulação entre educação e economia, educação e desenvolvimento ou educação e modernização/modernidade. Uma articulação que também faz ressurgir as críticas ao que é visto como um retorno à crença no poder redentor da educação e à idéia da educação como alavanca da transformação social. ${ }^{80}$

\footnotetext{
${ }^{80}$ Veja-se, por exemplo, Candau, num texto onde discute as reformas educacionais na América Latina e refere-se a esse retorno: "é possível identificar o ressurgimento de uma antiga postura em relação à educação que, para muitos, parecia já superada. Trata-se da forte crença no poder 'redentor' da educação, de um certo messianismo pedagógico, que afirma serem a mudança nos sistemas educativos e a renovação pedagógica os eixos fundamentais para a superação de todos os problemas e de todas as dificuldades que enfrentam atualmente nossos países em acelerado processo de modernização" (1999, p. 30).
} 
As costuras que precedem a emergência do "novo cidadão" e cujos traços característicos são relacionados com o mundo moderno e com as suas demandas podem ser encontradas na revista Nova Escola da década de 80. Por exemplo, numa matéria de dezembro de 1988 sobre um "Programa de Treinamento de Criatividade" voltado para professores da cidade de Ceilândia e que foi desenvolvido pelo Instituto de Psicologia da Universidade de Brasília. Nessa reportagem, entre outras coisas fala-se da mudança ocorrida em algumas professoras depois do "treinamento", uma mudança definida por traços que também concernem aos alunos. ${ }^{81}$ No box intitulado "Preparando-se para enfrentar desafios", esses traços são vinculados às exigências do "mundo moderno":

A crescente complexidade do mundo moderno exige a formação de pessoas com pensamento criativo, inovador, capazes de encontrar soluções para os novos problemas que surgem, de criticar e reformular o conhecimento existente. (p. 33)

Esse tema, relacionado com o par modernização/modernidade, entra na pauta do país impulsionado pelo discurso político, em particular pelo presidente Collor, que dele se apropria para articular a promessa de um "Brasil novo e moderno". Um tema que encontra eco na Nova Escola e que começa a ganhar alguma evidência no início dos anos 90 . Em agosto/91, por exemplo, pode ser encontrado um informe publicitário do governo Collor com este título: "Modernidade e educação básica". Eis o primeiro parágrafo:

Desde a posse do presidente Fernando Collor, ocorrida há mais de um ano, a palavra Modernidade passou a fazer parte do dia-a-dia do povo brasileiro. Mas, afinal, o que significa Modernidade? Com o objetivo de obter maio clareza do seu real significado especificamente no campo educacional, a Secretaria Nacional de Educação Básica (Seneb) organizou um Ciclo de Estudos com a participação de conferencistas de tendências e posturas ideológicas consideradas diversas. 82

Segundo esse "informe MEC-SENEB", com esse "Ciclo de Estudos" deu-se início a "um processo de reflexão crítica sobre Modernidade e Educação". Um processo que se pretende aprofundar, tendo em vista "o interesse maior da Seneb", isto é, "que a Modernidade chegue à mentalidade das pessoas, que haja realmente a consciência da Modernidade". Quanto a esse primeiro evento, o

\footnotetext{
${ }^{81}$ Cf. "Uma lição de idéias, técnicas e muita liberdade", Nova Escola, n 27, dez./88, pp. 30-3.

${ }^{82}$ Cf. Nova Escola, n 50 , ago./91.
} 
"informe" apresenta algumas opiniões e falas dos que nele participaram, ressaltando-se o nexo modernidade/educação, além de outras articulações, como se observa nestes trechos:

- (...) 0 "vocábulo Modernidade está no ápice de transformações socioeconômicas que se operam em vários países, tendo por roteiro básico uma concepção neoliberal de Estado e Sociedade". [professor Célio da Cunha da Seneb]

- (...) "que nenhum país pode entrar na era da Modernidade com um contingente tão elevado de analfabetos". [professora Nanci Martins de Paula, responsável pela organização e coordenação do evento]

- "A Modernidade na educação básica", a seu ver [professora Nanci], "também passa necessariamente pela formulação de uma política que oriente o projeto educacional comprometido com o presente e voltado para o futuro."

- (...) o professor Benício aborda o pensamento de intelectuais alemães que afirmam "que o Estado mínimo é a expressão máxima da Modernidade". A Democracia é necessária, sem ela não há solução.

- "A descentralização do processo de educação precisa ser real para servir à escola básica que hoje deverá ser universal e de qualidade", disse a professora Guiomar Namo de Mello, ao expor sobre Modernidade e Educação.

Nesse "informe" comparecem vários significantes-mestres que definem os pontos de ressonância próprios do discurso político e que nesse momento coincidem ou são articulados com os que correspondem ao discurso educacional, tendo como eixo o significante-mestre modernidade. Nesse "informe", na série significante cujo rumo é definido por esse significante-mestre, podem ser destacados os seguintes pontos: analfabetismo, qualidade de ensino, democracia, Estado mínimo, transformações socioeconômicas, neoliberalismo e futuro.

Nesse mesmo ano, nas séries significantes que nutrem o moderno, já pode ser encontrado o significante-mestre construtivismo, que é o significante que tende a atrair e abrigar tudo o que ganha relevância no campo educacional, como é o caso do que converge nos dois significantes-mestres do campo educacional acima destacados: analfabetismo e qualidade de ensino. Naquele "informe", o significante construtivismo não comparece. Talvez porque, nesse momento, as linhas que unem a nova modernidade com a educação estão sendo estabelecidas e, em relação ao construtivismo, esses vínculos são por demais tênues, pelo menos na revista Nova Escola. Nesta, a presença do construtivismo no curso do significante-mestre moderno pode ser observada, por exemplo, no editorial da 
edição em que o "caminho construtivista" surge com seus três pontos de estrutura, em maio/91. Esse "caminho", no editorial, já é implicitamente inscrito na trilha do moderno ou, mais exatamente, no rumo do "avanço" e da "modernização":

Típicos de todos os processos, o da Educação brasileira rumo ao avanço e à modernização também apresenta incongruências, percalços e momentos de dificuldades bastante curiosos. Veja, nesse sentido, o balanço que nossa matéria de capa faz a respeito do trabalho de alfabetização na linha construtivista (...) (p. 3)

Para pensar esse processo de modernização, uma referência fundamental são os países do chamado Primeiro Mundo. Deles, em 1991, a revista Nova Escola destaca as reformas educacionais que nesse período estão se processando no continente europeu. Essas reformas constituem o tema de uma série de duas matérias feitas nesse ano, que consistem basicamente em entrevistas com "autoridades educacionais" de quatro países: Espanha, França, Itália e Portugal. Nessas entrevistas, Paulo Freire, Emilia Ferreiro, Piaget e construtivismo são os únicos significantes de arremate usados pela revista nessas duas reportagens, em perguntas sobre as idéias ou concepções pedagógicas aplicadas na Espanha, no caso do primeiro, e na França, no caso dos últimos três significantes. Ou seja, são esses os significantes de arremate que de forma explícita orientam a formulação de questões sobre esse assunto, pelo menos nos casos acima assinalados. Segundo a revista, esses quatro países "estão modificando seu sistema educacional básico, para colocá-lo em sintonia com as exigências de uma sociedade industrializada do século XXI". ${ }^{83}$ São reformas necessárias para "enfrentar os desafios do futuro" ${ }^{84}$ um futuro que nesse caso envolve "um salto" que já adquire a feição de algo ameaçador, como é possível perceber em um trecho de um box que a revista apresenta para situar essas mudanças:

É dessa forma que os países do chamado Primeiro Mundo estão se preparando para enfrentar os desafios do século XXI. Armam um salto que certamente ampliará a distância que os separa dos países que formam o mundo do lado de cá do planeta, os quais, se não reagirem a tempo,

\footnotetext{
${ }^{83}$ Cf. "A Europa constrói a escola do século XXI", Nova Escola, n 51, set./91, p. 18.

${ }^{84}$ Ibidem.
} 
estarão condenados a um crescente subdesenvolvimento, atraso tecnológico e dependência econômica e cultural ${ }^{85}$

O que vai se configurando nesses discursos constitui uma nova dobra nas demandas feitas à escola e ao professor, principalmente do ensino público. Segundo o que se afirma em uma das reportagens, investir na educação básica "é a garantia mais segura do futuro promissor de um povo". ${ }^{86}$ Um futuro que surge sob a ameaça do atraso. Para evitá-lo, para sustar essa ameaça e alcançar esse "futuro", além de resolver o histórico problema do analfabetismo e do fracasso escolar, é necessário enfrentar tudo o que aquele "salto" supõe. É necessário sobretudo formar os "novos cidadãos". E, para isso, primeiramente é preciso dirigir a nossa atenção para a escola: "A formação de cidadãos plenos começa na escola" (ibidem).

"Como ajudar a formar o novo cidadão" é precisamente a manchete de capa da Nova Escola de março/93. No título da matéria principal, esse cidadão torna-se "o jovem participativo" cujo principal exemplo são os "caras-pintadas": os jovens que fizeram ressurgir o "movimento estudantil" e que participaram do "formidável movimento popular que tomou as ruas e praças de norte a sul do Brasil - exigindo ética na política e punição dos responsáveis pelo escândalo Collor-PC Farias". ${ }^{87}$ A reportagem descreve brevemente várias experiências desenvolvidas em escolas públicas e particulares, mencionando iniciativas tomadas em nível estadual e municipal em diversos Estados. Essas escolas estão derrubando "alguns mitos", como o de que a "escola não é lugar de discutir política" e de que "apenas adultos formados devem participar de movimentos de reivindicação", conforme é destacado no olho que abre a reportagem (ibidem). Além disso, no mesmo olho, sublinha-se que essas escolas estão "tentando plantar em seus alunos a consciência de verdadeiros cidadãos", "cidadãos críticos e atuantes". Essa temática mobiliza diversas referências, como o conservadorismo dos professores, o regime militar, os símbolos nacionais — dos quais aponta-se a recuperação de seu prestígio —-, as "práticas que fortalecem o sentido de cidadania" (os grêmios estudantis, os Conselhos de escola, as eleições

\footnotetext{
${ }^{85}$ Cf. "Entrevista Antonio Moreno Montero. 'A Espanha busca a escola autônoma'", no box intitulado "A Europa reorienta o ensino básico", Nova Escola, n 50, ago./91, p. 23.

${ }^{86}$ Cf. "A Europa constrói a escola do século XXI", Nova Escola, n 51, set./91, p. 18.

${ }^{87}$ Cf. "Como ajudar a formar o jovem participativo", Nova Escola, n 64, março/93, p. 9.
} 
diretas de diretores), a importância da convivência com as diferenças e a divergência, a luta da comunidade no relato de uma experiência, um professor que instiga seus alunos a pensar e raciocinar, cobrando coerência de atitudes, a escola aberta à participação e a participação efetiva e consciente para que as mudanças sociais e econômicas possam acontecer. Enfim, esses são alguns dos elementos do texto principal, onde deve ser destacado o significante política e sobretudo o significante-mestre cidadania/cidadão, que perpassa toda a matéria.

A reportagem apresenta também dois box. No primeiro, bem pequeno, é definido o que é cidadania, recorrendo-se ao dicionário Aurélio, à fala de um professor e a um livro (p. 10). O segundo box, bem maior que o anterior, inscreve o significante cidadania num outro registro, se comparado com o que predomina no corpo da reportagem. Intitulado "'Sem educação competente, não há cidadania'", o registro que aí predomina concerne à relação capital-trabalho, conforme fica em evidência na frase inicial: "'De forma consensual, Capital e Trabalho vêem na carência da educação fundamental o principal entrave à construção da Nação."' (p. 14). Esse trecho, informa-se no box, é o início da "Carta Educação, um dos documentos divulgados em junho do ano passado pelo Fórum Capital/Trabalho", do qual participaram "as principais lideranças empresarias e sindicais do país" (ibidem). A seguir, destaca-se o que nesse debate foi mais importante:

A idéia que norteou o debate partiu do pressuposto de que está havendo uma revolução tecnológica mundial nos processos de produção, que exige dos trabalhadores uma "formação básica universalizada" e uma capacidade de adaptação rápida a novas tecnologias, que estão em constante aperfeiçoamento. "A educação fundamental torna-se, por isso, condição estratégica essencial" (...) (ibidem)

A maior parte do que resta desse box são trechos da fala do professor Sérgio Costa Ribeiro, do qual destaca-se, entre outras coisas, a sua indignação com a "pedagogia da repetência" e a sua defesa de uma "educação competente". Sem ela, até mesmo o Brasil, como nação, pode sucumbir:

Segundo Sérgio Costa Ribeiro, se não houver um investimento na direção da melhoria significativa da educação básica no Brasil, será perda de tempo falar-se em cidadania, porque em pouco tempo o país não terá como competir na economia mundial, correndo o risco de deixar de existir como nação. "O conceito de cidadania moderno é exatamente o indivíduo 
capaz de dominar os códigos internacionais nos conhecimentos universais para poder competir a nível internacional", arremata.

Convocado para fazer face ao "futuro", o cidadão moderno acima suposto surge atrelado a demandas que procedem do campo econômico. E mais, o seu lugar é definido por meio de significantes que são próprios desse registro, como "Capital/Trabalho", "revolução tecnológica", "qualificação da mão-de-obra", "produção", "produtividade", "competências", "competir".

Com o que é acrescentado e destacado nesse box, a formação do "novo cidadão" fica sob a injunção de dois registros. De um lado, no corpo da matéria, o registro que é próprio do significante cidadania: a política e a democracia. De outro, destacado no seu principal box, o registro que desde fins da década de 80 sobrepuja o discurso político: a nova ordem econômica mundial. São dois registros que nessa reportagem encontra-se bem separados, digamos que a sua articulação, pelo menos nesse caso, é precária. ${ }^{88} \mathrm{O}$ que fundamentalmente os vincula são os significantes educação/formação e cidadania/cidadão.

O moderno cidadão dos anos 90 nasce sob essa articulação, uma articulação significante que coloca a educação escolar sob uma nova ordem, sob um novo e ao mesmo tempo velho ideal: o moderno. À primeira vista, o Novo Moderno resulta do discurso econômico que se impõe com o fim da ordem bipolar que caracterizou a geopolítica mundial durante boa parte do século $X X$, em razão da colapso da União Soviética e dos regimes comunistas da Europa Oriental. Entretanto, se atentarmos ao modo como esse novo discurso moderno se

\footnotetext{
${ }^{88} \mathrm{Na}$ revista Nova Escola, o registro relativo à "nova ordem mundial" ainda não é considerado na primeira reportagem voltada para a questão da cidadania e destacada na capa, na edição $n^{\circ} 31$, de junho/89. Intitulada "A cidadania começa nos bancos escolares", o que nessa reportagem é central passa pelos significantes-mestres cidadania/cidadão, democracia, escola e educação/formação. E o que aí está em pauta, relacionado com a "primeira eleição presidencial direta após quase três décadas de privação compulsória deste direito democrático", não é a formação do "novo cidadão" e sim de "cidadãos conscientes, críticos e participativos", conforme é assinalado no olho que sucede ao título (pp. 12-3). Nessa matéria, nas diversas falas e opiniões ali reproduzidas, o sentido da mudança que todos defendem em relação à escola e à formação do aluno tem como horizonte último a democracia. A única ocasião em que surge a referência ao "mercado de trabalho" ou à "produção", o seu sentido está bem distante do que pouco anos depois tornou-se hegemônico. Eis a fala que toca nessa temática: "'o que temos é uma escola anticidadão", acusa Moacir Gadotti (...) Para ele, a concepção que ainda vigora na escola brasileira é a baseada nas propostas dos filósofos iluministas (...) para quem a Educação tem por função disciplinar os trabalhadores para a produção e fazer deles cidadãos passivos. "A escola desenvolve valores individualistas, exaltando a apropriação individual do saber como uma forma de melhor colocação da pessoa no mercado de trabalho" (p. 13).
} 
configura, veríamos também que a sua emergência envolveu o (re)ordenamento dos discursos precedentes, que são os que o sustentaram e projetaram no cenário brasileiro, definindo desse modo alguns de seus principais traços. Não é o objetivo deste trabalho aprofundar essa questão. O que se busca é tão-somente assinalar a sua estreita relação com a configuração do discurso pedagógico construtivista e indicar algumas das costuras que os vinculam e que finalmente criam o encaixe que acolhe o construtivismo na estrutura do Novo Moderno. Para tanto é necessário seguir na trilha desse "futuro" que nesse mesmo ano de 1993 surge sob a forma da "ameaça", que agora, além de explícita, chega à capa da Nova Escola.

"Brasil. O futuro ameaçado" é precisamente o título de uma extensa reportagem da revista Nova Escola de dezembro/93, com direito a esta chamada na capa: "Futuro: o Brasil ameaçado pela má qualidade da escola". ${ }^{89}$ No olho que precede o corpo da reportagem, lembra-se que o Brasil vai entrar no próximo século com o acesso à educação fundamental praticamente garantido para todas as crianças. Mas, afirma-se em seguida, isso "esconde uma verdadeira tragédia nacional", pois:

O país investe muito mal no ensino básico (...) e não consegue oferecer uma escola de qualidade às suas crianças. Se nada mudar, o Brasil terá comprometido seu desenvolvimento ao formar gerações de perdedores pessoas incapazes de competir em um mercado internacional cada vez mais dominado pela tecnologia. ${ }^{90}$

Essa ameaça é retomada ao longo da reportagem, sendo hiperbolicamente acentuada logo no início, ao serem enumeradas várias tragédias que preparam a pior de todas: a extinção de um país, o fim do Brasil. Ou mais exatamente, o seu "futuricídio":

O país dos escândalos, dos massacres de meninos de rua, de favelados, de trabalhadores rurais sem terra, de presos e indígenas indefesos e também de uma das mais altas taxas de inflação do planeta, da escandalosa concentração da riqueza e do aumento brutal da miséria ainda não se deu conta de que, lenta e sistematicamente, prepara para si mesmo uma tragédia de proporções ainda mais assustadoras: o futuricídio.

\footnotetext{
${ }^{89}$ Esse tema é também o primeiro a ser mencionado e destacado no texto do editorial dessa edição.

${ }^{90}$ Cf. "Brasil. O futuro ameaçado", Nova Escola, n 72, dez./93, p. 10.
} 
Nessa matéria, mas também em discursos que encontram ressonância em diversos âmbitos, a educação básica é a que em grande medida afigura o lugar onde deve ser gestada a solução dessas tragédias, em especial a que parece condensá-las e que fica embutida no significante futuro: a "exclusão" do Brasil desse complexo e competitivo mundo moderno do século XXI. ${ }^{91}$ Esse "futuro", com tudo o que nesse ponto é amarrado, é o que em grande parte tensiona a educação escolar e, sobretudo, o lugar do professor, que nesse período é onde tendem a confluir as mais fortes demandas em prol da melhoria da qualidade de ensino.

Nessa reportagem da Nova Escola, o que adquire maior relevância são os investimentos voltados para a educação básica. Para evidenciar a sua importância, no último parágrafo da matéria, são lembrados estes exemplos:

Países como China, Cingapura, Coréia do Sul e Formosa, além de outros do Terceiro Mundo que até muito recentemente estavam em situação pior do que a do Brasil, experimentam hoje um desenvolvimento acelerado, como conseqüência direta dos investimentos que fizeram em educação nas últimas décadas. O Brasil já perdeu esse século. "Se a gente não fizer essa revolução agora, não vamos conseguir competir no próximo século", prevê Sérgio Costa Ribeiro.

Para tratar desse tema - ou seja, dos recursos investidos na educação pública e básica —, são arrolados diversos dados que expõem a "realidade sombria" do ensino brasileiro, uma realidade que os "números oficiais (...) conseguem o efeito de apresentar como rósea" (p. 10). Entre outras coisas, são apresentados dados sobre os níveis de escolarização, analfabetismo, repetência e evasão, número de escolas e professores, salário dos professores, percentual do PIB investido em cada nível do ensino e os investimentos feitos pela União, Estados e municípios. São também referidas as determinações legais sobre o financiamento da educação pública e aponta-se a queda, "que vem acontecendo", dos investimentos na área educacional nas três esferas (nacional, estadual e

\footnotetext{
${ }^{91}$ Amarrado a esse "futuro" também deverão se afirmar os discursos educacionais que tendem a crescer por uma via aparentemente diversa do discurso construtivista, em fins dos anos 90 . Ou seja, os discursos que operam com a oposição exclusão/inclusão. Uma oposição que já se anuncia nessa mesma reportagem da Nova Escola, pois a "ameaça" concerne justamente à possibilidade do Brasil ficar à margem de tudo o que esse "futuro" promete. Um "futuro" relativo ao novo "mundo tecnológico que tende a excluir os despreparados" (p. 10). Essa é uma das trilhas onde nasce e se fortalece a chamada educação inclusiva, concomitante a certo refluxo perceptível no uso do significante-mestre construtivismo.
} 
municipal), destacando-se aí a situação da educação fundamental, agravada porque recebe "uma fatia cada vez menor" do "bolo de recursos de que o MEC dispõe" (p. 13). Além disso, a reportagem ressalta que "o país investe mal" e apresenta brevemente diversos fatores ou aspectos relacionados com isso e com a escassez de recursos (burocracia, clientelismo político, excesso de funcionários, desvios de recursos, corrupção e sonegação de impostos) (pp. 157). Na última parte da reportagem, afirma-se que esses "dados estarrecedores (...) não mostram ainda a pior face da tragédia. Apenas conduzem a ela". O pior problema, o "consenso nacional", diz respeito à "qualidade de ensino" (p. 18).

Nessa matéria também é mencionada "A pedagogia da repetência", sendo esse o título de um box que compara a evasão, considerada pequena, com os altos índices de repetência. Nesse box e ao longo da reportagem é novamente citado Sérgio Costa Ribeiro para lembrar, entre outras coisas, do "novo paradigma produtivo" — que "exige competências 'que não são adquiríveis na idade adulta"' (p. 12) - e repetir uma máxima já usada na matéria sobre "o novo cidadão": "'O que distingue um cidadão de um não-cidadão é exatamente a educação"' (ibidem).$^{92}$ Mas é claro que não se trata de qualquer educação. Tem de ser uma educação adequada ao "mundo" já delineado em matérias anteriores e que novamente é lembrado:

(...) um mundo em permanente transformação tecnológica e cada vez mais competitivo no campo do trabalho, onde as economias nacionais tendem a se entrelaçar continuamente seguindo a lógica do capital internacional ( $p$. 14).

\subsection{Uma educação adaptada ao futuro}

O "mundo" acima esboçado comparece num box com este sugestivo título: "Procura-se a educação do futuro". Nesse box são mencionadas três "tendências" apresentadas pela professora Maria Inês Salgado de Souza na "conferência internacional Educação do Futuro", realizada em São Paulo nesse mesmo ano, em 1993. Trata-se de uma classificação que na verdade não vinga, mas que reforça e opera com três lugares: os primeiros dois em confronto e um terceiro que procura superar essas posições que parecem constituir dois extremos. A

\footnotetext{
${ }^{92}$ Cf. "Como ajudar a formar o jovem participativo", Nova Escola, n 64 , março/93, p. 15.
} 
primeira tendência é chamada de "mecanicista" e "vigora nos países ricos", tendo como objetivo primordial o "sucesso econômico" (p. 14). Para a professora, essa "'visão economicista visa treinar pessoas para ocupar postos de trabalho e competir na economia de mercado'" (ibidem). A "segunda corrente", que é "predominante no Brasil", entende que "O Estado é a base de tudo. 'É a educação estatal, que combate a visão mecanicista, mas que está impregnada de concepções populistas sobre o ensino'", de acordo com a mesma professora (ibidem). Essa tendência é chamada de "terceiro-mundista". E ainda temos a tendência que define este "terceiro lugar":

Segundo Maria Inês, vem ganhando força uma terceira concepção educacional, qualificada por ela de culturalista, que pretende superar as duas anteriores. "É a educação que vai sair dos movimentos sociais (...)" (p. 14)

A "educação do futuro" já havia sido objeto de uma matéria no ano anterior que consistia, basicamente, em uma entrevista realizada com Werner Markert - 0 especialista vindo do Primeiro Mundo (Alemanha) que há dois anos, como professor na Universidade Federal do Rio de Janeiro, "vem intrigando os professores brasileiros com a idéia de Educação para o Futuro". ${ }^{93}$ Antes mesmo da entrevista, o que é primeiramente lembrado é a "inadequação" do "atual sistema de ensino" em relação às "necessidades" da sociedade atual; mas também em face dos "interesses da sociedade do futuro, em que a tecnologia evolui em alta velocidade, exigindo um tipo especial de mão-de-obra" (p. 18). O que aí está em pauta é o trabalhador, "mas também o cidadão", conforme é lembrado ainda na introdução. De qualquer modo, esse cidadão é sobrepujado, do início ao fim da entrevista, pelas demandas advindas do "mercado de trabalho".

Segundo Markert, os chamados "cidadãos competentes" precisarão "muito mais de formação geral do que de habilidades concretas e específicas" (p. 18). Ademais:

No futuro, a procura será por operários e funcionários qualificados com atuação autônoma e com muita autoconfiança. São qualificações abrangentes que incluem a competência técnica, a competência social,

${ }^{93}$ Cf. "'Não estamos formando os vencedores, mas os perdedores de amanhã'", Nova Escola, n 60, set./92, p. 18. 
como cidadão e como pessoa. A pessoa terá de ser capaz de aprender de maneira autônoma a superar situações profissionais complexas.

O "futuro" exige desenvolver "competências" — eis aí um significante que ainda demorará alguns anos para adquirir relevância e sobrepujar outros significantes que tendem a definir o mesmo lugar. ${ }^{94}$ Para desenvolver as "qualificações abrangentes" ou "competências" a que Markert alude, é preciso darIhes atenção desde as primeiras séries e realizar várias mudanças:

\begin{abstract}
Para tanto, é preciso mudar o próprio método de ensino, com menos memorização, menos conhecimento passado pronto e mais trabalhos que exijam cooperação e decisão. As escolas teriam de se organizar em outros moldes, formando grupos pequenos de alunos, incumbidos de tarefas amplas e não havendo mais lugar para as aulas expositivas. No lugar delas, teríamos projetos envolvendo toda a escola, cada grupo atuando de acordo com seu nível de capacidade. Mudaria inclusive a relação do professor com os alunos. O professor deixaria de ser um repassador de conhecimentos prontos. A escola ensinaria como agir (...) O professor seria mais democrático com seus alunos. (p. 19)
\end{abstract}

O que nesse trecho da entrevista é recusado não seria arbitrário chamar de tradicional. Esse significante-mestre, mesmo que não compareça, é "naturalmente" evocado nessas poucas linhas. Mas também outros, um explícito e outro implícito, pelo menos na pergunta que é formulada em seguida, pela revista:

NE - Esse tipo de escola ao qual o senhor se refere não seria o mesmo de algumas escolas privadas que temos por aqui, conhecidas por seus métodos alternativos ao sistema, e freqüentadas mais pelos filhos de uma classe média intelectualizada?

Markert - Sim. Seria mais ou menos como essas escolas, criticadas porque não são acessíveis à maioria dos alunos, que são pobres e não podem pagar um ensino privado. É preciso dar uma escola nova para o aluno pobre também (...) (p. 19)

Na pergunta formulada pela jornalista que realiza a entrevista, o "tipo de escola" que "temos por aqui" — no Brasil, mas também na Nova Escola — e que é adequada ao "futuro" já existe na rede particular de ensino. Ou seja, dessa rede procede o ideal já realizado, o ideal onde todas as escolas devem se espelhar, principalmente as da rede pública. Pois, para o "aluno pobre", também é preciso "dar" essa "nova escola". Nisso, precisamente, está empenhada essa publicação,

\footnotetext{
${ }^{94}$ Esse parece ser o caso das "capacidades" do aluno, cujo desenvolvimento concerne aos objetivos educacionais definidos nos Parâmetros Curriculares Nacionais e outros documentos curriculares elaborados no âmbito do MEC na segunda metade da década de 90.
} 
que há vários anos criou esse lugar com o seu próprio nome. Genericamente, como ideal simbólico, uma escola construtivista, mas encarnada, como já vimos, na escola-paradigma, na Escola da Vila, outrora uma escola alternativa, com "seus métodos alternativos ao sistema" e freqüentada por "uma classe média intelectualizada". Uma escola que nessa mesma edição de setembro/92 é destacada na capa, na imagem que corresponde a uma matéria que neste trabalho já foi comentada. ${ }^{95}$

Nessa entrevista com o professor Werner Markert encontramos parte das costuras que ligam o construtivismo à ordem discursiva que está sendo instaurada com o significante-mestre moderno e seus equivalentes. ${ }^{96}$ Mas elas são por demais incipientes, ainda exigem certo esforço interpretativo para fazer emergir os significantes de arremate do discurso pedagógico então hegemônico. Ou seja, nesse período, o significante-mestre construtivismo mal havia penetrado nos circuitos que o significante-mestre moderno e seus equivalentes estavam (re)estabelecendo. É claro que é possível alegar que o construtivismo é um discurso moderno, um discurso que chama "naturalmente" esse significantemestre, ainda mais em razão dos significantes-mestres que definem o seu ponto de arremate, como ciência e Piaget. Nada disso aqui está sendo negado, pelo menos faz sentido sob um certo ponto de vista, que não corresponde ao deste trabalho. Com efeito, se considerarmos os enunciados efetivamente produzidos, veremos que tudo isso corresponde a uma visão retrospectiva, que liga períodos históricos e significantes que foram previamente soldados pelo ponto de basta que é próprio do Novo Moderno. O que chamamos de moderno é sempre relativo a uma amarração que os discursos - este incluído - realizam em determinado momento. Essa amarração é (re)feita nos anos 90. O moderno que então emerge concerne a essa costura, a esse ponto de basta que cria certo encaixe para o discurso construtivista, um encaixe que esse mesmo discurso pedagógico ajudou a criar.

\footnotetext{
${ }^{95}$ Cf. "Como trabalhar o erro", Nova Escola, $n^{\circ}$ 60, set./92. A foto da capa foi tirada na Escola da Vila.

${ }^{96} \mathrm{O}$ modo como essas costuras vão sendo feitas também pode ser observado no texto do editorial desse número, onde o "futuro" tende a abraçar tudo o que é ressaltado nessa edição, a começar pelo destaque de capa.
} 
Se seguirmos as pistas presentes na revista Nova Escola, o ano que pode ser tomado como referência primeira dessa costura é 1993, pelo menos da costura que faz emergir o "novo cidadão", o cidadão sobrepujado pelas exigências do Novo Moderno. Com esse ponto de basta, opera-se uma inversão análoga à que já foi assinalada quando da emergência do nome Emilia Ferreiro, em 1989. O "novo cidadão", que pelo menos desde 1993 é alçado à posição de maior ideal educativo, em grande parte já existia. Ele corresponde à criança que é e deverá ser o sujeito atuante, participativo, criativo, consciente, reflexivo e crítico que desde a década de 70 vinha sendo configurado no campo dos chamados discursos educacionais críticos e que posteriormente é incorporado ao "caminho construtivista", sob a ordem da "criança que constrói seu próprio conhecimento". Ou seja, o que há mais de uma década vinha sendo gestado em diversos circuitos é transformado numa demanda feita pela novo mundo moderno, em particular pela nova ordem econômica. O mercado globalizado é o que agora faz essa demanda de um "novo cidadão" e das mudanças que é necessário introduzir nos sistemas de ensino e nas escolas para formá-lo. Essa nova ordem exige um profissional/trabalhador/cidadão com certo perfil, como se esse "novo cidadão" viesse a reboque dessa exigência. Entretanto, como acima foi assinalado, boa parte dos traços do "novo cidadão" correspondem ao ideal formativo do discurso que surge no encalço do nome Emilia Ferreiro e que também concerne aos discursos educacionais (re)ordenados nesse mesmo processo. Por isso, antes do que criados pelas demandas do "futuro" ou do novo mundo moderno, os traços que definem o "novo cidadão" - mas também outros que definem o novo ensino, a Nova Escola, etc. - e que antecederam essas demandas são os que na verdade criaram boa parte do terreno que é próprio do mundo desenhado por esse novo ou renovado discurso moderno.

Esse discurso surge ancorado no mesmo e largo terreno que sustenta a emergência do discurso construtivista, pressupondo também o (re)ordenamento de inúmeros discursos precedentes. Em outras palavras, o Novo Moderno é um discurso que sobrepuja todos os discursos educacionais, por meio de um (re)ordenamento que em muito extrapola o campo educacional. Nesse campo, o seu principal efeito foi o de transformar a educação escolar numa prioridade nacional, tendo em vista este objetivo: colocar o Brasil na direção do "futuro" que 
esse mesmo discurso moderno gerou. E aí se encaixa o construtivismo, como objeto que promete soldar a fissura que o novo imperativo moderno (re)criou.

Já não se trata de responder, unicamente, às velhas demandas feitas à educação escolar, relativas ao problema do analfabetismo, do fracasso escolar e da qualidade de ensino. Tampouco está em questão a criação de "um outro caminho" que contribua para a construção da democracia e a "libertação", como era próprio dos discursos educacionais críticos do início da década de $80 .{ }^{97} \mathrm{~A}$ libertação, na década de 90, praticamente saiu de cena. Agora surge uma outra exigência, à qual responde o construtivismo. Este, até então, constituía um "caminho" necessário para a construção da democracia, que desde fins da década de 70 costumava ser definida em relação ao passado, ou seja, em relação à ditadura militar, que no Brasil tendia a afigurar o seu oposto. Com o novo ponto de basta, a principal referência deixa de estar no passado. O que agora constitui uma exigência é olhar para o "futuro", o futuro desenhado pelo novo discurso moderno.

Na primeira metade da década de 90 surge então uma outra equação. Considerando os discursos educacionais críticos do início da década de 80 , podese dizer que o que neles tendia a predominar correspondia a esta articulação significante: educação crítica/democracia/libertação, com todos os significantes equivalentes que aí podem ser considerados, como socialismo, no caso do último elemento. Dos três, esse precisamente é o que tende a sair de cena no período em que o construtivismo se torna hegemônico. Com esse novo discurso educacional "crítico", articulado a tudo o que o significante-mestre moderno e outros equivalentes então sobrepujam, a educação escolar fica sob uma nova injunção, relativa a uma articulação significante que também pode ser pensada com três elementos: construtivismo, democracia e um terceiro elemento que é difícil de precisar, pois diversos significantes-mestres poderiam ser colocados nesse lugar, dado que nos discursos é por demais variável. É sociedade moderna, mundo moderno, Primeiro Mundo, globalização, revolução tecnológica, etc.; com o significante-mestre moderno e seus derivados (modernização, modernidade, etc.)

\footnotetext{
97 A "libertação", a sociedade sem opressores e oprimidos, o fim do antagonismo que divide a sociedade de classes, é o horizonte último das reflexões teóricas de Paulo Freire e Dermeval Saviani, que são os autores primeiramente lembrados no campo dos discursos críticos em disputa naquele período. $O$ primeiro nome vinculado à educação popular ou educação alternativa e, o segundo, à pedagogia dos conteúdos.
} 
sendo apenas um deles, mas que aqui está sendo destacado. Tomando-o como referência, pode ser constituída esta articulação significante, presente em muitos discursos quando considerados os significantes equivalentes: construtivismo/democracia/mundo moderno.

Essa articulação significante é criada quando se fazem confluir os vários "paradigmas" que circulam nos discursos educacionais. ${ }^{98}$ Para produzir essa confluência, um primeiro passo é dado quando o significante moderno e seus equivalentes começam a comparecer no discurso construtivista, que é um discurso cujos significantes de arremate "naturalmente" evocam o significante moderno, bastando apenas convocá-lo, ou seja, começar a usá-lo. É dessa forma que esse significante se torna um imperativo ou, pelo menos, parte dele, como pode ser observado na Apresentação do livro Construtivismo Pós-Piagetiano, publicado em 1993 (Grossi e Bordin, 1993b). ${ }^{99}$ O que nesse livro está em pauta é um "novo paradigma", nesse caso sobre aprendizagem. Na Apresentação, escrita por Esther Grossi, uma educação "eficaz e moderna" já constitui uma exigência ou, como ela afirma, "uma educação escolar efetivamente eficaz e moderna, que parta de uma reforma do pensamento, é um imperativo" (p. 9).

Dessa forma, aparecendo nas falas de um ou outro construtivista, como a "pioneira" acima citada, no início dos anos 90 o construtivismo começa a responder aos imperativos que surgem com os novos e os renovados significantes-mestres que ressoam nos campos político e econômico, em virtude do giro discursivo que repõe o significante-mestre moderno como ponto aglutinador de várias forças que o disputam. Dentre elas, as que concernem aos discursos que no campo educacional tendem a ficar com o significante crítico um significante que nesse período já se encontrava sob a órbita do construtivismo.

Com o Novo Moderno, a criança, o aluno ou o futuro adulto prefigurado nos discursos educacionais críticos da primeira metade da década de 80 não apenas não é mais o mesmo, como também é quase que o oposto do que esses

\footnotetext{
${ }^{98}$ Um deles, ou melhor, aquele que está no centro do novo ponto de basta é o "novo paradigma de desenvolvimento". A respeito desse "novo paradigma", veja-se por exemplo Paiva e Warde (1993). 99 O livro reúne uma diversidade de textos, autores e concepções. Esses textos foram apresentados no "Seminário Internacional sobre Aprendizagem" realizado em Porto Alegre, no final de 1992.
} 
discursos então definiam. O sujeito crítico, na medida em que entra no registro do cidadão moderno, não mais possui uma "consciência crítica", como era destacado no discurso da educação popular. Ademais, é cada vez menos o sujeito educado para transformar a sociedade opressora. Sem o horizonte da Libertação, o sujeito crítico ainda é o sujeito que luta por uma sociedade democrática, é o sujeito que constrói a democracia. Esse é o horizonte onde o construtivismo de início se encaixa, isto é, como um objeto necessário à construção da democracia. Sob esse horizonte, o significante crítico continua em pauta. E mais, permanece num primeiro plano, mas sofre um certo esvaziamento, menos pronunciado nos discursos onde comparecem o significante-mestre Paulo Freire e a rede significante característica da educação popular. Digamos que o sujeito crítico tende a ser sobrepujado pela "criança que constrói seu próprio conhecimento".

Com a inflexão que é própria do Novo Moderno, tudo isso fica sob uma nova ordem. Aqueles ideais, relativos ao sujeito crítico e à "criança que constrói seu próprio conhecimento", são inseridos na ordem que é própria do "novo cidadão", do cidadão moderno. Com esse novo ponto de basta, antes do que formar um sujeito crítico capaz de lutar em favor da transformação da sociedade, o que se torna premente é preparar as crianças para responder às demandas da sociedade do "futuro" - uma sociedade que de certo modo já está no presente, nos modelos que esses mesmos discursos criam quando se referem ao Primeiro Mundo. Essas crianças devem aprender a viver nesse complexo e competitivo mundo moderno que é desenhado tendo em vista a oposição excluídos/incluídos. Digamos que todos devem ser educados para serem "incluídos" nesse "futuro". E, dessa forma, antes do que a transformação da sociedade, o que tende ficar num primeiro plano é a adaptação ao novo "imperativo" moderno. Em última instância, o que muitos discursos presumem é que a crescente e bem sucedida preparação do cidadão moderno, do cidadão adaptado ao "futuro", constitui um fator decisivo para o surgimento da sociedade moderna do Primeiro Mundo.

O construtivismo é o discurso que melhor e mais facilmente se acomoda a essa nova exigência, a essa nova ordem moderna, uma ordem cuja emergência é quase que simultânea à definição da estrutura desse discurso pedagógico. Tudo parece ocorrer como se a emergência do Novo Moderno corresse mais ou menos paralela e imbricada com a estruturação do discurso construtivista, que é um 
discurso que já é hegemônico no momento em que o Novo Moderno está começando a adquirir contornos mais definidos, pelo menos se tomarmos como referência a revista Nova Escola. ${ }^{100}$ Ao encaixar-se em sua estrutura, o construtivismo torna-se um dos pontos de ancoragem do Novo Moderno e este, por sua vez, torna-se o Outro que desde então começa a pautar o seu "caminho", o Outro que o construtivismo transforma em um de seus pontos de ressonância: a sua "origem" e último destino. ${ }^{101}$ Por isso, aliás, ele próprio ganha o nítido semblante de um discurso moderno cujo parentesco com outros discursos igualmente considerados modernos, da atualidade e do passado, daí em mais é investigado e explorado, seja para aclamá-lo ou criticá-lo. Em outras palavras, o construtivismo torna-se uma vertente do novo discurso moderno, de modo que ele próprio pode ser chamado de Novo Moderno.

Para a produção daquele encaixe foi fundamental 0 crescente tensionamento da educação escolar na direção do "futuro" pressuposto toda vez que se fala do "novo cidadão". Na revista Nova Escola, esse tensionamento continua na segunda metade dos anos 90, em matérias de natureza diversa e num período em que parece arrefecer a oposição a tudo o que o significantemestre escola tradicional representa. Em 1995, por exemplo, numa matéria sobre o "método Kumon de Matemática", num pequeno box é feita esta crítica, em nome do "futuro":

O professor Antônio José Lopes (...) não poupa críticas ao método Kumon. Segundo ele, a filosofia que norteará os professores de Matemática na virada do milênio privilegiará a compreensão e não a repetição. Lopes afirma que há uma revolução mundial no ensino da Matemática, cuja meta é tornar a disciplina uma ferramenta de comunicação e trabalho da civilização moderna e não mais um elenco de fórmulas misteriosas (...)

\footnotetext{
${ }^{100}$ Em certos setores, como na "classe média intelectualizada", o novo discurso moderno já parece ter os seus contornos bem definidos em fins da década de 80 . A esse respeito, veja-se o capítulo "O 'novo' moderno", em minha dissertação de mestrado (Revah, 1994).

${ }^{101}$ É desse modo, precisamente, que é tomado até por seus críticos, como pode ser observado em artigo de Corazza (1996b). Nesse artigo, o construtivismo é concebido como uma continuidade ou repetição do "discurso pedagógico da Modernidade, que começa a ser produzido desde o Renascimento" (p. 218). Além disso, o construtivismo é vinculado ao "projeto neoliberal". Um outro exemplo dos efeitos retroativos e prospectivos produzidos pelo novo ponto de basta, pelo Novo Moderno, pode ser encontrado em artigo de Miranda (1995). Nesse texto, a "escalada do construtivismo na educação" é pensada a partir desta hipótese: as "afinidades" entre "a explicação piagetiana de inteligência" e "os requisitos de uma concepção de inteligência consoante às exigências de qualificação para as mudanças tecno-organizacionais no mundo do trabalho" ( $p$. 324).
} 
(...) "Nos próximos anos, as empresas procurarão profissionais versáteis, que saibam criar e pesquisar, e não os que decorem fórmulas", prevê. $^{102}$

Em outra matéria, do mesmo ano, intitulada "Fachada antiga e alma nova", os que respondem ao apelo que vem do "futuro" são os colégios jesuíticos, conforme consta no olho que segue ao título: "Pioneiros da educação no Brasil, onde começaram a surgir logo após o descobrimento, os colégios jesuíticos modernizam seus métodos com base em várias concepções de ensino". ${ }^{103}$ Essas "várias concepções" logo são elencadas no primeiro parágrafo:

Há três anos, o colégio implantou o método do jesuíta francês Pierre Faure, que leva o nome de ensino personalizado comunitário. Na prática, trata-se de uma equilibrada mistura da matriz teórica piagetiana com recursos didáticos montessorianos, temperada com a formação inaciana e o antiautoritarismo da Escola Nova. Além disso, a nova orientação educacional combina a atenção individualizada ao aluno com a formação de uma consciência do trabalho coletivo, bem nos moldes de Célestin Freinet.

"Estamos preocupados em respeitar a construção do conhecimento pela própria criança e fazer dela um futuro cidadão, consciente de seus deveres e direitos, e que saiba trabalhar por uma sociedade mais justa", receita com orgulho o padre Luiz Fernando Klein (...) (ibidem)

O que está em foco nessa reportagem é "o tradicional Colégio Santo Inácio", uma escola privada do Rio de Janeiro "cuja fama se deve em parte à disciplina e à formação cristã" (ibidem). Na sua "nova metodologia", "o aluno passa a ser o verdadeiro protagonista do seu processo educativo e o professor tem o papel de orientador" (ibidem). Mas isso não significa, conforme "apressa-se em esclarecer o padre Klein", que seja "um método espontaneísta" (ibidem). ${ }^{104} \mathrm{Na}$ verdade, a "equilibrada mistura" de seu método — um método que é apresentado de modo a não evidenciar qualquer oposição em face do ensino tradicional ${ }^{105}$ encontra-se ao abrigo do significante-mestre construtivismo. É o que pode ser vislumbrado na maior foto da matéria, na sua legenda: "O padre Klein entre os

\footnotetext{
102 Cf. "Kumon, a febre japonesa", Nova Escola, n 82, março/95, p. 34.

${ }^{103}$ Cf. Nova Escola, no 83 , abr./95, p. 38.

${ }^{104}$ Essa é última matéria encontrada na revista Nova Escola onde é utilizado o significante espontaneísmo ou seus derivados.

${ }^{105}$ A matéria menciona as "escolas que seguem os métodos convencionais" e as "escolas de linha construtivista", mas de um modo que a oposição aí implicada não adquire qualquer relevância: "Neste ano, o Santo Inácio estará enfrentando um novo desafio: preparar a mudança nas quintas séries - ponto neurálgico tanto das escolas que seguem os métodos convencionais como nas escolas de linha construtivista" (p. 39).
} 
alunos: zelo construtivista e preocupação em formar alunos dispostos a trabalhar por uma sociedade mais justa". Esse viés construtivista é expresso de modo claro e abraçando toda a matéria apenas no sumário dessa edição (p. 3):

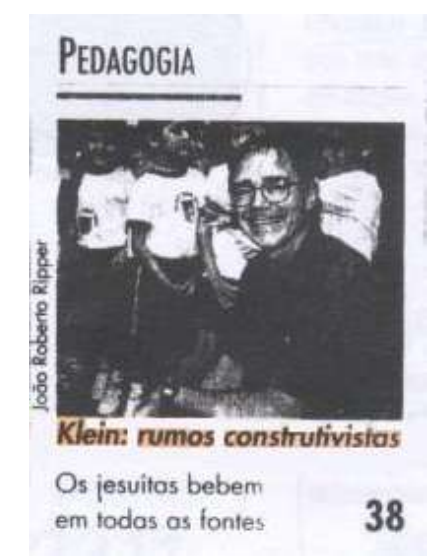

Os "rumos construtivistas", nutridos por "todas as fontes", correspondem aos rumos da "modernização", nesse caso metodológica. O objetivo último é a formação do "futuro cidadão", a preparação das "cabeças brasileiras que vão povoar o século XXI" (p. 39).

O encaixe e a identificação com o Novo Moderno, implicados na matéria acima comentada, podem ser claramente observados numa reportagem que é o destaque de capa de março/98. Nela, o "futuro" que está no presente é o que impulsiona as mudanças no ensino, como evidenciam o título - "A didática nunca mais será a mesma" - e o olho que abre a reportagem de capa: "A chegada de 100 mil microcomputadores nas escolas públicas vai obrigar os professores brasileiros a mudar sua maneira de ensinar". ${ }^{106}$ Afinal, "a nova tecnologia", "Computadores e Internet não combinam com aulas tradicionais" (p. 15). Mudar "o estilo de aula", porém, não é uma tarefa fácil, o "professor tem dificuldade", conforme é constatado num dos subtítulos que divide a reportagem. Um subtítulo complementado por este olho: "Dar liberdade para a classe procurar informações na Internet obriga os mestres a abrir mão do privilégio de ser os detentores exclusivos do conhecimento". Aqui, "abrir mão" desse "privilégio" não está mais no registro que é próprio de quem defende determinada visão de mundo, posição ideológica ou perspectiva pedagógica ou educacional baseada em determinados princípios. Antes de mais nada está no registro do que tende a se impor por si só,

${ }^{106}$ Cf. Nova Escola, n 110, março/98, p. 10. 
como uma necessidade natural, objetiva. É uma mudança imposta pela presença da "nova tecnologia", ou melhor, do "mundo moderno", que aí comparece com os vários significantes-mestres que circulam nessa reportagem, como novas tecnologias, computadores, Internet, informática. ${ }^{107} \mathrm{O}$ caráter obrigatório dessa mudança, porém, não é absoluto: "quando a escola adota uma tecnologia inovadora como a da informática e não altera sua pedagogia conservadora, os efeitos do computador são limitados". E como prova disso é dado o exemplo de escolas e professores de Nova York - uma referência que domina boa parte da reportagem.

O "mercado de trabalho" e o "futuro" a ele vinculado nessa reportagem comparecem tanto para prometer o melhor dos mundos - isto para quem "dominar a informática" e tiver o perfil do "bom profissional" 108 _, quanto também para tudo negar, pois "Não há futuro para o analfabeto digital" (p. 16). Um "futuro", portanto, que se mantém ameaçador, como tende a ser configurado por esta imagem presente na reportagem, como que sugerindo a ameaça que os computadores representam para todos os que "resistem", como é o caso dos professores tradicionais ou conservadores (pp. 15 e 17):

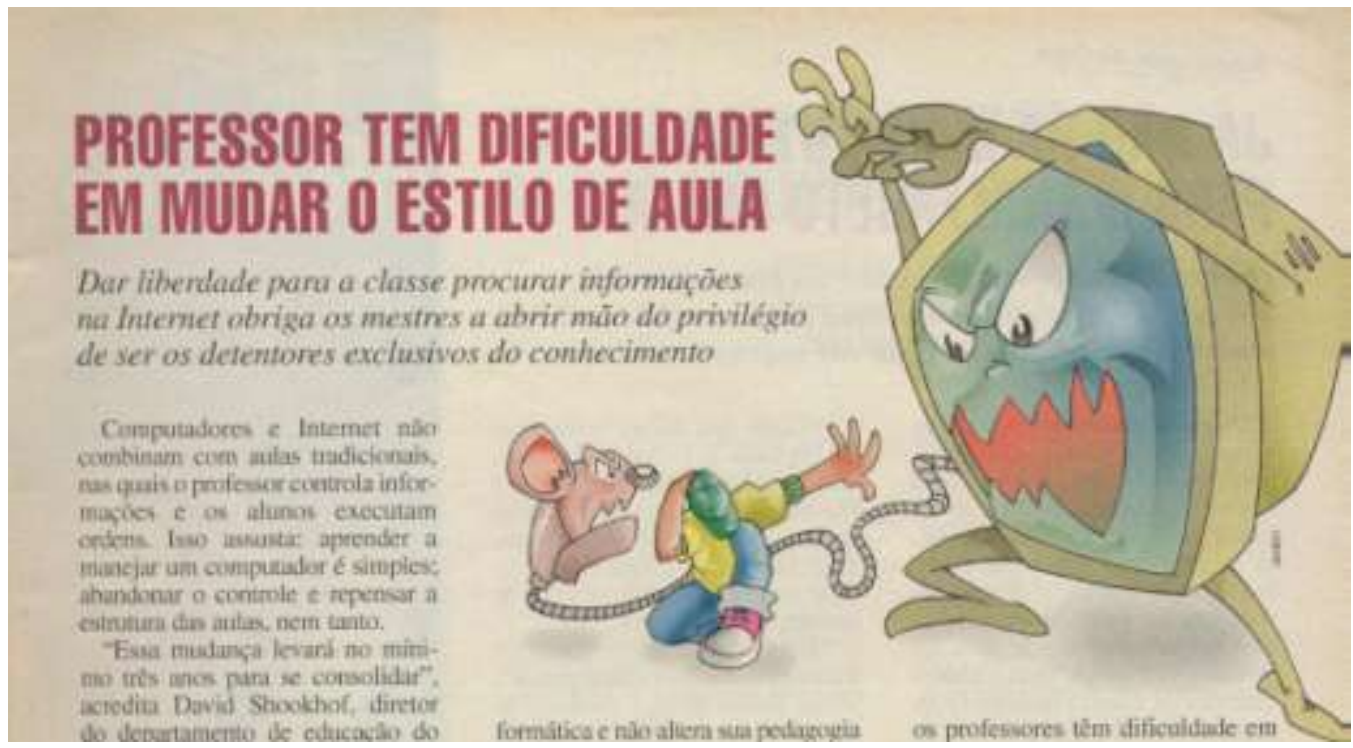

\footnotetext{
107 Outro trecho onde a mudança adquire o mesmo caráter impositivo encontra-se num box com este subtítulo: "Alunos já não conseguem ter uma atitude passiva". Eis o que segue no primeiro parágrafo: "As mudanças trazidas pela tecnologia obrigam as escolas a mudar na marra os seus métodos, antes que se tornem usinas do obsoleto" (ibidem, p. 16).

${ }^{108}$ Os traços desse "bom profissional" correspondem a vários já mencionados. Na matéria, entre outras coisas afirma-se que o "bom profissional (...) define-se pela capacidade de encontrar e associar informações, de trabalhar em grupo e de se comunicar com desenvoltura" (ibidem, p. 16).
} 
Nessa reportagem, o que é primeiramente contraposto à "educação tradicional" é a "nova tecnologia", como também fica evidente neste quadro ( $p$. 15):

\begin{tabular}{|c|c|c|}
\hline & Na educação tradicional & Com a nova tecnologia \\
\hline O professor & um especialista & um facilitador \\
\hline O aluno & um receptor passivo & um colaborador ativo \\
\hline A ênfase educacional & memorização de fatos & pensamento crítico \\
\hline A avaliação & do que fol retido & da Interpretação \\
\hline O método de ensino & repetição & interação \\
\hline $\begin{array}{l}\mathrm{O} \text { acesso ao } \\
\text { conhecimento }\end{array}$ & limitado ao conteúdo & sem limites \\
\hline
\end{tabular}

Certamente, na coluna relativa à "nova tecnologia" e no lugar desse significante não seria arbitrário colocar o significante-mestre construtivismo. A substituição significante que aí encontra-se implicada corresponde ao encaixe e à identificação já mencionados, do construtivismo com o que é da ordem do Novo Moderno.

Nessa extensa reportagem, o significante-mestre construtivismo comparece apenas na última parte, num box intitulado "Informática e construtivismo", como que sugerindo certo encaixe ou sintonia entre esses dois elementos. Algo que fica mais nítido no subtítulo - "A Internet é boa para construir o conhecimento" - e no texto que vem a seguir, onde também se afirma que a Internet cai "como uma luva":

O método construtivista de ensino é cada vez mais popular nos Estados Unidos. À medida que sugere uma participação ativa dos alunos na construção do próprio conhecimento, essa proposta pedagógica faz aumentar a demanda por novas mídias. Os alunos pedem fontes de 
informação, comunicação com o mundo externo e espaço para exibir seu trabalho, o que faz a Internet cair como uma luva. (p. 17)

Em 1998, continua a se afirmar e defender que a "Educação deve se adaptar ao futuro". ${ }^{109}$ Mas, entre os que assim pensam já parece consensual que a educação, método ou proposta pedagógica que esse futuro demanda já existe, há vários anos, sob a guarda do significante-mestre construtivismo. Nesse momento, entretanto, já há uma versão do construtivismo que tende a se tornar dominante e cujo nome sobrepuja o significante de arremate até então consagrado. Trata-se da versão que vinha sendo anunciada pelo governo federal e também pela revista Nova Escola e outras publicações desde meados da década de 90, em geral por meio deste significante-mestre: Parâmetros Curriculares Nacionais ou PCN. Essa primeira proposta curricular, relativa às quatro primeiras séries do Ensino Fundamental, é ampliada posteriormente para outros níveis e modalidades de ensino, mas com outros nomes. Mesmo assim, entre inúmeros professores e outros profissionais da educação, a versão oficial do discurso construtivista e que concerne a todos os documentos curriculares produzidos pelo MEC tende a ser identificada por meio daquele significantemestre.

Os PCN já nascem modernos, adaptados portanto à demanda que vinha crescendo desde a primeira metade da década de 90 . Em outras palavras, a versão oficial e nacional do discurso pedagógico construtivista surge quando o significante-mestre construtivismo já se encontrava sob a órbita do significantemestre moderno e seus equivalentes. $\mathrm{Na}$ (re)produção desse encaixe, além do que já foi assinalado, devem ser considerados os discursos e ações do próprio governo Fernando Henrique Cardoso, os quais desde o início revestem-se dessa áurea, ou seja, do que é expressamente concebido como moderno. É o que pode ser acompanhado seguindo-se as matérias presentes na revista Nova Escola. Uma revista cuja adesão ao novo presidente é exibida em suas páginas desde os primeiros momentos, como se observa na edição de dezembro/94, quando a imagem de novo presidente da República preenche a capa acompanhado desta manchete: "Exclusivo. O professor-presidente revela como vai sacudir o ensino

\footnotetext{
${ }^{109}$ Esse é um dos subtítulos de uma matéria intitulada "Ensino é assunto de toda a sociedade". Cf. Nova Escola, $n^{\circ} 113$, junho/98, p. 49.
} 
básico" - um destaque nunca antes alcançado pelos presidentes que o precederam. Nessa matéria, na parte que apresenta o novo presidente e que antecede a entrevista que ele concede à Nova Escola, essa adesão torna-se ainda mais nítida logo nas primeiras linhas:

Para o sistema brasileiro de ensino de $1^{\circ}$ e $2^{\circ}$ Graus, a roleta das urnas não poderia ter estacionado seu ponteiro diante de candidato mais sensível e familiar a esse universo sucateado pela evasão, pela repetência e pela prestação de serviços de qualidade reconhecidamente calamitosa. $^{110}$

Após apresentar o novo presidente, na revista segue a entrevista com este título: "A receita do novo presidente para sacudir o $1^{\circ}$ Grau" - um título que começa com um significante que rapidamente deverá ganhar relevância na Nova Escola, cada vez mais parecida com um manual de instruções repleto de "receitas" didáticas ou pedagógicas, sobretudo em 1996. Na entrevista, afora as grandes linhas das políticas a serem implementadas pelo novo governo, encontram-se algumas das articulações discursivas que são próprias do discurso moderno que já comparecia em suas páginas. Isso tanto na fala do presidente quanto nas perguntas formuladas pela revista. Por exemplo, quando se alude ao "processo de modernização da escola", à preparação de "novos cidadãos mais habilitados e competitivos" e à necessidade de ter "um sistema público de Educação justo, moderno e eficiente" (p. 12).

$\mathrm{Na}$ edição seguinte, de março/95, quando o construtivismo é "trocado em miúdos", é a vez do ministro da Educação Paulo Renato Souza, numa entrevista anunciada numa breve chamada na capa. Na introdução, afirma-se que ao ministro cabe "o monumental desafio de transformar o ensino público de primeiro grau numa máquina azeitada e eficiente". ${ }^{111}$ Tendo como prioridade a melhoria da qualidade do ensino, essa "máquina" moderna será posta em marcha, por assim dizer, com quatro ações básicas que nessa entrevista já são enumeradas, a começar pela instituição de "pautas curriculares mínimas" (p. 51). As outras ações referem-se à produção de material didático, à implementação de "sistemas de treinamento de professores" e ao estabelecimento de "um sistema nacional de televisão para a educação básica". Em outra parte da entrevista, a quarta

\footnotetext{
${ }^{110}$ Cf. "FHC. O destino da educação nas mãos de um professor", Nova Escola, n 81, dez./94, p. 8.

${ }^{111}$ Cf. "O que esperar e o que não esperar do MEC", Nova Escola, n 82, março/95, p. 50.
} 
preocupação mencionada pelo ministro, no lugar da última acima mencionada, concerne à avaliação (dos sistemas, das escolas, dos alunos) (p. 50). Aliás, a avaliação está diretamente relacionada com o tipo de ação colocada em primeiro lugar (definir "pautas curriculares mínimas"), pois, para avaliar, é preciso ter "uma medida de qualidade do sistema" (p. 52). Tendo por base essas informações advindas da avaliação, o que o ministro espera é que seja cobrado dos dirigentes "a modernização daqueles sistemas que apresentam deficiências" (ibidem).

$\mathrm{Na}$ edição seguinte, de abril/95, também com uma pequena chamada na capa, a revista desce mais um degrau na hierarquia do novo governo e entrevista a professora lara Prado, titular da Secretaria de Ensino Fundamental do MEC. ${ }^{112}$ O ponto central, destacado no título, é o "Currículo básico nacional", que "Mais do que uma lista de conteúdos de ensino obrigatório" deverá constituir "uma 'bússola' para orientação do professor e uma base homogênea sobre a qual avaliar o desempenho das escolas", conforme se informa no olho que sucede ao título ( $p$. 52). Na entrevista, os agora chamados "parâmetros curriculares" já estão no centro das ações a serem implementadas pelo MEC. Neles confluem e deles dependem - ou pelo menos essa é a tendência - as outras ações básicas necessárias para alcançar a tal almejada qualidade de ensino, como se observa mais tarde nas políticas efetivamente implementadas pelo MEC, além de ser expresso nas primeiras falas sobre o assunto, como pode ser vislumbrado na fala da professora lara Prado: "A existência de parâmetros curriculares facilita a avaliação do ensino, a formação de professores em âmbito nacional e a produção de livros didáticos" (ibidem). A entrevista vem acompanhada de uma coluna com declarações dos secretários da Educação de cinco estados, reafirmando a necessidade e a importância de um currículo mínimo nacional. Enfim, desse modo, com essas e outras costuras, os "parâmetros curriculares" surgem instalados num lugar que na verdade já havia sido criado vários anos antes por meio das costuras feitas com o significante-mestre construtivismo. Ou melhor, é um lugar definido por um significante-mestre que inúmeros educadores já utilizavam para reconhecer um tipo de linha ou proposta pedagógica cuja implementação prometia resolver, senão todos os problemas do ensino público, o principal deles, ou seja, a qualidade do ensino. E o que MEC produz como motor

${ }^{112}$ Cf. "Currículo Básico Nacional. O que vem aí", Nova Escola, n 83, abr./95, pp. 52-3. 
da sua "máquina", o que escolhe como elemento primeiro das suas políticas, concerne precisamente ao que é da ordem de uma proposta pedagógica. Ou, para sermos mais precisos, é uma proposta curricular, uma proposta construtivista, mas com um nome que nos debates educacionais deverá ressoar tão ou mais intensamente do que o nome construtivismo. Um fato do discurso que pode ser observado na revista Nova Escola a partir de 1997, quando o significante-mestre PCN ou Parâmetros Curriculares Nacionais começa a ganhar terreno e até mesmo superar o uso do significante construtivismo e seus derivados.

A costura que é própria desse novo ponto de basta começa a adquirir contornos mais definidos quando surgem as primeiras versões dos PCN. Na revista Nova Escola, os PCN começam a ser apresentados pelo menos desde março/96. Nessa edição, que apresenta uma pequena chamada na capa, em apenas duas páginas são resumidas as "propostas do ministério" para as quatro primeiras séries do Ensino Fundamental, nas áreas de Língua Portuguesa, Matemática, História e Geografia, Ciências e Temas Transversais. ${ }^{113}$ Antes disso, os leitores são informados que essas "sugestões" foram escritas por "uma equipe de 42 especialistas, a maioria ligada à respeitada Fundação Carlos Chagas, de São Paulo". Afirma-se também que se trata de "uma proposta democrática", pois "ninguém terá de adotá-la", e já é antecipado o seu sucesso: "o sucesso junto às 27 secretarias estaduais de Educação do País é quase certo" (p. 49). Nesse mesmo ano, o combate à repetência e à evasão já começa a ficar sob a órbita dos PCN, como se observa numa matéria de dezembro/96. Além de informar que os professores deverão receber o novo currículo em 1997, essa matéria refere-se brevemente ao trabalho desenvolvido em municípios que já estão usando os PCN com sucesso. É o caso da cidade gaúcha de Carazinho, que "já está trabalhando com os Parâmetros Curriculares de Matemática" e que "combate a repetência e a evasão com alterações na ordem dos conteúdos e na metodologia". ${ }^{114}$

Em 1997, na revista Nova Escola, a adesão às políticas do MEC e a construção de seu sucesso antes mesmo de que essas ações sejam plenamente implementadas continua a ocorrer e até parece intensificar-se. Um bom exemplo

\footnotetext{
${ }^{113}$ Cf. "Currículo. Um pacote de novidades", Nova Escola, n 91, março/96, pp. 50-1.

${ }^{114}$ Cf. "Professor vai receber novo currículo", Nova Escola, n 99, dez./96, p. 48.
} 
desse ano é a edição do mês de maio, cuja reportagem de capa põe em evidência a "estratégia unificadora" do governo federal. A manchete de capa, nesse caso, é construída com um significante-mestre que costumava definir o lugar onde o construtivismo encontrava-se instalado, pois esse significante define o principal problema enunciado pela maioria dos discursos sobre a educação pública, ou seja, o problema da qualidade do ensino. A manchete de capa é "Qualidade à vista", um enunciado que fica bem realçado em razão da ausência de qualquer imagem. Na matéria, com o mesmo título, anuncia-se a grande possibilidade de estarmos diante de "uma nova era", "se tudo correr conforme estratégia do MEC", uma estratégia que envolve um "conjunto coerente" de ações, medidas e projetos já realizados ou a realizar (Emenda Constitucional 14, Parâmetros Curriculares Nacionais, descentralização de recursos, etc.). ${ }^{115}$ Segundo a revista, essa "estratégia unificadora por trás de cada medida (...) traduz um extraordinário fortalecimento do papel coordenador do governo federal na educação básica" (ibidem). E mais, esse papel coordenador vem sendo desempenhado "como não se via desde que nossos primeiros mestres-escolas, os jesuítas, aqui desembarcaram, quase cinco séculos atrás" (ibidem).

A "qualidade" que essa "estratégia unificadora" deverá possibilitar, pondo em marcha para tanto a "máquina azeitada e eficiente" da Nova Escola, mas não apenas dela, corresponde obviamente ao que o "mundo moderno" demanda. É o que se observa nas falas do ministro da Educação, ${ }^{116}$ de outras autoridades e nessa mesma publicação. Nesta, em 1998, os PCN são transformados na temática principal durante oito edições seguidas. Não porque sejam destacados nas capas desses números. Na verdade, a revista quase que cria uma outra publicação inserida nela própria, pois, de abril a dezembro, todas as edições são acompanhadas de um fascículo sobre os PCN. Os fascículos, que o leitor pode destacar e reunir num único bloco, apresentam um resumo do que é proposto em cada área do novo currículo e exemplos de atividades em sala de aula. O título do

\footnotetext{
${ }^{115}$ Cf. "Qualidade à vista", Nova Escola, n 102, maio/97, p. 8.

${ }^{116}$ Eis uma dessas falas do ministro, reproduzida numa matéria da Nova Escola: "'A globalização e a nova revolução industrial significam novas exigências (...) Toda a população precisa ter o segundo grau completo (...) o sistema educacional deve preparar as pessoas para que elas se adaptem rapidamente às mudanças tecnológicas'". Cf. "Sem sacudir a educação, o Brasil não terá uma economia avançada", Nova Escola, no 107, nov./97, p. 44.
} 
suplemento mensal é precisamente PCN e sempre vem acompanhado desta frase colocada em destaque: "Fáceis de entender".

O primeiro fascículo, dedicado à área de Língua Portuguesa, vem com uma pequena introdução com várias perguntas sobre os PCN que a própria revista responde de modo breve. O título dessa introdução é "Novo tempo na escola" e a primeira pergunta é "Por que novos parâmetros curriculares?", com uma resposta que já é antecipada no olho que sucede ao título. O que aí é destacado é a necessidade da educação se "adaptar" às "mudanças econômicas e sociais", sendo assim (re)produzido o encaixe que já havia sido criado com o significante construtivismo:

A educação terá de adaptar-se às mudanças econômicas e sociais pelas quais passa o Brasil. Os Parâmetros Curriculares Nacionais trazem orientações e sugestões para você mudar sua prática na sala de aula. [texto do olho]

(...) O Brasil está mudando rapidamente. $\mathrm{E}$ isso diz respeito diretamente à educação. O mercado de trabalho, os costumes e a escola já não são os mesmos do seu tempo de estudante. Para formar os cidadãos desses novos tempos, os conteúdos e o ensino das disciplinas terão de se adaptar. É sobre esses novos rumos que falam os Parâmetros Curriculares Nacionais (PCN).

Com a versão oficial do construtivismo, esse significante-mestre alcançou o seu ápice. Ao mesmo tempo, porém, iniciou o seu declínio, como já se observa nas edições da Nova Escola de 1998 e naquele primeiro fascículo sobre os PCN, onde o significante-mestre construtivismo e seus derivados sequer comparecem. Um efeito talvez das crescentes críticas ao construtivismo, mas relacionado também com o impacto que a sua versão oficial produziu quando de seu lançamento, sobrepondo-se a qualquer outro tema no âmbito dos debates sobre a educação pública. As críticas, desde então, tendem a desviar-se para a versão oficial, para os PCN. Não na revista Nova Escola. Nesta, o que sobressai é a celebrada presença da nova sigla, uma sigla cada vez mais vigorosa, pelo menos até o fim de 1998. Ao que parece, não mais se menciona o "caminho construtivista". Os professores têm o seu rumo redefinido pela versão construtivista oficial, pelos $\mathrm{PCN}$, desde o início sob o horizonte que já havia sobrepujado aquele "caminho": o novo "mundo moderno" — o "futuro" aonde a maioria dos discursos educacionais conflui. 


\section{3. $O$ construtivismo em estado puro}

Na revista Nova Escola, determinados efeitos que são próprios do Novo Moderno começam a ficar nítidos em 1995 e sobretudo em 1996, quando o discurso pedagógico ganha um claro viés tecnicista. Antes disso, porém, nessa publicação ocorreu uma mudança importante. Em outubro/94, os leitores são informados que a sua diretora de redação, Ana Maria Sanchez, que desempenhava essa função desde o primeiro número da revista, estava se afastando da Fundação Vitor Civita. O novo diretor de redação é o jornalista João Vitor Strauss, "experiente profissional, vindo da revista Caras" (p. 4). Segundo o editorial desse número, a vinda desse jornalista para a direção de redação "faz parte de um processo de aprimoramento da qualidade editorial da revista" (ibidem). O sentido desse "aprimoramento", que envolve "a progressiva reformulação gráfica da revista", ${ }^{117}$ não demora a aparecer e já se anuncia na primeira edição do ano seguinte, em março/95, quando a revista de certo modo antecipa a unificação e padronização operada pelos PCN com a sua própria versão do construtivismo, a versão dos "50 pontos básicos trocados em miúdos". Em 1996, esse "aprimoramento" prossegue e se acentua, sendo isso antecipado no editorial de dezembro/95, quando se afirma que a revista "agora entra numa nova fase de apresentação visual e de maximização do uso do seu espaço, oferecendo mais informações aos seus leitores" (p. 3). Vejamos então algumas dessas mudanças, que podem ser consideradas correlativas a certo viés que parece preponderar nesse mesmo período nos discursos pedagógicos, a maioria sob a órbita do significante-mestre construtivismo. Um viés, portanto, que é impossível dissociar do que se configura nas páginas dessa revista.

Nesse período, muitas matérias que tratam das atividades realizadas por determinado professor reduzem sensivelmente a narração ou relato do que ocorreu em sala de aula, assim como a reprodução de falas do professor, o comentário de um ou outro aluno e detalhes da situação. Nos casos em que esses relatos não diminuem tanto, eles costumam ficar subordinados à divisão estabelecida pela revista, tendo em vista as etapas, passos ou a seqüência do exercício, atividade, método ou técnica que o professor desenvolveu ou aplicou.

\footnotetext{
117 A essa reformulação refere-se o diretor de redação no editorial ou "Carta ao leitor" de agosto/95, p. 3.
} 
Ou seja, separa-se o que é narrado de acordo com as etapas da atividade, que por vezes são numeradas. ${ }^{118}$ Essas e outras mudanças ocorridas na revista Nova Escola ficam mais evidentes quando comparamos as chamadas reportagens. Para podermos comparar, vejamos primeiro um trecho do relato presente numa reportagem de capa de setembro/87 sobre a nova perspectiva de alfabetização. Eis o início da reportagem:

No início deste ano, os alunos de $1^{\circ}$ série da professora Rosana Dutoit levaram para casa uma tarefa diferente: procurar, em revistas e embalagens, rótulos de produtos conhecidos. Com o material coletado, primeiro eles inventaram na classe uma brincadeira de comprar em supermercado. Depois selecionaram os recortes e montaram, junto com a professora, um cartaz supercolorido. A principal regra dessa atividade era que todos tinham que ler o que estava escrito nos recortes.

- Neste aqui está escrito MINGAU — disse um aluno.

A maioria concordou. Então, embaixo do rótulo (que na verdade era de Neston), Rosana escreve MINGAU. Enquanto escrevia, foi lendo para a turma, apontando as sílabas. Nesse momento, algumas crianças perceberam que não era mingau a palavra do recorte. Elas haviam feito a comparação entre as letras das palavras MINGAU e NESTON.

Após a leitura de palavra por palavra do rótulo, sempre localizando para as crianças o que estava sendo lido, Rosana explicou que Neston é a marca de um produto, com o qual se faz mingau.

- Rosana, agora sou eu. Eu vou ler: BOLACHA - disse uma aluna, apontando para a palavra Tostines. Alguns se adiantaram:

- Não, esse (o tos) não é o BO que tem na palavra BONECA.

- Isso mesmo - disse Rosana. - Esse não é o BO. Vamos ver como se escreve BOLACHA. Olhem só.

- Ih, tem BOLA dentro de BOLACHA — descobriu alguém.

- E tem CHÁ também! ${ }^{119}$

Quando está em foco a atividade desenvolvida por um professor ou professora, relatos semelhantes ao acima apresentado são relativamente freqüentes nas "reportagens" da Nova Escola até pelo menos $1994 .{ }^{120}$ Mas, daí em mais, tudo o que é da ordem da narrativa tende a esmorecer e até mesmo se extingue. A tendência é que a multiplicidade de elementos, marcas ou traços que singulariza determinada situação e que permite reconhecer determinado professor, experiência ou escola, seja, em sua maior parte, abstraída ou ignorada,

\footnotetext{
${ }^{118}$ Um exemplo pode ser encontrado na matéria intitulada "Ponha algo mais em sua aula", no subtítulo "Um exemplo na primeira série", pp. 42-3, em Nova Escola, n 91, março/96.

${ }^{119}$ Essa matéria já foi comentada no capítulo III. Cf. "Há um novo caminho para ensinar a ler e escrever", Nova Escola, n 15, set./87, p. 10.

120 Desse ano, veja-se por exemplo a reportagem de capa intitulada "O aprendizado que vem da vida do próprio aluno", Nova Escola, n 78, set./94, pp. 10-20.
} 
pelo menos se considerados os textos escritos. Isto porque essas marcas ou traços em grande parte parecem transladar-se para as fotos, aí sendo de certo modo acolhidos. As imagens, aliás, em muitas matérias predominam sobre os textos escritos, que a elas se subordinam ou delas dependem, pois sem as imagens, sem os textos visuais, essas matérias tornar-se-iam incompreensíveis ou ficariam truncadas. ${ }^{121}$

Nessa fase, os recursos visuais e gráficos são ampliados de forma notável e muda o uso do espaço, com maiores informações. Tudo isso interferindo sobre a leitura, pois esses recursos e a organização do espaço parecem dirigi-la de modo mais incisivo. Ademais, sob o espírito prático que domina essa publicação, ao leitor tudo é "facilitado": abundam os textos enxutos, com muitas divisões, com os tópicos claramente distinguidos e as hierarquias bem estabelecidas, tudo de uma forma clara e objetiva, com regras fáceis de entender e aplicar. O que importa é mostrar ao leitor-professor o que pode ser generalizado, o que ele pode usar e aplicar em sala de aula, com outras crianças e em outras circunstâncias. E evidenciar isso de um modo ágil, rápido, direto, sem as delongas próprias dos relatos que buscam recuperar as peculiaridades de certa situação e seu contexto. O viés jornalístico que caracterizava muitas das matérias da Nova Escola parece mesmo se extinguir e ganham espaço textos de caráter instrucional, sendo assim reduzido tudo o que é da ordem da narrativa, da experiência e de seu contexto (as características da escola, da comunidade atendida, do bairro, a trajetória de determinada professora, etc.). As reportagens já não são recheadas com histórias de professores e escolas, nem com a reprodução de falas, comentários e opiniões dos que participaram de determinada experiência, como professores, alunos, pais de alunos, diretores e dirigentes de determinada rede de ensino. Tudo isso é filtrado e em geral transformado em tópicos, passos, etapas, dicas, aí sendo incluída uma ou outra fala. A tendência é que seja abortado todo e qualquer "ruído" que desvie do essencial. E o que é essencial é apresentar em estado "puro" um saber situado nesse registro da prática, um saber imediatamente útil, fácil de apreender e aplicar e que, mais do que nunca, tende a adquirir o

\footnotetext{
${ }^{121}$ Um exemplo onde as imagens são fundamentais e no qual a narrativa desaparece quase que por completo encontra-se no Anexo B, que reproduz uma página onde é apresentada a atividade desenvolvida por uma professora. Trata-se de uma reportagem de capa intitulada "Criatividade. Aulas de dar água na boca". Cf. Nova Escola, n 91, março/96, p. 13.
} 
semblante de uma mercadoria que está sendo divulgada entre os leitores, concebidos primeiramente como potenciais consumidores. Esse saber concerne, em primeiro lugar, a tudo que é da ordem dos materiais didáticos, dos conteúdos do ensino (conceitos, informações, conhecimentos, etc.) e das técnicas (métodos, receitas, exercícios, jogos, atividades, etc.). Ou seja, tudo o que diz respeito a essa espécie de "núcleo didático" definido pelos significantes-mestres acima mencionados, considerados aí todos os significantes equivalentes e as articulações discursivas que lhes dão sentido. Digamos que esses são os pontos de ressonância que se destacam e (re)ordenam o discurso pedagógico nesse período, ainda sob a guarda do significante-mestre construtivismo, um significante cuja rede continua a capturar quase tudo o que adquire um sentido positivo.

Vejamos agora alguns exemplos, começando pela reportagem de capa intitulada "Ensinando tudo com histórias", de dezembro/95. Eis alguns trechos do texto introdutório, que ocupa menos de meia página:

Nas escolas de linha construtivista e nas Waldorf, por exemplo, a literatura é usada como instrumento didático básico (...)

Alguns professores estão até criando "receitas" de como aproveitar as histórias (...) Os educadores tentam entender por que o ensino com ajuda de histórias traz tão bons resultados (...) "Não há uma resposta simples nem fácil, para explicar porque as histórias funcionam", diz João Ribeiro [coordenador do Centro de Estudos Pedagógicos do Colégio Galileu Galilei, de São Paulo]. "Mas que funcionam, funcionam", garante ele.

Acompanhe, nas páginas seguintes, as experiências das escolas, os livros mais usados e as dicas para escolher as melhores obras. ${ }^{122}$

Na maioria e nas principais matérias dessa fase tecnicista, o que dá ótimos resultados, o que funciona, o que encanta as crianças, o que afinal constitui a razão do êxito da ação do professor não concerne propriamente ao professor. Os louros decorrentes dessa ação, o seu sucesso, o êxito alcançado, tende a ser atribuído em primeiro lugar a tudo o que é da ordem do "núcleo didático" já referido. No caso acima analisado, o que torna a ação do professor eficiente ou o que "funciona" são as histórias infantis, como os contos de fada e as fábulas. Para que elas "funcionem" bem, entretanto, devem ser seguidas algumas orientações. Daí as "dicas" dadas nessa reportagem e a separação que ela opera, sugerindo quais histórias e livros devem ser usados para trabalhar os conteúdos de

\footnotetext{
${ }^{122}$ Cf. "Ensinando tudo com histórias", Nova Escola, n 90, dez./95, p. 9.
} 
determinadas áreas ou "disciplinas do primeiro grau" (Português, História, Geografia, Matemática, Ciência, Ambiente e Cidadania). Para cada uma dessas áreas é destinada uma página, a maioria acompanhada de um box onde as "dicas" anunciadas no seu título são enumeradas e explicitadas. Ademais, cada história ou livro adequado para determinada área é apresentado com um breve resumo, o nome do autor e da editora e, ainda, as tais "experiências das escolas" anunciadas na introdução. Experiências essas que são reduzidas à sua mínima expressão, por assim dizer, pois o que delas é apresentado são informações bem breves e objetivas: nome da escola, idade ou série das crianças com as quais foi trabalhada determinada história e uma indicação do objetivo que se pretendia alcançar ou do que foi desenvolvido. Em "Português", por exemplo, dentre outras histórias e livros é destacada uma fábula por meio deste subtítulo: "A raposa e as uvas". Eis a parte do texto que se refere às escolas:

A história é usada na primeira série do Colégio Santo Estêvão, de São Paulo, para trabalhar o conceito de adjetivo, ou seja, para mostrar que objetos e pessoas têm qualidades. No caso, são analisadas expressões como "uvas verdes" e "raposa esperta". No jardim 2 do Galileu Galilei, outra história lida para abordar o conceito de adjetivo, com crianças de 5 anos, é O Segredo do Rei, de Carmem Berenguer (Editora Ática). Nele, as palavras-chave são "jovem" e "discreto". (ibidem, p. 10)

A propósito das "dicas" que acompanham cada disciplina, por vezes com um sentido que parece contradizer outras sugestões ou prescrições presentes na mesma matéria ou nas próprias "dicas", veja-se abaixo as que estão na página destinada a "Português":

1. Escolha textos de boa qualidade. "Histórias curtas e com temas profundos interessam sem cansar", assegura Virgínia Balau, psicopedagoga e orientadora de Português.

2. Atenção. Os contos de fada devem ser aproveitados para discutir conceitos globais. Em geral eles não funcionam para temas "áridos", como a gramática. "Deixem os contos de fada serem contos de fada", pede a escritora Tatiana Belinky.

3. Para descobrir de que maneira uma história pode ser útil para sua aula, tente seguir a característica mais forte do texto. "Se só um personagem tem nome próprio e os outros não, esta é uma boa oportunidade para estudar nomes próprios", sugere Virgínia.

A matéria apresenta ainda um box com informações sobre a origem dos contos de fada e um outro com este título: "Emoção, o segredo do sucesso". Esse título é dado a um texto onde as histórias infantis continuam desempenhando o 
papel de principais protagonistas, pois a elas tende a ser creditada a possibilidade de melhorar o relacionamento professor-aluno e o ensino:

Contar histórias é um ato de amor, um momento de intimidade entre o adulto e a criança, e por isso pode ajudar o relacionamento professoraluno. Elas são eficientes para ensinar justamente porque encantam as crianças. Não é impressionante como elas nunca se cansam de ouvir, muitas e muitas vezes, a mesma historinha? É fácil entender esse fascínio, basta lembrar que a literatura tem como matéria-prima a emoção. "Se as histórias, que são encantadoras, vêm junto com informações de natureza científica, didática, fica muito mais fácil de entender tais conteúdos", diz João Ribeiro. (ibidem)

Essa "reportagem de capa", bem diferente do que anteriormente era assim denominado, apresenta por último uma lista de editoras com endereços e telefones. Essa informação certamente facilita o contato do leitor com algo que é de seu interesse, mas sobretudo de interesse dessas editoras. Estas, nessa peculiar reportagem, que antes parece um texto publicitário, encontram um bom veículo para divulgar seus produtos.

Nesse período, precisamente, a maioria das matérias da Nova Escola adiciona e destaca, na introdução ou no fim, os endereços e/ou telefones dos professores, especialistas ou instituições que serviram como referência (o autor de determinado livro ou material didático, o professor ou especialista que inventou uma nova técnica, a escola onde foi realizada determinada atividade, etc.). E essa informação, mesmo que seja de interesse dos leitores, não poucas vezes adquire um claro viés comercial, inexpressivo ou pouco comum nas reportagens anteriores a essa nova fase da revista. ${ }^{123}$ Nessa fase também se amplia, de forma significativa, a presença das escolas privadas como referências importantes, senão únicas, em muitas matérias. Vale reparar também em alguns detalhes que afirmam o mesmo viés, como a inédita informação sobre as roupas de grife das "muito bem" vestidas crianças que aparecem nas capas das edições de abril e junho de 1996, nunca antes com crianças tão especialmente "produzidas" para figurar nesse importante lugar. Essa informação é dada nos créditos das capas, como a que segue: "Camisa: Lacoste; jeans: Levi's Wonderfit; tênis: M2000;

\footnotetext{
123 Esse tipo de informação pode ser encontrada em matérias anteriores a esse período, mas apenas nessa nova fase parece tornar-se parte de um procedimento sistemático.
} 
mochila: Le Postiche; relógio: Swatch". ${ }^{124}$ Nesse mesmo e único ano, as duas jovens e supostas professoras das capas de junho e maio passam também pelo mesmo crivo da "produção", o leitor sendo disso informado nos créditos correspondentes. ${ }^{125}$

Essa crescente presença de tudo o que é da ordem do mercado nota-se ainda no uso do significante-mestre construtivismo com fins explicitamente comerciais e publicitários. Esse é o caso de um amplo "informe publicitário" da "tradicional" Fundação Bradesco na edição da revista Nova Escola de novembro/94. ${ }^{126} \mathrm{O}$ título do informe, que ocupa duas páginas e que poderia ser confundido com uma matéria da revista, é "Canuanã, a geração construtivista", sendo complementado por este subtítulo: "O internato modelo da Fundação Bradesco faz 21 anos e inicia uma autêntica revolução no ensino". ${ }^{127}$ Com esse informe, pode-se dizer que é registrada e produzida a entrada de mais um membro no "novo caminho", um membro que também o configura. Desta vez trata-se de um importante braço do capital financeiro, com uma de suas escolas, uma escola que podemos qualificar de moderna, pois ela introduziu "a moderna linha de ensino inspirada nas idéias de Piaget, onde o aluno é estimulado a desenvolver todo o seu potencial criativo" (ibidem). Nessa mesma época também entram em cena ou ganham visibilidade os materiais didáticos qualificados de construtivistas, como já se observa na edição de março/95, que apresenta um texto publicitário, de uma página, sobre uma "Coleção didático-pedagógica da linha construtivista", com este apelo: "Professor... Comece o ano novo, inovando. Comece com sala de aula construtivista! (...) Este é o tijolinho que faltava no seu

\footnotetext{
${ }^{124}$ Cf. Nova Escola, n 92, abril/96, p. 3.

${ }^{125}$ Esse tipo de informação, relacionada com a produção da capa da revista, somente volta a ser dada em dezembro/97, não havendo nada semelhante em 1998.

${ }^{126}$ A respeito das escolas mantidas pela Fundação Bradesco, por vezes reconhecidas por meio do significante-mestre ensino tradicional ou escola tradicional, eis a caracterização de Cunha (1991, pp. 343-4): "A Fundação BRADESCO mantém escolas de $1^{\circ}$ grau situadas nas mais diversas regiões (...). Nelas se oferece um ensino gratuito e de boa qualidade, em termos técnicopedagógicos, revestido de um código de conduta extremamente rígido. Os professores são selecionados do ponto de vista de sua conduta pessoal, e os estudantes são obrigados a assinar uma declaração de princípios que sintetiza os valores que todo patrão gostaria que os empregados respeitassem: amor ao trabalho, disciplina, respeito à hierarquia. Além disso, os alunos devem prometer não beber, não fumar e não praticar nenhum ato 'contra a moral e os bons costumes', sob pena de serem excluídos da escola".

${ }^{127}$ Cf. Nova Escola, n 80, nov./94, p. 42.
} 
construtivismo". ${ }^{128}$ Uma escalada que tem o seu ponto alto quando as "cartilhas construtivistas" se tornam o destaque de capa em outubro/96.

Nessa fase, determinados assuntos tendem a sair de cena, desaparecendo das capas da revista. Para realçá-los, vale a pena destacar algumas manchetes de capa de anos anteriores e compará-las com as de 1996, ou seja, com as do ano em que o viés mercantil, moderno e didático parece chegar a seu auge. Vejamos: ${ }^{129}$

- "AS FERAS DA PERIFERIA. Como são esses jovens que assustam qualquer professor" (março/91)

- "SALÁRIOS. A sobrevivência cada vez mais difícil de uma categoria" (dezembro/91)

- "GRÊMIOS. O que está impedindo essa conquista" (junho/92)

- "Jequitinhonha. A ESCOLA NO CORAÇÃO DA MISÉRIA" (dezembro/92)

- "GANGUES JUVENIS" (maio/93)

- "São Francisco: como uma escola melhora a vida dos barranqueiros" (novembro/93)

- "INFÂNCIA PERDIDA. Mais de 7 milhões de crianças que deveriam estar na escola trabalham. Muitas como escravas" (maio/94)

- O Projeto Axé encara o desafio de educar os MENINOS DE RUA" (outubro/94)

Passemos agora para 1996, indicando apenas que as marcas da pobreza, da miséria, da violência, das lutas de estudantes e professores já esmoreceram em 1995, sobretudo a partir de meados desse ano. No ano seguinte, então, se alguma coisa semelhante sobrou está no texto complementar da manchete de capa de novembro/96, a que anuncia um "SHOW DE DIDÁTICA". Eis o texto complementar: "No interior do Rio Grande do Norte surgem técnicas de ensino na medida certa para as carências da região". Para enfrentar as "carências", como se vê nesse enunciado, o que é mobilizado, o que a própria manchete destaca, é da ordem da didática ou das técnicas de ensino. Algo bem distante, por certo, do que os enunciados antes reproduzidos tendem a configurar.

O que nessa trajetória da revista desaparece, mas também do discurso pedagógico, corresponde a tudo o que vinha no encalço dos significantes-mestres

\footnotetext{
${ }^{128}$ Cf. Nova Escola, n 82, março/95, p. 35.

${ }^{129} \mathrm{Em}$ maiúscula foram colocadas as palavras que nas manchetes aparecem com letras maiores.
} 
comunidade, popular e outros equivalentes e que tende a desaparecer das capas da revista, mas também em suas páginas, em suas matérias, junto com aqueles significantes-mestres. Estes parecem entrar e ficar numa região proibida, uma região cujo acesso teria sido vedado aos discursos dessa publicação. Um fato do discurso que na verdade corresponde à trajetória dos discursos educacionais e/ou pedagógicos, pois o que aí está em causa diz respeito aos pontos de ancoragem do discurso construtivista. Quando esses significantes de ancoragem deixam de cumprir a sua função, parecem perdem-se nos limites ou margens do discurso pedagógico, ou seja, são "esquecidos", aqueles pelo menos, pois outros continuam como pontos de ressonância do novo discurso. Ademais, quando esses significantes eventualmente retornam, já não são mais os mesmos, o seu lugar é outro, comparado ao de alguns anos antes. ${ }^{130}$

Isso pode ser notado numa matéria intitulada "Trabalho conjunto de classes", de dezembro/95. Nela, o que está em foco é a relação estabelecida entre a escola particular Recanto e a Escola União Comunitária de Vila Ariana. Embora se fale em "trabalho conjunto", em "cooperação" e "convivência entre as crianças 'ricas' e 'pobres'" (no olho que sucede ao título), o tipo de relação aí criada é também definido por meio do significante "adotar", como se observa na chamada do índice ("Escola rica adota escola carente em Recife", p. 3) e também no corpo do texto. ${ }^{131}$ Neste, o que na verdade transparece é certa tensão relacionada ao uso desses significantes: "a Recanto 'adotou' a escola da Vila Aritana. Na verdade, as professoras do Recanto não gostam que se use essa expressão: 'adotar'. Preferem falar em cooperação" (ibidem). No entanto, a revista insiste em falar em "adoção", o que certamente está relacionado com o lugar que ela configura para essa escola comunitária. O que aqui interessa ressaltar é que nessa configuração nada restou das lutas das escolas comunitárias, da sua relação com os movimentos populares ou da sua suposta superioridade em face das escolas oficiais. O que temos, nesse caso, é uma escola "adotada" por uma escola particular, numa relação que também é vista como de cooperação e convívio entre ricos e pobres. São escolas com crianças que a revista também se

\footnotetext{
${ }^{130}$ Em relação a outras "palavras proibidas" e às mudanças que ocorrem quando retornam, mas no âmbito dos discursos educacionais alternativos, veja-se a minha dissertação de mestrado (Revah, 1994).

${ }^{131}$ Cf. "Trabalho conjunto de classes", Nova Escola, n 90, dez./95, p. 44.
} 
empenha em definir claramente o seu lugar, com um quadro que apresenta vários itens (atenção, aproveitamente, disciplina, etc.), com pequenos textos que caracterizam e diferenciam os dois tipos de alunos (ricos e pobres).

Concomitante a essa nova configuração, bem como ao esvaziamento dos lugares outrora definidos pelos significantes de arremate dos discursos alternativo-populares (como escolas comunitárias e educação popular), o que tende mesmo a se extinguir é o professor participativo, crítico, consciente e capaz de refletir sobre a sua ação, tal como desenhado por aqueles discursos. Um professor que na verdade já tinha ficado sob a injunção da configuração discursiva que opera com a ciência no lugar de comando. Mas até mesmo esse comando foi sobrepujado, de modo que as palavras são (re)inscritas num outro registro, aparentado com o anterior. Nessa fase moderna, a palavra que transforma, a palavra que regia a educação popular, que é ação e reflexão, como propunha Paulo Freire, desaparece como horizonte possível, junto com aqueles significantes de arremate e com esse nome próprio. Digamos que a sua face reflexiva, que já tinha ficado sob a injunção das palavras da ciência, sofre agora a sua derradeira investida, pois o discurso tende a cair no puro registro imaginário que ele próprio configura, o registro definido tão-somente por regras ou prescrições que têm em vista a ação imediata, com o seu sucesso garantido. ${ }^{132}$ Esse é o novo registro das posturas do professor e das "teorias" e palavras que o orientam.

Das palavras que transformam (educação crítica, educação popular, educação alternativa) passamos então para as palavras da ciência (Emilia Ferreiro, Construtivismo, Piaget), nesse lugar produzindo-se mais um giro, mas sem que se saia desse mesmo lugar. Um giro moderno cuja direção é dada pelas palavras de ordem técnica, pelas palavras que melhor parecem se adaptar ao que o Novo Moderno exige. Em nosso caso e tendo em vista o que se configura na revista Nova Escola, essas palavras técnicas concernem primeiramente ao registro do significante didática, com o "núcleo" já referido. Posteriormente, no entanto, elas ganham um outro estofo, com os PCN, quando a todos tende a ser

${ }^{132}$ A expressão registro imaginário alude ao que Lacan assim denomina. 
exigido a aprendizagem fiel, sem distorções ou alterações, da linguagem técnica que eles (re)criam.

A presença do aqui chamado "núcleo didático" é tão forte nessa fase moderna da Nova Escola que praticamente se impõe como único foco das suas capas, sobretudo se consideramos o que nelas é destacado no período que vai de meados de 1995 até o início de 1997. Antes disso, observando as manchetes de capa, não parece possível encontrar um foco temático que persista durante tanto tempo e em edições que se sucedam. A sua emergência corresponde ao percurso do significante didática e seus derivados (livro didático, material didático, etc.), pelo menos se atentarmos para as capas da Nova Escola desde o seu primeiro número, em 1986. Pesquisando todas elas, percebe-se que até o fim do primeiro semestre/94 esse significante é utilizado somente duas vezes, em pequenas chamadas das capas de junho/88 ("As mentiras dos livros didáticos") e maio/89 ("O que o aluno pensa dos livros didáticos"). Daí em mais, apenas volta a ser empregado no segundo semestre/94, não no enunciado relativo à manchete da matéria principal, mas nas chamadas de capa, mais destacadas que as precedentes. Uma sobre a reprovação da "maioria dos didáticos" pelo MEC (agosto) e uma outra (outubro) que destaca o significante "Didáticos", sobre uma entrevista com Magda Soares onde ela "dá dicas" para escolher "os melhores" livros didáticos de Português. Em 1995, a presença desse significante se amplia, na chamada de uma matéria de agosto ("livros didáticos") e nos enunciados que complementam as manchetes de duas edições. Nesse ano, em setembro, a manchete é "Malba Tahan", acompanhada deste texto complementar: "No centenário do nosso maior professor de todos os tempos, inspire-se na didática pioneira que ele criou". $E$, em outubro, a manchete é "A matemática fácil de pegar", com um texto complementar que faz referência aos "400 jogos didáticos da Unicamp para o primeiro grau". Em 1996, que é o ano que poderíamos chamar de "ano tecnicista" ou "ano didático", em razão do que nele predomina, o significante-mestre didática (ou derivados) é também utilizado nos enunciados relativos à matéria principal e em uma das chamadas. Primeiro surge no enunciado que complementa a manchete de capa do mês de maio ("Sucata"), escrito em letras menores: "Crie o melhor material didático quase de graça". Em outubro, há uma pequena chamada com este enunciado: "20 instrumentos didáticos para ciências". Por último, em novembro, pela primeira vez na revista 
Nova Escola, o significante-mestre didática compõe o enunciado da manchete de capa, na edição do mês de novembro: "Show de didática na sertão do Seridó". Em 1997, na edição de março também surge na própria manchete: "Dê asas à sua didática com Monteiro Lobato". No mês de junho surgindo novamente ("material didático") no texto que complementa à manchete "Brincando com a ciência". No último ano pesquisado, em 1998, surge uma única vez no mês de agosto ("roteiros didáticos"), no texto que complementa à manchete. Enfim, guiados apenas pela presença e o valor do significante-mestre didática nas capas da Nova Escola, pode-se dizer que a sua escalada ocorre exatamente no período aqui considerado. Um fato do discurso que uma análise atenta das capas logo revela e que está relacionado com o que esse significante-mestre amarra nesse período.

Outro fato do discurso relacionado com essa amarração concerne ao aparecimento da seção ou rubrica "Didática" no sumário ou índice da revista. ${ }^{133}$ Essa rubrica pode ser encontrada apenas em 1996, em quatro edições (março, abril, agosto, novembro). Algumas vezes, anteriormente, nesse mesmo ano ou depois dele, podem também ser encontradas as rubricas livro didático, material didático ou jogo didático, mas não "Didática", cujo sentido é menos específico que as rubricas anteriores. Os significantes "Pedagogia" e "Psicologia" ou "Psicologia infantil", que também parecem estreitamente relacionados com o que se configura na revista nessa mesma fase, surgem igualmente com a função de nomear seções ou destacar o assunto das matérias indicadas no sumário ou índice. Nessa função, o significante "Pedagogia" foi encontrado pela primeira vez em abril/95, continuando em 1996 (maio e dezembro), 1997 (março, setembro e dezembro) e 1998 (setembro). Quanto às rubricas Psicologia ou Psicologia Infantil, elas surgem pela primeira vez em 1996 (abril, junho, agosto, setembro e dezembro), 1997 (abril) e 1998 (março e junho). Considerando-se tudo isso, poder-se-ia dizer que existe aí uma articulação significante emergente, feita com

\footnotetext{
${ }^{133}$ Em relação a esse ponto, vale esclarecer que as seções destacadas nesse sumário (ou índice, desde agosto/95) variam bastante no período aqui pesquisado (de 1986 a 1998), algumas mantendo-se durante vários anos e outras aparecendo algumas vezes, para em seguida desaparecer. Muitas vezes, ademais, antes do que o nome de uma seção, o que temos são rubricas ou palavras-chaves que são destacadas (com letras maiores e/ou em negrito) e que situam o leitor em relação ao tema ou assunto da matéria. Essas palavras-chaves precedem ou estão junto com um pequeno texto que informa o leitor sobre a matéria que vai encontrar na página indicada. Às vezes, inclusive, há somente um texto breve para indicar o assunto da matéria, sem que exista qualquer rubrica ou palavra que seja aí destacada.
} 
esta série: didática/psicologia/pedagogia. ${ }^{134}$ Uma série que parece comandada pelo significante-mestre didática, provavelmente em razão do que ele costura.

Ao que tudo indica, o que o significante-mestre didática costura, o que ele amarra, junto com seus equivalentes e a série significante que ele sobrepuja, é o que nesse momento considera-se essencial para melhorar a qualidade do ensino, uma qualidade então sujeita às demandas mercantis e modernas que proliferam nas páginas da Nova Escola. O que nesse momento é essencial não é mais a interpretação de uma determinada teoria, linha ou proposta pedagógica; a questão básica não mais concerne ao conhecimento e implementação da proposta construtivista, seja por uma rede de ensino, uma escola ou um professor. Tampouco estão em causa os professores que devem trabalhar a sua postura para adequá-la ao que essa ordem teórica determina. Tudo isso parece ter passado para um segundo plano. $E$ aqui vale ressalvar que isso não significa que determinada referência teórica e construtivista tenha se tornado irrelevante. Muito pelo contrário, ela emerge em um momento preciso, de modo imponente e excepcional, como ainda veremos. O que nesse período é mesmo transformado numa prioridade, tendo em vista a atuação do professor, é um saber que pode ser facilmente destacado da figura de determinado especialista, professor ou escola. É um saber que circula com fluidez no circuito que então se impõe, que não é difícil de assimilar e que pode ser vendido e comprado para uso imediato, ou melhor, para consumo imediato. Basta adquiri-lo e aplicar a receita com precisão e na situação adequada. Esse viés predomina em não poucas matérias, sendo uma vez ou outra matizado pela presença de outras questões.

Para avançar nesse ponto, vejamos uma matéria onde são dadas "algumas sugestões sobre boas aulas", numa seção denominada "Didática", na primeira

\footnotetext{
${ }^{134}$ A emergência dessa série é concomitante ao desaparecimento do significante "cultura" como rubrica do sumário, exatamente quando ocorre a mudança do diretor de redação. Nessa função, esse significante começa a ser utilizado em março/91 e desaparece em outubro/94. Um caso parecido é o da rubrica "Ação Comunitária", usada algumas vezes desde a década de 80 e que não mais se encontra de 1995 em diante, até 1998, quando uma única vez surge uma rubrica com o significante comunidade ("Educação e Comunidade", em junho/98). Mas o que esse significante aí delimita já é uma outra comunidade, como pode ser notado lendo a matéria correspondente, onde o que sobressai são "as novas exigências econômicas" e as demandas do "futuro" (cf. "Ensino é assunto de toda a sociedade", pp. 48-9). Certamente, uma investigação e análise em separado e sistemática de todas essas seções e a busca de possíveis relações entre elas revelaria outras dimensões implicadas nas mudanças que ocorrem na revista, mas também nos discursos pedagógicos. Um trabalho que aqui foi feito apenas de modo parcial.
} 
ocasião em que essa seção surge na revista. Logo no início, no olho que sucede ao título, já é feita esta advertência: "Os especialistas avisam: entrar na sala e tentar dar uma aula de improviso não leva a lugar nenhum". ${ }^{135}$ Afastado esse equívoco, que também poderia ser situado com o significante espontaneísmo, o que ganha relevância é o planejamento: "Dar uma boa aula mistura disposição, sensibilidade, talento, adequação à realidade dos alunos e, especialmente, uma enorme dose de planejamento". Depois vem uma breve introdução que destaca dois extremos que o professor deve considerar para dar uma "boa aula", a qual, é claro, exige manter um certo "equilíbrio":

A maioria dos especialistas ensina: boa aula é aquela que oferece um equilíbrio entre o aprendizado significativo e o mecânico e na qual o mecânico, embora indispensável, fique subordinado ao significativo. Por isso, é necessário planejar as aulas com cuidado. O resultado do improviso pode ser um desastre. (p. 40)

Não é difícil enxergar nessas poucas linhas a presença dos pontos de estrutura do discurso pedagógico construtivista, com a sua conhecida articulação. O que aí comparece, implicitamente, é a oposição básica escola tradicional/aprendizado mecânico x construtivismo/aprendizado significativo, com este último ficando mais próximo do conhecido extremo onde o aluno é a figura central, não sem que seja recusado o que aí concerne ao significante-mestre espontaneísmo - o "improviso". Além disso, é preciso que o apredizado mecânico fique "subordinado" ao significativo — um poder que é característico do significante de arremate. ${ }^{136}$ Tudo isso em prol de uma "boa aula", de uma aula "equilibrada".

Depois de serem traçadas essas linhas básicas, essa "plataforma" primeira, vêm as sugestões divididas em vários box. O primeiro, intitulado "Use os fatos do cotidiano", começa assim:

Despertar o interesse da turma para o assunto a ser lecionado não é fácil. A professora Ana Maria Lopasso, da quarta série do Colégio Pueri Domus, de São Paulo, tem um método que funciona muito bem. Ela pega um tema que faça parte da vida das crianças e estabelece uma ligação entre esse assunto e o conteúdo a ser ensinado. (...) "O professor tem que

\footnotetext{
${ }^{135}$ Cf. "Ponha algo mais em sua aula", Nova Escola, n 91, março/96, p. 40.

${ }^{136}$ Nessa matéria, o aprendizado significativo é assim definido: "aquele no qual o aluno apreende o assunto e consegue discorrer sobre ele com as próprias palavras" (ibidem).
} 
achar a fórmula para fazer a turma envolver-se com o assunto", diz a professora. (...) Em disciplinas como Ciências Sociais, o método é fácil (...) (p. 40)

Como se vê, o que "funciona" é o método, cabe ao professor "achar a fórmula", nesse caso para "despertar o interesse da turma". Algo semelhante continua a ser sugerido no box seguinte, intitulado "Esteja pronto para mudar". Nele, no início, é destacado o planejamento, considerado necessário para driblar o desinteresse e estar "pronto" para mudar de técnica quando ela "não dá resultados":

A aula está indo bem, mas, de repente, começa a desandar. Instalou-se o desinteresse. Como evitar isso? Mais uma vez, a resposta está no planejamento. $O$ professor precisa pensar não só em como vai introduzir o tema da aula, mas em como vai desdobrar cada conceito. Tudo isso, lógico, acompanhado de muita flexibilidade. O professor deve estar sempre atento para as manifestações da turma e pronto a mudar se a técnica escolhida não dá resultados. (p. 41)

Conhecer muitas técnicas parece ser o grande segredo de uma "boa aula" e, a julgar pelo que a revista Nova Escola prioriza nessa fase tecnicista, o professor também deve estar ao dia com os novos materiais didáticos e conhecer os conteúdos que precisa ensinar. Mas é claro que não é só isso, pois é preciso que tudo (técnicas, planos, exercícios, o ritmo e a explicação do professor) esteja "de acordo com a idade e o desenvolvimento da classe", com a "capacidade dos alunos", senão "'eles se desinteressam mesmo"', como lembra uma das professoras consultadas. (p. 41). Daí a necessidade de atentar para as "manifestações da turma" e a importância da avaliação, realçada no terceiro box: o professor "precisa saber rapidamente como os alunos estão assimilando a aula e fazer sua avaliação". Tudo isso, poder-se-ia pensar, exige muito trabalho por parte do professor, diluindo-se assim a impressão que a própria revista tende a criar de que basta conhecer uma técnica ou um material didático e usá-lo. $\mathrm{Na}$ verdade, o recado que parece ser dado é o antes assinalado: é necessário conhecer muitos desses componentes didáticos. Com que objetivo? Para sempre dispor do que nesse momento é considerado fundamental para "ajustar a ajuda" do professor ao aluno, a "ajuda pedagógica", como diria César Coll (1996:401-4). Ademais, é preciso investir no planejamento, sempre, pois todo ano é preciso considerar: 
(...) a personalidade da turma. "Cada turma é tão específica que não é possível aproveitar planos ou exercícios de um ano para outro", diz a professora Vera Lúcia Machado, da Escola Municipal (...) $)^{137}$

A "personalidade da turma" é justamente o tema do último box, intitulado "Sinta o pulso e planeje". Nele, à semelhança do que nessa revista predomina desde que o construtivismo foi "trocado em miúdos", as turmas são devidamente classificadas em categorias: "em todas as classes há um tipo de atitude que predomina. Os especialistas costumam citar quatro grandes grupos: a classe rebelde, a acomodada, a exigente e a imatura" (p. 42). Quanto ao valor desse "fator", em seguida o leitor é esclarecido: "A personalidade da turma é fator preponderante na hora do planejamento" (ibidem). Para cada tipo de turma, além de uma breve caracterização, são dadas algumas sugestões para o professor. Eis um exemplo, com as "técnicas" cumprindo um papel fundamental:

Rebelde é a turma em que os alunos geniosos dão o tom, mesmo se estiverem em minoria. Costuma ser barulhenta, indisciplinada e pouco produtiva. Exige do professor firmeza para impor a autoridade, paciência e muita disponibilidade, para testar várias técnicas até encontrar um foco de interesse capaz de prender a atenção.(p. 42)

Finalizando a matéria, há mais um texto com este subtítulo "Um exemplo na primeira série", de uma professora de escola pública que "imita apresentador de circo para estimular os alunos", conforme informa-se no olho (ibidem). No texto, depois de uma breve introdução, é descrita uma aula, com uma narrativa que pontua o que vai acontecendo em cada momento e recupera detalhes da situação, com falas da professora e das crianças. Mas tudo isso separado em nove etapas ou momentos, com a numeração correspondente. $\mathrm{Na}$ introdução, onde essa "campeã de boas aulas" é apresentada, informa-se que a professora "aplica o método construtivista":

(...) considerada pelas colegas uma campeã de boas aulas. Está sempre à procura de novidades para sua turma do tipo ansiosa, com trinta alunos na faixa dos 7 anos. Ela aplica o método construtivista na alfabetização (...) (pp. 42-3)

À semelhança da classificação que é feita para definir a "personalidade da turma", nesse mesmo período podem ser encontradas várias matérias onde a criança surge sob o mesmo gume, sob o mesmo espírito racionalizador que tudo

${ }^{137}$ Cf. "Ponha algo mais em sua aula", Nova Escola, n 91, março/96, p. 42. 
retalha para "trocar em miúdos". Assim, exatamente, é apresentada a criança configurada pela revista um pouco mais tarde, em junho/98: ${ }^{138}$

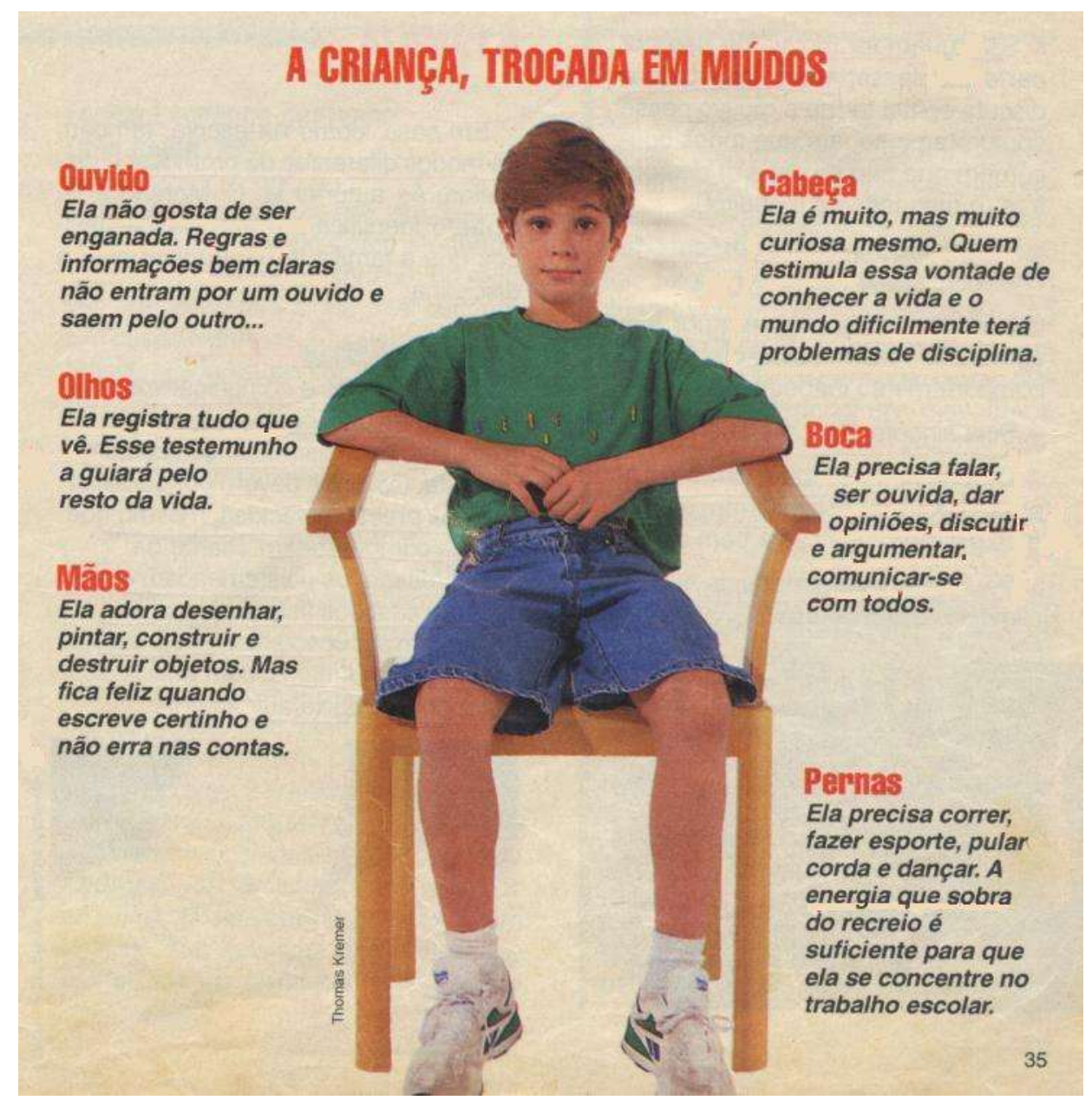

Vejamos agora outro exemplo, desta vez de 1996, na primeira matéria que surge sob a rubrica "Psicologia Infantil". Intitulada "O acordar do sexo", a matéria promete esclarecer "Como lidar com as dúvidas dos pequenos" (subtítulo). E mais: "Saiba o que está acontecendo com eles e como tratar cada situação" (no olho que sucede ao subtítulo). O saber aí prometido é apresentado de várias formas. Uma delas é a síntese feita num breve box (um terço de uma página) colocado no final da matéria, com este título: "Freud explica as fases da sexualidade". Depois de uma sucinta introdução, as fases ou etapas que "a criança vive" são sumariamente descritas. Eis um exemplo: "FASE ORAL - 0 A 2 anos. O bebê tem como principal fonte de prazer a alimentação, principalmente pelo seio materno, e faz da boca o centro de sua libido". Em seguida vem a descrição da fase seguinte, até a última (anal, fálica, latência), todas nitidamente

${ }^{138}$ Cf. "Indisciplina: como lidar com ela?", Nova Escola, n 113, junho/98, p. 35. 
discriminadas. Além dessa síntese, nessa matéria não faltam as orientações e conselhos dados ao professor por meio das falas e explicações dos especialistas que a revista consultou, de modo a situar claramente o que ele deve fazer em face de cenas embaraçosas ou perguntas diretas formuladas pelas crianças. Há inclusive várias dessas perguntas acompanhadas de exemplos de respostas que os professores podem dar, sempre em conformidade com "as motivações e a maturidade dos alunos", com a sua idade ou nível. Eis um exemplo: "Por que os pais dormem juntos? Para ficar juntos também de noite. Esse é um hábito entre adultos".

Esse estilo objetivo e breve, esse saber que não deve dar margem a dúvidas, também adquire a feição de um teste de múltipla escolha, no começo da matéria, como para que o leitor-professor sinta a autoridade que é própria de quem tem a resposta certa e única:

Durante o recreio, os alunos da pré-escola se divertem no pátio. Todos, menos um casalzinho que a professora encontrará, no banheiro, olhando atentamente os órgãos genitais um do outro. Nesse caso, a professora deve:

a) Sair discretamente, pois a curiosidade infantil é normal;

b) dizer às criança, carinhosamente, que isso não é bonito e levá-las de volta ao pátio;

c) perguntar-lhes o que estão fazendo e dizer que, então, se já viram que meninos e meninas são mesmo diferentes, é hora de aproveitar o resto do recreio;

d) levá-los de volta ao pátio em silêncio e tratar de avisar os pais.

A resposta certa é a C, como se verá adiante. Mas, se você ficou em dúvida, não se culpe. Ter segurança para lidar de modo apropriado com tais situações é privilégio de poucos educadores (...)

A Nova Escola situa-se justamente nesse lugar, de quem tem essa segurança, esse saber certo, esse saber positivo, aí reduzido a uma resposta objetiva, a uma regra que pode ser aplicada em qualquer situação semelhante sem que exista qualquer possibilidade de erro ou de equívoco. ${ }^{139}$

\footnotetext{
139 O que se configura nas páginas da revista Nova Escola corresponde ao crescente esquadrinhamento dos alunos em escolas consideradas construtivistas, por meio de determinados instrumentos ou estratégias que (re)emergem e proliferam nesse mesmo período. Um bom exemplo são as chamadas "Pautas de Avaliação" ou "Indicadores de Avaliação" usados em escolas de São Paulo (Rocha e Mingues, 1996, p. 67), bem como os "Pareceres Descritivos" utilizados em escolas da rede municipal e estadual de ensino de Porto Alegre e analisados por Corazza $(1995,1996 a)$.
} 
A infinidade de receitas e regras que a revista Nova Escola fornece nesse período parece responder ao intuito de todo saber positivo: ser universal. Uma universalidade que nesse caso só pode ser conquistada pela incessante proliferação de receitas e regras devidamente acompanhadas de orientações claras para a sua aplicação. Tudo isso, ademais, depurado dos "ruídos" já referidos, os quais poderiam introduzir uma indesejável falta de clareza e objetividade. Essa depuração, aliás, é um dos fios que liga o saber técnico e o saber científico, ambos com a mesma necessidade de filtrar esses "ruídos". E esse também é um dos fios que tende a ligar e perpassar os vários construtivismos, os vários discursos sob a égide desse significante-mestre, os desta estrada moderna e os precedentes. Os desta estrada, porém, além de excluírem os "ruídos", tendem a "esquecer" as teorias.

Nesse período, se consideramos o que predomina na Nova Escola, já não é mais relevante destacar o esforço e as dificuldades próprias do professor que atua tomando como base a teoria ou teorias construtivistas, como é o caso da matéria que enaltece a professora Bernadete. ${ }^{140}$ Uma professora que muito teve que discutir, estudar e compreender da complexa teoria construtivista para que a sua prática pudesse ser assim reconhecida. Essa prática não é nada sem esse referencial teórico, conforme costumava-se pontuar em diversas matérias. Essa exigência, esse permanente recado para que os professores invistam no conhecimento da teoria ou teorias construtivistas como primeiro passo para ter uma boa prática, tornou-se menos presente e perdeu parte substancial de seu antigo vigor. Talvez porque é uma exigência que atenta contra o que nesse momento se impõe nas páginas dessa revista, como a busca de compreensão e consumo imediatos, aliada à necessidade de clareza e de total transparência. Tudo isso, vale ressalvar, não destitui a ciência do lugar já conquistado, como significante de arremate do discurso pedagógico. Ela continua sendo uma referência fundamental e as teorias continuam a comparecer nas páginas da Nova Escola, sempre de um modo superficial e simplificado. Agora, porém, como tudo o mais nessa revista, as teorias também foram "trocadas em miúdos", ou seja, foram filtradas daqueles indesejáveis "ruídos" presentes nas antigas reportagens e, não raro, despedaçadas. No extremo, poder-se-ia dizer que estamos diante de

\footnotetext{
${ }^{140}$ Cf. "As agruras do caminho construtivista", n 65, abr./93.
} 
um construtivismo sem "ruídos" e sem teorias. Esse é o construtivismo em estado puro. $^{141}$

Nessa fase, "as agruras do caminho construtivista" não mais existem ou pelo menos deixaram de aparecer nas páginas da Nova Escola. O "caminho", se ainda é possível dizer que existe, transformou-se numa veloz estrada moderna, na qual tudo flui com rapidez. Uma estrada que já não tende a ser regulada pela pesada temporalidade evolutiva que marcava aquele "caminho", o que não quer dizer que os três pontos de estrutura tenham desaparecido. Houve certamente uma rearticulação: "origem" e "destino" tornaram-se Um, tornaram-se modernos. Com isso, determinadas diferenças criadas por esses pontos começaram a se esfumaçar. Prevalece o presente, com certo futuro-presente tensionando suas margens e passados que ou desaparecem ou com esse presente começam a se confundir. Certo passado, por exemplo, tornou-se mais leve, deixou de afigurar um fardo, já não é incompatível com o construtivismo. Com esse passado, podese mesmo marcar um encontro, dar as mãos, exatamente no ponto de retorno que o construtivismo tecnicista cria, com seu "núcleo didático" e os seus representantes modernos, como se vê nesta imagem da capa de outubro/96:

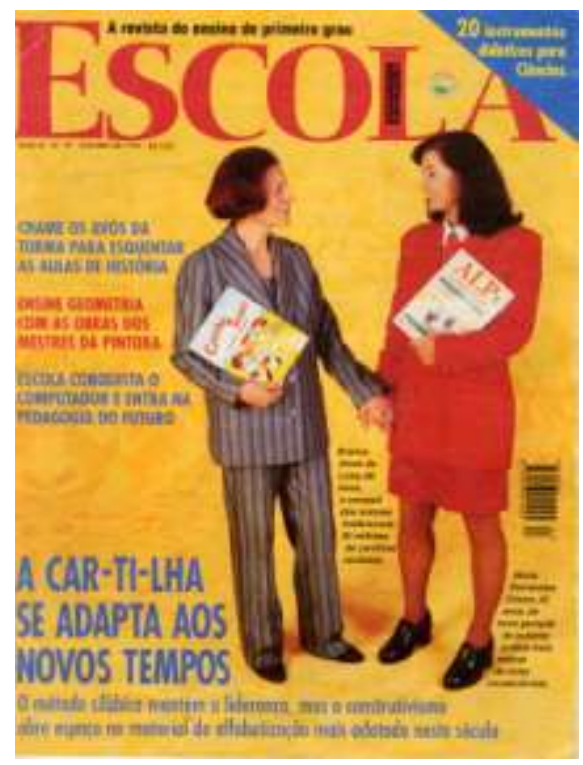

\footnotetext{
141 "É o construtivismo em estado puro" constitui o subtítulo de uma matéria de outubro/95, sem que esse enunciado tenha o mesmo sentido que acima foi dado. A não ser que consideremos a oportuna presença do significante-mestre receita na definição dessa "linha pedagógica" e o que ele configura na revista e nessa mesma matéria. No breve texto relativo a esse subtítulo, o construtivismo é definido por meio destas poucas palavras: "A receita é simples: 'Os alunos contam seu dia-a-dia e em cima dele explicamos os programas de Matemática, Português e Ciências", ensinam [as duas professoras destacadas na matéria]. A repetência foi reduzida a zero". Cf. "Exercício de imaginação", Nova Escola, n 88, out./95, p. 47.
} 
Nesse ano exemplar, com a especialista que adequou o que antes era inadequado, temos esse sugestivo (re)encontro entre autores de cartilhas. Conforme informa a capa, de um lado (à esquerda) temos a senhora Branca Alves de Lima, 86 anos, autora da tradicional cartilha Caminho Suave e "campeã dos autores tradicionais"; do outro, Maria Fernandes Cócco, 43 anos, a moderna representante da "nova geração de autores", com a "obra mais radical na linha construtivista". Esse construtivismo radical é a grande vedete desse ano, é o "núcleo didático" que a todos ocupa, como sugerem as imagens das crianças e da maioria dos adultos destacados nas capas desse "ano didático". Todos eles girando em torno do mesmo objeto: uma boa estratégia de ensino, um bom material didático, um conteúdo que "funciona". Algumas dessas figuras mostramse particularmente fascinadas ou envolvidas, como as crianças e as duas jovens e supostas professoras especialmente vestidas para a ocasião, nas edições de maio e junho. Nesse período, esses cobiçados objetos didáticos tendem a se sobrepor a qualquer outra consideração relativa à melhoria do ensino; eles são os verdadeiros protagonistas desse período; eles geram interesse e atraem, conduzem e envolvem as crianças, literalmente até - se nos deixarmos guiar pelo que predomina nas imagens dessas capas. ${ }^{142}$

Nesse "ano didático", se consideramos o que constitui o principal destaque em todas as suas capas, há uma única exceção, literalmente no seu centro: Jean Piaget, cuja figura jamais tinha reluzido tanto, pelo menos nessa revista. ${ }^{143}$ Destacado na capa do mês de agosto/96, o seu nome já havia comparecido nesse mesmo local em junho/94, mas compartilhando esse espaço e sendo levemente superado por um outro destaque - a "paixão pelo futebol". Agora, no entanto, a sua imagem sobressai, é o ano de seu centenário, embora não seja isso propriamente o que o torna tão relevante. ${ }^{144}$ Se compararmos essas duas capas, ambas com um dos significantes de arremate do discurso construtivista - 0

\footnotetext{
${ }^{142}$ Ver as capas das revistas desse ano no Anexo A.

${ }^{143}$ Ibidem.

${ }^{144}$ A esse respeito vale lembrar que, nesse mesmo ano, comemoravam-se os centenários de mais duas figuras de destaque no meio educacional, Freinet e Vigotsky, nem por isso transformados nas manchetes de capa. Para os dois foram reservadas as chamadas de capa relativas a duas matérias presentes nas edições de maio e dezembro de 1996. Para Paulo Freire, por exemplo, bem presente nessa publicação antes da sua fase moderna, é destinada uma pequena chamada na capa quando de seu falecimento, na edição de junho/97. No editorial desse número, ademais, nada é comentado, ao contrário do que se observa nos casos de Piaget e Freinet.
} 
último a emergir dentro do período aqui investigado —, podem ser notadas algumas diferenças que correspondem à mudança ocorrida nessa revista e nos discursos pedagógicos. Ou seja, essas diferenças concernem ao novo ponto de basta produzido pelo e com o significante-mestre construtivismo, quando (re)emerge em março/95. Vejamos então essas diferenças e o que é que elas sugerem.

Em junho/94, este era o enunciado presente na capa da Nova Escola: "Como a criança aprende, segundo PIAGET", com esse nome próprio em maiúscula e letras maiores. A única foto da capa, relacionada com o futebol mas também com a chamada da matéria sobre Piaget, é o de uma criança. De tudo isso, podemos ficar com estes significantes: criança, aprende, Piaget. Em agosto/96, a manchete é esta: "Sabe o que este velhinho fez pelo ensino básico?", acompanhada da imagem do rosto do epistemólogo suíço, que ocupa boa parte da capa. Ao lado dela, no canto inferior esquerdo e com letras bem menores, está escrito Jean Piaget. Além disso, no canto inferior direito tem este texto, com letras maiores que as do nome: "Ele sacudiu a Pedagogia do século XX decifrando como a criança raciocina". Da manchete, poderíamos destacar estes dois significantes: velhinho e ensino. Se os relacionamos com o título presente na capa de junho/94, é possível estabelecer uma equivalência entre Piaget e velhinho. Vemos também que o significante criança desapareceu da manchete, mas também a sua imagem, junto com a camisa de futebol verde-amarela que ela vestia e que aludia à "paixão" brasileira. Quanto às imagens, ainda é possível notar que no lugar da criança surge o rosto do epistemólogo suíço ou do "velhinho", conforme destaca a manchete. A criança, em 96, ficou num lugar subalterno, no texto que complementa a manchete: a criança que "raciocina", equivalente à "criança que constrói seu próprio conhecimento". Quanto à escrita do nome Piaget, o seu tamanho diminuiu sensivelmente. Em compensação, emergiu a sua imagem, que é o que agora interessa ressaltar. Nesse período, sob o domínio da imagem, é preciso "mirar-se" nesse espelho, nessa imagem, em Piaget, como sugere o título do editorial ou "Carta ao leitor": "Mire-se no exemplo de Jean Piaget" (p. 3). Comparando as manchetes de capa das duas edições, vemos também que desapareceu o significante "aprende" e surgiu o significante "ensino", que poderia ser tomado como equivalente do significante didática. Outra 
coisa a notar ou evidenciar é a alusão à "Pedagogia" do "século XX", sacudida pelo "velhinho".

Essa é uma análise voltada unicamente para o que é da ordem dos significantes, da materialidade significante, com um significante de arremate que está nos servindo de guia, junto com outros que nesse "ano didático" confluem em sua direção. Assim guiados, pelo movimento dos significantes, a eles dando-lhes primazia, podemos estabelecer várias relações e atentar para o que esse movimento nos ensina, qual a direção e sentidos que a sua articulação sugere, quais janelas nos abre, enfim, qual o saber que dele podemos extrair, e que já é possível vislumbrar.

O primeiro que pode ser apontado é a substituição significante que parece ocorrer nos enunciados das manchetes: ensinar no lugar de aprender (ou "aprende"). Com essa alteração, o nome e a figura de Piaget tendem a ficar sob uma nova injunção, sob um novo domínio, o domínio do ensino, mas também da didática, se aí provocarmos um pequeno deslizamento. Tendo em vista essa substituição operada nos títulos, poderíamos perguntar o que aconteceu com a criança que aprende, "a criança que constrói seu próprio conhecimento", que "raciocina"? Como já vimos, ficou num lugar subalterno, como que subordinada ao que nesse momento é o grande foco do discurso pedagógico. É claro que a criança-aluno continua sendo fundamental, como vimos na matéria sobre uma "boa aula": é preciso conhecer os alunos, a sua idade, seu nível de desenvolvimento, avaliar o que estão assimilando, "levar em conta a personalidade da turma". ${ }^{145}$ Mas isso tudo fica subordinado aos significantes então capitais: "boa aula", ensino, didática, com tudo o que neles conflui e que assim nutre o ponto de ressonância que define "o que" falta. Nesse momento é preciso atentar para esses significantes-mestres. Quanto às crianças-alunos, que então são devidamente esquadrinhadas com a ajuda do saber psicológico — ou do que dele sobrou, no caso da Nova Escola -, elas ficam sob a ordem das técnicas, dos matérias didáticos, dos conteúdos do ensino e do circuito onde tudo isso circula com a avidez. Sob essa ordem a criança perde boa parte de seu estofo anterior. Um processo que corresponde ao que se observa nos títulos das

\footnotetext{
${ }^{145}$ Cf. "Ponha algo mais em sua aula", Nova Escola, n 91, março/96, p. 41.
} 
duas edições que aqui estão sendo comparadas. O significante criança desaparece da manchete de capa de agosto/96 e a capa, nesse caso, tampouco apresenta a imagem de uma criança, como em junho/94, quando temos a foto de uma criança marcada pela "paixão" brasileira. Um fato do discurso que faz pensar sobre a "realidade da criança", da criança brasileira. O que temos em 1996? Sem dúvida, pouco sobrou dessa criança, exatamente no ano em que a figura de Piaget ficou no seu centro, com certo circuito mercantil e didático configurando o seu entorno. Nesse ano temos a criança-grife e desapareceram os traços que vez por outra surgiam nas capas da Nova Escola no período em que o significante classes populares comparecia em suas páginas.

Essas alterações poderiam levar a pensar que o professor tornou-se a figura central, na esteira da vertente do construtivismo que insistia no seu papel o papel de alguém que intervém no processo educativo. Uma intervenção que deve ser adequada e planejada, de acordo com o que vez por outra é lembrado até o significante planejar ganhar um primeiro plano, na manchete de capa de fevereiro/98. Para intervir, o professor agora conta, como nunca antes, com toda a parafernália didática, que também parece servir para afastar o risco de cair no espontaneísmo. Desse modo, poder-se-ia pensar, a ação do professor se potencializa e a sua figura ganha destaque. Entretanto, em vez dele próprio tornar-se a figura central, o que ocupa o seu lugar é a parafernália didática. No construtivismo tecnicista o professor mesmo tende a desaparecer, na mesma medida em que, de novo, é transformado em um executor, em um aplicador de técnicas, de materiais didáticos e de conteúdos.

Na revista Nova Escola, há um pequeno detalhe que parece corresponder a essa substituição. E envolve o nome da revista, ou melhor, um pequeno enunciado colocado logo abaixo do nome desde a primeira edição, com letras bem pequenas: "Para professores do 1ำ Grau". Um enunciado que pouco muda em março/95: "PARA PROFESSORES DE PRIMEIRO GRAU". Essa insignificante mudança, entretanto, já indica um dos locais então visados para realizar as alterações que se produzem com o novo diretor de redação, ou seja, o lugar onde é definido o destinatário da revista. Em agosto/95, efetiva-se o que aqui interessa destacar: o enunciado anterior é retirado e substituído por outro, colocado agora acima do nome, precedendo-o. O enunciado é "A revista do ensino de primeiro 
grau", tornando-se "A revista do ensino fundamental" em fevereiro/98. Quer dizer, o significante professores desaparece. A Nova Escola "para professores", tornouse a "revista do ensino". Nada mais apropriado para esse momento, com a entrada em cena do novo protagonista.

Sem dúvida, o lugar do professor mudou e esse fato pode ser pensado de vários modos. Eis um deles. Primeiro, a principal demanda endereçada ao professor era a compreensão e a correta interpretação da teoria ou teorias construtivistas, para que a partir dessa compreensão pudesse derivar uma prática pedagógica adequada. Posteriormente, com o construtivismo radical, a compreensão da teoria perdeu relevância e até mesmo parece ter deixado de constituir um grande problema, afinal de contas ela foi "trocada em miúdos". Ademais, o que ganha relevância é ter um certo saber didático cuja aquisição é igualmente facilitada pela sua redução ao que é da ordem das receitas. Da aplicação de um saber teórico passamos então à aplicação de um saber técnico, surgindo por último esta demanda: aplicar corretamente o construtivismo oficial (os PCN e outras propostas curriculares). Quer dizer, com o construtivismo, o que muitos esperam é que o professor saiba "aplicar" o que tende a ser gerado num âmbito diverso daquele onde realiza a sua atuação — um âmbito ao mesmo tempo estranho e familiar. Eis aí uma outra versão do longo "caminho construtivista".

Retomemos agora as duas matérias sobre Piaget relativas às capas antes destacadas. O título da matéria de 1994 é idêntico à chamada de capa desse ano ("Como a criança aprende segundo Piaget"), enquanto na matéria de 1996 é "Jean Piaget" (em letras bem grandes) precedido pela palavra "Centenário" (com letras bem menores). O subtítulo é "A lógica própria da criança como base do ensino". Novamente o significante ensino comparece, o que não se observa na primeira matéria, onde o que importa é "como a criança aprende", à semelhança do que é ressaltado em outros dois títulos desse mesmo ano, nas matérias sobre Freinet (abril/94) e Montessori (outubro/94). ${ }^{146}$ A "lógica própria da criança", embora continue sendo fundamental, agora deve ser explícita e claramente relacionada com o significante ensino. $O$ que nesse período parece perder terreno

\footnotetext{
146 "Como a criança aprende segundo Freinet", Nova Escola, n 74, abr./94, pp. 24-8; "Como a criança aprende, segundo Montessori", Nova Escola, n 79, out./94, pp. 26-9.
} 
e que as matérias sobre Piaget reforçam é o "como se aprende", em favor do "como se ensina". Quanto a Piaget, como acima foi sugerido, as novas costuras inscrevem seu nome e figura no interior de um campo cuja crescente relevância como que obriga a colocar algum significante que o evoque, como é o caso do significante ensino. Para realizar essas costuras, na capa de agosto/96 também é convocado o significante pedagogia. Afinal, foi Piaget quem "sacudiu a Pedagogia", um "psicólogo", como lembra a introdução da matéria: "O impacto talvez mais forte recebido pela escola básica neste século não partiu de um educador. Foi obra de um psicólogo, o suíço Jean Piaget". ${ }^{147}$ E aqui vale lembrar que, nessa nova fase moderna da revista e do Brasil, quem "sacode" o "ensino básico" é o "Professor-Presidente", como já havia sido antecipado pela manchete de capa de dezembro/94: "O Professor-Presidente revela como vai sacudir o ensino básico". Ou seja, Fernando Henrique Cardoso também "faz pelo ensino básico", como aquele "velhinho". Nesse caso, a pedagogia "sacudida" e que "sacode", com o mesmo nome-do-pai, com o mesmo ponto de arremate, concerne às propostas curriculares oficiais, a começar pelos PCN. Essas, enfim, são algumas das confluências relativas à série significante já destacada: didática/psicologia/pedagogia.

A menção ao século $\mathrm{XX}$, destacando sobretudo as primeiras décadas, corresponde ao recuo que se observa nas "origens" do construtivismo. Um ponto do passado irrelevante na matéria sobre Piaget de junho/94. ${ }^{148} \mathrm{Em} \mathrm{1996,} \mathrm{no}$ entanto, é preciso colocar isso num primeiro plano, nos primeiros textos da matéria, indicando também que o construtivismo é uma das "três grandes correntes teóricas empenhadas em explicar como a inteligência humana se desenvolve", além de ser o nome de uma "linha pedagógica". ${ }^{149}$ As outras duas correntes são o empirismo e o racionalismo, todas elas brevemente definidas em três box. Essas "correntes" nutrem e assim definem os três pontos de estrutura do discurso pedagógico construtivista, três pontos que aí igualmente comparecem em sua versão pedagógica, com o significante-mestre escola tradicional e com

\footnotetext{
147 Cf. "Jean Piaget. A lógica própria da criança como base do ensino", Nova Escola, n 95, ago./96, p. 9.

${ }^{148}$ A única relação com esse passado resume-se a este enunciado: "Da idéia dos estágios saiu o construtivismo, que mudou toda a organização e o planejamento da escola moderna", p. 22.

149 Cf. "Jean Piaget. A lógica própria da criança como base do ensino", Nova Escola, n 95, ago./96, p. 10.
} 
este recado: "Entender que a criança constrói seu próprio conhecimento não torna o professor dispensável". ${ }^{150} \mathrm{O}$ texto que define o construtivismo desse modo tem este título: "Afinal, o que é construtivismo?, com a resposta já antecipada no olho que vem em seguida: "Das alturas da pesquisa teórica para a sala de aula" ( $p$. 10). A enorme distância estabelecida com esse enunciado, entre o construtivismo teórico e o construtivismo na "sala de aula", corresponde ao caráter excepcional da figura de Piaget (na capa de agosto/96) em face do que é destacado em todas as demais capas desse ano. Ainda nesse texto, Piaget é vinculado à Escola Nova e aos anos 20:

Já nos anos 20, pedagogias inovadoras encontraram em sua obra a sustentação científica que Ihes faltava. "Destacando o papel ativo da criança no aprendizado, seus trabalhos deram base aos educadores da Escola Nova", explica Lino de Macedo (...) (p. 11)

A obra de Piaget forneceu o que faltava: ciência. Ademais, ela é "a matriz do construtivismo", conforme explicita a matéria no texto introdutório e é confirmado por um amplo consenso nacional (p. 9). Eis aí duas boas razões para ser a manchete de capa. Entretanto, o que em 1996 tende a fornecer o que falta, o que todos procuram, concerne ao circuito configurado em torno desse astro que está nas "alturas", como sugere o texto. O que não significa que esse circuito não dependa desse astro ou desse centro que parece inatingível para a maioria dos leitores da revista, de acordo com o que ela configura nessa mesma matéria. Pensando neles, em particular nos " professores do $1^{\circ}$ Grau", poderia ser proposta esta pergunta: o que é que pode diminuir tamanha distância? O trabalho dos especialistas, que nesse ano excepcional emergem nas capas da Nova Escola como nunca antes. Com efeito, observando-se todas elas desde o primeiro número, em nenhum ano anterior encontram-se tantos especialistas destacados num mesmo ano. ${ }^{151} \mathrm{Em} 1996$ são quatro e as suas fotos sobressaem nas capas de três edições seguidas, logo após a emergência do epistemólogo suíço, como se ele os tivesse convocado para fazer essa mediação entre a teoria, que está nas "alturas", e a prática em "sala de aula". Eis os especialistas, ou melhor, as especialistas: uma "especialista em brincadeiras e jogos infantis" (setembro), as

\footnotetext{
${ }^{150}$ Reprodução da fala de Maria Anita Martins, diretora da Faculdade de Educação a Pontifícia Universidade Católica de São Paulo (p. 13).

${ }^{151}$ O único ano em que surge algo parecido é 1989, quando nas capas aparecem as fotos de Emilia Ferreiro, Paulo Freire e Marta Suplicy.
} 
duas autoras de cartilhas (outubro) e uma "educadora" ou "pedagoga" que é coordenadora de uma "Oficina de Recursos Didáticos" e "treina professores de primeiro grau" (novembro), conforme informa a matéria. ${ }^{152}$

Os modernos especialistas têm um saber didático então muito valorizado e que na revista Nova Escola tende a ser reduzido a um conjunto de receitas didáticas. É um saber cujo valor não concerne apenas ao sucesso então garantido ao professor. O seu valor é sobretudo econômico. O novo saber didático é primeiramente uma mercadoria, há tempos vendida pelos que saíram na frente nesse agora cobiçado mercado, com cada vez mais especialistas, assessores, Centros de Estudos, tudo sob a égide do significante-mestre construtivismo. Nesse período, os espaços de reflexão e troca de experiências entre educadores ou professores, se já vinham recuando, agora então parecem recuar de forma mais pronunciada, exatamente com o construtivismo radical. Com ele, tudo se compra e se vende. Em outras palavras, a troca entre educadores tende a ser mediada pela mercadoria-mãe, a mercadoria universal, o equivalente universal: o dinheiro. Este é um dos significantes de ressonância do Novo Moderno, o significante-mestre que define "o que" falta e que cria o semblante de que nada falta, com ele no bolso, é claro. É o discurso do Capital, com seus efeitos retroativos e prospectivos, pois tudo transforma em mercadoria, o passado e o futuro, ambos diluídos no eterno presente que o seu "feliz" predomínio produz. Esse é o mestre que define o lugar do significante de arremate Piaget quando emerge no "ano didático", na mesma medida em que se sobrepõe ao "velhinho" e o encerra em seu circuito envolvente, no seu encaixe. Ele é o verdadeiro centro em 1996, junto com a mercadoria-fetiche: a didática.

Sob o domínio desse circuito, definido por esse fetiche, não mais existe troca entre educadores, mas valores de troca, num circuito onde todo saber oriundo da sala de aula - extraído inclusive dos bons professores, das boas experiências escolares - retorna para esse mesmo lugar, mas com algo a mais, com um a mais, $0+1$ necessário para a ação pedagógica ser plenamente eficaz — "o tijolinho que faltava no seu construtivismo", como se afirma no texto

${ }^{152}$ Cf. "O Sertão do Seridó cria sua didática", Nova Escola, n 98, nov./96, p. 8. 
publicitário já mencionado. ${ }^{153} \mathrm{Um}$ retorno mediado pelos modernos especialistas, que filtram, sistematizam e ordenam as experiências escolares tendo em vista a qualidade do ensino, mas também a transformação daquele saber, expropriado de um outro circuito, numa atraente mercadoria: a mercadoria didática. Isso, pelo menos, é o que predomina no circuito moderno do significante-mestre construtivismo, o circuito definido pela didática-mercadoria, que tudo ordena e ensina. Diferente, por certo, do que na revista Nova Escola surgiu como uma primeira inscrição: "uma didática científica". ${ }^{154} \mathrm{O}$ seu destino moderno a inscreveu num outro circuito, mas aparentado com o anterior, pois a estrada construtivista desde o início foi sendo pavimentada com esta substância primeira: um saber positivo.

Com essa substância e com aquele mestre, com o mestre Capital, a tendência é que o nosso "caminho", a nossa superfície moebiana, fique sem fissuras e sem limites, com a sua "origem" e horizonte igualmente apagados. $O$ mesmo ocorrendo com o registro subjetivo que é próprio da fantasia, não exatamente porque as fantasias ou fantasmas acabem, mas antes porque eles se tornam a nossa realidade, toda a realidade, subjetiva e social. Quer dizer, com o renovado domínio daquele mestre secular tendem a cair todos os véus e a nossa realidade é invadida por aquilo que costumamos guardar em segredo - o segredo necessário para que o laço social opere sem que irrompa a violência que impede a circulação da palavra. Sob o domínio dessa renovada configuração, esse laço tende a se extinguir, ou melhor, reifica-se, torna-se uma relação entre coisas, assim também se extinguindo parte fundamental da ordem humana — um efeito que certa tradição marxista discute e que Marx já indicara ao analisar o circuito que se configura quando tudo é transformado em mercadoria. ${ }^{155}$ É claro que aqui essa ordem humana é concebida de outro modo, como sendo a ordem do desejo e de "coisas" que não conseguem preenchê-lo. Coisas e "coisas": as primeiras no registro positivo do que nada falta; as segundas, marcadas pela insuficiência do que é desconhecido e que assim há de permanecer. Sob a configuração do Capital, as primeiras tomam o lugar das segundas, com um efeito

\footnotetext{
${ }^{153}$ Cf. "Professor ... Comece o ano novo, inovando. Comece com sala de aula construtivista!, Nova Escola, n 82, março/95, p. 35.

${ }^{154}$ Veja-se, no capítulo III, o item "O nome Emilia Ferreiro".

${ }^{155}$ Dentre os autores brasileiros, veja-se por exemplo Paulo Silveira (1989).
} 
sobre o laço social que pode ser indicado com as mesmas palavras usadas por Marx quando tratou do fetichismo da mercadoria: "Uma relação social definida, estabelecida entre os homens, assume a forma fantasmagórica de uma relação entre coisas" (1980:81). Por essa via pode ser pensado o que ocorre com os componentes didáticos nas páginas da Nova Escola. Esses componentes parecem cobrar vida, tornando-se eles próprios os agentes da ação. Ou seja, são eles os que definem o que é da ordem do laço social, nesse caso relativo à ação educativa.

Piaget e outros nomes que "entram" no novo circuito mercantil e didático certamente não são mais os mesmos. Na revista Nova Escola isso já foi parcialmente evidenciado ao serem comparadas as duas matérias sobre Piaget, de junho/94 e agosto/96. Nelas ainda é possível destacar outros aspectos. $\mathrm{Na}$ primeira, por exemplo, há uma longa apresentação de uma escola e do trabalho que nela é desenvolvido, inspirado sobretudo na obra de Piaget. A escola é "A Chave do Tamanho", de Lauro de Oliveira Lima, e nessa apresentação é situada a sua história, fala-se do "método psicogenético" e há relatos de atividades desenvolvidas em sala de aula, com detalhes que trazem à tona aspectos singulares das situações que são descritas. Nessa matéria, além de uma primeira parte sobre a trajetória de Piaget e aspectos da sua obra, há dois box, sobre os "Princípios inspirados em Piaget" e outro sobre "A teoria dos estágios". Há ainda um outro box sobre "Os agrupamentos da Chave do Tamanho". Na matéria de agosto/96, também são descritos os estágios e destacados aspectos de sua obra, além de momentos de sua biografia, no final da matéria claramente discriminados com os anos mais importantes. Há também vários box com depoimentos de alguns educadores e um box que se refere às comemorações. Tudo isso é precedido pelo texto sobre as já comentadas "três grandes correntes teóricas", exceto uma breve introdução e um pequeno texto que toca em aspectos da biografia do chamado "gênio suíço". Mas o que é mais importante é que, desta vez, nenhuma experiência é apresentada e não faltam as "Dicas do mestre para professores", com trechos retirados dos textos de Piaget, devidamente separados.

$\mathrm{O}$ que ocorre com Freinet também evidencia a mudança ocorrida. $\mathrm{Na}$ matéria de abril/94, intitulada "Como a criança aprende segundo Freinet", os títulos dos dois primeiros box já situam o que nela é valorizado: "Os princípios de 
Freinet", "Ser freinetiano é mais que usar limógrafo e correio". Quanto à matéria de maio/96, ela é precedida pelo nome da seção "Pedagogia", em letras pequenas. Mas o que sobressai não é o título (em letras pequenas e difícil de ser reconhecido como título) e sim as imagens, quatro ao todo. Uma delas, a maior, é uma foto de Freinet, e as outras três, bem menores, referem-se às "técnicas" por ele criadas. O pequeno título, logo abaixo das fotos, é este: "Confira: em seu centenário, o grande educador continua vivo na sala de aula". Como se vê, o que importa é a "sala de aula". Ademais, o que nessa matéria sobressai são as "técnicas" desenvolvidas por Freinet, lembradas logo no primeiro parágrafo e nas imagens-título, nas imagens-nome. Além disso, essas "técnicas" são destacadas em cinco de seus seis box, os quais constituem quase que a metade do texto da matéria. Eis os títulos desses cinco box: "Aula-passeio", "A imprensa escolar", "Texto livre", "Livro da vida" e "Correspondência". Sem fazer uma análise mais profunda dessa matéria, já é possível notar que Freinet, com a inflexão que é próprio do novo ponto de basta, tornou-se basicamente um criador de técnicas "eficientes", como de fato é sugerido na introdução. Em outras palavras, Freinet já não está mais sob a injunção da "criança que constrói seus próprios conhecimentos", pelo menos não é ela que sobrepuja o seu nome.

Com o construtivismo "didático", nesse circuito onde nada parece faltar, tanto o professor quanto a criança tendem a ficar num segundo plano, como se fossem meros coadjuvantes. O que na Nova Escola importa é de uma outra ordem, como o ideal já em curso da "máquina azeitada e eficiente", um curso incompatível com a existência de "erros". Estes, aliás, em nome da "qualidade total" devem ser mesmo "esmagados", conforme sugere o diretor de Redação João Vitor Strauss na "Carta ao leitor" da edição de junho/97. Nesse texto, o diretor de redação refere-se aos "erros" que eventualmente aparecem na revista e ao papel de cada membro da sua equipe. Uma equipe "em que cada profissional deve assegurar a qualidade total do próprio trabalho", sobretudo a "editora especial" que cuida do "controle final de qualidade", apresentada justamente nesse texto. Antes de expor com clareza o que pensa sobre os "erros", o diretor de redação lembra destes dois ditados: "na prática, a teoria é outra" e "errar é humano". Feita essa ressalva, Strauss então esclarece qual é a sua posição, qual é o lugar do "erro" nesse registro da "qualidade total": 
Da nossa parte, resta não sucumbir à inevitabilidade do erro. É da natureza humana cometer falhas, mas isso não nos consola nem dá pretexto à acomodação. Aqui, detestamos o erro. Lutamos contra ele dia a dia, página a página, linha a linha. Nossa utopia constante é entregar ao leitor uma revista sem um único ponto fora de lugar. Felizmente, interceptamos em tempo a maioria de nossos erros. Da minha parte, confesso, sinto um prazer quase sádico em esmagá-los como pulgas. ${ }^{156}$

Nesse ponto de gozo, do erro "esmagado", (re)nasce uma Nova Escola/Nova Escola, com um diretor de redação que se afasta da sua direção justamente nesse ano de 1997, mas com a consciência do dever cumprido. Afinal, conseguiu inserir a Nova Escola no circuito por todos almejado e que essa publicação tudo fez para criar:

Cabia a ele renovar o visual e o conteúdo dessa revista sem perder um centímetro sequer de credibilidade e do respeito conquistados junto ao público. Strauss cumpriu sua missão. O número de leitores triplicou e multiplicaram-se as cartas e os telefonemas à redação. ${ }^{157}$

Quem escreve essa carta ao leitor, em novembro/97, é Guiomar Namo de Mello, na ocasião em que apresenta a nova diretora de redação Elizabeth De Fiore. Nesse momento, Mello era Diretora Executiva da Fundação Victor Civita e havia começado a desempenhar essa função nesse mesmo ano, sendo apresentada por Roberto Civita na "Carta ao leitor" de abril/97. Com ela, a revista começa a mudar. O que é da ordem da narrativa e do contexto das práticas pedagógicas começa a reaparecer. Mas o que sobretudo emerge são duas coisas. As políticas do governo Fernando Henrique Cardoso na área educacional chegam às capas da revista, ganham visibilidade. E, em 1998, com os fascículos dos PCN, estes são os que criam o grande contexto para as práticas escolares. Com eles, poder-se-ia pensar, finalmente temos um "modelo pedagógico", uma boa proposta pedagógico-didática para orientar os professores, como almejavam os intelectuais que na década de 80 articulavam a chamada pedagogia dos conteúdos, dentre eles a professora Guiomar Namo de Mello. No âmbito desse discurso, essa era a urgência desse momento para democratizar a escola pública. ${ }^{158} \mathrm{Com}$ os $\mathrm{PCN}$, esse imperativo de certo modo encontra acolhida, encontra uma resposta. Mas, agora, antes do que democratizar a escola trata-se

\footnotetext{
${ }^{156}$ Cf. "Errar é humano - e detestável", Nova Escola, n 103, junho/97, p. 3.

${ }^{157}$ Cf. "Um caminho feito de desafios", Nova Escola, n 107, nov./97, p. 3.

${ }^{158}$ A esse respeito, veja-se o item "Um outro caminho", no capítulo III.
} 
de torná-la moderna. Busca-se uma "escola eficaz", com a sua eficácia definida pelo circuito moderno do significante-mestre construtivismo. E é isso que também (re)emerge nesse momento: a escola, ou melhor, uma Nova Escola Moderna.

\subsection{Uma Nova Escola Moderna}

A Nova Escola de maio/97, logo após a edição que apresenta Guiomar Namo de Mello, pode ser tomada como o número onde é feito o primeiro ponto importante da torção que deverá tornar os PCN o novo significante de arremate do discurso pedagógico, um significante que redefine o lugar do significante-mestre construtivismo e de tudo o que nele conflui. É o número já comentado em que a manchete de capa é "Qualidade à vista", relativa a uma matéria onde são delineadas "As mudanças que devem revolucionar a Educação", conforme se afirma no sumário (p. 3). Nesse primeiro e enfático anúncio da "nova era", os PCN constituem apenas uma das várias medidas da "estratégia unificadora" do MEC, tendo em vista a "qualidade" de ensino.

Em relação a esse ano e fazendo parte dessas costuras, também é necessário destacar a edição de agosto, com esta manchete: "O check-up do ensino". Nessa reportagem de capa estão em causa "os testes de rendimento escolar aplicados em grande escala" ("o que são, quais são e para que servem"), conforme destaca o texto que complementa a manchete de capa. ${ }^{159}$ Esses "supertestes" concernem à política de avaliação do MEC e envolvem também os testes aplicados pelas Secretarias de Educação de alguns estados. Além da "avaliação", o que nessa matéria ganha relevância é a "escola eficaz" — um significante-mestre que junto com outros equivalentes faz a costura do que pode ser considerado um ponto de ressonância do discurso pedagógico hegemônico nesse momento. A "escola eficaz" é apresentada logo no primeiro box, junto com uma imagem que ocupa boa parte das duas primeiras páginas e que bem indica e demarca o lugar do olhar moderno então dirigido à escola pela revista e pelos "supertestes":

${ }^{159}$ Cf. "Avaliação. O check-up do ensino", Nova Escola, n 104, agosto/97. 


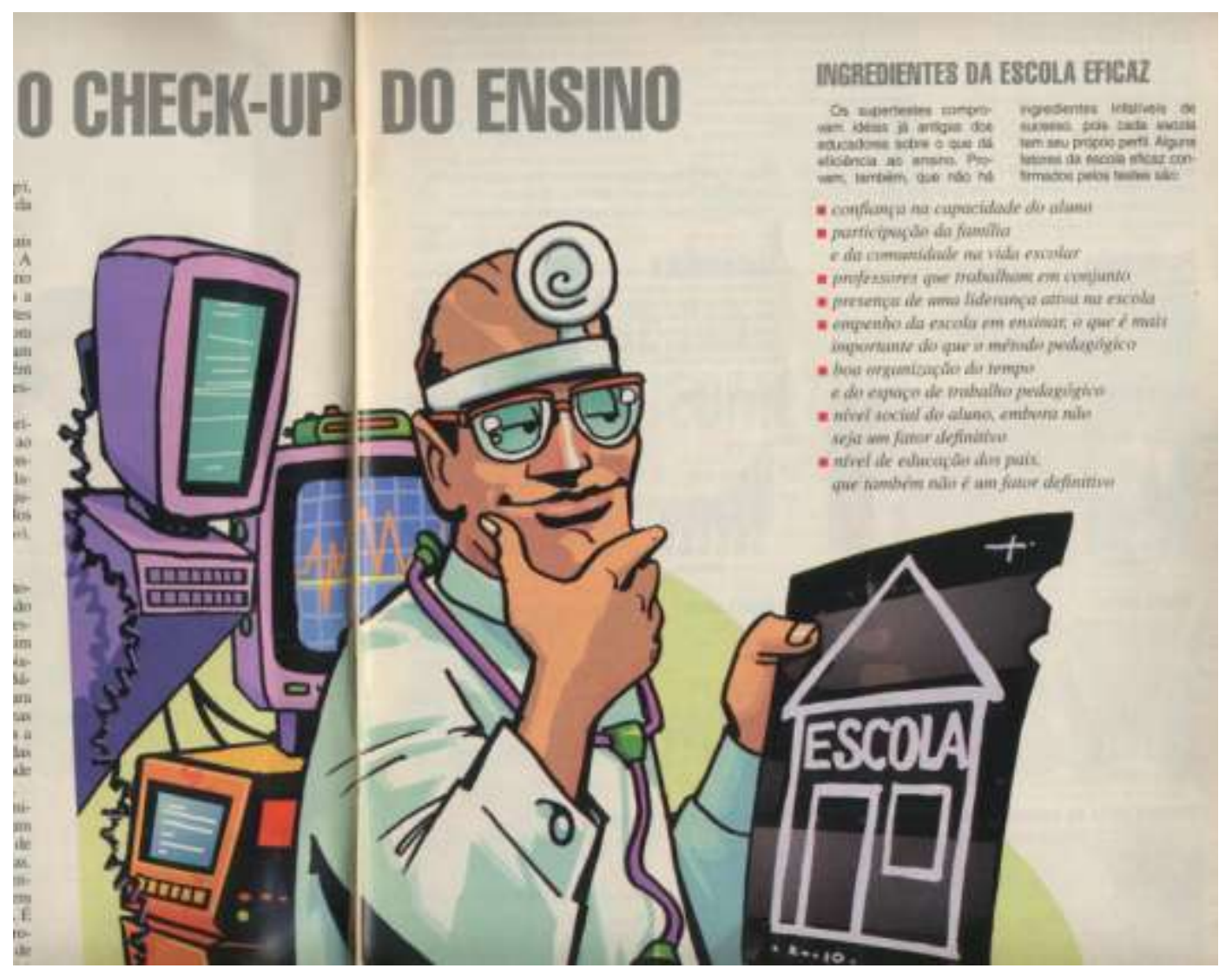

Nesse box, adverte-se que os "supertestes" provam que "não há ingredientes infalíveis de sucesso, pois cada escola tem seu próprio perfil". Essa ressalva, porém, não impede que a revista forneça a lista de "fatores da escola eficaz confirmados pelos testes" logo na linha seguinte, como que atenuando o efeito do enunciado anterior. A "escola eficaz" continua presente até o fim dessa reportagem de capa, em particular nos quatro subtítulos de maior destaque. Em cada um deles, nos seus textos, é focalizada uma escola pública. Eis os quatro títulos, junto com o olho que os complementa:

Um ateliê na aula de geometria

Escola aposta em atividades para tentar reverter baixos índices obtidos na avaliação paulista de 1996

\section{Escola desperta para a qualidade}

Diretora responde à chamada dos supertestes e convoca todos os professores para uma reviravolta na didática

Xeque-mate ao baixo rendimento

Numa jogada de mestre e inspirada na avaliação, escola usa jogo de xadrez para melhorar desempenho

Aprenda a lição da escola nota 10

Sistema confirma qualidade da Joaquim Fontes, onde não há evasão e, no ano passado, a aprovação beirou $100 \%$ 
Com a crescente relevância do significante escola e do que ele condensa, o foco no aqui chamado "núcleo didático" é ampliado, mantendo-se ainda a hegemonia do mestre Capital e seus equivalentes. Com ele e com o que nesse período constitui um modelo de eficácia, a escola alcança um primeiro plano na edição de novembro/98. Esse modelo de eficácia é a empresa, que emerge junto com a escola em um "casamento" que nesse momento "dá certo":

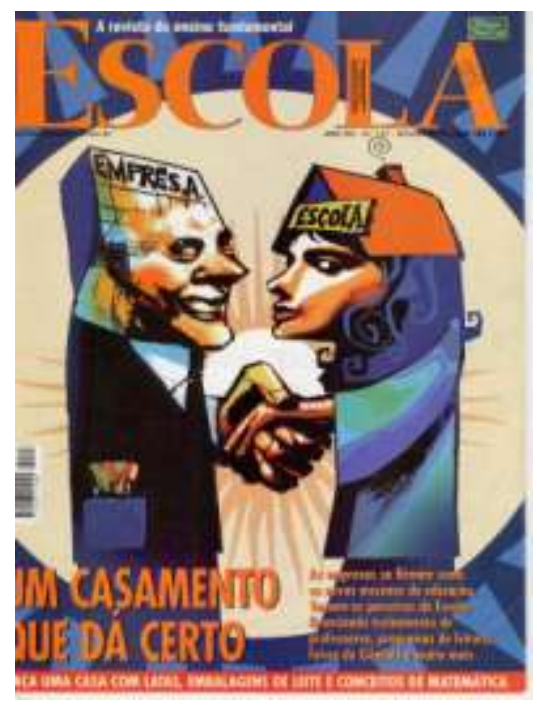

O significante-mestre empresa é o que nessa emergência define o lugar da escola, em particular o da escola pública. Um fato do discurso que nessa publicação não era novo. Afinal, até mesmo no início, em set./86, pode ser encontrada uma delimitação mais ou menos próxima do que vários anos mais tarde deverá ganhar relevância. Um dos raros exemplos desse período inicial é uma reportagem intitulada "Faça sua classe render mais", que basicamente consiste numa reprodução da fala da orientadora educacional Nereide Tolentino, uma pedagoga ligada à "escolinha Casa da Vovó" e que "dá assessoria empresarial na área de desenvolvimento de executivos" (p. 55). O que aí está em foco não é a escola, mas o professor, que é comparado a um "gerente". Eis um trecho da fala da pedagoga que, segundo informa o olho que sucede ao título, "explica como abrir esse novo caminho":

"Como responsável pelo resultado do trabalho em sala de aula, o professor está ali, por exemplo, como o gerente de uma fábrica de móveis: a preocupação de ambos é o bom rendimento de seus 'comandados'. E tanto o gerente quanto o professor sabem que a resposta à questão 'Quem está em minha sala?' é uma das duas condições importantes para a obtenção daquele ambicionado bom rendimento (ou da produtividade). (...)" (p. 52) 
$\mathrm{Na}$ fala da pedagoga comparece também o professor da "escola tradicional", aí contraposto ao professor-gerente, que conhece "a personalidade e o ritmo de cada aluno" e que sabe que esse fator é "muito importante para conseguir um bom rendimento" (ibidem).

Na primeira metade da década de 90, há também matérias em que a empresa constitui o grande modelo, com é o caso de duas que serão comentadas a seguir, com o significante empresa demarcando o lugar da escola e ele próprio ficando sob a guarda da "qualidade total". A primeira é de março/93, que basicamente trata da proposta da professora Cosete Ramos e de seu livro Excelência na Educação — A Escola de Qualidade Total. ${ }^{160}$ Conforme destaca o olho que sucede ao título, a "Professora defende a adaptação da gestão empresarial ao ensino", de acordo com uma proposta que nasceu nos Estados Unidos e que nessa matéria tem como referência importante a "fábrica japonesa": "A escola pode melhorar muito se funcionar de forma parecida a uma eficiente fábrica japonesa" (p. 52). A professora garante que essa forma de administração é "'eficaz para redução dos índices de repetência e evasão, do custo por aluno e do desperdício de esforços verificados no país'". Essa forma de administração produz um impacto muito peculiar sobre os alunos, pais e "toda a comunidade que rodeia a escola", pois todos eles são transformados em "clientes" (p. 53).

Sob o signo da "qualidade total", encontra-se também uma escola municipal destacada numa matéria de novembro/95. Trata-se da Escola Municipal Tereza Benguela, de Cuiabá, que adotou "um programa de qualidade inspirado nas empresas privadas", conseguindo assim "melhorar o desempenho das professoras e o rendimento dos alunos". ${ }^{161}$ Nessa escola, as "reuniões de equipe de educadores (...) quase lembram as assembléias de acionistas de uma grande empresa" (p. 52). Segundo adverte a matéria, ela ainda está "longe de ser uma empresa. Mas em alguns pontos vem se parecendo cada vez mais com uma - e daquelas bem modernas" (ibidem). A escola "instalou um programa de gestão de qualidade total. A meta é simples: a escola quer educar os seus alunos com mais eficiência" (ibidem). Com essa gestão, "os bons resultados estão em todas as

\footnotetext{
${ }^{160}$ Cf. "Uma escola com controle de qualidade total", Nova Escola, n 64, março/93, p. 52.

${ }^{161}$ Trechos do olho que sucede ao título. Cf. "Mudança de qualidade no ensino", Nova Escola, n 89, nov./95, p. 50.
} 
etapas da produção" (p. 51). Ademais, "O aprendizado hoje é muitíssimo mais rápido, garante a diretora" (ibidem). Sem contar "a surpreendente redução dos índices de repetência e evasão" (ibidem).

Matérias como essas registram e produzem a circulação de todo um conjunto de significantes que (re)configuram o lugar da escola, sobretudo o da escola pública, que é a que tende a ganhar um primeiro plano após a fase áurea do novo tecnicismo. Nessas matérias encontram-se os traços que precedem aquele "casamento", que precedem e constituem o ponto de basta que no discurso hegemônico transforma a escola em uma empresa, em uma empresa eficiente e moderna. Essa é a "escola eficaz", a escola adaptada ao "futuro", a Nova Escola Moderna que tende a predominar no circuito igualmente moderno do significante-mestre construtivismo, mas já sobrepujado pelos PCN.

$\mathrm{Na}$ reportagem de capa sobre o "casamento que dá certo", sobre as "Alianças que realizam sonhos", as empresas são consideradas os "novos mecenas" da educação. ${ }^{162}$ Elas patrocinam "reformas, cursos para professores e notáveis saltos na qualidade das escolas", conforme é destacado no olho do título. O seu patrocínio não envolve apenas ser uma "fonte de recursos": "Grandes ou pequenas, nacionais ou multinacionais, as empresas estão atuando mais diretamente junto às escolas, das mais diversas maneiras" (p. 10). Vejamos então, de forma sucinta, algumas dessas várias maneiras destacadas nessa extensa reportagem.

Ao todo, são dados nove exemplos, sempre envolvendo escolas públicas e algum tipo de "parceria" — um "conceito" que vem do "setor privado" e que "está enriquecendo o ensino brasileiro" (p. 10). A primeira envolve uma Escola Técnica Federal de Santa Catarina cujos professores perceberam que "os alunos chegavam despreparados e desmotivados" para essa nova etapa em sua vida escolar. E a "desistência durante o curso era de quase 50\%" (p. 11). Decidiram então adotar "um enfoque inusitado, mas eficiente":

resolveram melhorar o ensino das escolas de $5^{\mathrm{a}}$ a $8^{\mathrm{a}}$ série, antes, portanto, que os alunos cheguem ao Ensino Médio. Com financiamento da Fundação Vitae, a Escola Técnica (...) vem oferecendo cursos para 130

${ }^{162}$ Cf. "Alianças que realizam sonhos", Nova Escola, n 117, nov./98, p. 10. 
professores de seis escolas municipais. O objetivo não é apenas ensinar os alunos a lidar com editores de texto e programas multimídia, mas, sobretudo, renovar as concepções pedagógicas por meio da informática. "Buscamos um ensino mais cooperativo e interessante", diz Eduardo Beck, coordenador do projeto e professor de Eletrônica na Escola Técnica (...) os professores são treinados nas novas concepções de ensino, tornando as aulas menos expositivas. (ibidem)

Nesse exemplo, assim como em todos os outros e à semelhança das duas matérias antes comentadas, não comparece qualquer nome ou significante de arremate que permita reconhecer um determinado discurso educacional ou pedagógico. Ademais, o contraste com o período em que não existia qualquer "parceria" é feito de vários modos, mas em nenhum caso é usado o significantemestre escola tradicional ou qualquer equivalente. É claro que, em certos exemplos, comparecem algumas articulações discursivas que poderiam trazê-lo à tona, mas isso não ocorre. Nessas matérias, os antigos contrastes foram atenuados, diluíram-se e até mesmo desapareceram, junto com os significantes de arremate correspondentes. O que prevalece nesse período, embora não nessa reportagem, é a sigla PCN, essa é a marca da "qualidade".

O segundo exemplo destaca uma professora "com nota dez em ousadia", de uma escola estadual de São Paulo. Ela, a professora Fátima, procurou "uma das filiais brasileiras da Siemens, multinacional alemã vizinha da escola", e das conversas com essa empresa resultou "um acordo entre a APM e a Fundação Peter von Siemens". Eis os resultados dessa "parceria":

Aos poucos, Fátima não só conseguiu uma nova pintura e um tratamento anticupins para a escola, como também provocou mudanças profundas no comportamento dos docentes. É o caso da professora Rosana Marigliani. Após 20 anos de magistério, ela dava aulas mecanicamente. Tinha uma relação fria e distante com os alunos. "Eu repreendia sem dó nem piedade", diz ela. Há quase um ano, ainda que a contragosto, Rosana começou a freqüentar as sessões de acompanhamento psicológico, promovidas pela Siemens, com base na teoria da Inteligência Emocional.

Resultado: Rosana tornou-se mais paciente e sensível com os alunos na sala de aula. A Fundação paga os salários não só dos psicólogos que semanalmente atendem pais, alunos e mestres, como também dos professores que dão aulas de Educação Física e Música, novidades introduzidas na escola. Desta vez, quem exibe mudanças é Alan Pacheco, de 10 anos, da $4^{\text {a }}$ série. Antes retraído, ele agora vive cantando. "Às vezes eu chego triste na escola, mas a aula de Música é tão boa que eu esqueço de tudo", diz ele. (...) como a escola não tem 
biblioteca, a Siemens está financiando uma sala de leitura e a compra de livros.

Em relação a essa reportagem, o que aqui interessa destacar é como determinadas transformações relacionadas com a escola pública e a qualidade do ensino são inscritas no registro da empresa moderna. A empresa torna-se aí o principal agente dessas mudanças, mesmo que a sua presença seja atribuída à iniciativa de uma professora ou de um diretor. Ela "tutela" (p. 12), "adota" (p. 13) e assessora as escolas, contribui com recursos, melhora as instalações físicas, compra livros, mas também incide sobre o comportamento de professores e alunos, desenvolve as "competências da equipe pedagógica", contribui para criar um "projeto pedagógico" que valoriza o ambiente em que as crianças vivem, incentiva as "práticas educativas originais", amplia a "visão de mundo" de professores e alunos e até torna a escola mais solidária. Nessa reportagem, o significante empresa é o que sobrepuja todos os demais, a começar pelo significante escola, mas também outros que servem para definir o sentido da "parceria". É o que pode ser observado na introdução, onde se fala da "participação de empresas, fundações e os mais diferentes tipos de entidades no financiamento de projetos na área educacional" (p. 10). Ou no exemplo do "Fórum de Educação do Pacto de Cooperação do Ceará": o Pacto "procura formar parcerias entre o governo, os empresários, a igreja e outros organismos da sociedade, para que as coisas aconteçam" (p. 13). Entidades, instituições, especialistas, assessores, professores, enfim, direta ou indiretamente tudo fica sob a guarda da empresa. Até mesmo comparecem os professores-gerentes, desta vez porque foram "nomeados gerentes" do Programa Leia Brasil. (p. 17).

Além das "parcerias" apresentadas nos exemplos, a reportagem dá algumas orientações para "fazer um bom projeto", um projeto que "vai competir com outros, em busca dos mesmos recursos" (p. 16). Ou seja, quem vai competir são as escolas públicas, elas são as que entram nessa concorrida disputa, desse modo sendo criado um circuito "ainda" no início. Por isso, aliás, é bom começar a se familiarizar e acostumar, conforme parece sugerir a reportagem já no primeiro parágrafo: "Ao terminar de ler esta reportagem, você nunca mais verá o governo como a única fonte de recursos para manter o ensino - embora continue sendo a principal, provavelmente por muito tempo ainda" (p. 10). Pelo menos, poder-se-ia acrescentar, assim será enquanto não prospere o ideal da privatização do ensino. 
Para se dar bem nesse novo circuito moderno, no olho do texto que fornece as orientações para "fazer um bom projeto", dois significantes são destacados: coerência e objetividade. Considerá-los é fundamental, pois deles depende a presença de recursos: "Para obter apoio financeiro de empresas ou agências de financiamento, apresente as idéias com coerência e objetividade" (ibidem). Ao lado dessas orientações, numa coluna, são também fornecidos os nomes, endereços e telefones dos "mecenas do ensino Brasil". ${ }^{163}$

\subsection{Um saber positivo, um saber sistêmico}

Os traços ou articulações discursivas que precedem e sustentam o feliz "casamento" entre a empresa e a escola são os que igualmente colocam o significante "qualidade de ensino" num novo registro, inexiste na revista Nova Escola nos seus primeiros anos: o registro da "qualidade total", da "excelência" na educação, da "escola nota 10". Ou seja, o registro empresarial e moderno do erro "esmagado", tal como o diretor de redação Vitor Strauss tão ardentemente desejava em 1997. Esse registro é também o da "nova era" anunciada em maio/97, na edição em que o significante-mestre qualidade emerge com a manchete "Qualidade à vista". Nessa edição, o significante-mestre qualidade é sustentado por todo um "conjunto coerente" de "medidas" atribuídas ao governo federal. Desse "todo coerente", o que se destaca é a sigla PCN, não exatamente nessa reportagem, mas antes nos discursos oficiais, nos suplementos de 1998 da revista Nova Escola e nos discursos pedagógicos da segunda metade da década de 90. PCN é o significante-mestre que (re)ordena esses discursos e que também está no centro das políticas educacionais que o MEC implementa. Para finalizar este capítulo, vejamos então uma parte ao menos do que esse novo significantemestre instaura, começando pela Nova Escola.

Nessa publicação, desde 1998 os PCN fornecem o "contexto" teórico, primeiro e básico da maioria das atividades desenvolvidas por professores e escolas, em particular nos fascículos ou suplementos publicados a partir de abril. Neles, além de ser apresentada uma síntese e comentários sobre o que os PCN

\footnotetext{
163 Os "mecenas" apresentados nessa coluna são estes: Instituto C\&A, Fundação Abrinq, Fundação Banco do Brasil, Fundação Clemente Mariani, Fundação Ford, Fundação Kellogg, Fundação de Amparo à Pesquisa do Estado de São Paulo (Fapesp), Fundação Odebrecht, Fundação Vitae, Petrobras, Unibanco Ecologia (p. 16).
} 
propõem em cada área e das "dúvidas levantadas por professores do ensino fundamental" respondidas por "especialistas", são fornecidos "exemplos de atividades em sala de aula que se aproximam das propostas por eles apresentadas". ${ }^{164}$ Vários desses exemplos podem ser encontrados em edições de anos anteriores, em textos onde os PCN sequer eram mencionados e até mesmo inexistiam. Já no primeiro suplemento, relativo à área de Língua Portuguesa, a imagem que preenche o que pode ser tomado como a sua capa inaugural é a foto de capa da revista Nova Escola de abril/90. Nessa edição, a manchete era "Multisseriadas. O sucesso dos gaúchos", sobre uma reportagem que destacava o sucesso de escolas rurais do Rio Grande do Sul, como as de Ajuricaba, na região de ljuí, onde "pais, professores e universidade trabalham juntos, construindo uma educação crítica e adequada ao seu público", conforme destacava o olho que abria a matéria. ${ }^{165} \mathrm{Nela}$, o significante-mestre construtivismo não é utilizado, mas são mencionados os nomes Piaget, Paulo Freire e Emilia Ferreiro (pp. 15 e 17). Oito anos mais tarde, aquela mesma foto da capa da Nova Escola fica sob a sigla PCN, sem qualquer informação que indique essa procedência. Outro exemplo é o do suplemento $n^{\circ} 4$ de Ciências Naturais, sobre um "trabalho realizado na Escola da Vila, da rede paulistana". ${ }^{166}$ As duas fotos presentes nesse fascículo são as mesmas usadas na reportagem relativa à manchete de capa de outubro/92, de uma extensa reportagem sobre o ensino de Ciências nessa mesma escola — "um estabelecimento particular que há 10 anos trabalha na linha construtivista". ${ }^{167}$ Cerca de seis anos mais tarde, sob a sigla PCN, é feito um resumo de menos de meia página daquela reportagem e 0 significante-mestre construtivismo desaparece. Tampouco existe qualquer indicação que permita ao leitor saber que na verdade se trata de um resumo de uma matéria de 1992. Um outro caso encontra-se no suplemento de matemática, de novembro/98, sobre atividades desenvolvidas numa escola privada de São Paulo, o Colégio Magno. ${ }^{168} \mathrm{Em}$ meia página do suplemento são reproduzidas as fotos e quase todo o texto de um dos

\footnotetext{
${ }^{164}$ Cf. Suplemento $n^{\circ} 1$, p. 2, da Nova Escola $\mathrm{n}^{\circ} 111$, abril/98.

${ }^{165}$ Cf. "O sucesso das multisseriadas gaúchas", Nova Escola, n³8, abril/90, pp. 10-8.

${ }^{166}$ Cf. Suplemento n 4, p. 30, na Nova Escola n 114, ago./98.

${ }^{167}$ Cf. "Oba. Hoje tem aulas de ciências!", Nova Escola, n 61, out./92, p. 10.

${ }^{168}$ Cf. Suplemento no 7, Nova Escola, n’ 117, nov./98, 52.
} 
subtítulos de uma reportagem de capa de junho/96. Esse exemplo, em 1996 ainda não se encontrava sob a sigla PCN. ${ }^{169}$

Esses exemplos são suficientes para evidenciar o efeito retroativo do ponto de basta que o significante-mestre PCN produz, na mesma medida em que o passado, mas também o futuro, fica sob o influxo dessa sigla. Quer dizer, aquelas experiências de alguns anos antes, quando os PCN sequer existiam, ficam agora sob a sua guarda, ou seja, tornam-se "exemplos de atividades em sala de aula" relativos às propostas presentes nos PCN. E o mesmo acontece com muitas atividades ainda inexistentes, que igualmente passarão a ser vistas como exemplos do que os PCN propõem, pouco importando quanto esse documento oficial é conhecido por quem desenvolve determinada atividade ou experiência.

As atividades ou experiências transformadas em exemplos dos PCN, em particular as das matérias que predominam no "ano didático", em 1998 parecem ter encontrado a "teoria" que o construtivismo tecnicista deixou de lado. Desta vez, demanda-se aos professores que conheçam essa proposta curricular, com seus fundamentos teóricos e os desdobramentos que a partir desses fundamentos derivam no tratamento de questões de ordem didática. Tudo isso, é claro, facilitado pela Nova Escola em seus didáticos fascículos. Agora, poder-se-ia pensar, pelo menos temos um referencial teórico, nesse caso situado no âmbito da educação escolar e que não fica nas "alturas", como a epistemologia genética, pois nele há um "caminho" descendente que conduz do patamar teórico até um registro que fica bem próximo das práticas do professor na sala de aula. Entre a teoria e a prática, entre um saber teórico e um saber prático. É nesse ponto intermediário que os PCN procuram situar-se no período em que a tendência era reduzir o construtivismo a um saber meramente técnico. Um lugar outrora preenchido por professoras como a Bernadete, que soldou esses extremos com a ajuda da sua "fada madrinha"170, e que posteriormente desapareceu como lugar problemático graças ao "núcleo didático" e ao trabalho dos especialistas que, na Nova Escola, tudo pareciam preencher com as suas precisas, claras e objetivas orientações. Com o novo ponto de basta que os PCN produzem, os especialistas continuam fazendo a mediação necessária entre a teoria (ou teorias) que está nas

\footnotetext{
${ }^{169}$ Cf. "Olimpíadas. Sua aula pode ganhar com elas", Nova Escola, n 94, junho/96, p. 11.

${ }^{170}$ Cf. "As agruras do caminho construtivista", Nova Escola, n 65, abr./93, pp. 8-14.
} 
"alturas" e a sala de aula. Desta vez criando um "elo" bem sólido, com os PCN sendo situados exatamente nesse ponto, no "hiato entre os dois extremos", à semelhança do que vinha sendo proposto por César Coll - o mentor da concepção de currículo que serviu de modelo à reforma do sistema educacional espanhol e também aos especialistas do MEC. Eis a concepção de currículo de Coll (2000): $:^{171}$

O currículo é um elo entre a declaração de princípios gerais e sua tradução operacional, entre a teoria educacional e a prática pedagógica, entre o planejamento e a ação, entre o que é prescrito e o que realmente sucede nas salas de aula. (p. 34)

O currículo deve levar em conta as condições reais nas quais o projeto vai ser realizado, situando-se justamente entre as intenções, princípios e orientações gerais e a prática pedagógica. É função do currículo evitar o hiato entre os dois extremos; disso depende, em grande parte, sua utilidade e eficácia como instrumento para orientar a ação dos professores. (p. 44)

Situados nesse lugar intermediário, os PCN procuram superar as deficiências de outras propostas curriculares oficiais. A maioria dessas propostas "apresenta um descompasso entre os objetivos anunciados e o que é proposto para alcançá-los, entre os pressupostos teóricos e a definição de conteúdos e aspectos metodológicos". ${ }^{172}$ Essa deficiência, esse nexo mal costurado, essa "contradição", é precisamente o que os PCN buscam "superar", como se afirma logo em seguida: "A estrutura dos Parâmetros Curriculares Nacionais buscou contribuir para a superação dessa contradição" (ibidem). As "questões de tratamento didático" visam justamente estreitar o campo de emergência de "coisas" que possam introduzir algum grau de ambigüidade ou contradição. O que importa é "garantir coerência entre os pressupostos teóricos, os objetivos e os conteúdos, mediante sua operacionalização em orientações didáticas e critérios de avaliação" (ibidem). Numa proposta curricular, esse aspecto não pode ser descuidado, sempre é preciso "velar pela coerência do conjunto", como propõe Coll (2000:43). É isso o que sobretudo interessa tornar efetivo com e nos PCN: coerência e unidade.

\footnotetext{
171 O modelo elaborado por Coll data de meados da década de 80 , quando foi utilizado pelo Departamento de Ensino da Prefeitura da Catalunha (Coll, 2000, p. 26).

172 Cf. "Introdução aos Parâmetros Curriculares Nacionais", p. 57.
} 
Para construir essa "coerência do conjunto", os especialistas convocados pelo MEC jogaram um papel central, a começar pelos dois "consultores" internacionais mencionados na "Ficha Técnica" da proposta curricular que primeiro foi concluída (os PCN de $1^{\text {a }}$ a $4^{\text {a }}$ série). Um deles é César Coll, desde a década de 80 empenhado em formular uma "boa teoria" da e para a prática pedagógica. A outra consultora internacional é Delia Lerner de Zunino, que em seus trabalhos e reflexões evidencia ter como preocupação central o tratamento de questões de ordem didática. ${ }^{173}$ Se considerarmos o perfil desses dois consultores internacionais, poder-se-ia dizer que a sua escolha foi orientada pelos significantes-mestres que definem os extremos que os PCN procuram soldar. Afinal, de um lado temos o consultor empenhado em formular uma "teoria educacional" - "uma explicação coerente, suficientemente articulada, precisa e com sólidos apoios empíricos, das mudanças educativas" (Coll:1996:390) — e, do outro, a especialista em didática - uma especialista próxima do registro que é próprio da prática pedagógica, sobretudo do ensino, pelo menos de acordo com o que os PCN estabelecem quando tratam das chamadas "orientações didáticas, que são subsídios à reflexão sobre como ensinar" (p. 93).

Em relação ao processo de elaboração dos $\mathrm{PCN}$ de $1^{\text {a }}$ a $4^{\mathrm{a}}$ série, também é preciso destacar as especialistas que exerceram a sua "Coordenação", conforme é indicado logo no início daquela mesma "Ficha Técnica". Três das quatro "coordenadoras" haviam sido professoras e orientadoras educacionais e/ou pedagógicas na Escola da Vila. ${ }^{174}$ Ou seja, a "coordenação" dos PCN coube, de

\footnotetext{
${ }^{173}$ As reflexões de Delia Lerner desenvolvem-se sobretudo no campo da didática da língua materna e didática da matemática, mas também em torno de questões e conceitos que extrapolam essas duas áreas (transposição didática, contrato didático, etc.). Em suas reflexões, apóia-se no acompanhamento, assessoria e investigação que realiza em determinadas experiências escolares e, como lembra Emilia Ferreiro no Prefácio a livro de Lerner (2002, p. 8), ela "incorpora fortemente o pensamento francês de uma corrente conhecida como Didática da Matemática". Lerner concebe a didática como uma ciência que estuda a comunicação do saber, envolvendo as modificações que essa comunicação produz nos usuários desse saber e no próprio saber. Entende também que o saber didático não se deduz diretamente de outros saberes, que antes de mais nada há didáticas (da matemática, da língua materna, das ciências naturais, etc.) e que o saber que é próprio dessa ciência deve advir da investigação e reflexão sobre a prática docente. Essas apreciações têm por base o que ela apresenta em alguns textos, palestras dadas no Brasil (por exemplo, em março/96, no V Seminário Internacional organizado pelo Centro de Estudos da Escola da Vila, intitulado "O Conhecimento didático e a tarefa do professor",) e um breve contato estabelecido com Lerner em Buenos Aires em meados da década de 90, quando pude conhecer uma escola particular que ela assessora e o trabalho que nesse momento estava desenvolvendo junto a professores dessa instituição. Nos PCN, nota-se a presença das suas reflexões em várias partes.

${ }^{174}$ São elas Maria Cristina Ribeiro Pereira, Maria Tereza Perez Soares e Neide Nogueira.
} 
certo modo, à escola-paradigma, à escola privada que sabia interpretar e aplicar a teoria construtivista corretamente, sem distorções, pelo menos de acordo com a imagem criada por essa instituição de ensino e pela versão há anos divulgada pela revista Nova Escola, antes mesmo de surgirem os PCN. Em razão disso, poder-se-ia dizer que a escola-paradigma situa-se também naquele mesmo ponto intermediário entre a teoria e a prática, de modo a fazer a mediação necessária para preencher o espaço que surge entre esses dois significantes-mestres (teoria e prática), não raro de forma ameaçadora. Nesse caso, coube aos PCN e à escola paradigma sustar essa ameaça, uma ameaça que é própria do lugar onde emergem os "restos" não assimilados e não assimiláveis do discurso, as "coisas" que escapam do registro da coerência. Exatamente nesse lugar, mas do avesso, como lugar do ideal, devem situados os PCN e a escola-paradigma. Os dois (re)criam e ocupam um lugar que é marcado pela duplicidade e alternância que é própria da ordem do desejo: entre o que opera cindindo o sujeito e o que promete suturar essa fenda, sem que isso afinal aconteça, a não ser que a incessante busca de coerência e unidade resulte em um "caminho" onde tudo flui com rapidez, nada sendo capaz de oferecer resistência.

O lugar preenchido pelos PCN, entre a teoria e a prática, na segunda metade da década de 90 tornara-se mais central do que nunca, pois essa proposta curricular (mas também todos os documentos curriculares produzidos posteriormente) é transformada no eixo das políticas educacionais do governo Fernando Henrique Cardoso. Dela são supostamente derivadas todas as "medidas" consideradas necessárias para melhorar e alcançar a tão almejada qualidade de ensino. À semelhança, aliás, do que César Coll propõe depois de definir o currículo como um "elo". Se ele cumpre com uma função tão vital — qual seja, preencher o vazio que emerge entre a teoria e a prática — , nada mais "lógico" que o "currículo ocupe um lugar central":

É lógico, portanto, que a elaboração do currículo ocupe um lugar central nos planos de reforma educacional e que freqüentemente ele seja considerado como ponto de referência para guiar outras atuações (por exemplo, formação inicial e permanente do corpo docente, organização dos centros de ensino, confecção de materiais didáticos, etc.) e assegurar, em última instância, a coerência das mesmas. (Coll, 2000:34) 
Os PCN constituem um "referencial de qualidade" para o Ensino Fundamental cuja "função é orientar e garantir a coerência dos investimentos no sistema educacional". ${ }^{175}$ Esses investimentos envolvem diferentes frentes e estão relacionados com as "ações políticas" do MEC. Estas, assim como esses investimentos, nos discursos oficiais dependem desse "referencial de qualidade". Tudo portanto converge nesse ponto de arremate, como é expresso quando são definidos os "níveis de concretização curricular":

Os Parâmetros Curriculares Nacionais constituem o primeiro nível de concretização curricular. São uma referência nacional para o ensino fundamental; estabelecem uma meta educacional para a qual devem convergir as ações políticas do Ministério da Educação e do Desporto, tais como os projetos ligados à sua competência na formação inicial e continuada de professores, à análise e compra de livros e outros materiais didáticos e à avaliação nacional.

O documento destaca mais três níveis de concretização curricular. O segundo nível envolve as propostas curriculares dos Estados e Municípios, o terceiro a instituição escolar e seu projeto educativo, enquanto o quarto e último concerne ao professor com a sua programação, devidamente adaptada a seu grupo de alunos (pp. 37-8). Esses diferentes níveis de concretização curricular supõem a realização de adaptações ou adequações em cada nível, não necessariamente de cima para baixo, embora essa seja a direção primeira. A abertura e flexibilidade dos PCN dizem respeito, precisamente, a essas "adaptações":

Apesar de apresentar uma estrutura curricular concreta, os Parâmetros Curriculares Nacionais são abertos e flexíveis, uma vez que, por sua natureza, exigem adaptações para a construção do currículo de uma Secretaria ou mesmo de uma escola. Também pela sua natureza, eles não se impõem como uma diretriz obrigatória: o que se pretende é que ocorram adaptações, por meio do diálogo, entre estes documentos e práticas já existentes, desde as definições de objetivos até as orientações didáticas para a manutenção de um todo coerente.

Esse "todo coerente" é o sonho que nesse momento quer se ver realizado. Um sonho moderno nutrido por muitos intelectuais, a começar pelos construtivistas, como o professor Lino de Macedo, que escreveu a Apresentação brasileira do livro Psicologia e Currículo, onde Coll expõe o seu modelo curricular.

\footnotetext{
${ }^{175}$ Cf. "Introdução aos Parâmetros Curriculares Nacionais", p. 13.
} 
Nela, essa "visão de sistema" é celebrada e, claro, relacionada com Piaget — o "todo coerente" epistemólogo suíço cuja obra é consensualmente considerada a matriz do construtivismo. Eis algumas das linhas dessa Apresentação:

A interdependência, ao menos no construtivismo de Piaget, é um critério fundamental. César Coll, em seu plano, jamais se esqueceu dele. Interdependência é uma noção dialética, relacional. É um critério para uma interação sujeito-objeto, ou sujeito-sujeito, na qual uma qualidade majorante estará sempre presente. Implica ser parte e todo ao mesmo tempo. Parte porque, em uma visão de sistema, nada pode ser considerado independentemente. (...) Todos são parte de uma rede que, por diferenciá-los, os integra em um sistema único, global, holístico. (...) Ser parte de é ser dependente de. Dependente em seu sentido maior, isto é, majorante, libertário. (...) A dependência, no sentido construtivista, é que torna possível a vida comunitária (...) A interdependência supõe, igualmente, ser todo, e não apenas parte (...) Ser todo, em um contexto de interdependência, é ser único (como pessoa ou grupo), é poder ser responsável por si mesmo, ser autor de suas decisões, de sua história ou destino. Por isso, a interdependência tem uma qualidade majorante, de uma relação para melhor, que promove o crescimento. Enquanto parte, nos liberta; enquanto todo, nos reduz a nós mesmos, de preferência ao melhor de nós mesmos. Não é assim em um plano curricular? Cada parte (avaliação, ensino, aluno, professor) deve ser considerada em função das outras, mas, simultaneamente, cada qual compõe um todo, com suas características e especificidades. (pp. 17-18)

A interdependência sistêmica que Lino de Macedo elogia é semelhante à que transforma as políticas do MEC numa malha cerrada cuja intenção última é fechar o cerco a tudo que possa gerar desperdício, a tudo que possa escapar do registro da qualidade total. É claro que tudo isso sob o marco estabelecido pelo Estado mínimo, que implica na utilização de um mínimo de recursos com um máximo de eficiência, pelo menos certa eficiência, principalmente a que pode ser traduzida em números. Essa malha cerrada, com a sua liberdade "majorante", supõe a possibilidade de que todos possam realizar "adaptações" a partir do Todo já estabelecido, que é claro pode mudar, mas sempre sob o ideal da interdependência sistêmica, da coerência do Todo. A flexibilidade e abertura dos PCN encontram os seus limites e o seu sentido exatamente nesse ponto de ressonância: o "todo coerente", o sistema "único, global, holístico" — o ideal último de toda construção sob a égide desse discurso pedagógico.

Tendo em vista esse ponto de ressonância, pode ser melhor compreendida a fala oficial que nega o caráter impositivo dos PCN e que vez por outra lembra 
que não são obrigatórios. O que esse ponto de ressonância instaura é justamente o contrário. Daí que esse "desvio", esse "desvio" de entendimento que as falas oficiais sempre procuram corrigir, revele não mais do que a verdade que esse ponto de ressonância cria e torna hegemônica. Uma verdade instituída na mesma medida em que seu ponto de gozo, o do erro "esmagado", exige o controle absoluto sobre todos os pontos de fuga, sobre tudo o que aflui ao ponto de arremate e que ameaça fazer emergir as "coisas" que geram "ruídos" indesejáveis. Nesse registro podem ser pensadas as três "ações políticas" relacionadas com o "primeiro nível de concretização curricular" e que foram antes citadas: a formação de professores, a compra de livros e outros materiais didáticos e a avaliação nacional. Ou seja, com essas ações o poder central procura sustar as imperfeições do sistema, procura cercar os erros nessas três esferas, usando para tanto o "referencial de qualidade" em nível nacional, o referencial que também define e cria tudo o que da ordem do erro. Amparado nesse saber positivo e sempre tendo em vista a unidade e coerência do Todo, o poder central procura garantir que os professores não recebam uma formação errada, orienta a escolha de livros didáticos para que os professores não errem nesse importante momento e, com a avaliação nacional, verifica o funcionamento do sistema para realizar a auto-regulação necessária à correção dos erros ainda existentes. Sempre sob a guarda do "referencial de qualidade", do referencial construtivista que a todos unifica.

Certamente, a leitura acima realizada é uma leitura "forçada", pois tudo é lido tendo como guia alguns significantes-mestres e os que eles criam, como é o caso dos significantes qualidade total, excelência na educação e erro "esmagado". Todos eles significantes equivalentes e que se harmonizam muito bem com o ideal sistêmico e majorante que opera regido pelo "erro construtivo", isto é, um erro que em algum momento há de desaparecer, mais precisamente no momento em que as "adaptações" sejam bem sucedidas. É claro que, qualquer construtivista diria, sempre existe a abertura para outros possíveis, para o que não está dado, para novos e velhos ideais (liberdade, justiça, solidariedade, etc.). É verdade, mas sempre sob a ordem do sistema, guiados por essa paixão pelo sistema, pela busca incessante e crescente da coerência do Todo, seja qual for esse Todo em que cada parte ou cada ser "autônomo" encontre o seu devido lugar. Os PCN, assim como as reflexões de vários intelectuais empenhados em 
delinear os contornos de uma "boa teoria" construtivista, atenuam essa vocação sistêmica e unificadora de vários modos e em diferentes graus. Mas ela é o que nesse momento tende a sobressair e sobrepujar os discursos oficiais e os discursos pedagógicos em geral. Uma vocação sistêmica e unificadora que é própria do Estado moderno, mas também da ciência.

Enquanto saber positivo e sistêmico, a ciência certamente é um saber necessário à vida humana, mas não é o único. Ademais, a prolongada hegemonia do discurso científico redunda em efeitos nocivos, ainda mais no campo da educação. Efeitos que no limite concernem ao pior, ou seja, à ordem do gozo, à ordem da morte, como bem perceberam Adorno e Horkheimer, indicando esse "triunfal" desfecho em seu conhecido ensaio Dialética do esclarecimento. Nele, em particular no capítulo "O Conceito de esclarecimento", o que em grande parte está em causa é a vocação sistêmica da ciência e os efeitos decorrentes da sua prolongada hegemonia. Os autores remetem essa vocação a um longo percurso do pensamento que se inicia nos mitos e que é guiado por este objetivo: livrar os homens do medo e investi-los na posição de senhores (p. 19). Entretanto, a dialética desse percurso resulta no seu contrário: "a terra totalmente esclarecida resplandece sob o signo de uma calamidade triunfal" (ibidem). O "esclarecimento", aí entendido como sendo esse longuíssimo "progresso do pensamento" que busca subjugar as forças que desconhecemos e que nos dominam, tem como ideal o "sistema":

De antemão, o esclarecimento só reconhece como ser e acontecer o que se deixa captar pela unidade. Seu ideal é o sistema do qual se pode deduzir toda e cada coisa. Não é nisso que sua versão racionalista se distingue da versão empirista. Embora as diferentes escolas interpretassem de maneira diferente os axiomas, a estrutura da ciência unitária era sempre a mesma. (Adorno e Horkheimer, 1986:22)

Acima poderíamos acrescentar que nesse ideal tampouco reside a diferença entre a versão de ciência piagetiana-construtivista e as anteriores, pois todas elas abraçam com a mesma paixão o que é da ordem do sistema. Uma paixão que tem no número o seu cânon, como sugerem Adorno e Horkheimer ao referir-se ao "anseio de toda desmitologização: o número tornou-se o cânon do esclarecimento" (ibidem). Não é de estranhar, por isso, a paixão pelo número que acometeu os sistêmicos responsáveis pelas políticas educacionais do governo Fernando Henrique Cardoso, preocupados em avaliar e evidenciar o bom 
funcionamento da sua "máquina azeitada e eficiente" tendo como primeira referência o que é da ordem desse cânon. Os números são os que sobrepujam boa parte das avaliações feitas pelos novos reformadores para manter o sistema de ensino bem amarrado sob Um mesmo centro, sendo secundário e até mesmo de nenhum valor o que resta quando esses números são deixados de lado. Um centro que também concerne aos lugares onde são definidos a direção e o sentido das políticas do Estado mínimo em países em desenvolvimento asfixiados com as suas crescentes dívidas externas, como é o caso do Brasil.

Sobre os efeitos decorrentes da prolongada hegemonia do discurso científico, vale ressalvar que não é apenas essa configuração discursiva a única a produzir efeitos que podem ser considerados nocivos. Na verdade, toda e qualquer forma que o discurso assume parece se tornar nociva ao que é da ordem do laço social quando se torna hegemônica e nesse lugar se perpetua, pelo menos em determinados campos, como é o caso da educação. Para que isso não ocorra é preciso que o discurso gire, caso contrário determinadas posições fixadas através do laço social se eternizam, não mudam, estreitando assim as possibilidades inerentes à rede intersubjetiva que nos vincula. Digamos que o efeito é semelhante a um discurso que começa a chiar, que começa a produzir ruídos que afetam e estreitam o campo da comunicação, o campo da significação. Isso, precisamente, é o que Lacan parece sugerir quando ele diz que, se o discurso "não gira, range" (Lacan, 1969-1970:170).

No discurso pedagógico hegemônico, esse giro parece começar a ocorrer no momento em que o construtivismo alcança o auge da sua hegemonia, ou seja, quando também se insinua um certo refluxo. Para tanto foram fundamentais as críticas que vinham se avolumando há vários anos e que agora confluem para pôr em causa a proposta construtivista oficial. Essa proposta, no entanto, tende a se manter bem erguida, contribuindo para isso o fascínio que a "visão de sistema" nesse momento produz com a bem amarrada arquitetura conceitual dos PCN. Uma arquitetura cuja expansão em nível nacional alimenta os sonhos de muitos educadores empenhados na melhoria do ensino público. Essa rede de saber encontra-se bem assentada sobre a "plataforma" primeira que há décadas vinha sendo sedimentada pelos discursos pedagógicos e que é a que discursivamente garante a hegemonia do construtivismo oficial. $E$ nesse ponto também é preciso 
considerar o amplo terreno criado — e assentado sobre essa "plataforma" — com tudo o que os PCN incorporaram de experiências escolares, discussões e reformulações que vinham sendo realizadas desde a década de 80 , relacionadas com as diferentes áreas curriculares.

Nessa proposta curricular oficial não faltam então os pontos de estrutura do discurso construtivista, como pode ser observado na Introdução aos PCN, na parte onde são delineadas as principais "tendências pedagógicas". Segundo essa Introdução, na "tradição pedagógica brasileira" é possível identificar "a presença de quatro grandes tendências: a tradicional, a renovada, a tecnicista e aquelas marcadas centralmente por preocupações sociais e políticas" (p. 39). Ao tratar destas últimas, ou seja, da também chamada "educação crítica", envolvendo a "pedagogia libertadora" e a "pedagogia crítico-social dos conteúdos", os PCN referem-se ainda às "teorias crítico-reprodutivistas" (p. 41). Essa classificação das tendências pedagógicas segue basicamente os recortes feitos por Dermeval Saviani em seu livro Escola e Democracia, publicado no início da década de 80. Quanto ao construtivismo, ele é situado num lugar criado por meio de uma costura que opera com esses vários nomes, com esses vários significantes-mestres e com o que eles condensam, criando para si o já comentado "terceiro lugar", mesmo que não surja assim explicitado. Para analisar melhor essa costura, podemos partir da "orientação" que os PCN apresentam depois de serem delineadas aquelas tendências e uma vez feitas as devidas advertências sobre os equívocos já ocorridos em relação à interpretação do construtivismo:

A orientação proposta nos Parâmetros Curriculares Nacionais reconhece a importância da participação construtiva do aluno e, ao mesmo tempo, da intervenção do professor para a aprendizagem de conteúdos específicos que favoreçam 0 desenvolvimento das capacidades necessárias à formação do indivíduo. (p. 44)

Temos aí os dois lados ou pólos que sempre é preciso considerar, mas sem que nenhum deles seja por demais valorizado. Nesse momento, essa é uma condição básica para qualquer discurso pedagógico que busca assentar-se sobre o que se tornou consensual, ou melhor, para qualquer discurso que, de imediato, quer se tornar hegemônico. Em outras palavras, já no primeiro delineamento da "orientação" dos PCN é necessário evidenciar um certo equilíbrio, valorizando "ao mesmo tempo" a "participação construtiva do aluno" e a "intervenção do 
professor". Dessa forma os PCN afastam-se igualmente das tendências pedagógicas que sobrevalorizam um ou outro pólo da relação pedagógica e que concernem às duas grandes linhas paralelas e em oposição criadas pelos discursos pedagógicos e destacadas por Saviani no início da década de 80. Elas também comparecem nos PCN e aqui continuarão sendo tomadas como guias para orientar esta análise. Vejamos então como são definidas.

De um lado, temos a "pedagogia tradicional", que "é uma proposta centrada no professor" (p. 39). "A função primordial da escola, nesse modelo, é transmitir conhecimentos disciplinares para a formação geral do aluno" (ibidem). Ou seja, nessa "concepção" os "conteúdos do ensino" são fundamentais. Eles "correspondem aos conhecimentos e valores sociais acumulados pelas gerações passadas como verdades acabadas" (p. 40). Do outro lado temos a "pedagogia renovada", que inclui várias correntes "ligadas ao movimento da Escola Nova ou Escola Ativa" (p. 40). E nesse ponto é lembrada a oposição entre a Escola Tradicional e a Escola Nova. Nessas "várias correntes", "o centro da atividade escolar não é o professor nem os conteúdos disciplinares, mas sim o aluno, como ser ativo e curioso. O mais importante não é o ensino, mas o processo de aprendizagem" (ibidem). Quanto ao professor, ele é um "facilitador no processo de busca de conhecimento que deve partir do aluno".

Nos PCN, à diferença do que Saviani sugere (1984:15), o "tecnicismo educacional" que proliferou na década de 70 tende a ficar do lado da "pedagogia tradicional", pois:

(...) inspirado nas teorias behaviorista da aprendizagem e da abordagem sistêmica do ensino (...) definiu uma prática pedagógica altamente controlada e dirigida pelo professor, com atividades mecânicas inseridas numa proposta educacional rígida e passível de ser totalmente programada em detalhes. (p. 41)

Ao realçar o professor, pelo menos nesse trecho inicial, o "tecnicismo educacional" tende a ficar próximo do lugar definido pelo significante de arremate escola tradicional. Uma proximidade criada também com outros elementos ("atividades mecânicas", proposta "rígida") e reforçada pelo lugar que nessa perspectiva é destinado ao aluno: "um indivíduo que reage aos estímulos de forma a corresponder às respostas esperadas pela escola" (p. 41). Quanto à diferença e 
distanciamento em face da Escola Tradicional, isso também fica por conta do professor, que na seqüência do mesmo parágrafo perde todo o seu poder:

O que é valorizado nessa perspectiva não é o professor, mas a tecnologia; o professor passa a ser um mero especialista na aplicação de manuais e sua criatividade fica restrita aos limites possíveis e estreitos da técnica utilizada. (p. 41)

Em relação à "educação crítica" e sobre a "pedagogia libertadora", afirmase que "a atividade escolar pauta-se em discussões de temas sociais e políticos e em ações sobre a realidade social imediata", tendo em vista a transformação da realidade social e política (p. 42). Nessa proposta, o "professor é um coordenador de atividades que organiza e atua conjuntamente com os alunos" (ibidem). Ademais, fala-se das suas "origens nos movimentos de educação popular" do "final dos anos 50 e início dos anos 60, quando foram interrompidos pelo golpe militar de 1964"; ocorrendo uma retomada dessa perspectiva no final dos anos 70 e início dos 80. Quanto à "pedagogia crítico-social dos conteúdos", indica-se que surge no final dos anos 70 e início dos 80 e que ela "se põe como uma reação de alguns educadores que não aceitam a pouca relevância que a 'pedagogia libertadora' dá ao aprendizado do chamado 'saber elaborado'" (ibidem). Essa proposta "assegura a função social e política da escola mediante o trabalho com os conhecimentos sistematizados". Nela entende-se que "não basta ter como conteúdo escolar as questões sociais atuais" (ibidem).

A costura que os PCN aí realizam incorpora os elementos básicos destacados nas duas propostas críticas, mas tendo em vista a "reação" da pedagogia dos conteúdos em face dos discursos da educação popular. O professor não é definido como um "coordenador", como na educação popular. Nesta, o professor tende a ficar próximo do lugar estabelecido na "pedagogia renovada", pelo menos se considerada a sua proximidade com o aluno (o professor "organiza e atua conjuntamente com os alunos"). Nos PCN, o professor deve ser, primeiramente, um professor que "intervém" para que o aluno aprenda "conteúdos específicos", como era ressaltado no âmbito da pedagogia dos conteúdos, assim sendo valorizando o ensino tradicional. Por meio desse jogo implícito de aproximações e distanciamentos, os PCN distanciam-se da "pedagogia libertadora" exatamente no ponto onde ela fica por demais próxima do pólo onde é situada a "pedagogia renovada". Ao mesmo tempo, aproximam-se do 
lado oposto, sem com ele se confundir, aí servindo como anteparo a "participação construtiva do aluno", ou seja, "a criança que constrói seu próprio conhecimento".

O mesmo não ocorre com os "temas sociais", valorizados nas duas propostas críticas. Eles são incorporados e destacados por meio do "tratamento transversal" (são os chamados temas transversais). Ademais, enfatiza-se o papel do que a pedagogia dos conteúdos destacava no próprio nome. Agora, porém, os "conteúdos" são ampliados. Não se trata apenas dos clássicos "conteúdos conceituais", pois também é preciso considerar os chamados conteúdos procedimentais e atitudinais. Enfim, nessa costura "consensual" são usados dois significantes-mestres: temas sociais e conteúdos. Esses significantes, junto com as articulações discursivas que Ihes dão sentido, consigo arrastam os significantes de arremate dos discursos críticos.

Relacionado ainda com a "educação crítica", é necessário destacar que o objetivo dos PCN é a "formação de cidadãos autônomos, críticos e participativos", "cidadãos capazes de interferir criticamente na realidade para transformá-la" ( $p$. 47). Isso define a "qualidade de ensino" no registro da "educação crítica". Mas os PCN também se encontram sob o registro do "novo cidadão", do cidadão moderno que precisa se adaptar às "novas demandas":

Um ensino de qualidade, que busca formar cidadãos capazes de interferir criticamente na realidade para transformá-la, deve também contemplar 0 desenvolvimento de capacidades que possibilitem adaptações às complexas condições e alternativas de trabalho que temos hoje e a lidar com rapidez na produção e na circulação de novos conhecimentos e informações, que têm sido avassaladores e crescentes. A formação escolar deve possibilitar aos alunos condições para desenvolver competências e consciência profissional, mas não restringirse ao ensino de habilidades imediatamente demandadas pelo mercado de trabalho. (p. 47)

Na Introdução aos PCN também se faz referência às "tendências didáticas de vanguarda" presentes no final da década de 70: "aquelas que tinham um viés mais psicológico e outras cujo viés eram mais sociológico e político" (p. 42). A partir dos anos 80, ainda segundo os PCN, "surge com maior evidência um movimento que pretende a integração entre essas abordagens". Além do "enfoque centrado no caráter social do processo de ensino e aprendizagem", sobre esse momento de "integração" destaca-se que ele foi "marcado pela influência da 
psicologia genética". Desta última, ademais, afirma-se que "propiciou aprofundar a compreensão sobre o processo de desenvolvimento na construção de conhecimentos", em seguida sendo lembrada a "pesquisa sobre a psicogênese da língua escrita" e o seu "grande impacto" em meados dos anos 80, "revolucionando o ensino da língua nas séries iniciais" (ibidem). Dessa forma, a psicologia genética, que é a que coloca no centro "a criança que constrói seu próprio conhecimento", torna-se a "marca" sob a qual se processa essa "integração" num "único esquema explicativo", que é o da "abordagem construtivista". Isso mesmo é afirmado em outros trechos do documento, assim explicitando o que está no centro dessa costura:

O núcleo central da integração de todas essas contribuições referese ao reconhecimento da importância da atividade mental construtiva nos processos de aquisição de conhecimentos. (p. 50) ${ }^{176}$

A abordagem construtivista integra, num único esquema explicativo, questões relativas ao desenvolvimento individual e à pertinência cultural, à construção de conhecimentos e à interação social. (p. 52)

Enfim, basicamente os PCN reproduzem as costuras que há vários anos vinham sendo feitas com o significante-mestre construtivismo, mas sem evidenciar as inversões e recalques relativos a essa emergência. Para tanto, os PCN implicitamente operam com as duas linhas mestras e opostas mobilizadas pelos discursos pedagógicos, de modo a aproximar as tendências pedagógicas de acordo com o que já era consensual. O que permanece implícito, mas que efetivamente parece orientar a caracterização das tendências que os PCN apresentam e a reposição do "terceiro lugar" onde tudo é "integrado", são estas duas séries significantes situadas em lados opostos: Escola Tradicional/tecnicismo educacional/pedagogia dos conteúdos; Escola Nova/pedagogia renovada/educação popular.

O que nessas séries significantes não comparece e que já tinha desaparecido do discurso pedagógico é o aqui chamado discurso alternativorenovado. Digamos que ele escoou pela abertura que é própria da separação operada quando são delineadas as "tendências didáticas de vanguarda": umas de viés mais psicológico e outras de viés mais sociológico e político. A "liga" que aí

\footnotetext{
176 Dentre outras, as "contribuições" ou "influências" relacionadas à "configuração do marco explicativo construtivista" e que são destacadas no parágrafo anterior ao acima reproduzido são estas: a psicologia genética, a teoria sociointeracionista e as explicações da atividade significativa.
} 
produziam os discursos alternativos-renovados inexiste nessa reconstrução histórica, uma reconstrução de certo modo feita sob a "coordenação" da escolaparadigma, que deve ser situada exatamente nesse ponto, nesse ponto limítrofe. Nele, precisamente, um pequeno trecho da história da educação escolar se perde, desaparece. O único que dela subsiste surge sob a forma dos "equívocos" que envolvem a interpretação do construtivismo e que caem no lugar delimitado pelo significante-mestre espontaneísmo, mesmo que nessa Introdução não seja utilizado. Esse, precisamente, é o lugar que na trajetória da escola-paradigma corresponde à sua "origem", quando se acreditava que as crianças aprendiam fazendo "do seu jeito", conforme a versão divulgada pela Escola da Vila. ${ }^{177}$ Eis então o que a Introdução aos PCN assinala:

(...) um duplo equívoco: redução do construtivismo a uma teoria psicogenética de aquisição de língua escrita e transformação de uma investigação acadêmica em método de ensino. Com esses equívocos, difundiram-se, sob o rótulo de pedagogia construtivista, as idéias de que não se devem corrigir os erros e de que as crianças aprendem fazendo "do seu jeito". Essa pedagogia, dita construtivista, trouxe sérios problemas ao processo de ensino e aprendizagem, pois desconsidera a função primordial da escola que é ensinar, intervindo para que os alunos aprendem o que, sozinhos, não têm condições de aprender. (pp. 43-4)

Essa avaliação é própria da vertente construtivista que se tornou dominante, em grande parte sob a "coordenação" da escola-paradigma. É uma vertente que explicitamente se distancia da "origem" do construtivismo e que destaca o papel do ensino, dos conteúdos e a intervenção do professor, ou seja, elementos que eram fundamentais na crítica da pedagogia dos conteúdos ao campo da educação alternativa.

$\mathrm{Na}$ Introdução aos PCN, o lugar do espontaneísmo também é esboçado quando o documento trata da pedagogia renovada:

A idéia de um ensino guiado pelo interesse dos alunos acabou, em muitos casos, por desconsiderar a necessidade de um trabalho planejado, perdendo-se de vista o que deve ser ensinado e aprendido. Essa tendência, que teve grande penetração no Brasil na década de 30 , no âmbito do ensino pré-escolar (jardim de infância), até hoje influencia muitas práticas pedagógicas). (p. 41)

\footnotetext{
${ }^{177}$ Cf. "Como trabalhar o erro", Nova Escola, n 60, set./92, p. 16.
} 
Nos PCN o construtivismo é situado, implicitamente, em linha de continuidade com a Escola Nova e também concerne ao lugar definido pelo significante-mestre espontaneísmo, um lugar do qual o construtivismo oficial procura se afastar. Afinal, ele é um construtivismo maduro, que já percorreu um certo "caminho". Enfim, desse modo, com todos os significantes de arremate aqui referidos e mobilizados nesse documento, temos reproduzida a "plataforma" primeira que vários anos antes havia sido criada pelos discursos pedagógicos, no Brasil mas também em outros países. Daí a especial sintonia entre os PCN, a escola-paradigma e o consultor internacional César Coll.

Para finalizar esta análise sobre as séries significantes que sustentam os PCN, mas também o conjunto "coerente" de ações políticas que neles convergem, ainda é preciso destacar a chamada "unidade orientadora" dessa proposta curricular: "os objetivos, que definem capacidades, e os conteúdos, que estarão a serviço do desenvolvimento dessas capacidades". ${ }^{178}$ Nessa proposta curricular, os conteúdos constituem um meio necessário para promover o desenvolvimento de capacidades do aluno. Capacidades várias (de relação interpessoal, cognitivas, afetivas, motoras, éticas, estéticas, etc.) e cujo desenvolvimento "torna-se possível mediante o processo de construção e reconstrução de conhecimentos" (p. 46). Quer dizer, o desenvolvimento de toda e qualquer capacidade, à qual os conteúdos se subordinam, tende a ser pensado sob o modelo da construção sistêmica, da "criança que constrói seu próprio conhecimento", a criança guiada pela busca incessante de coerência e unidade, como o epistemólogo suíço Jean Piaget - o Mestre cuja figura é transformada na manchete de capa da revista Nova Escola exatamente no ano em que é concluído o primeiro pilar do saber positivo e sistêmico com o qual pretende-se orientar todas as escolas do país. Um Mestre que na Nova Escola define o lugar onde o "futuro" começa e onde a "boa professora" inicia o seu "caminho", de mãos dadas com a sua criança/aluno e com o rumo igualmente definido por todos os nomes e figuras que sucedem ao epistemólogo suíço e que foram incorporados ao discurso pedagógico construtivista. Isso, ao menos, é o que pode ser pensado tendo em vista o que até aqui foi analisado, aliado agora à sugestiva capa da Nova Escola que abre o "século XXI", da edição de janeiro/fevereiro de 2001:

${ }^{178}$ Cf. "Introdução aos Parâmetros Curriculares Nacionais", p. 57. 


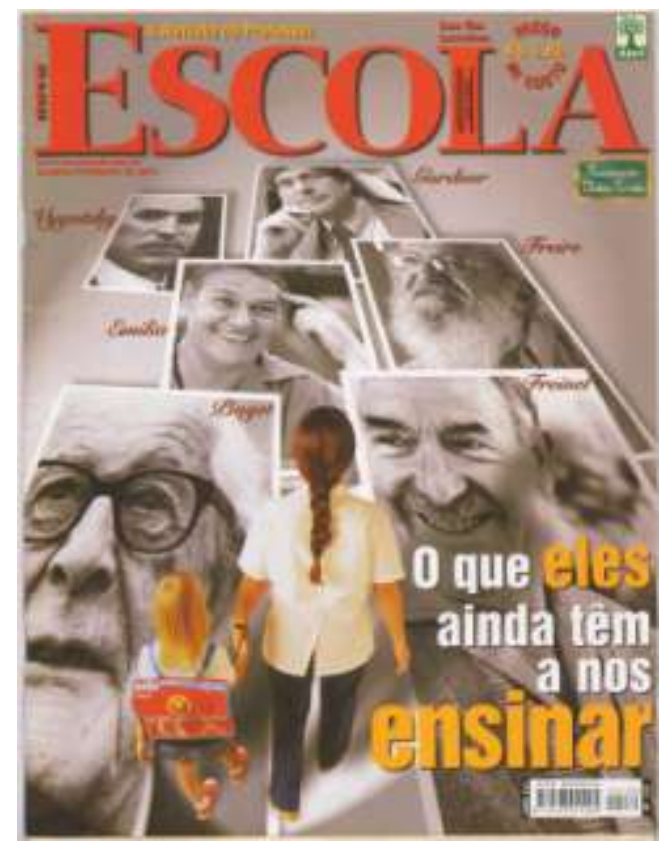




\section{Piaget: um todo coerente}

Até hoje é praticamente consensual que a obra de Piaget é a matriz do que na educação escolar é lícito identificar por meio do significante construtivismo. Este trabalho, no entanto, até o momento procurou mostrar quanto o discurso pedagógico construtivista procede de outros discursos que não aqueles geralmente considerados as suas primeiras fontes. Sem deixar de lado essa perspectiva, este capítulo pretende focalizar exatamente essa matriz, pelo menos num primeiro momento, para depois destacar certos efeitos relacionados com a sua presença no discurso pedagógico brasileiro. Dessa matriz, o que de início extrairemos é a criança - o principal guia do epistemólogo suíço durante boa parte da sua obra. Aqui ela também será o nosso guia, o nosso significantemestre. Ademais, será realçada a "visão de sistema" que norteia toda "construção" piagetiana e que é própria do tipo de saber que a ciência moderna constitui, enquanto ciência positiva e sistêmica. Em outras palavras, neste capítulo "caminharemos" de mãos dadas com a criança sobre o registro unificador que todo pensamento sistêmico cria. Portanto, "caminharemos" tendo em vista o ideal que o significante-mestre sistema define — um ideal da ciência moderna e ao qual Piaget amarrou a (sua) criança. Esse significante-mestre, junto com seus equivalentes, define também o último e áureo destino do discurso pedagógico construtivista na segunda metade dos anos 90, com os Parâmetros Curriculares Nacionais (PCN). Estes, vale lembrar, constituem o primeiro e fundamental pilar do saber sistêmico com o qual pretendia-se ordenar todas as escolas do país, definindo ainda o ponto onde deveriam confluir as políticas educacionais do MEC nesse período.

Ainda em relação à criança, não ficaremos apenas com a criança piagetiana. No segundo e último item deste capítulo, percorreremos a revista Nova Escola pondo em destaque as crianças/alunos cujas fotos aparecem em suas capas, em algumas edições e anos, desde o início dessa publicação até o momento em que nessas crianças/alunos surgem as primeiras marcas dos PCN. O que está em causa nessa segunda parte é o efeito unificador do saber que o discurso pedagógico construtivista (re)cria em consonância com o ideal sistêmico da "todo coerente" obra piagetiana. 


\section{A criança constrói seu próprio conhecimento}

O modo como Piaget concebe a criança está diretamente relacionado com as questões que ainda jovem o preocupavam, relacionadas com o conhecimento e a ciência. Por isso e para melhor situar essa criança, bem como a incessante busca de coerência sistêmica que a caracteriza e que igualmente define a teorização piagetiana em outros campos (como se observa em seus escritos sociológicos), vale a pena recuperar seus primeiros passos como pesquisador e as suas principais questões e preocupações. Vejamos então esse primeiro ponto.

\subsection{Piaget epistemólogo}

Afeiçoado pela filosofia, naturalista e biólogo por formação, ainda jovem Piaget estabeleceu para si mesmo uma meta: fornecer um fundamento científico a temas próprios da teoria do conhecimento, como a relação entre sujeito e objeto, as fontes do conhecimento e os mecanismos que explicam a sua constituição. Esses temas clássicos na filosofia tornaram-se então o grande eixo das suas pesquisas e reflexões, sob uma perspectiva que muito deve à sua formação. ${ }^{1} \mathrm{Em}$ outras palavras, todos os seus esforços e investigações acabaram tendo como horizonte último a epistemologia, inclusive os estudos que desenvolveu na área à qual dedicou boa parte da sua obra e da sua vida: a Psicologia da criança, na qual focalizou as questões relacionadas com o desenvolvimento cognitivo e 0 conhecimento.

A epistemologia é concebida por Piaget como um campo de investigação cuja questão central é a gênese do conhecimento, em particular o conhecimento científico, tendo como pressuposição básica a sua evolução. Por isso, trata-se essencialmente de investigar como se passa de um estado ou nível de conhecimento inferior para um outro de grau superior. Sob esse horizonte, a Psicologia genética constitui apenas um dos campos de investigação da epistemologia. Esta também investiga o conhecimento científico numa perspectiva

\footnotetext{
1 Com apenas onze anos Piaget começou a pesquisar e catalogar moluscos no Museu de Neuchâtel, na Suiça, sendo portanto precoce o seu interesse pela biologia e a sua iniciação como pesquisador (Piaget, 1973b, p. 12). Ainda jovem, manteve também forte interesse pela filosofia, à qual inicialmente havia decidido consagrar-se, mas da qual afasta-se em direção à ciência, conforme um processo de "desconversão" que o próprio Piaget relata e justifica (pp. 11-49).
} 
histórica e social. O que Piaget chama de epistemologia genética estuda então a evolução dos conhecimentos deste modo:

(...) sob o duplo aspecto de sua formação psicológica e de sua evolução histórica, depende tanto da sociologia quanto da psicologia, a sociogênese dos diversos modos do conhecimento não se revelando nem mais, nem menos importante que sua psicogênese, pois são estes dois aspectos indissolúveis de toda formação real. Sob esse ponto de vista, duas questões devem ser especialmente discutidas, posto que de sua solução depende em definitivo toda a epistemologia genética: a das relações entre a sociogênese e a psicogênese na formação das noções na criança no processo de socialização e a das mesmas noções na elaboração das noções científicas e filosóficas que se sucederam na história. (Piaget, 1973a, p. 25)

Sob essa dupla perspectiva da psicogênese e da sociogênese, ampliada também pela referência que Piaget faz à ontogênese e à filogênese — assim prolongando a sua perspectiva no campo onde começou a sua atividade de pesquisador (a biologia) —, o conhecimento é concebido como uma construção contínua onde não há "começos absolutos": "tudo é gênese" ou "a gênese recua indefinidamente" (Piaget, 1990, pp. 3-5).

Ao tratar da epistemologia genética e delinear a sua concepção construtivista e dialética, que diferencia de outras que também considera construtivistas, o pesquisador suíço sublinha justamente a dimensão estrutural e construtiva de todo conhecimento. Em todos os domínios do saber, afirma Piaget, é possível verificar periodicamente a presença de dois patamares, um mais complexo do que o outro e, nesse sentido, superior a ele. São estruturas ou construções de níveis diferentes, sendo que a superior deriva da inferior através de transformações, havendo entre elas uma assimilação recíproca, pois a primeira enriquece a última integrando-se a ela (pp. 110-1).

Ao desenvolver a sua concepção epistemológica, mas também quando discute as teorias biológicas e psicológicas, Piaget refere-se a várias linhas teóricas que agrupa em pólos opostos ou, pelo menos, indica a sua maior ou menor proximidade em relação a eles (1988, pp. 7-11; 1990; 1996, pp. 24-9). Segue, na verdade, a divisão clássica na filosofia entre o empirismo e o apriorismo ou inatismo. De modo que as concepções construtivistas em relação ao conhecimento são discutidas a partir dessa oposição primeira, que assim baliza a própria concepção piagetiana. Ao formular a sua concepção, Piaget 
recusa igualmente os dois pólos. De um lado, as tendências que reduzem a fonte do conhecimento e o que o determina ao que seria de ordem endógena. Elas sustentam a idéia de que o conhecimento é inato ou um a priori estabelecido biologicamente, portanto presente no indivíduo desde o seu nascimento, mesmo que entendido como virtualidade que se atualiza no decurso do desenvolvimento. De outro, temos a concepção segundo a qual o meio ou o que é concebido como externo ao indivíduo é o fator determinante e a única fonte de todo conhecimento. Nesse caso, o conhecimento é uma espécie de cópia do real sobre uma folha inicialmente em branco, esta representando o intelecto nos seus primórdios. ${ }^{2} \mathrm{Em}$ face dessas teses extremas, aí obviamente simplificadas, Piaget postula que a ação do sujeito está na origem de todo conhecimento e que o conhecimento é fundamentalmente uma construção que resulta da interação entre o sujeito e o meio físico e social.

A Piaget interessava sobretudo a investigação da gênese de conhecimentos de caráter novo e mais evoluídos e não propriamente a aquisição de conhecimentos pré-existentes na sociedade, como é o caso das aprendizagens escolares. Por essa via é possível pensar a pouca relevância que os temas educacionais e os relacionados com o ensino têm no conjunto da sua obra. Isso não significa que o epistemólogo suíço desdenha-se essa temática, muito pelo contrário, embora tenha sido escassa a sua produção a esse respeito. Em seus poucos escritos sobre educação, Piaget não deixou de posicionar-se em favor dos métodos ativos, da escola ativa e contra o ensino tradicional, alinhando-se assim do mesmo lado do chamado Movimento da Escola Nova. Além desses escritos, participou em instituições cuja principal finalidade relacionava-se com a educação, desenvolvendo atividades que contribuíram para associar o seu nome aos temas educacionais:

Dentre as participações institucionais, talvez as que mais concorreram para que as idéias de Piaget fossem associadas à educação foram suas vinculações, de 1929 a 1967, ao Bureau Internacional de l'Éducacion e, de 1946 até 1980, à UNESCO. (Vasconcelos, 1996, p. 53)

\footnotetext{
2 Piaget refere-se também à denominação utilizada pelos "autores americanos": ambientalismo e maturacionismo, vinculados respectivamente ao empirismo e ao inatismo (Piaget, 1990, p. 58).
} 
Enfim, mesmo que interessado por questões educacionais, Piaget dedicouse basicamente a investigar problemas próprios do campo epistemológico, portanto relativos ao conhecimento científico, em particular como evolui, qual a sua formação e o seu desenvolvimento histórico - um empreendimento que remete às suas preocupações juvenis (Piaget, 1973b, p. 39). Esse é o objetivo último da sua obra, sendo ela própria um bom exemplo do que Piaget entendia por ciência e conhecimento.

\subsection{Erros construtivos}

O conhecimento, segundo Piaget, é essencialmente construção. Se procurássemos a procedência dessa concepção em seus trabalhos, certamente chegaríamos até as suas primeiras pesquisas sobre a Psicologia da criança, quando Piaget começa aplicando testes de raciocínio em crianças parisienses, em fins da primeira década do século passado. Ao ter que padronizar esses testes, o jovem pesquisador deteve-se justamente no que nesse tipo de pesquisas, voltadas para a quantificação dos sucessos e insucessos das crianças, era desprezado: as respostas erradas e os processos subjacentes pelos quais as crianças chegavam a essas respostas. ${ }^{3}$ Piaget nota que as crianças sempre se equivocam do mesmo modo, que os erros no raciocínio infantil seguem uma lógica própria, diferente da que regula o pensamento adulto. São erros sistemáticos e que devem ser diferenciados dos que ocorrem por uma mera falta de atenção ou de memória. Essa forma de conceber os erros no raciocínio infantil Ihe permitiu explicar determinadas diferenças que já eram percebidas entre 0 adulto e a criança, diferenças essas que Piaget remete e vincula a estágios do desenvolvimento cognitivo. Esses estágios são concebidos como estruturas de conjunto que condicionam o pensamento infantil.

Essa primeira forma de conceitualizar os erros cometidos pelas crianças concerne à dimensão estrutural do desenvolvimento cognitivo e não à sua gênese. Trata-se de erros sistemáticos que permitem situar o que a criança pode ou não pode fazer, eles estabelecem os limites do seu pensamento ou da sua

\footnotetext{
${ }^{3}$ Esse é o momento em que Piaget sente ter encontrado a via para conciliar a investigação epistemológica com o devido respeito aos fatos, que não encontrara na filosofia. Daí a sua dedicação, durante boa parte da sua vida, ao estudo do desenvolvimento cognitivo e à Psicologia da criança (Piaget, 1973b, p. 18).
} 
ação, mas ainda não dizem respeito à dimensão propriamente construtiva do desenvolvimento. Como afirma Lajonquière, ainda não são erros construtivos. Apenas adquirem esse caráter na década de 70, quando é feita uma série de estudos centrados na dinâmica do processo do desenvolvimento cognitivo:

(...) agora o objetivo é centrar-se na dinâmica do processo genético e construtivo, os erros passam a indicar as marchas e contramarchas às quais todo sujeito está condenado (a suportar) na sua laboriosa tentativa para conhecer mais, e não só aquilo que o sujeito pode ou não pode fazer num dado nível, como acontecia anteriormente (por isso mesmo, são qualificados como construtivos). (Lajonquière, 1996, p. 60)

Essa mudança de foco, própria dos estudos desenvolvidos pela Escola de Genebra e por Piaget nesse período, retoma as primeiras inquietudes do epistemólogo suíço, que até então havia dedicado boa parte do seu trabalho para tratar dos aspectos estruturais do desenvolvimento cognitivo (Lajonquière, 1996, pp. 55-7). ${ }^{4}$ Agora, além do enfoque estrutural, o que importa é a passagem de uma estrutura a outra, o seu mecanismo formador, a dimensão propriamente construtiva e genética do conhecimento. Trata-se de atentar para a fonte dos conhecimentos errôneos das crianças e para os mecanismos de sua superação. O que no fundo está em causa é o "mecanismo interno de todo construtivismo", ou seja, o processo de equilibração - um dos fatores gerais que segundo Piaget explicam a psicogênese (Piaget e Inhelder, 1985, p. 132).

Os conceitos de erros sistemáticos e erros construtivos são parcialmente discutidos por Emília Ferrerio e Ana Teberosky no livro Psicogênese da língua escrita (1986, pp. 21-32), que é onde expõem os resultados da sua pesquisa sobre os processos de aquisição da língua escrita. Esse tipo de erros tem um papel fundamental nessa pesquisa, pois um de seus objetivos era justamente identificar os erros construtivos na gênese das conceitualizações infantis acerca da escrita (p. 30). Afora a retomada desses conceitos por essa pesquisa, que não é qualquer pesquisa, porque ela está no cerne do (re)ordenamento discursivo que se processa no Brasil desde a segunda metade dos anos 80, aqui interessa destacar o seu papel nesse período e nesse (re)ordenamento discursivo. Falar sobre os erros infantis produzia uma reverberação toda especial nos discursos

\footnotetext{
${ }^{4}$ Sobre essas primeira inquietudes, o próprio Piaget (1973b, p. 16) lembra as duas idéias que nunca abandonou: uma relativa aos aspectos estruturais (todo conhecimento é sempre assimilação de um dado exterior às estruturas do sujeito) e a outra sobre o mecanismo formador das estruturas (a necessidade de equilíbrio por autoregulação).
} 
pedagógicos da época, em particular entre os que criticavam as perspectivas pedagógicas consideradas conservadores, autoritárias e identificadas com a chamada escola tradicional. Nesse período, no âmbito desses discursos críticos, insistia-se em que o importante era ver o que as crianças ou alunos sabiam, quais as suas preocupações, seus interesses, e atentar para o seu modo de pensar e sentir, sendo criticados os professores que costumavam ressaltar o que as crianças não tinham, o que Ihes faltava ou o que nelas avaliava-se como errado e que, por isso, precisava ser imediatamente corrigido de acordo com o modelo adulto. Tratava-se então de trazer à luz o que a criança era e não o que não era. E é justamente nesses discursos que os erros construtivos fazem pleno sentido, constituem uma espécie de arma que a própria ciência fornece na luta contra tudo o que o significante de arremate escola tradicional então condensava. Essa arma adquire a sua forma concreta e linguística em alguns termos que rapidamente se popularizam e que concernem às hipóteses infantis sobre o sistema alfabético de escrita, tais como Ferreiro e Teberosky as formalizaram e divulgaram em seus escritos.

\subsection{Fatores do desenvolvimento psíquico}

$\mathrm{Na}$ extensa obra deixada por Piaget é possível encontrar diversas formulações sobre os fatores gerais do desenvolvimento psíquico, sendo basicamente os mesmos, embora variem a forma de articulá-los e a sua importância relativa, como lembra Freitag (1985, p. 23). Em A psicologia da Criança, por exemplo, são mencionados quatro fatores: a maturação orgânica, o papel do exercício e da experiência adquirida na ação sobre os objetos, as interações e transmissões sociais e o mecanismo interno de equilibração (Piaget e Inhelder, 1985, pp. 129-34). A conjugação desses quatros fatores é o que explica a psicogênese.

O primeiro fator diz respeito ao crescimento orgânico e à "maturação do complexo formado pelo sistema nervoso e pelos sistemas endócrinos". A importância da maturação orgânica reside principalmente nas possibilidades novas que abre, constituindo assim uma condição necessária para o aparecimento de certas condutas, embora por si só não seja suficiente. É preciso ainda que "a maturação seja acrescentada de um exercício funcional e um mínimo de experiência" (Piaget e Inhelder, 1985, p. 130). 
Ao tratar do segundo fator, relativo à ação do sujeito sobre os objetos, Piaget distingue dois tipos de experiência: a experiência física e a experiência lógico-matemática. Dessas experiências resultam conhecimentos de ordem diferente. Na experiência física, o sujeito age sobre os objetos para deles abstrair as propriedades. No caso da experiência lógico-matemática, onde o sujeito também age sobre os objetos, ele está empenhado em conhecer o resultado da coordenação das suas ações, de modo que o conhecimento é abstraído da ação e não dos objetos (Piaget e Inhelder, 1985, p. 131). Em outras palavras, enquanto na chamada abstração empírica o sujeito abstrai propriedadas das coisas, na abstração reflexiva ou reflexionante abstrai propriedades das formas de ação. As estruturas lógico-matemáticas são o resultado desse processo de abstração reflexionante que está na base da própria abstração empírica, pois esta não ocorre sem um mínimo de coordenação das ações. Segundo Piaget e Inhelder, a "experiência física, nada tem de simples registro de dados", ela "constitui uma estruturação ativa, porque é sempre assimilação a quadros lógico-matemáticos" (p. 131).

O terceiro fator, relativo à dimensão social do desenvolvimento psíquico, concerne também a um processo de estruturação ativa por parte do sujeito. $\mathrm{Na}$ perspectiva piagetiana, a socialização é uma estruturação "para a qual o indivíduo contribui tanto quanto dela recebe" (Piaget e Inhelder, 1985, p. 132). Ao interagir com os outros, o indivíduo envolve-se num processo de assimilação ativa, presente também na transmissão social. Sem essa assimilação ativa essa transmissão seria ineficaz.

Quanto à equilibração, Piaget considera que ela é "o mecanismo interno de todo construtivismo", o mecanismo próprio do estado ou condição de todo sujeito que, na sua relação como o meio (físico e social), não tem outra opção a não ser agir sobre ele e por ele ser afetado, ou seja, interagir. Como? Principalmente realizando uma construção, (re)construindo ele próprio e o mundo que o cerca. $\mathrm{O}$ mecanismo interno dessa construção é o que afinal dá unidade ao desenvolvimento, é ele que produz a articulação necessária entre os três fatores já mencionados, de modo a possibilitar uma evolução cuja direção seja regular evolução, em primeiro lugar, das estruturas cognitivas que sempre na mesma ordem sucedem-se ao longo do desenvolvimento. Em outros palavras, para que 
essa construção progressiva ocorra, todos os fatores são necessários, mas cabe a um deles um papel capital: a equilibração é necessária para "conciliar as contribuições da maturação, da experiência dos objetos e da experiência social" (Piaget e Inhelder, 1985, p. 133). Esse mecanismo endógeno é concebido conforme um modelo que Piaget empresta da cibernética, pois a equilibração é uma auto-regulação, isto é:

(...) seqüência de compensações ativas do sujeito em resposta às perturbações exteriores e de regulagem ao mesmo tempo retroativa (sistemas de anéis ou feedbacks) e antecipadora, que constitui um sistema permanente de tais compensações. (Piaget e Inhelder, 1985, p. 132)

Esse é o mecanismo interno que faz como que essa construção, que parte da atividade mais rudimentar e global do lactante, avance em direção a formas cada vez mais evoluídas de relação com o meio físico e social. Essas formas de equilíbrio provisório entre o sujeito e o meio sucedem-se até a idade adulta, segundo uma equilibração progressiva que Piaget chamou de majorante. ${ }^{5}$

\subsection{Funcionamento constante, estruturas variáveis}

O mecanismo interno de equilibração é o mecanismo próprio das ações inteligentes, ele está no cerne do funcionamento cognitivo. Esse funcionamento mantém as mesmas características gerais ao longo do desenvolvimento, à diferença das estruturas cognitivas, que passam por diversas e sucessivas transformações. Ou seja, enquanto as estruturas variam, o funcionamento permanece constante ou invariante.

Essas estruturas cognitivas não são inatas, não fazem parte da herança biológica do indivíduo, portanto não estão dadas de antemão, nem virtualmente. Elas resultam da conjugação dos quatro fatores gerais antes referidos, aí incluído um tipo de funcionamento que, este sim, é inato. Em outras palavras, apesar de

\footnotetext{
${ }^{5}$ Segundo Freitag (1985, p. 28), a "equilibração passou a ser para Piaget o fator fundamental" para a explicação da psicogênese. A autora também lembra que Piaget foi relegando o papel do fator social (p. 19), em parte recuperando a sua importância na fase final da sua obra (p. 37). Ademais, no início de seus trabalhos, particularmente em alguns deles, "a ação infantil sobre o meio foi interpretada muito mais como uma interação entre pares que como ação no sentido de comportamento do organismo e atuação sobre objetos físicos, conotação que passou a assumir depois" (p. 28). Inclusive, "os indivíduos assumem o mesmo estatuto de objetos físicos" (p. 29).
} 
Piaget negar o caráter inato das estruturas da inteligência, de recusar o préformismo e o apriorismo nessa dimensão estrutural, concebe o funcionamento intelectual como um prolongamento do funcionamento biológico, como um caso particular da atividade orgânica (Piaget, 1987, pp. 13-29). A inteligência é esse tipo de atividade cujas características mais gerais são herdadas. Nesse sentido, ela é um a priori biológico e funcional que possibilita o surgimento das diversas estruturas: é "uma atividade organizadora cujo funcionamento prolonga o da organização biológica e o supera, graças à elaboração de novas estruturas" (1987, p. 379). É sob essa perspectiva que Piaget concebe a ação do sujeito, embora também a considere alicerçada pelas relações que o sujeito estabelece com o meio externo. Por tudo isso, a ação — seja ela movimento, pensamento ou sentimento, ação individual ou social, interna ou externa - é a base do desenvolvimento psíquico, a ação é o que sustenta e promove esse desenvolvimento. Ou seja, o sujeito precisa agir para se desenvolver.

Em relação a esse funcionamento, Piaget destaca uma dupla invariante funcional de caráter geral: a organização e a adaptação. Esta última, por sua vez, envolve um mecanismo de dupla face: a assimilação e a acomodação. Vejamos então em que consiste essa dupla invariante funcional.

À semelhança de outros seres vivos, o ser humano relaciona-se com o meio externo realizando algum tipo de atividade, em algum grau estruturada ou organizada, seja essa organização a do puro reflexo, como no recém nascido, ou a das formas lógicas mais avançadas. O sujeito adapta-se ao meio sustentado por essa organização e, ao se adaptar, transforma a organização da qual partiu. Em outros termos, o sujeito adapta-se ao meio na medida em que se organiza, na medida em que aperfeiçoa as suas estruturas ou construções no sentido de tornálas cada vez mais estáveis e móveis. E, reciprocamente, organiza-se na medida em que se adapta, na medida em que se envolve num processo de (re)construção de si próprio tendo em vista os objetos em relação aos quais essa adaptação se 
efetiva. Tomando como referência o pensamento, ${ }^{6}$ é assim que Piaget apresenta essa dupla invariante funcional:

A "concordância do pensamento com as coisas" e a "concordância do pensamento consigo mesmo" exprimem essa dupla invariante funcional da adaptação e da organização. Ora, esses dois aspectos do pensamento são indissociáveis: é adaptando-se às coisas que o pensamento se organiza e é organizando-se que estrutura as coisas. (1987, p. 19)

Em relação a adaptação, ainda é preciso considerar as duas faces antes referidas: a assimilação e a acomodação. A primeira consiste no processo pelo qual os objetos são incorporados às estruturas do sujeito, sendo para tanto transformados por essas mesmas formas de organização da ação. Todo processo adaptativo, entretanto, leva também à transformação dessas estruturas, na mesma medida em que o sujeito se acomoda às características desses objetos. Segundo Piaget (1987, p. 15), a inteligência é uma adaptação, ou seja, uma atividade orientada pela busca de um equilíbrio progressivo entre o sujeito e 0 objeto, este entendido num sentido geral. As formas provisórias de equilíbrio são adaptações, estados provisórios e relativamente estáveis que resultam dessa mesma atividade inteligente ou adaptativa. De modo que podemos pensar a adaptação como atividade e também como estado que só é alcançado quando a adaptação atinge uma estrutura ou um sistema estável, ou seja, "quando existe equilíbrio entre a acomodação e a assimilação" (p. 18).

De forma análoga, pode-se dizer que toda construção concerne simultaneamente aos aspectos dinâmico e estático do desenvolvimento, ou melhor, ao processo e ao seu resultado. Ou ainda, às duas dimensões do desenvolvimento psíquico que Piaget considerou igualmente importantes: a genética e a estrutural. Duas dimensões assim relacionadas: toda estrutura tem uma gênese e toda gênese parte de uma estrutura à qual encontra-se subordinada, resultando numa outra estrutura que não está dada de antemão (Piaget, 1982, p. 136).

${ }^{6}$ Para Piaget, o pensamento nada mais é do que a inteligência potencializada pela função semiótica. Como afirma Freitag (1985, p. 25), referindo-se à perspectiva piagetiana, o "critério de distinção" entre a inteligência e o pensamento é a linguagem: "o pensamento sem a linguagem é inconcebível". 
E aqui é preciso fazer algumas considerações importantes sobre esse processo de construção. Nem toda atividade resulta numa adaptação ou desencadeia a (re)construção das estruturas cognitivas. Ou seja, nem toda atividade consiste num movimento por parte do sujeito cujo sentido seja o da busca de uma forma de equilíbrio mais estável e móvel. Ademais, toda assimilação ativa, toda atividade ou ação inteligente, depende em última instância de estímulos (externos ou internos) que desestabilizem o sujeito, de perturbações que o obriguem a se envolver num processo de (re)equilibração. E não é qualquer estímulo que cumpre com essa função, na mesma medida em que eles só se tornam perturbações que o obrigam a realizar algum tipo de regulação dependendo dele próprio, do sujeito, em particular dos esquemas de assimilação com que ele conta nesse momento. ${ }^{7}$ São esses esquemas os que afinal definem o caráter desses estímulos e dos objetos que o sujeito assimila. Esses objetos são interpretados em função desses esquemas assimilativos, tornando-se iguais para diferentes sujeitos se os esquemas com que são interpretados são iguais. Não existe portanto o objeto separado do sujeito. A (re)construção dos esquemas ou estruturas cognitivas - e a própria (re)equilibração portanto - depende do caráter que esses estímulos ou objetos adquirem para determinado sujeito, sem contar os recursos e meios que esse sujeito é capaz de mobilizar para dar conta do que para ele se transformou em um conflito cognitivo. Esse tipo de conflito pode resultar tanto do desajuste entre os esquemas assimilativos do sujeito e determinada realidade, quanto da incoerência ou lacunas existentes entre os próprios esquemas cognitivos. São esses conflitos os que mobilizam o sujeito

\footnotetext{
7 "Um esquema é a estrutura ou a organização das ações" (Piaget e Inhelder, 1985, p. 15), é uma espécie de estrutura elementar, primeira. O esquema pode ser pensado como um "saber fazer" através do qual o sujeito assimila os objetos às suas estruturas. Uma estrutura, por sua vez, é composta por um conjunto de esquemas. Ela "supõe um conjunto de elementos e uma relação entre eles, tal que as seguintes características estejam sempre presentes: totalidade, transformação e auto-regulação" (Macedo, 1994, p. 146). O sistema cognitivo é composto por um conjunto de estruturas (p. 147). Em relação à equilibração, Piaget descreve três formas: a primeira consiste numa assimilação dos objetos aos esquemas de ação do sujeito e a acomodação desses esquemas aos objetos; a segunda forma de equilibração assegura as interações entre os subsistemas ou esquemas, ela resulta da sua assimilação e acomodação recíproca; e a terceira forma de equilibração intervém nas interações das partes com o todo, ela assegura a integração de esquemas (ou subsistemas) em outro mais geral (Macedo, 1994, p. 147; Lajonquière, 1996, p. 67). Quanto ao que possibilita essas formas de equilibração, nos três casos é o ajuste progressivo entre a assimilação e a acomodação (Lajonquière, 1996, p. 67).
} 
para o encontro de um novo ponto de equilíbrio, pois é próprio do sujeito epistêmico não tolerar incoerências no seu sistema cognitivo. ${ }^{8}$

Um outro aspecto importante em relação ao funcionamento da inteligência é que ele é inconsciente, tanto quanto as estruturas que estão sendo construídas, pelo menos no momento mesmo em que isso ocorre. Esse funcionamento é o que Piaget chamou de inconsciente cognitivo, além das estruturas que guiam esse funcionamento e as que dele resultam, as quais podem se tornar conscientes. Trata-se portanto de um inconsciente composto de estruturas (Lajonquière, 1996, pp. 33 e 80-1). Em relação ao conhecimento, isso significa que "o processo de construção do conhecimento é comandado, em última instância, por um funcionar inconsciente" (p. 84).

Em suma, as formas de equilíbrio e portanto de adaptação ao meio mudam ao longo do desenvolvimento psíquico, no sentido de uma adaptação cada vez mais precisa à realidade, mantendo-se constante o que corresponde à dimensão funcional, aos aspectos funcionais do desenvolvimento psíquico. Todo e qualquer processo de construção em que o sujeito se envolve diz respeito a esse funcionamento, do qual vimos algumas características gerais: organização, adaptação, assimilação e acomodação. Esse funcionamento é próprio da espécie, por isso é natural e espontâneo. Se não houver nada que o limite, que o condicione colocando-lhe um freio, esse funcionamento automático e inconsciente impõe-se e produz desenvolvimento, de maneira tanto mais efetiva quanto mais favoráveis sejam os fatores que o condicionam e sem os quais o desenvolvimento psíquico tornar-se-ia igualmente inviável. ${ }^{9}$ Em relação a esse funcionamento, vale lembrar ainda que todos agimos impingidos pelo mecanismo interno que está no âmago de todo desenvolvimento individual: a equilibração por auto-regulação, que é também uma característica geral desse funcionamento. A inteligência é, justamente, essa atividade auto-reguladora que nos obriga a agir de maneira coerente e organizada, integrando as nossas ações em sistemas onde a busca do equilíbrio é a sua tendência intrínseca.

\footnotetext{
${ }^{8}$ Desenvolver mais amplamente esse ponto, relativo à teoria de equilibração desenvolvida por Piaget, escapa às intenções deste trabalho. Quanto às breves considerações feitas a esse respeito, veja-se Lajonquière (1996, pp. 29-88) e Macedo (1994).

${ }^{9}$ Esses fatores dizem respeito à maturação orgânica e à relação com o meio físico e social.
} 
As formas de equilíbrio mais gerais são construções ou estruturas de conjunto que se sucedem no curso do desenvolvimento psíquico segundo uma ordem que é constante. Essas estruturas caracterizam cada estágio e a partir delas é possível explicar as principais reações particulares do sujeito (Piaget e Inhelder, 1985, p. 129). Além disso:

As estruturas de conjunto são integrativas e não se substituem umas às outras: cada uma resulta da precedente, integrando-a na qualidade de estrutura subordinada, e prepara a seguinte, integrando-se a ela mais cedo ou mais tarde. (ibidem,p. 130)

Ao caracterizar essas estruturas cognitivas, Piaget as agrupou de diversos modos ao longo da sua obra. ${ }^{10} \mathrm{Em}$ A psicologia da criança, Piaget e Inhelder discriminam três grandes períodos, que por sua vez podem ser divididos em subperíodos ou subestádios. Vejamos brevemente algumas das suas características.

A primeira grande construção do desenvolvimento intelectual corresponde ao nível sensório-motor (do recém nascido até por volta do ano e meio). Esse é o nível que prolonga e ultrapassa as estruturas orgânicas (Piaget e Inhelder, 1985, p. 129). No início, temos as atividades espontâneas e totais do organismo e os chamados reflexos. Estes são concebidos como diferenciações dessas atividades e como capazes de acarretar a formação de esquemas de ação por meio do exercício funcional. Esses reflexos, por meio desse exercício, se diferenciam e generalizam, dando origem a esquemas de ação inicialmente isolados, mas que depois são coordenados, integrando-se num esquema sensório-motor de conjunto. Primeiramente, integram-se pela via de uma coordenação linear (os esquemas possuem o mesmo valor) e depois por meio da sua diferenciação em esquemas-meios e esquemas-fins. Já no fim desse nível ou estágio, a criança torna-se capaz de criar esquemas assimilativos novos: por tateio, ao descobrir novos esquemas-meios por experimentação ativa, e depois por insight, por meio de uma compreensão súbita. E aqui já estamos nos primórdios do outro grande

\footnotetext{
${ }^{10}$ É comum, entre os que retomam a obra piagetiana, lembrar da divisão feita por Piaget em quatro estágios: sensório-motor, pré-operatório, operações concretas e operações formais. Outra divisão feita pelo pesquisador suíço é a que se encontra em Seis estudos de Psicologia, onde são discriminados seis estágios (p.13).
} 
período, quando se inicia a função simbólica ou semiótica e o pensamento (Piaget e Inhelder, 1985, pp. 12-18; 1987).

Nesse período inicial é construída uma estrutura intelectual de natureza geral própria da inteligência prática: o chamado grupo prático dos deslocamentos. Nele encontra-se o essencial do que posteriormente será reconstruído no plano da representação. Inclusive há um esboço de reversibilidade que, na sua forma acabada, no período das operações formais, tornar-se-á um sistema completo, inteiramente equilibrado (Piaget e Inhelder, 1985, p. 134). Afora a constituição dessa lógica das ações inerente ao percurso da inteligência sensório-motora, nesse nível o sujeito também encontra-se voltado para a organização do real, ou seja, constrói as grandes categorias da ação: os esquemas do objeto permanente, do espaço, do tempo e da causalidade. ${ }^{11}$

Graças à função semiótica, com a qual advém a representação, as ações podem ser interiorizadas, iniciando-se assim o segundo grande período (até os 10 ou 11 anos). Nele, os esquemas de ação construídos no estádio anterior são reconstruídos no novo plano da representação e assim ultrapassados, resultando na construção das estruturas operatórias concretas. Se na etapa anterior houve um crescente descentramento no plano da ação sensório-motora, agora o sujeito descentra-se nesse novo plano da representação ${ }^{12}$; se antes havia conquistado a reversibilidade no plano da ação efetiva, agora estende essa conquista para o nível representativo, tornando-se capaz de realizar diversas operações. ${ }^{13}$ Esse

\footnotetext{
${ }^{11}$ Nesse percurso é preciso considerar o desenvolvimento das percepções, que constituem um caso particular das atividades sensório-motoras (Piaget e Inhelder, 1985, p. 30). Nas percepções são também fundamentais os esquemas de ação, que também podem ser considerados uma espécie de lógica que regula as percepções.

${ }^{12} \mathrm{O}$ esquematismo cognitivo, no nível sensório-motor, parte de um estado inicial centrado nas próprias ações do sujeito em direção a um universo objetivo e descentrado, implicando também uma diferenciação progressiva entre o eu e os objetos (coisas e pessoas) (Piaget e Inhelder, 1985, pp. 24-5). No segundo grande período, no plano da representação, o sujeito começa igualmente centrado em suas próprias ações, nos "aspectos figurativos momentâneos dos setores do real", nas suas idéias e pontos de vista. Posteriormente, descentra-se e constitui os "sistemas operatórios de transformações" e as noções de conservação que "liberam a representação do real de suas aparências figurativas ilusórias", avançando também no sentido de diferenciar, considerar e coordenar outros pontos de vista, além do próprio (p. 108-9).

13 As operações são ações mentais, portanto internas, que não existem isoladas e cuja característica distintiva é a de serem reversíveis. Em outras palavras, as operações consistem em transformações reversíveis (Piaget e Inhelder, 1985, p. 82). A sua existência supõe que o sujeito seja capaz de inverter mentalmente uma ação e de considerar simultaneamente o estado inicial e final de uma transformação, pois a uma transformação real pode opor uma transformação virtual (em pensamento). Nesse segundo período, Piaget destaca as operações que possibilitam à criança classificar e seriar objetos, de modo que a classificação e a seriação tornam-se lógicas.
} 
segundo grande período, que constitui uma transição entre a ação e as estruturas lógicas mais gerais relativas ao período das operações formais, Piaget o divide em dois sub-períodos: pré-operatório - caracterizado por uma inteligência intuitiva - e operatório — ou melhor, operatório concreto, limitado portanto em suas possibilidades.

Nesse nível das operações concretas, o sujeito consegue operar sobre objetos mas ainda permanece incapaz de operar baseado em hipóteses ou de raciocinar logicamente com proposições — ou seja, com formas sem qualquer conteúdo. É apenas no terceiro grande período (entre 11-12 e 14-15 anos) que o sujeito consegue liberar-se do concreto e operar sobre operações. É o último descentramento, quando culmina a construção das estruturas características do pensamento hipotético-dedutivo, do raciocínio proposicional ou formal. ${ }^{14}$

Em cada um desses grandes períodos o sujeito pode alcançar determinado nível de conhecimento, relativo às possibilidades abertas pelas estruturas gerais construídas ao longo dos mesmos. Temos então definidos, no decurso do desenvolvimento cognitivo, três planos de conhecimento. $\mathrm{O}$ primeiro, relativo às ações sensório-motoras, que em si mesmas carregam um savoir faire, sem vir associado a qualquer conceituação. A seguir, temos 0 nível próprio da conceituação que toma os seus elementos da ação, pela via de uma tomada de consciência da mesma. E por último, o plano do conhecimento que corresponde ao pensamento formal (Lajonquière, 1996, p. 79).

\subsection{Sob a ordem dos sistemas de ação}

O desenvolvimento psíquico ou das condutas envolve vários aspectos que Piaget considerava indissociáveis: aspectos cognitivos, afetivos e sociais (Piaget e Inhelder, 1985, p. 97). A relação entre eles, bem como a conceitualização dos dois

Outro aspecto importante é o aparecimento das noções de conservação (de comprimento, substância, peso, volume).

${ }^{14}$ Em relação a esse último período, Piaget destaca a formação de duas estruturas novas: a combinatória e o grupo INRC. A primeira concerne ao fato do adolescente conseguir relacionar, de modo completo e sistemático, todas as combinações possíveis a partir das variáveis apresentadas em determinado problema. Quanto à segunda estrutura, ela diz respeito à possibilidade de imaginar simultaneamente dois movimentos ou ações que se superpõem (dupla reversibilidade). Em outros termos, o adolescente torna-se capaz de manipular transformações segundo as quatro possibilidades seguintes: I (transformação idêntica), N (inversa), R (recíproca) e C (correlativa) (Piaget e Inhelder, 1985, pp. 111-19). 
últimos, constituem os pontos menos desenvolvidos da sua teoria psicogenética. Além disso, em geral julga-se que são os mais problemáticos. E, de fato, no Brasil das últimas décadas, deram lugar a polêmicas e questionamentos diversos, em particular quando relacionados aos temas educacionais. ${ }^{15}$ Piaget produziu poucos trabalhos voltados para a investigação e elucidação dessas relações e dos aspectos afetivos e sociais. ${ }^{16} \mathrm{E}$ aqui é necessário lembrar que a sua principal preocupação ou interesse dizia respeito ao desenvolvimento cognitivo e ao sujeito do conhecimento, o sujeito epistêmico, este sendo concebido como a parte comum a todos os sujeitos de um mesmo nível de desenvolvimento, sem consideração das diferenças individuais. Por conseguinte, Piaget não se preocupou com o que era de ordem singular, nem com aquilo que poderia explicar as características próprias de determinado sujeito e dos seus processos peculiares de raciocínio, ou ainda, com a eventual incidência dos aspectos afetivos nesses processos singulares. ${ }^{17}$ A sua principal preocupação, pelo menos no âmbito da sua teoria psicogenética, dizia respeito ao que os discursos pedagógicos brasileiros captaram de modo claro com esta articulação significante: "a criança que constrói seu próprio conhecimento". Uma criança que corresponde ao sujeito até aqui descrito tendo como referência a obra piagetiana. Esse sujeito epistêmico, que age de modo a criar sistemas de ação cada vez mais complexos,

\footnotetext{
${ }^{15}$ No Brasil, várias investigações e reflexões foram desenvolvidas nas últimas décadas com o intuito de avançar nesses pontos da teoria piagetiana. Por exemplo, o estudo realizado por Barbara Freitag e publicado em 1984 no livro Consciência e Sociedade, com o qual a autora busca revelar a influência de fatores sócio-econômicos no desenvolvimento psicogenético, tendo investigado para tanto crianças de classes sociais distintas. Ou os trabalhos de Yves de La Taille (1992a; 1992b; 1993), voltados para o esclarecimento e desenvolvimento de aspectos relativos à dimensão social e moral do desenvolvimento psíquico numa perspectiva piagetiana, com a intenção de avançar nos pontos que julga problemáticos, como a relação entre ação e juízo moral (1992b, pp. 63-72). Sem contar a produção em outros países, como a do psicólogo norteamericano Lawrence Kohlberg, que remonta ao final dos anos 50, quando dá continuidade aos estudos piagetianos sobre a moralidade. A elaboração teórica de Kohlberg inspirou também trabalhos no Brasil, os quais igualmente se apóiam na obra de Piaget, como o de Venturi (1997), sobre a moralidade sexual. Sobre essa produção, veja-se também Lajonquière (1996, pp. 126-7), que faz referência a alguns trabalhos voltados para o esclarecimento do lugar da afetividade e dos problemas que essas iniciativas enfrentam, no interior do campo delimitado pela teoria piagetiana.

${ }^{16} \mathrm{Em}$ relação às dimensões afetivas e sociais do desenvolvimento psíquico, Piaget produziu apenas dois trabalhos de importância: O juízo moral na criança (publicado em 1932) e Estudos sociológicos (que reúne escritos produzidos na década de 40 e publicados em 1965), este último raramente utilizado como referência nos trabalhos acadêmicos ou nas discussões sobre a obra de Piaget.

${ }^{17}$ Esse viés da perspectiva piagetiana é apontada, por exemplo, por Lajonquière (1996, pp. 115 27), que também lembra do deslocamento de interesse nos trabalhos e pesquisas da Escola de Genebra a partir da década de 70: do sujeito epistêmico universal ao sujeito psicológico singular (p. 125).
} 
estáveis e móveis, é o que se impõe como matriz para pensar o desenvolvimento psíquico como um todo. ${ }^{18} \mathrm{Na}$ perspectiva piagetiana, os sistemas de ação são os grandes unificadores do sujeito, constituindo também a instância reguladora das relações entre o sujeito e o meio físico e social. Por isso, pode-se dizer que tudo no sujeito fica sob a ordem dos sistemas de ação. Ademais, nas reflexões de Piaget, esses sistemas de ação extrapolam o sujeito e as suas relações imediatas, expandindo-se em outras direções, como pode ser observado em seus escritos sociológicos. Essa unificação, essa "obra unificadora" própria da inteligência piagetiana ${ }^{19}$ mas também da ciência moderna, a sua "visão de sistema" e a expansão que lhe é correlata, é o que agora será destacado.

Consideremos primeiro os dois aspectos que Piaget costumava destacar ao tratar das condutas no indivíduo: o aspecto cognitivo e o aspecto afetivo. "O aspecto cognitivo das condutas consiste na sua estruturação e o aspecto afetivo na sua energética" (Piaget e Inhelder, 1985, p. 24). A estrutura das condutas ou os meios que o sujeito emprega para alcançar determinado objetivo dizem respeito à dimensão cognitiva; a afetividade constitui o motor da ação, ela fornece os fins, concerne aos interesses e sentimentos da criança. Esses dois aspectos da conduta são irredutíveis, indissociáveis e complementares (ibidem). Um não pode ser reduzido ao outro: "a estruturação não explica a energética nem o inverso". Ademais, "nenhuma das duas poderia funcionar sem a outra" (p. 97). A conduta é una, não existe conduta que não comporte fatores afetivos, nem "estados afetivos sem a intervenção de percepções ou compreensão, que constituem a sua estrutura cognitiva" (p. 133).

\footnotetext{
${ }^{18}$ Aqui vale lembrar que Piaget, ao longo da sua obra, formulou diversos modelos psicogenéticos. De acordo com Barbara Freitag (1985), esses modelos são três. Os primeiros dois encontram-se nos estudos que realizou até a década de 1930 relacionados com a linguagem e a moralidade. Neles, Piaget partia "de um modelo psicogenético muito mais abrangente que o modelo do pensamento lógico, que no final acabou prevalecendo" (p. 18-9). Segundo Freitag, com o "Piaget jovem", "a dinâmica da construção das estruturas cognitivas decorre (...) muito mais de um paradigma interacionista, que de um paradigma bio-cibernético" (p. 36). Na análise que aqui será feita, essas e outras diferenças nos trabalhos de Piaget não serão destacadas, sobretudo porque o que interessa neste item é sublinhar o caráter sistêmico e unificador da sua perspectiva, que é algo que perpassa e prevalece no conjunto da sua obra.

${ }^{19}$ É desse modo, como "obra unificadora", que o próprio Piaget refere-se ao que a inteligência produz (Piaget, 1998, p. 160).
} 
Os aspectos cognitivos e afetivos são, por sua vez, indissociáveis do que em todo desenvolvimento constitui a sua dimensão social ou interindividual. Com efeito, as relações sociais são fundamentais para o surgimento das estruturas da inteligência e as próprias trocas sociais comportam uma dimensão cognitiva, são trocas cognitivas. Estas evoluem da total indiferenciação entre o sujeito e os objetos e do egocentrismo que caracteriza o raciocínio infantil na primeira infância, em direção a um sistema de trocas sociais e cognitivas de caráter lógico, nas quais o sujeito não fica centrado em seu próprio ponto de vista.

Nos escritos de Piaget sobre o desenvolvimento psíquico, a dimensão social torna-se particularmente importante quando está em causa a evolução da afetividade. Para Piaget, em todas as relações sociais encontra-se implicada a dimensão afetiva e a afetividade evolui justamente em função dessas relações. Delas procedem, em última instância, os sentimentos morais e tudo o que concerne ao desenvolvimento moral.

Vejamos agora mais detidamente como Piaget relaciona esses aspectos, avançando por essa via na sua caracterização, sobretudo no que se refere à afetividade e à dimensão social. Retomemos então, para começar, a relação entre os aspectos cognitivos e afetivos.

Embora a afetividade seja concebida como uma energia, como o motor da ação, em nenhum momento Piaget a considera como algo que possa ser encontrado em estado puro, por assim dizer. A afetividade não é explicitamente concebida como um caos ou pelo menos nunca torna-se propriamente algo caótico, sempre encontra-se subordinada a uma estrutura, desde as manifestações mais elementares do lactante. Nesse primeiro momento, do "adualismo", de total indiferenciação entre o eu e os objetos que o cercam ainda não diferenciados em termos de pessoas e coisas —, os afetos iniciais já dependem da primeira grande forma que molda as reações sensório-motoras: a estrutura de ritmos. No começo ritmos gerais, que correspondem aos das atividades espontâneas e globais do organismo, como as alternâncias entre os estados de tensão e relaxação (Piaget e Inhelder, 1985, pp. 25-6).

Essas estruturas mais gerais, entendidas também como mecanismos, são três: os ritmos, as regulações e os agrupamentos (Piaget e Inhelder, 1985, pp. 23- 
4; Piaget, 1973a, pp. 17-113). Elas concernem à organização e coordenação das ações, são portanto estruturas da inteligência. Essas formas sucedem-se de modo tal que as precedentes só desaparecem quando surgem as seguintes (Piaget e Inhelder, 1985, p. 23). Elas não devem ser confundidas com os três grandes períodos do desenvolvimento mental já referidos, embora façam parte deles. No período sensório-motor, no início temos a estrutura de ritmos, que não permanecerá nos períodos subseqüentes. Dos ritmos iniciais às regulações, há um avanço na mobilidade e coordenação das ações, as quais atingem uma semireversibilidade, com compensações parciais, própria das regulações. Já os agrupamentos supõem a presença de reversibilidade e a elaboração de determinada invariante, sem a qual não existiria reversibilidade. No nível sensóriomotor, por exemplo, constitui-se o esquema do objeto permanente e um princípio de reversibilidade, nesse caso no plano da ação efetiva, motora, e tão-somente de forma precária - um esboço do que serão as transformações operatórias próprias da inteligência representativa, com os esquemas de conservação correspondentes (Piaget e Inhelder, 1985, p. 82). Embora a estrutura do agrupamento esteja como que anunciada no primeiro grande período, nele não há propriamente agrupamentos. Nos níveis ulteriores (de 2 a 15 anos), a evolução dessa organização e coordenação das ações, agora no plano interno, da representação - e por isso evolução do pensamento — , será dominada "por uma passagem geral das regulações à reversibilidade interiorizada ou operatória, isto é, à reversibilidade propriamente dita" (p. 24). É o que ocorre, por exemplo, com a seriação e a classificação, que passam por certas etapas até se tornarem formas de regulação completas, fechadas e por isso lógicas, ou seja, agrupamentos (pp. $87-88) .{ }^{20}$

\footnotetext{
${ }^{20}$ Para Piaget (1973a, pp. 57 e 67), o ritmo marca a fronteira entre o mental e o fisiológico, entre o material e o espiritual. A sucção, por exemplo, é uma conduta rítmica cujo movimento é cíclico, é uma forma inicial caracterizada por uma reversibilidade estereotipada (Macedo, 1994, p. 154). Quando o sujeito reage ou responde a perturbações do meio e procura controlar a sua ação efetiva, por exemplo através de compensações parciais e em função das alterações observados no meio, estamos diante de uma regulação. Enquanto nos ritmos os obstáculos são superados por um esforço para recuperar o ciclo, nas regulações a retomada da ação é modificada pelos resultados da ação anterior, seja mantendo/reforçando ou corrigindo aspectos dessa ação anterior (feedbacks positivos ou negativos). Na formação dos primeiros hábitos já existem tentativas de regulação da ação, sempre apoiadas na ação efetiva, motora, sem existir ainda qualquer aspecto antecipador ou virtual. A existência desse aspecto caracteriza os agrupamentos. Nestes, as regulações adquiriram uma reversibilidade completa, isto é, as ações transformaram-se em operações (p. 155). Por exemplo, uma criança que precisa conferir se o fato de mover uma peça, de um conjunto de peças disposto sobre uma mesa, altera a quantidade, ainda não opera, não
} 
Os afetos dependem dessas estruturas gerais cuja forma final corresponde à reversibilidade que é própria de cada grande período do desenvolvimento intelectual. Elas constituem uma espécie de condição que a própria evolução das ações - e portanto da inteligência - impõe à afetividade. Ou seja, o valor que os objetos e as pessoas adquirem, a modalidade das trocas entre o sujeito e o meio (físico e social) e que resultam em sentimentos interindividuais e interesses variados em relação às coisas, dependem dessas formas gerais relativas à coordenação das ações. Entretanto, não explicam inteiramente a afetividade. Os afetos, os sentimentos, o valor que os objetos e as pessoas adquirem não podem ser compreendidos a partir dessa única referência dada pelas estruturações e as estruturas que dela resultam.

Quanto ao papel da afetividade em face da inteligência, enquanto esta última estabelece uma espécie de molde para a primeira, na medida em que organiza o mundo afetivo, a afetividade condiciona o desenvolvimento cognitivo apenas no sentido de possibilitar uma maior ou menor fluidez nesse processo de estruturação ou construção próprio das ações inteligentes. A afetividade, como lembra Lajonquière (1996, pp. 128-9), não tem o poder de modificar as estruturas da inteligência, pode estimular ou perturbar, atrasar ou acelerar o processo de equilibração majorante, mas as características desse mecanismo geral e as estruturas que dele resultam não dependem da afetividade.

Em relação a essas estruturações ou construções, é preciso considerar ainda o seu caráter social. As estruturas não resultam apenas de um processo individual, são também o produto de estruturações ou construções relativas às trocas sociais, que ganham crescente importância ao longo do desenvolvimento, constituindo sistemas de trocas cada vez mais complexos e cuja forma de equilíbrio final é isomorfa à lógica. Assim, às operações individuais, que são transformações reversíveis, corresponde uma forma de ação social que igualmente compartilha essa característica: a cooperação, que não se limita às

consegue antecipar o resultado. Uma criança que opera e que portanto é capaz de realizar ações internas reversíveis, não precisa verificar se a quantidade mudou. A regulação já está antecipada num sistema onde imperam necessidades lógicas. Esse é o caso do agrupamento, que consiste num sistema de relações de implicação e não de relações causais. O fator tempo, por exemplo, não conta, como seria o caso das últimas, pois trata-se de um sistema lógico. 
trocas cognitivas, pois também envolve a afetividade. ${ }^{21}$ Afinal, o desenvolvimento psíquico é um processo de conjunto, os diversos aspectos da conduta fazem parte desse processo mais geral relativo à coordenação das ações e às suas formas sucessivas (ritmos, regulações, agrupamentos). As ações são tanto individuais (intra-individuais) quanto sociais (interindividuais), de modo que o desenvolvimento é obra tanto do indivíduo quanto da sociedade, não fazendo sentido "a gente perguntar se é a cooperação (ou as co-operações) cognitiva que engendra as operações individuais ou se é o contrário" (Piaget e Inhelder, 1985, pp. 100-1). Trata-se de um mesmo processo de conjunto, relativo a ações igualmente condicionadas pelo seu mecanismo endógeno $-\mathrm{com}$ as características próprias do funcionamento biológico - e pelas relações sociais.

Entretanto, poder-se-ia dizer que essa unidade não é completa: há um "paralelismo funcional" (Piaget e Inhelder, 1985, p. 133) e uma analogia nas fases do desenvolvimento cognitivo e afetivo ou social (p. 100). Piaget fala em desenvolvimentos que correm paralelos e que são indissociáveis, pois fazem parte do mesmo processo de conjunto, não sendo, porém, idênticos. Em outras palavras, trata-se de um único processo de conjunto, um mesmo desenvolvimento, mas ao mesmo tempo ele consiste em vários desenvolvimentos que correm paralelos. ${ }^{22}$ São evoluções relativas à cognição e à afetividade, mas também progressos na socialização. São desenvolvimentos sujeitos à mesma lei ou leis, por isso é possível falar de um mesmo processo evolutivo. Essa lei do desenvolvimento diz respeito à evolução das ações, cuja tendência é tornarem-se reversíveis e compor sistemas. Isso é o que na verdade são os agrupamentos: sistemas de transformações reversíveis, sistemas operatórios. Essa é a forma de equilíbrio final para a qual tendem as ações do indivíduo.

\footnotetext{
${ }^{21}$ Para Piaget (1973a, p. 105), cooperar é operar em comum, co-operar, isto é: "ajustar por meio de novas operações (qualitativas ou métricas) de correspondência, reciprocidade ou complementaridade, as operações executadas por cada um dos parceiros."

${ }^{22} \mathrm{Em}$ relação às diferenças relativas a esse único processo de conjunto também podem ser consideradas as "decalagens", relativas à ausência de total sincronismo entre os diferentes planos da ação e do pensamento, complicando-se assim o quadro dos estágios. É o que afirma Piaget, referindo-se entre outras coisas a provas realizadas com crianças tendo em vista a noção de causalidade: "existem todas as espécies de decalagens quando passamos de uma prova especial a outra: uma criança que pertence a um dado estágio no que se refere a uma questão particular de causalidade pode muito bem estar num estágio mais avançado com respeito a uma questão de causalidade seguinte" (Piaget, 1998, pp. 174-5).
} 
Mesmo quando Piaget trata das sociedades concebe o agrupamento como a forma ou o mecanismo de equilíbrio mais avançado e terminal. É o que argumenta em Estudos Sociológicos (1973a), onde trata dessa questão. Nessa obra, define a sociedade como sendo essencialmente um sistema de interações ou de atividades cujas interações elementares consistem em "ações se modificando umas às outras, segundo certas leis de organização ou de equilíbrio" (p. 34). Portanto, na base das sociedades também coloca a ação. Ademais, nelas é possível encontrar as três formas ou mecanismos de equilíbrio já mencionados (ritmos, regulações e agrupamentos), embora não seja possível falar propriamente na existência de um processo evolutivo semelhante ao desenvolvimento individual:

Encontram-se, de fato, na análise das formas de equilíbrio social estas três estruturas [ritmos, regulações, agrupamentos]. A diferença com o desenvolvimento individual é entretanto a seguinte: a evolução social não consistindo numa equilibração regular, a sucessão dessas estruturas não aparece como necessária, exceto precisamente no único domínio onde uma evolução dirigida é possível: o das normas racionais. (1973a, p. 57)23

Apesar das diferenças entre a psicogênese e a sociogênese, Piaget não deixa de estabelecer paralelismos. Por exemplo, se no indivíduo é possível falar de uma construção relativa às ações em três momentos (ação prática, pensamento egocêntrico e pensamento operatório), nas sociedades também é possível encontrar os seus equivalentes:

(...) as ações reais, que constituem a infra-estrutura da sociedade; a ideologia que é a conceitualização simbólica dos conflitos e das aspirações nascidas destas ações; e a ciência que prolonga as ações em operações intelectuais, permitindo explicar a natureza e o homem, e descentrando este dele mesmo para reintegrá-lo nas relações objetivas que elabora graças à sua atividade. Assim (...) o processo do conhecimento objetivo supõe uma descentração semelhante na sociedade e no indivíduo; assim como o indivíduo se libera de seu egocentrismo intelectual tomando consciência de seu ponto de vista próprio para situá-lo entre os outros, assim também o pensamento coletivo se libera do sociocentrismo (...)(1973a, p. 93)

\footnotetext{
${ }^{23}$ Quanto a essas três estruturas, no caso dos ritmos pode-se pensar nos ritmos sociais elementares, ligados às atividades econômicas mais simples (caça, pesca) e que dependem dos ritmos naturais (estações do ano, etc.). As trocas econômicas, reguladas pela oferta e a demanda, é um exemplo de regulações. No caso dos agrupamentos, o sistema de regras jurídicas aproximase de um sistema de regras completo, onde uma regra implica outra. Entretanto, no caso do sistema jurídico, ele está sujeito a adaptações e por isso não constitui um sistema inteiramente fechado, como seria o caso de um sistema lógico (Piaget, 1973a, pp. 57-78).
} 
Esse paralelismo está diretamente relacionado com o que é comum ao indivíduo e à sociedade: as ações, cuja evolução tende para o equilíbrio lógico, sendo a lógica a forma de equilíbrio como que imanente ao processo de desenvolvimento dessas ações. Se seguirmos a análise de Piaget, apesar dele recusar qualquer tipo de pré-formismo, em última instância a lógica formal é o equilíbrio ideal e comum ao qual efetivamente tendem as funções individuais e as funções sociais, as quais já vimos não podem ser dissociadas. ${ }^{24}$ Uma inclusive é necessária ao desenvolvimento da outra e vice-versa:

(...) o agrupamento resultante do equilíbrio das operações individuais e o agrupamento exprimindo a troca mesma se constituem juntos e são somente as duas faces de uma mesma realidade. Nunca um indivíduo só seria capaz de conservação inteira e de reversibilidade completa, e estas são exigências da reciprocidade que lhe permitem esta dupla conquista (...) Mas em troca a reciprocidade só é possível entre sujeitos individuais capazes de pensamento equilibrado, isto é, apto a esta conservação e a esta reversibilidade imposta pela troca. (Piaget, 1973a, p. 93)

Muito embora as relações sociais sejam fundamentais, elas não têm o poder de modificar as características do mecanismo interno que está na base do desenvolvimento intelectual. Podem, em todo caso, facilitar ou inibir, mas não mudar as suas características. Estas sempre se mantém, fazem parte da ordem biológica, são próprias de um tipo de funcionamento que é inato. Segundo Piaget, o que resulta desse funcionamento coincide com o que a análise sociológica permite detectar nas sociedades, tanto mais evoluídas quanto mais as formas de equilíbrio social estejam próximas do agrupamento. À semelhança do que Piaget afirma em relação ao indivíduo, a sociedade é concebida como uma totalidade que em suas formas evoluídas e apenas tendencialmente, porque nunca atingível, consiste numa espécie de todo harmônico, um sistema equilibrado, nunca estático, pois trata-se de um sistema de co-operações.

Ao postular a convergência entre o desenvolvimento individual e a evolução das relações sociais, que nem sempre evoluem, Piaget está supondo a existência de uma espécie de acordo entre a ordem natural e a ordem social, entre o que

\footnotetext{
${ }^{24}$ Piaget recusa qualquer tipo de pré-formismo, isto é, que as estruturas já se encontrem definidas antes de surgir, tanto em relação ao desenvolvimento individual (1987, p. 25), quanto do ponto de vista da epistemologia genética. Esse é um dos pontos que diferencia a sua concepção construtivista de outras que também são construtivistas. Para ele, o processo geral relacionado com a construção de estruturas novas tem um poder constitutivo e não se reduz a "um método de acesso" a estruturas já existentes ou virtuais (1990, p. 112).
} 
resulta do funcionamento inteligente (que prolonga a ordem biológica) e o produto das relações sociais que evoluem. Em ambos os casos, o sentido mais geral da evolução é o mesmo: o da crescente organização e mobilidade das ações, que tendem a compor sistemas reversíveis cada vez mais complexos e, em conseqüência, mais equilibrados. Esse é o sentido último do que Piaget concebe como evolução e é idêntico nos dois casos. Essa coincidência decorre, ao que tudo indica, do seguinte fato: tudo é unificado por essa espécie de unidade elementar que Piaget coloca na base da vida humana, ou seja, a ação, com a sua particular tendência para constituir sistemas. As dimensões ou aspectos dessa unidade elementar (cognitivos, afetivos, sociais) é o que Piaget separa para analisar, considerando-os de fato indissociáveis, pois trata-se de um mesmo e único elemento. A ação sistêmica constitui a unidade básica que impulsiona e orienta a evolução individual e coletiva. Ademais, pode-se dizer que o conceito de ação, com tudo o que ele implica, está na base de toda a elaboração teórica de Piaget, cuja perspectiva é a de tudo considerar sob esse viés sistêmico e unificador. Um viés que faz com que Piaget fique alinhado do mesmo lado de certa tradição moderna igualmente "apaixonada" pela unificação que todo saber sistêmico promete, como é o caso da tradição positivista, mesmo que dela se distancie em relação a outros pontos. ${ }^{25}$

As relações sociais e os processos de socialização, cujo papel e relevância já foram destacados no que se refere ao desenvolvimento cognitivo, são particularmente importantes na evolução da vida afetiva, pois a dimensão social é a que primordialmente parece incidir sobre a dimensão afetiva, mesmo que Piaget insista na perspectiva de conjunto. Não apenas porque as relações sociais participam da estruturação da afetividade - uma estruturação cognitiva, simultaneamente individual e social -, mas também porque dessas relações resultam as suas principais características. Para aprofundar um pouco mais esse ponto, vejamos então como os aspectos sociais e afetivos encontram-se imbricados em sua teoria psicogenética.

\footnotetext{
${ }^{25}$ No campo sociológico, por exemplo, o que acima é chamado de tradição positivista concerne à que procede da obra de Comte, prolongando-se em autores como Durkheim e Parsons. Esse "telos de sistematicidade" que caracteriza a concepção de ação desenvolvida por Piaget já foi apontado por Freitag, que também indica a sua proximidade com a perspectiva desenvolvida por Parsons e outros "teóricos da ação social" (1985, pp. 32-3).
} 
Desde o seu primeiro e único trabalho de pesquisa sobre a moralidade infantil, $O$ juízo moral na criança ${ }^{26}$, publicado em 1932, Piaget dividiu as relações sociais em duas categorias: relações de coação e relações de cooperação, vinculando cada uma delas à gênese de um tipo de moral: a moral heterônoma e a moral autônoma. À semelhança de Durkheim, cuja obra constitui uma importante referência na discussão que realiza sobre as questões morais, em particular para dela se distanciar e criticar, Piaget concebe "os fatos morais como fatos sociais" (1977, p. 321) e considera que o essencial da moral está nas regras:

Toda moral consiste num sistema de regras, e a essência de toda moralidade deve ser procurada no respeito que o indivíduo adquire por essas regras. (Piaget, 1977, p. 11)

O papel da moral em face da afetividade é análogo ao que Piaget atribui à lógica em relação à inteligência. Em ambos os casos trata-se de regras de controle que, como vimos, dizem respeito ao mesmo processo de conjunto. $E$ essas regras morais, como também os sentimentos morais, têm uma gênese estreitamente vinculada aos processos de socialização, que por sua vez dependem dos dois tipos de relação social antes mencionados. Ademais, à semelhança da lógica, que não é coextensiva à inteligência, a moral tampouco é coextensiva à vida afetiva (Piaget, 1977, p. 345). Há um primeiro momento de anomia, de ausência de regras ou normas morais, não se tratando apenas de anomia afetiva, pois também é intelectual (p. 347).

\footnotetext{
${ }^{26}$ Esse é o nome da última edição e tradução para o português do livro Le jugement moral chez l'enfant, inicialmente publicado no Brasil com outro título, que muda ligeiramente o sentido: $O$ julgamento moral na criança, como figura na bibliografia deste trabalho. Esse livro é o resultado da pesquisa realizada por Piaget com o objetivo de estudar o juízo moral na criança e não os comportamentos ou os sentimentos morais, embora eles sejam também transformados em objeto das suas reflexões $(1977$, p. 7). Para tanto, interrogou crianças de diferentes idades, além de observar a sua atuação em determinados jogos de regras. De início, procurou saber o que vem a ser o respeito à regra do ponto de vista das crianças, tomando como referência jogos de regras comuns entre elas (jogo de bolinhas de gude, no caso dos meninos, e de "pique", que é "uma das formas mais primitivas do esconde-esconde", no caso das meninas, p. 67). Preocupou-se nesse caso com a prática e a consciência da regra. Também investigou as "regras especificamente 'morais', prescritas pelos adultos", para saber "qual a imagem que a criança faz a si mesma desses deveres particulares". E estudou ainda os "princípios provenientes das relações das crianças entre si". Uma das questões mais importantes investigadas junto às crianças foi a respeito da idéia de justiça (p. 7). Aqui Piaget discute vários temas relacionados com as concepções infantis, como as noções do justo e do injusto, as justiças retributiva e distributiva, tipos de responsabilidade e a questão das sanções. Em cada parte ou tema, preocupa-se sempre com a determinação de etapas ou estágios de desenvolvimento. Ademais, em suas reflexões finais, estabelece vários paralelos entre o desenvolvimento do indivíduo e a evolução das sociedades.
} 
No subperíodo pré-operatório, como resultado das relações afetivas entre a criança e os pais ou adultos, surgem os primeiros sentimentos morais de obrigação de consciência. Esse sentimento de obrigação é engendrado nessa relação que Piaget chama de coação, que adquire esse sentido apesar das intenções do adulto. É uma espécie de relação que se impõe em face da condição da criança, cujo sentimento em relação ao adulto é um misto de afeição e temor, "ligado à situação do inferior em relação ao superior" (Piaget e Inhelder, 1985, p. 104). Esse sentimento é uma das duas formas possíveis de respeito, sendo o respeito "um sentimento de indivíduo para indivíduo" (Piaget, 1988, p. 65). Nesse caso trata-se de respeito unilateral. Ele é a fonte do sentimento do dever e engendra na criança pequena uma moral de obediência, caracterizada pela heteronomia. ${ }^{27} \mathrm{~A}$ essa moral heterônoma correspondem determinadas reações afetivas e estruturas específicas relativas ao juízo moral da criança, como é o caso do realismo moral e a responsabilidade objetiva. ${ }^{28}$

Em face da anomia anterior, a heteronomia representa um avanço. Ela implica num certo recuo do egocentrismo inicial, pois as relações de respeito unilateral e de coação contribuem no sentido de constituir um primeiro tipo de controle lógico e moral, mesmo que seja exterior ao indivíduo, ou seja, heterônomo (Piaget, 1977, p. 347). A pressão exercida pelo que é exterior ao sujeito cumpre então um papel fundamental:

É só pelo contato com os julgamentos e as avaliações dos outros que esta anomia intelectual e afetiva perderá terreno progressivamente, sob a pressão das regras lógicas e morais coletivas. (1977, p. 347)29

\footnotetext{
${ }^{27}$ Em relação ao sentimento do dever, Piaget considera que duas condições são simultaneamente necessárias para que apareça: a criança tem que receber ordens ou recomendações de outras pessoas e essas pessoas devem ser objeto de respeito por parte da criança, para que assim exista "aceitação interna" (1988, pp. 65-6). Em outras palavras, essas pessoas devem ser objeto de afeição e medo.

${ }^{28}$ De acordo com esse realismo moral que caracteriza o juízo moral da criança pequena, "as obrigações e valores são determinados pela lei ou pelas instruções em si mesmas, independentemente do contexto das intenções e relações". A responsabilidade objetiva, concebida como uma forma de avaliação da responsabilidade em relação a determinado ato, implica que "o ato é avaliado em função do seu grau de conformidade material com a lei" e não em função das intenções, boas ou más (Piaget e Inhelder, 1985, pp. 106-7).

${ }^{29} \mathrm{Em}$ O juízo moral da criança, o papel do que Piaget concebe como exterior ao sujeito adquire um valor para a psicogênese raramente encontrado em seus outros escritos. É um fator de controle e regulação essencial. A esse respeito, veja-se o seguinte trecho: "O controle próprio da inteligência sensório-motora é de origem externa: são as coisas mesmas que obrigam o organismo a selecionar seus comportamentos, e não a atividade intelectual inicial que procura ativamente o verdadeiro. Igualmente, são as pessoas exteriores que canalizam os sentimentos elementares da criança, e não estes que tendem, por si próprios, a se regularizarem do interior." (1977, p. 345). A
} 
Nessa afirmação de Piaget, já está implícito que as relações de coação, por si mesmas, são insuficientes para tirar a criança do egocentrismo. Para tanto, novas relações são necessárias: as relações de cooperação. Com efeito, somente destas últimas surgem relações morais novas, em função sobretudo dos progressos da cooperação entre as crianças, concomitantes aos progressos no plano da cognição (com as operações). Com esses progressos, a criança passa a exigir a reciprocidade na estima e o respeito torna-se mútuo, conduzindo assim para uma moral autônoma.

Do ponto de vista dos valores, a moral do respeito mútuo se opõe à do respeito unilateral. Entretanto, do ponto de vista da "causalidade da evolução", a primeira procede da segunda:

(...) à medida em que a criança se torna homem, suas relações com o adulto tendem para a igualdade. O respeito unilateral, próprio à coação, não é uma forma estável de equilíbrio, e o equilíbrio para o qual tende não é outra coisa senão o respeito mútuo. (Piaget, 1977, pp. 288-9)

O respeito mútuo surge na medida em que a criança estabelece relação com seus iguais ou com os que tendem a tornar-se tais, mesmo sendo adultos, pois nesse caso é "feita abstração de qualquer autoridade" (Piaget, 1988, p. 67). Conforme a criança cresce, ela descobre que o próprio adulto submete-se ou procura se submeter às recomendações que faz, de modo que a lei é sentida como superior aos seres respeitados. Ademais, a criança "faz a experiência da multiplicidade de recomendações", devendo efetuar opções e estabelecer hierarquias por si mesma (pp. 66-7). Nesse processo de transição, decorrente sobretudo das relações de cooperação, o "elemento quase material de medo", presente no respeito unilateral, desaparece "em favor do medo totalmente moral de decair aos olhos do indivíduo respeitado" (1977, p. 331). O medo continua como uma espécie de nexo entre uma moral e outra, mudando porém o seu

dimensão social, nesse texto, cumpre um papel capital, a tal ponto que Piaget chega a afirmar que "a razão, sob seu duplo aspecto lógico e moral, é um produto coletivo", pois somente na relação com os outros é que o indivíduo é capaz de tomar consciência dessa procura funcional de organização imanente às suas ações. $O$ espírito tira normas desse funcionamento, constitui estruturas ou normas pela via de uma tomada de consciência dos equilíbrios funcionais. Desse processo resulta a "consciência lógica" e a "consciência moral" (p. 346). A primeira concerne ao que também chama de consciência intelectual ou razão pura, relativa portanto ao desenvolvimento cognitivo e ao conhecimento; enquanto a segunda concerne ao que também chama de razão prática, conforme a terminologia que empresta de Kant (Piaget, 1988, p. 65). Quanto a essas diversas ênfases e nuanças presentes nos diferentes escritos piagetianos, neste estudo não se pretende aprofundar essa discussão, já feita inclusive por outros autores, como Freitag (1985). 
caráter. O mesmo ocorre com o sentimento do dever: os deveres decorrem agora de obrigações mútuas estabelecidas de comum acordo. O respeito unilateral, que é uma forma precária de equilíbrio, tende então para uma forma de equilíbrio superior, conforme um processo de equilibração peculiar:

(...) a necessidade de ser respeitado equilibra, por conseguinte, a de respeitar, e a reciprocidade que resulta desta nova relação basta para aniquilar qualquer elemento de coação. A ordem desaparece no mesmo tempo para tornar-se acordo mútuo, e as regras livremente consentidas perdem seu caráter de obrigação externa. (1977, p. 331)

Segundo Piaget, as relações de cooperação social e as regras que delas resultam são as únicas democráticas, pois não estão baseadas numa autoridade externa ao sujeito e sim numa autoridade consentida, que resulta da consideração de vários pontos de vista. Ademais, não implica em qualquer imposição, a não ser a que deriva da exigência de reciprocidade, própria desse tipo de relações sociais. Essas relações de cooperação são estabelecidas entre iguais, senão de fato, pelo menos de direito. ${ }^{30} \mathrm{~A}$ idéia de autonomia supõe que os ideais e regras que orientam o indivíduo surjam nessas e dessas relações de reciprocidade, por meio de uma elaboração e um acordo que também devem ser internos. Como afirma Piaget, "a autonomia é um poder que só se conquista de dentro e que só se exerce no seio da cooperação" (1977, p. 321).

O sentimento de justiça surge também em decorrência desses avanços na cooperação social, ele é um produto do respeito mútuo e da reciprocidade. Segundo Piaget, a justiça "sobreleva a própria obediência e torna-se norma central, equivalente, no terreno afetivo, às normas de coerência no terreno das operações cognitivas" (Piaget e Inhelder, 1985, p. 108). ${ }^{31}$ Nesse caso são normas baseadas na reciprocidade, que é uma espécie de lei de equilíbrio das relações sociais. A reciprocidade é um ideal que define o próprio bem (1977, p. 333). Este, portanto, procede das relações de cooperação, ao contrário do dever, cuja origem e gênese diz respeito às relações de coação.

\footnotetext{
${ }^{30}$ A esse propósito, Piaget afirma: "Não existem iguais, senão de direito. Portanto, é bastante possível que o respeito mútuo nunca se apresente no estado puro e constitua, apenas, uma forma ideal de equilíbrio para a qual se orienta o respeito unilateral, quando as desigualdades de idade ou de autoridade social tendem, elas próprias, a desaparecer" (1977, pp. 333-4).

${ }^{31}$ Em relação à justiça, Piaget também distingue períodos de desenvolvimento (1977, pp. 271-80).
} 
A moral autônoma afirma-se no subperíodo das operações concretas, quando as crianças tornam-se capazes de cooperar. Esse desenvolvimento, entretanto, prossegue ainda no período das operações formais. Dadas as novas possibilidades do pensamento formal, a autonomia moral adquire "uma dimensão a mais no manejo do que se poderia denominar valores ideais ou supraindividuais" (Piaget e Inhelder, 1985, p. 128). Em relação a esse terceiro período, Piaget destaca outros aspectos, mas pouco avança, mantendo como fundamental a divisão já estabelecida, entre uma moral heterônoma e outra autônoma. O ponto culminante dessa evolução é o que ele chama de personalidade, isto é, "o indivíduo enquanto se submete às normas da reciprocidade", as quais constituem uma espécie de necessidade interna que impinge o indivíduo a agir moralmente, uma "necessidade interior à própria razão" $\left(1977\right.$, p. 320). ${ }^{32}$

As relações de coação e de cooperação fazem parte do processo de socialização da criança, mas também constituem tipos extremos passíveis de serem encontrados na sociedade. Esta também é concebida como o conjunto das relações sociais e pode tanto contribuir como inibir o desenvolvimento intelectual e moral, pois ele depende dessas relações (Piaget, 1977, p. 342). De modo que as sociedades onde predominam as relações de coação são pouco propícias para 0 desenvolvimento da autonomia intelectual e moral. A cooperação, concebida como um método que obriga os indivíduos a se situarem uns em relação aos outros, é a única forma de relação social capaz de levar à moral do bem, à moral autônoma, além de promover o progresso intelectual (p. 351): "só a cooperação leva à autonomia" (p. 349). A diferença entre a coação e a cooperação é que a primeira impõe regras totalmente elaboradas, enquanto a segunda impõe um método de elaboração das próprias regras, baseado na reciprocidade (p. 84). Para Piaget, esse é o método próprio da democracia e dos sistemas pedagógicos que favorecem o desenvolvimento da personalidade. Ainda sobre a diferença entre as duas, enquanto a coação consagra o que é, a cooperação "é a única a permitir a distinção entre o direito e o fato" (p. 298). Por isso, ela é mais do que

\footnotetext{
32 Piaget distingue o indivíduo da personalidade ou pessoa: "O indivíduo é o eu centrado sobre si mesmo e obstaculizando, por meio desse egocentrismo moral ou intelectual, as relações de reciprocidade inerentes a toda vida social evoluída. A pessoa, ao contrário, é o indivíduo que aceita espontaneamente uma disciplina, ou contribui para o estabelecimento da mesma, e dessa forma se submete voluntariamente a um sistema de normas recíprocas que subordinam a sua liberdade ao respeito por cada um" (1988, p. 52).
} 
um método: a cooperação é o ideal da sociedade democrática (p. 298), a forma ideal de equilíbrio para o qual tende a sociedade que rompeu com o conformismo (p. 299). Desse equilíbrio nos aproximamos na medida em que praticamos esse método, que é justamente a cooperação, a qual se constitui pelo seu próprio exercício (p. 86).

Ao tratar do desenvolvimento moral, Piaget também estabelece diversos paralelos com a evolução das sociedades, em particular quando discute as concepções de Durkheim, no livro 0 juízo moral na criança. ${ }^{33}$ Nesse livro, referese às sociedades primitivas ou inferiores e às nossas sociedades civilizadas ou modernas, tomando como principal padrão de comparação a divisão por ele estabelecida entre relações sociais de coação e de cooperação. As relações de coação, segundo Piaget, são típicas das sociedades inferiores, bem como a moral da autoridade e um tipo de responsabilidade igualmente primitiva (objetiva e comunicável). A evolução dessas sociedades, que se tornaram cada vez mais complexas, com crescente diferenciação social e a concomitante afirmação de relações sociais de cooperação, envolveu também transformações no plano moral, que ocorreram justamente em função das variações relativas à estrutura dessas sociedades (Piaget, 1977, p. 296). ${ }^{34}$ Em outras palavras, em face do crescente predomínio das relações de cooperação, a moral do dever foi cedendo em favor de uma moral do respeito mútuo, uma moral autônoma - um processo que corresponde a "uma espécie de emancipação gradual dos indivíduos" ( $p$. 291). Além das mudanças na noção justiça, que fica desvinculada de qualquer autoridade externa (a tradição, por exemplo), a responsabilidade tornou-se subjetiva e individual, passando a predominar sobre o tipo de responsabilidade primitivo (pp. 183-7). Em suma, para Piaget, as sociedades humanas evoluíram das relações de coação para as relações de cooperação, da heteronomia para a autonomia, da moral do dever para a moral do bem, da "teocracia gerontocrática" para a "democracia igualitária" (p. 280). E essa evolução guarda um forte parentesco com o desenvolvimento moral no indivíduo. Existe aí uma

\footnotetext{
${ }^{33}$ Nesse texto, a evolução das sociedades é uma idéia exposta de um modo mais categórico do que no livro Estudos Sociológicos.

${ }^{34}$ Ao se referir a esse processo, Piaget afirma que houve uma luta entre dois tipos de relações sociais e dois tipos de morais (1977, p. 294).
} 
convergência, como já tinha sido apontado em relação ao desenvolvimento intelectual.

Enfim, todas essas convergências parecem resultar do papel capital atribuído à ação e ao modo de concebê-la: ações orientadas no sentido de criar uma crescente, complexa e coerente ordem sistêmica. Esse é um ponto significante que define o lugar da obra piagetiana e que encontra particular ressonância no discurso pedagógico brasileiro de meados dos anos 90 . Um bom exemplo são os Parâmetros Curriculares Nacionais, dos quais pode-se dizer que foram costurados do mesmo modo. Afinal, eles (re)criam o mesmo ponto significante: o das "ações" ou "medidas" que convergem para criar o Todo sistêmico que os PCN e outras propostas curriculares oficiais sustentam e promovem.

\subsection{A educação da criança piagetiana}

Para concluir o nosso percurso pela obra do epistemólogo suíço, sempre tendo em vista a criança piagetiana e a "visão de sistema" que lhe é inerente, veremos agora alguns aspectos relacionados com as suas reflexões sobre educação.

Da sua teoria psicogenética, Piaget não deixou de tirar conseqüências para a educação e o ensino, apesar das advertências que fez a esse respeito. ${ }^{35} \mathrm{~A}$ começar pelo principal objetivo da educação: o pleno desenvolvimento da personalidade. Um objetivo relacionado com a sua concepção de desenvolvimento psíquico, mas também com a Declaração Universal dos Direitos do Homem aprovada pelas Nações Unidas e que ele comenta no texto em que destaca esse objetivo (1988, p. 51). ${ }^{36}$ Piaget também afirma, por exemplo, que cabe à "sociedade fixar os objetivos da educação que ela fornece às gerações

\footnotetext{
${ }^{35}$ Entre outras coisas, Piaget adverte que a "Pedagogia está longe de ser uma simples aplicação do saber psicológico" e afirma que "só a pedagogia experimental é competente" (1977, p. 352).

${ }^{36}$ Esse texto de Piaget, de 1948, toma como ideal da educação o que é definido no artigo 26 da Declaração Universal dos Direitos do Homem, aprovada pelas Nações Unidas nesse mesmo ano: "A educação deve visar ao pleno desenvolvimento da personalidade humana e ao fortalecimento do respeito pelos direitos do homem e pelas liberdades fundamentais" (1988, p. 27). Esse amplo objetivo é discutido por Piaget a partir das suas concepções sobre o desenvolvimento psíquico, afirmando que ele "consiste em formar indivíduos capazes de autonomia intelectual e moral e respeitadores dessa autonomia de outrem, em decorrência precisamente da regra de reciprocidade que a torna legítima para eles mesmos" (p. 53).
} 
ascendentes" (1998, p. 26) e que educar é "adaptar" o indivíduo ao meio social adulto, isto é, "transformar a constituição psicobiológica do indivíduo em função do conjunto de realidades coletivas às quais a consciência comum atribui algum valor" (pp. 139 e 154). Ao destacar a "adaptação", o que Piaget faz não é mais do que tornar central o que constitui o eixo da "personalidade" antes referida: o sujeito epistêmico, o sujeito da inteligência. Afinal, "a inteligência é a adaptação por excelência" (1998, p. 161). Ou seja, com a "adaptação", o que fundamentalmente sobrevém é "a criança que constrói seu próprio conhecimento", se quisermos usar a articulação significante empregada no discurso pedagógico construtivista. A adaptação aí também deve ser entendida sob o horizonte da democracia, pois, em última instância, ela supõe uma evolução cujo ideal é a sociedade democrática, é claro que nos termos sistêmicos em que Piaget a concebe. $^{37}$

Quando Piaget trata de questões educacionais, em particular nos textos mais antigos, o papel da dimensão social é especialmente destacado, à semelhança do que ocorre quando trata dos aspectos afetivos. Em "O direito à educação no mundo atual", publicado no final da década de 40, o fator social ou educativo constitui uma condição fundamental do desenvolvimento:

Falar de um direito à educação é pois, em primeiro lugar, reconhecer o papel indispensável dos fatores sociais na própria formação do indivíduo. (p. 29)

(...) a educação não é uma simples contribuição que se viria a acrescentar aos resultados de um desenvolvimento individual espontâneo ou efetuado com o auxílio apenas da família (1988, p. 35).

Esse papel tão preponderante atribuído à educação, aí incluída a educação escolar, é afirmado em face do que a criança dispõe no início da sua vida:

(...) a evolução interna do indivíduo apenas fornece um número mais ou menos considerável, segundo as aptidões de cada um, de esboços suscetíveis de serem desenvolvidos, anulados ou deixados em estado inacabado. Trata-se porém apenas de esboços, e unicamente as

\footnotetext{
${ }^{37}$ Essas diversas formulações sobre os fins ou objetivos gerais da educação, de textos e períodos diferentes, são feitas em escritos que não tem como única referência a sua teoria psicogenética, pois Piaget também alude, por exemplo, à evolução da pedagogia e da psicologia, aos métodos de ensino, às disciplinas escolares, à formação dos professores e a experiências pedagógicas que visitou e conheceu.
} 
interações sociais e educativas haverão de transformá-los em condutas eficazes ou destruí-los para sempre. (ibidem)

A educação então é essencial para que esses esboços se afirmem e se transformem em condutas cada vez mais evoluídas, na sua dupla dimensão intelectual e moral. Mas não é qualquer educação a que pode propiciar o desenvolvimento da personalidade. Dado esse objetivo geral, Piaget discute um problema central no âmbito do discurso pedagógico e que pode ser assim formulado: "como" educar?, como alicerçar e nutrir esse processo de desenvolvimento?, como formar enfim a personalidade, o indivíduo capaz de autonomia moral e intelectual? É o clássico problema dos meios ou dos métodos, de extrema relevância para Piaget, pois "semelhante ideal não poderia ser alcançado por qualquer um dos métodos em vigor" (1988, p. 71). E aqui a sua posição é clara: contra a escola tradicional e os métodos tradicionais e a favor da escola ativa e dos métodos ativos - significantes que já evidenciam o que para Piaget era essencial: a atividade, a ação.

Os métodos que Piaget defende são aqueles que se aproximam ou que correspondem ao modo como ele próprio conceitualiza a ação. Esta, como já vimos, é o que unifica os aspectos por Piaget separados para analisar as várias linhas de desenvolvimento do mesmo processo de conjunto, relativo justamente à evolução das ações. Uma educação adequada a esse processo, com aspectos e desenvolvimentos considerados indissociáveis, na perspectiva piagetiana é uma educação que também deve ser pensada como um todo indissociável. Em outras palavras, a educação intelectual e a educação moral não podem nem devem ser separadas:

Na realidade, a educação constitui um todo indissociável, e não se pode formar personalidades autônomas no domínio moral se por outro lado o indivíduo é submetido a um constrangimento intelectual de tal ordem que tenha de se limitar a aprender por imposição sem descobrir por si mesmo a verdade: se é passivo intelectualmente, não conseguiria ser livre moralmente. Reciprocamente, porém, se a sua moral consiste exclusivamente em uma submissão à autoridade adulta, e se os únicos relacionamentos sociais que constituem a vida da classe são os que ligam cada aluno individualmente a um mestre que detém todos os poderes, ele também não conseguiria ser ativo intelectualmente. (1988, p. 61)

Para Piaget, os métodos ativos são os únicos que mantém essa visão de conjunto e que consideram o "paralelismo" existente entre a formação moral e a 
formação intelectual (1988, p. 33). Ademais, colocam no centro do processo a ação da criança, que por si mesma deve construir o conhecimento e os seus valores e regras morais. $O$ direito à educação implica justamente o direito da criança a agir, o direito a construir, a fazer a sua própria construção (1988, pp. 2935). Essa construção é necessária porque nem a lógica nem as regras e sentimentos morais são inatos. A criança precisa construí-los, o que não significa que o faça solitariamente, muito pelo contrário. Daí o grande valor que o pesquisador suíço atribuiu à educação e à dimensão social, em particular às relações de cooperação. Para formar a personalidade é necessário que a criança participe de relações de cooperação, cabendo à escola fomentá-las entre os alunos e entre eles e o professor. Entre outras coisas, isso requer um ambiente de liberdade, onde as crianças possam atuar de modo espontâneo e natural, movidas pelas suas necessidades e interesses e sem que sejam constrangidas por regras impostas externamente.

Em seus efeitos sobre a criança, as relações de cooperação coincidem com - que o próprio funcionamento da inteligência produz, nesse caso um funcionamento cujas características prolongam a ordem biológica. Essa "feliz" coincidência entre a ordem natural e social, apesar de virtualmente dada, pois toda evolução humana como que confirmaria esse fato, deve ser criada. E aqui entra o método do professor e o seu papel, próprio de quem é capaz de deixar de lado a autoridade que tradicionalmente lhe é conferida para tornar-se "um simples companheiro para as crianças". A esse respeito vale lembrar que, para Piaget, o que procede de uma relação hierárquica e assimétrica, como a do adulto com a criança, está relacionado em sua teoria psicogenética com que há de mais primitivo, de menos evoluído. É a fonte de boa parte do que na educação deve ser evitado e do que necessariamente é deixado para trás no desenvolvimento intelectual e moral. Tal é o caso, por exemplo, da sanção expiatória ou das formas primitivas da justiça retributiva (1977, p. 254). Disso tudo decorre o valor que Piaget atribui à relação entre as crianças e o particular papel imputado ao professor, como pode ser visto em 0 juízo moral na criança, quando critica Durkheim e a sua concepção de disciplina:

(...) não acreditamos absolutamente, com Durkheim, que caiba ao professor impor ou sequer "revelar" a regra à criança. Abstenhamo-nos de fazer do professor da escola um "sacerdote": é um colaborador mais velho 
e, se tem envergadura para isto, deve ser um simples companheiro para as crianças. Só então surgirá a verdadeira disciplina, consentida e desejada pelas próprias crianças. (1977, p. 314)38

A verdadeira disciplina é a que surge nas relações de cooperação. São regras fundadas no respeito mútuo e na reciprocidade, regras que a criança incorpora porque participou da sua elaboração, compreendeu o seu sentido e concordou, passando então a desejá-las. Para Piaget, a escola deveria criar as condições necessárias para que isso ocorra, para que a prática de democracia seja uma realidade no seu interior, pois as crianças são capazes de democracia (1977, p. 317). Em outras palavras, nas relações de cooperação e obrigadas pelo respeito mútuo, as crianças são capazes de elaborar a regra que as obriga.

Embora Piaget defenda essa idéia, não deixa de notar que às vezes não é possível empregar esse método, sendo inevitável dar ordens que devem ser cumpridas sem que a criança compreenda. Defende a prática da cooperação, a prática da democracia na escola, "desde que esta seja psicologicamente possível" (1977, p. 319). Piaget não descarta portanto a "pressão do adulto", que corresponde à socialização típica da escola tradicional. Esse "mecanismo de pressão", ao qual é reduzida a socialização no caso da educação tradicional, também está presente na escola ativa, na avaliação do próprio Piaget. Segundo ele, na escola ativa são distinguidos "dois processos de resultados bem diferentes e que só se tornam complementares com muito cuidado e tato: a pressão do adulto e a cooperação das crianças entre si" (1998, p. 182).

Enfim, a construção de conhecimentos e das regras e valores morais "requer uma ambiência social específica, constituída não apenas de submissão" (1988, p. 33). É necessário criar um ambiente de cooperação, "uma atmosfera social constituída de afeição e de liberdade (isto é, não de obediência, mas de responsabilidade livremente assumida" (p. 64), caso contrário será inibido o processo de desenvolvimento intelectual e moral.

Para Piaget, a escola constitui um meio social formador fundamental e o seu papel não pode ser reduzido à mera instrução (1988, pp. 29-35). Nesse

\footnotetext{
${ }^{38}$ A referência de Piaget ao professor como um "sacerdote" está relacionada com o fato de Durkheim conceber desse modo o papel do "professor leigo", como um sacerdote da sociedade (Piaget, 1977, p. 309).
} 
sentido é semelhante à família, desta se diferenciando em outros pontos. A escola, por exemplo, é "o lugar de transição necessário" para o âmbito social mais amplo (1977, p. 319). Mas também é muito mais do que isso, se considerarmos o seu papel na formação do indivíduo e, por essa via, na própria possibilidade de vir a se firmar uma sociedade democrática. Sobre a escola na verdade recai o forte valor que Piaget atribui aos processos genéticos e construtivos, implicando a exigência de nela serem desenvolvidas relações de cooperação, pelo menos se o horizonte for uma sociedade democrática - ou seja, relações sociais baseadas na reciprocidade e na cooperação. Nessa perspectiva, portanto, a democracia na escola e a democracia na sociedade encontram-se mutuamente implicadas, são indissociáveis, como provavelmente diria Piaget.

A educação intelectual e a educação moral, embora indissociáveis, também são abordadas por Piaget separadamente para tratar das suas especificidades. Para cada uma Piaget define objetivos e discute formas do professor proceder em razão das questões próprias de cada tipo de formação. Nesse ponto, relativo à metodologia do professor, as suas recomendações seguem um postulado geral: "Há pois que ser realizado todo um ajustamento dos métodos didáticos aos dados psicológicos do desenvolvimento real" (...)" (1988, p. 59). ${ }^{39}$ Esse postulado geral, de forte ressonância no discurso pedagógico construtivista, é desdobrado por Piaget de acordo com as especificidades de cada formação (intelectual ou moral) e das áreas do conhecimento envolvidas. No caso da "metodologia da matemática", por exemplo, ele faz recomendações para que sejam consideradas as "leis de evolução" da elaboração intelectual espontânea, nesse caso das noções matemáticas. Essas noções "principiam por uma construção qualitativa antes de adquirirem caráter métrico" e primeiro exigem a ação efetiva, concreta, exercida sobre as coisas, para depois alcançar a abstração (1988, p. 59). Seja qual for a área do conhecimento envolvida ou o tipo de formação em questão, o

\footnotetext{
${ }^{39}$ Esse postulado é formulado de diversas maneiras, em diferentes textos e períodos, como se observa nestes trechos:

Se o pensamento da criança é qualitativamente diferente do nosso, o objetivo principal da educação é compor a razão intelectual e moral; como não se pode moldá-la de fora, a questão é encontrar o meio e os métodos convenientes para ajudar a criança a constituí-la ela mesma, isto é, alcançar no plano intelectual a coerência e a objetividade e no plano moral a reciprocidade.

(Piaget, 1998, p. 163)

(...) conhecer suficientemente as leis do desenvolvimento mental para encontrar os métodos mais adequados ao tipo de formação educativa desejada. (Piaget, 1998, p. 20)
} 
professor deve ajustar ou adequar seus métodos ao desenvolvimento da criança, à evolução de seus sistemas de ação, das construções que realiza e das noções que elabora. Por isso, conhecer a criança é fundamental. $O$ professor deve procurar ter acesso ao processo de construção da criança para assim definir os estímulos adequados a cada aluno, de maneira que esses estímulos possam se tornar fonte de perturbações ou de conflitos cognitivos que o façam avançar.

As idéias que Piaget defende em relação à educação e o ensino não têm como única fonte a psicologia ou as pesquisas e experiências desenvolvidas por ele e seus colaboradores. Em áreas como matemática e física, desenvolve as suas idéias apoiando-se diretamente nos resultados obtidos em pesquisas que realizou e que tinham como principal foco o sujeito epistêmico - desvinculadas portanto de questões especificamente escolares. Entretanto, Piaget também menciona instituições que visitou ou conheceu, diretamente ou através de estudos e livros, pontuando um ou outro aspecto, como o trabalho em grupo, o autogoverno e o ensino baseado no interesse e na atividade. Além disso, recorre à história da educação e da pedagogia, mencionando diversas obras e autores para discutir e avaliar os métodos de ensino. Nesse tipo de discussão sempre se posiciona em favor dos métodos ativos e a escola ativa ou da educação e escola modernas, contrapondo-se sobretudo à escola tradicional e ao empirismo, que é a posição epistemológica que Piaget mais combateu, vinculando-a ao ensino tradicional (Piaget, 1977, 1988, 1998).

O que Piaget reunia sob o significante escola ou ensino tradicional por vezes envolvia autores e posições que hoje em dia poderiam provocar certo estranhamento, em particular se considerarmos os pontos de estrutura do discurso pedagógico construtivista. É o que se observa no texto que segue, onde o que está em causa é o inatismo e seus desdobramentos na escola:

Por muito tempo se acreditou que a lógica fosse inata no indivíduo (...) Descartes assim considerava o "bom-senso", isto é, a faculdade de raciocinar logicamente, como sendo a coisa mais corriqueira do mundo, e Rousseau baseava todo o seu sistema pedagógico na oposição entre as perfeições congênitas do indivíduo e os desvios posteriores decorrentes da vida social. Essas são as noções que inspiraram as doutrinas da escola tradicional: estando o homem preformado já na criança, e consistindo o desenvolvimento individual apenas em uma atualização de faculdades virtuais, o papel da educação se reduz então a uma simples instrução; trata-se exclusivamente de enriquecer ou alimentar faculdades já 
elaboradas, e não de formá-las. Basta, em suma, acumular conhecimentos na memória, ao invés de conceber a escola como um centro de atividades reais (...) $(1988$, pp. 30-1)

O discurso pedagógico construtivista opera com um outro recorte, pelo menos quando faz corresponder o empirismo à escola tradicional e o inatismo a certa perspectiva pedagógica situada no extremo oposto e que às vezes é fixada por meio do significante-mestre espontaneísmo. Nessa articulação discursiva, o construtivismo pedagógico ocupa um lugar equidistante dos extremos. Agora, se considerarmos o texto de Piaget acima citado, pode-se dizer que esses extremos desaparecem sob o significante-mestre escola tradicional, pois os desdobramentos do empirismo e do inatismo ficam sob a órbita desse significantemestre. A união desses extremos pode ser observada ainda no trecho que segue, onde certo empirismo, em sua aplicação pedagógica, aproxima-se do inatismo:

(...) um tal empirismo implica, apesar de tudo, na noção de uma estrutura assimiladora que evolui com a idade. Limitemo-nos a observar que, em suas aplicações pedagógicas, a doutrina chega a um otimismo tão grande como se o desenvolvimento fosse inteiramente determinado por fatores de maturação interna. De fato, na pequena escola de Malting House, em Cambridge, Mrs. Isaacs e seus colaboradores se abstinham rigorosamente de qualquer intervenção adulta (...) (Piaget, 1998, p. 172)

Em relação a esse particular encontro entre posições concebidas como opostas, cabe lembrar que no discurso pedagógico construtivista essa aproximação também é feita quando está em causa a prática pedagógica. Por exemplo, nas falas que fazem confluir as posturas do professor consideradas equivocadas, sejam elas concebidas como tradicionais ou espontaneístas. Nesse caso, esses pólos ou extremos confundem-se no lugar que é próprio dos "desvios, confusões, equívocos ...", como já foi assinalado no capítulo anterior. Quanto ao lugar que nesse discurso pedagógico surge sob o significante espontaneísmo, ele corresponde ao lugar que Piaget recusa quando lembra daquela escola de Cambridge em que se abstinham de "qualquer intervenção adulta". Desse extremo Piaget também procura se distanciar, como pode ser observado nestes trechos sobre a escola ativa ou moderna:

A escola moderna, ao contrário [da escola tradicional], apela para a atividade real, para o trabalho espontâneo baseado na necessidade e no interesse pessoal. Isto não significa, como diz muito bem CLAPARÈDE, que a educação ativa exige que as crianças façam tudo o que queiram; "ela exige que eles queiram tudo o que façam: que ajam, não que sejam manipulados" (...) (Piaget, 1998, p. 155) 
Certamente, salvo alguns casos extremos, os novos métodos de educação não tendem a eliminar a ação social do professor, mas a conciliar com o respeito do adulto a cooperação entre as crianças, e a reduzir, na medida do possível, a pressão deste último para transformá-la em cooperação superior (ibidem, p. 184)

Nessas ponderações de Piaget pode ser vislumbrado o "terceiro lugar" ou "ponto de equilíbrio" (re)configurado pelo discurso pedagógico construtivista e que Piaget também cria quando trata das aplicações pedagógicas das pesquisas psicológicas, dos métodos novos de educação e da escola ativa, à semelhança do que ele formula quando situa a sua concepção construtivista no campo da epistemologia e das teorias psicológicas. Segundo Piaget, as pesquisas psicológicas relativas ao desenvolvimento da inteligência e das estruturas cognitivas permanecem distribuídas "em três direções cujos significados são bastante diferentes no que diz respeito às aplicações pedagógicas" (1988, p. 10). Refere-se aí, em síntese, ao empirismo, ao inatismo e à "terceira direção", de "natureza construtivista" (ibidem,pp. 10-1). Em relação aos métodos novos e à escola ativa, Piaget lembra da "doutrina do justo meio":

Quanto aos métodos novos de educação que tiveram o êxito mais duradouro e constituem sem dúvida o ponto de partida da escola ativa de amanhã, eles se inspiram todos mais ou menos na doutrina do justo meio, dando lugar de um lado à maturação estrutural e de outro às influências da experiência e do meio social e físico. Ao contrário da escola tradicional, que nega a existência do primeiro desses fatores, identificando desde o início a criança ao adulto, esses métodos consideram os estágios de desenvolvimento mas, ao contrário das teorias baseadas na noção de maturação puramente hereditária, acreditam na possibilidade de agir sobre essa evolução. (1998, p. 173)

Enfim, em Piaget, os lugares relativos aos três pontos de estrutura do discurso pedagógico construtivista encontra-se claramente estabelecidos, mas a sua análise nem sempre fica restrita ao que essa estrutura impõe, como pode ser observado quando trata dos "métodos intuitivos" (1998, p. 77) ou na já referida inclusão dos desdobramentos do inatismo no âmbito da escola tradicional. 


\section{Da realidade da criança ao padrão nacional}

O objetivo desta segunda parte é evidenciar alguns dos efeitos da unificação que é própria do "caminho construtivista" até o momento em que surge a proposta curricular que tenciona ordenar todas as escolas do país, na segunda metade da década de 90. Dentre esses efeitos, o que aqui será focalizado diz respeito às crianças/alunos destacados pela revista Nova Escola em algumas edições e capas.

Nos primeiros anos dessa publicação, vez por outra as crianças/alunos eram caracterizados tendo em vista $\circ$ que $\circ$ significante realidade então condensava, relacionado sobretudo com questões de ordem social e cultural. Quer dizer, aludia-se às crianças/alunos fazendo-se referência ao contexto em que viviam, ao grupo social a que pertenciam, às características do bairro e da família, não preponderando um tipo de caracterização psicológica ou referenciada em níveis ou estágios, fossem eles relacionados ou não a determinada área do conhecimento, como é o caso dos níveis de conceitualização relativos à psicogênese da língua escrita. Digamos que nesses primeiros anos a "realidade da criança" e a diversidade social e cultural nela implicada ainda não havia sido sobrepujada pela "criança que constrói seu próprio conhecimento" nem por qualquer outro modelo ou paradigma característico do "caminho construtivista". Para aproximarmo-nos do sentido e amplitude do que a "realidade da criança" então definia, uma via possível é atentar para as imagens e manchetes de todas as capas do primeiro ano da revista Nova Escola em que aparecem crianças/alunos. Vejamos então essas capas:

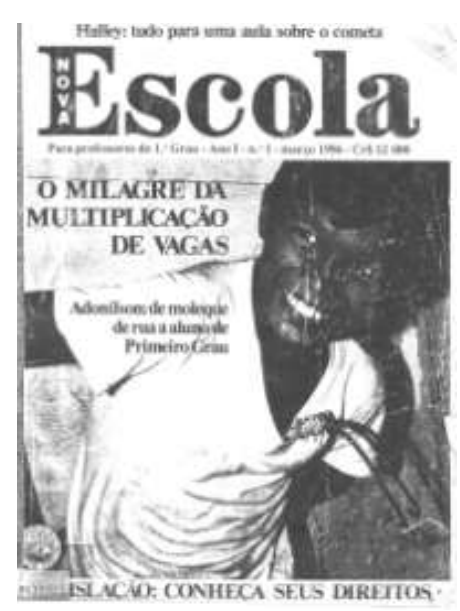

março

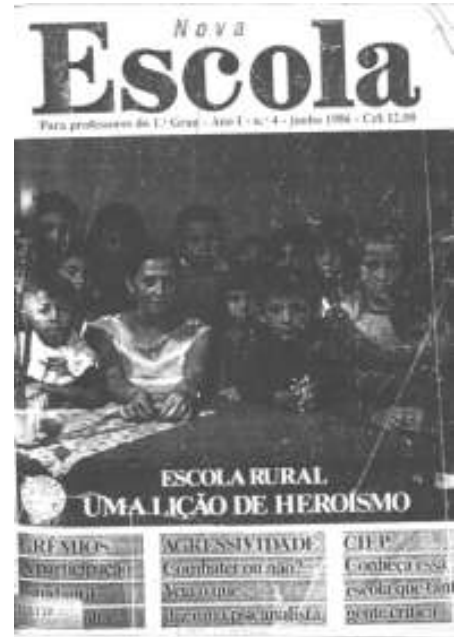

junho

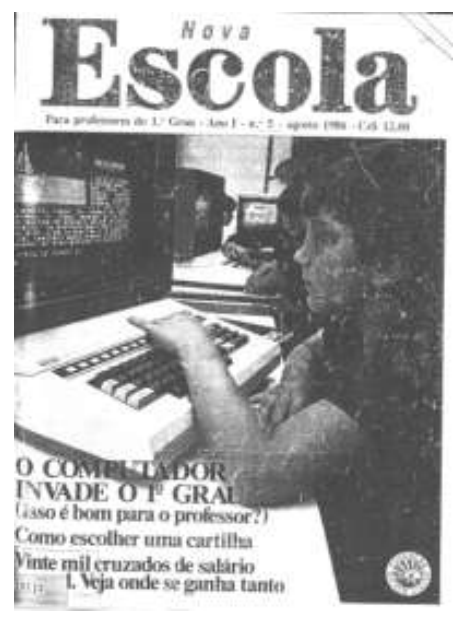

agosto 


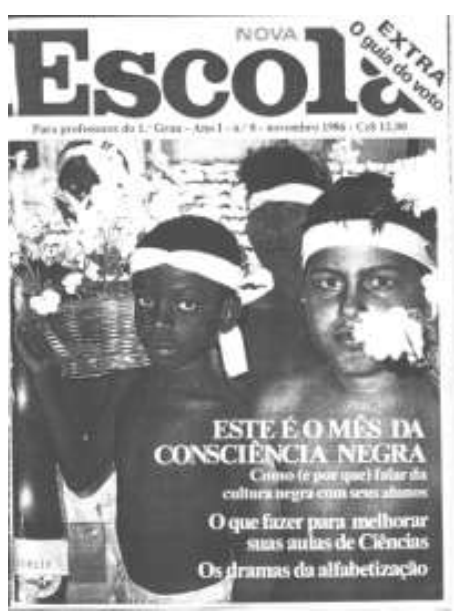

novembro

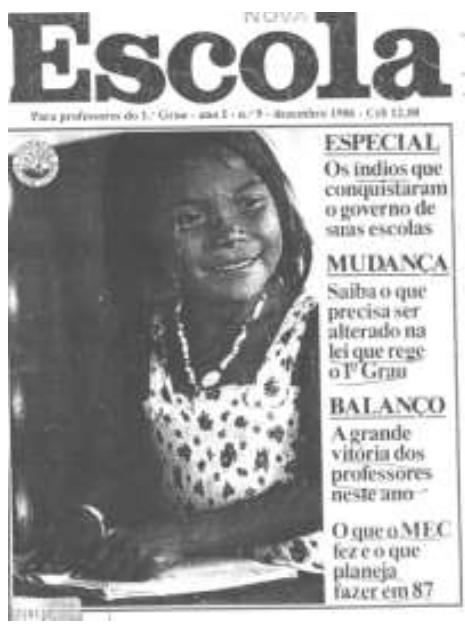

dezembro

Uma observação superficial das capas de 1986 rapidamente situa em que consiste a "realidade da criança" que a Nova Escola configura e destaca nesse período. Por certo, é uma "realidade" social e cultural bem diversa: um "moleque de rua", alunos de uma "escola rural" acompanhados pela sua professora, um aluno usando um computador, uma menina índia e alguns alunos negros no "mês da consciência negra". Para aproximarmo-nos um pouco mais dessa "realidade" e da diversidade aí implicada vale a pena reparar em outros aspectos relacionados com essas capas ou apresentados nas matérias correspondentes. Por exemplo, o que a capa de agosto destaca é antes de mais nada "o computador" e secundariamente um aluno de uma escola particular, do colégio Objetivo de São Paulo. ${ }^{40}$ Portanto, uma criança de um grupo social privilegiado, à diferença do que se observa em todas as demais capas desse ano com fotos de crianças/alunos. Há, pode-se dizer, um nítido predomínio de "realidades" de grupos ou setores sociais de baixa renda, marginalizados, historicamente oprimidos ou que precisam enfrentar e superar diversas dificuldades para ter acesso à escola.

Esse é o caso do Adonilson, o sorridente menino da primeira capa da Nova Escola. Ainda com o seu estilingue pendurado na camiseta, numa foto que desse modo delimita o lugar do aluno e da escola que a revista já começa a configurar, o menino Adonilson - transformado em "aluno de Primeiro Grau" — é um exemplo de "O milagre da multiplicação de vagas" destacado na primeira reportagem de

\footnotetext{
${ }^{40}$ Veja-se os créditos da foto de capa, p. 3.
} 
capa. ${ }^{41} \mathrm{O}$ texto da reportagem começa precisamente situando quem é Adonilson, para depois explicar como está ocorrendo essa "multiplicação de vagas":

Adonilson Moraes da Rocha, 10 anos, pequena estatura, corpo franzino. Durante muito tempo, cheirava cola e fumava como adulto, enquanto vadiava pelas ruas. Seu pai vendia sacos, sua mãe trabalhava como doméstica. Assim era a vida que Adonilson ia levando.

No ano passado, a Secretaria de Educação de Manaus instalou doze barracas de lona, em praças do centro e dos bairros da cidade. Nelas se abrigam 600 crianças, com idades de 7 a 14 anos, que abandonaram uma vida de pedinte. Ali elas começaram a ficar cerca de dez horas por dia. Estudam, trabalham e se alimentam. (p. 47)

A reportagem é aberta com a foto de uma escola-barraca na rua e fotos de Adonilson e outros alunos. No olho que sucede ao título, lembra-se que "São cinco milhões as crianças que não obtêm vagas nas escolas espalhadas pelo Brasil" e a matéria trata justamente das iniciativas que procuram "ampliar o número de vagas" com "arrojo e inventividade". Em relação à Adonilson, a reportagem continua a mencionar aspectos relativos à vida que levava na rua e à sua mudança quando começou a freqüentar as barracas da prefeitura. São também reproduzidas algumas críticas feitas a esse projeto e apresentadas outras iniciativas, desenvolvidas em Recife (escolas dentro de ônibus) e em Brasília (escolas funcionando em barracas).

Em relação à edição de junho/86, com a foto de uma professora com seus alunos da escola rural, a reportagem correspondente logo destaca uma foto que ocupa as duas primeiras páginas com a imagem de quatro crianças atravessando um rio numa canoa, quando estão retornando da escola. Sobre essa imagem, além de ter sido impresso o título ("Aventuras e heroísmo nas escolas de Cananéia") e as legendas dessa e de outras fotos, encontra-se o texto do olho que abre a reportagem e que assim começa:

Viajar de pé, em frágeis canoas e, na mata, se expor ao perigo de cobras, onças e aranhas são alguns dos muitos sacrifícios feitos por alunos e professores das 19 escolas das ilhas paulistas de Cananéia, próximas ao Paraná. ${ }^{42}$

${ }^{41}$ Cf. "O milagre da multiplicação. Escolas improvisadas criam novas vagas", Nova Escola, n 1 , março/86, pp. 46-9.

${ }^{42}$ Cf. "Aventuras e heroísmo nas escolas de Cananéia", Nova Escola, nº 4, junho/86, p. 8. 
Ao longo da reportagem são reproduzidas as falas de moradores, alunos e professores das escolas rurais da região, dentre elas as da professora destacada na capa, Maria Silva Freitas, que fala sobre as dificuldades que tem de enfrentar como professora de uma escola rural. Mas o que está em causa não são assuntos de ordem pedagógica ou didática e sim relacionados com as condições em que ela e seus alunos vivem e estudam:

Esteve, por exemplo, na escola do Taquari, de onde saiu depois que seu filho nasceu, porque lá não havia água potável.

- Nós usávamos a água do rio, que pegávamos com um balde. Era uma água suja. Às vezes morriam bois dentro do rio e seus restos ficavam boiando.

Outra escola em que ela trabalhou, a de Lages, é uma das de mais difícil acesso naquela região. Para chegar até ela é preciso atravessar dois quilômetros sobre pedras grandes e altas, depois andar mais seis quilômetros pela praia. Maria conta:

- Uma vez escorreguei nas pedras e sofri um deslocamento de rótula numa das pernas. Fiquei 15 dias com o joelho enfaixado, em Cananéia. A rótula ficou mal fixada até no final do ano. Soltava quando alguma coisa batia nela. Acabaram as aulas e saí da escola, para as férias, acompanhada por um aluno. Estávamos andando por cima das pedras e, de repente, esqueci da rótula. Tentei subir numa pedra maior, escorreguei e caí no chão. Desta vez, a perna ficou roxa e tive de engessá-la. (ibidem, p. 10)

Em novembro, no "mês da consciência negra", o destaque é para a "Cultura Negra", se considerarmos o que é realçado no título da reportagem. ${ }^{43}$ Quanto aos alunos destacados na capa, eles pertencem à Escola Barão de Macaúbas, segundo o que pode ser inferido ao serem observadas outras fotos presentes na reportagem e as legendas correspondentes. Trata-se de uma escola que desenvolve o Projeto Zumbi, lançado em 1984 pela Secretaria de Educação e Cultura do Rio de Janeiro. Com esse projeto, apoiado pela sua diretora - "que por ser negra teve que enfrentar a oposição de um ativo setor da comunidade quando assumiu o cargo" -, as crianças "são introduzidas na cultura negra através das artes" (p. 18). Ao longo da reportagem, entre outras coisas destaca-se a figura de Zumbi e a história do Quilombo dos Palmares, menciona-se o Movimento Negro Unificado, fala-se da luta contra os preconceitos raciais e a discriminação que as crianças negras sofrem nas escolas públicas, dos esforços

\footnotetext{
${ }^{43}$ Cf. Cultura Negra. Um assunto que a História oficial esqueceu", Nova Escola, n 8, nov./86, pp.
} 12-8. 
para introduzir a História do Negro nos currículos oficiais e da Mini-Comunidade Obá Biyi - uma escola da periferia de Salvador "idealizada pela Yalorixá (o mais alto posto na hierarquia feminina do Candomblé)" e "mantida durante algum tempo com verbas do Ministério da Educação" e com professores pertencentes à Secretaria Municipal de Educação (pp. 14-15). Em alguns momentos, o trabalho desenvolvido junto aos alunos é brevemente descrito, falando-se também dos preconceitos presentes em livros didáticos enviados às escolas pelo MEC.

A última edição de 1986 apresenta uma menina índia que, tudo indica, é de uma das aldeias mencionadas na reportagem. Ela freqüenta uma das escolas que as próprias "tribos decidem como deve ser", de acordo com o que é destacado no título. ${ }^{44}$ A principal referência dessa matéria são experiências desenvolvidas em escolas do Acre e do sul do Amazonas integradas "ao projeto Uma experiência de Autoria, desenvolvido há quatro anos pela Comissão Pró-índio - CPI, do Acre, em convênio com a Fundação Nacional do Índio - Funai" (p. 20). O projeto, segundo a matéria, "adota uma proposta de interação, rejeitando o conceito de integração do índio à sociedade, dominante na maioria das escolas indígenas do país" ( $p$. 20). À semelhança de outras reportagens desse período, a matéria é iniciada recuperando aspectos peculiares a determinada experiência, relacionados nesse caso com o perfil de seus alunos e com a escola em questão, sendo também brevemente descritas situações em sala de aula. Eis os primeiros parágrafos:

Para os alunos da aldeia de Paroá, à beira do rio Envira, no interior do Acre, tudo é novidade. Sol ardente, pés descalços, carregando às vezes apenas um caderno e um lápis, eles se dirigem apressados para a aula, onde vão aprender Estudos Sociais, Matemática e tomar conhecimento do que é um ônibus, um avião ou a luz elétrica.

A escola é construída de palha e coberta com folhas de palmeira. Lá dentro, regida por professores índios, a aula se desenrola devagar, sem nenhum burburinho que atrapalhe. Apenas os sons da mata que circunda a cabana concorrem com as explicações do monitor.

(...)

Para lidar com os números, tirar porcentagem ou fazer regra de três, os alunos costumam usar também grãos de milho, ou palitinhos de madeira, que são manuseados com rara habilidade. (p. 18)

\footnotetext{
${ }^{44}$ Cf. "Educação Indígena. Tribos decidem como dev

e ser sua escola", Nova Escola, n 9, dez./86, pp. 18-23.
} 
Pela via que esses primeiros relatos estabelecem, posteriormente a reportagem trata de aspectos de natureza mais geral, como o vínculo com o projeto já mencionado, objetivos da educação indígena ("um convívio não submisso com o branco") e as tentativas de "integração" levadas a cabo por grupos de missionários e que são fortemente criticadas. Também são mencionadas outras experiências similares à experiência descrita no início da reportagem, com relatos sobre a atuação dos professores índios (ou monitores) e a confecção de cartilhas e livros com histórias que fazem parte da tradições orais dos povos indígenas. Quando está em foco a formação dos monitores e o trabalho de alfabetização destaca-se o uso do Método Paulo Freire. Ademais, não deixa de comparecer o significante "escola tradicional" para definir o que seria contrário ao tipo de alfabetização desenvolvido nessas escolas indígenas.

Os elementos até aqui levantados são suficientes para evidenciar as transformações que ocorrem quando os discursos da Nova Escola começam a operar com o significante-mestre construtivismo, ainda na década de 80 . Para acentuar o contraste em face do que predomina em 1986, realizaremos agora um "salto" de dez anos, tendo em vista o ano de 1996, quando a figura de Piaget é pela primeira vez transformada no principal destaque de capa, exatamente no centro das edições desse ano, no mês de agosto. Para realizar essa comparação, aqui ficaremos apenas com todas as edições cujas capas apresentam imagens de crianças/alunos. Eis então esses números:

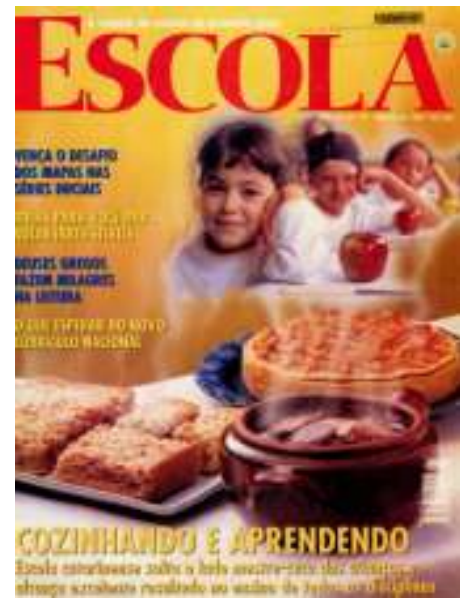

março

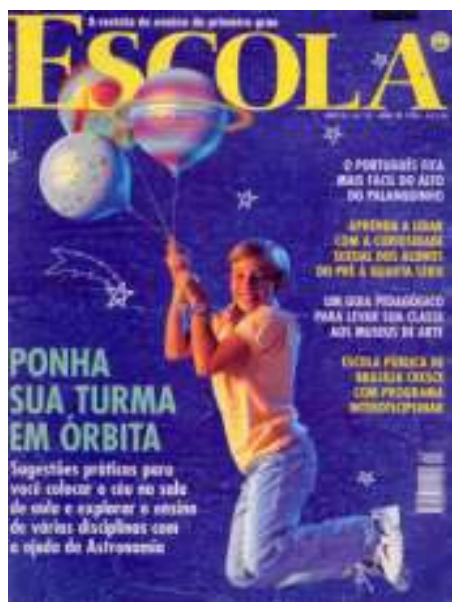

abril 


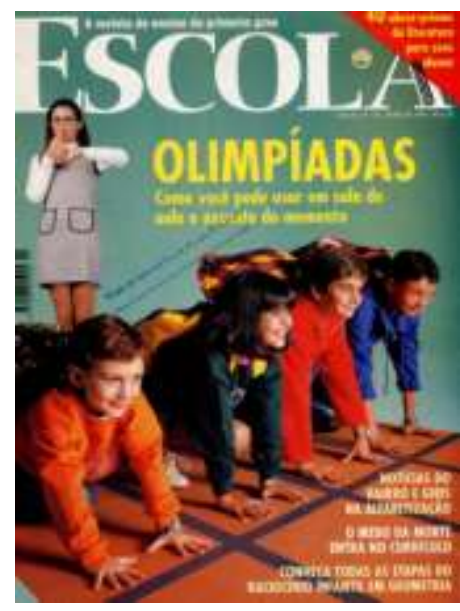

junho

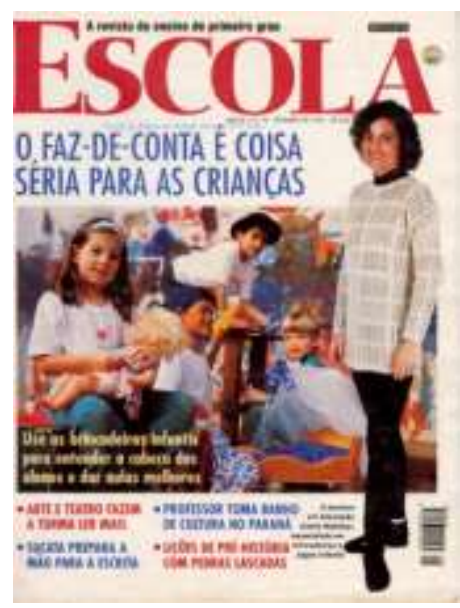

setembro

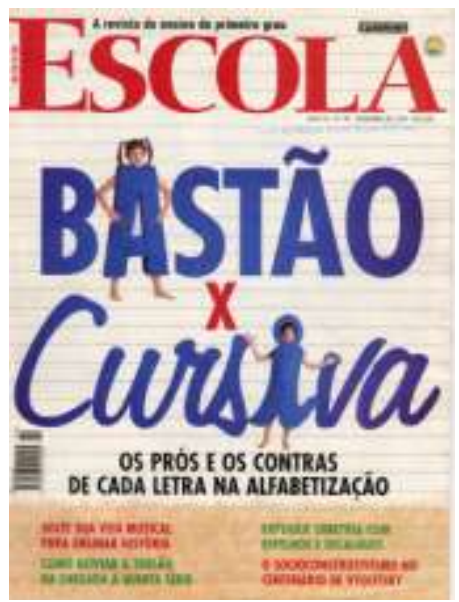

dezembro

Numa primeira comparação com as capas das edições de 1986 que já foram comentadas percebe-se que a "realidade da criança" mudou sensivelmente. Das diversas "realidades" então destacadas, a que parece próxima do que agora predomina é apenas a que corresponde à capa de agosto/86, com a imagem de um computador sendo usado por um aluno do colégio Objetivo. Nas capas com crianças/alunos de 1996, o que prevalece é também da ordem dos "meios", dos recursos, estratégias ou técnicas que o professor utiliza ou pode utilizar para ensinar "mais e melhor". São eles os que então comandam o discurso pedagógico, daí a sua particular ressonância entre as crianças/alunos destacados nas capas dessas edições, todos muito envolvidos com e pelas atividades, materiais e conteúdos que professores e especialistas desenvolvem ou usam. O caso extremo nesse "envolvimento" é o da capa de dezembro/96, com duas crianças que se confundem com o "núcleo didático" que nesse momento parece seduzir todos os que comparecem nas páginas da Nova Escola. ${ }^{45}$ Dessas crianças, aliás, nada é possível saber, sobre elas não existe qualquer informação, são meros acessórios. Transformadas em letras e representando cada lado do "dilema" que "aflige" os professores que têm que decidir "qual é a melhor letra para alfabetizar" (bastão x cursiva) ${ }^{46}$ as duas crianças da capa vestem as "fantasias" especialmente produzidas para a ocasião, conforme informa a revista nos créditos da foto. ${ }^{47}$ Essas e outras "fantasias", com tudo o que delas se espera, foram criadas pelo circuito "mercantil e didático" configurado pela Nova Escola,

\footnotetext{
${ }^{45}$ Sobre esse "núcleo didático", veja-se o capítulo IV.

${ }^{46}$ Cf. "Bastão ou cursiva?", Nova Escola, n 99, dez./96, p. 9.

47 "Capa:foto de Luís Gomes com fantasias de Antônio Marciano" (p. 3).
} 
mas não apenas por ela. Ademais, poder-se-ia dizer que elas são exigidas pelo olhar que professores e especialistas dirigem às crianças/alunos e a tudo o que se relaciona com a educação escolar. Nesse momento, o que esses educadores procuram concerne basicamente ao "núcleo didático". Esse núcleo, portanto, não pode faltar. Sem ele, o discurso pedagógico então hegemônico perderia boa parte da sua consistência, além de se tornar bem pouco atraente. Em outras palavras, esse "núcleo" é essencial a certo gozo que aquele circuito "mercantil e didático" promete e efetivamente produz.

Nesse circuito, nas crianças/alunos, não existe qualquer traço que lembre os grupos ou setores sociais que predominavam nas imagens de capa de 1986. Poder-se-ia dizer até que essas capas sofreram um certo "embranquecimento", junto com a sensível redução da diversidade social e cultural em face do que se observa no primeiro ano da Nova Escola. Quem são as crianças/alunos presentes nas capas da Nova Escola em 1996?

No caso extremo, em dezembro/96, encontramos as crianças já referidas - crianças-anônimas. Quanto aos outros, podemos começar pelas já mencionadas crianças-grife, das edições de abril e junho, tão anônimas quanto as anteriores. ${ }^{48}$ São crianças que vestem as cobiçadas roupas de grife mencionadas nos créditos das fotos de capa e que, portanto, foram especialmente produzidas tendo em vista os potenciais consumidores dessas roupas e imagens, agora de crianças com e em outras "fantasias". Em nenhum caso existe qualquer informação ou pista que indique tratar-se de alunos pertencentes às escolas mencionadas nas reportagens correspondentes. Todas as crianças-fantasia, por assim dizer, vêm não se sabe de onde, não têm nome nem escola. Para os leitores, são crianças/alunos sobre os quais nada sabe, a não ser que se aventure a indagar sobre o sentido de tudo o que emerge quando percorre o circuito que as (suas) "fantasias" definem.

As crianças da capa de março/96 são, tudo indica, alunos do Colégio Machado de Assis, uma escola particular de Santa Catarina. A reportagem trata sobre a "estratégia pedagógica original" adotada pela escola e criada por uma de

\footnotetext{
${ }^{48} \mathrm{O}$ mesmo pode ser dito em relação à suposta professora da capa de junho/96. Em relação às crianças-grife, veja-se o capítulo IV.
} 
suas professoras, cuja foto e nome são apresentados logo no início. ${ }^{49} \mathrm{~A}$ estratégia "eclética" desenvolvida pela professora - que "Tira muito proveito do construtivismo, mas não recusa algumas pitadas dos métodos tradicionais de ensino" (p. 15) - envolve a preparação de diversos pratos da "culinária nacional". A reportagem é semelhante às que predominam nessa fase da revista. ${ }^{50}$ Apresenta uma breve introdução, muitas fotos, com orientações para o professor realizar determinada atividade ou aula, indicando o que foi ou o que pode ser trabalhado em diferentes séries e áreas do conhecimento (Matemática, Português, Ciências, etc.). Portanto, o que está em foco é a sala de aula e o aqui chamado "núcleo didático". Sobre a escola são dadas poucas informações, não faltando, como é praxe nesse período, o endereço e o telefone. Em relação aos alunos, as famílias e a outros aspectos que à primeira vista extrapolam a sala de aula, o que é mencionado concerne diretamente à "estratégia" desenvolvida pela professora e às possibilidades de trabalho em cada série. Eis um trecho relacionado com a "estratégia" então em destaque:

A professora Ana Lúcia observou por algum tempo os hábitos dos alunos. Em Joinville, a comida feita em casa tem um valor imenso. As mães só mandam para os filhos lanches que elas fazem. O comércio fecha na hora do almoço. Ela resolveu tirar proveito da importância dada às refeições em família e lançou a culinária em sala de aula. Deu certo. O novo jeito de ensinar é aplicado hoje por dezesseis professoras, do maternal à quarta série. (p. 9)

Vejamos agora as crianças/alunos precedidos pela imagem da "especialista em brincadeiras e jogos infantis" da capa do mês de setembro/96. Esses alunos aparecem novamente na foto que abre a reportagem, na legenda sendo dados seus nomes e outras informações, como o nome da escola particular paulistana a que pertencem (Escola Viva) e o nome da especialista destacada na capa e que "assessora" essa instituição. ${ }^{51}$ Na primeira página, além dessa foto, há um texto introdutório, no final sendo fornecidos os telefones da assessora e da Escola Viva, a única escola mencionada na reportagem.

\footnotetext{
${ }^{49}$ Cf. "Criatividade. Aulas de dar água na boca”, Nova Escola, n 91, março/96, p. 9.

${ }^{50}$ A esse respeito, veja-se o capítulo IV.

${ }^{51}$ Cf. "Faz-de-Conta. Como obter o máximo de imaginação infantil com o mínimo de interferência", Nova Escola, $n^{\circ}$ 96, set./96.
} 
A introdução começa pondo em destaque a assessora e toca em questões de natureza geral, conforme pode ser observado logo no primeiro parágrafo:

Se você leciona para crianças até a quinta série, já meditou pra valer sobre a importância da brincadeira na vida de seus alunos? E já pensou em usar essa atividade nas aulas? "Ela é ótima para transmitir conteúdos, conhecer a personalidade das crianças e saber quais são as dúvidas e os conhecimentos delas", garante Gisela Wajskop, socióloga e doutora em Educação pela Universidade de São Paulo (USP). (p. 8)

Embora na fala da assessora seja ressaltado que, no brincar, "A interferência do adulto deve ser mínima" (ibidem), o que tende a ficar em foco é essa interferência, sempre tendo em vista o máximo de "eficiência", como pode ser notado em vários enunciados em destaque. Por exemplo, o enunciado da legenda da foto colocada no box do editorial dessa edição - "Escola Viva: brincadeiras para ensinar de maneira mais eficiente" (p. 3) - ou o próprio título da matéria - "Faz-de-Conta. Como obter o máximo de imaginação infantil como o mínimo de interferência" (pp. 8 e 9). Nessa introdução, além das brincadeiras, menciona-se "outras práticas bastante usadas nas escolas", que "também são importantes e valiosas", mas que a "assessora" "insiste em distinguir" das brincadeiras. São elas a recreação e o jogo didático. Essas três práticas são definidas separadamente após essa introdução, sendo indicadas as diferenças e o grau de interferência do professor em cada uma delas.

Nas páginas seguintes, o leitor continua a ser orientado sobre "como aproveitar as brincadeiras, de acordo com as indicações de Gisela", não sendo descrita qualquer experiência ou situação ocorrida com as crianças da escola de onde parecem proceder todas as fotos da reportagem. Ou seja, a reportagem segue o padrão que é próprio da Nova Escola nesse período, assemelhando-se a um manual de instruções: são discriminados e explicados os "quatro passos" para a diversão virar aula (pp. 10-1), indica-se quais são os brinquedos mais importantes, é apresentada uma classificação que separa esses brinquedos em grupos, com as suas funções devidamente esclarecidas, há jogos com a indicação da idade das crianças mais adequada ao seu uso, é fornecida a receita para fazer alguns brinquedos e há "dicas para fabricar brinquedos e inventar jogos" (p. 15). Nas últimas páginas o destaque é para os alunos que nunca querem brincar. São então mencionadas as "causas dessa atitude" e dadas algumas orientações para 
o professor tomar as "atitudes certas" e "acabar com esses problemas" (p. 17). Eis um exemplo de "atitudes muito eficientes": "Se você propõe um jogo e o tema não interessa ao aluno, tente outro. Depois outro e outro" (ibidem). Nesse caso, como é comum nesse período, a atuação do professor e a solução do "problema" envolve primeiramente o que é da ordem do "núcleo didático" já referido, com os elementos que o compõem e que então definem os pontos de ressonância do discurso pedagógico construtivista.

Em face do que predominava em 1986, nas matérias de capas de 1996 até aqui brevemente comentadas, percebe-se que a porta de entrada para os assuntos em pauta não é mais a descrição de uma determinada experiência ou situação ou das condições em que vivem e estudam as crianças e professoras de determinada região ou grupo social. O que é de ordem estritamente singular, relacionado com as peculiaridades de determinada experiência, região ou grupo social tende a desaparecer em face de considerações de natureza geral, relacionadas sobretudo com questões de ordem didática. O que importa é orientar claramente o professor sobre como deve atuar em sala de aula tendo em vista determinado conteúdo, certa estratégia didática bem sucedida ou o uso de determinado material didático, pouco importando as experiências que servem como fonte. Antes o que vale é a fala do especialista e o discurso que consegue transformar uma diversidade de experiências e situações que se desenrolam em sala de aula em regras fáceis de entender e aplicar.

Quanto às crianças/alunos que aparecem nas fotos das capas de 1996, além das crianças-fantasia e das crianças-grife - todas elas crianças-anônimas —, o que temos são crianças/alunos de escolas particulares mencionadas nas matérias correspondentes. Houve, assim, uma notável homogeneização social e cultural em prol de crianças/alunos que pertencem a setores sociais economicamente privilegiados, minoritários portanto na sociedade brasileira. $\mathrm{E}$ isso ocorre no ano em que o discurso pedagógico gravita, como nunca antes, em torno do epistemólogo suíço - um fato do discurso que a revista Nova Escola em parte produz e evidencia quando destaca a sua figura e nome na edição de agosto/96. Piaget, coincidentemente, opera de forma semelhante, isto é, homogeneizando as crianças e a sociedade, de modo a desconsiderar diferenças 
de ordem econômica, social e cultural. ${ }^{52}$ Poder-se-ia dizer até, que o que ele exclui está bem próximo das "realidades" que na Nova Escola foram igualmente excluídas. Em outras palavras, transcorridos dez anos desde o início dessa publicação, as crianças/alunos da Nova Escola ficaram mais próximas da criançasuíço-piagetiana. Afinal, essa criança é a que está na "base" do ensino, conforme institui o discurso pedagógico então hegemônico e a própria matéria que corresponde ao destaque de capa de agosto/96, intitulada "Jean Piaget" e aberta com este subtítulo: "A lógica própria da criança como base do ensino". Tudo isso, enfim, diz respeito ao que predomina no circuito "mercantil e didático" (re)criado com e pelo significante-mestre construtivismo em meados dos anos 90 .

Nesse circuito são unificadas as crianças/alunos brasileiros de acordo com os ideais que nesse momento predominam e que as capas da Nova Escola também configuram. Esse circuito apresenta determinados pontos de ressonância, como os que definem o "núcleo didático". Ademais, ele resulta de um "caminho" que sofreu algumas inflexões. Delas, duas parecem fundamentais e correspondem aos únicos dois momentos em que o significante-mestre construtivismo foi transformado na manchete de capa da revista Nova Escola. Nessas capas há também imagens de crianças/alunos, ou pelos menos desenhos que a elas aludem. E essas imagens apresentam certos elementos ou traços que mais tarde deverão se destacar e predominar no circuito já referido. Eis as imagens dessas capas:

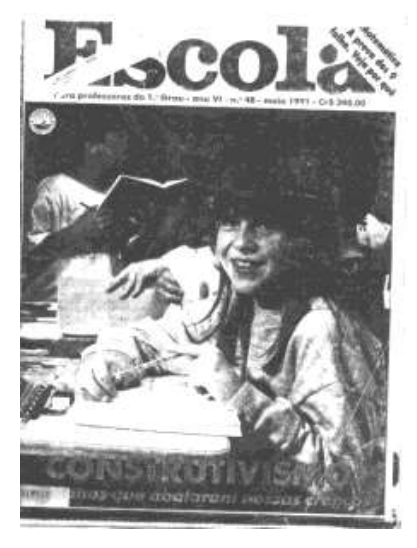

maio/91

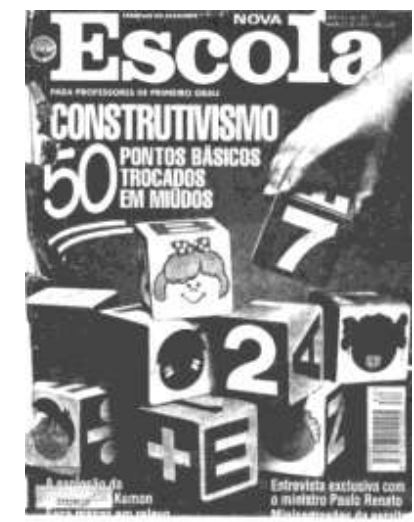

março/95

\footnotetext{
${ }^{52}$ Essa dimensão da teorização piagetiana é apontada e criticada por diversos autores, como Bárbara Freitag, para quem Piaget tem uma "visão sociologicamente ingênua e possivelmente etnocêntrica", com a sociedade sendo concebida como um "meio" social ou cultural homogêneo e indiferenciado (Freitag, 1985, pp. 37-41).
} 
$\mathrm{Na}$ primeira capa, de maio/91, temos a foto de alguns alunos, com a imagem de uma menina num primeiro plano, sentada em sua carteira, com um lápis em suas mãos e o que parece ser um caderno ou um livro. Na matéria correspondente, o que está em causa são os "Dez anos de construtivismo no Brasil", nela sendo feito um balanço sobre a propagação da proposta de alfabetização baseada nas idéias de Emilia Ferreiro. Segundo os créditos da foto, na capa temos "crianças da Escola da Vila", a escola particular paulistana que no discurso da revista se tornou uma espécie de pioneira e paradigma de escola construtivista, como já é sugerido nessa matéria. ${ }^{53}$ De modo que o significante construtivismo emerge pela primeira vez com essa imagem, nela sendo destacada uma criança/aluno com os materiais básicos para escrever e que freqüenta uma escola particular, é branca e, como qualquer leitor poderia presumir, provém de um setor social privilegiado. Ademais, nas crianças/alunos caracterizadas pelo discurso construtivista tendem a ganhar relevância todos os traços que são próprios da "criança que constrói seu próprio conhecimento", como é o caso das conhecidas hipóteses da criança sobre o sistema de escrita. Os traços que definem essa criança piagetiana sobrepujam todos os outros, e certamente isso contribui para a redução da diversidade social e cultural presente nas páginas da Nova Escola. Tudo isso, enfim, aponta na direção do que mais tarde tornar-se-á dominante no circuito "mercantil e didático" que é próprio do construtivismo tecnicista.

Quanto à segunda e última ocasião em que o significante construtivismo é transformado na manchete de capa, em março/95, ela corresponde à fase em que a revista Nova Escola tem um novo diretor de redação: Vitor Strauss, que substituiu Ana Sanchez em outubro/94, a qual desempenhava essa função desde o primeiro número. Nessa edição em que o construtivismo é "trocado em miúdos" e que de certo modo antecipa a unificação e padronização posteriormente realizada pelos $\mathrm{PCN}$, a imagem de capa destaca certo material didático, com alguns desenhos estilizados que aludem a crianças de raças diferentes e uma mão que sugere o uso desse material. Estampadas nas faces de alguns cubos, como se deles dependessem, essas "crianças" constituem meros acessórios,

\footnotetext{
${ }^{53}$ Cf. "Dez anos de construtivismo no Brasil", Nova Escola, n 48, maio/91, p. 16. Essa matéria já
} foi analisada no capítulo IV deste trabalho. 
elementos secundários em face do material didático que nesse caso é o grande destaque, pelo menos na imagem. ${ }^{54}$ Se considerarmos os elementos que dessa imagem foram aqui evidenciados, poder-se-ia dizer que nessa capa, em relação às crianças/alunos, está sendo demarcado um lugar próximo do que deverá predominar nas capas do ano seguinte, em 1996.

Por último, para finalizar este capítulo, vejamos a capa da Nova Escola de dezembro/97:

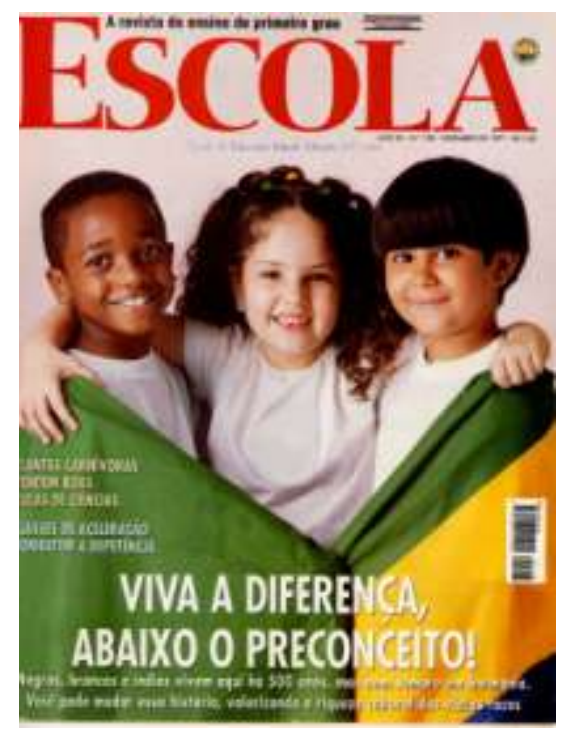

Esse número da revista Nova Escola é o primeiro com a diretora de redação Elizabeth de Fiore, que sucede a Vitor Strauss. Na capa temos uma foto com três crianças unidas pela bandeira brasileira. Por meio delas alude-se aos negros, brancos e índios que "vivem aqui há 500 anos" e sugere-se a possibilidade de uma convivência harmônica, graças ao trabalho do professor, que "pode mudar essa história, valorizando a riqueza cultural das várias raças", conforme sugere o enunciado que complementa a manchete. Dessas crianças, especialmente produzidas para essa foto, nada é possível saber na reportagem correspondente. E os créditos da foto informam apenas que os "modelos" são da "Agência Arte Bambini" (p. 3). ${ }^{55}$ Essas crianças-modelo abrem ainda a reportagem, e continuam unidas pela bandeira brasileira, mas também pelo que nesse momento estabelece o que nacionalmente deve ser concebido como

\footnotetext{
${ }^{54}$ A capa dessa edição e a matéria correspondente já foram analisadas no capítulo IV deste trabalho.

55 "Capa: Foto de Vladimir Fernandes, produção de Márcia Pecci, modelos da Agência Arte Bambini, cabelo e maquiagem de Carla Corrêa", p. 3.
} 
criança/aluno, ou melhor, como "criança que constrói seu próprio conhecimento". Com efeito, os PCN são mencionados logo no primeiro parágrafo da reportagem. O que está em foco é a "Pluralidade Cultural", o assim chamado "tema transversal" que, conforme informa a revista, constitui um dos capítulos dos Parâmetros Curriculares Nacionais. ${ }^{56}$ Ainda nessa parte introdutória, no primeiro subtítulo ("A pluralidade brasileira"), procura-se responder a esta pergunta: "o que é diversidade cultural?". Mencionam-se então diferentes "povos que deram origem ao brasileiro genuíno", destacando que negros e índios foram os mais atingidos pela discriminação (p. 11). Além das "diversidades raciais", a reportagem trata das diferenças de gênero e dos preconceitos contra a mulher, destacados no segundo subtítulo ("Igualdade de sexos"). Nas primeiras páginas há também um box onde o tema é precisamente esse, conforme se observa no seu título: "Preconceito se desaprende na escola" (ibidem). Nas páginas seguintes são apresentadas experiências desenvolvidas por professores de escolas públicas e privadas em torno dessas temáticas. Nesses exemplos há breves descrições de situações e atividades desenvolvidas por professores. São descrições que recuperam falas de alunos e professores, além de dimensões e aspectos que singularizam essas experiências.

Essas características de certo modo aproximam essas matérias do tipo de reportagem que predominava quando a diretora de redação era Ana Sanchez. Entretanto, há outros elementos que operam no sentido contrário. Para evidenciar isso basta considerar a diversidade social e cultural sugerida pelas capas de 1986 que já foram comentadas e comparar com o que se configura em 1997, em particular na edição e na reportagem que aqui está sendo comentada. Nesse ano, nos discursos pedagógicos sob o influxo dos PCN, toda diversidade social e cultural tende a ser unificada pela "Pluralidade Cultural", ou seja, pelo recorte presente nessa proposta curricular nacional. ${ }^{57}$ Uma unificação que na revista

\footnotetext{
${ }^{56}$ Cf. "Viva a diferença. Abaixo o preconceito!", Nova Escola, n 108, dez./97.

${ }^{57} \mathrm{O}$ processo acima implicado, relativo ao percurso do discurso pedagógico, pode ser analisado seguindo outras trilhas, por exemplo a do significante reforma. O segundo número da revista Nova Escola, de abril/86, trazia esta manchete: "A reforma silenciosa. Como nossos professores estão mudando o $1^{\circ}$ grau". Na reportagem correspondente, no olho que sucede ao título, volta a ser destacado o papel dos professores, que, "discretos e eficazes", "corajosos e criativos", realistas e aplicados", estavam tentando "descobrir um novo caminho para a Educação de $1^{\circ}$ Grau" (p. 10). A matéria trata do que chama de "movimento", surgido graças a iniciativas individuais ou de pequenos grupos e cujos efeitos "já se mostram amplos o suficiente para merecerem o batismo de 'reforma'" (ibidem). Afirma-se, ademais, que "o movimento não tem precisado de leis, decretos ou
} 
Nova Escola será mais incisiva no ano seguinte, em 1998, com os fascículos mensais sobre os PCN, os quais trazem experiências e atividades que são apresentadas como se fossem exemplos ou aplicações do que é sugerido nessa proposta curricular. Por enquanto, nessa reportagem de capa de dezembro/97, essa unificação não é mais do que insinuada, pois os PCN não são mencionados em nenhum dos exemplos, não constituindo uma referência ou fonte nas experiências apresentadas. Estas, porém, não deixam de ficar sob a sua guarda, pelos menos implicitamente e se considerarmos a disposição das fotos das crianças-modelo nas páginas em que essas experiências são apresentadas. Cada criança-modelo, além de aparecer em fotos junto com a suas congêneres (na capa e na foto que introduz a reportagem), abre e precede as duas páginas destinadas aos exemplos relacionados com os temas e significantes que ela evoca. Ao todo são três temáticas, que podem ser situadas com estes significantes: negros (escravidão, racismo, cultura negra, etc.), mulheres (questões de gênero, preconceitos, etc.) e índios (tradições, costumes, etc.). Como exemplo, vejamos duas dessas fotos:

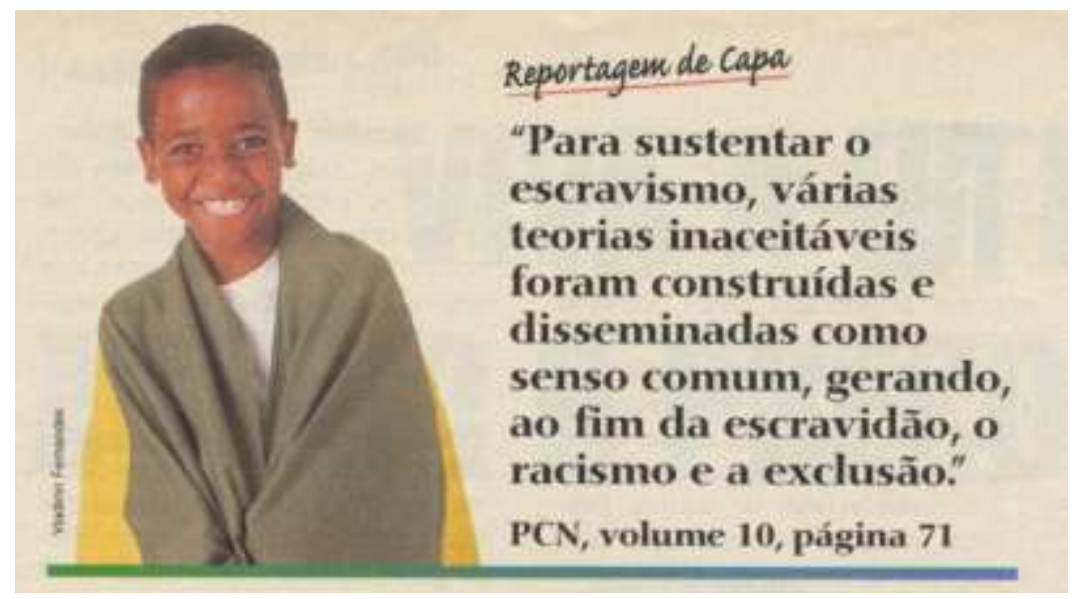

das clássicas 'ordens superiores' para legitimar-se" (ibidem). Ao longo da reportagem são arroladas diversas iniciativas, envolvendo várias secretarias de Educação municipais e estaduais. Cerca de 10 anos depois, chegam os novos reformadores, destas vez especialistas contratados pelo MEC para realizar uma ampla reforma educacional, de caráter nacional, unificada e envolvendo vários níveis e modalidades de ensino. A presença dos modernos reformadores é também celebrada na Nova Escola/Escola Nova, que desde o início encontrava-se na trilha dos reformadores. Em dez anos, portanto, a diversificada, dispersa e difusa "reforma silenciosa" tornase a reforma unificada. Um "caminho" semelhante ao da "realidade" da criança. 


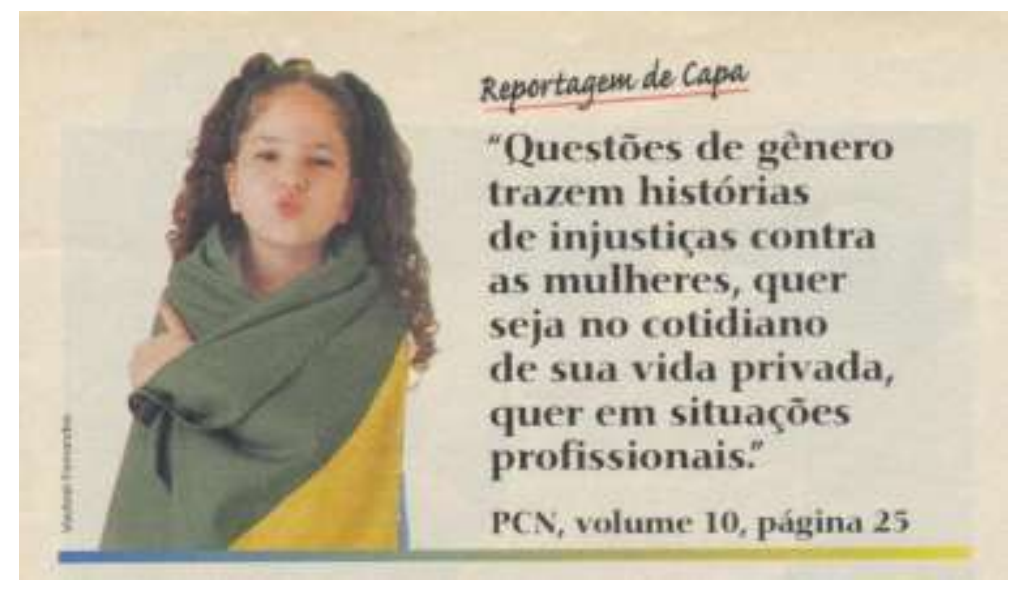

A foto de cada criança-modelo, agora como que vestindo a bandeira brasileira, precede as duas páginas destinadas aos temas vinculados à sua imagem. Ademais, cada foto vem acompanhada de um pequeno texto, retirado precisamente dos PCN.

Enfim, Pluralidade Cultural, bandeira nacional, PCN, podem ser considerados alguns dos fios que ligam as crianças-modelos e os exemplos que elas precedem. Nessa revista, em 1997, o significante-mestre PCN ainda é um fio tênue, é uma agulha que participa de poucas costuras, mas cujo vigor e presença aumentará de modo sensível no ano seguinte, quando a Nova Escola é nitidamente sobrepujada pelo renovado e construtivista padrão nacional. 


\section{O lugar do saber}

O passado murmura nas correspondências ${ }^{1}$

$\mathrm{Na}$ perspectiva da psicanálise lacaniana, unir saber e verdade é um empreendimento impossível. Sobre essa impossibilidade, em torno dela, procurou-se estruturar este trabalho. Como? Essa precisamente é a pergunta que aqui será tomada como guia para aproximar estas últimas linhas desse lugar, que é o que sobretudo interessa neste trabalho, ou seja, o lugar de um saber que não se sabe, mas que opera. Isso pode ser pensado em, pelo menos, dois sentidos. De um lado, no registro do saber não sabido que opera no discurso pedagógico construtivista; de outro, considerando o que neste trabalho opera sem que isso possa ser propriamente aprendido pelo autor, a não ser, talvez, posteriormente e de modo parcial, uma vez concluído este percurso. De qualquer modo, aqui, neste último capítulo, é experimentada uma primeira aproximação, antes de mais nada tendo em vista o discurso construtivista. Para tanto serão desenvolvidos três pontos.

Em primeiro lugar, trata-se de recuperar o movimento dos significantesmestres implicados na emergência e configuração do discurso pedagógico construtivista, (re)situando nessa discussão o que aqui está sendo chamado de pontos de ressonância (com os vários nomes utilizados para marcar as suas diferenças) e os momentos discriminados nesse "caminho", envolvendo discursos e configurações discursivas diferentes. Em que consistem algumas dessas configurações, o que está sendo considerado um giro discursivo e o lugar do saber em cada uma delas serão então objeto de discussão.

Num segundo momento, a intenção é colocar em relevo o registro fantasmático que define as coordenadas do circuito construtivista e que explica a sua hegemonia, com as formas de gozo que ele parece configurar e proporcionar; formas essas articuladas ao que é da ordem do sintoma, não apenas sintomas subjetivos, mas antes e em primeiro lugar sociais. Por essa via será ensaiado o retorno a nosso ponto de partida — o lugar da verdade.

\footnotetext{
${ }^{1}$ Cf. Walter Benjamim, 1975, p. 55.
} 
Por último, procura-se recuperar alguns aspectos da análise do discurso aqui realizada, em particular o que norteou essa análise e como foi efetivada.

\section{Discurso e saber}

A emergência do construtivismo, aqui entendido como um discurso pedagógico que se configura no Brasil na segunda metade da década de 80, resulta do (re)ordenamento discursivo que nesse período se processa sob o comando de alguns significantes-mestres, que são os significantes de arremate desse discurso: Emilia Ferreiro, Piaget, construtivismo. Em virtude das costuras feitas com esses significantes, neles tendem a confluir uma infinidade de enunciados que ficam como que condensados nesse único ponto: o ponto de arremate desse discurso. Esse ponto de ressonância é definido por qualquer um daqueles significantes-mestres, os quais nesse discurso cumprem com a mesma função, por isso são equivalentes. A função dos significantes de arremate - ou de seus derivados (para construtivismo: proposta construtivista, linha construtivista, etc.) - é a de enlaçar toda a rede significante e assim contê-la. Desse modo, ao se tornarem o Um que representa a totalidade da rede, esses significantes de ressonância adquirem o poder de delimitar e regular os enunciados em que explícita ou implicitamente encontram-se implicados. Em outras palavras, eles tornam-se o Outro que regula as falas dos sujeitos implicados nesse e por esse discurso.

Nessa rede significante é necessário considerar ainda outros pontos significantes, outros pontos de ressonância que a definem e que também atraem e condensam inúmeros enunciados em razão das costuras feitas com os significantes de ressonância que criam esses mesmos pontos. Portanto, como qualquer significante-mestre, cada um desses significantes de ressonância contém a sua própria rede. Além disso, devido a que fazem parte de determinado discurso ou em razão de ficarem sob a sua órbita, esses significantes de ressonância, entre si vinculados de diversas maneiras, tornam-se parte de uma bateria significante sob o comando de um outro significante-mestre, que a todos contém. Esse comando, em nosso caso, é exercido pelo significantes de arremate do discurso pedagógico construtivista. 
Dentre esses significantes de ressonância subordinados aos significantes de arremate, é necessário distinguir os que promovem e sustentam a emergência do discurso construtivista, antecedendo portanto a sua configuração. Trata-se dos significantes relativos aos aqui chamados pontos de ancoragem desse discurso e que já existiam como pontos de ressonância no campo dos discursos educacionais. Essa denominação, portanto, aqui foi utilizada apenas para pôr em relevo significantes de ressonância que participam dessa configuração, que alavancam e sustentam o discurso pedagógico construtivista durante algum tempo, mas que não necessariamente continuam enquanto tais, ou seja, fazendo a costura que (re)cria determinado ponto de ressonância. Esses significantes de ancoragem são significantes de ressonância em discursos que antecedem a emergência do construtivismo. Alguns deles tornam-se significantes de ressonância do novo discurso, enquanto outros parecem cumprir com essa função de modo transitório, como se nutrissem o construtivismo até o momento em que a hegemonia desse discurso torna-os dispensáveis, tanto esses significantes como os pontos de ressonância que eles (re)criam.

Um exemplo é o significante-mestre Paulo Freire, que pode ser considerado de várias formas. Em primeiro lugar concerne ao ponto de arremate de um outro discurso, junto com outros significantes de arremate equivalentes, como educação popular, escolas comunitárias e educação alternativa. Entretanto, o significante de arremate Paulo Freire torna-se ele próprio um significante de ancoragem do novo discurso pedagógico, pelo menos é o que pode ser notado na revista Nova Escola, onde surge em diversas matérias e falas como referência importante no âmbito do discurso construtivista. E nesses casos não se trata simplesmente de um nome, pois podemos supor aí a existência de toda uma rede significante a ele atrelada, com as torções que a sua inserção e subordinação ao novo discurso produz. Em outras palavras, no discurso construtivista, em uma de suas vertentes, a rede significante própria do discurso da educação popular em parte comparece, embora subordinada ao âmbito de outro discurso. Desse modo serve-lhe de suporte, contribuindo para projetá-lo. E ela comparece de vários modos, com alguns de seus significantes de ressonância, como é o caso do significante de arremate Paulo Freire, que na revista Nova Escola tende a desaparecer, não mais sendo lembrado nos enunciados que (re)definem o lugar do construtivismo na segunda metade da década de 90 . Com ele também tendem 
a sair de cena outros significantes de ressonância, como classes populares, com seus equivalentes ou derivados (comunidade, setores populares, etc.).

Isso não ocorre com outros significantes de ressonância que configuram o novo discurso e que cumprem com a mesma função de sustentá-lo e projetá-lo durante a sua emergência. Um exemplo é o significante de ancoragem postura, quando está em causa a postura do professor construtivista. Ele antecede essa emergência e continua (re)criando o ponto de ressonância correspondente, sendo desse modo incorporado ao novo discurso, embora pareça perder parte de seu vigor na segunda metade da década de 90. Falar da postura do professor, com tudo o que esse significante-mestre condensava, era essencial nos discursos educacionais alternativos. Ao ser incorporado ao novo discurso pedagógico, com o (re)ordenamento que lhe é correlato, o significante-mestre postura continua demarcando um lugar de forte ressonância entre professores e especialistas da educação.

Outro exemplo é o significante-mestre democracia, de forte ressonância no discurso político mas que também fica sob órbita de vários discursos educacionais, dentre eles o construtivismo. Neste, esse significante-mestre serveIhe também de plataforma, é um significante de ancoragem, prolongando a sua presença para sustentar o novo discurso pedagógico no período em que ele se torna hegemônico. Constitui, portanto, um de seus significantes de ressonância.

Pontos de ressonância do discurso pedagógico construtivista são também os que se configuram com essa emergência, inexistindo antes dela, não sendo portanto pontos de ancoragem, embora a dúvida quanto isso seja legítima. Tomemos, por exemplo, os significantes que procedem da rede conceitual que é própria dos trabalhos de Emilia Ferreiro, Piaget e outros autores que nutrem o mesmo campo teórico. Esses significantes criam pontos de ressonância que podem ser reconhecidos como próprios desse discurso e de nenhum outro. É o caso das tão repetidamente lembradas hipóteses infantis sobre a escrita e cuja simples menção costuma implicar a exigência feita ao professor no sentido de sempre considerar o que a criança pensa, o que ela sabe, o que ela construiu em termos de conhecimento. Mas aí é que poderíamos dizer que essa exigência de certo modo já existia, embora formulada de um outro modo. Por exemplo, nos discursos educacionais alternativos ou da educação popular, quando era exigido 
que o educador ou professor considerasse a "realidade da criança". Nesses discursos, o significante-mestre "realidade da criança" definia um ponto de ressonância que é retomado e recriado no construtivismo, não sem que nesse ponto ocorresse um forte deslocamento, com o uso de outros significantesmestres. Afinal, passamos da "realidade da criança" para "a criança que constrói seu próprio conhecimento", com uma última torção quando o construtivismo tornase o circuito mercantil e moderno da didática e das aqui chamadas criançafantasia ou crianças-anônimas, nas quais desaparece todo e qualquer traço daquela "realidade da criança" configurada pelo discurso da educação popular. Considerando tudo isso, é possível pensar que o mesmo ponto de ressonância foi recriado com outros significantes de ressonância, mudando por isso de forma significativa. Se é ou não o mesmo ponto, é uma questão em aberto cujo tratamento exige um certo desenvolvimento.

Apesar das dúvidas, problemas ou ambigüidades surgidas em razão da distinção aqui estabelecida entre pontos de ressonância e pontos de ancoragem (com os últimos sendo considerados um caso particular dos primeiros), manter essa distinção ou trabalhar o que aí encontra-se implicado não é sem importância, pois nesse ponto do passado que até agora não foi muito bem definido - e que o conceito de ponto de ancoragem pretende reter - parece escorregar o que projeta e sustenta o discurso pedagógico construtivista. Trata-se de algo que ficou para trás, mas não completamente. E a razão disso, talvez, é que nesses pontos reside o que afinal o sustenta: os passados não reconhecidos no âmbito desse discurso pedagógico, passados que foram recalcados e que vez por outra retornam, como é o caso de Paulo Freire quando volta transformado em um construtivista. O que desses passados é reconhecido parece ter ficado cristalizado nos significantes-mestres que definem os limites do discurso construtivista e que correspondem aos lugares onde esse discurso fracassa e onde a ação pedagógica igualmente fracassa. São os aqui chamados pontos limítrofes ou pontos de fuga, que também são pontos de ancoragem. Escola tradicional e espontaneísmo, em geral usados para demarcar dois lugares situados em pólos opostos, são exemplos de significantes limítrofes. O lugar que eles definem também pode ser concebido como um único ponto de ressonância, como de fato foi entendido no início deste trabalho, quando se fez referência aos "desvios, confusões, equívocos ...", sempre lembrados no âmbito desse discurso para 
condenar ou advertir os que não teriam compreendido o construtivismo corretamente.

Ainda sobre os pontos de ressonância, no decorrer deste trabalho foram chamados de pontos de estrutura o seu ponto de arremate e os pontos limítrofes, sendo-Ihes assim atribuída uma função particular: a de estruturar esse discurso. Digamos que tudo no discurso pedagógico construtivista passa por esses pontos e aflui em sua direção. Nada se sustenta sem eles. Esses pontos criam o tecido básico desse discurso, a sua plataforma primeira. Tudo o mais que nele emerge sustenta-se sobre ela. Algo que foi expresso ou sugerido ao longo deste trabalho de diversos modos, como no capítulo inicial, quando foi apontado que a palavra construtivismo, ao ser simultaneamente utilizada como nome-síntese da teoria de Piaget e do que na educação escolar é delimitado com o mesmo nome, repõe seguidamente a divisão inerente à matriz simbólica construtivista: o lugar da "boa teoria" e a sua aplicação, esta sujeita à ordem dos "desvios, confusões, equívocos ...". Ou seja, junto com o significante de arremate, que delimita o que é da ordem dos ideais, sempre temos o que constitui o seu avesso, os significantes limítrofes e os pontos que eles definem, os quais também sustentam e configuram os ideais. De modo que com esse corte, com o corte do significante de arremate, o que é (re)produzido é uma estrutura significante, sempre a mesma, uma estrutura que estabelece o regime das falas dos sujeitos implicados nesse discurso pedagógico. Ademais, essa estrutura supõe e define determinadas posições subjetivas, de acordo com a configuração que nesse discurso tende a prevalecer e que igualmente condiciona o que é da ordem do laço social.

Essa forma de entender o discurso tem como referência primeira o que Lacan sugere a esse respeito, a começar pela idéia de que o discurso é o estatuto do enunciado. Para Lacan, o discurso é uma estrutura significante que em muito ultrapassa a palavra e que, sem ela, "pode muito bem subsistir (...) em certas relações fundamentais" (1969-1970, p. 11). É uma aparelho "cuja mera presença (...) domina e governa tudo o que eventualmente pode surgir de palavras". São "discursos sem a palavra, que vem em seguida alojar-se neles" (ibidem, pp. 1589). Isso não significa que dela possam prescindir. As palavras e a linguagem são necessárias para que aquelas relações fundamentais se mantenham. E mais do 
que isso, o que é da ordem dessa estrutura surge das próprias palavras, do uso da linguagem.

Esse aparelho opera com quatro termos: o significante-mestre $S_{1}$, a rede discursiva $\mathrm{S}_{2}$ nele amarrada, o sujeito do desejo aí implicado e o que causa a sua incompletude, afigurando uma perda - o chamado objeto a. Esses quatro termos, essas quatro funções do discurso, com as relações que entre si estabelecem, constituem uma matriz simbólica, uma estrutura básica que ultrapassa e antecede os enunciados, mesmo que deles mesmos provenha. Quando aqui se fala no corte produzido pelo significante, o que está em jogo é essa estrutura significante e a inscrição que ela produz, com as quatro "funções radicais" que comporta. Essas funções, articuladas de determinada maneira, são as que produzem o que é da ordem de uma escrita, de um saber que opera num lugar ao qual o sujeito não tem acesso. São funções, portanto, que operam e penetram no real, no real do corpo. É dessa forma que Lacan concebe o que chama de função: "Função vem a ser esse algo que entra no real, que nele jamais havia entrado, e que corresponde (...) a escrever" (1969-1970, p. 179).

O discurso, com esse termo usado no singular e referido ao construtivismo, tem sido aqui pensado do mesmo modo, como uma matriz simbólica que é preciso diferenciar dos enunciados ou falas efetivamente proferidas - e neste trabalho por vezes situadas com o mesmo termo (discurso ou discursos), mas no sentido mais corriqueiro. Os elementos dessa matriz simbólica, bem como a própria matriz, aqui tem sido usados de um modo que extrapola o âmbito da clínica. E aí também não se faz mais do que dar continuidade ao que Lacan insinua em vários momentos. Por exemplo, quando afirma que "esses pequenos termos mais ou menos alados, $S_{1}, S_{2}, a, \$$, digo-lhes que podem servir em um número muito grande de relações. É preciso simplesmente familiarizar-se com seu manejo" (1969-1970, p. 180).

Reduzido a quatro funções (significante-mestre, saber, sujeito e gozo) ou quatro letras $\left(S_{1}, S_{2}, \$\right.$, a), o discurso também comporta quatro lugares para cada uma dessas funções ou letras. ${ }^{2}$ A combinação desses termos nos lugares

\footnotetext{
${ }^{2}$ A definição dos termos do discurso usando tão-somente letras torna árduo e até mesmo impossível o trabalho de quem pretende fixar-Ihes determinada significação, pois com essas letras, na articulação que essas fórmulas criam, o que é da ordem do sentido não encontra um ponto de
} 
correspondentes - isto é, nos lugares que corresponderia ao funcionamento efetivo dos discursos - resulta em quatro estruturas ou figuras do discurso, de acordo com a elaboração que Lacan apresenta no final da década de $60 .{ }^{3}$ Como o discurso é o que faz laço social, os quatro discursos correspondem a quatro formas possíveis de vínculo social e às posições que os sujeitos podem ocupar na rede intersubjetiva que os vincula. Eis então como Lacan apresenta essas quatro estruturas:

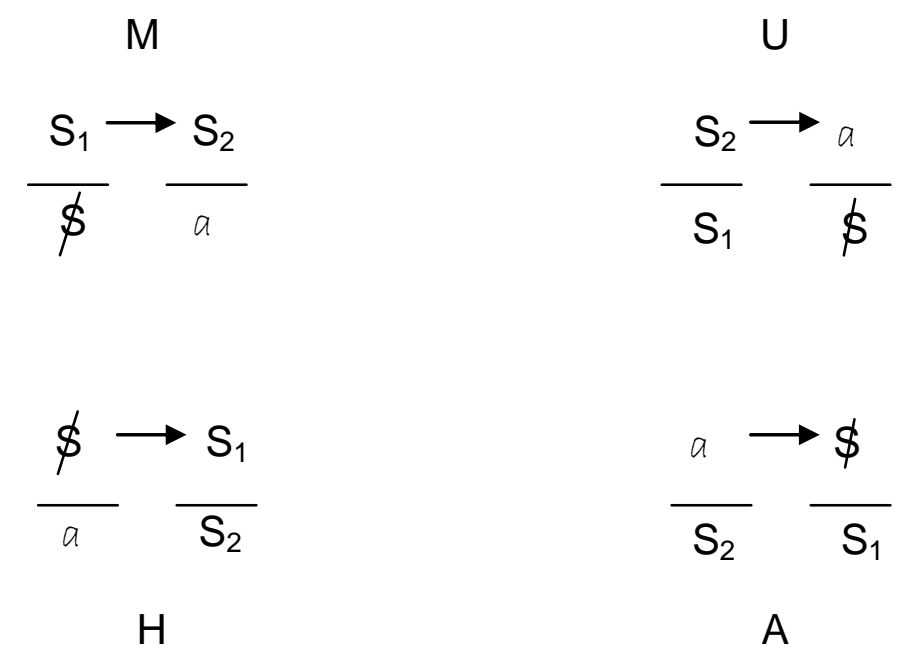

No sentido horário e começando pelo canto superior esquerdo, nessas quatro fórmulas, relativas a quatro configurações discursivas, temos o discurso do Mestre, o discurso Universitário, o discurso do Analista e o discurso da Histérica. Com relação ao manejo dessas fórmulas para tratar dos discursos, Lacan afirma que é preciso seguir certas regras, que ele sugere de forma dispersa, vaga, sem muita precisão, a não ser nesses mesmos "esqueminhas quadrípodes" por meio de flechas e outros recursos (1969-1970, p. 193). Depois de formalizar os quatro

repouso, a não ser na própria estrutura. Os sentidos são inúmeros e se multiplicam toda vez que colocamos em movimento esse "aparelho de quatro patas". São fórmulas precisas na sua escrita, mas imprecisas quanto ao referente. Este permanece como que envolto em uma nuvem de interrogações, o qual, na verdade, é da natureza do que desse referente conseguimos nos apropriar. Essa proliferação de sentidos, essa dificuldade para fixar determinada significação, era mesmo a intenção de Lacan ao criar essas fórmulas e inventar outros tantos recursos, sendo isso sugerido em falas como esta: "Há vários termos. Se só forneci aqui estas letrinhas, não foi por acaso. É que não quero meter coisas aí que tenham a aparência de significar. Não as quero significar, de modo algum, e sim autorizá-las" (1969-1970, p. 161).

${ }^{3}$ Cf. O seminário, livro 17. 
discursos, alguns anos mais tarde, em 1972, numa conferência em Milão, Lacan apresenta um quinto discurso, o discurso do Capitalista, com esta fórmula:

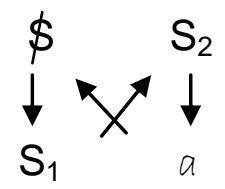

Quanto aos lugares do discurso que os quatros termos ou funções podem ocupar, assim Lacan os nomeia e situa: ${ }^{4}$

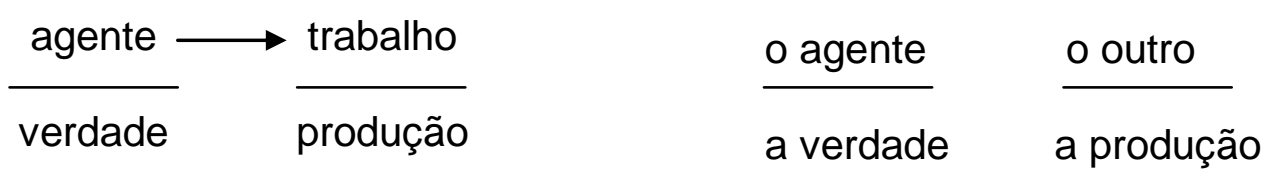

Neste trabalho, as formas do discurso antes apresentadas, em particular as quatro primeiras, serviram como referência para pensar os giros discursivos envolvidos na emergência e configuração do discurso pedagógico construtivista, bem como as posições dos sujeitos aí implicados e o que nelas muda, relacionado com as formas de ligação social que se tornam dominantes. Ou seja, essas configurações discursivas, junto com o que elas sugerem, foram tomadas apenas como uma via para poder pensar e avançar nas questões centrais deste estudo. $E$ desse modo continuarão sendo consideradas, detendo-nos em uma ou outra, conforme esta reflexão assim o exija. Em relação a seu valor, Lacan o situa com esta advertência: esses "esqueminhas quadrípodes (...) não é a mesa espírita da história. Não é obrigatório que isto sempre passe por ali, e que gire no mesmo sentido. É só um meio de dar-lhes referências em relação ao que bem pode-se chamar de funções radicais" (Lacan, 1969-1970, p. 179). Esses esquemas, essas fórmulas, constituem não mais do que um artifício para articular um saber que, do mesmo modo que esse artifício, que já é um saber, mostra-se falho, como Lacan

\footnotetext{
${ }^{4}$ Sobre esses quatro lugares do discurso, veja-se Lacan, 1969-1970, p. 161; 1972-1973, p.27.
} 
sabia e frisava, vendo-se por isso obrigado a criar outros tantos artifícios para assim se aproximar do lugar da verdade, ou melhor, para contorná-lo. Uma verdade que concerne ao real, ao real do gozo, e que é indemonstrável. Eis uma afirmação que certamente nos coloca diante desta pergunta: como saber então se o nosso saber tem algum valor de verdade? Quanto a isso, o que aparentemente nos resta é ficar nos "talvez", cuja repetição sugere precisamente a dimensão da verdade. Isso é o que Lacan postula a respeito do sentido, ou melhor, de um sentido que faça mesmo sentido: "Talvez não seja o verdadeiro. Mas também iremos certamente ver que há muitos desses talvez não seja o verdadeiro, cuja insistência nos sugere propriamente a dimensão da verdade" (ibidem, p. 13). Uma verdade que diz respeito ao sujeito do significante e não ao sujeito do conhecimento. O que aqui está em foco, portanto, é a ordem do desejo e tudo o que permite situá-lo, o qual nos remete, é claro, ao que é central neste capítulo: o saber não sabido, o inconsciente.

Agora, para avançar em direção ao que foi concebido como um giro discursivo e o que nele está em jogo, antes é necessário retomar alguns momentos do "caminho construtivista", a começar pelo momento em que são produzidas as suas primeiras costuras, com o nome Emilia Ferreiro, um nome que em pouco tempo é sobrepujado pelo significante-mestre construtivismo. Com esse significante-mestre, que surge no cenário brasileiro atrelado a determinada ordem discursiva, que é a da ciência, produz-se um giro discursivo que na verdade já vinha ocorrendo no âmbito dos discursos educacionais em que o construtivismo inicialmente se afirma, ou seja, nos discursos críticos. A pedagogia dos conteúdos é o discurso que nesse campo dos discursos críticos há anos vinha produzindo todo um conjunto de deslocamentos cujo sentido é semelhante ao sentido que deverá se afirmar com o construtivismo. Ambos tendem a entronar a mesma configuração discursiva, a que Lacan chama de discurso Universitário. E aqui cabe indagar, então, qual era a configuração discursiva que esse girou sobrepujou e que predominava nesse campo dos discursos críticos.

Para articular uma resposta, é preciso voltar a nossa atenção para os discursos educacionais alternativos, que são os que basicamente estão em causa quando a pedagogia dos conteúdos surge nesse campo dos discursos críticos. Dentre eles, aqui tomaremos como primeira referência os que nutrem a vertente 
do construtivismo que se tornou dominante, em particular o discurso típico entre as camadas médias do campo alternativo no período em que esse debate encontrava-se bem acirrado, com as experiências alternativas sendo fortemente questionadas. Esse é o caso das escolas alternativas paulistanas, cujo percurso aqui será parcialmente retomado para tratar desse ponto.

Desde fins dos anos 70, os educadores que trabalhavam nessas escolas privadas articulavam um discurso fortemente questionador quanto aos valores então vigentes. Questionar toda e qualquer autoridade, num período em que no Brasil vivia-se sob um regime militar, confundia-se então com o que o significantemestre crítico definia, o que não quer dizer que o sentido do crítico aí se esgotasse. Esse questionamento por vezes resultou em experiências que procuraram trilhar o caminho da autogestão, tornando todos os educadores de uma mesma escola partícipes das decisões que nelas eram tomadas, com a tendência a diluir as mais diversas hierarquias, inclusive entre adultos e crianças. E desse modo, com o esvaziamento do lugar de toda e qualquer autoridade, o que não raro emergia era o que afigurava o seu oposto e que constituía, precisamente, o que se pretendia combater: o autoritarismo - um efeito impensado para quem o situava fora do âmbito em que essas experiências se desenrolavam. Ou seja, as falas desses educadores, os seus questionamentos, articulavam-se tendo em vista o lugar do mestre, do senhor, da lei, ou de qualquer um que viesse ocupar esse lugar, então freqüentemente definido com este significante-mestre: ditadura militar. Contudo, uma vez atingido o alvo, uma vez derrubado o mestre, este retornava, até mesmo numa versão piorada, porque despótico. Em vista desse mestre despótico, em vista do autoritarismo que emergia não se sabia de onde, o reencontro do lugar da autoridade tornou-se essencial. Mas houve para tanto um pecurso. Nele, impôs-se ao que parece certa oscilação: entre a derrubada do mestre e o seu retorno, igualmente desejado. Eis aí um circuito em que a comunicação se estabelece de um modo que poderíamos qualificar de histérico, para desde já situarmos a configuração discursiva que nesse caso parece estar em jogo.

Esse circuito, o circuito que essas falas definiam, nem sempre adquiria esses contornos tão histéricos, por assim dizer. Vejamos por um outro ângulo, destacando um outro percurso do mesmo circuito. Nessas experiências 
alternativas, nessas "experiências proibidas", a interrogação ou questionamento quanto ao que se dizia e fazia definia o lugar de onde essas falas partiam e se articulavam, endereçadas a um outro que nesse discurso era situado por meio de diversos significantes-mestres, não apenas ditadura militar ou escola tradicional. $\mathrm{O}$ outro a quem as demandas do agente-educador eram também endereçadas, dele exigindo um trabalho que articulasse alguma resposta, concernia ao lugar do grupo, do coletivo, que, como vimos, por vezes tornava-se o lugar de onde um mestre despótico emergia. Um fato que a superposição implicada no mesmo ponto parece explicar. E aí também deveríamos incluir os significantes-mestres que no discurso da educação popular definiam o mesmo lugar, como povo, comunidade, classes populares. O outro em jogo nesse caso - ou seja, o grupo, a comunidade, o povo - afigurava a fonte de um saber que ainda deveria advir, em decorrência da sua ação, com o desenrolar da experiência, com o uso dessa palavra que era - ou pretendia-se que fosse - ação e reflexão, como a definia Paulo Freire. Um saber que em grande medida permanecia no registro de um saber não sabido, a não ser quando se produzia o giro que o transformava num saber de senhor, num saber Universitário, exatamente no ponto em que certas dúvidas tendiam a desaparecer, beirando por isso o que é da ordem do dogma.

Nesse discurso alternativo, em particular entre as camadas médias, o lugar do outro correspondia também ao lugar demarcado pelo significante-mestre criança, sendo efetivamente ocupado por ela ou por elas. Sob a forma do discurso histérico, com o educador ou professor no lugar dominante, no lugar do agente, configurava-se então um circuito onde a criança transformava-se no senhor, no mestre, de quem esperava-se pudesse emergir a referência que permitisse estabelecer a sua própria posição, a posição do educador ou professor. Ou seja, esperava-se que desse lugar demarcado com o significante-mestre criança pudesse emergir um saber-natural que ao adulto fornecesse a chave para fechar as interrogações que então o consumiam. Um saber que, é claro, sempre mostrava-se insuficiente, mas que permitia fechar o circuito que é próprio dessa configuração discursiva. O que resultava desse tipo de vínculo pode ser vislumbrado adentrando na palavra que em determinado momento ecoava em todas as escolas alternativas: limites. Um significante-mestre relacionado não apenas com as questões surgidas no âmbito do vínculo adulto-criança, mas também e sobretudo no plano dos laços estabelecidos entre os adultos. Esse 
significante-mestre, com tudo o que ele articulava naquele período, parece ter ficado encerrado no lugar que o significante-mestre espontaneísmo cristaliza no discurso construtivista, aí se perdendo e não sendo reconhecido, a não ser fora dessa história "alternativa" e de outras semelhantes. Talvez isso corresponda ao percurso de todo significante que é transformado em um conceito, como é o caso de limites, que foi transformado em um conceito, ${ }^{5}$ mas que muito pode "dizer" se o convertemos no que era: um significante-mestre. Com ele, com esse guia, abre-se certamente uma das vias de acesso à verdade do discurso construtivista.

Muito embora o discurso educacional alternativo corresponda em grande parte ao que Lacan chama de discurso da Histérica, não pode ser abordado tomando como base essa única configuração. Aqui apenas está sendo posto em relevo o que parece predominar, sem que se avance no modo como outras configurações discursivas comparecem e na discussão dos giros discursivos aí implicados, pois neste trabalho está se supondo que em alguma medida excetuando situações extremas em que determinada configuração como que anula as outras - o discurso sempre gira, fazendo com que mude a posição que os sujeitos ocupam na rede intersubjetiva que os vincula e o tipo de vínculo que os liga. Já foi indicado, por exemplo, que o discurso educacional alternativo também podia se configurar sob a forma do discurso Universitário, inclusive no âmbito propriamente educativo, do vínculo estabelecido entre educadores e educandos, professores e aprendizes, viabilizando desse modo o que é da ordem da educação e do ensino, se considerarmos que é com esse discurso que se articula esta impossibilidade: educar. Feitas essas ressalvas, aqui importa continuar destacando o discurso da Histérica, pois é essa a configuração discursiva que parece predominar no discurso educacional alternativo, em particular no "momento dos limites", um momento que antecede o giro discursivo que se consolida com o construtivismo. Ainda sobre o discurso alternativo, poderíamos indagar sobre o que é da ordem da sua verdade, apoiando-nos para tanto no que o discurso da Histérica sugere. Vejamos.

\footnotetext{
${ }^{5}$ Um bom exemplo disso é o livro de Yves de La Taille intitulado Limites: três dimensões educacionais, onde é possível encontrar uma conceitualização que muito deve, tudo indica, ao que procede das experiências educacionais alternativas, ou melhor, ao que nelas e a partir delas já vinha sendo elaborado, como pode ser observado em Revah (1994, ver capítulo "Limites").
} 
O lugar dominante no discurso da Histérica, o lugar do agente, é aí ocupado pelo sujeito, o sujeito dividido, em falta, que deixa exposto ou à vista o que é dessa ordem, da ordem da falta que o consome e que corresponde ao dilaceramento sintomático que a histérica ou histérico expõe. A fala do agente articula-se aí sob a forma de uma interrogação sobre o ser, o seu ser, um ser para o outro/Outro. A sua demanda procede desse lugar em que um abismo parece se abrir e é endereçada a um outro que nessa configuração discursiva corresponde ao significante-mestre, o senhor a quem se demanda trabalhar. Para produzir o quê? Um saber que o sustente nessa posição de mestre, pois o que a histérica quer é "que o outro seja um mestre, que saiba muitas e muitas coisas, mas, mesmo assim, que não saiba demais (...) quer um mestre sobre o qual ela reine. Ela reina, e ele não governa" (Lacan, 1969-1970, p. 122). A histérica sempre derruba o mestre. Afinal, ele produz um saber que sempre se mostrará insuficiente ou impotente para dar conta do que toda demanda deixa nas entrelinhas. A insatisfação é a marca da histérica, ela própria é a marca da insatisfação primeira, por isso deixando à vista, escancarada, a interrogação que é própria do desejo: o que o outro quer de mim?; o que preciso para ser desejada? Uma resposta necessária para articular o que é da ordem da sua verdade: "Sua verdade é que precisa ser o objeto a para ser desejada" (ibidem, p. 167). Por isso, aliás, por mais que faça o mestre cair da sua posição, esse lugar não pode ficar vago. A histérica não se sustenta sem um mestre, sem um outro que articule um saber que nesse circuito opera produzindo a divisão que a consome, por mais impossível que isso pareça. Um saber no lugar apropriado para que nesse discurso se configure a posição que corresponde à verdade de seu agente, que é a de ser o objeto que o mestre deseja, que causa o seu desejo, o desejo do mestre. Em outras palavras, a histérica opera no sentido de articular esta impossibilidade: "fazer desejar". 6

Seguindo o que isso sugere, pode-se dizer que o discurso educacional alternativo articulava essa impossibilidade de diversos modos. Para pensar um deles, podemos partir do seguinte: o que o discurso alternativo visava era ultrapassar certos limites "proibidos": as experiências alternativas eram

\footnotetext{
6 Isso é o que Lacan sugere em relação ao que o discurso da Histérica articula como impossibilidade (1969-1970, p. 165).
} 
"experiências proibidas". Isso significa que se instalavam numa região da experiência e do discurso marcada pelo significante-mestre proibido e seus equivalentes. O "fazer desejar", portanto, deve ser pensado em relação à ordem do "proibido" que esse campo configurava. Digamos que esse circuito, bem como outros que se articulavam de forma semelhante, operava no sentido de "fazer desejar" o "proibido", com tudo o que isso então implicava, resultando em efeitos diversos, desde o crescente impulso das lutas pela democracia até os inúmeros problemas das experiências onde qualquer autoridade tendia a ser suprimida, para apenas mencionar dois exemplos.

No âmbito do discurso da educação popular, o saber popular então visado devia operar no sentido de transformar a situação de opressão em que os setores populares viviam. Sob esse discurso, sob essa configuração discursiva, que em grande medida também parece corresponder ao discurso da Histérica, articulouse efetivamente o que é da ordem de uma mudança, de um "fazer desejar" em direção ao que então era proibido. Um fato que podemos colocar na conta do saber popular que então se configurou, um saber estreitamente ligado à ação, à ação do povo, da comunidade, dos trabalhadores, dos setores populares, de todos os que afiguravam o outro do educador popular ou de qualquer um que se situasse na posição do agente do discurso histérico, participando das lutas e organizações populares que emergiram no final dos anos 70 .

A mesma configuração discursiva pode ganhar diferentes contornos, diferentes feições, como se procurou indicar nas análises precedentes. Isso significa que em cada forma de discurso o que é da ordem de uma impossibilidade articula-se de diversos modos, sem que a estrutura mude. É o que Lacan evidencia em suas análises. Por exemplo, ao pensar o discurso da Histérica de várias maneiras, embora isso não implique em novas estruturas, em novas formas de discurso. Com essa mesma estrutura, Lacan refere-se à histérica mesmo e ao discurso da ciência, este último concebido como um discurso que nasce sob a dúvida hiperbólica do cogito cartesiano. Vejamos então agora como entender o mesmo discurso da Histérica sob um outro ângulo, de maneira que nos permita enxergar em que medida esse discurso corresponde ao discurso da ciência. 
No lugar em que a ciência moderna nasce, mas também onde ela se renova, sempre temos como ponto de partida uma interrogação, uma ou inúmeras dúvidas. São elas as que estão no lugar de onde o discurso se ordena, de onde partem os mandamentos. Agora, essas questões ou dúvidas são endereçada a quem? O que o aparelhinho de Lacan sugere é que esse outro é um mestre, um mestre cujo trabalho resulta num saber. Mas um saber que, a princípio, não está à vista, que subjaz ao trabalho do mestre e que dele resulta, um produto que de certo modo lhe escapa, estando no registro do saber não sabido. Essa poderia ser uma leitura da fórmula que Lacan nos apresenta tendo em vista o lugar do saber $\left(\mathrm{S}_{2}\right)$, embaixo do lugar que corresponde ao significante-mestre $\left(\mathrm{S}_{1}\right)$. E que parece fazer sentido desde que entendamos isso relacionado ao momento da criação, quando um novo saber está sendo delineado. Um saber que não é mais do que um esboço de algo que exige uma formulação clara, com uma amarração consiste e passível de ser posta à prova pelas vias que o discurso científico estabelece. Mas nesse caso, com o saber formalizado e positivado, marcado também pelo significante-mestre ciência, não mais estamos no âmbito do discurso da Histérica. Aí encontra-se implicado um giro que torna o saber produzido nesse circuito da Histérica um saber de senhor. Portanto, um saber que é próprio do discurso Universitário. É dessas duas formas que neste trabalho foi concebido o discurso marcado pelo significante-mestre ciência, muito embora em geral corresponda no caso do discurso pedagógico construtivista - à configuração que é própria do discurso Universitário.

Isso pode ser tomado como algo que procede da relação que existe entre um discurso e outro, o qual, aliás, é o modo como Lacan concebe e opera com os discursos, sempre relacionados e girando. Por exemplo, quando se refere ao que o discurso do Analista produz. O que esse discurso produz, segundo Lacan, é o discurso do Mestre, "já que $S_{1}$ vem no lugar da produção" (1969-1970, p. 168). Uma afirmação que nos permite avançar sobre o que aqui está em causa, pois 0 mesmo poderia ser dito em relação a outros discursos, como o discurso da Histérica. O que ele produz é o discurso Universitário. Ou, dito de outra maneira, o que o discurso da ciência produz é o discurso Universitário. Este, segundo Lacan (ibidem, p. 97), "em sua disposição fundamental, é o que mostra onde o discurso da ciência se alicerça". Quer dizer, a ciência se consolida com e no discurso 
Universitário, que é onde o saber fica no lugar de comando, no lugar que no discurso é o dominante.

Tudo isso indica que estamos diante de duas configurações diferentes marcadas pelo significante-mestre ciência, como o próprio Lacan parece sugerir em sua teoria do discurso. Ademais, de uma configuração para outra, o lugar do saber muda. Em sua "situação universitária", o saber está do lado do mestre, é por ele sustentado: o $S_{1}$ "constitui o segredo do saber" (ibidem, p. 175). Por isso o saber adquire o semblante do que é incontestável - não se contesta o que o mestre ordena. Quer dizer, não há lugar para questões ou perguntas que apontem em direção ao que nesse discurso fica obscurecido, relacionado com o que é da ordem da sua verdade. No discurso Universitário toda pergunta sobre a verdade é silenciada ou esmagada, como sugere Lacan (ibidem, p. 98). Da verdade, é claro, que concerne ao desejo. E, portanto, ao gozo.

Vejamos agora como se produz o giro discursivo que se completa com o construtivismo e que, como foi apontado, já vinha ocorrendo no campo dos discursos críticos. Para enunciá-lo de um modo conciso, pode-se dizer que o discurso da Histérica entronou o discurso Universitário, na mesma medida em que o primeiro produziu um saber que ficou no lugar de comando. Um saber que resultou da confluência de um sem números de enunciados num mesmo ponto, o ponto de arremate que os condensa e que se configura graças às costuras feitas com os significantes de arremate do novo discurso. A emergência desse novo ponto de arremate, desse novo discurso pedagógico - o discurso construtivista -, deve ser creditada à confluência de tudo o que é da ordem da produção do discurso histérico sobre o mesmo ponto, desde a obra piagetiana - com seus desdobramentos, sobretudo a produção da pesquisadora Emilia Ferreiro e seus colaboradores no campo da alfabetização - até o que procede dos discursos educacionais alternativo-renovados, consideradas aí as suas diferenças e peculiaridades. Dentre elas, as que permitiram a projeção de determinadas instituições privadas, como a Escola da Vila, e das chamadas "pioneiras" do construtivismo, de acordo com a denominação usada pela revista Nova Escola em referência a alguns educadores cuja experiência profissional foi alicerçada, 
precisamente, nesse campo alternativo. ${ }^{7}$ Nesse giro também é preciso destacar a pedagogia dos conteúdos, que já nasce sob a configuração discursiva que é própria do discurso Universitário. Enfim, essas confluências todas, com as configurações discursivas aí envolvidas e o giro já assinalado, é o que parece explicar a emergência do novo discurso Universitário. Com ele, com o discurso construtivista, uma nova rede de saber é mobilizada para dar conta do que na segunda metade dos anos 80 continuava sendo o grande problema da educação brasileira: o fracasso escolar, inseparável do analfabetismo.

Relacionado com essa emergência e com a vertente do construtivismo que se tornou dominante, vale a pena considerar certo lugar de escuta criado no âmbito das experiências educacionais alternativas da cidade de São Paulo, mas que resta investigar em que medida ele surge em outros espaços. No "momento dos limites", em várias escolas alternativas paulistanas procurou-se um novo profissional para trabalhar os impasses e aflições próprias desse momento, quando as referências básicas do campo alternativo estavam ruindo. Trata-se do "analista institucional", em geral psicólogos com formação em psicanálise. Com esses "analistas", além de aflorar o que é da ordem de certa fantasmática implicada nesses processos, esses educadores, essas experiências, essas escolas privadas, encontraram um novo lugar, suficientemente depurado dos chamados "fantasmas" ou "fantasias" que então tanto perturbavam. Certas "palavras proibidas", antes excluídas do discurso, começaram a comparecer, como disciplina e lucro. E essas escolas privadas começaram a se perceber, agora sim, dentro de onde efetivamente estavam: um mercado, com pais de alunos com outras exigências. Nesse processo ganha impulso a sua "modernização" e a busca de referências pedagógicas sólidas, que é o que o construtivismo cria.

Com esse lugar de escuta, com os "analistas", o que desse processo de "análise" parece ter resultado é aquilo que é próprio da produção do discurso analítico: o discurso do Mestre, praticamente excluído na fase de maior radicalização dessas "experiências proibidas". Essa exclusão do que é da ordem

7 Esses e outros educadores procedentes do campo alternativo-renovado são os que com freqüência, no começo, encarnaram o lugar que no discurso construtivista é o dominante, ou seja, o lugar do saber, o lugar do S2. 
do mestre - ou seja, o governo, pois é essa a impossibilidade que o discurso do Mestre articula - parece corresponder a certa fixação do discurso alternativo na configuração que é própria do discurso da Histérica, impedindo assim que o discurso gire. E quando o discurso não gira, ele range, como afirma Lacan, justamente no lugar "onde as coisas colocam problemas, quer dizer, no nível do posicionamento de algo que se escreve a" (1969-1970, p. 170). Nesse caso, a "experiência proibida". É desse modo que poderia ser pensado o impasse antes mencionado e o que então surge como demanda: a escuta de um "analista", posicionado provavelmente no lugar então problemático. O que resultou desse processo pode ser avaliado pelos seus visíveis efeitos: a situação ingovernável dessas instituições mudou significativamente. Digamos que os problemas começaram a ser administrados, hierarquias foram estabelecidas e o que é da ordem do mestre tornou-se possível, ou seja, governar, fazer com que "as coisas andem". No momento em que isso ocorre, saem de cena os "analistas institucionais" e, em contrapartida, demanda-se a presença de certos especialistas.

Esse percurso corresponde, por exemplo, ao da Escola da Vila, que é a instituição que na revista Nova Escola surge como uma espécie de paradigma de escola construtivista. Nessa escola privada, procura-se entre outras coisas o saber de especialistas em marketing, em recursos humanos e dos que possuem um saber didático. E aí já pode-se vislumbrar a conjunção que no discurso pedagógico parece tornar-se hegemônica na década de 90, do discurso Universitário com o que é da ordem do Capital, não sem que aí também se encontre implicado o discurso do Mestre. Aliás, o que primeiro parece consolidarse é justamente esta articulação: entre o discurso Universitário e o discurso do Mestre. Com essa particular conjunção, que parece duplicar o que é da ordem do discurso do Mestre - ou seja, emitir mandamentos, ordenar, fazer com as coisas andem de acordo com a vontade do mestre —, essas experiências alternativas tendem a reencontrar a própria escola, ou melhor, a injunção que historicamente define o lugar da educação, pelo menos desde o momento em que foi transformada numa questão de Estado, como nos lembra Voltolini (2001, p. 102).

Além do tipo de configuração discursiva que corresponde ao discurso do Analista, com uma aparição um tanto fugaz na trajetória daquelas experiências, o 
que é da ordem do discurso da Histérica é o que nelas tende a se esvanecer. Um fato que cabe atribuir ao entronamento do discurso do Mestre, a um mestre que desta vez não cai. Esse esvanecimento não deve ser tomado como algo sem conseqüências, como se fosse um simples apagamento. Ao que tudo indica, ele produz efeitos bem particulares, pois o que se apaga é justamente o que sobrevive e opera desde um lugar onde não é reconhecido. O que se apaga é o aqui chamado "passado alternativo", que sobrevive recalcado e sustentando a posição do novo mestre, ou seja, operando desde esse lugar. No aparelhinho de Lacan, esse lugar corresponde ao lugar da verdade e ao que nele opera sob a forma da função que nesse caso o define. O que fica nesse lugar da verdade é o que sustenta o novo mestre, o novo $S_{1}$. De que modo? Operando sob a forma que é própria desta função: $S$, o sujeito dividido — a função que é dominante no discurso da Histérica. Em outras palavras, aqui está se supondo que o passado recalcado no âmbito dessas experiências, mas também do novo discurso pedagógico, concerne precisamente ao discurso da Histérica. Esse é o discurso que opera no lugar da verdade do novo mestre, sustentando-o em sua posição. Uma conclusão nada arbitrária se levarmos em consideração o que vez por outra retorna no e com o discurso pedagógico construtivista. O que nele retorna - ou parte do que retorna - é justamente da ordem do discurso histérico, e num âmbito que produz os efeitos por vezes reconhecidos por meio do significante limítrofe espontaneísmo. Esse âmbito é o educativo e nele parece operar, sob a forma do discurso histérico, parte do que no discurso construtivista não é reconhecido, porque recalcado. Esse resto "espontaneísta" costuma incomodar, é "algo" aparentemente indesejado e seus efeitos podem ser considerados nefastos, pois o que nesse âmbito deveria ser articulado é a comunicação de um saber. No entanto, esse resto insiste, provavelmente porque nele se articula o que é da ordem de um gozo.

Para avançar nesse ponto, nesse ponto limítrofe, tendo em vista as configurações discursivas antes referidas e o modo como se relacionam, uma via possível é considerar separadamente dois registros da experiência. De um lado, o registro que concerne aos vínculos que os profissionais da educação estabelecem entre si e, de outro, o âmbito propriamente educativo, dos vínculos que se estabelecem entre professor e alunos. Comecemos então pelo primeiro, sempre tomando como base os discursos já analisados ao longo deste trabalho. 
O tipo de configuração discursiva que nitidamente prevalece no plano dos vínculos estabelecidos entre os profissionais da educação é o discurso Universitário, com os especialistas e o seu saber teórico-científico-técnico na posição de comando, no lugar do agente. O outro desses especialistas, o outro a quem esse saber é endereçado são os professores, que postos a trabalhar nessa configuração discursiva deveriam se tornar seres pensantes, com questões e dúvidas, e por isso precisando articular uma fala que lhes permita costurar as aberturas que esse trabalho gerou. Isso não é mais do que uma forma de entender o que fica no lugar da produção do discurso Universitário: o sujeito barrado, o sujeito dividido - ser pensante, mas também alienado ao saber positivado $\left(\mathrm{S}_{2}\right)$ que nesse discurso está no lugar do agente. Um saber, nesse caso, sobre a educação escolar e sobre tudo o que gira em torno da "criança que constrói seu próprio conhecimento". Alienando-se nesse saber, o professor tornase um construtivista. Esse professor, enquanto outro do agente do discurso Universitário, ocupa o lugar do aluno, do aprendiz, do educando; é o objeto desse saber que o impulsiona e o faz trabalhar em prol do que nesse circuito constitui a sua produção. Como objeto, ou melhor, como objeto a, a posição em que o professor é situado supõe que ele realize um trabalho no qual algo é amarrado sem que essa amarração se complete, pois algo sempre deve escapar. É da natureza da objeto a que nele a rede simbólica sempre fracasse, pois é um elemento heterogêneo em relação a essa ordem, à ordem simbólica. Com esse fracasso articula-se precisamente a produção desse discurso: o sujeito do desejo, o sujeito dividido, um sujeito com questões e dúvidas, mas que não ficam à vista, conforme sugere o aparelhinho de Lacan. Para que isso ocorra seria necessário um giro discursivo. Mas esse giro é o que no discurso pedagógico construtivista custa a acontecer. Quando isso ocorre, um ser pensante pode efetivamente surgir, ou seja, um sujeito histérico, capaz de pôr em movimento o aparelhinho onde no lugar da produção configura-se o que é da ordem de um novo saber. Em outras palavras, esse giro é o que permite romper o círculo da alienação primeira em que todo aprendiz precisa situar-se. É o que dá lugar a um outro posicionamento e a um outro tipo de laço social, que nesse caso corresponde ao discurso da ciência, da ciência que não foi imobilizada. 
Tudo isso sugere algumas questões. Por que o discurso pedagógico construtivista tende a se fixar, repetidamente e no âmbito acima considerado, na configuração que é própria do discurso Universitário, tornando-se uma espécie de dogma e adquirindo um viés religioso? O que faz com que isso ocorra? Por que o giro discursivo acima apontado não ocorre com mais freqüência? Por que torna-se raro? Enfim, por que o discurso construtivista não gira ou pouco gira nesse registro do vínculo que se estabelece entre os profissionais da educação?

Uma resposta poderia ser ensaiada pondo em foco o que neste mesmo trabalho ficou obscurecido na análise do discurso construtivista: o discurso do Mestre. Algo que provavelmente tem relação com o modo como este estudo foi situado, mas também com o que o discurso pedagógico construtivista exclui no plano do enunciado. O que esse discurso enuncia tende a ficar circunscrito ao âmbito do trabalho do professor na sala de aula, às questões de ordem didática ou metodológica e à proposta pedagógica, em geral deixando completamente apagado o que é da ordem da escola enquanto instituição. O lugar do professor nesse discurso configura-se sob esse horizonte, ou seja, excluindo questões de ordem institucional, além de outras que ficaram no "passado". Ademais, esse lugar é definido de um modo que corresponde ao que o discurso Universitário instaura, se consideramos aí não o plano educativo, mas o tipo de vínculo que se estabelece entre os profissionais da educação. Simplificando um pouco e tomando como base o que muitos enunciados desse discurso configuram, poderse-ia dizer que o professor construtivista é aquele que compreendeu a teoria ou teorias construtivistas, delas derivando uma postura adequada e uma prática que segue os princípios construtivistas. Lembremos, por exemplo, da professora Bernadete, que teve a sua "fada madrinha", ou seja, a especialista que a guiou nesse pedregoso "caminho" em direção à teoria e à ciência. ${ }^{8}$ Para quê? Para tornar-se uma "boa" professora, uma professora construtivista. A especialista está no lugar do saber, do $S_{2}$, ensinando, e por isso ela conduz a professora Bernadete pelo "caminho" que julga necessário trilhar para que essa professora se torne uma construtivista. A especialista é um mestre, muito embora fique obscurecido o que é mesmo da ordem do mestre: ordenar. Esse é o discurso Universitário.

\footnotetext{
${ }^{8}$ Cf. capítulo IV.
} 
Vejamos agora o lugar do professor por um outro ângulo que igualmente evidencia 0 que no discurso construtivista fica nas entrelinhas, relacionado também com aquilo que sustenta a posição do especialista. Partamos desta pergunta: qual é o discurso que incide sobre o lugar do professor em seu cotidiano escolar, não necessariamente na sala de aula, mas nos âmbitos em que questões de ordem funcional ganham um primeiro plano? $\mathrm{Na}$ teia de relações que predomina nas instituições escolares e que faz com que elas "andem", com que administrem seus problemas, o que é dominante é o discurso do Mestre. Digamos que o professor, afora o que corresponde ao ato educativo, sempre vive às voltas com a necessidade de cumprir os seus deveres funcionais, seja numa escola pública ou num escola particular. Esse tipo de discurso está bem presente e de modo evidente onde o discurso construtivista comparece. Mas esse discurso pedagógico não incorpora explicitamente o que é da ordem do mestre nesse plano dos vínculos entre especialistas e professores, ambos diferentemente implicados nesse discurso. Implicados, lembremos, sob a injunção que resulta da sobreposição das duas configurações aí envolvidas: o discurso Universitário e o discurso do Mestre, com este último um tanto quanto apagado e por isso, talvez, operando de um modo mais eficaz. Na produção desse ativo apagamento certamente contribuem determinadas articulações discursivas que vinculam o construtivismo e a democracia, confundindo-os no mesmo lugar e assim obscurecendo as dimensões implicadas nesse construtivismo do dia-a-dia escolar.

Aquela sobreposição pode também ser vista de um outro modo, que não exclui o anterior. Sob a injunção do discurso Universitário, o professor, como outro, é posto a trabalhar para que desse lugar surja esta produção: um ser pensante, sob a forma que corresponde a esse discurso, ou seja, um professor construtivista. Entretanto, a injunção que é própria do discurso do Mestre exige que cumpra ordens, que faça com que as coisas sigam o "seu" curso para produzir o que o mestre precisa, o a mais que a sua posição exige. Essa sobreposição, essa espécie de duplicação do discurso do Mestre - com o mestre antigo (discurso do Mestre) e o mestre moderno (discurso Universitário) —, é o que parece explicar o fato do discurso pedagógico construtivista não girar ou pouco girar. Digamos que a produção do ser pensante que é própria do discurso Universitário não chega a se constituir, na mesma medida em que o professor sempre tem que fazer "andar" alguma coisa, seguindo os mandamentos de quem 
fica no lugar do agente. Ou então, constitui-se de um modo insuficiente ou de uma forma que impede que esse ser pensante assuma o lugar que no discurso é o dominante. Para que isso possa ocorrer, determinados espaços são imprescindíveis. Digamos que eles deveriam ser multiplicados: os espaços onde o mestre possa cair da sua posição, para ser substituído por outro, que também pode perder o seu lugar, para um outro novamente emergir. Ou seja, espaços onde a palavra circula sob a forma do discurso histérico, no plano que aí está em jogo, relativo aos vínculos que os profissionais da educação entre si estabelecem. Mas a questão é justamente essa, isto é, essa possibilidade parece ter sido reduzida ao mínimo, em particular no período em que predominou o construtivismo tecnicista. Desse modo foram igualmente reduzidas as possibilidades de pensar as questões da educação escolar sob outros ângulos, trazendo à tona outras questões, sobretudo as que inquietam os que nesse discurso Universitário estão no lugar do objeto a, ou seja, os professores. Mas também, poderíamos acrescentar, os pais de alunos, que em face dos especialistas e também dos professores ficam na mesma posição, sendo desse modo impedidos de assumir a palavra, outra palavra, diferente da que é pautada pelo discurso Universitário. A instauração dessa região de silêncio corresponde ao apagamento de tudo 0 que determinados significantes de ressonância instauravam antes e durante a emergência do novo discurso, mas que não mais o fazem.

Sob esse novo discurso Universitário, o professor tampouco parece efetivar o que é da ordem do objeto a, ou melhor, da função que opera no lugar do trabalho. Algo que talvez corresponda a ausência de um lugar de escuta, ou seja, do discurso do Analista, que não necessariamente devemos supor exija a presença de um analista. Lembremos que o objeto a é um objeto que sempre escapa, que não pode ser apreendido, embora tudo tenda a confluir em sua direção. Essa função, do objeto que tudo atrai sem que nele se fixe qualquer significação, parece ter ficado esvaziada, na mesma medida em que no seu lugar encontra-se o que é da ordem de uma outra função, que sobrepuja a primeira. $\mathrm{O}$ que nesse lugar do trabalho encontramos, ao sobrepor o discurso do Mestre ao discurso Universitário, é um saber que responde sem questionar - e como pode - aos mandamentos do mestre. Esse lugar do professor, ademais, foi cercado por uma espessa e "todo coerente" rede simbólica que procura, a todo custo, fixar- 
Ihe um lugar. Para isso, exatamente, servem os extremos, os significantes limítrofes que são próprios desse discurso, mas também os exemplos bem concretos de professores construtivistas, professores esses que imaginariamente encontraram o seu lugar — o lugar "ideal".

Com forte presença no âmbito das relações que os profissionais da educação estabelecem entre si, o discurso Universitário não mantém o mesmo vigor onde deveria, no plano dos vínculos professor-alunos. Ele desaparece na mesma medida em que comparece "a criança que constrói seu próprio conhecimento" junto com um professor que dela pretende extrair algum saber sobre a sua própria posição. É nesse ponto que parece emergir o que é da ordem do discurso da Histérica, esvanecendo-se aí o que constitui o seu avesso. A força dessa configuração discursiva em que a criança, como outro, torna-se o mestre, pode ser avaliada tomando como base os inúmeros enunciados que criam os lugares aí supostos. Voltemos para a professora Bernadete, a professora construtivista. A bem da verdade, não foi apenas a sua "fada madrinha" que a ajudou a encontrar o seu lugar. Com as crianças e nas crianças, os seus alunos, ela se reencontrou, encontrou o seu lugar, podendo no final do "caminho" dispensar a sua "fada madrinha". Afinal, já sabia "caminhar" de mãos dadas com as suas crianças-alunos.

As vias pelas quais se insiste no acesso a um saber localizado na criança, para assim criar um circuito em que o professor figura no lugar de quem interroga, de quem coloca questões a suas crianças-alunos para definir a sua posição, o seu lugar, são várias. Se nos deixarmos levar pelo que o discurso da Histérica sugere, esse circuito é estabelecido tendo em vista o que é próprio desse discurso, o que é próprio do lugar onde se configura a sua verdade, isto é, o que seu agente deseja é ser desejado. Por quem? Pelas suas crianças-alunos. Mas, na medida em que isso ocorre, na medida em que esse circuito se realiza, tende a diluir-se o que é próprio do ato educativo. Isso não significa que a educação e o ensino exijam a exclusão das outras configuração discursivas no âmbito dos vínculos professor-alunos. Até mesmo o discurso da Histérica parece necessário em determinados momentos, para produzir determinados giros. A arte de educar talvez se encontre nisso, em saber manejar o que é da ordem desses giros sem 
perder de vista o que nesse âmbito é central: o discurso Universitário, o saber na posição de comando.

O que até aqui foi discutido concerne basicamente ao período que antecede a emergência do construtivismo tecnicista. Essa emergência ocorre quando esse discurso sofre a injunção de tudo o que o significante-mestre moderno e seus equivalentes criam. Digamos que é uma segunda fase, entre o momento em que o construtivismo emerge e se torna hegemônico e o momento em que surge a versão oficial do construtivismo, com os Parâmetros Curriculares Nacionais. O construtivismo tecnicista, que é o discurso que prevalece na revista Nova Escola em 1996, no ano "mercantil e didático", configura-se graças a esta particular cópula: do discurso Universitário com o que é da ordem do Capital. Vejamos o que isso significa.

Com o construtivismo tecnicista, o que ganha relevância, o que tende a sobrepujar todo o discurso, não é mais "a criança que constrói seu próprio conhecimento", mas o que concerne à ordem dos meios para atingi-la, ou seja, o que neste trabalho foi chamado de "núcleo didático", envolvendo tudo o que é da ordem das técnicas de ensino, dos materiais didáticos e dos conteúdos. São eles os que comandam o discurso. Um discurso que agora parece bem posicionado, por assim dizer, na medida em que o seu semblante é o do discurso Universitário. Afinal, o que no "caminho construtivista" ganhou relevância é o professor que intervém, que tem de ensinar, que domina muitas e muitas técnicas, além de conhecer e saber usar os outros componentes do "núcleo didático". Nessa fase, os extremos do discurso construtivista, o seus pontos limítrofes, tendem a se esvair. O "caminho" já não é mais pedregoso, tudo o que nele entra agora parece fluir com facilidade. O "caminho construtivista" tornou-se uma veloz estrada moderna, um estrada que agora está sob um novo comando, o do mestre que tende a se impor na década de 90 nos mais diversos campos, tanto no Brasil quanto no mundo globalizado.

Sob o domínio do Capital, o que tende a ocorrer é o apagamento de tudo o que é da ordem da falta, como se o sujeito em falta pudesse facilmente encontrar o que lhe falta. No caso do professor, guiando-nos pelo que prevalece na revista Nova Escola em 1996, poderíamos dizer que o que lhe falta concerne ao "núcleo didático", que está aí, ao alcance de seu "bolso", sob a forma de um saber que os 
especialistas possuem e que a revista divulga, junto com tudo o que facilita esse vínculo que o mercado cria. Um saber que antes de mais nada é técnico, um saber técnico, facilmente apreensível através de regras formuladas de modo sucinto e claro. Nesse período, a "criança que constrói seu próprio conhecimento" perde boa parte de seu vigor e o professor também tende a se apagar, a se esvair. O "objeto didático" parece ficar no seu lugar, fazendo o que ele deveria fazer. Esse objeto sobrepuja e domina o professor, mas também as criançasalunos, que são conduzidas e seduzidas pelos "objetos didáticos" que então proliferam. Se aí há um sujeito, a esse sujeito nada falta e está no lugar do objeto, em razão de um objeto que adquire mais e mais valor, com um valor que nele se acumula, apagando assim o que é da ordem do sujeito.

Se tomarmos como referência o aparelhinho que corresponde ao discurso Universitário, de início tendo em vista o vínculo estabelecido entre especialistas e professores, poderíamos dizer que o que se apaga é a barra que separa o objeto a e o sujeito dividido, que deixa de sê-lo na medida em que essa separação se esvanece. No ponto extremo, com o que é da ordem do objeto a sobrepujando totalmente o sujeito, até absorvê-lo, tornando-se ele próprio o Sujeito, ficamos apenas com um termo do lado direito da fórmula: o Sujeito que se basta a si próprio: S, sem qualquer barra, sem qualquer divisão. Mas um Sujeito que ainda parece depender de algo, que é o que corresponde ao que está do lado esquerdo do aparelhinho de Lacan.

O que temos desse lado? Acima, um saber $S_{2}$, a bateria significante, suportada ou sustentada pelo mestre $S_{1}$, que em nosso caso corresponde ao que é da ordem do Capital. Digamos que o $\mathrm{S}_{1}$ é a forma mercadoria, em sua forma de equivalente universal, em sua forma dinheiro. Este é o que sustenta o discurso nesse período, é o que faz com que as coisas andem com fluidez, em direção aos consumidores. $\mathrm{E} \mathrm{O} \mathrm{S}_{2}$ ? Como bateria significante, com todos os significantes de ressonância que aí encontramos, $0 \mathrm{~S}_{2}$ torna-se uma bateria de significantes equivalentes, na mesma medida em que tudo tende a se transformar numa mercadoria. Todos tornam-se equivalentes sob o reino do equivalente universal, do $S_{1}$ que está em todos lados. No extremo, o $S_{2}$ parece torna-se igual ao $S_{1}$. $O$ que equivale a dizer que o $S_{1}$ reina sozinho, anulando-se assim o que é da ordem de uma repetição sempre diferente, anulando-se o que é da ordem do traço 
unário. Não há mais 1 e 2, com a abertura que podemos supor entre um significante e outro. Se não há mais abertura, se não há mais barra desse lado, se não há mais um significante que represente um sujeito para outro significante, não há mais sujeito. O que é o mesmo que dizer que o predomínio absoluto do discurso do Capital extingue a vida, a vida humana. Na fórmula da qual partimos, tudo isso pode ser expresso deste modo: $\mathrm{S} \rightarrow \mathrm{S}$. Ou seja, o equivalente universal é o que define a posição do "sujeito", que em nosso caso é o "núcleo didático". Mas a flecha que Lacan utiliza para indicar uma impossibilidade, a impossibilidade que cada discurso articula, nesse caso não faz sentido. Na verdade, essa flecha poderia ser retirada e ambos lados reunidos num mesmo ponto, no S. Afinal, o Sujeito mesmo é o equivalente universal, é o dinheiro, é o Capital. Digamos que essa seria a tendência de um circuito que sob o domínio do Capital e conjugado ao discurso Universitário anula o que é da ordem da falta. O que disso resulta, o que disso podemos esperar, é o pior, a começar pelo que é da ordem da violência e da morte. E é claro que aqui não está se falando apenas do que corresponde ao discurso pedagógico, pois o que está em causa é algo que extrapola esse discurso e que foi configurado pelos mais diversos discursos no decorrer da década de 90, envolvendo esta particular fusão: ciência positiva e dinheiro.

Essa conjugação é o que dilui a matriz simbólica construtivista e faz com que o discurso Universitário, que nela tende a predominar, gire sobre os mesmos lugares, por assim dizer. Um giro cuja tendência é suprimir toda e qualquer fenda. Um fato do discurso que acima foi expresso deste modo: $S \rightarrow S$. O primeiro $S$ relativo ao Significante, agora Uno, pois ele próprio se basta, equivale a qualquer Um; o segundo S relativo ao Sujeito, não mais dividido. Os dois se confundem, talvez porque aí estamos em face de um significante-signo, um significante-gozo, um significante-mãe, um "significante" capaz de fechar qualquer sutura. Pelo menos é o que ele promete, ou melhor, o que o Capital sempre promete e até realiza, sobretudo quando nada resta para oferecer resistência. Temos então um discurso transparente no seu mais alto grau, um Outro não barrado, um Sujeito onipotente e onipresente. Por isso, o que esse discurso institui é mesmo o presente, o lugar do presente com a sua superfície infinita. Esse parece ser o lugar do gozo, o lugar onde é preciso começar a retroceder para que a vida prossiga. Um gozo que, é claro, sempre implica o corpo. Mas onde estão esses corpos? Nos "efeitos mortíferos" que a hegemonia daquele mestre produz. 
Vejamos agora, em poucas linhas, o que tende a ocorrer sob a mesma injunção no registro propriamente educativo. Com o saber técnico, com o "saber didático", com esse "núcleo" que comanda a ação pedagógica, podemos supor que ocorre o que é próprio de toda ação meramente técnica. Tudo é transformado em algo manipulável, inteiramente manipulável, extinguindo-se assim o que seria da ordem do objeto a, do objeto que não se deixa capturar, e que corresponde ao lugar do aluno. Este é fixado de um modo simples, claro, preciso, estabelecendose regras que definem o que o professor deve fazer, os passos que ele deve seguir para cada situação, com cada tipo de aluno ou tipo de turma, como vimos na revista Nova Escola em sua fase "mercantil e didática", quando os textos instrucionais predominam. ${ }^{9}$ Quer dizer, o que aí deveria se articular como uma impossibilidade, para que a educação torne-se mesmo possível, não se articula propriamente dessa maneira, mas antes como algo plenamente possível. O problema aí é essa plenitude, que é o que torna essa operação - educar impossível mesmo, plenamente impossível. Em outras palavras, a ação educativa fracassa. $E$ fracassa porque a fantasia que nutre toda ação pedagógica articula-se como se fosse mesmo real, extinguindo-se assim o que opera produzindo, articulando e separando os diferentes registros do sujeito. Extingue-se portanto a ordem significante. No extremo, a fantasia tornada real supõe a eliminação de toda e qualquer distância entre o sujeito dividido e o objeto causa do desejo, por isso o que afinal se extingue é o desejo. E aí, é claro, o real como que "explode". ${ }^{10}$ O gozo torna-se o nosso meio, o nosso habitat.

Todas essas conclusões certamente são um tanto catastróficas, mas não por isso estranhas ao que o circuito do Capital tende a produzir quando se torna hegemônico e nessa condição anula crescentemente outras formas de discurso.

\footnotetext{
${ }^{9}$ Cabe aqui esclarecer que a revista Nova Escola, como toda publicação, desde o seu primeiro número encontrava-se sob a injunção que é própria de qualquer mercadoria. Ou seja, os seus textos sempre estiveram sob a injunção de um circuito mercantil. Mas isso não significa que o discurso educacional ou pedagógico fosse dominado pelo que é da ordem do mercado, como de fato ocorreu de modo visível em determinado momento.

${ }^{10}$ Isso é o que Lacan sugere ao tratar das quatro operações impossíveis (governar, educar, analisar e fazer desejar), relativas aos quatro discursos por ele formalizados (discurso do Mestre, discurso Universitário, discurso do Analista e discurso da Histérica), quando ocorre a "sua plena articulação como impossível", que é "o que nos dá o risco, a chance vislumbrada, de que o seu real, por assim dizer, exploda" (1969-1970, p. 165).
} 
Quando isso ocorre e esse limite é vislumbrado, configurando-se ademais o que é da ordem de uma resistência, as coisas que "andam" no circuito criado e imposto por aquele mestre podem começar a recuar, dando lugar a outras "coisas". É o que parece ter começado a ocorrer no campo do discurso pedagógico ainda na segunda metade da década 90. Digamos que começou a ganhar terreno um saber que fez circular algo que é da ordem de uma falta. Isso, precisamente, é o que as críticas ao construtivismo fizeram circular, mas sem abalar a hegemonia desse discurso. E aí já estamos no período em que o construtivismo oficial torna-se o eixo de boa parte das polêmicas sobre a educação escolar. Resta agora saber por que esse discurso pedagógico continuou tão firme, tão sólido, tão hegemônico. O que explica a sua hegemonia? Essa é uma resposta que deve ser procurada no que é da ordem da fantasmática que o sustenta e das formas de gozo que esse discurso proporciona. É o nosso próximo ponto.

\section{Um lugar de fantasmas}

O discurso pedagógico construtivista é uma estrutura significante que, além de regular o campo da palavra, fixa as posições dos sujeitos implicados no tipo de laço social que com ela prevalece. Como vimos, o tipo de laço social varia dependendo dos lugares institucionais em jogo (profissionais da educação, pais de alunos, alunos, etc.). Por isso, ao tratar dessa estrutura significante, do registro fantasmático nela implicada e do que com ela e nela se repete, é preciso voltar a diferenciar e considerar esses âmbitos. Antes, porém, vejamos o que está em jogo nessa repetição.

Primeiro, o que se repete é certa ordem significante. Em nosso caso, repetem-se determinados pontos de ressonância, que são os pontos desse discurso pedagógico, estruturado como vimos por três nós, os aqui chamados pontos de estrutura. Segundo, a repetição em si tem uma função, ela é uma função. Essa função é o gozo. Ou seja, repete-se para gozar, a repetição visa o gozo. E mais, a repetição é gozo (Lacan, 1969-1970, p. 43). Mas é um gozo sempre insuficiente, daí a repetição. Ou seja, algo sempre escapa, "há perda de gozo" (ibidem, p. 46). E o que escapa é justamente o que cada modalidade de discurso busca capturar a seu modo, como sugere Zizek (1992, p. 173). A função do objeto a diz respeito a essa captura e ao que ela põe em movimento para 
produzir um gozo a mais, o mais-de-gozar que é próprio da fantasia. Um gozo a mais que tampouco fecha o circuito, tornando a repetição um movimento que não cessa. Em outras palavras, a função do objeto perdido, do objeto a, surge no lugar dessa perda introduzida pela repetição (Lacan, ibidem, p. 46). Se "há um mais-degozar a recuperar", a razão disso é esse "desperdício de gozo", esse "efeito de entropia" que é próprio da repetição da ordem significante (ibidem, pp. 44-8). Essa ordem, essa estrutura significante, é o que produz o gozo, mas ela própria também cria um limite, na mesma medida em que produz uma perda, com o maisde-gozar constituindo a derradeira tentativa de capturar o que escapa, e que no fim é um resto nocivo, um "gozo ruinoso", o gozo da morte. Como afirma Lacan (1972-1973, p. 36), o significante é "a causa do gozo" e ao mesmo tempo "aquilo que faz alto ao gozo". O significante, portanto, produz a castração: a operação que define o nosso ponto de gozo, mas tão-somente como um contorno, um lugar a ser contornado, porque ele próprio permanece inacessível, interditado. Entrar nessa zona proibida, para nela tentar se instalar, implica mesmo a morte, o fim do sujeito do desejo. Por isso, toda estrutura significante, que é um aparelho de gozo, funda-se precisamente na sua interdição, na interdição do gozo. Eis a razão pela qual esse termo não está no aparelhinho de Lacan, ele não foi nomeado porque diz respeito ao que "não é nomeável" (Lacan, 1969-1970, p. 168).

Com a repetição da estrutura significante, duas formas de gozo estão em jogo. Uma é o gozo fálico, que é o que corresponde à repetição mesmo, à repetição como gozo. É o que podemos situar no registro do sintoma. A outra é o mais-de-gozar, que é o que se articula no registro do objeto a, no registro que é próprio da fantasia. O mais-de-gozar é uma função que surge "em suplência à interdição do gozo fálico" (Lacan, 1969-1970, p. 70), visando justamente o que nele e através dele, do sintoma, não se realiza.

No discurso pedagógico construtivista, o que se repete em cada âmbito (entre profissionais da educação, na sala de aula, etc.), com as formas de discurso que em cada caso prevalecem, concerne primeiramente a determinadas posições. Posições subjetivas e tipos de vínculos que definem o que esse discurso instaura como sintoma, como sintoma social. Por exemplo, voltemos a tomar como referência a professora Bernadete, destacada na revista Nova Escola como professora construtivista. Ela parece ter produzido o giro que lhe permitiu 
sair do lugar do aprendiz, do lugar que corresponde ao outro do discurso Universitário, na mesma medida em que ela própria se tornou uma construtivista, ou seja, um agente desse discurso. Como agente, ela torna efetivo um lugar que se configura com outros agentes, com outros professores construtivistas, todos posicionados de modo a fazer com que esse "aparelho de gozo" — ou seja, o discurso pedagógico construtivista - funcione. Isso exige, é claro, um outro, o outro que esse discurso faz trabalhar. Por exemplo, os professores que ainda não são construtivistas ou os pais de alunos que precisam compreender a "nova proposta" pedagógica. Essas são posições que definem o que é da ordem do sintoma ou, mais precisamente, de um sintoma social instituído por determinado significante de arremate e sob determinada configuração discursiva. No caso, o significante-mestre construtivismo e o discurso Universitário. Eles definem as posições fundamentais, os lugares que os sujeitos ocupam para estruturar o que é da ordem de um sintoma social. Resta saber o que está em jogo na produção desse sintoma, ou melhor, no gozo que a sua repetição produz.

Uma via para avançar nessa questão é atentar para o lugar em que a professora Bernadete se situa, não a Bernadete construtivista, mas a candidata a construtivista, quando posicionada como aprendiz. É preciso olhar, portanto, para esse ponto de perda que o objeto a constitui. Nele encontramos, é claro, os pontos limítrofes, os professores em que "algo" falta, na medida em que neles "algo" não se realizou. "Algo" que o discurso construtivista promete proporcionarIhes para que possam sair desse lugar em que eles próprios afiguram a falta. Nesse lugar, configuram-se duas posições extremas: o professor tradicional e o professor espontaneísta, que se encontram no mesmo buraco, no a. Dois "tipos" de professores que ainda não compreenderam as teorias construtivistas e que costumam equivocar-se quando iniciam esse pedregoso "caminho", cometendo toda sorte de desvios e cada um caindo no extremo que lhe é próprio. O professor construtivista, no entanto, sabe situar-se no ponto adequado, no "ponto de equilíbrio", mesmo que isso exija continuar a estudar, a questionar e repensar o que faz, conhecer seus alunos, etc. Quer dizer, o "caminho" prossegue, não constitui algo acabado, é preciso continuar desdobrando o mesmo discurso, continuar a passar pelos mesmos pontos, pelos pontos de estrutura. 
A repetição acima implicada, necessária para desdobrar e tentar capturar o que escapa, é a que (re)cria os sintomas construtivistas. Ou seja, é a que repõe os mesmos lugares. No caso do professor, o lugar do ideal realizado e de seu avesso, do professor que fracassa, que fica sob a órbita dos pontos limítrofes. Esses pontos absorvem tudo o que é da ordem do fracasso, neles perdendo-se o que é fundamental para que esse discurso gire. Por isso, precisamente, são os que sustentam esse discurso. O sustentam na mesma medida em que não deixam à vista o que esse discurso apaga ou exclui. Uma exclusão que tem como contrapartida a criação de algo a mais, de algo que deve servir para tamponar as falhas que necessariamente aparecem e caem na conta do que o construtivismo produz sob a forma de "desvios, confusões, equívocos ...".

O bom professor, o professor construtivista, é também o professor com a sua criança-aluno construtivista: a "criança que constrói seu próprio conhecimento". Essa criança-aluno é o que primeiramente fixa a sua posição, com o complemento aí necessário: o fracasso escolar, como ponto extremo onde esse ideal não se realiza. Ponto limítrofe, o fracasso escolar abre-nos o acesso ao que nesse discurso é mesmo excluído, muito embora seja esse precisamente o problema que muitos educadores implicados por e nesse discurso procuram resolver, não sem que esse mesmo problema os sustente e promova. Em torno desse resto incômodo articula-se a fantasmática que sustenta esse discurso, com todos os fantasmas que the dão consistência e que o construtivismo faz circular, como é o caso de certo repertório de imagens que fica sob a órbita do significante limítrofe escola tradicional. São imagens retiradas de seu contexto original e que ganham um sentido particular no registro que o construtivismo (re)cria. Nesse lugar de fantasmas articula-se o que é da ordem de um saber, de um saber não sabido, mas que sustenta as falas construtivistas. São falas que seduzem em razão do que elas prometam, mesmo que essa promessa se articule nas entrelinhas, o qual, é claro, as potencializa.

O que elas prometem pode ser vislumbrado no que a professora construtivista Bernadete (re)encontrou em suas crianças-alunos: ela própria, como criança e sob a plenitude em que o construtivismo a deixou. $O$ qual implicou, por certo, o seu sucesso como professora, de acordo com o que esse discurso institui como ação bem sucedida. Uma ação cujo ponto de partida é situado na criança- 
aluno e que deve ser prolongada acompanhando sempre o percurso dos aprendizes. O professor construtivista tem de aprender a "caminhar" com suas crianças-alunos. É o que a professora Bernadete aprendeu.

A promessa que aí se articula, nos inúmeros enunciados que definem o lugar do professor construtivista, é a mesma que parece atravessar todo discurso pedagógico: a plena efetivação da relação pedagógica - uma meta que no discurso construtivista envolve a identificação do professor com o que é da ordem da criança. Como já foi apontado, efetivar essa meta tornaria a educação uma operação plenamente impossível. Assim como não há relação sexual, não há relação pedagógica. A cópula professor-aluno, se efetivada, tornaria sem efeito o que todo ato educativo supõe: a produção de um sujeito do desejo. Desejo que, sabemos, é do Outro, com o furo que opera impedindo essa cópula. Se a professora Bernadete produz algo que é da ordem da educação e do ensino, certamente isso se deve a um circuito que impede essa fusão. Digamos que, nesse caso, algo que é da ordem de um saber ainda subsiste, um saber que impõe recuar diante de determinados limites. Nisso talvez resida a fecundidade e não a eficácia - que resulta das ações de professores sob a injunção do discurso construtivista, sendo secundária toda a parafernália teórica e didática que muitos especialistas mobilizam para tornar a educação eficaz, ou melhor, para cumprir aquela promessa. Isso não quer dizer que o que é dessa ordem, da ordem pedagógica e didática, não seja necessário no âmbito da educação escolar.

Colocada como horizonte a ser realmente atingido, essa fantasia - que aquela única formulação tão-somente situa - é o que parece promover e sustentar a deriva do discurso construtivista em sua virada tecnicista, que é quando essa fantasia parece tornar-se mesmo real. Mas aí, nesse ponto, professor e aluno desaparecem. Sobra o que é da ordem do "núcleo didático". É "isso" o que pulsiona de modo manifesto na fase tecnicista: o professor-máquina. Nessa fase, vale lembrar, nas capas das revistas Nova Escola de 1996 aparecem também as crianças-fantasia, as crianças-anônimas, as crianças-grifes, que podem ser tomadas como esse algo a mais que tampona o que foi excluído. Oferecidas à professora-leitora, a seu olhar, o que esses particulares objetos revelam é o circuito que então se impõe e que vinha ganhando terreno há alguns 
anos: o circuito do ensino privado. Se aí se articula algo que é da ordem de um gozo, ele concerne ao que nessas imagens seduz, ao que nelas não é possível enxergar diretamente, a não ser como "algo" que não pode ser localizado de modo preciso. Lembremos, são imagens de crianças um tanto embranquecidas, bem vestidas, bem nutridas, sem quaisquer marca que lembre o que é da ordem da falta e daquela "realidade da criança" presente nas capas dessa mesma revista dez anos antes, em 1986. Essa "realidade" tende a ser excluída, como se evidencia se repararmos no nítido desaparecimento de determinados significantes-mestres, como classes populares e comunidade. Em contrapartida, as escolas privadas ganham espaço, junto com tudo o que é da ordem do mercado, em particular certo saber didático, o saber sob a forma do "núcleo" já referido. O "núcleo" que a todos seduz e que atravessa as capas e matérias da Nova Escola do ano "mercantil e didático". Os múltiplos objetos que esse "núcleo" gera são oferecidos à professora-leitora, à professora-consumidora, são feitos para causar o seu desejo. Esses objetos estão no lugar do que outrora prevalecia como destaque de capa dessa publicação, com as diversas "realidades" que aí compareciam, configuradas no âmbito dessa revista mas também pelo discurso educacional do período. O que esses objetos encobrem, portanto, é o que foi excluído, que nada mais é do que aquilo de que o novo mestre - o mestre Capital — prescinde.

No que foi excluído encontra-se a verdade do discurso pedagógico construtivista, um discurso que emerge e se afirma em virtude da operação de costura feita sobre o terreno dos discursos críticos. Esses discursos críticos, em especial o discurso educacional alternativo, deixaram de fazer sentido, na mesma medida em que se assentavam sobre uma ficção, sobre palavras de ordem que não mais ressoavam. Crescentemente corroídos, esses discursos quase que desapareceram na década de 90. Algumas palavras, como libertação, de forte ressonância no discurso da educação popular, nessa década perderam qualquer poder como significantes, isto é, a posição dos sujeitos educadores não mais passava por elas. Esses discursos, porém, no registro mesmo da ficção que configuravam, colocavam em primeiro plano questões de não pouca relevância no que se refere ao chamado fracasso escolar. Essas questões tendem a desaparecer com o discurso construtivista, como é o caso das que confluíam evidenciando e denunciando a profunda cisão em que se assenta a sociedade 
brasileira. Uma cisão que nos discursos críticos ficava exposta e que foi obliterada pela cordial e didática linguagem construtivista, em especial na sua fase tecnicista. Ou seja, aqueles discursos, sob a forma da fiç̧ão que produziam, retinham o que é da ordem de certa verdade, ou melhor, do enigma cujo desenvolvimento permitiria desatar alguns dos nós estruturantes do grande buraco que o significante-mestre fracasso escolar situa. Um buraco que corresponde ao abismo que separa determinadas camadas sociais e que diz respeito aos particulares contornos do capitalismo brasileiro. Desses contornos faz parte o fracasso escolar. ${ }^{11}$

Com o discurso construtivista, pouco é possível saber e avançar em relação ao que é da ordem do abismo acima referido. O que dele seria possível apreender, para assim ajudar a corroer o que sustenta o fracasso escolar, parece ter escapado no vão que distancia e separa a "realidade da criança" presente nas capas da Nova Escola de 1986 e a que comparece dez anos depois, em 1996. Nesse "caminho", que é onde este trabalhou procurou se instalar — ou seja, entre o momento imediatamente anterior à emergência do construtivismo e o ponto alto da sua hegemonia - perdeu-se "algo" que é da ordem desse abismo e do que ele configura no campo da educação escolar sob a forma do fracasso. Trata-se de "algo" ausente e simultaneamente presente, porque continua operando. Nele, justamente, encontram-se as chaves que fazem o discurso girar. E efetivamente, mesmo que tenha sido por demais tênue, o discurso hegemônico começou a girar, cedendo em pontos em que havia se cristalizado, no momento em que as falas dos educadores voltaram com alguma força para introduzir questões naquele ponto, no a - o ponto de gozo do discurso construtivista sob a égide do ensino privado e do Capital.

\footnotetext{
${ }^{11}$ O que acima foi desenvolvido é um forma de entender a tese lacaniana de que a verdade tem a estrutura de uma ficção e teve como fonte inspiradora certa análise feita por Zizek (1996, pp. 12-3).
} 


\section{Dos retornos}

Esta análise do discurso deu continuidade a certo percurso que eu realizei entre fins da década de 80 e início da seguinte, quando pesquisei as trajetórias das escolas alternativas paulistanas. Por isso, a constante referência a essa história, da qual eu mesmo participei. Mas há também outras razões, diretamente relacionadas com certo "passado" da vertente do construtivismo que se tornou dominante. Um "passado" que aqui foi tomado como "algo" que continuava operando, porque recalcado. E operando de modo a promover o novo discurso pedagógico, de modo a projetá-lo num lugar em que ficou solidamente instalado. Obviamente, essa hegemonia não se explica ou não se assenta nesse único "passado". Por isso, na medida do possível, da existência de outras fontes e tendo como base o que foi pesquisado para realizar este trabalho, o "passado" do discurso pedagógico construtivista foi ampliado. No caso daquelas trajetórias, trata-se de um "passado alternativo" que em grande parte corresponde a determinado momento, o "momento dos limites", que não é possível fixar dentro de uma ordem cronológica, a não ser que seja destacado o período em que esse momento se tornou dominante. Isso ocorreu, precisamente, quando se deu a inflexão discursiva que transformou as escolas alternativas, ou boa parte delas, em escolas construtivistas. Desse "momento dos limites", das marcas que ele deixou no autor destas linhas e da reflexão que ele suscitou, em boa parte procede a forma de operar com os discursos que aqui foi desenvolvida, muito embora tenha sido fundamental a referência teórica encontrada na psicanálise e na obra de Lacan. ${ }^{12}$ Essa forma de operar parece corresponder aos discursos que constituem o exato avesso dos discursos do Mestre (antigo e moderno), ou seja, o discurso do Analista e o discurso da Histérica. Quer dizer, ao que tudo indica, esta experiência implicou a configuração dos lugares que esses discursos supõem, com alguém, é claro, que os sustentou. Ademais, pode-se igualmente supor que o que aqui operou, como saber não sabido, foi "algo" que é da ordem daquele "passado".

Essa forma de operar, de realizar esta análise do discurso, tem nos limites o seu elemento central. E a psicanálise é justamente isso: uma ciência dos limites,

\footnotetext{
${ }^{12}$ A esse propósito, veja-se o capítulo "Limites", em Revah (1994).
} 
uma ciência limite ou limítrofe, que trabalha nas bordas, nesse lugar ambíguo onde abundam os "talvez", os inúmeros "talvez" que a nutrem. Diverso é o caso da ciência positiva, desse saber que tem no sistema o seu modelo, seja ele aberto ou fechado. Sob a razão sistêmica, celebra-se a coerência, a arquitetura bem amarrada e sem furos, apenas sobrando os que ainda não foram fechados, mas que a construção do edifício exige que sobre eles se avance, mesmo sabendo que outros deverão surgir, para novamente pôr o sistema em movimento e realizar o mesmo circuito. "Saber sempre mais", eis o imperativo que rege a ciência, com nos lembra Lacan (1969-1970, p. 98). Sob esse imperativo, as ambigüidades devem ser suprimidas. O que se busca é a certeza, a objetividade. E nada disso se constrói sobre os "talvez", sobre as ambigüidades e buracos que sustentam e nutrem as ciências limítrofes.

Trabalhar nas bordas é o que aqui foi experimentado na análise dos discursos educacionais, tendo como principal fonte os textos da revista Nova Escola. A respeito dessa análise, nessa revista, várias questões poderiam ser colocadas. De que modo esses textos foram tomados? Onde e como foram situados os implicados nesses discursos? Onde foi situado o produtor desses textos? São os autores da revista? A própria revista pode ser tomada como o Autor? Os autores são os jornalistas que escreveram as matérias? Como considerar toda a cadeia que faz parte da produção de uma matéria (pautar determinado assunto, entrevistas, anotações, delineamento da matéria, edição, etc.)? Em que medida o que se encontra nessa revista corresponde ao discurso pedagógico hegemônico? E como considerar os virtuais leitores? Como avaliar a sua leitura e o modo como esses leitores se apropriam e lidam com os textos das matérias? Enfim, as perguntas são inúmeras e as respostas certamente nos empurrariam para essa região obscura que é o lugar do Outro. Se existe um lugar onde se tentou situar esta análise foi precisamente nesse lugar do Outro, ou seja, "entre", nem do lado do suposto produtor do discurso (no caso, a revista Nova Escola e tudo o que se relaciona com esse âmbito da produção), nem do lado do supostos leitores. Ou seja, no limite, nesse lugar impreciso onde diversas referências e linhas se cruzam, inclusive tudo o que concerne ao autor deste trabalho. Um lugar aparentemente vazio, mas na verdade repleto de encontros "nada é tudo", é o que vez por outra Lacan nos lembra (1969-1970, p. 51). Um lugar de encontros que aqui não foi tomado de forma aleatória, na mesma medida 
em que os nossos guias foram os significantes-mestres, em relação aos quais nunca sabemos ao certo para onde nos conduzem, embora eles sempre nos conduzam na direção certa. Apenas é preciso aprender a escutá-los, localizando os que por alguma "razão", que desconhecemos, têm uma peculiar ressonância no campo em questão. São eles os que produzem aquele lugar vazio repleto de encontros, que é o lugar que neste tipo de análise é essencial: os pontos de ressonância.

A localização desses pontos não se extingue nas fontes escritas, até mesmo termina nelas. Escutar implica ultrapassar o registro dos enunciados, ou seja, o nosso alvo é o que deve ser situado no plano da enunciação. Um plano que aparentemente é mais difícil de penetrar tendo por base textos escritos, nos quais desaparecem os traços que são próprios da fala e dos contextos em que ela ocorre. Esses traços, a bem da verdade, não estiveram ausentes, na mesma medida em que fazem parte da escuta diária, no convívio ou contato com professores e especialistas, alunos, pais de alunos, em escolas, cursos, seminários, palestras e todos os âmbitos onde o campo da oralidade possibilita algum contato com "isso" que parece desaparecer nos textos escritos. E tudo isso, é claro, pertence ao campo do que aqui está mais implícito do que explícito, até mesmo para quem escreve. Em relação aos textos escritos, o que neles é relevante é o que se encontra nas entrelinhas, o que sobrevém nas correspondências que de súbito nos surpreendem e que devem ser situadas, não no plano do enunciado, mas antes nesse lugar impreciso onde é necessário situar-se para encontrar os vários "passados" que habitam um texto. Sem abandonar o plano dos enunciados, o que nesta análise procurou-se fazer é evidenciar determinadas articulações significantes cujos laços com esse plano não estavam à vista, porque foram cortados ou interrompidos. Um esquecimento ativo e cuja função é sustentar determinada ordem discursiva.

Para reestabelecer esses laços ou parte deles é fundamental estar embebido no que nesse caso interessa: os vários "passados" que nutrem determinado discurso e que não sabemos ao certo quais são. Por isso é preciso fazer as vezes de historiador, pesquisar e recorrer à história da educação. Ademais, na análise, é necessário deixar que esses vários "passados" nos acompanhem como "algo" que pode subitamente emergir, em razão da sua 
singular sintonia com o atual. Nesse "agora" reside o saber que aqui interessa, o saber com algum valor de verdade. Trata-se de um saber que emerge nas correspondências, nas sintonias repentinas entre dois pontos que se fundem e fazem Um. Aí, justamente, "entre" esses dois pontos, devemos deter-nos e trabalhar o que desse lugar emerge. É dessa emergência que sobrevém o sentido que uma análise como esta aguarda, ou melhor, o après-coup que (re)ordena a cadeia significante que o precedeu, assim advindo o que não estava posto, mas que os significantes mobilizados pela análise permitiu criar. Como? Com as pequenas costuras feitas no decorrer da análise e que foram deixando marcas, produzindo contornos, criando lugares. Tudo isso adquirindo a forma de um saber impreciso, difuso, baseado em detalhes e indícios que foram se acumulando. Um saber que encontra o seu ponto de basta mais adiante, no $S_{1}$ que fixa o lugar da cadeia $S_{2}$. Esse é o ponto em que certa imprecisão desaparece. É um ponto de certeza, mas não mais do que um ponto, junto com o que nele e dele escorrega.

Andar nas bordas, caminhar nos limites do discurso, significou aqui deter o pensamento e a escrita nos momentos em que emergia o que pode ser situado chamando-o de "campo da besteirada", entendido como aquilo que brota desse limite do qual o discurso analítico procura se aproximar, como nos lembra Lacan (1972-1973, p. 23). Limite, portanto, que concerne ao gozo, ao "campo do gozo", ao "campo lacaniano" (Lacan, 1969-1970, p. 77). Ou seja, precisamos deter-nos nos pontos em que "algo" nos surpreende, porque absurdo ou estranho, mas que simultaneamente guarda algum sentido que faz sentido. "Algo" que parece emergir de nós mesmos, mas também do texto que suscita essa emergência. Portanto, está "entre", no limite. Para nele avançar, para avançar no que realmente importa, esse "algo" precisa ser desdobrado, a nossa rede simbólica deve ser estendida em torno desse ponto de incoerência, mas sem tentar extinguir a ambigüidade que o nutre e que é a que possibilita os múltiplos e intermináveis desdobramentos da análise. Essa foi uma via aqui explorada, a qual exigiu descartar aquilo que não fazia sentido mesmo, a "besteirada" que talvez algum dia faça sentido. São os restos que todo trabalho produz e que não são expostos.

Os restos do discurso constituem na verdade a matéria prima deste tipo de análise. O nosso percurso foi iniciado precisamente em torno deles, em torno do lugar dos "desvios, confusões, equívocos ...". Ademais, esses restos tornaram-se 
estruturantes, tornaram-se os nossos pontos de estrutura ou, mais precisamente, os pontos limítrofes, que são os que constituem o avesso do ponto de arremate. Este é sustentado por eles. O que é o mesmo que afirmar que o discurso pedagógico construtivista, junto com o que é da ordem de seus ideais, é sustentado pelo que se perdeu nesse lugar impreciso da "origem". Um lugar onde vários "passados" se encontram, em particular as duas linhas paralelas e opostas que os discursos educacionais criaram, com a Escola Tradicional e a Escola Nova constituindo os seus primeiros e visíveis pilares. Fazer este circuito, o "caminho construtivista", envolveu trabalhar um tecido feito com essas substâncias, as quais podem ser reduzidas a duas: a "origem" e os ideais, frente e verso da nossa superfície moebiana. ${ }^{13}$ Uma superfície que foi recriada e percorrida em duas voltas, segundo um trajeto cujo ponto "original" pode ser situado na segunda metade da década de 80 , quando foi feito o primeiro esboço da investigação que resultou na minha dissertação de mestrado, intitulada $\mathrm{Na}$ trilha da palavra "alternativa". Concluída essa volta, foi iniciado este retorno, do circuito gerado por uma outra palavra, uma palavra que os discursos educacionais transformaram em um significante-mestre. Esse circuito, do significante-mestre construtivismo, é o que foi percorrido nesta segunda volta. Uma volta que aqui termina e que cria uma espécie de fecho, implicando também um certo retorno. Mas agora, quem sabe, não mais dentro da ordem alternativa-construtivista e sim no âmbito da ordem que talvez tenha resultado dessas duas voltas. Duas voltas que, se são mesmo tais, correspondem ao corte que é próprio da análise, implicando igualmente um certo retorno. $\mathrm{O}$ retorno que corresponde à ordem do Um.

${ }^{13}$ Em relação a essa superfície, veja-se o Apêndice. 


\section{Referências}

ABRAMOVAY, Miriam, KRAMER, Sonia (1988). "O rei está nú": um debate sobre as funções da pré-escola. In: SOUZA, Solange Jobim e, KRAMER, Sonia. Educação ou Tutela? A criança de 0 a 6 anos. São Paulo : Loyola.

ADORNO, Theodor W., HORKHEIMER, Max (1986). Dialética do esclarecimento: fragmentos filosóficos. Rio de Janeiro : Zahar.

AMEPPE (Associação Movimento de Educação Popular Integral) (1989). O educativo no movimento social: a pedagogia das creches comunitárias. Educação Popular, Belo Horizonte/MG, Caderno n 4, abril.

ANDE, ANPed, CEDES (1985). Manifesto aos participantes da III Conferência Brasileira de Educação. Educação \& Sociedade, São Paulo, n 20, jan./abr.

ASSIS, Machado de. Dom Casmurro (1996). São Paulo : Ática.

AZANHA, José Mário Pires (1990). O abstracionismo pedagógico. In: Uma idéia de pesquisa educacional. Universidade de São Paulo, Faculdade de Educação. Tese de livre-docência.

BECKER, Fernando (1987). Uma socióloga lê Piaget: As confusões conceituais de Bárbara Freitag. Educação \& Realidade, Porto Alegre, 12(1):79-85, jan./jun. (1988). Piaget: a profissão empirista de Bárbara Freitag. Educação \& Realidade, Porto Alegre, 13(1):87-96, jan./jun.

(1993). Epistemologia e ação docente. Em Aberto. Brasília : INEP, ano 12, $n^{\circ} 58$, abr./jun.

(1994a). A propósito da "desconstrução". Educação \& Realidade, Porto Alegre, 19(1): 3-6, jan./jun.

(1994b). Modelos pedagógicos e modelos epistemológicos. Educação \& Realidade, Porto Alegre, 19(1): 89-96, jan./jun. 
BENJAMIN, Walter (1985). Sobre o conceito da história. In: Magia e Técnica, Arte e Política. São Paulo : Brasiliense.

BENJAMIN, Walter (1975). Sobre alguns temas em Baudelaire. In: BENJAMIN, Walter, HORKHEIMER, Max, ADORNO, Theodor W., HABERMAS, Jürgen : Textos Escolhidos. São Paulo : Abril Cultural. (Os Pensadores).

CAMPOS, Maria M. Malta (1989). Pré-escola: entre a educação e o assistencialismo - 1985. In: ROSEMBERG, Fúlvia (org.). Creche. São Paulo : Cortez.

(1981). Carta do editor. Cadernos de Pesquisa (36):2, fev.

CANDAU, Vera Maria (1999). Reformas educacionais hoje na América Latina. In: MOREIRA, Antonio Flavio Barbosa. Currículo: políticas e práticas. Campinas, SP : Papirus.

CARRAHER, Terezinha Nunes, CARRAHER, David Willian (1986). Ensinando Ciências e Estudos Sociais nas séries iniciais. In: ALVES, Maria L. (coord.). Isto se aprende com o ciclo básico. São Paulo : SE/CENP, Projeto Ipê.

CARVALHO, José Sérgio Fonseca de (2000). Construtivismo : uma pedagogia esquecida da escola. Universidade de São Paulo, Faculdade de Educação. Tese de doutorado.

CARVALHO, Marta M. Chagas de (1989). A Escola e a República. São Paulo : Brasiliense.

CAVALCANTI, Zélia (1997). A construção do projeto pedagógico da Escola da Vila. Pátio, Porto Alegre, ano I, n 0 , fev./abr.

CAVALCANTI, Zélia, DEHEINZELIN, Monique (1991). Professor da pré-escola. São Paulo : Globo.

COLL, César (1996). Um marco de referência psicológico para a educação escolar: a concepção construtivista da aprendizagem e do ensino. In: COLL, César, PALACIOS, Jesús, MARCHESI, Alvaro. Porto Alegre : Artes Médicas. 
(1998). Construtivismo e educação escolar: nem sempre falamos da mesma coisa e nem sempre o fazemos da mesma perspectiva epistemológica. In: RODRIGO, María José, ARNAY, José. Conhecimento cotidiano, escolar e científico: representação e mudança. São Paulo : Ática.

(2000). Psicologia e Currículo. Uma aproximação psicopedagógica à elaboração do currículo escolar. São Paulo : Ática.

CORAZZA, Sandra Mara (1994). Construtitivismo: que lugar é este? Educação \& Realidade, Porto Alegre, 19(1):121-24, jan./jun.

(1995). Currículo e política cultural da avaliação. Educação \& Realidade, Porto Alegre, 20(2):47-59, jul./dez.

(1996a). Olhos de poder sobre o currículo. Educação \& Realidade, Porto Alegre, 21(1):48-70, jan./jun.

(1996b). Construtivismo: evolução ou modismo?. Educação \& Realidade, Porto Alegre, 21(2): 215-232, jul./dez.

CUNHA, Luiz Antônio (1991). Educação, Estado e Democracia no Brasil. São Paulo : Cortez; Niteroi, RJ: Editora da Universidade Federal Fluminense; Brasília, DF : FLACSO do Brasil.

DELVAL, Juan (1998). Teses sobre o construtivismo. In: RODRIGO, María José, ARNAY, José. Conhecimento cotidiano, escolar e científico: representação e mudança. São Paulo : Ática.

DEWEY, John (1930). A criança e o programa escolar. Escola Nova. São Paulo : Órgão da Directoria Geral da Instrucção Pública, vol.1, n 1.

FERREIRO, Emilia (1985). A representação da Linguagem e o processo de alfabetização. Cadernos de Pesquisa. São Paulo : Fundação Carlos Chagas, $n^{\circ} 52$, fev.

(1991). Alfabetização em processo. São Paulo : Cortez.

(1993). Reflexões sobre alfabetização. São Paulo : Cortez. 
FERREIRO, Emilia, TEBEROSKY, Ana (1986). Psicogênese da língua escrita. Porto Alegre : Artes Médicas.

FREIRE, Madalena (1986). Relatos de (con)vivência: crianças na escola da Vila Helena. Cadernos de Pesquisa. São Paulo: Fundação Carlos Chagas, $n^{\circ}$ 56 , fev.

FREIRE, Paulo (1980). Pedagogia do oprimido. Rio de Janeiro : Paz e Terra.

(1984). Quatro cartas aos animadores de Círculos de Cultura de São Tomé e Príncipe. In: BEZERRA, Aída, BRANDÃO, Carlos Rodrigues (org.). A questão política da educação popular. São Paulo : Brasiliense.

FREIRE, Paulo, BETO, Frei (1988). Essa escola chamada vida. Depoimentos ao repórter Ricardo Kotscho. São Paulo : Ática.

FREITAG, Bárbara (1985). Piaget: encontros e desencontros. Rio de Janeiro : Tempo Brasileiro.

(1987). Um psicólogo lê Piaget: As confusões conceituais de Fernando Becker. Educação \& Realidade, Porto Alegre, 12(2):97-102, jul./dez.

(1994). Prefácio. In: GROSSI, Esther Pillar. Didática do nível pré-silábico. Rio de Janeiro : Paz e Terra.

FREUD, Sigmund (1900-1901). Psicopatologia de la vida cotidiana. Olvido de nombres propios. In: Sigmund Freud. Obras completas. Tomo I. Madrid : Biblioteca Nueva, 1996.

(1909). Psicoanalisis. Cinco conferencias pronunciadas en la Clark University (Estados Unidos). In: Sigmund Freud. Obras completas. Tomo II. Madrid : Biblioteca Nueva, 1996.

GHIRALDELLI JR, Paulo (1986). A vara teimosa. Debatendo com Paolo Nosella. Educação \& Sociedade, São Paulo, nº 24, ago. (1990). História da Educação. São Paulo : Cortez. 
GROSSI, Esther Pillar (1994). Didática da alfabetização. Didática do nível présilábico, v.1. Rio de Janeiro : Paz e Terra.

(1995). Didática da alfabetização. Didática do nível silábico, v.2. Rio de Janeiro : Paz e Terra.

(1996). Didática da alfabetização. Didática do nível alfabético, v.3. Rio de Janeiro : Paz e Terra.

GROSSI e BORDIN, Jussara (org.) (1993a). Paixão de aprender. Petrópolis, RJ : Vozes.

(1993b). Construtivismo Pós-Piagetiano - um novo paradigma sobre aprendizagem. Petrópolis, RJ : Vozes.

HARPER, B. et al (1981). Cuidado, escola! São Paulo : Brasiliense.

HORNSTEIN, Luis (1993). Práctica psicoanalítica e historia. Buenos Aires : Paidós.

JERUSALINSKY, Alfredo (1996). Para uma clínica psicanalítica das psicoses. Estilos da Clínica, ano I, $\mathrm{n}^{\circ}$ 1, $2^{\circ}$ semestre.

KAUFMAN, Ana Maria, RODRIGUEZ, Maria Elena (1995). Escola, leitura e produção de textos. Porto Alegre : Artes Médicas.

LACAN, Jacques (1949). O estádio do espelho como formador da função do eu tal como nos é revelada na experiência psicanalítica. In: Escritos. Rio de Janeiro : Zahar, 1998.

(1953-1954). O seminário, livro 1: Os escritos técnicos de Freud. Rio de Janeiro : Zahar, 1996.

(1954-1955). O seminário, livro 2: O eu na teoria de Freud e na técnica da psicanálise. Rio de Janeiro : Zahar, 1995.

(1955-1956). O seminário, livro 3: As psicoses. Rio de Janeiro : Zahar, 1997.

(1957). A instância da letra no inconsciente ou a razão desde Freud. In: Escritos. Rio de Janeiro : Zahar, 1998. 
(1960). Subversão do sujeito e dialética do desejo no inconsciente freudiano. In: Escritos. Rio de Janeiro : Zahar, 1998.

(1964). O seminário, livro 11: Os quatro conceitos fundamentais da psicanálise. Rio de Janeiro : Zahar, 1998.

(1966-1967). La lógica del fantasma. Seminario XIV. Biblioteca Lacan. Disponível em: <http://www.psiconet.org/lacan/textos>. Acesso em: agosto, 1999.

(1969-1970). O seminário, livro 17: O avesso da psicanálise. Rio de Janeiro : Zahar, 1998.

(1972-1973). O seminário, livro 20: Mais, ainda. Rio de Janeiro : Zahar, 1996.

LAJONQUIĖRE, Leandro (1996). De Piaget a Freud: para repensar as aprendizagens. A (psico)pedagogia entre o conhecimento e o saber. Petrópolis, RJ : Vozes.

(1997). Dos "erros" e em especial daquele de renunciar à educação. Notas sobre psicanálise e educação. Estilos da Clínica, ano II, $n^{\circ} 2,2^{\circ}$ semestre.

(1999). Infância e ilusão (psico)pedagógica. Escritos de psicanálise e educação. Petrópolis, RJ : Vozes.

LA TAILLE, Yves de (1992a). O lugar da interação social na concepção de Jean Piaget. In: LA TAILLE, Yves de, OLIVEIRA, Martha Kohl de, DANTAS, Heloysa. Piaget, Vigotsky, Wallon: teorias psicogenéticas em discussão. São Paulo : Summus.

(1992b). Desenvolvimento do juízo moral e afetividade na teoria de Jean Piaget. In: LA TAILLE, Yves de, OLIVEIRA, Martha Kohl de, DANTAS, Heloysa. Piaget, Vigotsky, Wallon: teorias psicogenéticas em discussão. São Paulo : Summus.

(1993). A dimensão ética na obra de Jean Piaget. In: ALVES, Maria L., DURAN, Marília C. G. (coord.). Construtivismo em revista. São Paulo : FDE, Série Idéias, $n^{\circ} 20$. 
(1998). Limites: três dimensões educacionais. São Paulo : Ática.

LERNER, Delia (2002). Ler e escrever na escola. O real, o possível e o necessário. Porto Alegre : Artmed.

LIBÂNEO, José Carlos (1982). Tendências pedagógicas na prática escolar. ANDE. São Paulo, (6): 11-9.

(1989). Democratização da escola pública. A pedagogia crítico-social dos conteúdos. São Paulo : Loyola.

MACEDO, Lino de (1994). Ensaios construtivistas. São Paulo : Casa do Psicólogo.

MARX, Karl (1980). A mercadoria. O Capital (Crítica da economia política). Livro 1: O processo de produção do capital. Volume 1, Parte Primeira. Rio de Janeiro, RJ : Civilização Brasileira.

MEC/SEF (1997). Parâmetros Curriculares Nacionais. Introdução aos Parâmetros Curriculares Nacionais. Brasília : MEC/SEF.

MELLO, Guiomar Namo de (1981). Ensino de $1^{\circ}$ grau: direção ou espontaneísmo?. Cadernos de Pesquisa. São Paulo : Fundação Carlos Chagas, $n^{\circ} 36$, fev.

MIRANDA, Marília Gouveia de (1995). Trabalho, educação e construtivismo: a redefinição da inteligência em tempos de mudanças tecnológicas. Educação \& Sociedade, São Paulo, n 51 , agosto.

NASIO, Juan-David (1989). Lições sobre os 7 conceitos cruciais da psicanálise. Rio de Janeiro : Zahar.

(1993). Cinco lições sobre a teoria de Jacques Lacan. Rio de Janeiro : Zahar.

NIETZSCHE, Friedrich (1983). O nascimento da tragédia no espírito da música. In: Nietzsche. Obras incompletas. São Paulo : Abril Cultural. (Os Pensadores). 
NOSELLA, Paolo (1986). Educação Tradicional e Educação Moderna. Debatendo com Saviani. Educação \& Sociedade, São Paulo, n 23, abril.

NÓVOA, António (1999). Os professores na virada do milênio: do excesso dos discursos à pobreza das práticas. Educação e Pesquisa, São Paulo, v.25, n.1, p.11-20, jan./jun.

OLIVEIRA, Marta Kohl de (1992). Vygotsky: alguns equívocos na interpretação de seu pensamento. Cadernos de Pesquisa. São Paulo : Fundação Carlos Chagas, $n^{\circ} 81$, pp.67-74, maio.

PAIVA, Vanilda, WARDE, Miriam Jorge (1993). Novo paradigma de desenvolvimento e centralidade do ensino básico. Educação \& Sociedade, São Paulo, n 44, abril.

PARRA, Nélio (1980). Estratégias de ensino-aprendizagem. In: PENTEADO, Wilma Millan Alves (org.). Psicologia e ensino. São Paulo : Papelivros.

PATTO, Maria Helena Souza (1985). A criança da escola pública: deficiente, diferente ou mal trabalhada? In: SÁ BARRETO, Elba S., DURAN, Marilia C.G. (org.). Revendo a proposta de alfabetização. São Paulo : SE/CENP, Projeto Ipê.

(1988). O fracasso escolar como objeto de estudo: anotações sobre as características de um discurso. Cadernos de Pesquisa. São Paulo : Fundação Carlos Chagas, $n^{\circ}$ 65, maio.

PIAGET, Jean (1973a). Estudos Sociológicos. Rio de Janeiro : Forense.

(1973b). Sabiduría e ilusiones de la Filosofía. Barcelona : Edicions 62.

(1977). O julgamento moral na criança. São Paulo : Mestre Jou.

(1982). Seis estudos de psicologia. Rio de Janeiro : Forense-Universitária.

(1987). O nascimento da inteligência na criança. Rio de Janeiro : Guanabara.

(1988). Para onde vai a educação? Rio de Janeiro : José Olympio. 
(1990). Epistemologia Genética. São Paulo : Martins Fontes.

(1996). Biologia e Conhecimento. Petrópolis : Vozes.

(1998). Psicologia e Pedagogia. Rio de Janeiro : Forense Universitária.

e INHELDER, Bärbel (1985). A psicologia da criança. São Paulo : DIFEL.

REVAH, Daniel (1994). Na trilha da palavra "alternativa": a mudança cultural e as pré-escolas "alternativas". Universidade de São Paulo, Faculdade de Filosofia, Letras e Ciências Humanas. Dissertação de Mestrado.

RIBEIRO, Mônica Cintrão França (1997). Dois estudos sobre o construtivismo na teoria e na prática de professores. Universidade de São Paulo, Instituto de Psicologia. Dissertação de Mestrado.

ROCHA, Ana Cláudia, MINGUES, Eliane (org.) (1996). Painel Temático: "Nossa Língua Portuguesa". Possibilidades de trabalho nas séries iniciais. São Paulo : Centro de Estudos da Escola da Vila, Plexus Editora Virtual.

ROSEMBERG, Fúlvia (1989). O movimento de mulheres e a abertura política no Brasil. O caso da creche - 1984. In: ROSEMBERG, Fúlvia (org.). Creche. São Paulo : Cortez.

SÁ BARRETO, Elba Siqueira de (1998). Tendências recentes do currículo do Ensino Fundamental no Brasil. In: SÁ BARRETO, Elba Siqueira de (org.). Os currículos do Ensino Fundamental para as escolas brasileiras. Campinas, SP : Autores Associados; São Paulo : Fundação Carlos Chagas.

SADER, Eder (1988). Quando novos personagens entraram em cena : experiências, falas e lutas dos trabalhadores da Grande São Paulo, 19701980. Rio de Janeiro : Paz e Terra.

SAUSSURE, Ferdinand de (2000). Curso de linguística geral. São Paulo : Cultrix.

SAVIANI, Dermeval (1984). Escola e Democracia. São Paulo : Cortez.

SERCOVICH, Armando (1977). El discurso, el psiquismo y el registro imaginario. Ensayos semióticos. Buenos Aires : Nueva Visión. 
SILVA, Tomaz T. da (1993). Desconstruindo o construtivismo pedagógico. Educação \& Realidade, Porto Alegre, 18(2):3-10, jul./dez.

(1994). Em resposta a um pedagogo 'epistemologicamente correto'. Educação \& Realidade, Porto Alegre, 19(2):9-17, jul./dez.

(1996). Entrevistas: César Coll, José Gimeno Sacristán. Educação \& Realidade, 20(1), jan./jun.

SILVEIRA, Paulo (1989). Da alienação ao fetichismo - formas de subjetivação e de objetivação. In: SILVEIRA, Paulo, DORAY, Bernard (org.). Teoria marxista da subjetividade. São Paulo : Vértice.

SOARES, Magda (1998). Letramento. Um tema em três gêneros. Belo Horizonte : Autêntica.

SOUZA, Maria Cecilia C. C. de (1998). À sombra do fracasso escolar: a psicologia e as práticas pedagógicas. Estilos da Clínica, ano III, n $5,2^{\circ}$ semestre.

SOUZA, Octavio (1991). Reflexão sobre a extensão dos conceitos e da prática psicanalítica. In: ARAGÃO, Luis Tarlei de et al. Clínica do Social. Ensaios. São Paulo : Escuta.

SPOSITO, Marília Pontes, RIBEIRO, Vera Masagão (1989). Escolas comunitárias: contribuição para o debate de novas políticas educacionais. São Paulo : CEDI, Documento 4.

TEBEROSKY, Ana (1989). Psicopedagogia da linguagem escrita. São Paulo : Trajetória Cultural; Campinas, SP : Editora da Universidade Estadual de Campinas.

(1992). Aprendendo a escrever. Perspectivas psicológicas e implicações educacionais. São Paulo : Ática.

VASCONCELOS, Mário Sérgio (1996). A difusão das idéias de Piaget no Brasil. São Paulo : Casa do Psicólogo. 
(1997). Bibliografia selecionada de livros e artigos relacionados às idéias de Jean Piaget no Brasil. In: FREITAG, Barbara (org.). Piaget: 100 anos. São Paulo : Cortez.

VENTURI, Gustavo (1997). Desenvolvimento moral e moralidade sexual: contribuições para se repensar programas de educação moral e orientação sexual. In: Piaget: 100 anos. São Paulo : Cortez.

VIEIRA, Martha Lourenço (1995). Construtivismo: a prática de uma metáfora. Forma/conteúdo do "construtivismo" em NOVA ESCOLA. FAE/UFMG. Dissertação de Mestrado.

VOLTOLINI, Rinaldo (2001). Do contrato pedagógico ao ato analítico: contribuições à discussão da questão do mal-estar na educação. Estilos da Clínica, vol. VI, $n^{\circ} 10,1^{\circ}$ semestre.

VORCARO, Ângela (1997). A criança na clínica psicanalítica. Rio de Janeiro : Companhia de Freud.

WEISZ, Telma (1985). Como se aprende a ler e escrever ou, prontidão, um problema mal colocado. In: SÁ BARRETO, Elba S., DURAN, Marilia C.G. (org.). Revendo a proposta de alfabetização. São Paulo : SE/CENP, Projeto Ipê.

ZIZEK, Slavoj (1991). O mais sublime dos histéricos. Hegel com Lacan. Rio de Janeiro : Zahar.

(1992). Eles não sabem o que fazem. O sublime objeto da ideologia. Rio de Janeiro : Zahar.

(1996). Introdução. O espectro da ideologia. In: ZIZEK, Slavoj (org.). Um mapa da ideologia. Rio de Janeiro : Contraponto. 


\section{Nova Escola (textos citados)}

\section{6}

"Carta do editor", n 1, março, p. 5.

"O milagre da multiplicação. Escolas improvisadas criam novas vagas", $\mathrm{n}^{\circ} 1$, março, pp. 46-9.

"Reforma Silenciosa", n², abril, pp. 10-7.

"Escola Aberta de Calabar", n², abril, pp. 54-6.

"Aventuras e heroísmo nas escolas de Cananéia", n 4, junho, pp. 6-12.

"Com uma didática revolucionária, sucata e alegria é fácil alfabetizar crianças pobres", n 6, setembro, pp. 40-4.

"Faça sua classe render mais", n 6, setembro, pp. 52-5.

"Cultura Negra. Um assunto que a História oficial esqueceu", n 8, novembro, pp. $12-8$.

"Educação Indígena. Tribos decidem como deve ser sua escola", n 9, dezembro, pp. 18-23.

\section{7}

"Ciclo Básico. Uma arma contra a repetência", n 11, abril, pp. 24-5.

"Escola Comunitária. Um jeitinho carioca de driblar a falta de vagas", $n^{\circ} 11$, abril, pp. 38-41.

“O aluno aprende. É só você parar de ensinar", n 12, maio, pp. 30-3.

"Professores estimulados melhoram o ciclo básico", n 14, agosto, pp. 56-60.

"Há um novo caminho para ensinar a ler e escrever", n 15, setembro, pp. 10-5.

"Como se escreve (por linhas tortas) o fracasso escolar de uma criança", $\mathrm{n}^{\circ} 17$, novembro, pp. 10-4. 
"Alfabetização. Que tal você começar pela matemática?", n 17, novembro, pp. 3640.

"Nos temas do presente, o início da aprendizagem", n 17, novembro, pp. 42-6.

\section{8}

"É melhor ensinar a pescar do que dar o peixe", nº 19, março, pp. 26-7.

"Pais x professores. O papel de cada um na alfabetização", $n^{\circ}$ 22, junho, p. 12-7.

"Uma fábrica sem controle de qualidade", n 26, novembro, pp. 12-22.

"Uma lição de idéias, técnicas e muita liberdade", n²7, dezembro, pp. 30-3.

\section{9}

"Um balanço da luta contra a evasão e a repetência na primeira série", $n^{\circ} 30$, maio, pp. 12-9.

"Por uma escola séria e alegre", $n^{\circ} 30$, maio, pp. 22-5.

"A cidadania começa nos bancos escolares", n 31, junho, pp.12-15.

"O que o professor eficiente tem de especial", n 31, junho, pp. 28-9.

"Sem afeto, não há alfabetização", n 32, agosto, p. 22-4.

“A criança se constrói na pré-escola", $n^{\circ} 33$, setembro, pp. 24-5.

"Emilia Ferreiro. Uma aula inédita para 10 mil professores", n 34, outubro, pp. 127.

"Meu trabalho não é um método", n 34, outubro, pp. 18-9.

"Um município mineiro muda a face do ensino no campo", n 34, outubro, pp. 226.

"Ação comunitária. Uma rede voltada para a organização popular", $\mathrm{n}^{\circ} 35$, novembro, pp. 32-4. 
1990

"O sucesso das multisseriadas gaúchas", n 38, abril, pp. 10-8.

"Quem disse que 'papagaio velho não aprende a falar'?", n 40, junho, pp. 10-7.

"A confusão entre autoridade e autoritarismo ou a pedagogia do chinelo", $n^{\circ} 45$, dezembro, pp. 18-22.

1991

"Dez anos de construtivismo no Brasil", n 48, maio, pp. 10-8.

"Entrevista Antonio Moreno Montero. 'A Espanha busca a escola autônoma"', n 50, agosto, pp. 20-5.

"Modernidade e educação básica", n 50, agosto.

"A Europa constrói a escola do século XXI", n 51, setembro, pp. 18-23

"História. O bonde que a escola perdeu", n 53, novembro, pp. 10-9.

1992

"O papel do professor que trabalha o interesse e o prazer", n 56 , abril, pp. 46-9.

"Como trabalhar o erro", n 60, setembro, pp. 10-7.

"'Não estamos formando os vencedores, mas os perdedores de amanhã"', $n^{\circ} 60$, setembro, pp. 18-20.

"Oba. Hoje tem aulas de ciências!", n 61, outubro, pp. 10-5.

1993

"Como ajudar a formar o jovem participativo", n 64, março, pp. 8-16.

"Uma escola com controle de qualidade total", nº 64, março, pp. 52-3.

"As agruras do caminho construtivista", n 65, abril, pp. 8-14. 
"Oficinas de leitura mudam a prática de educadores populares", n 71, novembro, pp. $42-5$.

"Brasil. O futuro ameaçado", n 72, dezembro, pp. 10-9.

\section{4}

"Como a criança aprende segundo Freinet", n 74, abril, pp. 24-8.

"Como a criança aprende segundo Piaget", n 76, junho, pp. 20-5.

"O aprendizado que vem da vida do próprio aluno", n 78, setembro, pp. 10-20.

"Como a criança aprende, segundo Montessori", n 79, outubro, pp. 26-9.

"Pedagogia Waldorf. De sete em sete anos", n 80, novembro, pp. 38-41.

"Canuanã, a geração construtivista", n 80, novembro, pp. 42-3.

"FHC. O destino da educação nas mãos de um professor", n ${ }^{\circ}$ 1, dezembro, pp. 8-13.

"Vygotsky com molho tropical", n 81, dezembro, pp. 44-6.

\section{5}

"A maratona do construtivismo", n 82 , março, p. 3.

"O tira-teima do Construtivismo: 50 grandes e pequenas dúvidas esclarecidas", $\mathrm{n}^{\circ}$ 82, março, pp. 8-13.

"Kumon, a febre japonesa", n 82, março, pp. 32-4.

"Professor... Comece o ano novo, inovando. Comece com sala de aula construtivista!", n 82, março, p. 35.

"O que esperar e o que não esperar do MEC", n 82, março, pp. 50-2.

"Fachada antiga e alma nova", n 83, abril, pp. 38-9.

"Currículo Básico Nacional. O que vem aí", n 83, abril, pp. 52-3. 
"Progresso com os números", n 87, setembro, pp. 56-7.

"Exercício de imaginação", n 88, outubro, pp. 46-7

"Mudança de qualidade no ensino", n 89, novembro, pp. 50-1.

"Ensinando tudo com histórias", n 90, dezembro, pp. 8-15.

"Trabalho conjunto de classes", n 90, dezembro, p. 44-6.

\section{6}

"Criatividade. Aulas de dar água na boca", n 91, março, pp. 8-15.

"Ponha algo mais em sua aula", n 91, março, pp. 40-3.

"Currículo. Um pacote de novidades", n 91, março, pp. 49-51.

"Olimpíadas. Sua aula pode ganhar com elas", n 94, junho, pp. 8-15.

"Jean Piaget. A lógica própria da criança como base do ensino", n 95, agosto, pp. 8-15.

"Faz-de-Conta. Como obter o máximo de imaginação infantil com o mínimo de interferência", n 96, setembro, pp. 8-17.

"O Sertão do Seridó cria sua didática", n 98, novembro, pp. 8-15.

"Bastão ou cursiva?", n 99, dezembro, pp. 8-15.

"Professor vai receber novo currículo", n 99, dezembro, pp. 48-9.

\section{7}

"Qualidade à vista", n 102, maio, pp. 8-15.

"Errar é humano - e detestável", n 103, junho, p. 3.

"Avaliação. O check-up do ensino", n 104, agosto, pp. 10-7.

"Um caminho feito de desafios", n 107, novembro, p. 3. 
"Sem sacudir a educação, o Brasil não terá uma economia avançada", n 107, novembro, p. 44.

"Viva a diferença. Abaixo o preconceito!", n 108, dezembro, pp. 10-7.

\section{8}

"A didática nunca mais será a mesma", n¹10, março, pp. 10-7.

"Indisciplina: como lidar com ela?", n¹13, junho, pp. 34-8.

"Ensino é assunto de toda a sociedade", n¹13, junho, pp. 48-9.

"Alianças que realizam sonhos", n¹17, novembro, pp. 10-7. 


\section{APÊNDICE}

Fita de Moebius
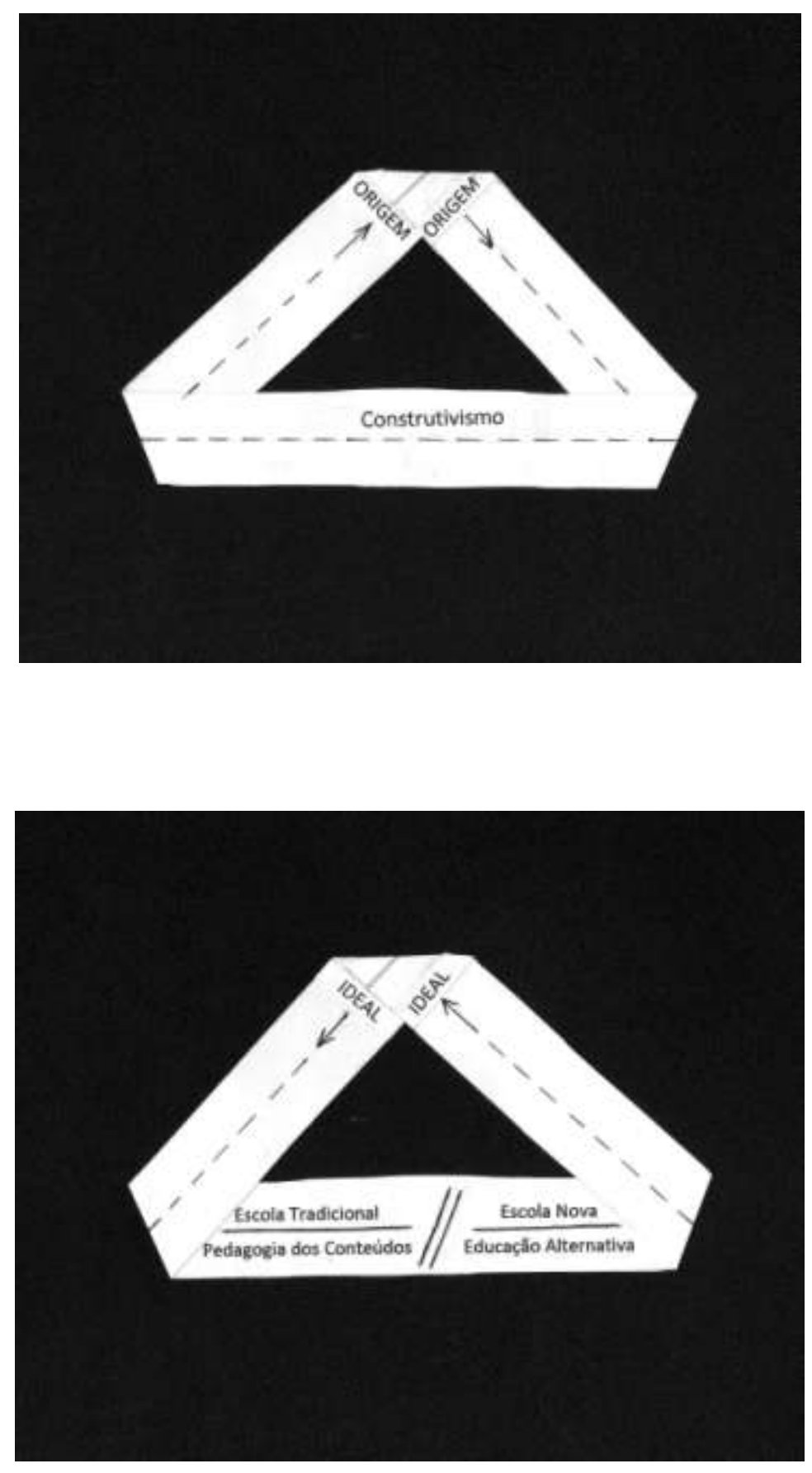


\section{ANEXO A}

Capas da revista NOVA ESCOLA 


\section{Ano: 1986 \\ Números: 1 a 9}

1

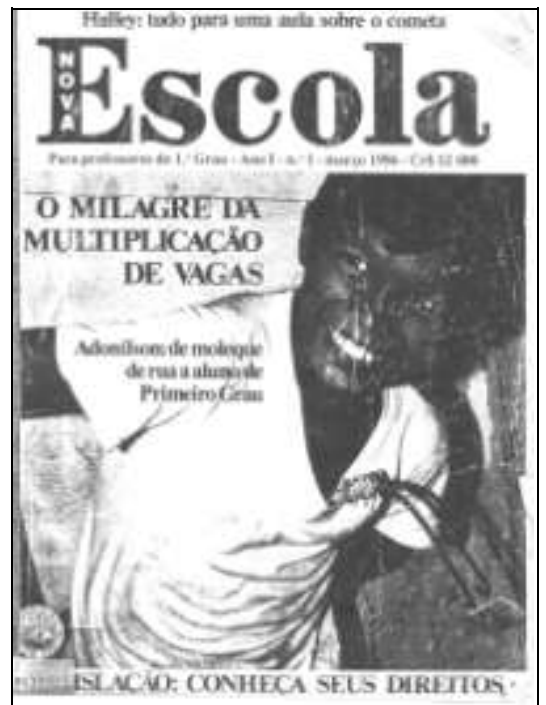

4

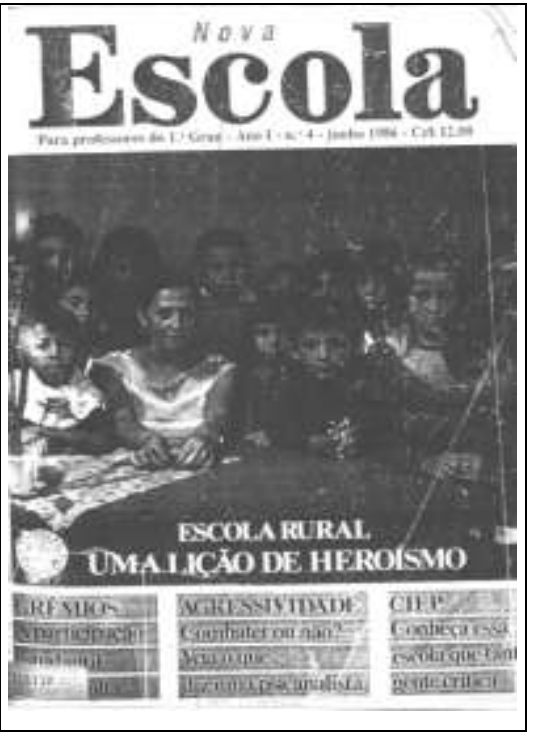

7
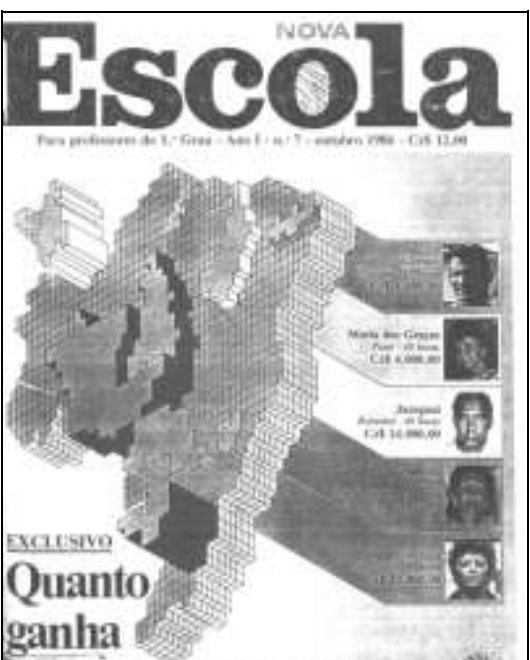

n nrofessor brasileiro
2

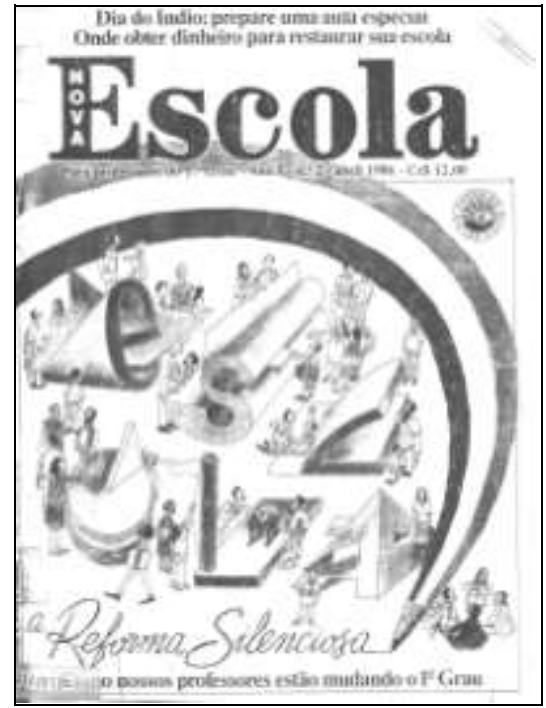

5
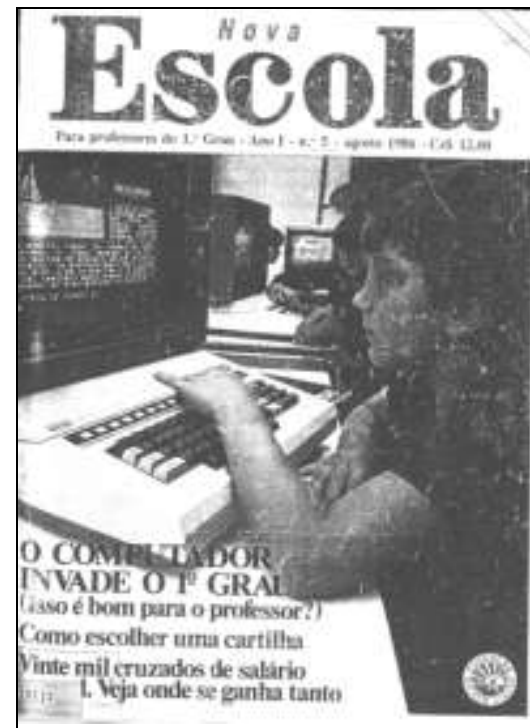

8
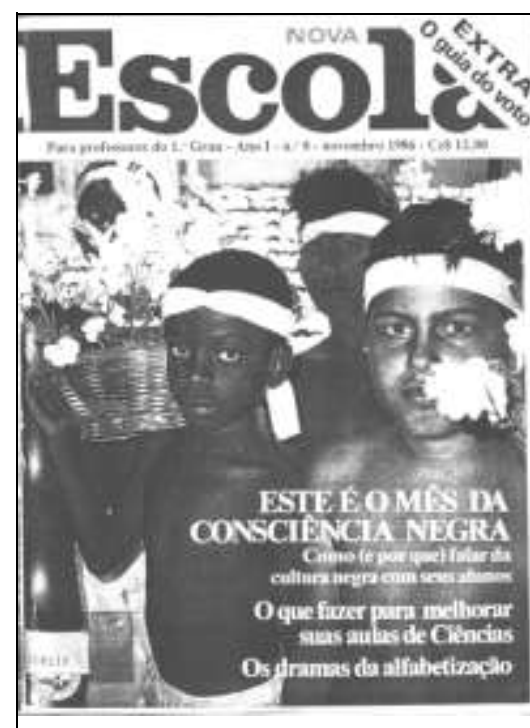

3

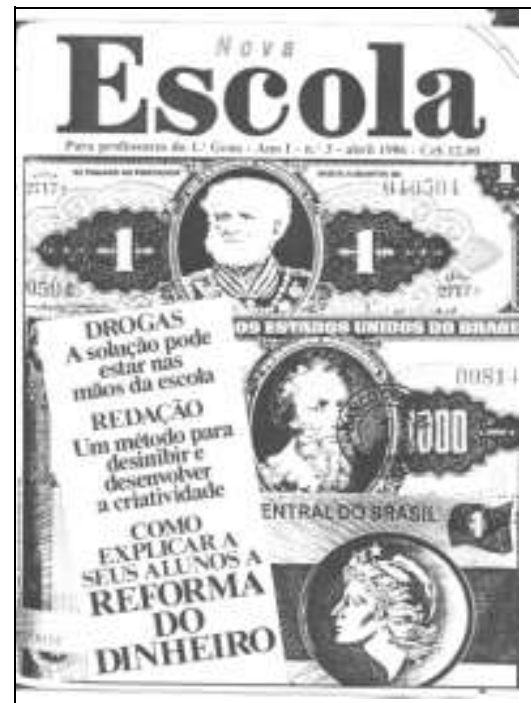

6
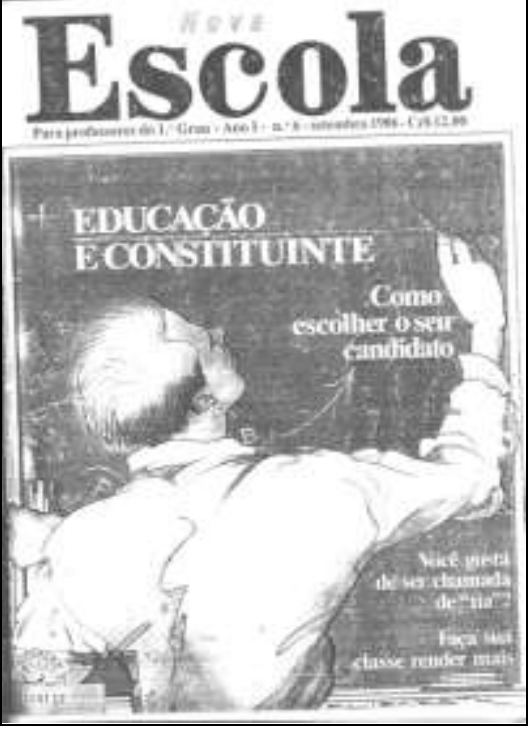

9
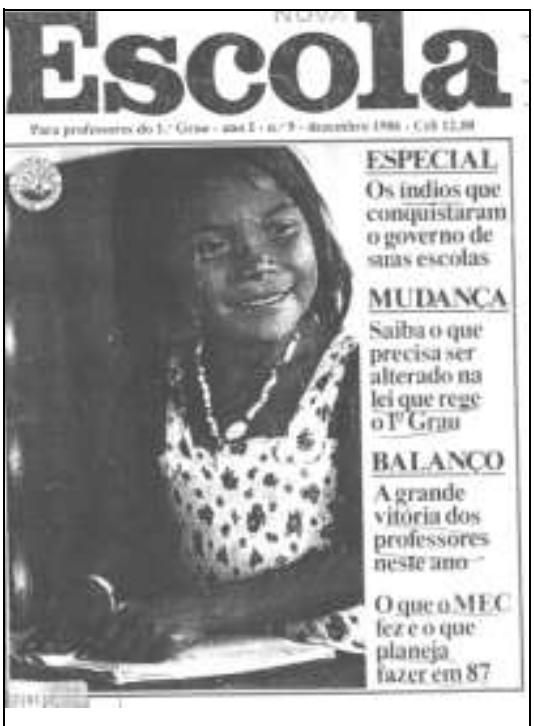


\section{Ano: 1987 \\ Números: 10 a 18}

10

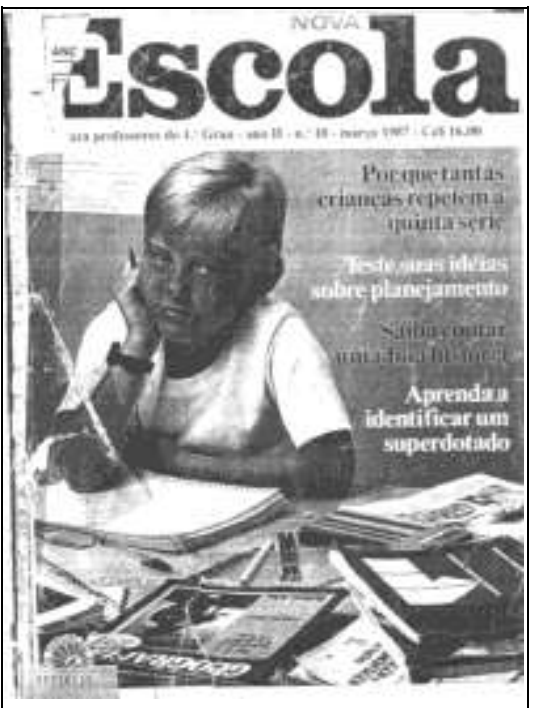

13
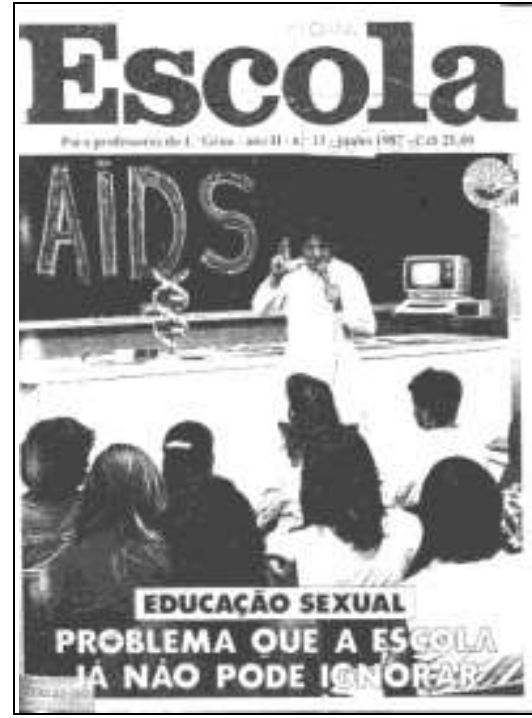

16
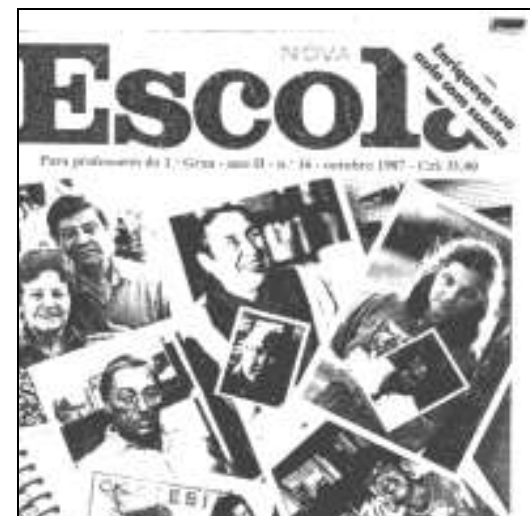

E. 5inon

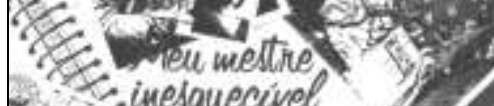

- Einesquecivel

- OUV FAZ A GenTE SE

GH MRRAR DFIE A VIRA TON
11

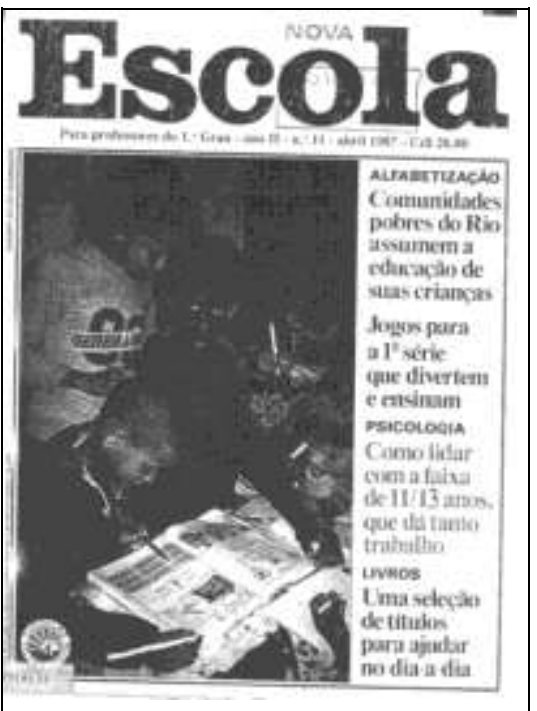

14
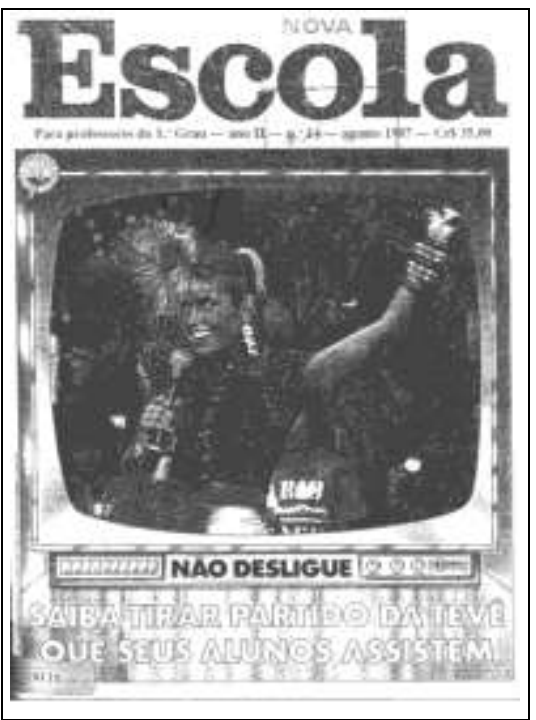

17
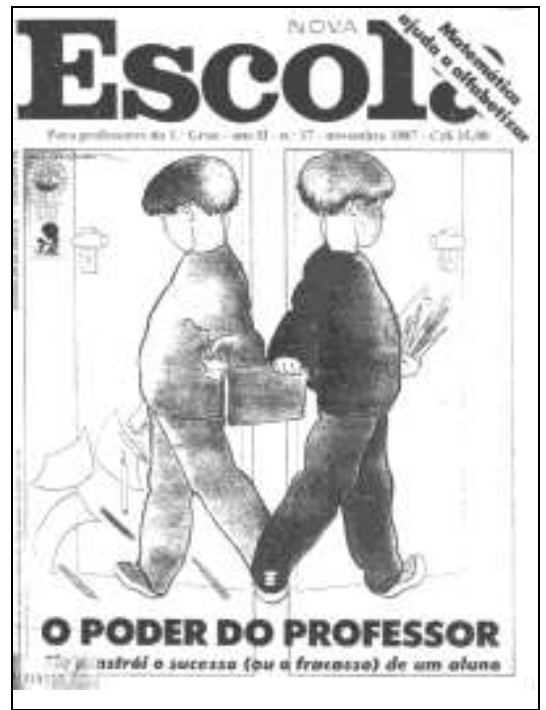

12

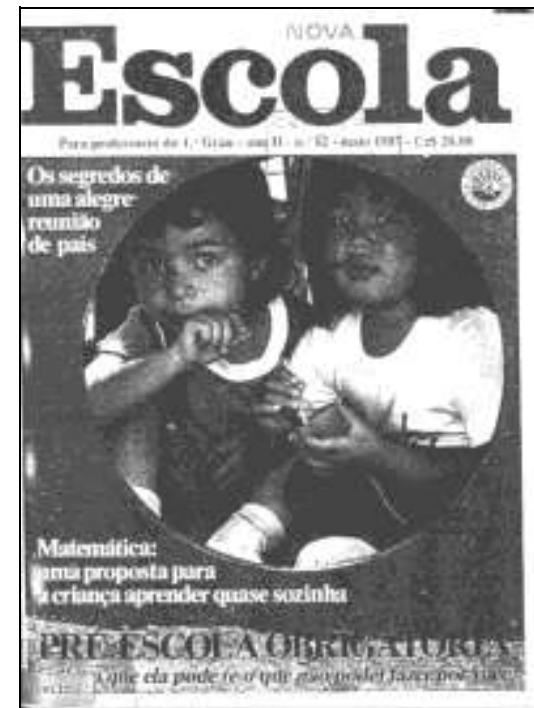

15
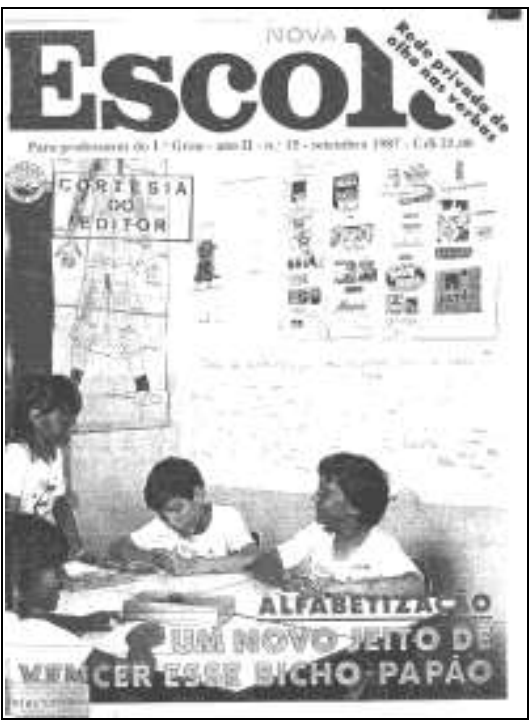

18
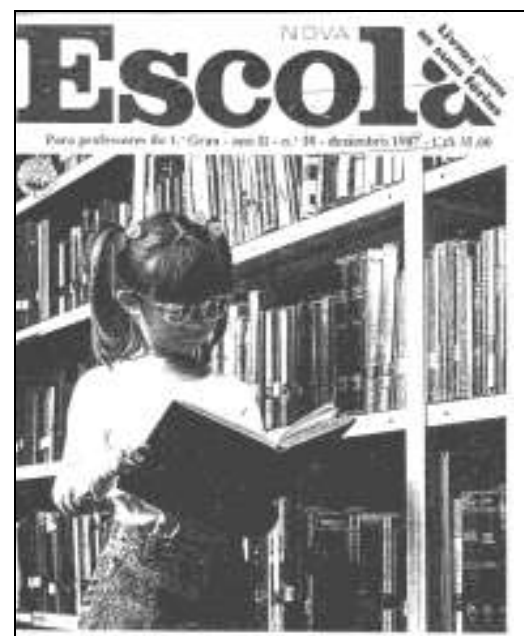

BIBLIOTECA PARA POUCOS

36tac horo de ocober rom essa friste realidode 
Ano: 1988

Números: 19 a 27

19

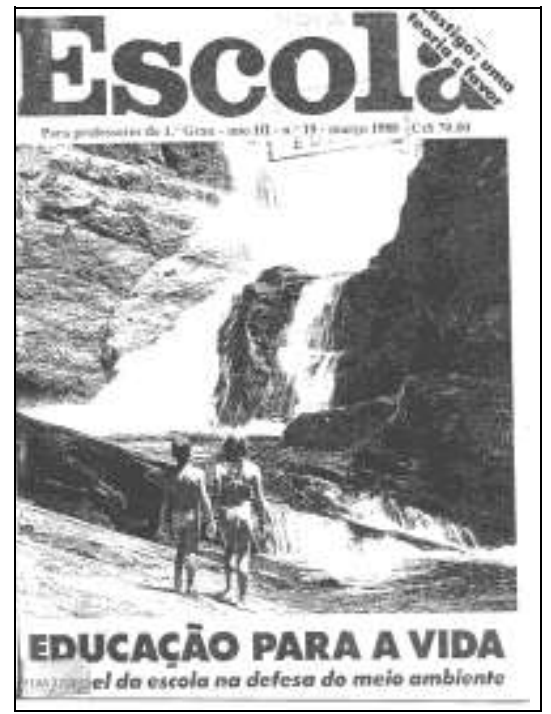

22
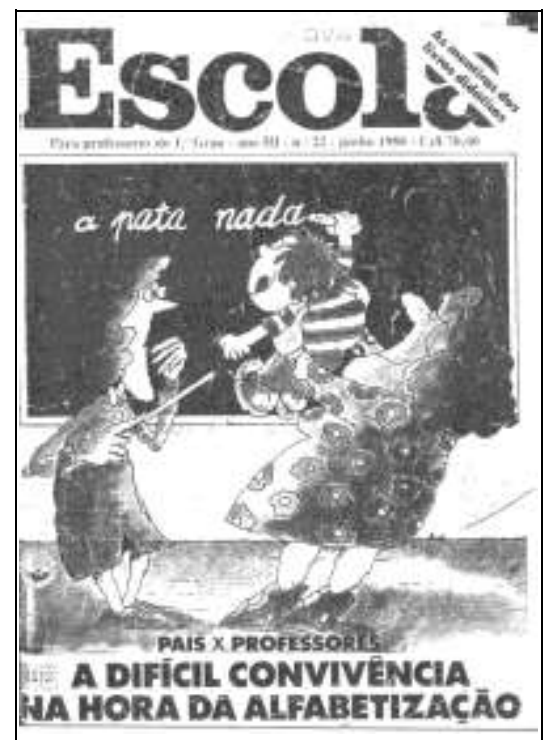

25
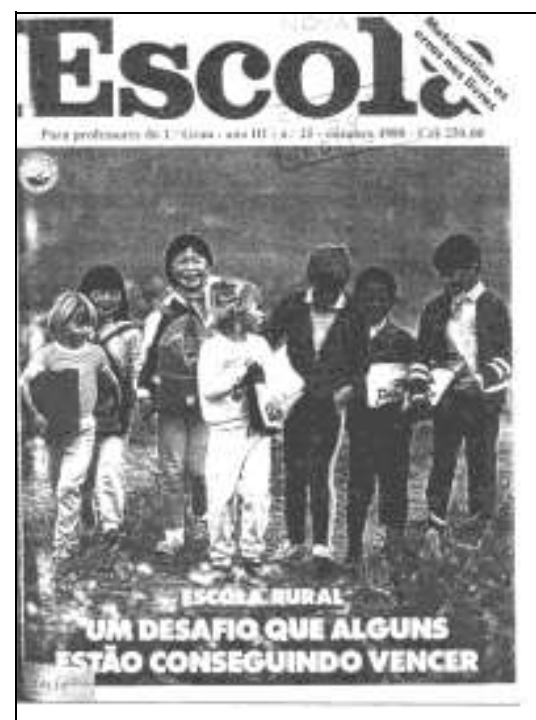

20

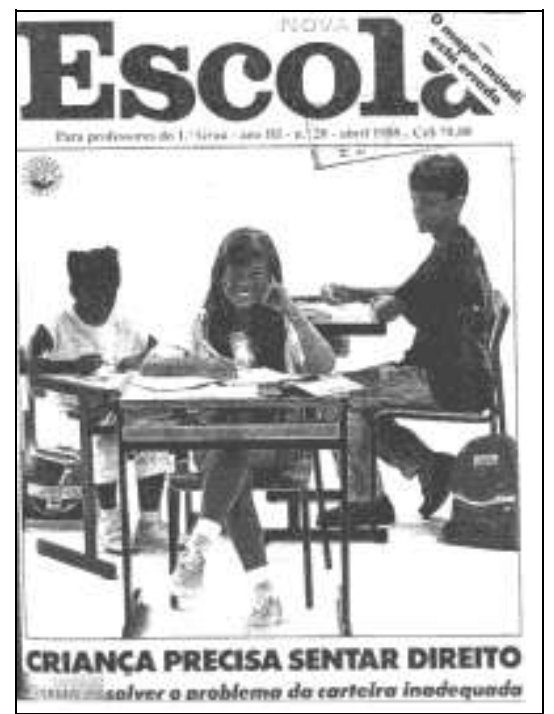

23

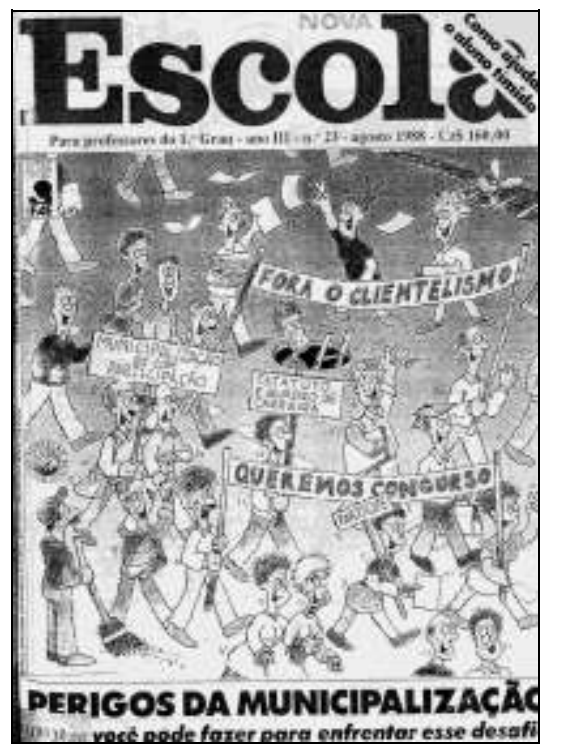

25
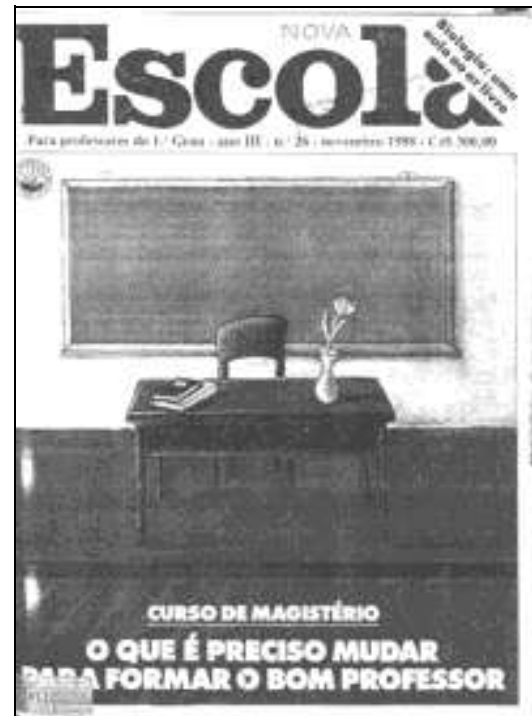

21

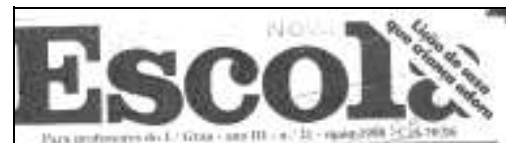

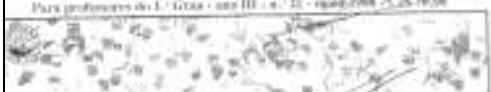

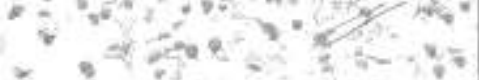

$\therefore \cdots$

Z - MAIS be

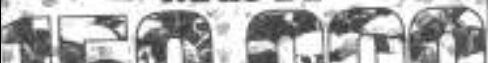

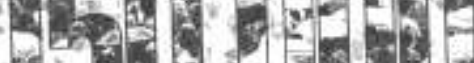

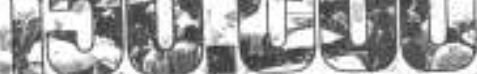
- TPROFESSORES GANHAM MENOS

OUE O MINIMO

WL f Rer para combatero solario ilegal 24
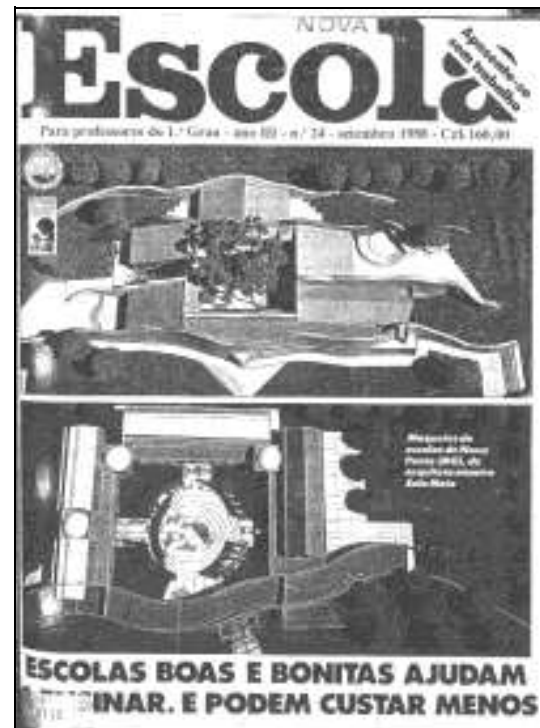

27
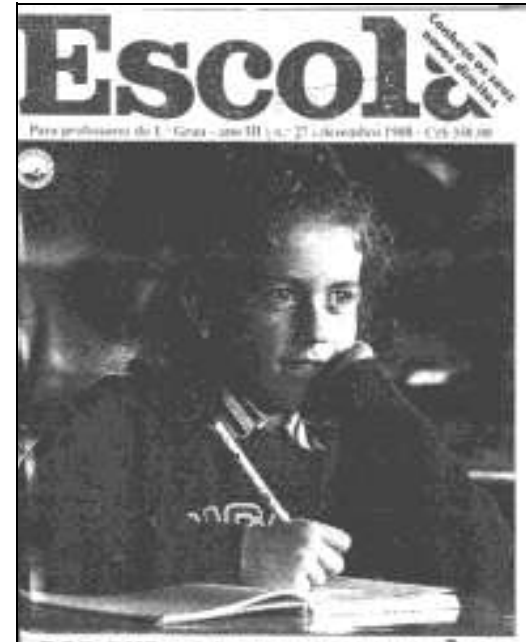

POR QUE NOSSAS CRIANCAS NĀO DUSE GUEM PRODUZIR BONS TEXTOS 
Ano: 1989

Números: 28 a 36

28

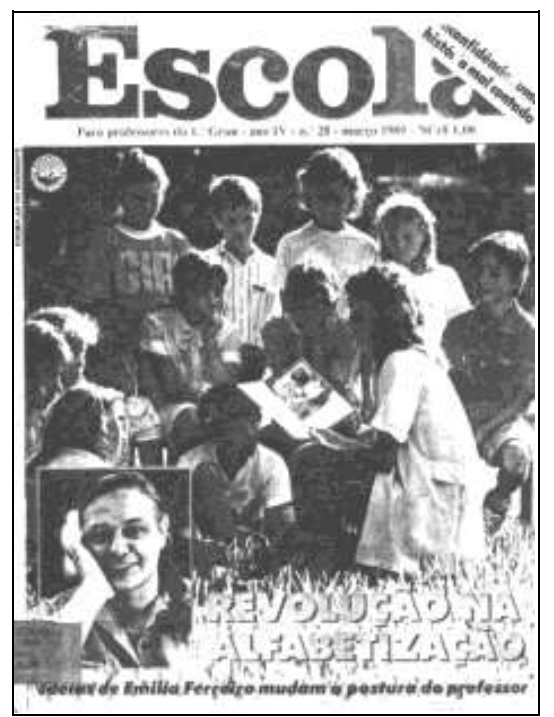

31
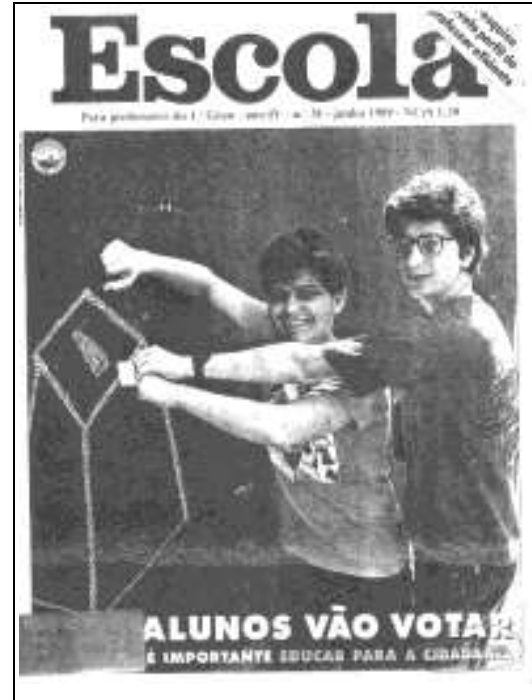

34

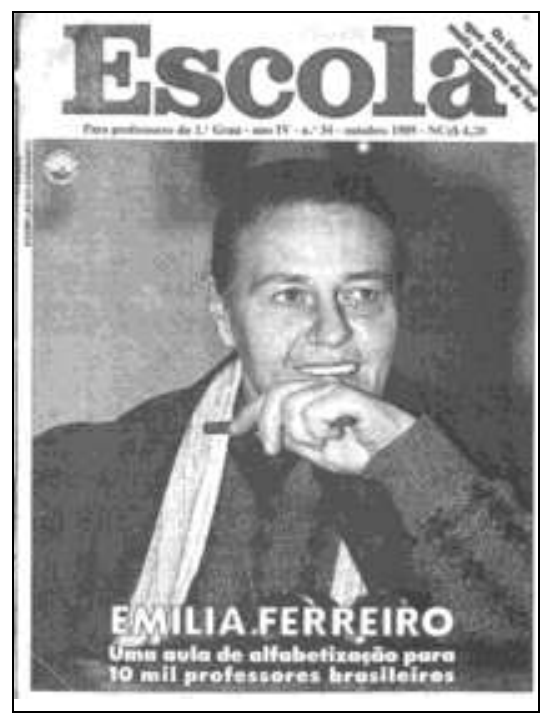

29
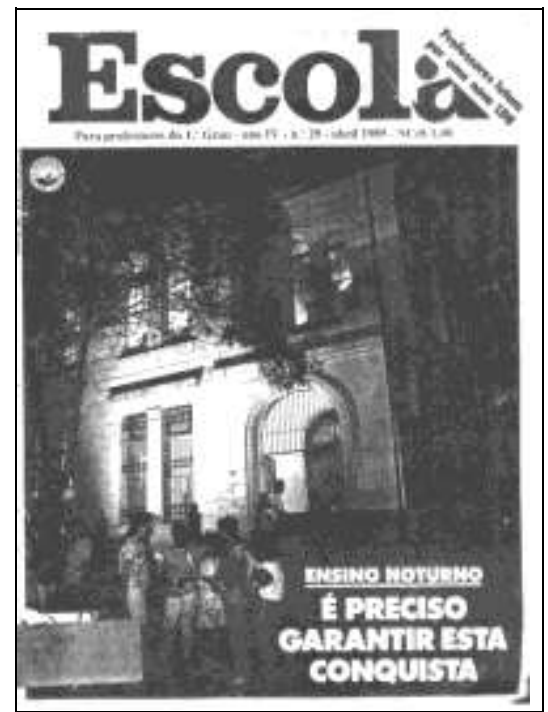

32
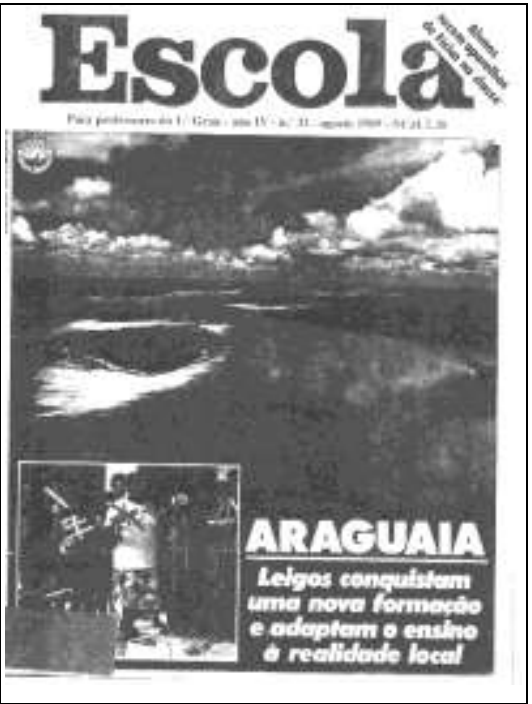

35

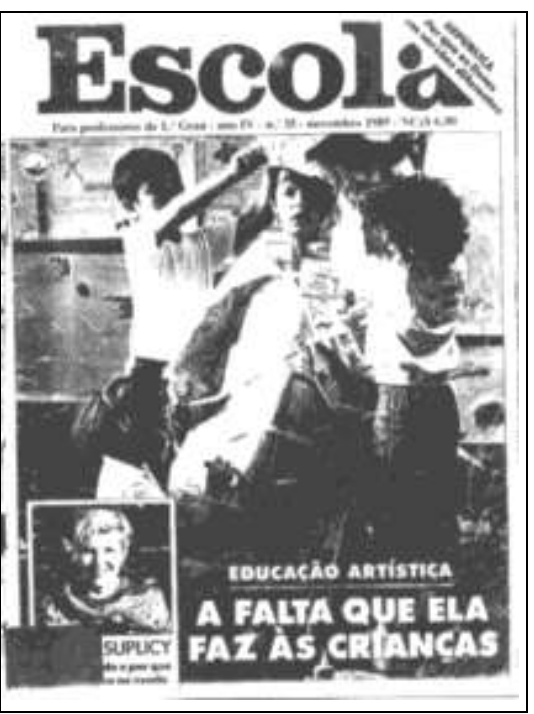

30

Escolai

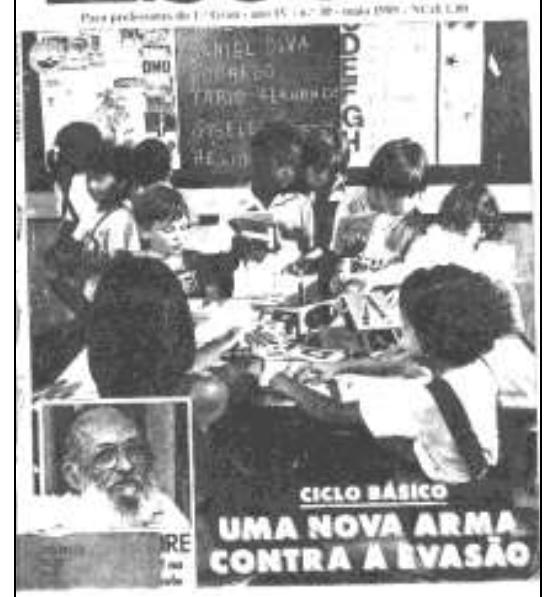

33

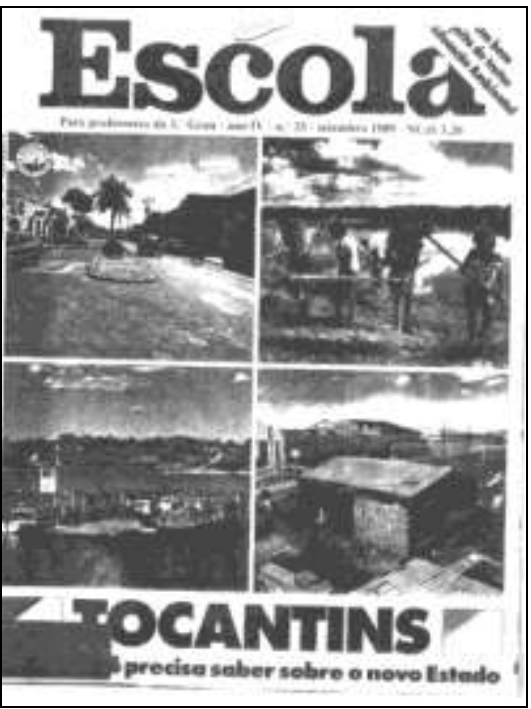

36

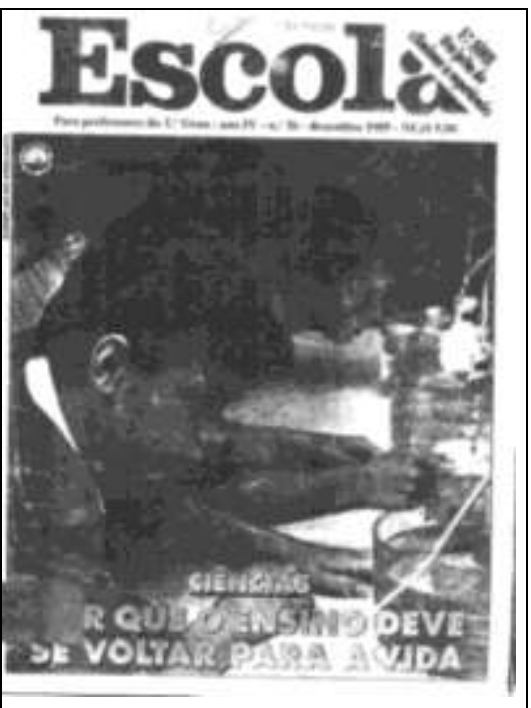


Ano: 1990

Números: 37 a 45

37

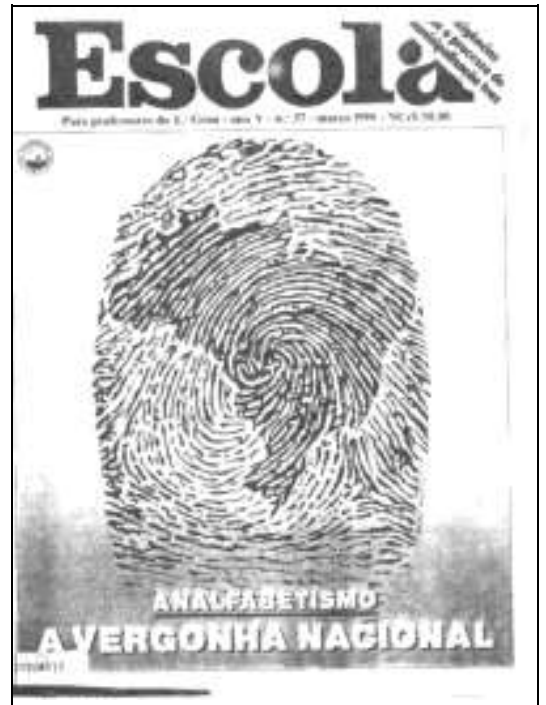

40

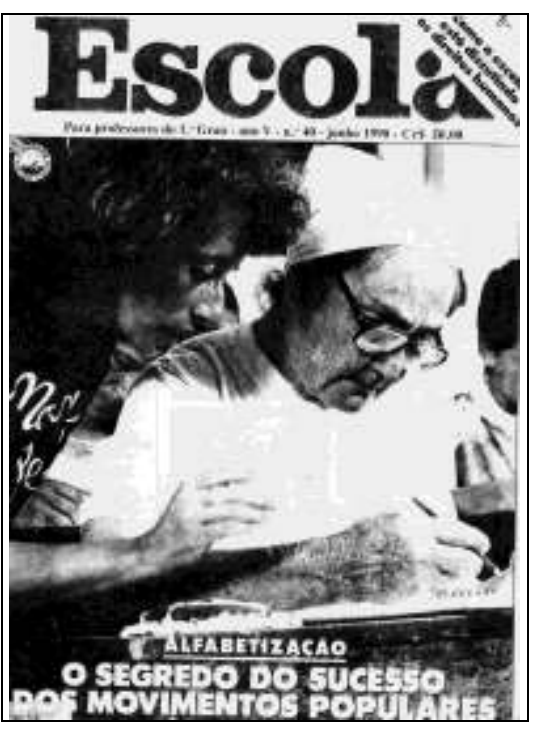

43

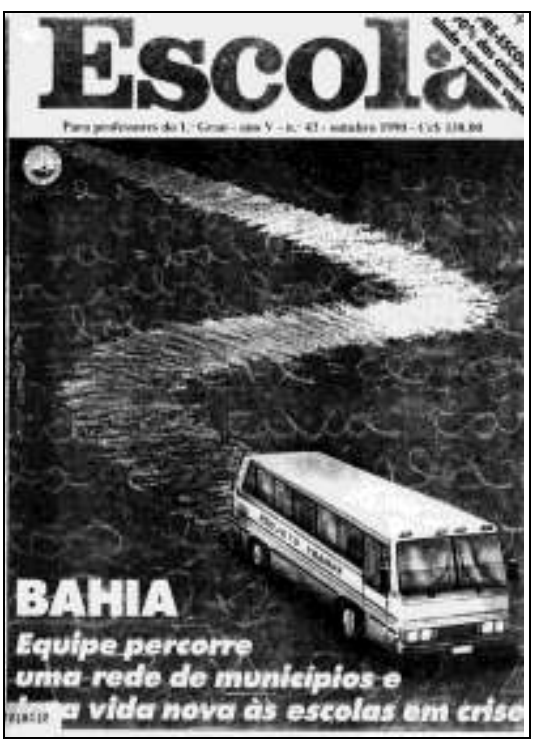

38

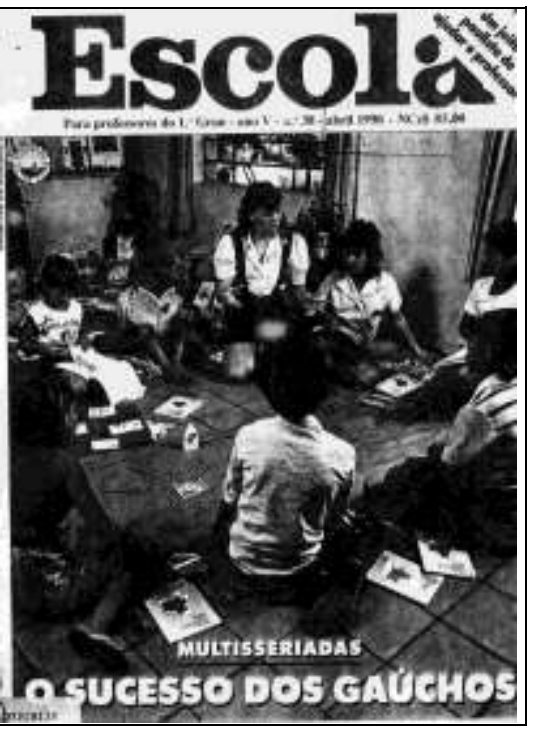

41
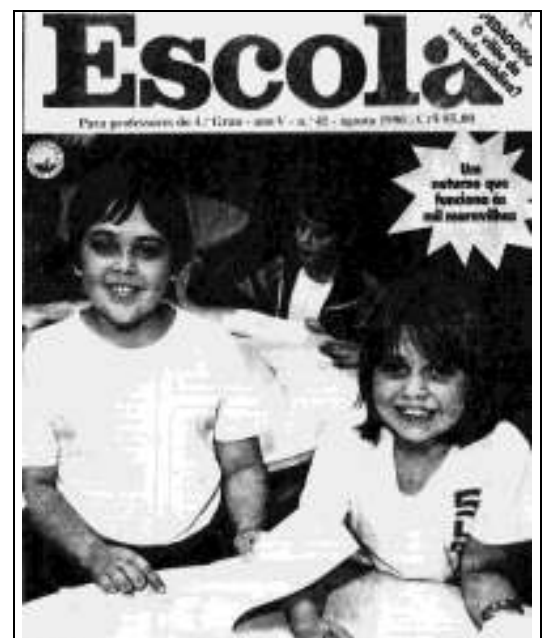

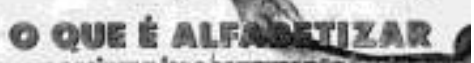
44

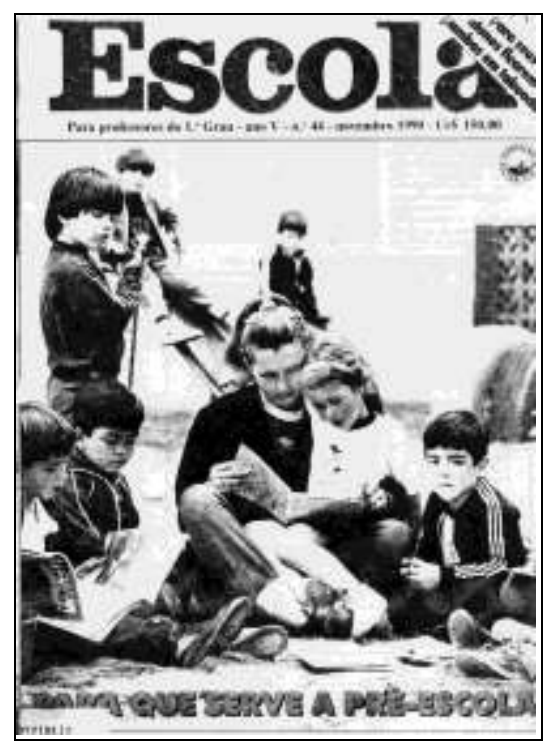

39

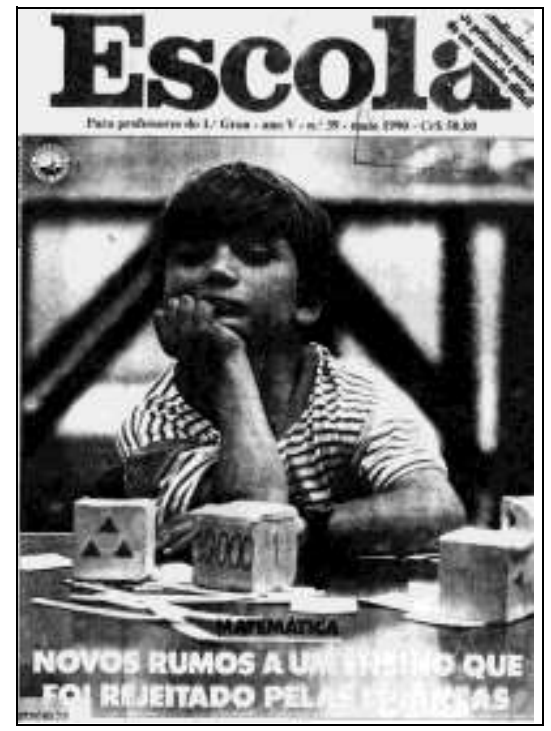

42

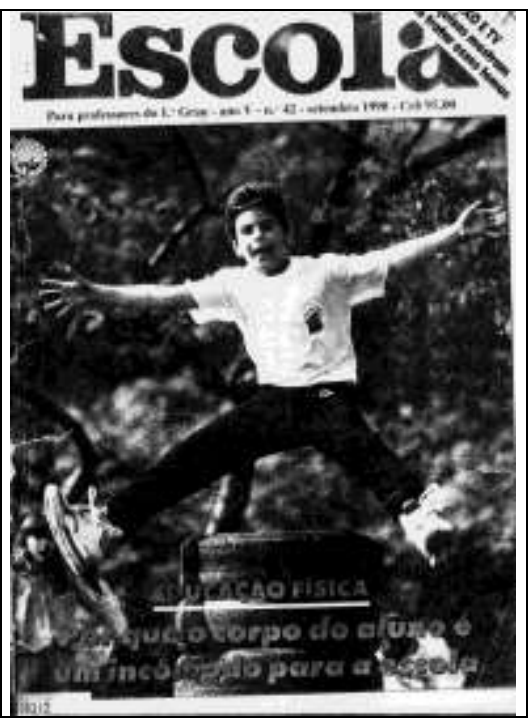

45

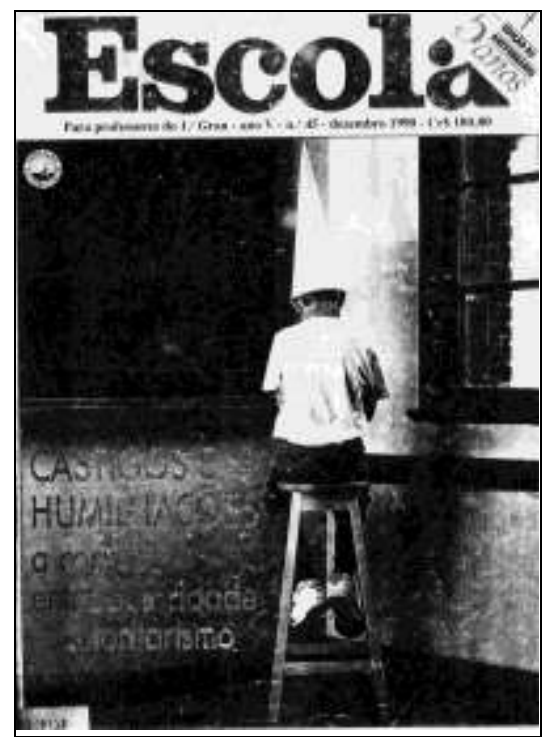


Ano: 1991

Números: 46 a 54

46

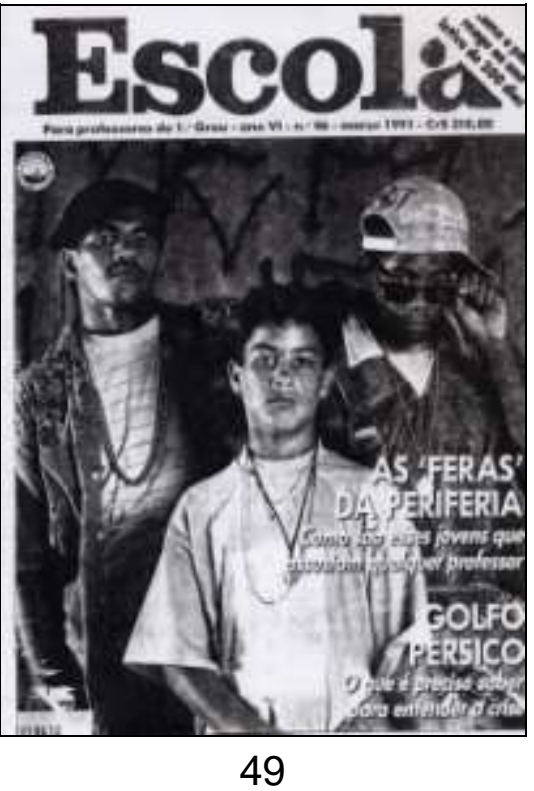

Escola

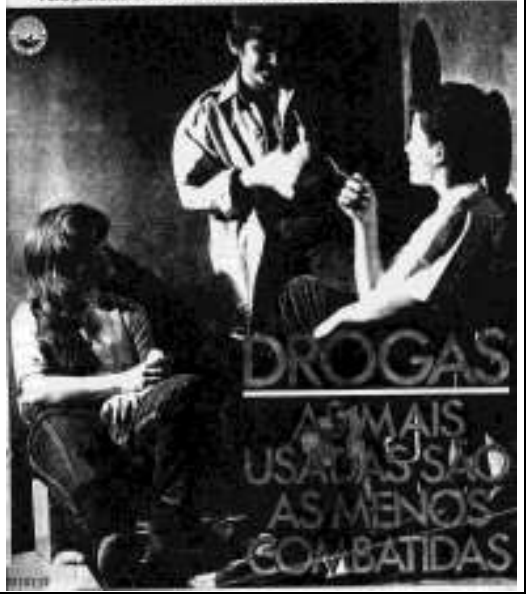

52

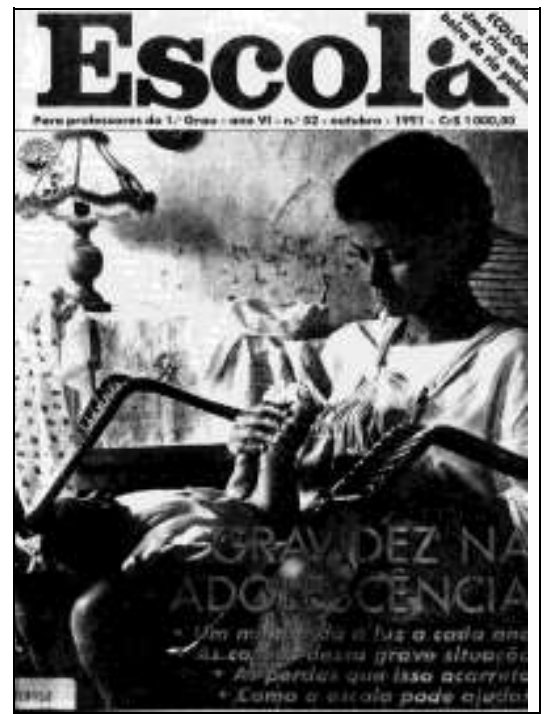

47

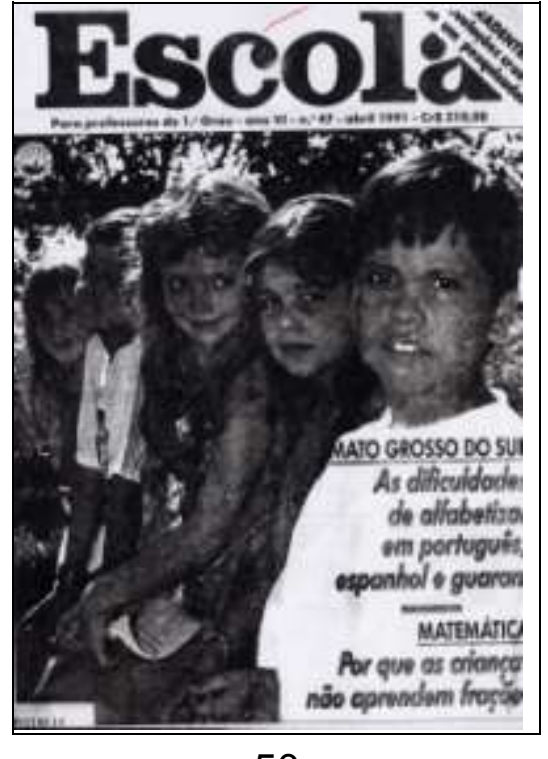

50
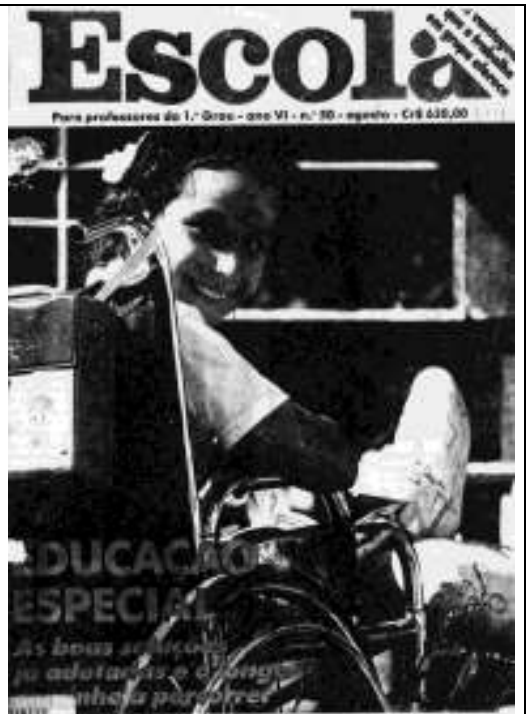

53

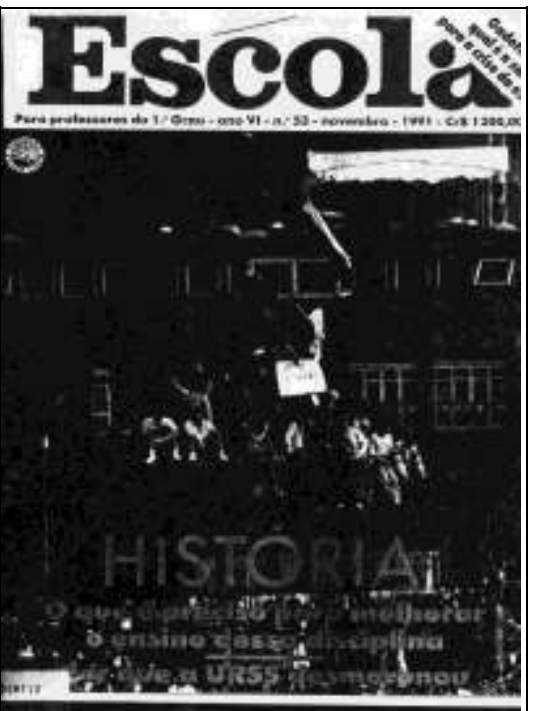

48

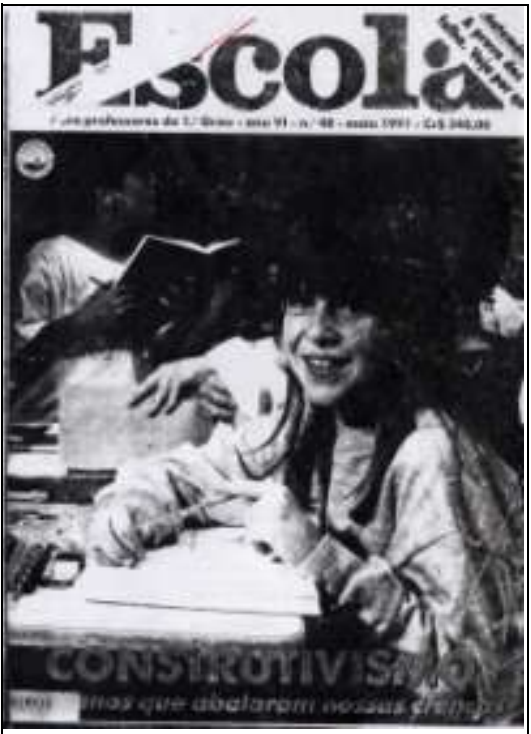

51
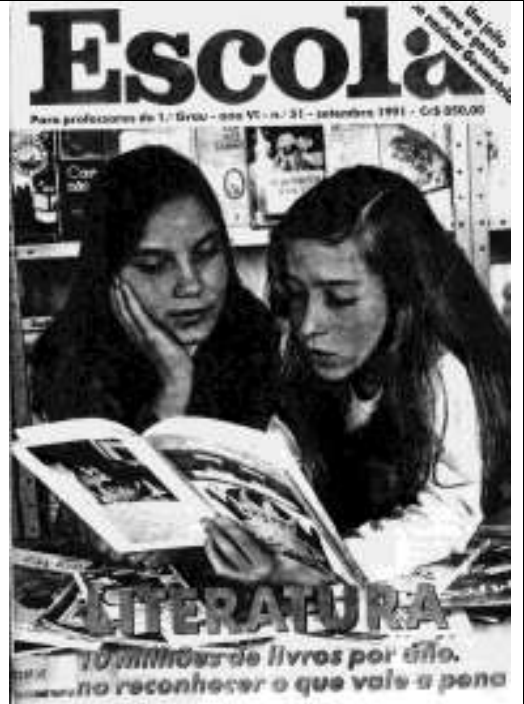

54

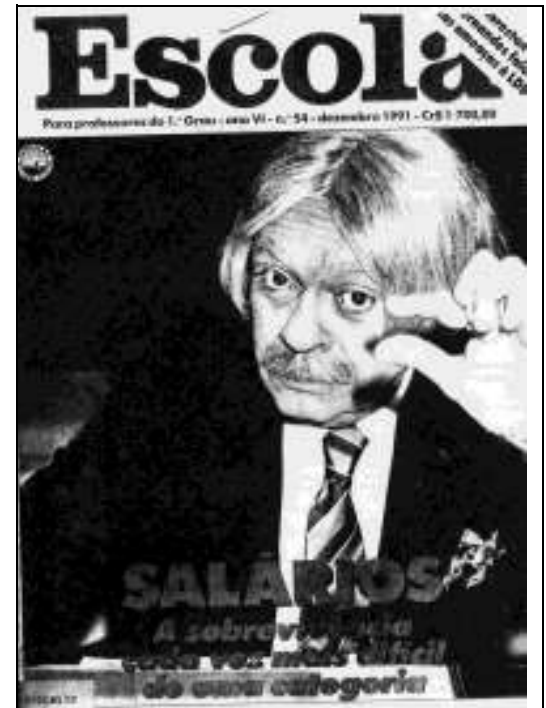


Ano: 1992

Números: 55 a 63

55

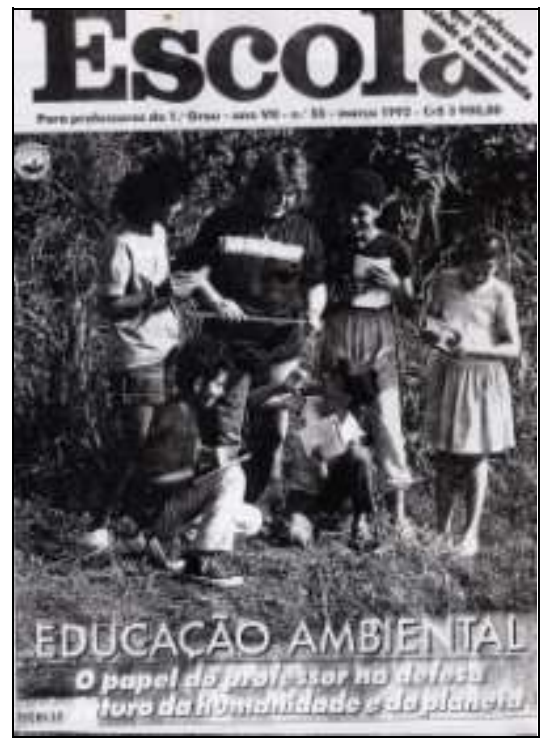

58

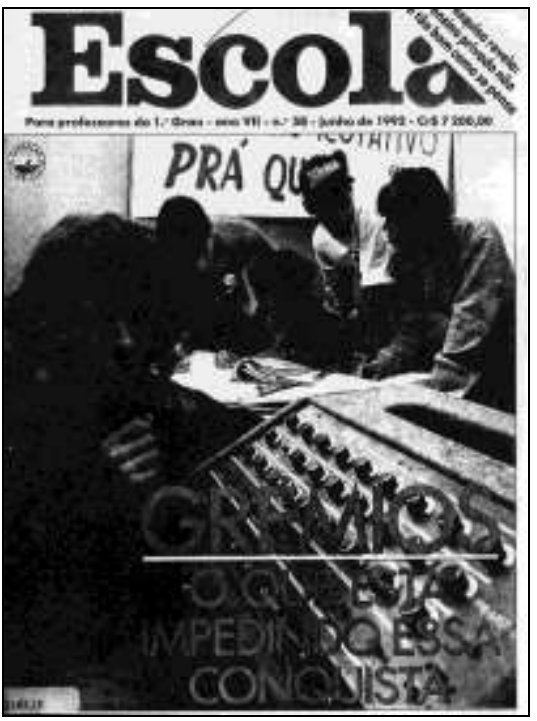

\section{1}

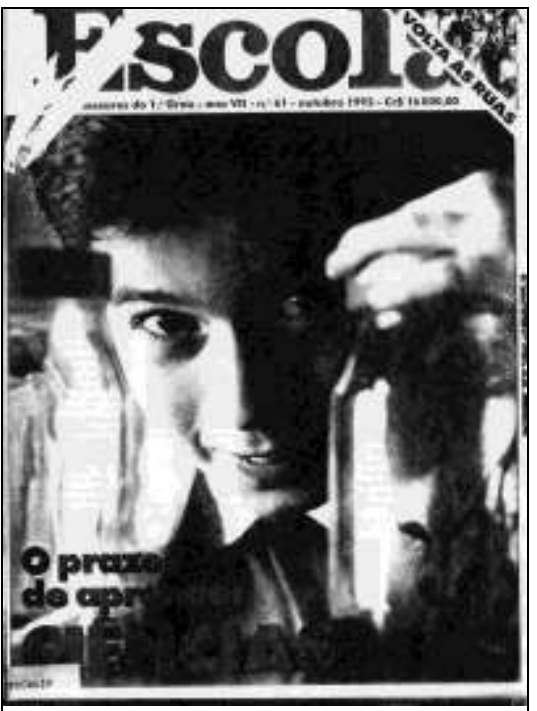

56

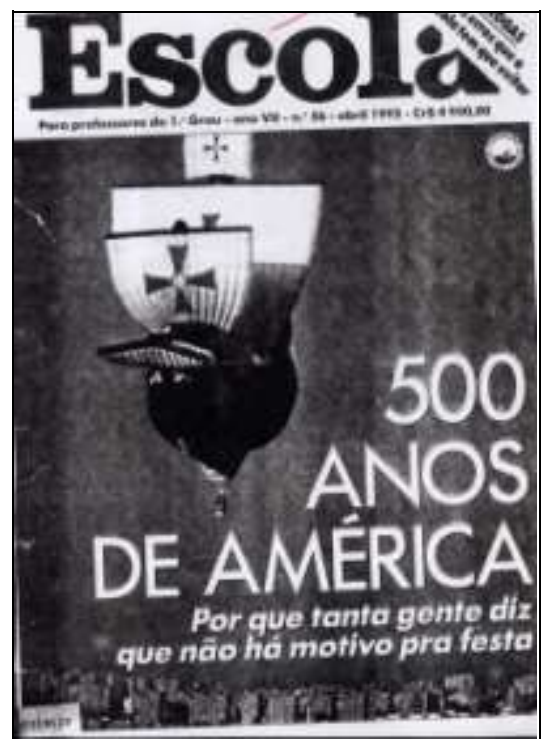

59

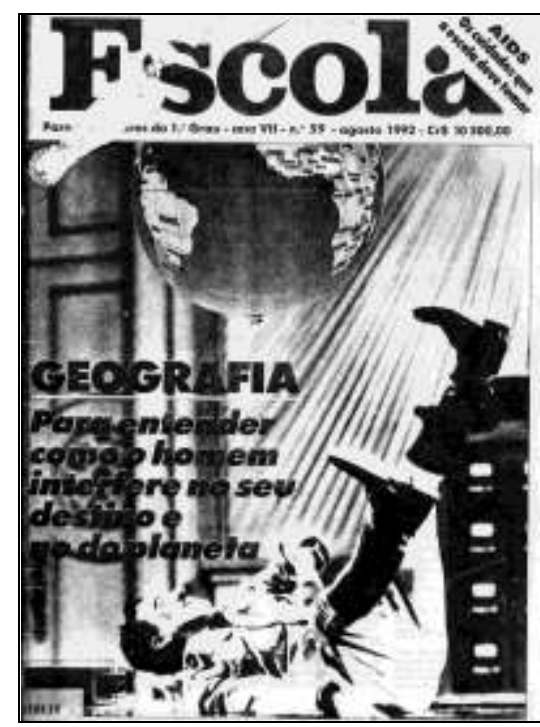

62

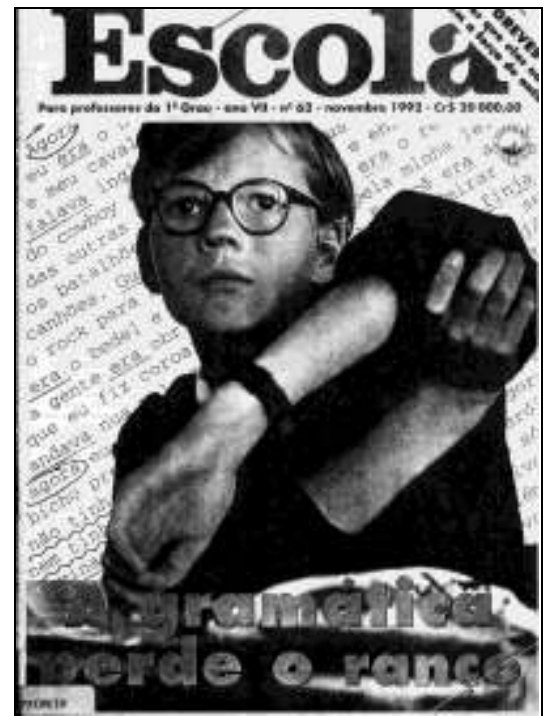

57
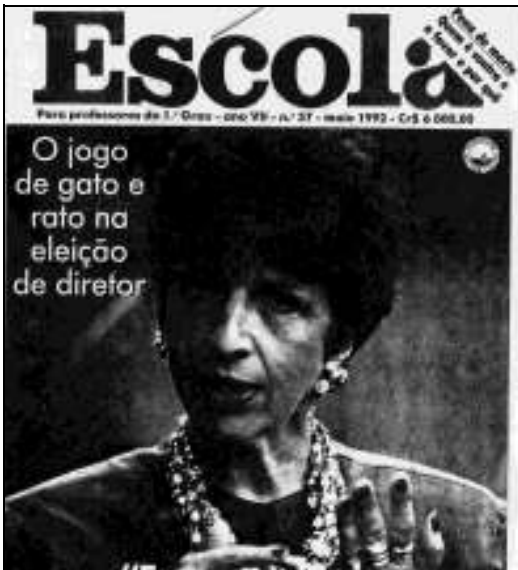

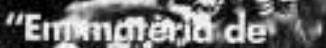

alfabetjzche damos banho no Primeiro Mundo

nin Lida

60

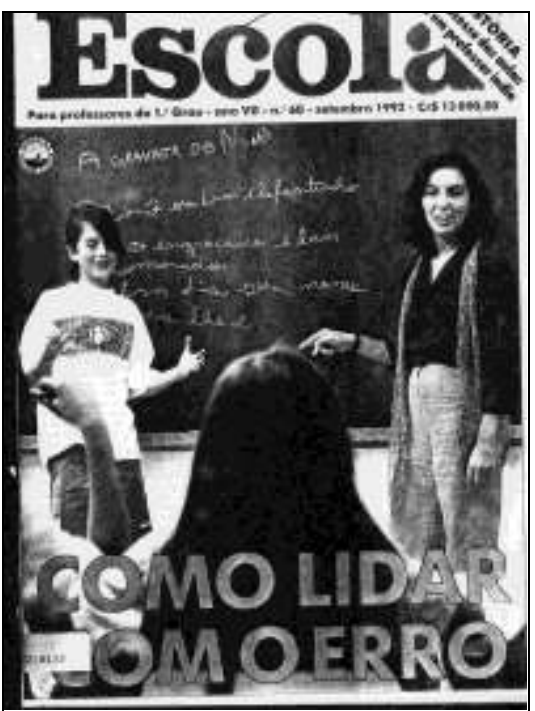

63

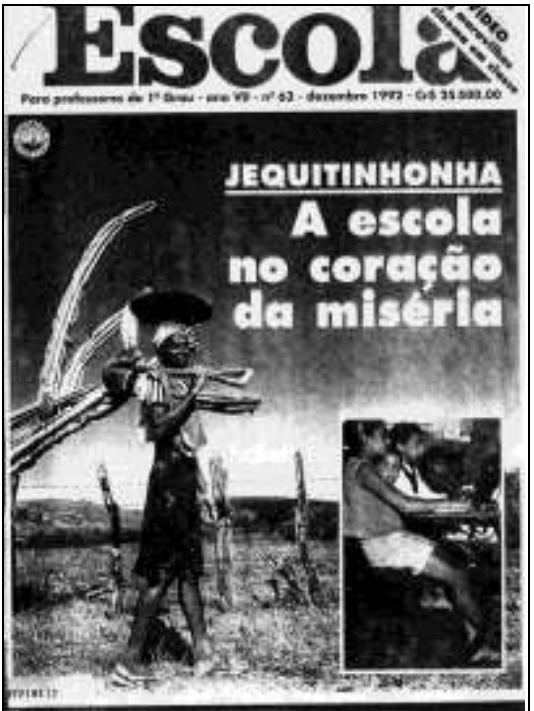


Ano: 1993

Números: 64 a 72

64

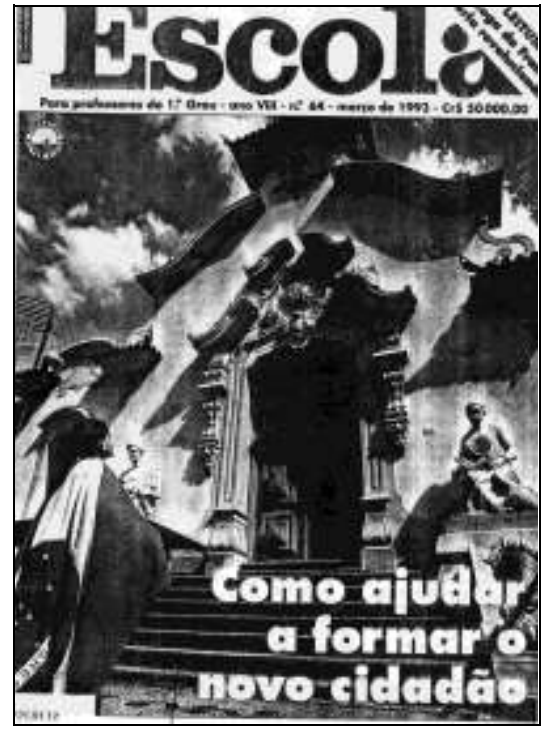

67

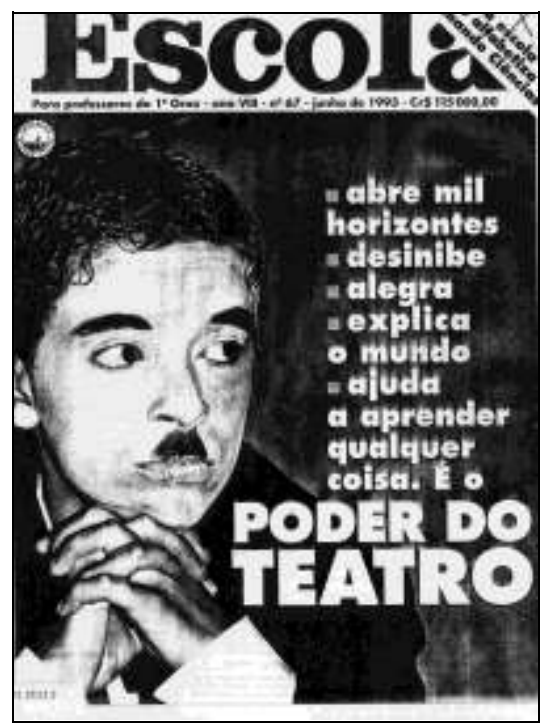

70

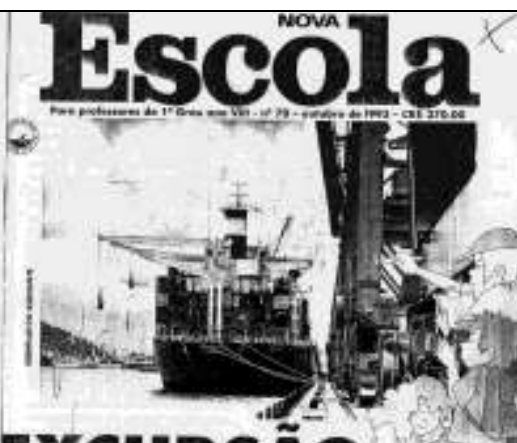

\section{EXCURSÃO}

Para aprender Geogrefin Portugues vendo tudo com os prbprios olhes

Yaxtucis SARA PAIN ITruma

O que faxer As ideiase Experièncio

quando um a práfica de uma francesa leva

e seusalunos educadora que o pré-eseolar a

mon-mito condux criences criticar ea
65

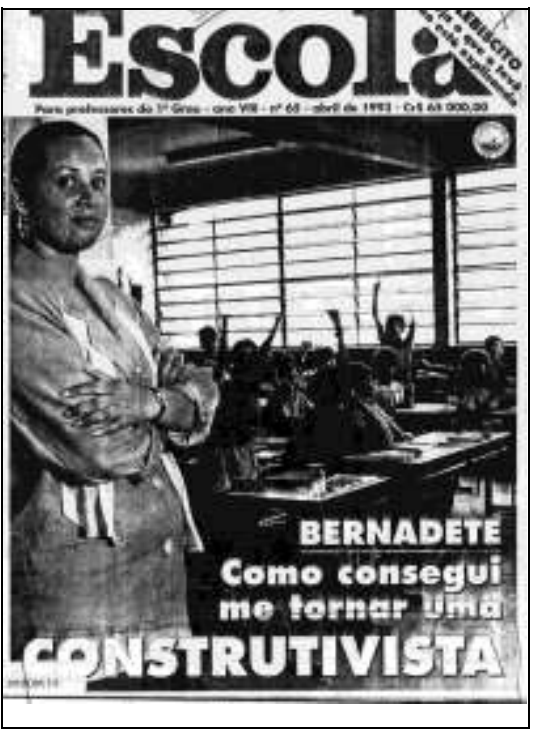

68
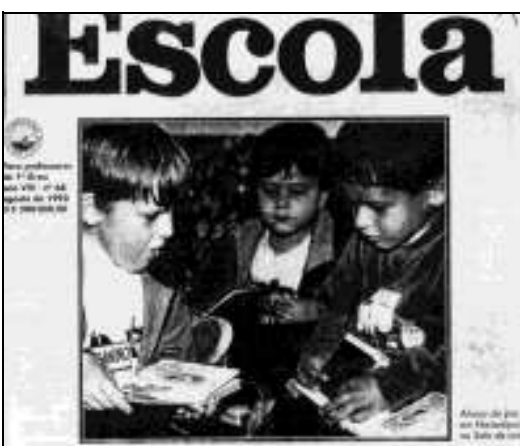

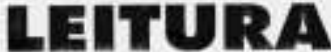

Um projeto para a

palavra escrita invadir a escola

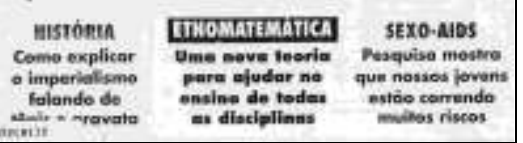

71

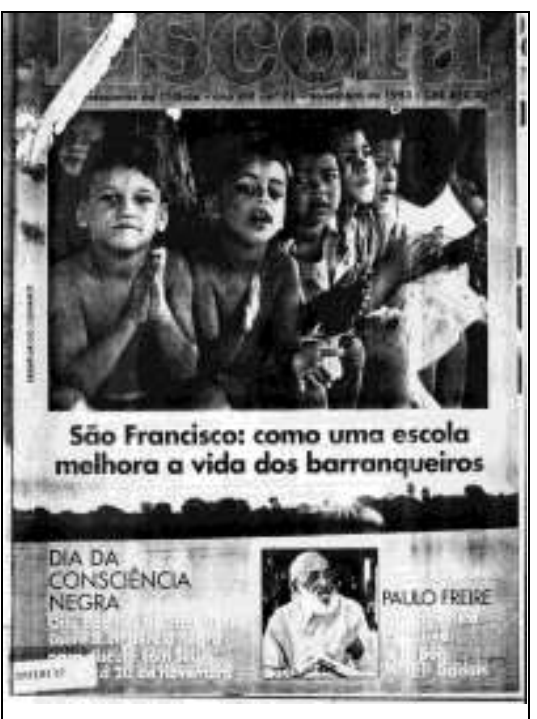

66

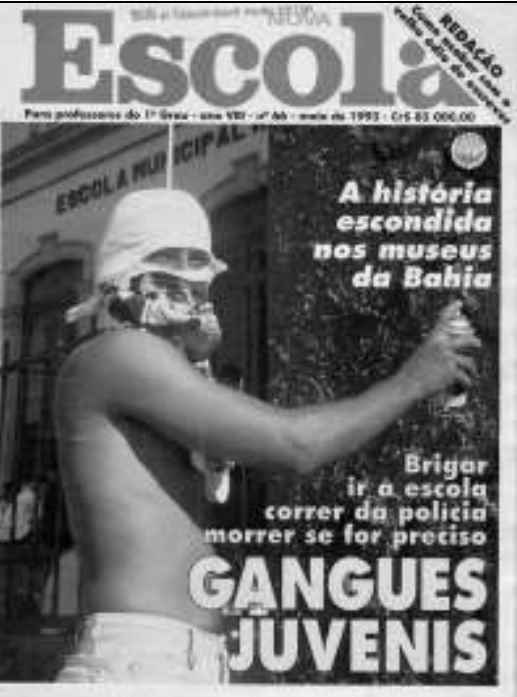

69
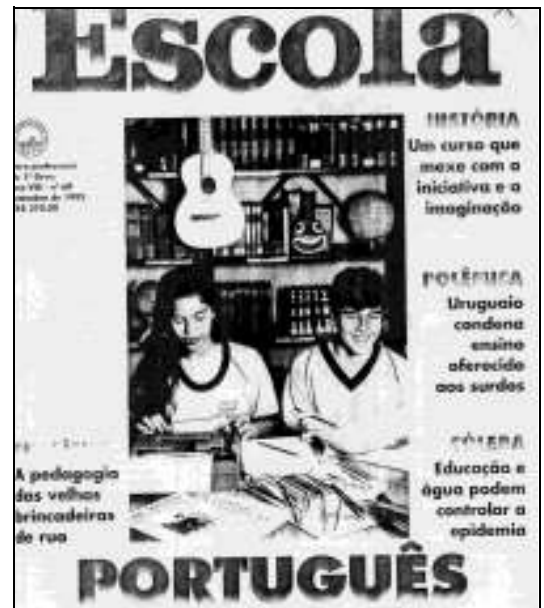

Recurses que levam os elunos a oesquisar, escrever, representar e ler ainit uito mais do que a escola exige

72
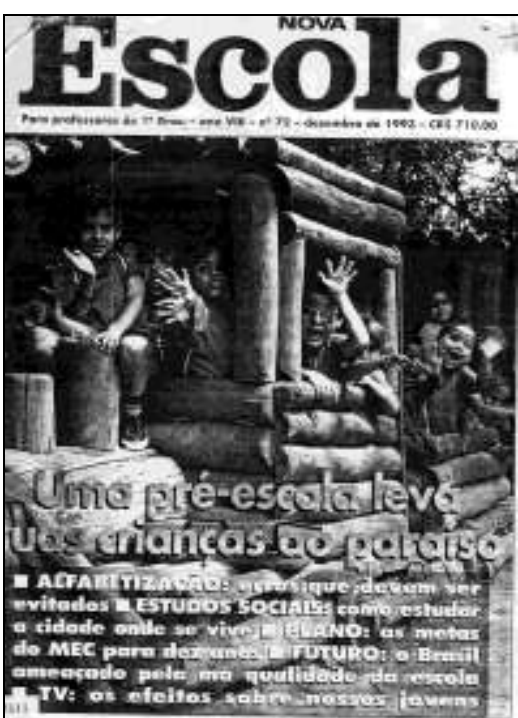
Ano: 1994

Números: 73 a 81

73

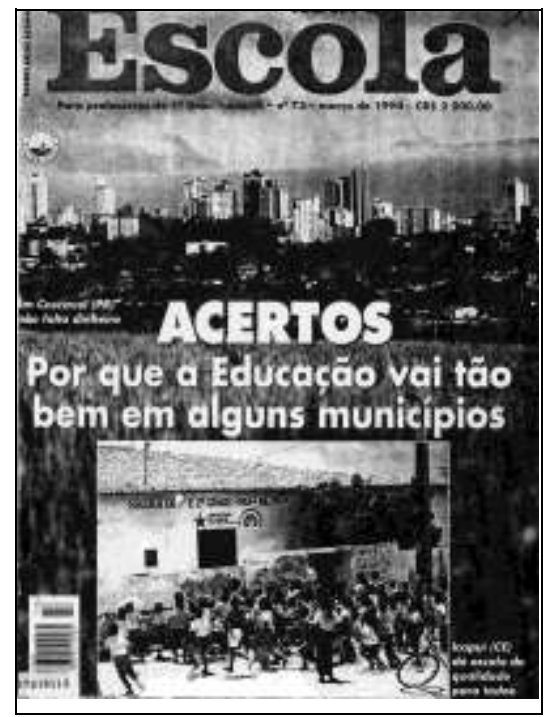

76

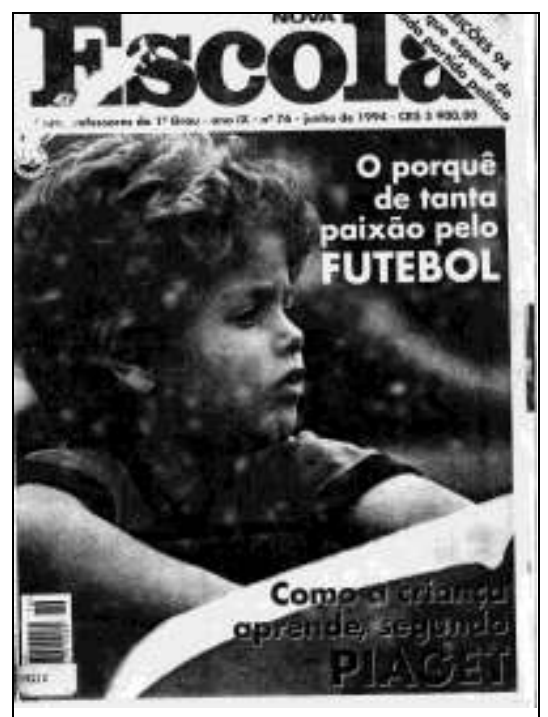

79
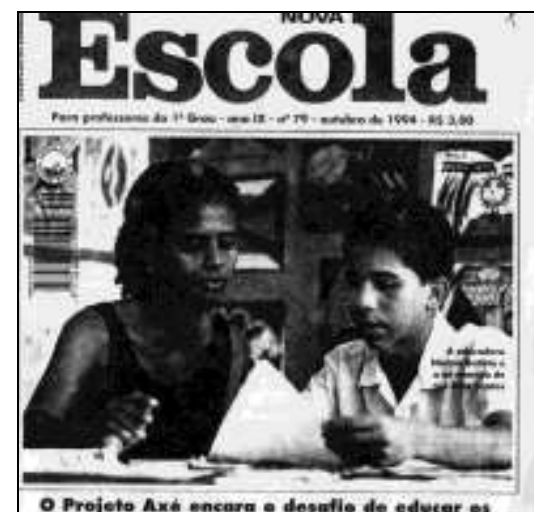
MENINOS DE RUA

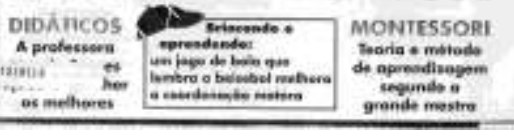

74
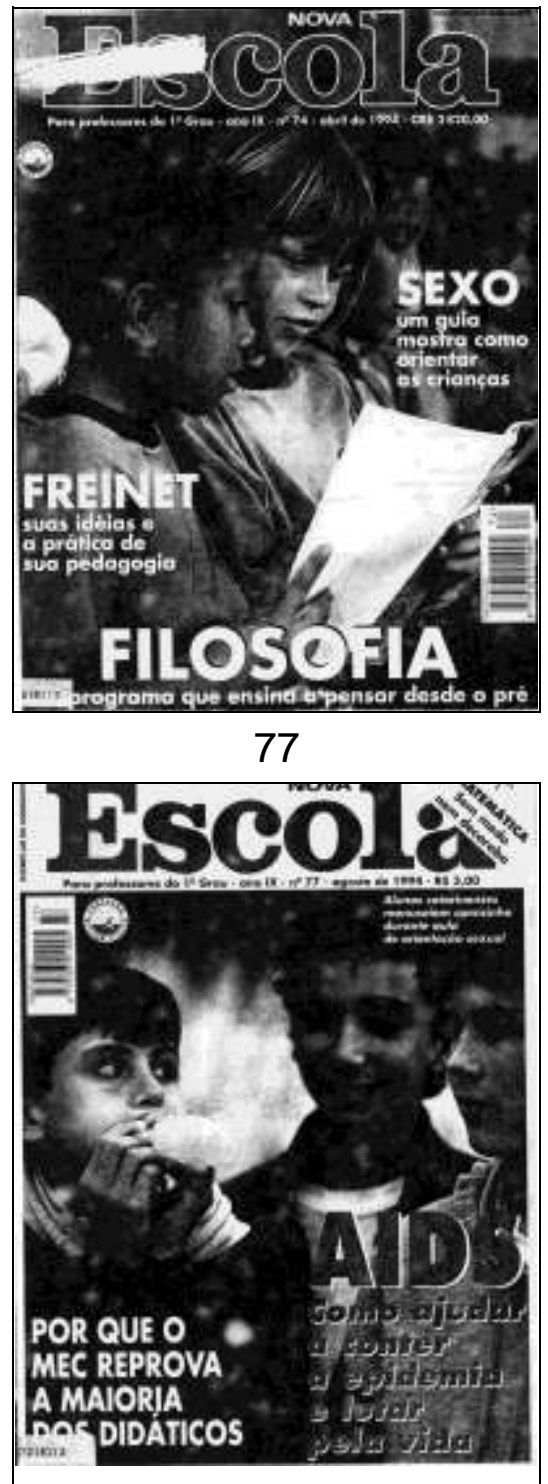

80

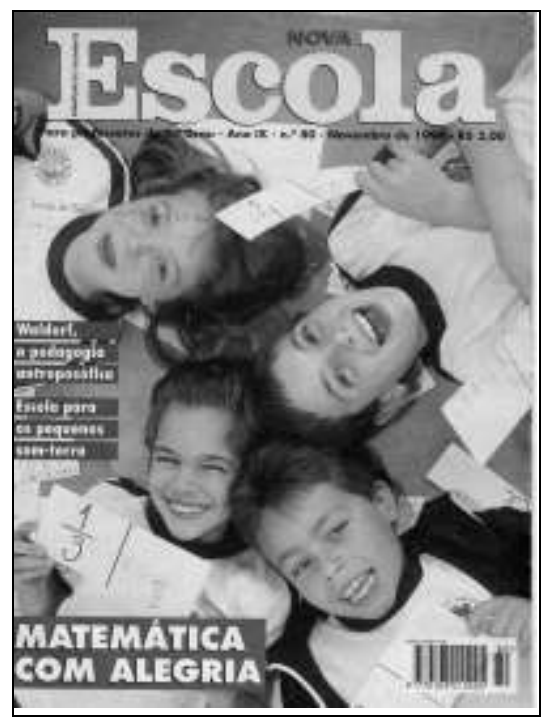

75

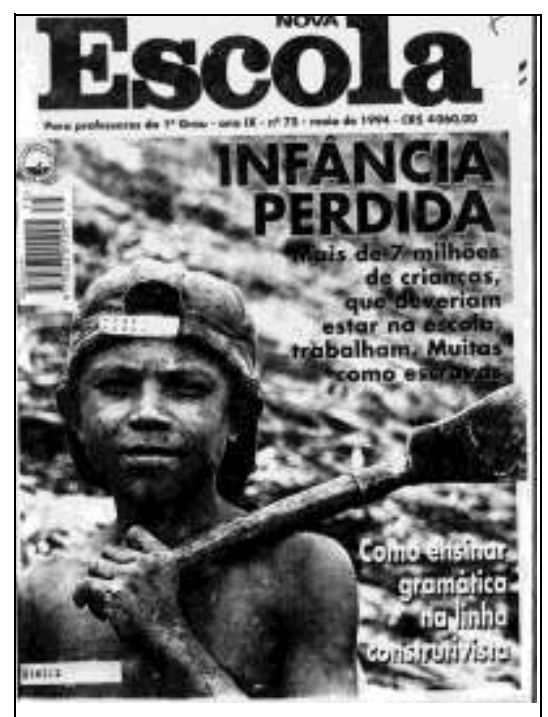

78
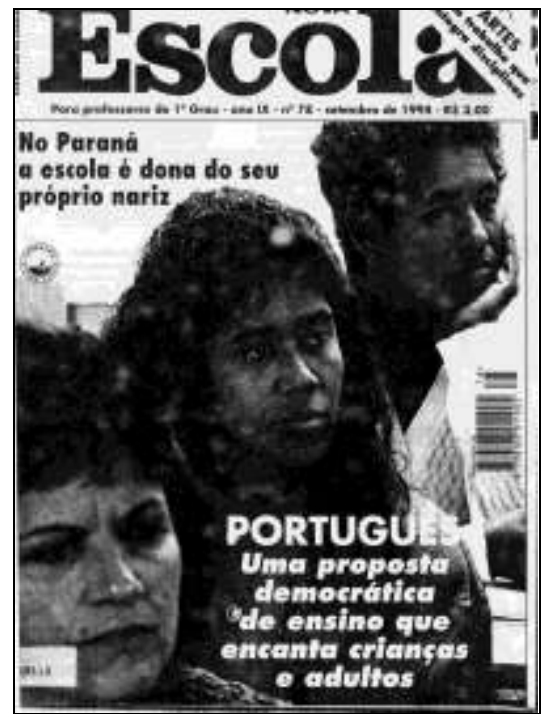

81

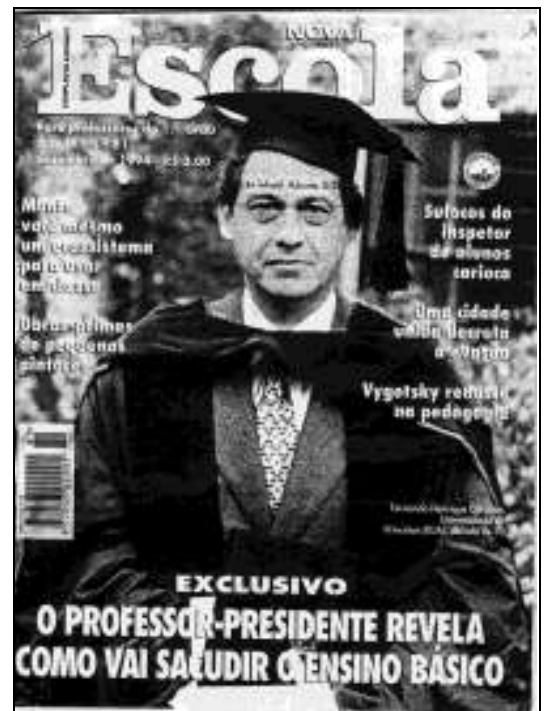


Ano: 1995

Números: 82 a 90

82

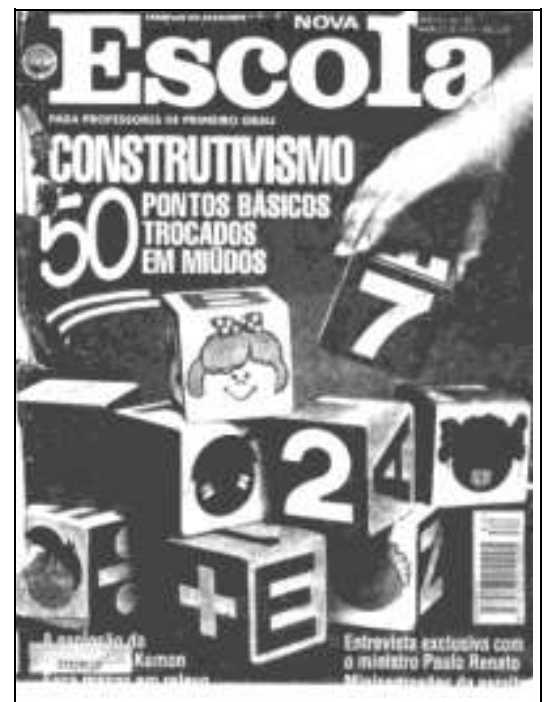

85

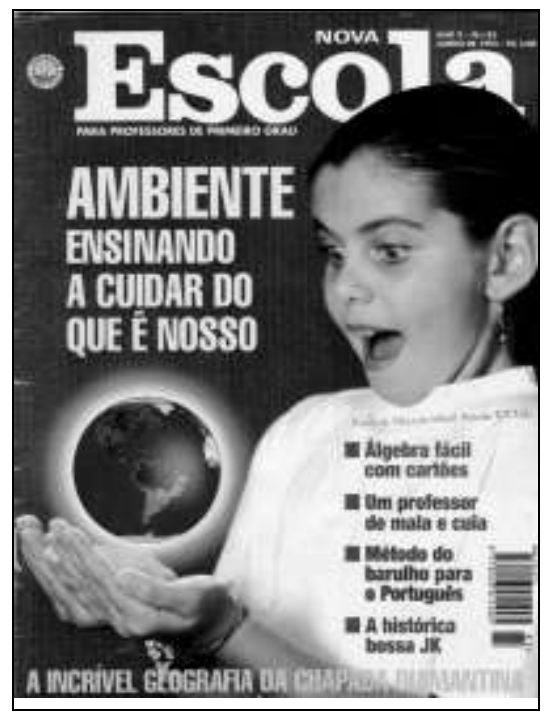

88

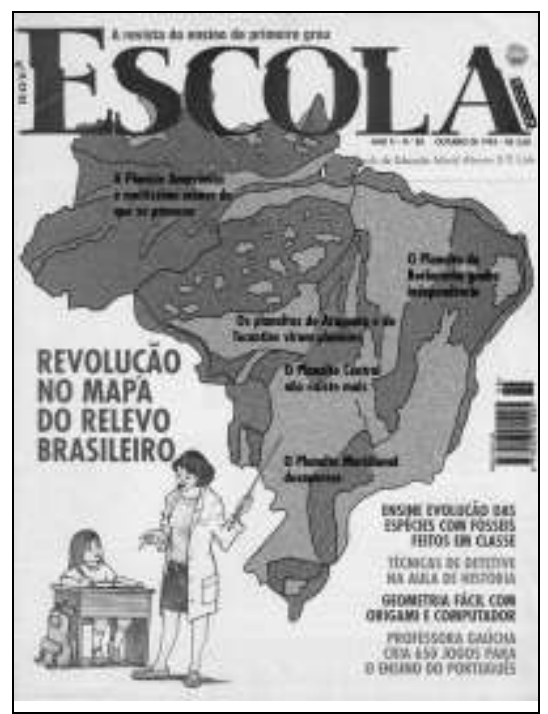

83

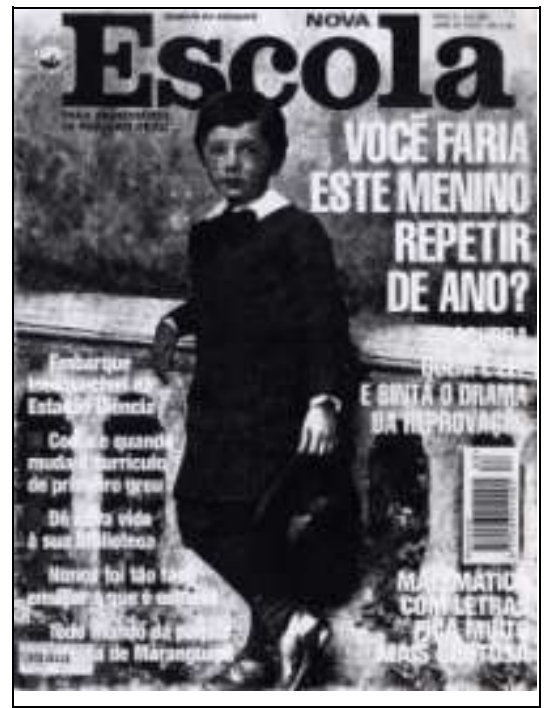

86

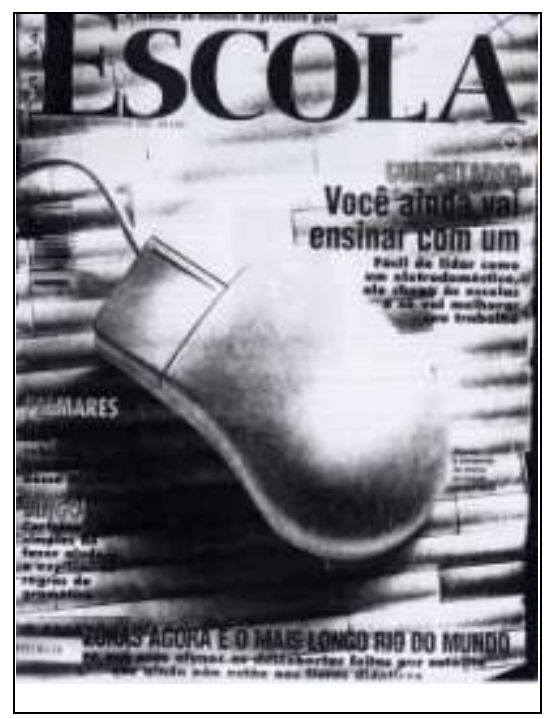

89

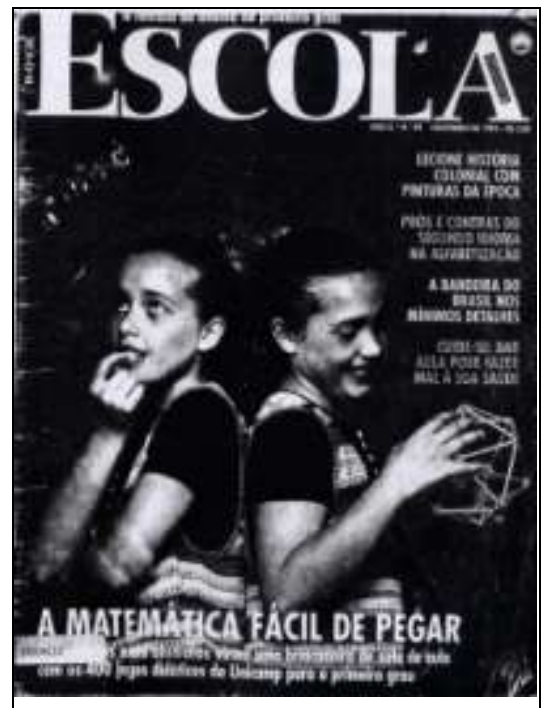

84

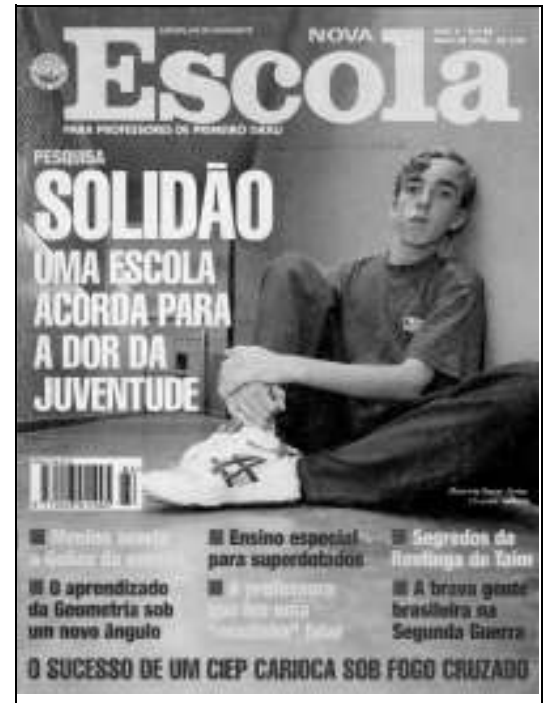

87
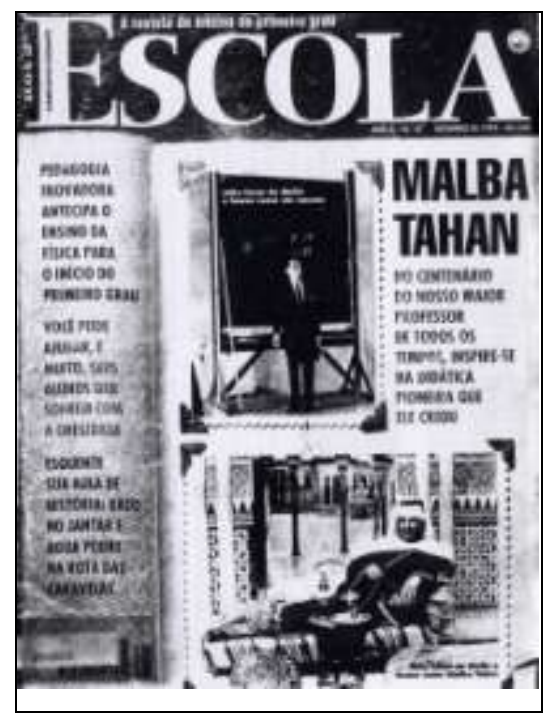

90

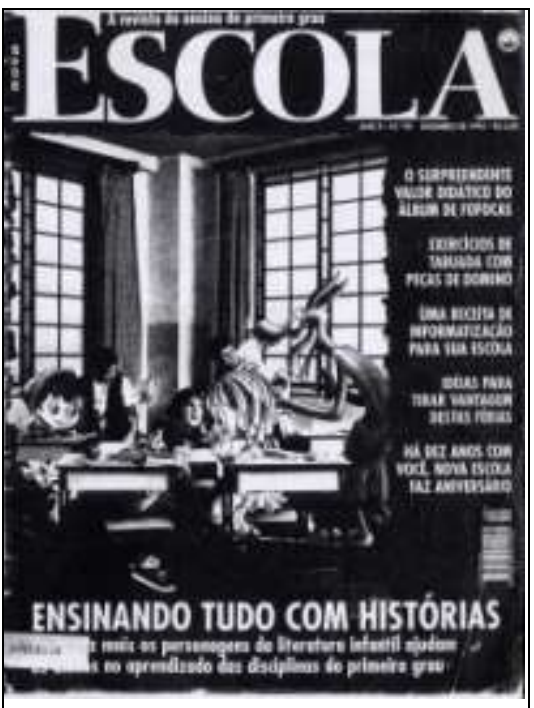


Ano: 1996

Números: 91 a 99

91

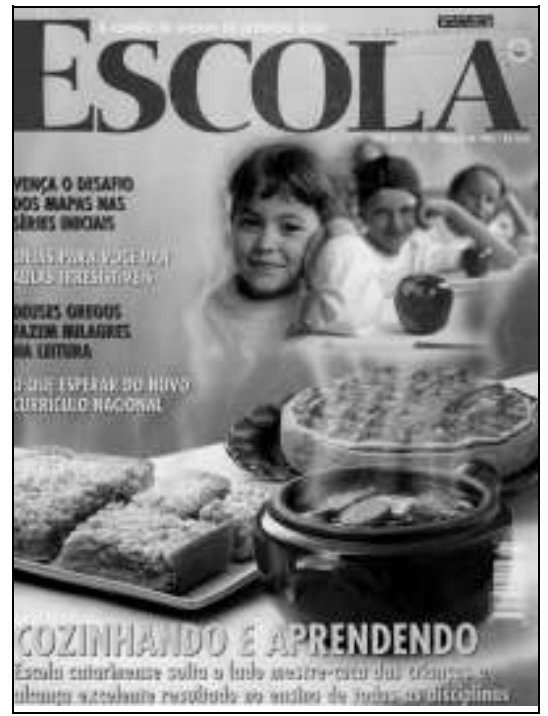

94

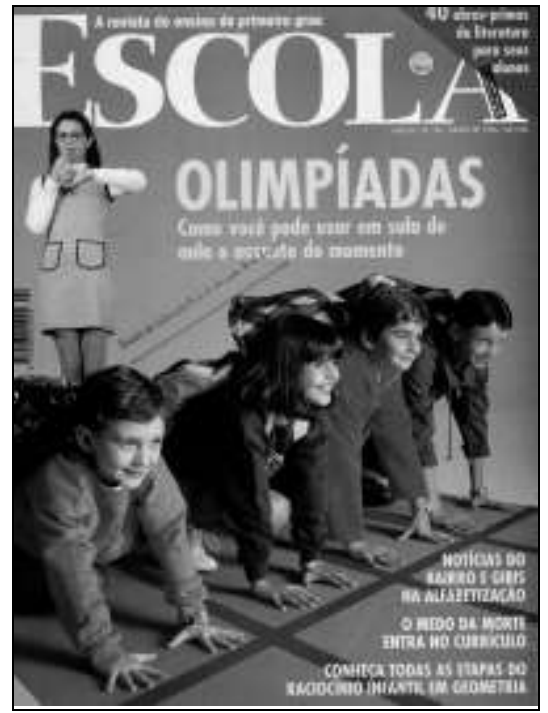

97

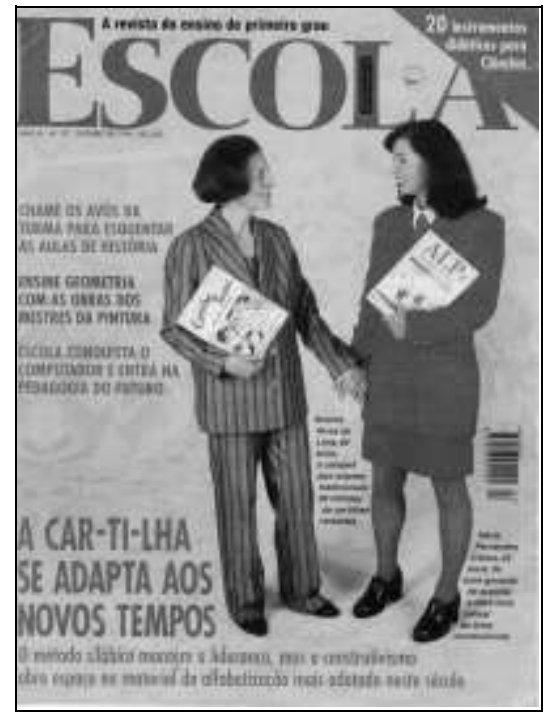

92

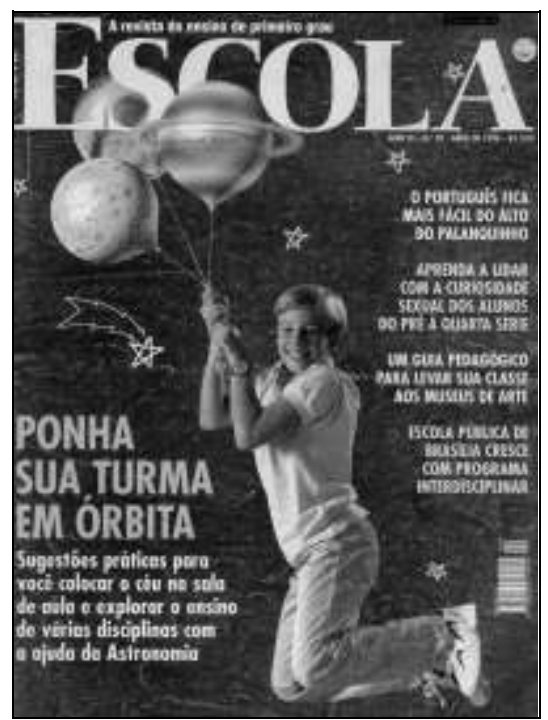

95

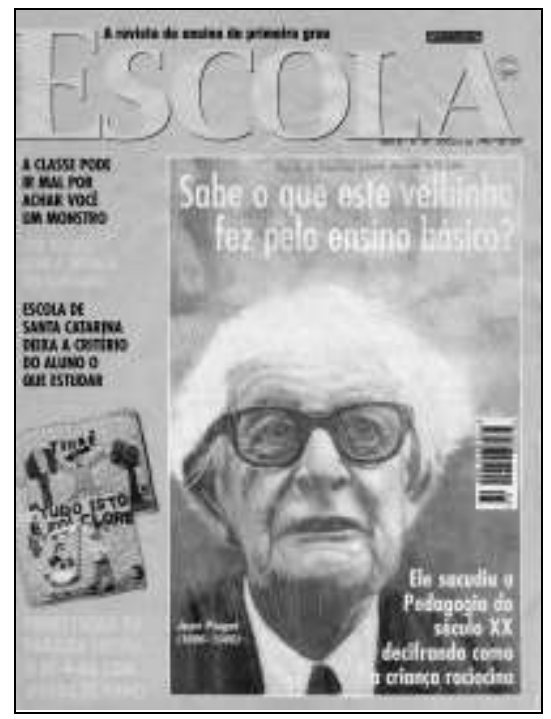

98

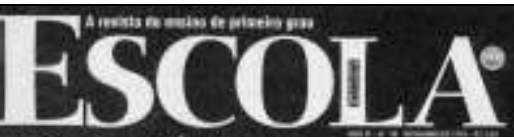

HOW DE DIDATICA NO

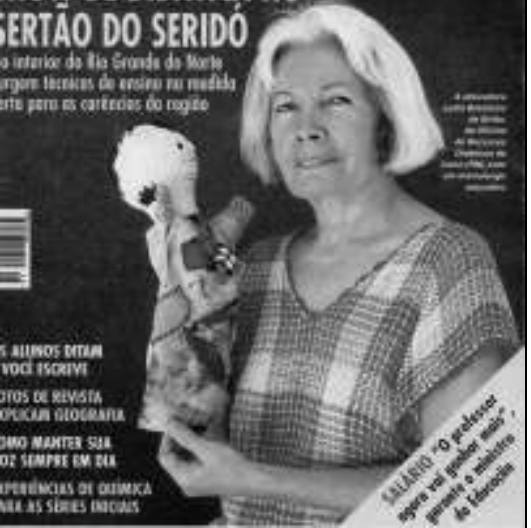

93
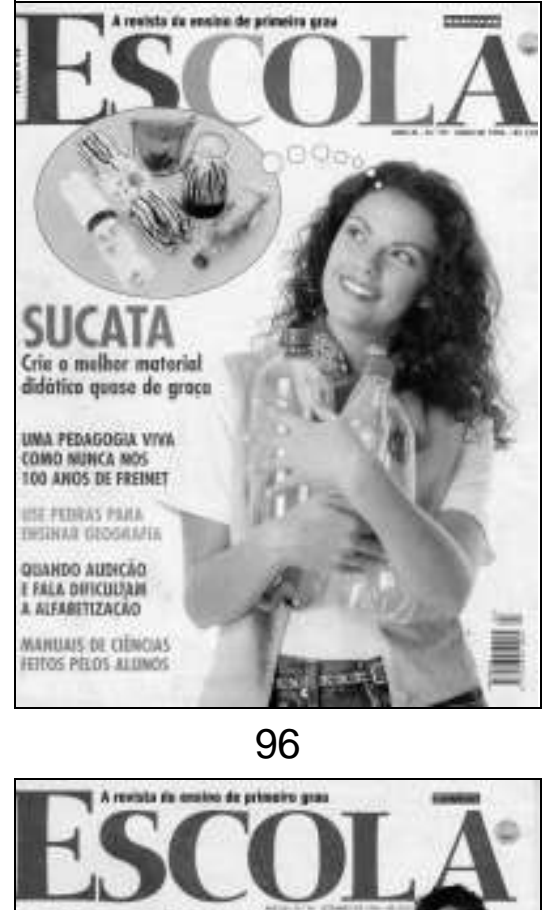

O FAZ-DE-CONTA E COISA

SÉRIA PARA AS CRIANCAS

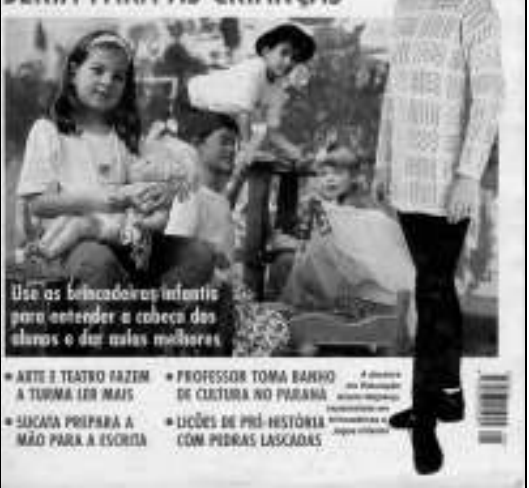

99
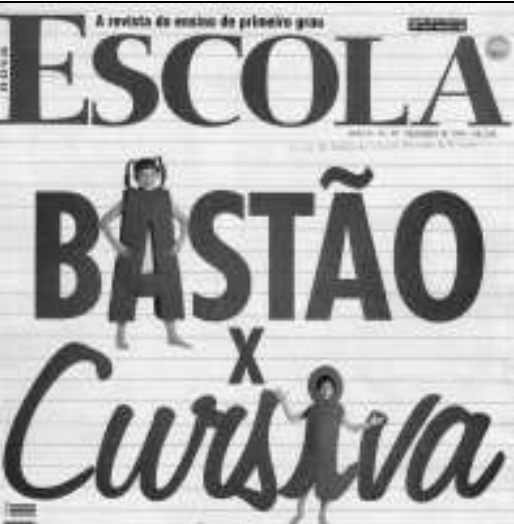

OS PROS E OS CONTRAS

DE CADA LETRA NA ALFABETIZACĀO

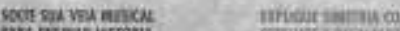

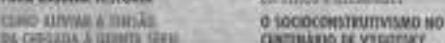


Ano: 1997

Números: 100 a 108

100

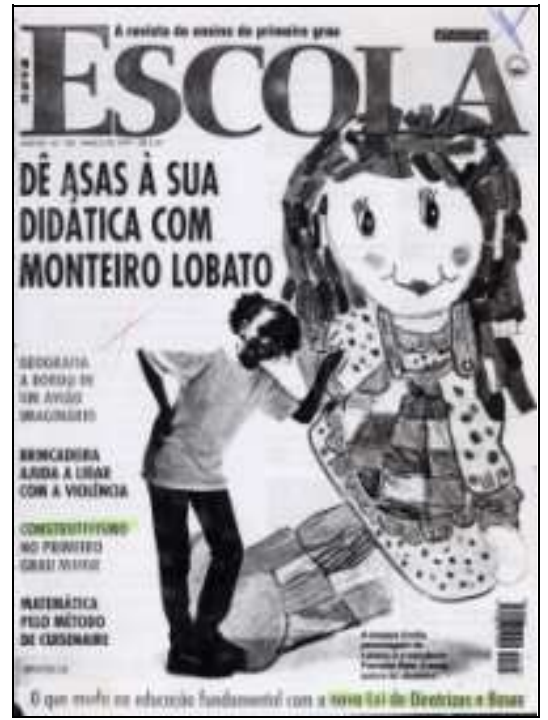

103

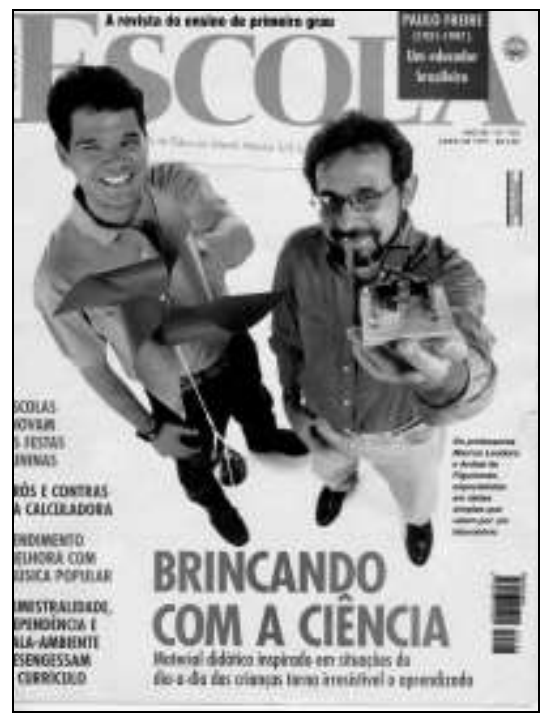

106

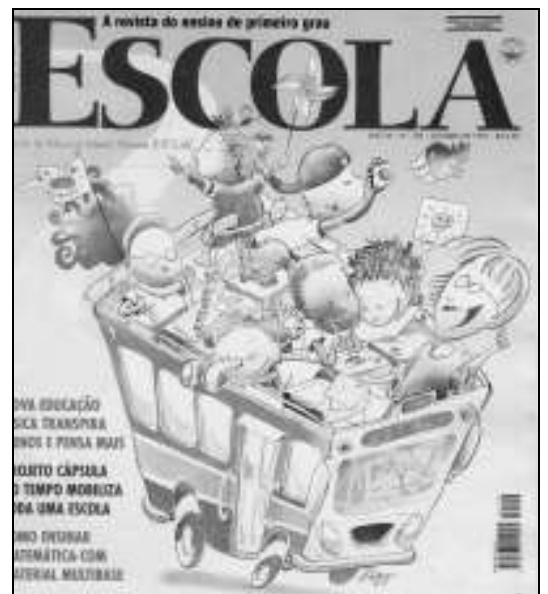

VAMOS APRENDER POR AÍ

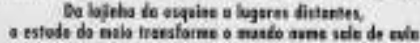

101

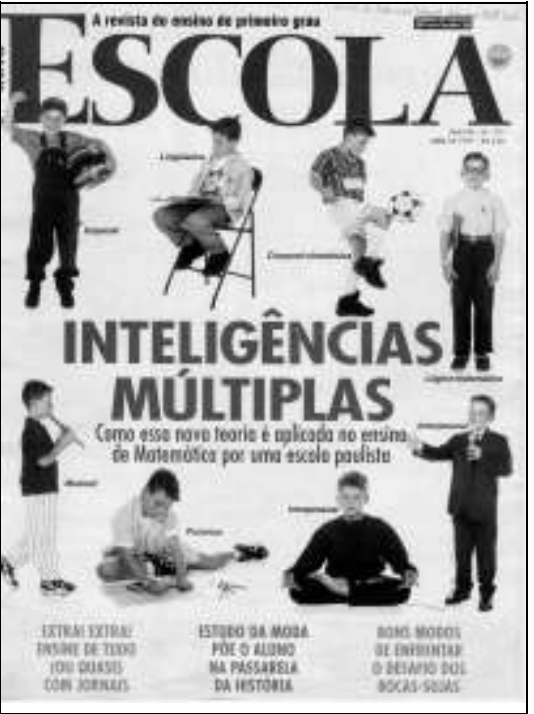

104
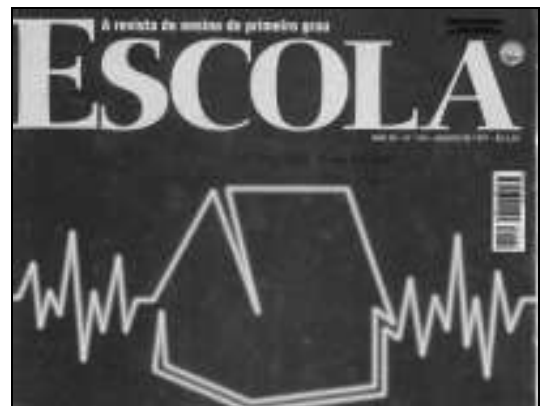

O CHECK-UP DO ENSINO

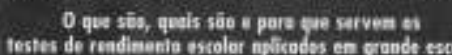

stes de readinanta ovolor milicades en grande escolo

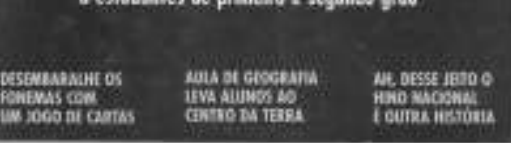

107

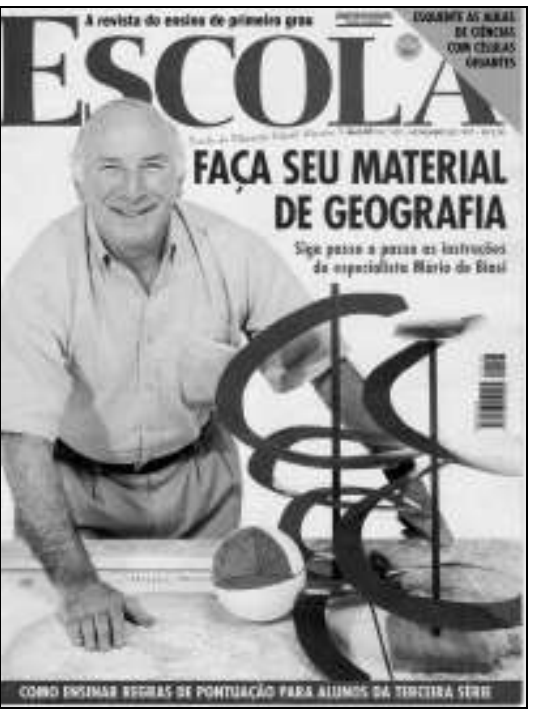

102

ESCOLA

QUALIDADE

A VISTA

Entenda a estrotegio do MCC por Iras des novidodes legishatives e odministratives dos iltimos deis anos pare e educexá̃o basica e flipe per dentro do que rinde este por vit

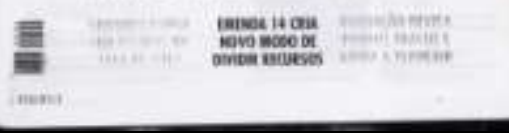

105

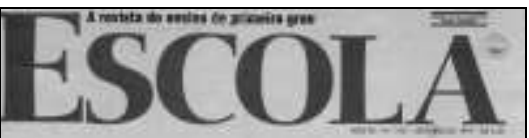

100 ANOS DE CANUDOS

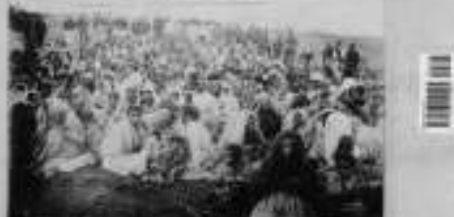

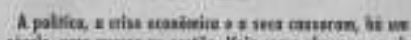

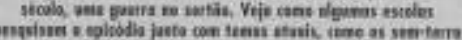

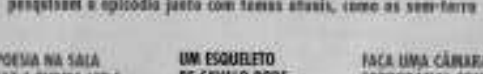

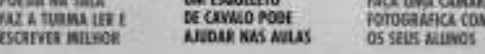
108

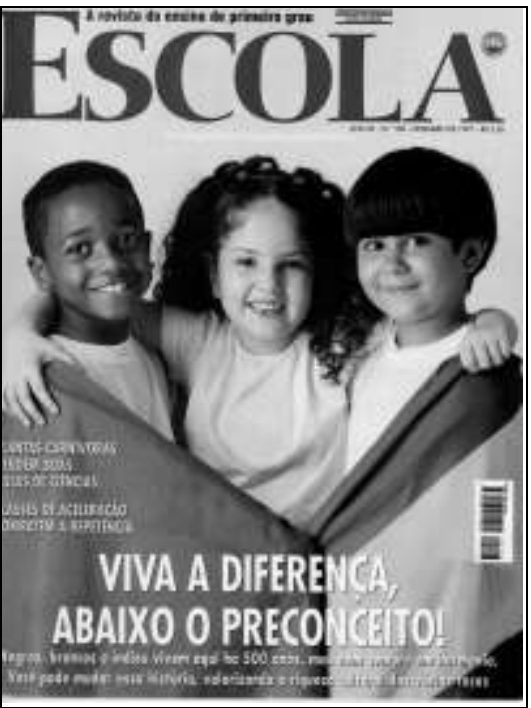




\section{Ano: 1998}

Números: 109 a 110

109

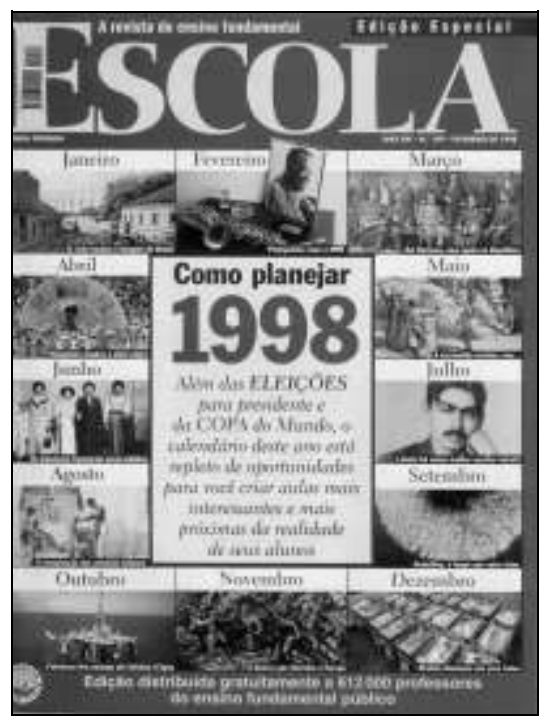

112

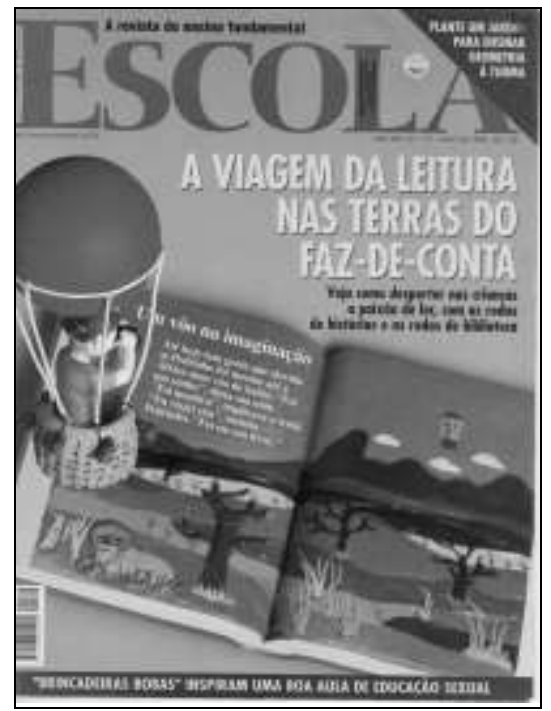

115

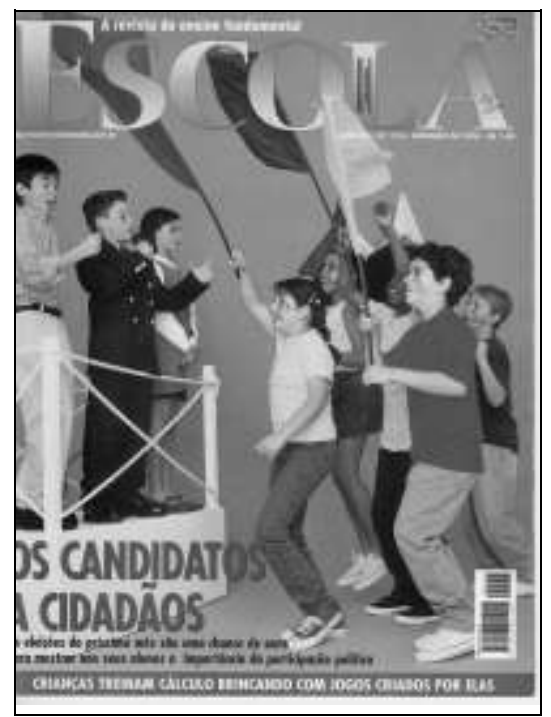

110

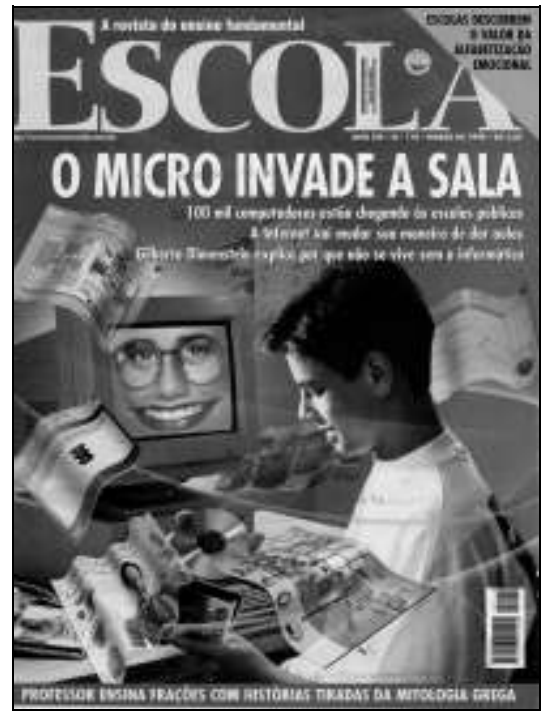

113

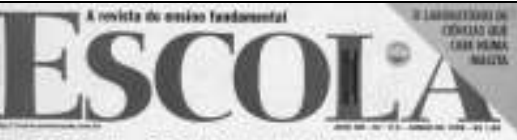

E AGORA, COMO DIVIDIR OS BOLOS?

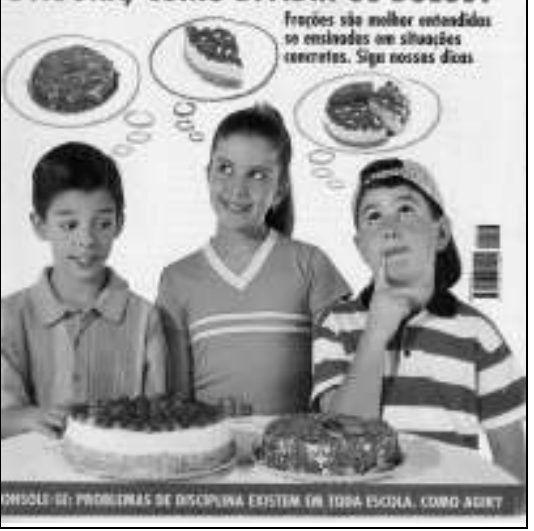

116

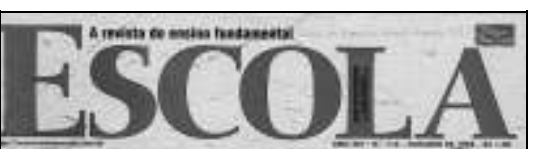

AWAGA REVELA IO

SUAS FORMULAS है

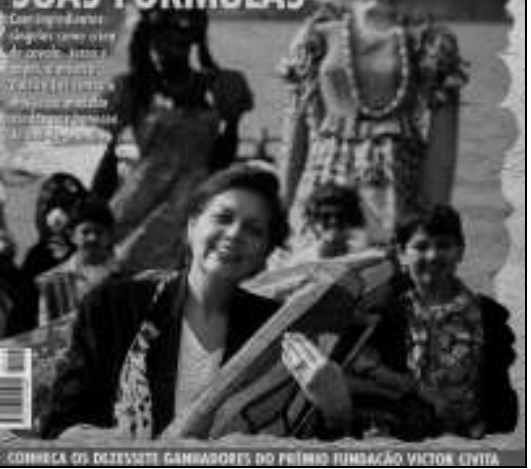

111

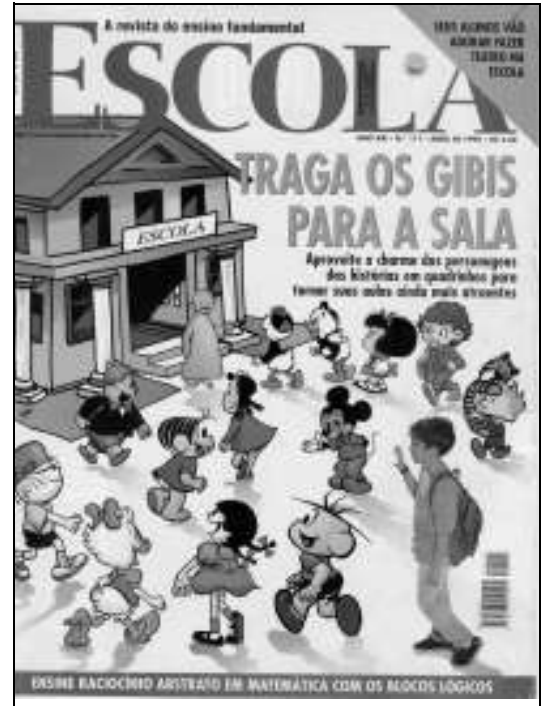

114

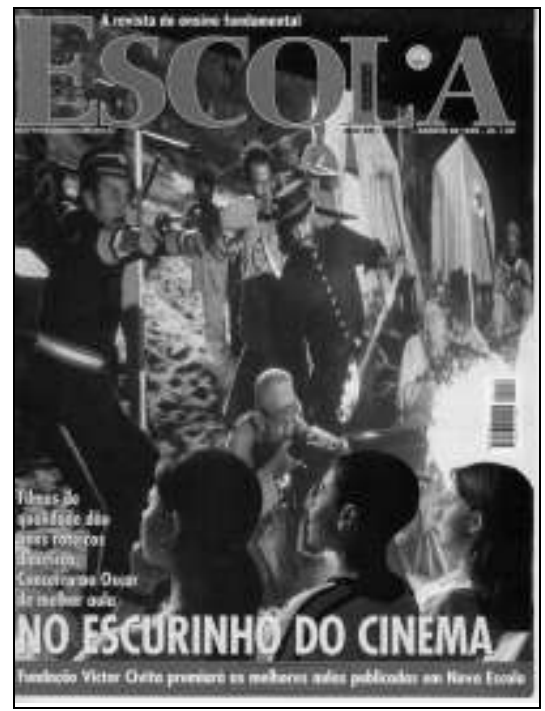

117

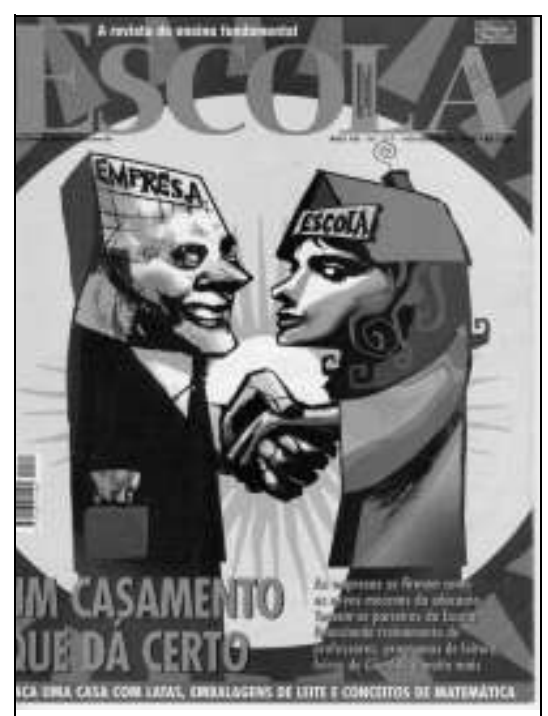


Ano: 1998

Números: 118

118

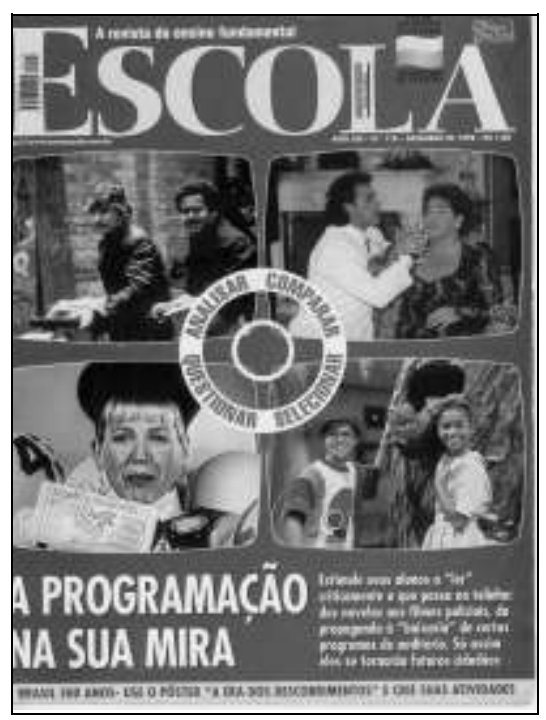




\section{ANEXO B}

Reprodução de uma página da reportagem intitulada "Criatividade. Aulas de dar água na boca" (Nova Escola, n91, março/96, p. 13) 


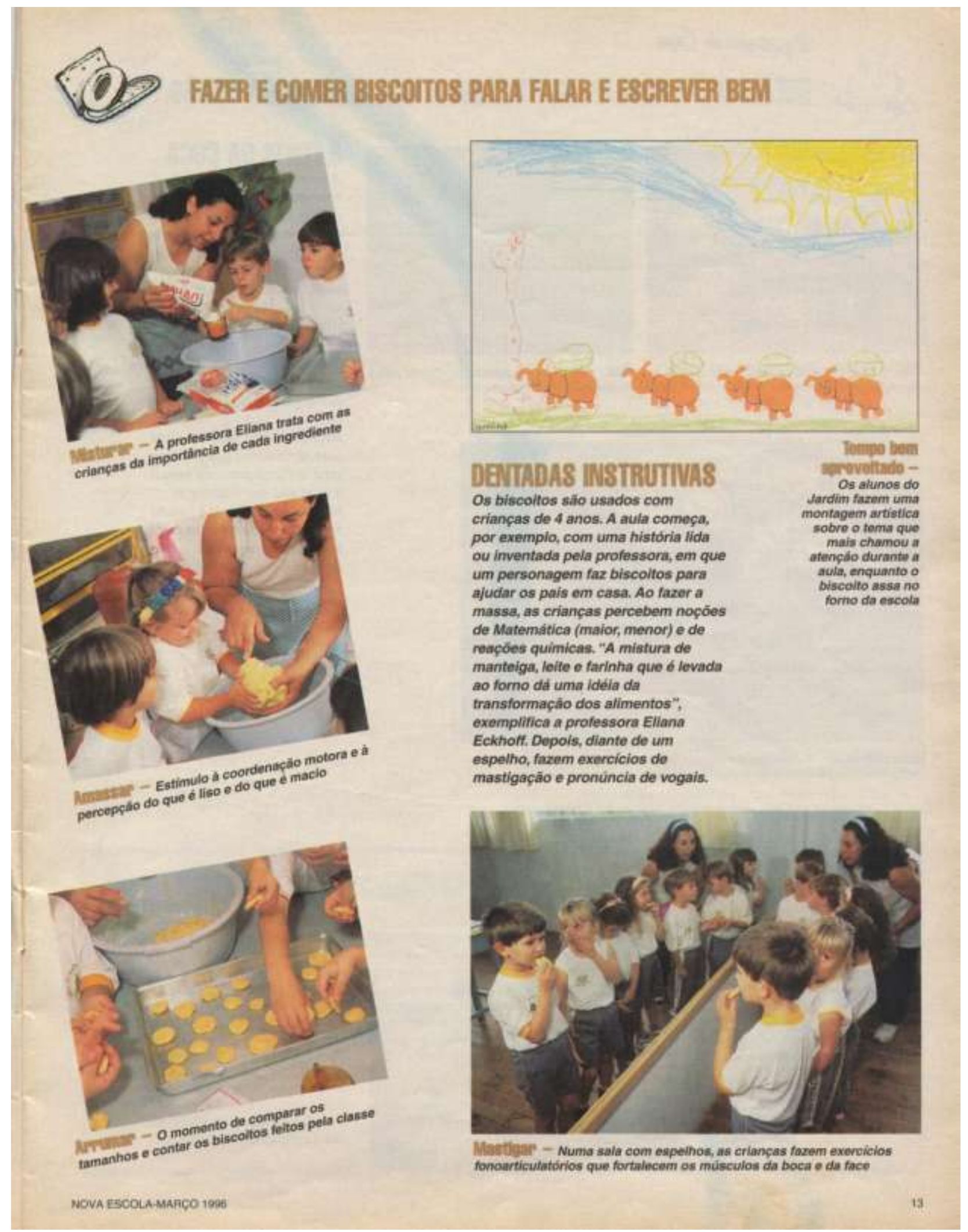


